\title{
Survey of Strong Motion Earthquake Effects on Thermal \\ Power Plants in California with Emphasis on Piping Systems
}

\section{Appendices}

Manuscript Completed: October 1995

Date Published: November 1995

Prepared by

J. D. Stevenson

Stevenson and Associates

9217 Midwest Avenue

Cleveland, OH 44125

Under contract to

Oak Ridge National Laboratory

Managed by Martin Marietta Energy Systems, Inc.

Oak Ridge National Laboratory

Oak Ridge, TN 37831-6285

N. Chokshi, NRC Project Manager

Prepared for :

Division of Engineering Technology

Office" of Nuclear Regulatory Research

U.S. Nuclear Regulatory Commission

Washington, DC 20555-0001

NRC FIN B0850

Under Contract No. DE-ACO5-84OR21400 


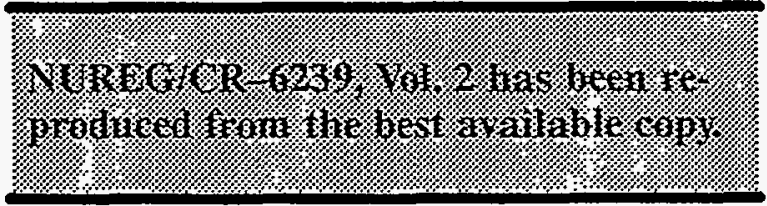




\section{DISCLAMMER}

Portions of this document may be illegible in electronic image products. Images are produced from the best available original document. 


\begin{abstract}
Volume 2 of the "Survey of Strong Motion Earthquake Effects on Thermal Power Plants in California with Emphasis on Piping Systems" contains Appendices which detail the detail design and seismic response of several power plants subjected to strong motion earthquakes. The particular plants considered include the Ormond Beach, Long Beach and Seal Beach, Burbank, El Centro, Glendale, Humboldt Bay, Kern Valley, Pasadena and Valley power plants. Included is a typical power plant piping specification and photographs of typical power plant piping specification and photographs of typical piping and support installations for the plants surveyed. Detailed piping support spacing data are also included.
\end{abstract}

\title{
DISCLAIMER
}

This report was prepared as an account of work sponsored by an agency of the United States Government. Neither the United States Government nor any agency thereof, nor any of their employees, makes any warranty, express or implied, or assumes any legal liability or responsibility for the accuracy, completeness, or usefulness of any information, apparatus, product, or process disclosed, or represents that its use would not infringe privately owned rights. Reference herein to any specific commercial product, process, or service by trade name, trademark, manufacturer, or otherwise does not necessarily constitute or imply its endorsement, recommendation, or favoring by the United States Government or any agency thereof. The views and opinions of authors expressed herein do not necessarily state or reflect those of the United States Government or any agency thereof. 


\section{Contents}

Abstract $\ldots \ldots \ldots \ldots \ldots \ldots \ldots \ldots \ldots \ldots \ldots \ldots \ldots \ldots \ldots \ldots \ldots \ldots \ldots \ldots \ldots \ldots \ldots \ldots \ldots \ldots \ldots \ldots \ldots \ldots \ldots \ldots$

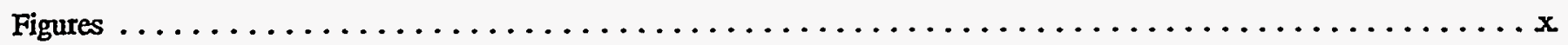

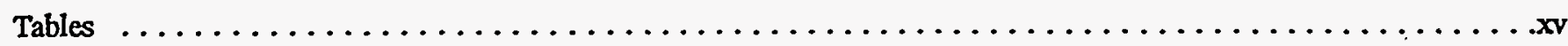

Acknowledgment $\ldots \ldots \ldots \ldots \ldots \ldots \ldots \ldots \ldots \ldots \ldots \ldots \ldots \ldots \ldots \ldots \ldots \ldots \ldots \ldots \ldots \ldots \ldots \ldots \ldots \ldots \ldots \ldots$

Executive Summary $\ldots \ldots \ldots \ldots \ldots \ldots \ldots \ldots \ldots \ldots \ldots \ldots \ldots \ldots \ldots \ldots \ldots \ldots \ldots \ldots \ldots \ldots \ldots \ldots$

Appendix A: Summary Description of the Ormond Beach Power Plant Response to the Point Mugu Earthquake of 21

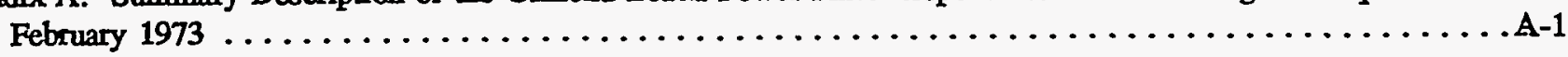

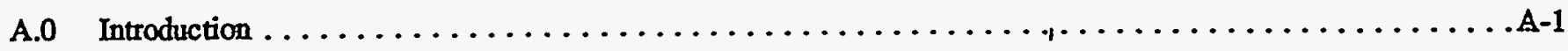

A.1 Description of Ormond Beach Generating Station $\ldots \ldots \ldots \ldots \ldots \ldots \ldots \ldots \ldots \ldots \ldots \ldots \ldots \ldots \ldots \ldots \ldots \ldots$

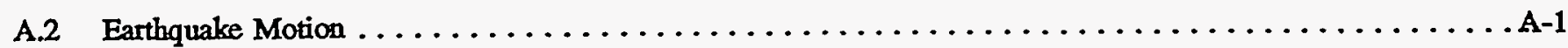

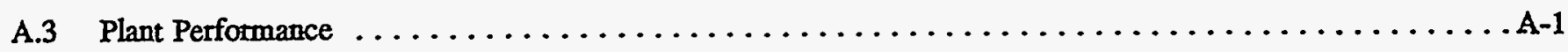

Appendix B: The Long Beach Earthquake of 1933 and Its Effect on the Long Beach and Seal Beach Steam Power

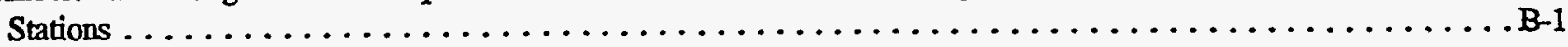

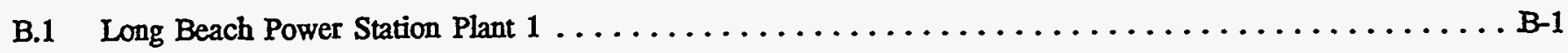

B.2 . Long Beach Power Station Plants 2 and $3 \ldots \ldots \ldots \ldots \ldots \ldots \ldots \ldots \ldots \ldots \ldots \ldots \ldots \ldots \ldots \ldots \ldots \ldots \ldots$

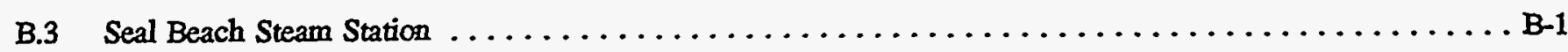

Appendix C: Typical Specifications Used in Construction of Power Plant Piping $\ldots \ldots \ldots \ldots \ldots \ldots \ldots \ldots$

Appendix D: Detailed Description of Selected Power Plants $\ldots \ldots \ldots \ldots \ldots \ldots \ldots \ldots \ldots \ldots \ldots \ldots \ldots \ldots \ldots \ldots$

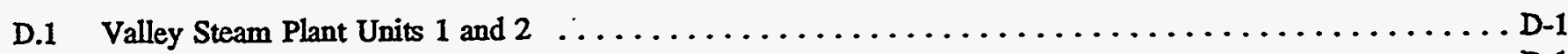

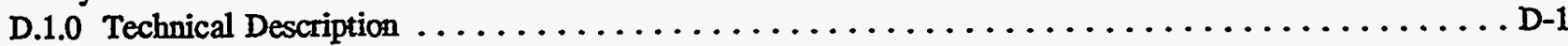

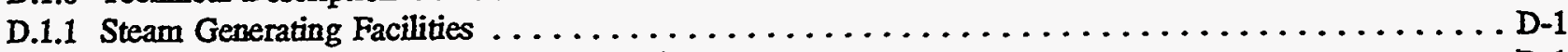

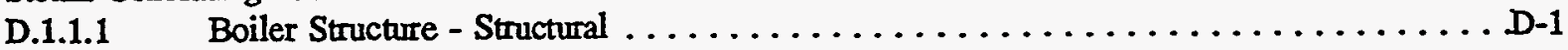

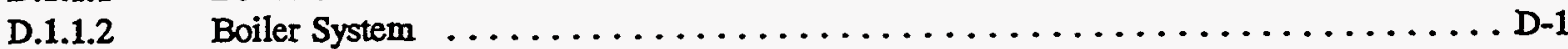

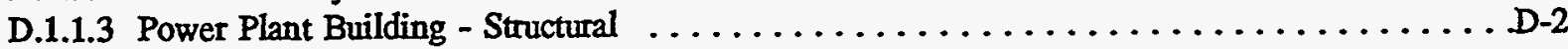

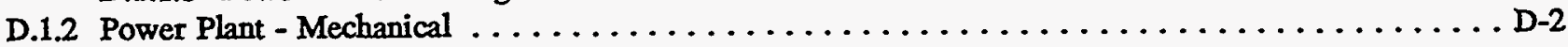

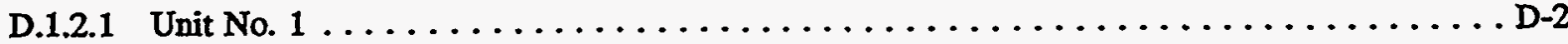

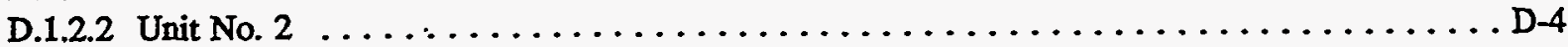

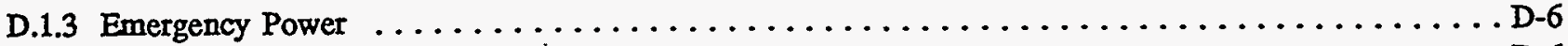

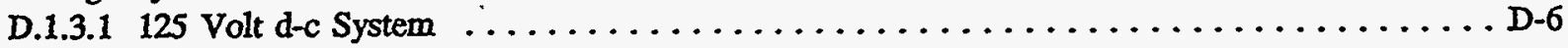

Appendix E: Photographs Showing Typical Piping and Support Installations

for the Power Plants Surveyed $\ldots \ldots \ldots \ldots \ldots \ldots \ldots \ldots \ldots \ldots \ldots \ldots \ldots \ldots \ldots \ldots \ldots \ldots \ldots \ldots \ldots$

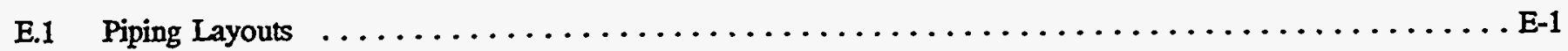




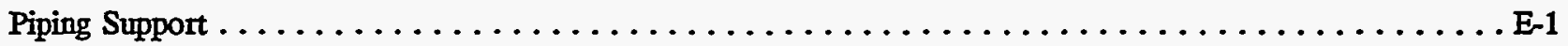

Appendix F: Piping Support Data Base Developed from Valley Steam Plants Units 1 to 4, El Centro Plants Units 1-4

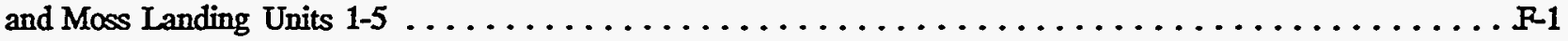

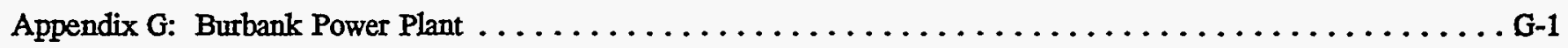

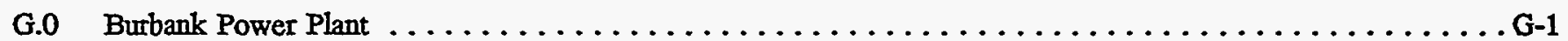

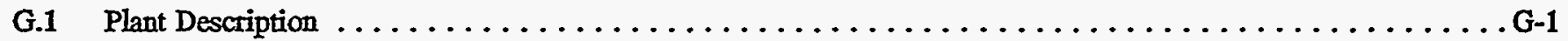

G.2 Summary Description of Effects From The San Fernando $\ldots \ldots \ldots \ldots \ldots \ldots \ldots \ldots \ldots \ldots \ldots \ldots$.

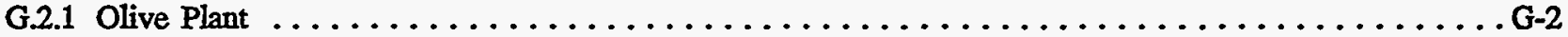

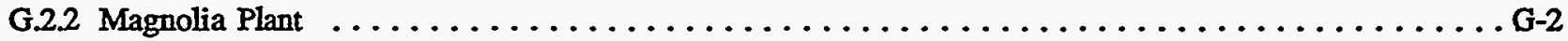

G.3 Time Sequence of Events Following The Earthquake $\ldots \ldots \ldots \ldots \ldots \ldots \ldots \ldots \ldots \ldots \ldots \ldots \ldots$

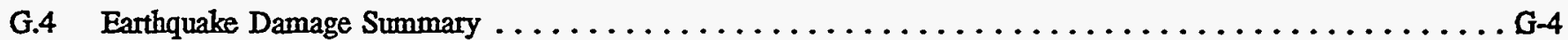

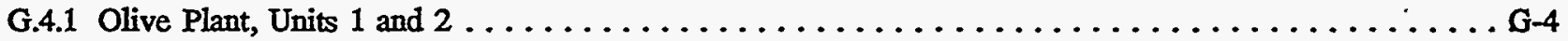

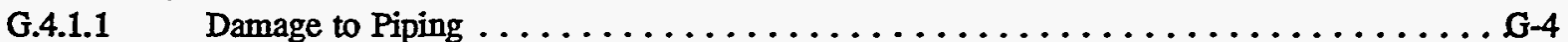

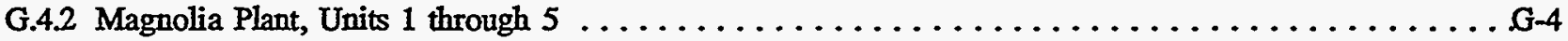

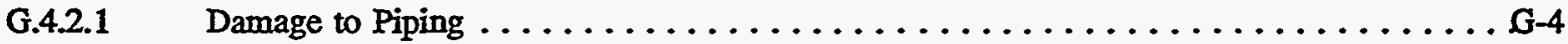

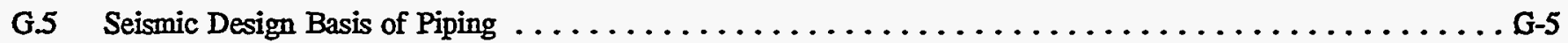

G.6 Seismic Demand From The San Fernando Earthquake $\ldots \ldots \ldots \ldots \ldots \ldots \ldots \ldots \ldots \ldots \ldots \ldots \ldots$

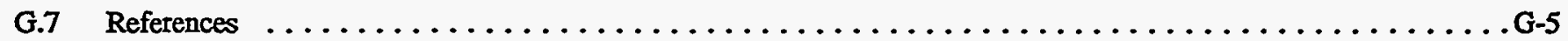

Appendix H: El Centro Power Plant $\ldots \ldots \ldots \ldots \ldots \ldots \ldots \ldots \ldots \ldots \ldots \ldots \ldots \ldots \ldots \ldots \ldots \ldots \ldots \ldots \ldots \ldots \ldots$

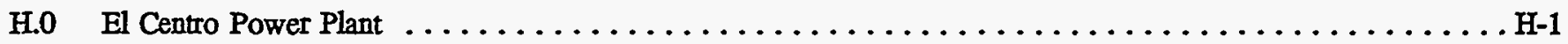

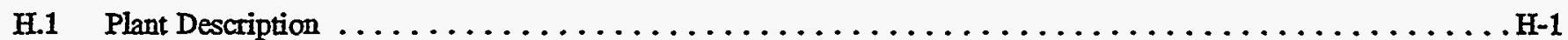

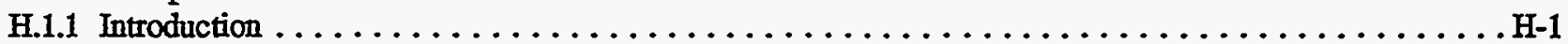

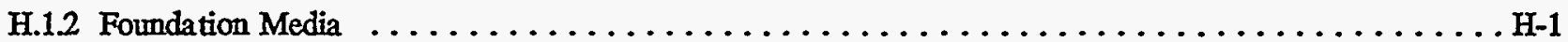

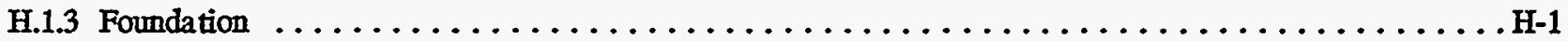

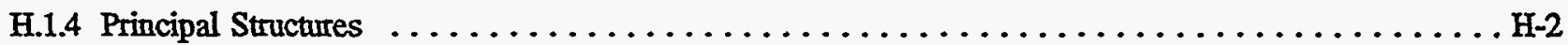

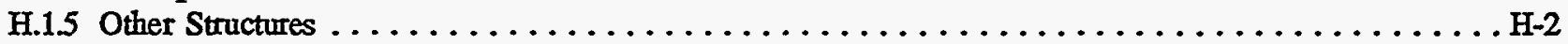

H.2 Summary of Effects from the El Centro-1979 Earthquake on the El Centro Power . . . . . . . . . . H-2

H.2.1 Structures, Mechanical and Electrical Equipment and Vertical Tanks . . . . . . . . . . . H-2

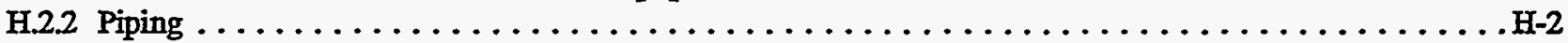

H.3 Summary of Effects from the Superstition Hills Earthquake of November 24, 1987 on the El Centro Power

Plant . . . . . . . . . . . . . . . . . . . . . . . . . . . . . . . . . .

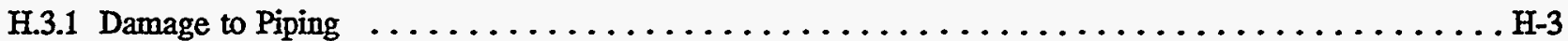

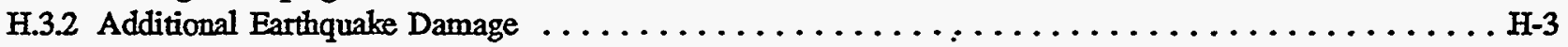

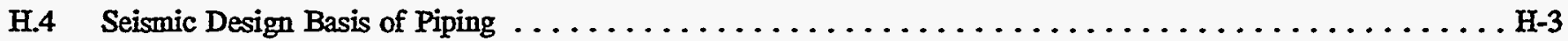

H.5 Seismic Demand from the Imperial 1979 Earthquak $\ldots \ldots \ldots \ldots \ldots \ldots \ldots \ldots \ldots \ldots \ldots \ldots$

H.6 Seismic Demand from the Superstition Hills Earthquake of November $24,1987 \ldots \ldots \ldots \ldots \ldots \ldots \ldots$. $\ldots \ldots$

NUREG/CR-6239 
Appendix I: Glendale Power Plant . I-1

I.0 Glendale Power Plant I-1

I.1 General Description

I.2 Summary of Recorded Effects from the San Fernando Earthquake

1.3 Time Sequence of Events Following the Earthquak

I.4 Earthquake Damage Summary, Piping

I.5 Seismic Demand from the San Femando Earthquake at the Power Plant Site I-4

I.6 Reference

Appendix J: Humboldt Bay Power Plant

J.0 Humboldt Bay Power Plant

J.1 Humboldt Bay Power Plant

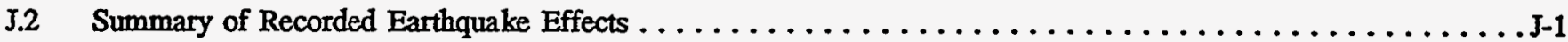

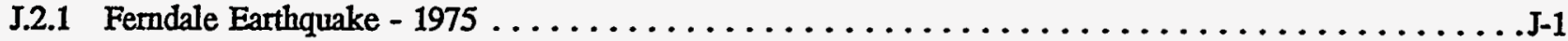

J.2.2 Eureka Earthquake - 1980

J.3 Time Sequence of Events Following the Earthquake $\ldots \ldots \ldots \ldots \ldots \ldots \ldots \ldots \ldots \ldots \ldots \ldots \ldots \ldots \ldots$

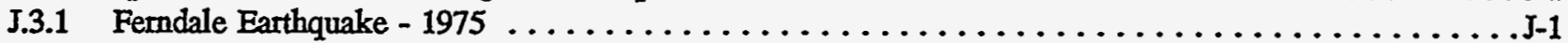

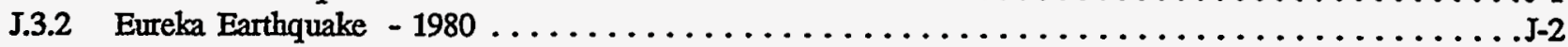

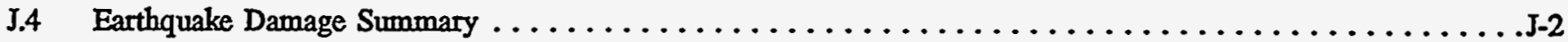

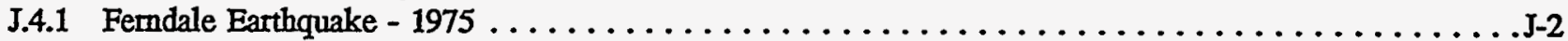

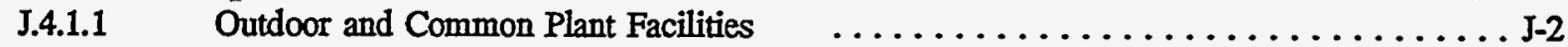

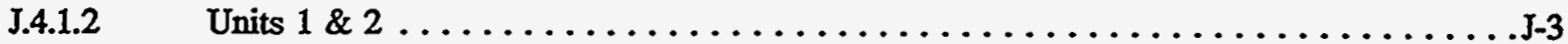

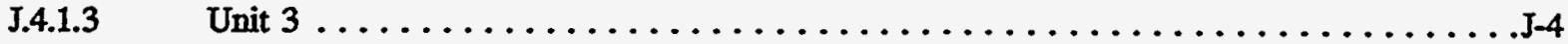

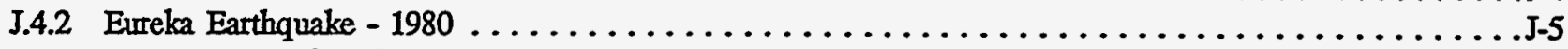

J.4.2.1 The Effects on Plant Structures, Tanks and Mechanical Equipment .......... J-5

J.4.2.2 Effects on Piping $\ldots \ldots \ldots \ldots \ldots \ldots \ldots \ldots \ldots \ldots \ldots \ldots \ldots \ldots$

J.5 Seismic Design Basis $\ldots \ldots \ldots \ldots \ldots \ldots \ldots \ldots \ldots \ldots \ldots \ldots \ldots \ldots \ldots \ldots \ldots \ldots \ldots \ldots . . . . \ldots \ldots$

J.5.1 Seismic Design Basis for Units 1 and 2 Building Structures and Piping $\ldots \ldots \ldots \ldots \ldots \ldots \ldots$ J-6

J.5.2 Seismic Design Basis for Unit 3 Building Structure and Piping $\ldots \ldots \ldots \ldots \ldots \ldots \ldots \ldots \ldots$

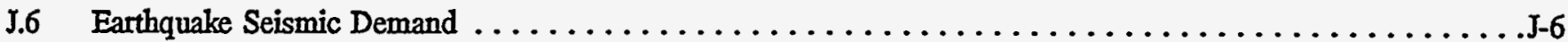

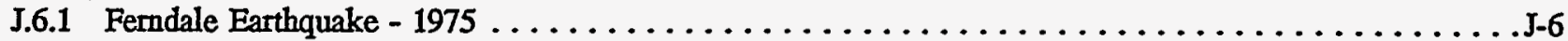

J.6.1.1 Strong-Motion Instrumentation and Calibration $\ldots \ldots \ldots \ldots \ldots \ldots \ldots \ldots . . .6$

J.6.1.2 Analyses of Digitized Data $\ldots \ldots \ldots \ldots \ldots \ldots \ldots \ldots \ldots \ldots \ldots \ldots \ldots \ldots \ldots \ldots$

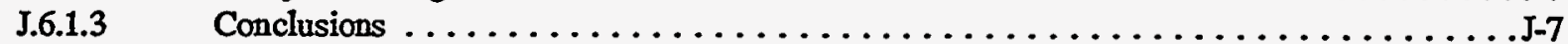

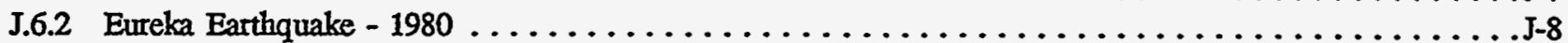

J.6.2.1 Instrumentation Records $\ldots \ldots \ldots \ldots \ldots \ldots \ldots \ldots \ldots \ldots \ldots \ldots \ldots \ldots$

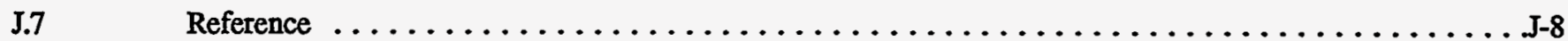




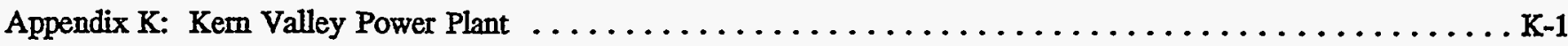

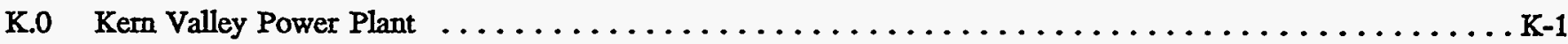

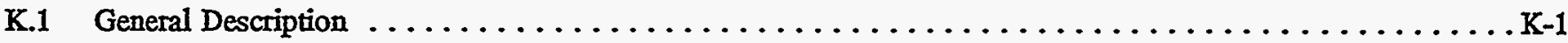

K.2 Summary of Recorded Earthquake Effects From the Kern County Earthquake of $7 / 21 / 52 \ldots \ldots \ldots \ldots \ldots$ K-1

K.2.1 Description of Repairs of Earthquake Induced Damage to Oil Storage Tanks $\ldots \ldots \ldots \ldots \ldots \ldots$ K-1

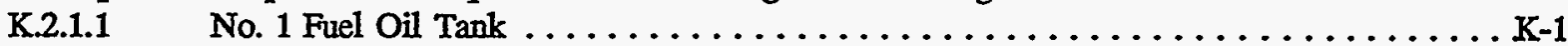

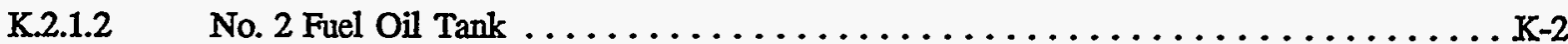

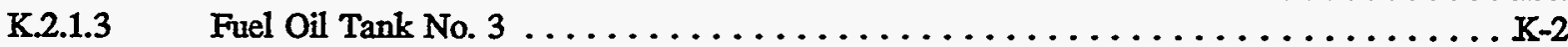

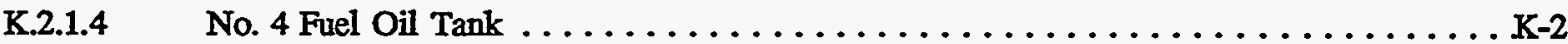

K.2.2 Description of Earthquake Damage to Bailey Boiler Controls $\ldots \ldots \ldots \ldots \ldots \ldots \ldots \ldots \ldots \ldots$ K-2

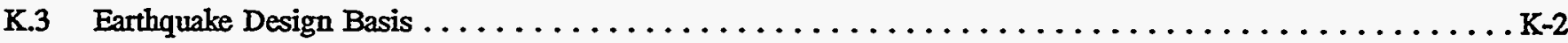

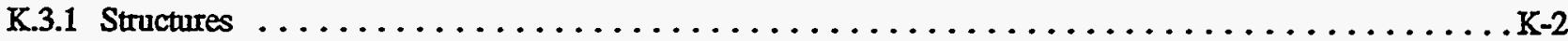

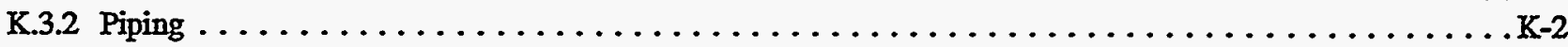

K.4 Seismic Demand from the Kern County Earthquake at the Kern Valley Power Station ........... K-2

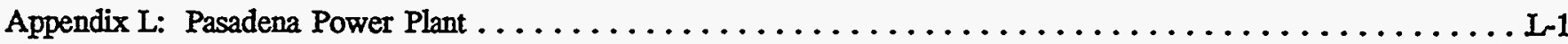

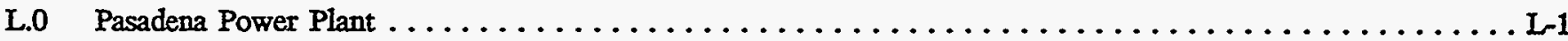

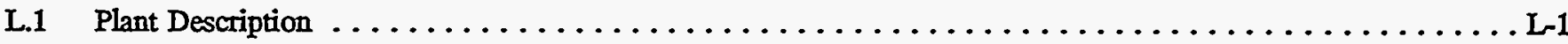

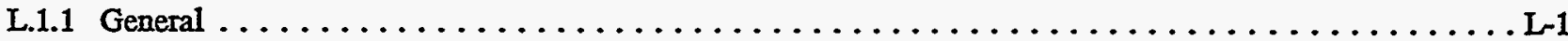

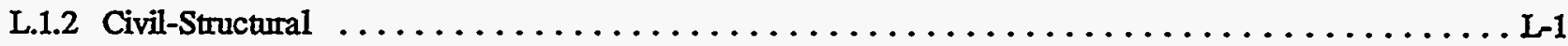

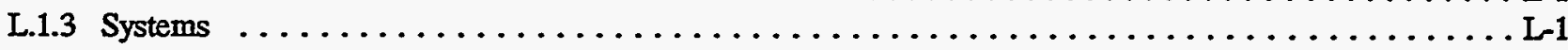

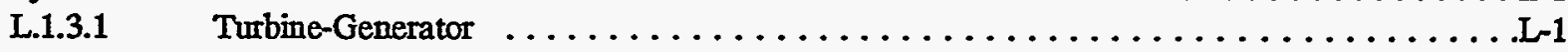

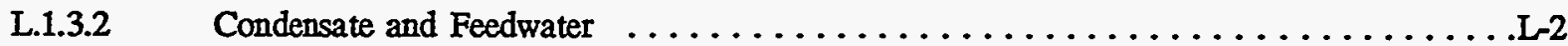

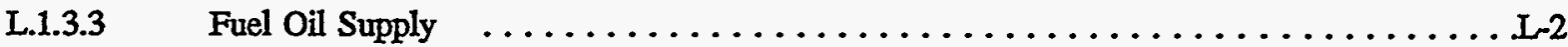

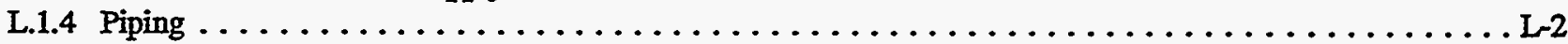

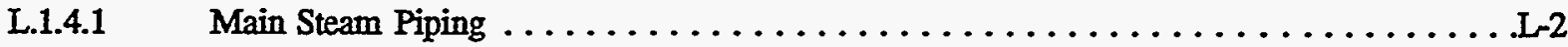

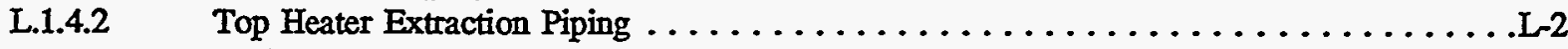

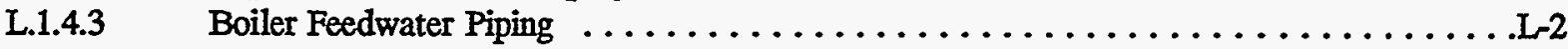

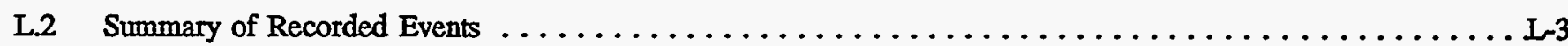

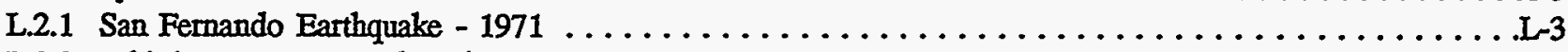

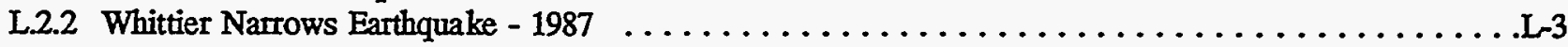

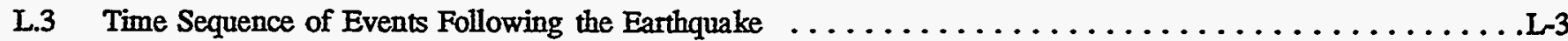

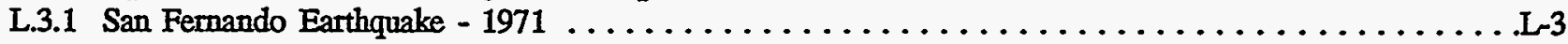

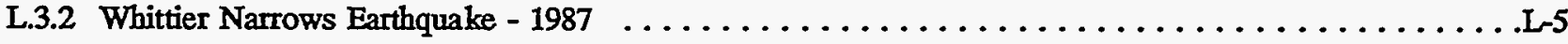

L.4 Earthquake Damage Summary $\ldots \ldots \ldots \ldots \ldots \ldots \ldots \ldots \ldots \ldots \ldots \ldots \ldots \ldots \ldots \ldots \ldots \ldots \ldots$

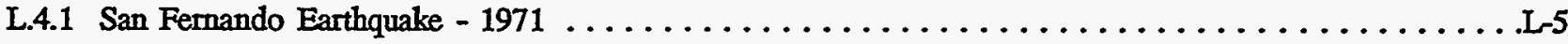

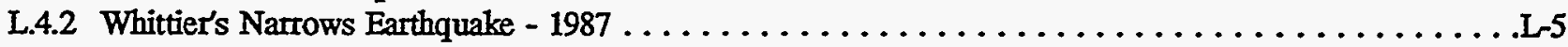

L.5 Seismic Design Basis for Building Structures and Piping $\ldots \ldots \ldots \ldots \ldots \ldots \ldots \ldots \ldots \ldots \ldots \ldots \ldots \ldots \ldots$

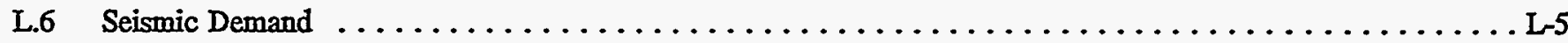

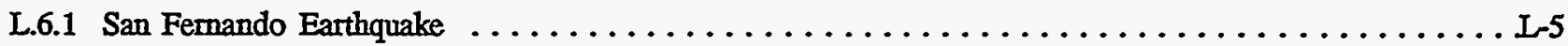

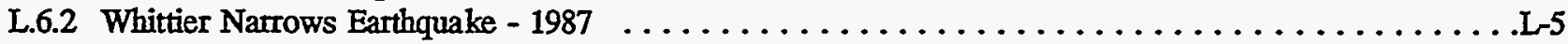

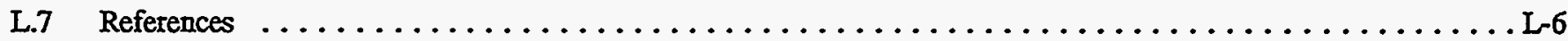

NUREG/CR-6239 viii 


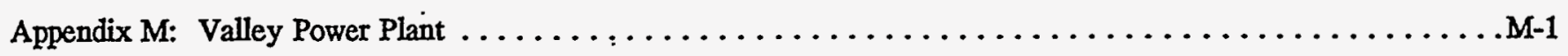

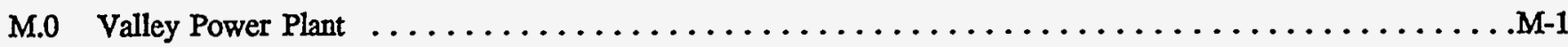

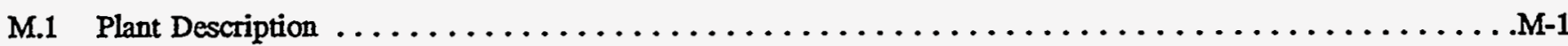

M.1.1 General . . . . . . . . . . . . . . . .

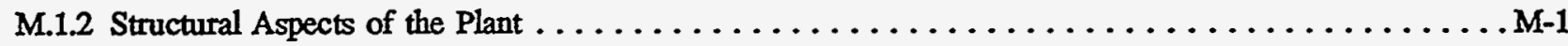

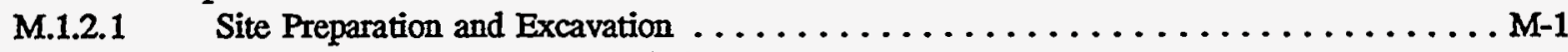

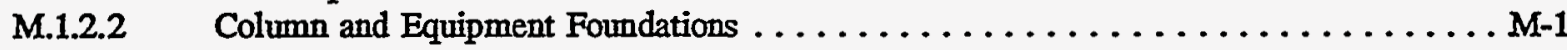

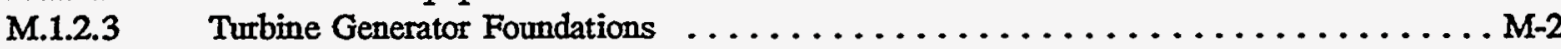

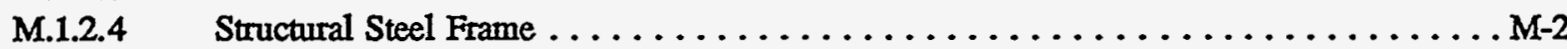

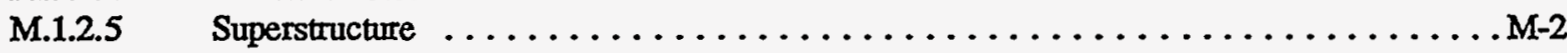

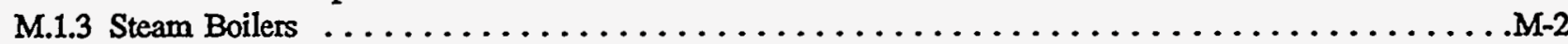

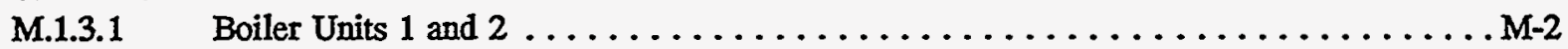

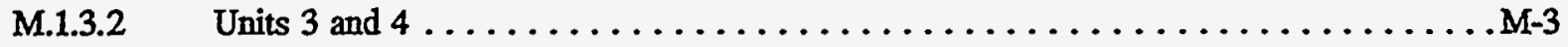

M.2 Summary of Recorded Effects from the San $\ldots \ldots \ldots \ldots \ldots \ldots \ldots \ldots \ldots \ldots \ldots \ldots \ldots \ldots \ldots$

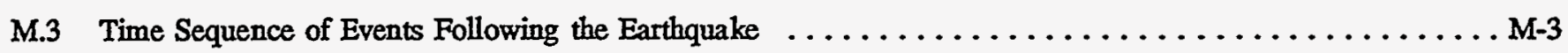

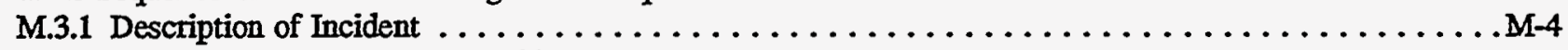

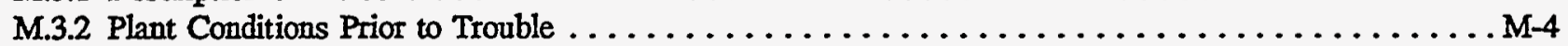

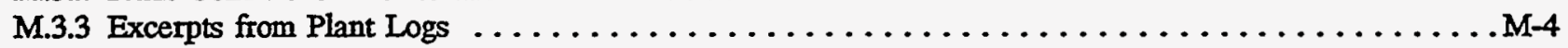

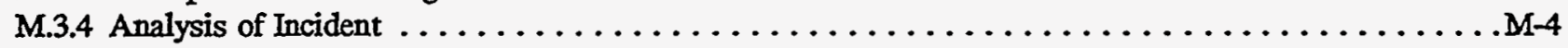

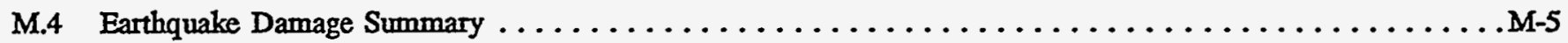

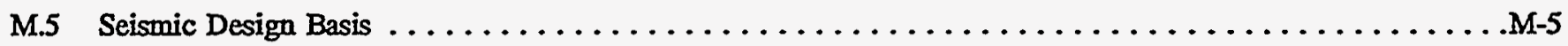

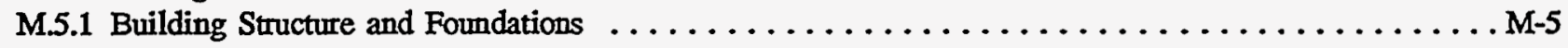

M.6 Seismic Demand from the San Fernando Earthquake $\ldots \ldots \ldots \ldots \ldots \ldots \ldots \ldots \ldots \ldots \ldots$

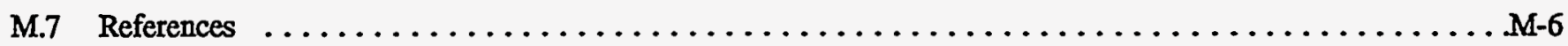




\section{Figures}

Figure A.1

Figure D.1

Figure E.1

Figure E.2

Figure E.3

Figure E.4

Figure E.5

Figure E.6

Figure E.7

Figure E.8

Figure E.9

Figure E.10

Figure E.11

Figure E.12

Figure E.13

Figure E.14

Figure E.15

Figure E.16

Figure E.17

Figure E.18

Figure E.19

Figure E.20
Location of Two Data Base Plants

Humbodlt Bay Steam Plant

D-18

Unsupported Șmall Bore Piping in Valley Unit 1 E-2

Unsupported Small Bore Piping in Humboldt Bay Unit $1 \ldots \ldots \ldots \ldots \ldots \ldots \ldots \ldots \ldots \ldots$

Unsupported Small Bore Piping in Humboldt Bay Unit 1

Unsupported Small Bore Piping with Noticeable Sag in Magnolia Unit 1 E-3

Unsupported Small Bore Piping in El Centro Unit 1 $. \mathrm{E}-4$

Unsupported Small Bore Piping in El Centro Unit 3 E-4

Unsupported Small Bore Piping in Valley Unit 3 E-5

Unsupported Small Bore Piping in Olive Unit 2 E-5

Unsupported Small Bore Piping in Magnolia Unit 3 E-6

Unsupported Small Bore Piping in El Centro Unit 2 .E-6

Unsupported Small Bore Piping in El Centro Unit 4 .E-7

Unsupported Long Vertical Runs in Small Bore Piping in $\mathrm{El}$ Centro Unit 4 E-8

Small Bore Piping Supporting Other Small Bore

Pipe in Kern Unit $1 \ldots \ldots \ldots \ldots \ldots$ E-9

Unsupported Small Bore Piping in Kern Unit 1.

.E-9

Example of Non-Flexible Branch Line Connection in

Olive Unit 2

Unsupported Corroded Bore Line in Valley Unit 3

Unsupported Cortoded Small Bore Line in

Humboldt Bay Unit 3

Snubber Support of Main Steam Line on Magnolia Unit 3

Snubber Support of Main Steam Line on Pasadena

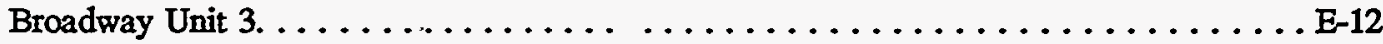

Snubber Support of Oil Feed Lines to Boiler on Humboldt Bay Unit 2. . E-13 
Figure E.21

Figure E.22

Figure E.23

Figure E.24

Figure E.25

Figure E.26

Figure E.27

Figure E.28

Figure E.29

Figure E.30

Figure E.31

Figure E.32

Figure E.33

Figure E.34

Figure E.35

Figure E.36

Figure E.37

Figure E.38

Figure E.39

Figure E.40

Figure E.41

Figure E.42
Snubber Support of Oil Feed Lines to Boiler on

Humboldt Bay Unit 2.

Snubber Support of Feedwater Line on Kern Unit 1.

Snubber Support of Main Steam Lines of

El Centro Unit 4.

Lateral Sway Brace Support of Large Bore Hot Line

in Valley Unit 3.

Pipe Supporting Pipe in Humboldt Bay Unit $2 . \ldots \ldots \ldots \ldots \ldots \ldots \ldots \ldots \ldots \ldots$

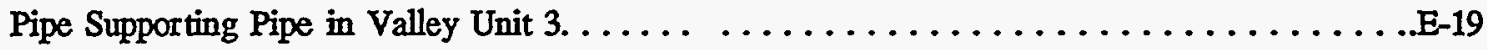

Pipe Supporting Pipe in El Centro Unit $1 . \ldots \ldots \ldots \ldots \ldots \ldots \ldots \ldots \ldots \ldots \ldots \ldots \ldots \ldots \ldots$

Pipe Supporting Pipe in Kern Unit $1 . \ldots \ldots \ldots \ldots \ldots \ldots \ldots \ldots \ldots \ldots \ldots \ldots \ldots \ldots \ldots \ldots \ldots \ldots$

Pipe Supporting Pipe in Kern Unit $1 \ldots \ldots \ldots \ldots \ldots \ldots \ldots \ldots \ldots \ldots \ldots \ldots \ldots \ldots \ldots \ldots \ldots \ldots$

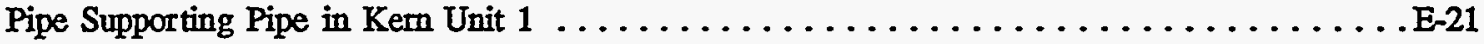

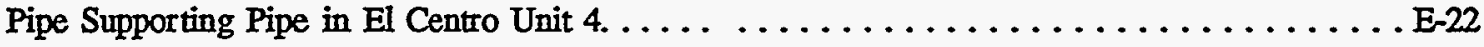

Field Fabricated Spring Hanger in Kern Unit $1 \ldots \ldots \ldots \ldots \ldots \ldots \ldots \ldots \ldots \ldots \ldots \ldots \ldots \ldots$

Field Fabricated Spring Hanger in Kern Unit $1 \ldots \ldots \ldots \ldots \ldots \ldots \ldots \ldots \ldots \ldots \ldots \ldots \ldots \ldots$

Spring Support for Main Feedwater Line for Pasadena

Broadway Unit $2 \ldots \ldots \ldots \ldots \ldots \ldots \ldots \ldots \ldots \ldots \ldots \ldots \ldots \ldots \ldots \ldots \ldots \ldots \ldots \ldots \ldots \ldots$

Spring Hanger for Large Bore Hot

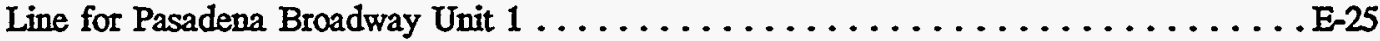

Spring Support for Main Steam Line

for Pasadena Broadway Unit 2

Spring Hanger for Large Bore Hot Line

for Pasadena Broadway Unit 1

Spring Trapeze Support Large Bore Hot

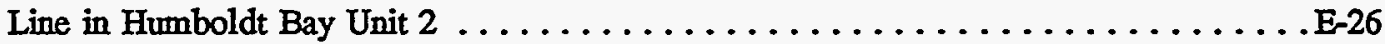

Knee Brace Support for Large Bore Cold

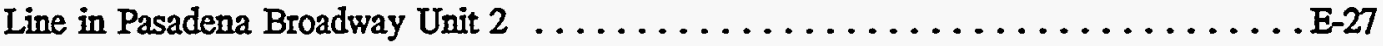

Field Fabricated Support From Platform

Steel in Humboldt Bay Unit 1 . .

Unseated Support of Large Bore Hot Line

in Humboldt Bay Unit 1.

Guide Supports for Large Bore Hot Line

in Glendale Unit 4 
Figure E.43

Figure E.44

Figure E.45

Figure E.46

Figure E.47

Figure E.48

Figure E.49

Figure E.50

Figure E.51

Figure E.52

Figure E.53

Figure E.54

Figure E.55

Figure E.56

Figure E.57

Figure E.58

Figure E.59

Figure E.60

Figure E.61

Figure E.62
Guide Supports for Large Bore Hot Line in Glendale Unit 4

Deadweight Support for Main Steam Line

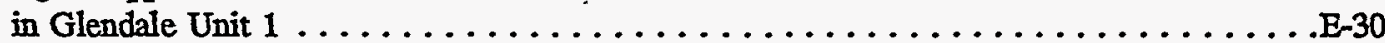

Deadweight Support for Main Steam Line

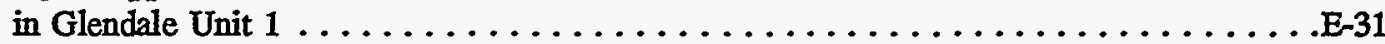

Spring Support for Large Bore Hot Line

in El Centro Unit 4

Guided Supports for Large Bore Hot Lines

in El Centro Unit 3

Guided Supports for Large Bore Hot Lines

in $\mathrm{El}$ Centro Unit 4

Expansion Loop in Small Bore Hot Line in Olive Unit 1

Guide Pipe and Support for Large Bore

Cold Lines in Glendale Unit 3 . .

Unseated Vertical Support in El Centro Unit 2

U-Bolt Vertical Lateral Restraint in Small

Bore Hot Pipe in Olive Unit 1.

Trapeze and U-Bolt Supported Small Bore

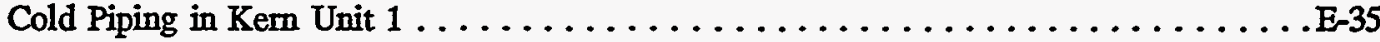

Field Fabricated Support in Kern Unit 1

Expansion Loop in Small Bore Hot Line in Glendale Unit 3

U-Bolt Support of Small Bore Hot Line in Glendale Unit 3

U-Bolt Support of Large Bore Hot Line in Pasadena Broadway Unit 2

U-Bolt Support of Large Bore Cold Line and Pipe Supporting Pipe in Valley Unit 1

U-Bolt Support of Large Bore Cold Piping in Valley Unit 1

Guided Small Bote Hot Lines in Valley Unit 2

Guided Small Bore Hot Lines in Pasadena

Broadway Unit 3

Anchor or Large Bore Hot Line in

Pasadena Broadway Unit 2 
Figure E.63

Figure E.64

Figure E.65

Figure E.66

Figure E.67

Figure E.68

Figure G.1

Figure H.1

Figure H.2

Figure H.3

Figure H.4

Figure H.5(a)

Figure H.5(b)

Figure H.5(c)

Figure H.6

Figure I.1

Figure J.1

Figure J.2

Figure J.3
Guided Restraint on Large Bore Hot Line Humboldt Bay Unit 3

Guided Restraint on Main Steam Line El Centro Unit 3.

E-42

Long Vettical Hangers and Springs for

Main Steam Line on El Centro Unit 2

Long Vertical Hangers for Large Bore Hot

Lines in Valley Unit $3 \ldots \ldots \ldots \ldots \ldots \ldots \ldots \ldots \ldots \ldots \ldots \ldots \ldots \ldots$

Field Fabricated Hangers in Olive Unit $2 \ldots \ldots \ldots \ldots \ldots \ldots \ldots \ldots \ldots \ldots \ldots \ldots$

Long Trapeze Supports for Large and Small

Bore Cold Lines in El Centro Unit $4 \ldots \ldots \ldots \ldots \ldots \ldots \ldots \ldots \ldots \ldots \ldots \ldots \ldots$

Burbank Power Plant - Olive and Magnolia Units $\ldots \ldots \ldots \ldots \ldots \ldots \ldots \ldots \ldots \ldots \ldots$

Plot Plan El Centro Steam Plant $\ldots \ldots \ldots \ldots \ldots \ldots \ldots \ldots \ldots \ldots \ldots \ldots \ldots \ldots$

N-S Elevation View of El Centro Unit $4 \ldots \ldots \ldots \ldots \ldots \ldots \ldots \ldots \ldots \ldots \ldots \ldots \ldots \ldots \ldots \ldots$

E-W elevation View of El Centro Unit $4 \ldots \ldots \ldots \ldots \ldots \ldots \ldots \ldots \ldots \ldots \ldots \ldots$

Map of El Centro Showing Location of Recording

Station CSMIP Station 01335 and USGS Station 5165

Relative to the El Centro Steam Station $\ldots \ldots \ldots \ldots \ldots \ldots \ldots \ldots \ldots \ldots$ H-8

Recorded Time-History and Resultant Response Spectra

at the VSGS Station No. 5165 Due to 1979 Earthquake

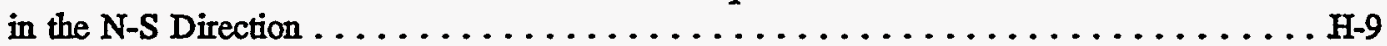

Recorded Time-History and Resultant Response Spectra

at the VSGS Station No. 5165 Due to 1979 Earthquake

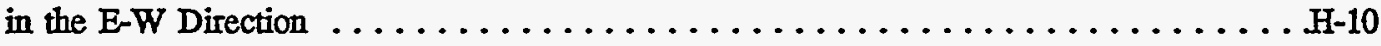

Recorded Time-History and Resultant Response Spectra

at the VSGS Station No. 5165 Due to 1979 Earthquake

in the Vertical Direction . . . . . . . . . . . . . . . . . . . . .

Recorded Time-History at CSMIP Station No. 01335

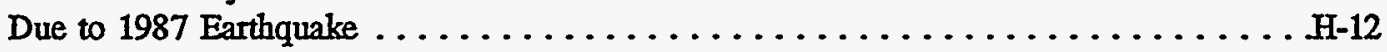

Glendale Power Station Units $1-5 \ldots \ldots \ldots \ldots \ldots \ldots \ldots \ldots \ldots \ldots \ldots \ldots \ldots$

Plan of Humboldt Bay Power Plant Showing

Location of Strong Motion Accelerographs

$\mathrm{J}-13$

Elevation View of Refueling Building, Facing North, Showing Location of Strong Motion Accelerographs ................J-14

Acceleration Time-Histories in the Storage Building

(Elevation +12) Due to 1975 Earthquake $\mathrm{J}-15$ 
Figure J.4

Figure J.5

Figure J.6

Figure J.7

Figure J.8

Figure J.9

Figure K.1

Figure K.2

Figure L.1

Figure L.2

Figure L.3

Figure L.4

Figure M.1

Figure M.2

Figure M.3

Figure M.4
Acceleration Time-Histories in the Refueling Building (Elevation +12) Due to 1975 Earthquake $\mathrm{J}-16$

Acceleration Time-Histories in the Refueling Building

(Elevation -66) Due to 1975 Earthquake

Response Spectra for Storage Building (Elevation +12 )

Due to 1975 Earthquake

Response Spectra for Refueling Building (Elevation +12)

Due to 1975 Earthquake

Response Spectra for Refueling Building (Elevation -60)

Due to 1975 Earthquake

Response Spectra Comparison for 2 percent Damped

Transverse Spectra at Various Locations due to

1975 Earthquake to a $0.25 \mathrm{~g}$ NRC R.G. 1.60 Spectra $\mathrm{J}-21$

End View of Kern Valley Units 1 and 2 Power Station $\mathrm{K}-4$

Side View of Kern Valley Unit 1 Power Station $. \mathrm{K}-5$

Structural Steel Framing for Broadway Unit 1 to 3 L-7

Glenarm Internal Cracking of Masonry Block

Due to Earthquake L-8

Glenarm Spalling Damage due to Earthquake

Snubber Support on Main Steam Line for Broadway Unit 3

Structural Steel Framing for Valley Unit 3 M-7

Structural Steel Framing for Valley Unit 3 Showing

Diagonal Vertical Bracing. M-8

Typical Sway Brace Used in Support of Pipe in Valley Unit 1

Estimated San Fernando Earthquake, Valley

Steam Plant Site Ground Response Spectra

M-10 


\section{Tables}

Table J.1 - Maximum Values of Acceleration (G's) Measured During the Ferndale 1975 Earthquake ........ J-9

Table J.2 - Maximum Values of Velocity and Displacement Computed from Measured Ferndale 1975 Accelerations . J-9

Table J.3 - Peak Spectral Shock Recorder Humboldt Bay Power Station $\ldots \ldots \ldots \ldots \ldots \ldots \ldots \ldots \ldots \ldots$ J-10

Table J.4 - Peak Spectral Shock Recorder Humboldt Bay Power Station $\ldots \ldots \ldots \ldots \ldots \ldots \ldots \ldots \ldots \ldots$ J-11

Table J.5 - Peak Spectral Shock Recorder Humboldt Bay Power Station $\ldots \ldots \ldots \ldots \ldots \ldots \ldots \ldots \ldots \ldots$ J $\ldots \ldots$ 


\section{Executive Summary}

The appendices included in Volume 2 of the "Survey of Strong Motion Earthquake Effects on Thermal Power Plants in California with Emphasis on Piping Systems" provide details concerning the design basis and seismic response for several power stations in California.

These appendices supply background information which supports the recommendations and conclusions reached in Volume 1. Included is a typical power plant piping specification and photographs of typical piping and support installations for the plants surveyed. Piping support spacing data is also included. 


\section{Appendix A: Summary Description of the Ormond Beach Power Plant Response to the Point Mugu Earthquake of 21 February 1973}

\section{A.0 Introduction}

The Point Mugu, California, earthquake occurred at 6:46 a.m. local time, on February 21, 1973. It had a Richter magnitude of about 5.75, and the strong motion of the main shock lasted about 6 to 8 seconds. The earthquake bears a resemblance to the San Fernando event. It, too, seems to have taken place on frontal fault systems of mountain blocks in the Transverse Ranges: the Santa Monica mountains. The fault movement that caused the earthquake was of the reverse or thrusting type, as was the case in the San Femando event.

The epicenter of the earthquake was located offshore from Point Mugu, which is southeast of Oxnard, Ventura County, California. The shock was widely felt throughout Southern and Central California and triggered several strong-motion instruments. The nearest record was obtained at Port Hueneme, about 11 miles northwest of the epicenter as shown in Figure A.1, ${ }^{\left(A_{11}\right)}$ where a PGA of $0.13 \mathrm{~g}$ was recorded. The horizontal accelerations were $0.13 \mathrm{~g}$ (north-south) and $0.085 \mathrm{~g}$ (east-west), and the vertical component of motion was $0.05 \mathrm{~g}$.

\section{A.1 Description of Ormond Beach Generating Station}

The station is owned and operated by Southern California Edison Co., SCE. The plant is a dual-unit, 1,500 MW oil-fired plant located a few hundred feet from the Pacific shoreline about 2 miles north of Point Mugu and south of Oxnard. The plant was designed and built by the Bechtel Power Corporation, Norwalk (Los Angeles). Unit 1 was operating at the time of the earthquake. Unit 2 was nearing completion when the Point Mugu earthquake occurred. The plant was completed a few months later, in 1973.

The plant structures were designed seismically for an equivalent static force of $0.2 \mathrm{~g}$ and is in general conformance with standard SCE criteria. Equipment was anchored for $0.2 \mathrm{~g}$ static equivalent overturning forces, and most piping, conduit, and tray supports were designed for dead-weight loads only. Only a few pipe braces were observed on pipes of large diameter.

Each unit consists of a 200-foot-high structural steel tower that supports the boilers. The steam turbines and generators are located on a separate concrete pedestal adjacent to the towers. There are several other small structures on the site. The plant is built over a filled lagoon, on soft sedimentary material.

\section{A.2 Earthquake Motion}

The plant is located 8 miles or less from the epicenter of the Point Mugu event. A Peak Ground Acceleration, PGA, of $0.13 \mathrm{~g}$ was recorded about 3 miles farther from the epicenter. The peak ground motion at the site was estimated on the basis of typical attenuation relationships for Califomia to be about 0.20g. (A) Applied Nucleonics Company ${ }^{(A 2)}$ estimated the same PGA on the basis of observation and measurement of the displacements of pipes that impacted adjacent structural members.

\section{A.3 Plant Performance}

Unit was operating at the time of the earthquake. It was tripped off line by the earthquake. The following list of damage to equipment is extracted from a report prepared by Douglas ${ }^{(1.3)}$

- The Unit One generator differential relay tripped while carrying $600 \mathrm{MW}$. The shaking of this relay's support panel was the apparent cause for the closing of the relay contacts. A CFVB voltage balance relay also tripped due to the earthquake. The closure of the generator differential relay was the main cause for the station to remain off-line until 3.46 a.m.

- A small fire also started next to the windbox of Unit One. This fire was the result of the down-comer pipe partially breaking away from the windbox. This fire was quickly extinguished. Minor repairs to the insulation and other related items of the downcomer pipe were required.

- A 10-inch support tod on one hydraulic snubber at approximately the $150 \mathrm{ft}$. level was buckled at about a 20 degree angle. The support rod on this particular snubber was the longest one observed out of the many snubbers at the plant. This longerthan-normal length of the support rod could have been the cause of this buckling failure. 
The location and size of these snubbers indicate that they were ambient vibration snubbers and not seismic snubbers.

- Four 75 foot vertical steam pipes and four 100 foot vertical steam pipes on the south and north sides of Units 1 and 2 collided with nearby catwalks and structural steel members. Consequently, dents were formed at various levels in the insulation covering of these pipes. from these dents it was determined that some of these pipes deflected over 13 inches. However, the dents in these steam pipes lines insulation were not serious enough to warrant replacement or repair.

Applied Nucleonics Company ${ }^{\left(A_{2}\right)}$ discusses these and other effects further. The following paragraphs are extracted from their report ${ }^{\left({ }^{2} .2\right)}$.

- To our understanding the Unit 1 plant was tripped and shut down due to excessive bearing accelerations of the turbines and recirculating fans.

- Our inspection of both units revealed three types of damage (we do not imply that these were the only forms of damage which occurred). Inspection of several dozen hydraulic shock and sway suppressors (snubbers) on piping indicated single amplitude motion of up to three inches. These motions were easily measured by inspecting the newly cleaned vs dusty portions of the piston. One snubber had buckled its support rod attached to the structural member. This threaded rod, about $1-1 / 2$ in diameter and 10 in. long was bent at about $20^{\circ}$. This particular snubber indicated a motion of about 2 in. We noted that of the many snubbers we saw, this damaged one had the longest support rod (i.e. $10 \mathrm{in}$ ) and this may explain the resulting failure.

- The next two forms of damage involved the insulation around the many large pipes in the structure. Typically, one to three inches of a fiber-glass type insulation surrounded the pipes. It was protected by thin sheet metal wrapping. Pipe diameters with insulation varied roughly from 6 in. to 24 in. On several vertical pipes, the insulation slumped downwards and exposed up to 2 in. of the pipe.

Several large pipes experienced motions large enough to cause them to collide with nearby structural members. Of special interest were eight vertical pipes about 24 in. in diameter and 75-150 feet in length on both units. By observing the collision dents in the insulation, estimates were made for their maximum response at midpoint. Motions up to nearly 14 inches were observed. Subsequent measurements with accelerometers while the pipes were pushed by two men determined their resonant frequencies (between 0.9 and $1.6 \mathrm{HZ}$ ) and dampings ( 0.3 to $1.8 \%$ ).

In summary, the damage to equipment at the Ormond Beach plant was limited to the buckling of a snubber support. It is possible that malfunctioning relays tripped the operating unit. The literature that was reviewed gave no indication of damage to the structures and components of the numerous other equipment items and systems. The plant shut down normally. Figures showing typical examples of equipment from the Ormond Beach Power Station are shown on Ref. A.1. 


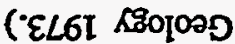

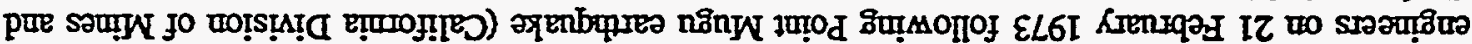

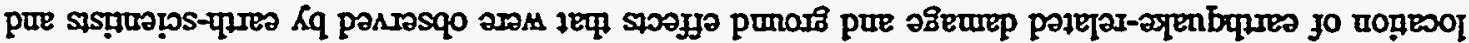

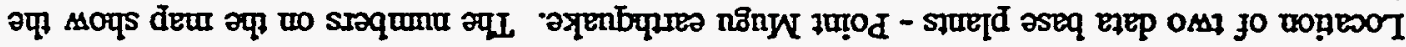

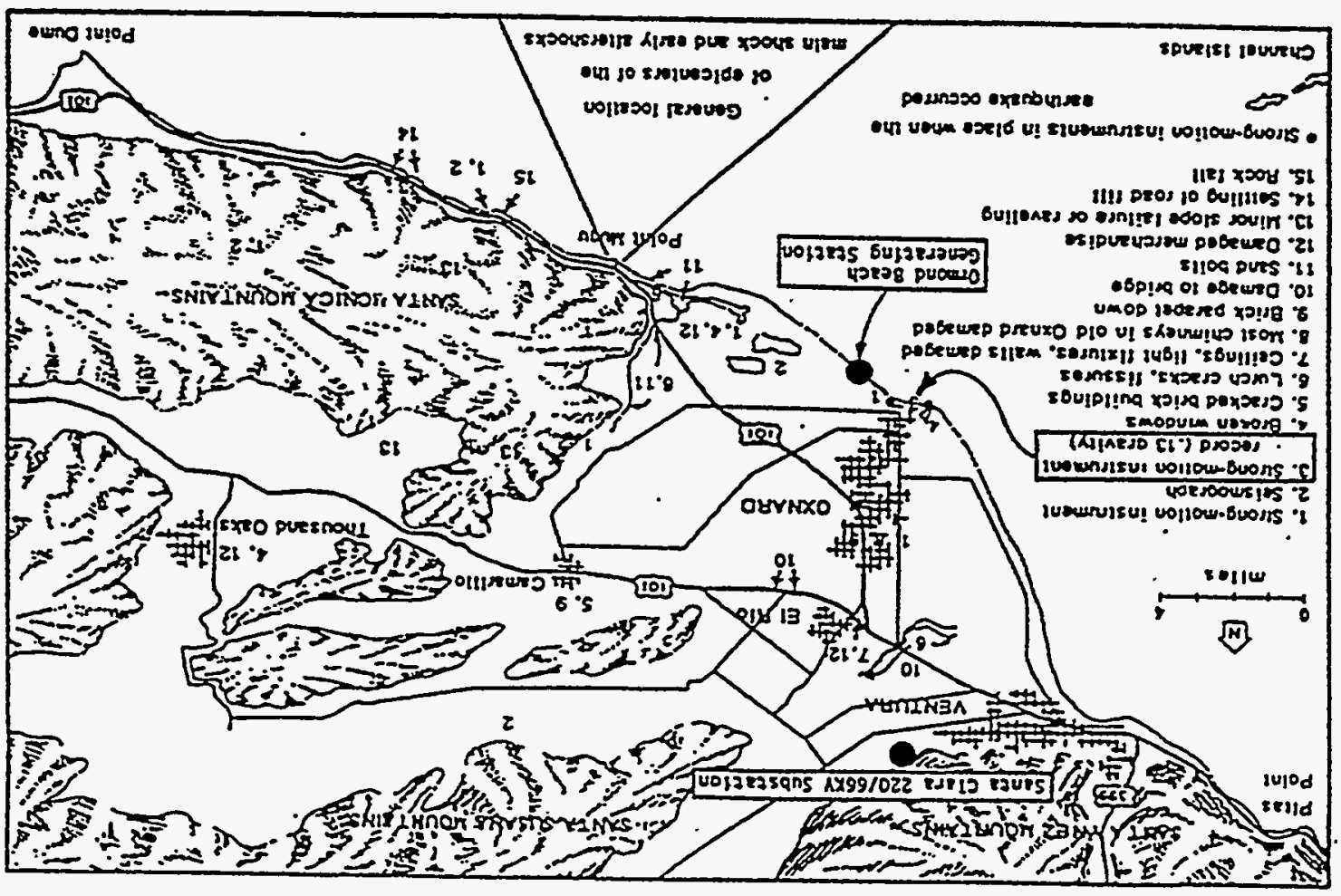




\section{Appendix B: The Long Beach Earthquake of 1933 and Its Effect on the Long Beach and Seal Beach Steam Power Stations}

\section{B.1 Long Beach Power Station Plant 1}

The Long Beach Power Station was located on Terminal Island in Long Beach, California, about four miles from the fault that caused the Long Beach earthquake on March 10, 1933. This earthquake was of magnitude 6.3 and caused accelerations at the site of the Long Beach steam plant estimated to be about $0.25 \mathrm{~g}$. Damage in Long Beach itself was very extensive, but there were no actual accelerometer records of the earthquake.

At the Long Beach Power Station site there were actually three independent plants. ${ }^{(B .1)}$ Plant 1 , built in 1910 , consists of two sections. The first section was of reinforced concrete; the second section was a light-steel frame with reinforced-concrete sidewalls and end filler walls. The building columns, walls, and principal machinery foundations were on piles, but the floors were of mat construction poured directly on backfill. All walls were finished with stucco plaster over the concrete surfaces.

After the March 1933 earthquake, there was apparent uneven settlement of the two buildings. The floor in the turbine room settled, causing severe cracking at the adjacent walls. Settlement of the floor around one boiler caused bad sagging of an adjacent roof panel and loosened the firing aisle windows that leaned in beyond the walls. The floor in the transformer house settled as much as 1 1/4 inches, and lesser settlement was noted in the machine shop floor. Severe settlement of the blacksmith and carpenter shops resulted in these buildings pulling away from the main building about 1 $1 / 2$ inches. Severe cracking of masonry walls occurred at wall junctions and construction joints and to a lesser degree in other areas. The entire wall of the generator room moved slightly in a southerly direction. A water standpipe $36 \mathrm{ft}$ in diameter and $100 \mathrm{ft}$ in height stretched its anchor bolts from $11 / 16$ inches to 2 inches. All the anchor bolts were stretched, which indicated a gyratory motion of the tank A considerable amount of breakage occurred in cast-iron pipes buried in the ground around the installation. Transformer oil piping lines were broken at welded and brazed joints.

\section{B.2 Long Beach Power Station Plants 2 and 3}

Plant 2 was built in 1922 and Plant 3 was built about
1928. They were extensions to Plant 1 . The Stone and Webster Engineering Corporation was the designer and builder of both Plants 2 \& 3 . Both plants were supported by wooden $40-\mathrm{ft}$ piles on 30 -in. centers driven to refusal in hard sand. The plant foundations consist of a heavy reinforced concrete mats on these piles, with pyramidal facing for concentrated loads. Building frames were integral with internal structures, resulting in a strong, probably well-damped, complex. These two plants survived the 1933 earthquake without serious damage. Minor damage to underground oil and water lines resulted in recommendations that these lines be run above ground for ease of inspection and repair. It is interesting to note that, up to 1958, these plants have undergone about $24 \mathrm{ft}$ of vertical subsidence with necessary adjustments in equipment and interconnections being made as the settling occurred. (This subsidence has not resulted directly from any earthquake but is thought to be a result of the removal of offshore oil deposits and the support they have afforded to coastal regions).

No information is available on seismic design of the piping and equipment, but considering the state of the art at the time, it is probable that either the $0.2 \mathrm{~g}$ static design was used, or else seismic design was not considered.

Neither plant, that is to say, none of the five units suffered any significant damage. Some minor damage such as to lighting fixtures was reported, however the steam plants either operated through the earthquake or were shut down due to loss of load and were back in operation the same day. The important point is that five steam units designed with at most static methods to a $0.2 \mathrm{~g}$ acceleration $\mathrm{PGA}$ probably actually experienced a $0.25 \mathrm{~g}$ PGA with little or no damage and in particular, no piping was damaged.

\section{B.3 Seal Beach Steam Station}

The Seal Beach Steam Power Station building structures were severely damaged in the 1933 earthquake. ${ }^{(B 2)}$ This damage is described in a letter from an eyewimess, H.C. Vander Heyden of the Southern Califormia Gas Company, formerly known as the Los Angeles Gas and Electric Corporation. Excerpts from the letter are as follows:

In the Long Beach earthquake of 1933, the Seal Beach power plant of the Los Angeles Gas and 
Electric Corporation was extensively damaged. The Plant was designed and constructed by Dwight P. Robinson and Company of Chicago for the Los Angeles Gas and Electric Corporation and was completed in May, 1925 and had a 70,000-kilowatt capacity. It is located in the City of Seal Beach on the south side of the inlet to Alamitos Bay which is about six miles southeast of the City of Long Beach and about $\mathbf{3 0}$ miles from the business center of Los Angeles.

The building and equipment foundation, operating floors, and the water tunnels are heavy reinforced concrete. The buildings are structural steel frame, and the interior and exterior walls were non-reinforced brick, constructed as filler walls only. The two 35,000-kiowatt generating units were located on a mezzanine operating floor in the open-type turbo room and were supported on structural steel columns and girders approximately $25 \mathrm{ft}$ above the main floor. The stack was of reinforced concrete, $375 \mathrm{ft}$ high, 25 ft. across the top, and it was supported above the boiler room floor on steel columns and girders; it provided natural draft for the six boiler settings. The electrical building was four stories high.

The soil at the site was coarse gravel with scattered rock formations capable of supporting foundation loads of 3500 psi when contained. The concrete structures under high tide level were ringed with continuous steel sheet piping, and the screen intake house had steel piping under the foundation as a water cutoff. There was no visible evidence of fissures or subsidence of the ground in the plant area.

The morning after the earthquake, the station looked to be in shambles. The majority of the brick walls had fallen either in or out of the buildings. The glass in the remaining windows was broken, the piping connections to the domestic water supply tank were broken and had dumped approximately 30,000 gallons of water on the roof. The structural girders, columns and braces supporting the turbine mezzanine floor were buckled, and rivets were sheared and popped; the structural frame supporting the stack was also bent, with many rivets sheared and popped.

All of the reinforced-concrete work, as well as the mechanical equipment except one turbine generator, all the piping and the boilers, and the electrical equipment with the exception of the transformers, remained in operating condition. In fact, one turbine kept running until the operators extinguished the fire from under the boilers.

The top one-third of the concrete stack was severely cracked and spalled. The main transformers, which were mounted on wheeled trucks for easy changeout, tipped over against the compartment walls, severing the electrical connections, which disconnected the electrical output from the station. This damage all happened in a period of about 30 seconds. Subsequent shocks caused additional bricks to fall without further structural damage.

The rebuilding of the station was started within one week after March 10, 1933 and the principle corrections made were:

The stack was cut 177 feet in height and forced draft fans installed.

The brick walls were replaced with reinforced brick, doweled into the floors, and tied into the steel frame of the building.

The cast-iron fittings and valves on the overhead domestic water tank were replaced with steel.

The steel columns and girders under the turbine floor were repaired and reinforced with additional heavy structural braces.

The steel braces and girders under the reduced stack (700 tons of weight removed) were repaired.

The main transformers were placed on larger and heavier constructed trucks.

The cost of rebuilding was approximately $\$ 300,000$. The original cost was about $\$ 85$ per kilowatt, in contrast to similar stations being built at that time, costing from $\$ 100$ to $\$ 110$ per kilowatt. It was evident that the majority of the saving was in the wall construction.

It was the opinion of the investigating committee that the station would have withstood this earthquake with a minimum of damage and expense if the brick walls had been designed of reinforced concrete and properly tied to the steel frame, if the stack had been supported by a concrete foundation at ground level and not carried on steel columns, and if the turbine supporting floor had been 
properly designed of heavier construction.

B-3

NUREG/CR-6239 
Appendix C: Typical Specifications Used in Construction of Power Plant Piping

C-1 


\section{Olive Unit \#2 Detail Specifications No. 928}

\section{1 General}

\section{REQUIREMENT}

(a) There shall be furnished materials, labor, equipment, transportation, etc., to complete the installation of the following items at the Public Service Department's Olive Power Plant, Unit No. 2 site, located at lake Street and 0live Avenue, Burbank, Califormia:

Ia. AII Process and Utility Piping (Item Ia, Bid Proposal, Page P-2).

Io. Unit Price Pipe Work (Item Ib Bid Proposal, Page P-2).

IIa. Instrument Installation and Instrument Piping (Item IIa Bid Proposal, Page $\mathrm{P}-2$ ).

ITb. Unit Price Instrument Work (Item IIb Bïd Proposal, Page P-2).

The Contractor shall furmish 271 materials required to complete the work of Items Ia and IIa unless specifically noted to be furnished by others in these specifications and drawings.

(b) Unit No. 2 includes a $55,000 \mathrm{kw}$ turbine generator reheat unit, operating at $1450 \mathrm{psig}, 1000^{\circ} \mathrm{F} / 1000^{\circ} \mathrm{F}$. The steam generating unit has a maximum capacity of $440,000 \mathrm{lbs} / \mathrm{hr}$. This is the second unit to be installed at the Olive Power Plant site, and is of the outdoor type design.

\section{CONSTRUCTION FACIIITIES AND SERVICES BY THE CITY}

(a) The City will furnish an engineer whose services will be available without charge to establish grades and Iines.

(b) The City will furnish to the Contractor limited space for pipe and equipment storage and work area directly adjacent to the plot area. The Contractor shall exercise care to avoid stockpiling materials and placing equipment where it will interfere with any other work which is in progress by the City or by other contractors.

\section{CITY INSPECTION}

(a) A City inspector will be available to see that the Contractor has complied with the requirements of these specifications, but his inspection shall not relieve the Contractor of his responsibility for the correct installation of the piping and equipment.

(b) The City inspector shall approve all radiographs and witness all magnetic particle tests. Any questions arising from these inspections shall be referred to the Engineer for final decision.

(c) The City inspector shall inspect each tank, heater and pressure vessel prior to installation of pipe and prior to starting up plant.

NUREG/CR-6239 C-2 


\section{CONTRACTOR'S INSPECTION}

(a) The Contractor shall be responsible for the quality of work done by his organization, and shall conduct tests not only of the welding process to determine its suitability to insure welds of the required quality and sirength, but also examine the welding operators to determine their qualifications and their ability to comply with the specified procedure. All welders employed on the work in the shop and in the field shall be certified for the class of work tiney are assigned to do. Welders shall be certified in accordance with Section IX of the ASME Boiler Construction Code, latest edition. The Contractor shail be familiar and comply with the provisions of the laws, codes and regulations governing, and be experienced in, welded pipe construction.

(b) The Contractor shall retain at nis own expense, both in the shop and in the field during the progress of the work, inspectors fully qualified to inspect and pass on matters pertaining to materials and workmansinip required under these Specifications.

(c) In 217 matters of fabricating detail, testing, and quality of workmanship, the ASA Code for Pressure Piping, B3I.I, latest edition, and the ASME Boiler Code, latest edition, shall govern, as far as they may apply. All high pressure welds shall be inspected and passed by the Hertford Steam Boiler Inspection and Insurance Company, and shall have been made by certified welders. Three copies of Hartiord inspection reports shall be submitted to the City.

(d) The cost of inspections and certification of work and material shall be included in the bid items.

\section{COORDINATION}

During the installation of piping and equipment there will be other Contractors and City personnel working in the same area. The Contractor shall coordinate his work with that of the other contractors and City personnel so that there will be a minimum of interference between working forces. The City's construction superintendent will arbitrate any problems involving coordination.

\section{PLANT SITE}

All bidders prior to submitting their bids shall visit the site of the work and thoroughly acquaint themselves therewith and carefully investigate and determine all conditions respecting the work to be performed. The bidders may contact the City's construction superintendent for information.

\section{SCHEDULE}

The Process and Utility Piping Work shall begin approximately December 2, 1963, and shall be completed no later than August 28, 1964. Instrument Installation and Instrument Piping Work shall be completed no later than September 4, 1964.

(a) Instrument installation and piping for ary piping system shall, in general, not commence until hydrostatic testing of that system is completed and after larger piping is installed in the area such that the risk of damage to instruments and small tubing is minimized. 
(b) Scheduled first turinine rollover is September 2, 1964. Prior to this time it iil be necessary for the City to check out piping systems, instrumentation, and aquipment for completion and performance. The Contractor shall endeavor to comjiete some of the systems and equipment installation so the City may begin its llant check out, flushing and startup procedures no later than July 15, 1964. Jontractor shall submit to the constmaction superintendent a daily report indicating lire by line completion of work on the process and utility piping and itemized instrument installation completion.

(c) The Engineer shall have the right during the course of construction of the Oower Plant Unit 2 to prescribe changes in schedules of the work performed by other contractors and in all or part of the work to be performed by the Coniractor under these Specifications No. 928, and the Contractor shall comply with and conform to any and alI changes ir schedules prescribed by the Engineer.

(d) Requests by the Coniractor for changes in the schedules of the work to be performed by the Contractor must be approved in writing by the Engineer. As approval of such requesis will require some time and may affect other work by the contractor and other contraciors, the Contractor shall submit all such requests to the Engineer in writing immediately when the necessity therefor becomes known $\doteqdot$ the Contractor.

(e) The Contractor is hereby notified that certain time lapses will occur between the various steam blow out and flushing phases mentioned in Paragraph 26 of these Detail Specifications and that tine Contractor must supply the labor and materials for installation and removal of necessary temporary piping shown on the drawings.

(f) Any and all interruptions in the continuity of the Contractor's work caused by chemical cleaning of piping and equipment in the plant, if such cleaning is perFormed, and any and all intermaptions in such work contemplated by the Contract Documents, including, without limiting the generality of the foregoing, intermptions due to scheduling of the work of the Coniractor and other contractors at the site of the work, testing of equipment and systems, steam blow out and flushing, application of insilation, corrections of deficiencies in piping and equipment installed by the Contractor and other contractors and persons, completion of the work of other contractors, ard changes in the schedules of the work of other contractors and of the Contractor under these Specifications No. 928, must be consiciered and taken into accolint by the Contractor in submitting his bid.

(g) The City reserves the right to interrupt the continuity of the Contractor's work as set forth in Subparagraph $(\hat{i})$ of this Paragraph and by causing changes, including extra work, to be made and performed in the Contractor's work in accordance with the provisions of Paragraph 31 of the General Conditions of these Contract Dociments, and the Contractor's bid shall include full compensation to the Contractor for any and all such intermuptions.

(h) Any and all intermutions in the Contractor's work mentioned or referred to in Subparagraphs $(f)$ and $(g)$ of this Paragraph which delay the Contractor in the performance of hijs work shall be deemed to be unavoidable and "causes clearly beyond the control of the Contractor" within the meaning of Paragraph 3 of the General Conditions of these Contract Documents. By execution of the Agreement provided for in these Contract Dccuments the Contractor covenants and agrees with the City of Burbank that the Contractor neither has nor shall have any claim, demand, action or cause of action against the City on account of or in respect to any of the. interruptions hereinabove mentioned and referred to or by reason of delay in periormance of the Contractor's work caused by any act or omission of the City. NUREG/CR-6239 


\section{AWARD OF CONTRACT}

Bidder's proposals shall be evaluated on the basis of the bid price and on the following:

(a) Ability of the Contractor to complete work in scheculed time.

(b) Experience of the Contractor in this type of work and work of comparable magnitude.

(c) Quality of past work of this nature performed by Contractor.

(d) Bidders shall possess a certificate of authorized use of the ASME Welded Power Piping Stamp as illustrated in Fig. P-4I - Section P-300 of Section I of the ASME Power Boiler Code.

\section{SCAFFOIDING}

Contractor shall provide all necessary scaffolding, platforming, etc. necessary for the installation, welding, stress relieving, testing, etc. of all lines included in these specifications.

\section{TESTS}

(a) Contractor shall hydrostatically test all lines except instrument air headers and instrument tubing winich shall be bubble tested prior to acceptance by the City. These hydrostatic field tests shall be made in strict accordance with the ASA Code for Pressure Piping. All lines shall be tested to $1-1 / 2$ times the service pressure rating as indicated on the line list. Any lines which do not have root valves shall be tested by using a blind flange or welding a temporary plate at the end of said line. Exception to this requirement will be the piping between the turbine case and the first valvo on 271 extraction lines.

(b) Any coupling or other connections including air vents on all high points and drains on low points necessary for testing shall be furmished and installed and later plugged by the Contractor. All openings in all lines will have to be plug. capped or otherwise closed off for testing and shaIl be done at the Contractor's expense, including the cost of any materials involved.

(c) All lines shall be hydrostatically tested using City water. After each line is made tight the final test water shall be drained and the Iine filled with water containing hydrozine or other oxidation prevention chemicals. All chemicals will be furnished by the City. This chemically treated water shall remain in the lines until such time as flushing or start up operations are started by the City.

\section{GRATING}

Contractor shall properly replace any grating, floor plate, handrail, toe boands, or any structural member which he or any of his subcontractors move, cut or loosen during the course of the contract. Contractor shall include in costs the cutiing and reinforcing with sleeves all holes required in the grating. Where bearing support is cut for pipe installation, angle supports shall be installed. Where pipe runs through the grating, the grating shall be cut and supported in such a manner as to be readily removable after pipe and insulation 
work is completed. Reinforcing sleeves shall be concentric with the pipe within zius or minus $1 / 2^{\prime \prime}$ maximum and shall be sized to allow for insulation and expansion movement. Sleeves shall project 4" above grating to serve as kick plate and insulation protection. Grating reinforcing rings shall be welded in place in a workable manner to make a neat appearance. It shall be done in strict sccordance with safety codes and grating manufacturer recomendation. AII icred metal graiing shall be cleaned and given one application of Galvatex. The iity's inspector will inspect each cutout.

\section{CLEANING UP}

The Contractor shall at all times keep the premises free from accumulations of waste materials and mabbish caused by the Contractor or subcontractors. Upon completion of the work the Contractor shall remove from site all tools, equipment, temporary structures, urused materials, scaffolding, rubbish and other pipe meterials belonging to him and used under his direction during construction, and shall leave all working areas broom clean. In the event of failure of the Coniractor to remove all materials and mibish, the same may be removed by the City $a t$ the expense of the Contractor.

\section{DELIVERY}

(a) The Contractor snall provide facilities and persornel for unloading and receiving $2 l l$ equipment and materials at the site of the work.

(i) The City may at the request of Coniractor, furnish the personnel and fecilities to unload, receive and warehouse a limited amouni of equipment and materials required under this contract, and Contractor agrees to promptly pay the expense of the use of City personnel and equipment in performing this service. For this service, Contractor shall send a copy of the bill of lading to the Engineer, and City will arrange to render the service. In performing this service the City shall aet as the agent of the Contractor. Although reasonable care will be taken to check and store the equipment and materials received under this paragraph, packaged materials will not be opened, and it is distinctly understood the City will in no event be responsible, nor does it assume any liability, for such equipment or materials. 
ITEM Ia - PROCESS AND UTILITY PIPING

14. SCOPE OF WORK

(a) The Contractor shail furnish all necessary materials (unless specifically designated on the drawings or in these specifications to be furnisined by others), transportation, shop and field fabrication and erection, labor, equipment, and tools for handling, cleaning, lifting, placing, cold springing, flanging, welding, stress relieving and testing all pipe, valves (manual, gravity, or air operated), relief valves, fitiings, and other specialties to install a complete and operable piping system in sirict accordance with the specifications and contract drawings listed herein. All terminal connections to equipment and tie-in connections to existing piping or piping by others shall be made by the Contractor under the se specifications.

(b) It is the intent of these specifications that the Contractor shall furnish a complete plant piping system, tested and ready for operation.

(c) The Pipe Lire Iist, drawing No. ES-1691 sheets $I$ and 2 , lists the pipe lines which constitute the plant piping system to be furnished and installed by the Contractor.

(d) In adiition to pipe lines as listed on the pipe line list the Contractor shall include the following as part of the installation of the process and utility piping:

1. Turbine deck drain piping (dwg. ES-1698).

2. Boiler roof drain piping (dwgs. ES-1623 thru 1629 incl.).

(e) In the case of small lines all unions may not be shown on drawings, but Contractor shall furnish and install unions where necessary for pipe make-up.

(f) Any pipe lines which are required by the City and not indicated on the line list or drawings shall be installed by the Contractor i $i_{1}$ accordance with paragraph 30 of these Detail Specifications, Unit Price Pipe Work.

(g) Back welding of all 300 PSI and higher pressure plugged vent and drain connections is required after hydrotest.

(h) Reinforcing Pads: Pipe reinforcing pads shall be provided on all lines where required in accordance with ASA Code for Pressure Piping B3I.I latest edition. Reinforcing pads called for specifically on drawings shall also be applied according to the code:

(i) A special stainless steel liner will be furnished to the pipe contractor for installation into a section of the cold reheat line in accordance with the manufacturer's recommendations. The cost of installation shall be included by the Contractor.

(j) The Contractor shall include in his bid the cost to install equipment drain and other miscellaneous piping that is shown on either the piping drawings and/or flow diagrams but does not carry a separate line number. 
(k) The Contractor shall include in his bid the cost of labor to install the large diameter circulating water pipe, expansion joints and valves furnished by the City as shown on drawing ES-1742. This labor shall include field measurements, fitting up, making up flanged and field welded joints and patching of cement lining. Contractor shall furnish all bolts and gaskets for this work.

(1) The Coniractor shall cineck boiler and turbine erection drawings under Specifications $\frac{\| 1}{11} 901$ and $\frac{\| 1}{\pi} 900$ respectively to avoid interferences with piping systems and equipment installed under those specifications.

\section{CONTRACT DRAWINGS (PROCESS AND UTIIITTY PIPING)}

(a) The piping drawings listed in this paragraph are intended to show location, piping design, layout and assembly of the unit piping systems and are hereby made a part of the Specifications. No warranty or representation, express or implied, is made with regard to accuracy of the dimersionirg of pipe $2^{\prime \prime}$ and smaller in diameter shown in these drawings. The Contractor is required to field fabricate a71 such pipe in accordance with the procedures specified in Paragraph 23 of these Detail Specifications.

(b) The routing of any piping 2-I/2" and larger in a manner different than that shown on the drawings shall be approved by the Engineer prior to fabrication and installation.

(c) All lines requiring stress analysis have been engineered as required.

(d) Dimensions on drawings are usually in feet and irches - inches only are shown when dimensions are less than I'-O". Dimensions are to pipe center lines and contact faces of flange.

(e) "F.W." denotes field weld. All field welds located by dimension shall be held to such indicated location.

(f) "F.S." denotes field support. Contractor shall measure, cut and fit and install as per drawing ES-1746.

(g) "C.S." denotes cold spring and has been noted on drawings as required.

(h) The piping drawings are listed as follows:

ES-1689 Rev. B

Piping Line List

ES-1691 Rev. B (2 Sheets)

Piping Flow Sheets

GS-12 Rev. B

ES-I751 Rev. B

ES-I705 Rev. B

ES-I849 Rev. B
Table of Contents TITLE

Piping Line List Sheets 1 and 2

Mechanical Flow Diagram - Stm., Cond. Fuel and Water

Mechanical Flow Diagram - Air \& Lube Oil Systems Heat Balance

Service \& Instrument Air Schematic 
Equipment Arrangement Drawings

\begin{tabular}{ll}
\hline ES-1709 & Rev. D \\
ES-1710 & Rev. B \\
ES-1713 & Rev. B \\
ES-1714 & Rev. B \\
ES-1715 & Rev. B \\
ES-1716 & Rev. B \\
ES-1717 & Rev. D \\
ES-1718 & Rev. B
\end{tabular}

Piping Detail Drawings

ES-I721 Rev. B

ES-I723 Rev. B

ES-1724 Rev. B

ES-1725 Rev. B

ES-1726 Rev. B

ES-1727 Rev. B

ES-I728 Rev. B

ES-I729 Rev. B

ES-1730 Rev. B

ES-1731 Rev. B

ES-1732 Rev. B

ES-1735 Rev. B

ES-1736 Rev. B

ES-1737 Rev. B

ES-1738 Rev. B

ES-1739 Rev. B

ES-1740 Rev. B

ES-174I Rev. B

ES-1742 Rev. B

ES-1743 Rev. B

ES-1744 Rev. B

ES-1745 Rev. B

ES-1746 Rev. B

ES-1747 Rev. B

ES-1750 Rev. B

ES-1752 Rev. B

ES-1753 Rev. C

ES-1690 Rev. B

ES-1692 Rev. B

ES-1693 Rev. B

ES-1694 Rev. B

ES-1695 Rev. B
Equipment Arrangement - Plan Elev. 556'-0"

Equipment Arransement - Plan Elev. 576'-0"

Equipment Arrangement - PIan Elev. 566'-0", $585^{\prime}-1^{\prime \prime}$ and $594^{\prime}-2^{\prime \prime}$

Equipment Arrangement - PIan Elev. 603'-2", $614^{\prime}-0^{\prime \prime}$ and $623^{\prime}-4^{\prime \prime}$

Equipment Arrangement - PIan Elev. 632'-8' and Boiler Rooí Plan

Equipment Arrangement - Sectional Elevation - East Equipment Arrangemeri - Sectional Elevation - West

Equipment Arrangemient - Sectional Elevation - South

Area Drawing Index

Piping Plan - Area A-I-Elev. 575'-0" to 556'-0"

Upper Piping Plan - Area A-I

Piping Plan - Area Bul-Elev. 575'-0" to 566'-0"

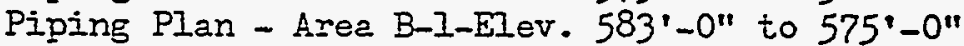

Piping Plan - Area B-I-Elev. 601'-0" to 583'-0"

Piping Plan - Area B-I-Elev. 622'-0" to 601'-0"

Piping Plan - Area B-I-Above Elev. 622'-0"

Piping Plan Elev. 565'-6" to Elev. 556'-0" and Section - Area F-I

Piping Plans - Elev. 565'-6" and Above - Area F-I

Pipir.s Plan and Sections Area D-1

Piping Plan - Aree G-I-Elev. 563'-6" to 556'-0"

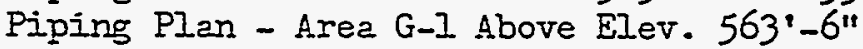

Piping Elevation-Area A-I \& B-I Lower West Section $A B-1$ (inboard)

Piping Elevation - Area A-I \& B-1-Upper West Section AB-I

Piping Elevation - Area A-I \& B-1 - Lower East Section AB-2 (Inboard)

Piping Elevation - Area A-1 \& B-I Upper East Section AB-2 (inboard)

Piping Elevations - Area A-I \& B-I Sections and Details.

Piping Sections Area G-I

Piping Sections Area G-I

Standard Butt Weld End Preparation

Piping Elevation Area B-l-Sections \& Details

Pipe Anchors, Guides, Hangers, Pipe Shoes, Field Supports, and Misc. Detajls (also see ES-1699)

Piping Details Area G-I

Piping Elevation - A-I \& B-I - Lower West Section AB-16 (Out board)

Piping Plans Area G-2, B-l and Misc. Details

Piping Materials Specifications

Unit No. I Additions - Below Elev. 576'-0"

Unit No. I Additions - Elev. 575'-0" to 556-0"

Temporary Blow-Off Piping

Temporary Blow-Off Piping - Sections \& Details

Condensate - Feed Water Spray Attemperator

Flushing System

NUREG/CR-6239 


$\begin{array}{ll}\text { ES-1696 } & \text { Rev. B } \\ \text { ES-1697 } & \text { Rev. B } \\ \text { ES-1698 } & \text { Rev. B } \\ \text { ES-1699 } & \text { Rev. C (4 Sheets) } \\ & \\ \text { Reference } & \text { Drawings } \\ \text { ES-1722 } & \text { Rev. B } \\ \text { ES-1748 } & \text { Rev. B }\end{array}$

Condensate - Feed Water Spray Attemperator Flushing Sy stem

Condensate - Feed Water Spray Attemperator Flushing System

Piping Plan and Sections - Turbine Deck Drains

Pipe Support Details, Sheets I thru 4 (see ES-I746)
Plant Underground - Piping Plan

General Plan - Underground - Yard Piping

\section{MATERIAI TO BE FURNISHED BY THE CITY}

install.

The City will furnish the following material to the Contractor for him to

(a) AII valves.

(b) All expansion joints.

(c) All strainers and steam traps.

(d) All orifice plates and restriction orifices (orifice flanges by Contractor) and flow meter elements.

(e) Major supporting structural steel (Contractor shall furnish hanger support steel as indicated on hanger support details on dwgs. ES-1699 sheets 1 thru 4).

(f) Control valves and safety valves.

(g) Weld in type thermowells for welding in piping.

(h) Reheat and mainsteam spray water flow measuring elements.

(i) Reheat attemporator spray nozle and lines for inserting in reheat steam line.

(j) Flow alarm switches, sight flow glasses and rotameters.

(k) Feedwater flow nozzle pipe assembly including mating weldneck ilanges.

(I) Large diameter circulating water Iine 2186WA-42" shown on drawing ES-1742.

\section{PIPE FITTING AND ASSEMBLY MATERIAI}

All pipe and fittings must be equal or better than the grades as listed on the Piping Materials Specifications dwg. ES-1753. These Piping Material Specifications define the material to be furnished by the Contracior to complete the work shown on the drawings, except as noted otherwise. Any proposed deviation from material specifications must have written approval by the City.

It shall be the Contractor's responsibility to compare all outlines of equipment, valves, instruments and specialty items to assure a proper mating connection. Certified outlines shall be used by the Contractor to determine the end to end, face to face, dimensional location of terminal points for the shop or field fabrication of all piping. Certified outlines will be furnished to the Contractor by the City for this purpose. In lieu of certified dimensional outlines permission may be obtained from the City to use correct catalog dimensions.

The Contractor shall provide the City with supporting papers identifying all materials which are used in completing the work covered in these specifications. 


\section{EQUIPMENT IDENTIFICATION}

The City will furnish the Contractor a complete equipment list, showing identification numbers for all equipment, valves, instriments, strainers, etc.

Material furnished by City will be stored in the City's warehouse adjacent to the site of tine work. All valves and specialty items will be identified by tag number. Contractor must make certain that each valve drawn from ths warehouse is tagged. The piping drawings indicate the valve and specialty item number corresponding to the identification tag for each given position.

In many instarces, two valves or specialty items may be of identical make, size, and shape; however, the internals may be different, hence the importance of proper valve identification. The City's field inspector will not accept the installation of any valve that does not have the proper identification tag. The Contractor's work shall include the hardling of all the valves and specialty items irom the City's warehouse to location of the completely assembled installation.

\section{WEIDING TO PIPE TO BE HEAT TREATED}

Insulation shoes, anchors, guides, support clips, insulation anti-slip bars, miscellaneous brackets and welded attachments shall be shop welded on all heat treated alloy or stress-relieved carbon steel pipe before heat treatment.

20. HANGERS, SUPPORTS, GUIDES AND ANCHORS

Except where specifically called out on the drawings as furnished by the City or by others, the Contractor shall furmish, handle, erect and attach to the pipe and properly adjust, all spring and rod hangers, supports, guides and anchors as indicated on the drawings. The design, fabrication and erection of structural sieel shall conform to the requirements of the current issue of AISC "Specification for the Design, Fabrication and Erection of Structural Steel for Buildings". The hangers, supports, guides and anchors shall be located as indicated on the drawings, and manufactured in accordance to MSS-Standard Practice SP-58. However, if locations as shown on drawings are not possible or additions are required, the Engineer shall be notified and a suitable location will be selected. The Contractor shall furnish, field fabricate in accordance with the procedures specified in Paragraph 23 of these Detail Specifications and install all necessary hangers and supports for piping and tubing $2^{\prime \prime}$ and smaller that may not be shown or located on the drawings. Size and spacing of these hangers shall conform to the requirements of the ASA Code for Pressure Piping. The major portion of the miscellaneous steel which is to be furnished by the Contractor is indicated on drawings ES-1746 and ES-1699.

Insulation shoes when field welded shall be centered over pipe supports in cold position after line is completely installed.

Boiler drain and blow down piping shall be supported as shown on the drawings to insure against overstressing due to downward growth of the boiler under operating conditions.

21. BENDS

Eends are not permitted in Al20 Spec. weld pipe. Bends are permitted in 
211 seamless pipe, using 5 diameters bending radius or as indicated on drawings. In no case is the wall to be thinned more than $5 \%$ bo bending. In case of thinning of walls in excess of $5 \%$ the size, wall thickness and line number shall be submitted to the City. The wall thickness will then be recalculated on basis of ASA-B31.1, by the Engineer and either accepted or rejected. The Engineer's decision will be final. Field fabricated pipe bends for small diameter pipe may be substituted for fittings shown on the drawings. Such bends are preferred to fittings where permitted by the Piping Material Specifications, drawing ES-I753.

\section{FABRICATION OF WELDED PIPE}

(a) General: Fabrication details shall be in accordance with ASA Code B3I.I, Iatest edition, unless otherwise specified in these specifications and contract drawings. Contractor shall provide, with his proposal, two copies of all welding procedures which will be required for these specifications for the City's approval. Alternate procedures must be submitted to the City for approval before use. In adition, the Contractor shall furnish to the City a photostat copy of his ASME certificate of authorization for high pressure piping.

(b) SIip-on flanges and reducing flanges shall be welded both inside and outside.

(c) Substitutions, including heavier or thicker materials, are not permitted without written approval.

(d) The Contractor shall insure that all installed pipe is free and clear of all foreign materials, construction debris, etc.

(e) Fabrication tolerances shall be in accordance with Pipe Fabrication Institute Standard ES3 as last revised. Any refabrication of shop piping due to faulty fabrication shall be corrected at Contractor's expense. Any refabrication of field fabricated pipe shall be at Contractor's expense unless the changes are caused by relocation of equipment, structures, ducts or piping by some person other than the Contractor.

(f) Carbon Steel Pipe

1. Base Metal - May be any of those Iisted in ASME Section IX Group

P-Number 1. Weld metal shall equal properties and analysis of base metal specifications.

\begin{tabular}{|c|c|c|c|c|c|}
\hline Base Meta & & Weld Metal & Process & Preheat & Postheat \\
\hline Pipe & $\begin{array}{l}\text { A53 } \\
\text { A]06 }\end{array}$ & $\begin{array}{l}\text { Carbon } \\
\text { Steel }\end{array}$ & $\begin{array}{l}\text { Metal Arc or } \\
\text { Inert }\end{array}$ & As needed & $\begin{array}{l}\text { Stress Relieve } \\
\text { per Code. ASA }\end{array}$ \\
\hline Fittịngs & $\begin{array}{l}\text { A234-WPA } \\
\text { A234-WPB }\end{array}$ & & $\begin{array}{l}\text { Arc Root } \\
\text { and Metal } \\
\text { Arc or sub- }\end{array}$ & & $\begin{array}{l}3 / 4^{\prime \prime} \text { or over } \\
\text { ASME same. }\end{array}$ \\
\hline Forgings & $\begin{array}{l}\text { A181 Grade } \\
\text { A181 Grade } \\
\text { A105 Grade } \\
\text { A105 Grade }\end{array}$ & $\begin{array}{l}I \\
I I \\
I \\
I I\end{array}$ & $\begin{array}{l}\text { merged } \\
\text { Arc } \\
\text { No Permanent } \\
\text { backing ring } \\
\text { unless approved } \\
\text { by the City }\end{array}$ & & \\
\hline
\end{tabular}


All butt welds on main boiler feedwater piping, lines 2013SH, 2014SH and 2015SH, shall be welded inert arc root and metal arc process with high deoxidizer filler metal added, or approved equal.

Cutting Bevels - Welding bevels and grooves shall be machine cut or torch cut and ground, and shall be chipped or brushed to remove cutting slag and heavy oxide scale.

2. Bending - Completed bends shall be tmue to dimensions and free of flat spots and corrugations.

Cold Bending - Cold bends shall be closely examined visually, or if required by the Engineer, shail be tested by the magnetic particle method to show an absence of surface cracking. Completed bends shall be heat treated as provided herein, when radius is less than five (5) times the nominal pipe size.

Hot Bending - Hot bending may be performed and will require no heat treatment other than to cool uniformly. Quenching or bend setting with water shall be minimized on Grade B pipe.

3. Straightening - Straightening of piping by heating bands or spots shall be done at a temperature not to exceed $1375^{\circ} \mathrm{F}$ and with no Iiquid quenching Cold straightening to correct minor misalignment is subject to approval by the City inspector.

4. Welding Procedures - Welding procedures and welders shall be qualified in accordance with ASME Code, Section IX. Two copies of all procedures and welding operator qualification test reports shall be transmitted to the City. Weld reinforcement shall be held to a minimum and edges shall merge smoothly with the base metal with no undercutting. All repairs shall be made with matching weld metal and ground flush to match normal contour.

Fit Up - Fit-up and groove dimensions shall be within tolerances of the qualified welding procedure to permit full penetration with internal reinforcement.

Tack Welds - Tack welds shall bs fully penetrated and confined to the bottom of the welding groove. They shall be of the same quality and analysis as the weld, and excessive thickness, improperly fused starts, and all cracks or faults shall be removed to sound metal before depositing the weld. Thermal gouging will be permitted only when base metal is at preheat temperature and surfaces are ground or chipped to remove heavy slag or oxide before welding.

Soundness - Peneiration shall be compleiely to the weld root to the full wall thickness. Each pass shall be completed around the pipe before depositing the next. Starts shall be staggered. In each layer of welding, improperly fused starts, checks, and surface defects shall be removed to sound metal before additional welding is performed.

5. Preheating - The base metal adjacent to the welding groove shall be heated as required to produce sound welds before tacking, flame or arc gouging and during welding. 
6. Heat Treatment - During heat treatment flange gasket faces, ring grooves and threads shall be protected against oxidation arid damage. Heat treatment of welds when required, unless otherwise specified, con'sists of stress relieving in accordance with ASA B3I.I or when covered by the ASME Boiler Code. Stress relief consists of heating uniformly and slowly to $1100-1200^{\circ} \mathrm{F}$, hold one hour per inch of wall thickness, minimum one-half hour, and cool slowly to $600^{\circ} \mathrm{F}$. The section may be cooled uniformly in the furnace or in still air. For local heat treating both ends of line shall be closed to prevent drafts during heat treating.

.g) Alloy Pipe $1 / 2$ to 2 Chrome - I/2 Moly Pipe

1. Base Metal - May be any of those listed in ASME Section IX Group P-Number 4. Weld metal shall equal properties and analysis of base metal specification.

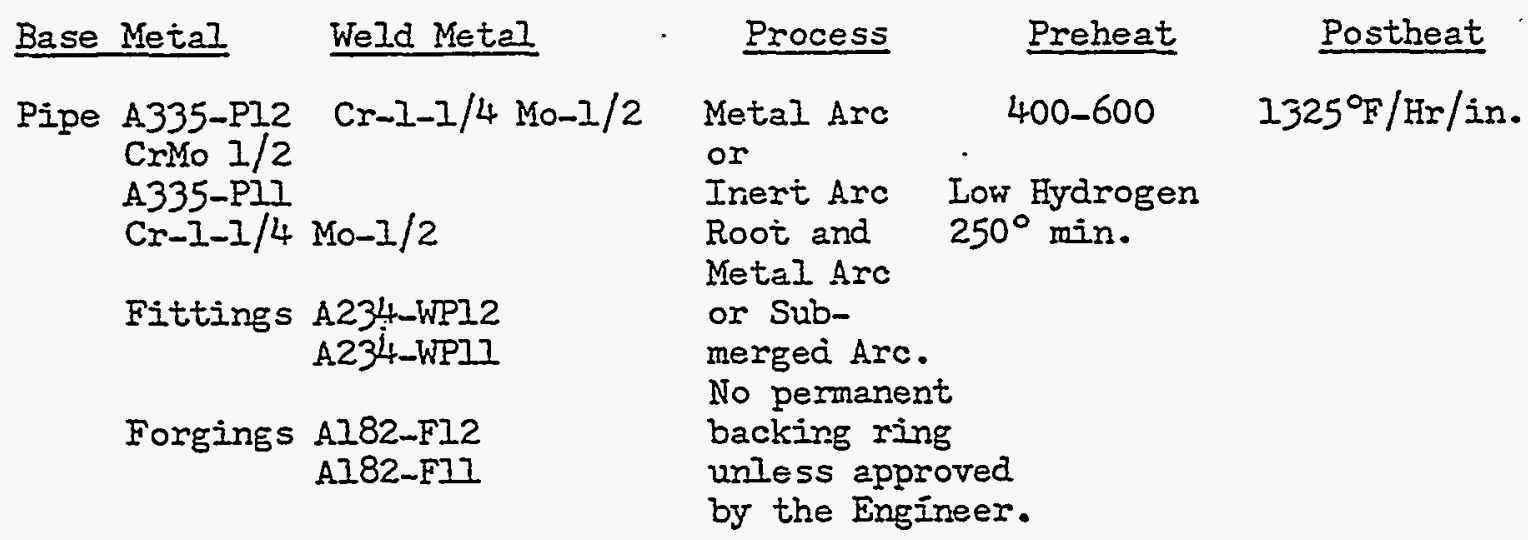

All butt welds or all alloy piping shall be inert arc root and metal arc except where special connections are specified.

Cutting Bevels - Welding bevels and grooves shall be machine cut or torch cui and shall be ground or chipped to bright metal.

2. Bending - Completed bends shall be true to dimensions and free of flat spots and corrugaitions. (See Par. 22 (f) Sab: 2)

Cold Bending - Cold bends shall be closely examined visually or by magnetic particle to show an absence of surface cracking. Completed bends shall be heat treated as provided herein. Prior to bending Brinell hardness shall not exceed $163 \mathrm{BHN}$.

Hot Bending - Hot bending may be performed between 1250 and $1400^{\circ} \mathrm{F}$, which will require no heat treatment, only covering to cool uniformly. Bending shall not be performed in the range of 1450 to $1700^{\circ} \mathrm{F}$, unless the entire surface of the completed bend is magnetic particle inspected. Completed bends made at $1450^{\circ} \mathrm{F}$ to $1700^{\circ} \mathrm{F}$ shall be heat treated as provided herein. Quenching or bend setiing with water shall not be permitied. Air cooling from above $1400^{\circ}$ requires full heat treatment.

3. Straightening - Straightening of piping by hoating bends shall be done at a temperature not to exceed $1375^{\circ} \mathrm{F}$ and with no liquid querching. Cold straightening to correct minor misalignment is 
subject to approval by the City inspector.

t. Welding Procedures - Welding procedures and welders shall be qualified in accordance with ASME Code, Section IX. Weld reinforcement shall be held to a minimum and edges shall merge smoothly with the base metal with no undercutiing. All repairs shall be made with matching weld metal and ground flush to match normal contour. Two copies of all procedures and welding operator qualification test reports shall be transmitted to the Engineer prior to proceeding with the work.

Fit-Up - Fit-up and groove dimensions shall be with tolerances of the qualified welding procedure to permit fill penetration without internal reinforcement.

Tack-Welds - Tack-welds shall be fully penetrated and confined to the bottom of the welding groove. They shall be of same quality and analysis as the weld, and excessive thickness, improperly fused starts and all cracks or faults shall be removed to sound metal before depositing the weld. Thermal gouging will be permitted only when base metal is at preheat temperature and surfaces are ground or chipped to bright metal before welding.

Soundness - Penetration shall be completely to the weld root to the full wall thickness. Each pass shall be completed around the pipe before depositing the next. Starts shall be staggered. Improperly fused starts, checks and surface defects shall be removed to sound metal before welding.

5. Preheating - The base metal adjacent to the welding groove shall be preheated to $400-600^{\circ} \mathrm{F}$ before tacking, flame or are gouging and during welding.

6. Intermiption of preheating and welding shall be permitied only after two passes minimum or one-third the groove depth has been completed. Weld shall be covered to cool uniformly. Preheat shail be established prior to continuation of welding.

7. Cooling After Welding - The completed groove weld shall be covered to cool uniformly from the preheat temperature if heat treatment is rot to be performed immediately before cooling below preheat temperature.

8. Heat Treatment - During heat treatment flange gasket faces, ring grooves and threads shail be protected against oxidation and damage. Heat treatment of welds is required and, unless otherwise specified, consists of subcritical anneal. Minimum strength of welded joint shall meet Code requirements.

Subcritical anneal consists of heating uniformly to $1300-1350^{\circ} \mathrm{F}$, in not less than two hours, hold one hour per inch of wall thickress, minimum one and one-half hours, and $\operatorname{cool} 100-150^{\circ} \mathrm{F}$ per hour to $1100^{\circ} \mathrm{F}$. Below $1100^{\circ} \mathrm{F}$ the section may be cooled uniformly in the furnace or in still air by covering a distance of two diameters 
or a minimum of one foot each side of weld with $1 / 4$-inch of asbestos. For local heat treating, both ends of line shall be closed to prevent drafts during heat treating.

(h) Bi-Metaliic Connections - Where different types of metal are connected together, the lower stress specification shall apply. When welding carbon steel pipe to alloy valves (SF \& SH specs) use 25-20 stainless steel welding electrode.

(i) Painting - AIl uninsulated, unprotected carbon steel pipe and supports shall be cleaned of rust, loose scale, oil, grease or other foreign substances, and given one coat of zinc chromate primer.

(j) Cleaning Pipe - All pipe shall be carefully inspected for internal cleanliness and all dirt and foreign material removed. All welds shall be inspected internally and all loose metal and slag removed prior to final installation. where a final weld cannot be visually inspected, an irert arc root weld is required and no acetylene gas eutiing will bo allowed. Prior to installation,. ends of spools shall be covered to keep out all dirt, foreign material, etc.

(k) Marking - Piping shall be piece marked by tagging and painiing identification. All alloy pipe shall be code colored on not less then two feet on each end of the pipe.

(I) Protecting for Shipment - Flange faces, machined surfaces and threads shall be clean and coated with corrosion preventative such as Rust Ban 324 or waterproof grease. Flange Iaces shall be protected by securely fastened wooden or metal covers. Couplings shall be protected by steel pipe plugs and threads by metal protectors.

\section{FIEID FABRICATION}

All lines sizes two (2) inches ard smaller as shown on the drawings shall be field fabricated unless the Contractor at his own risk ard responsibility chooses to shop fabricate such lines. No warranty or representation, express or implied, is made by the City with regard to accuracy of the drawings respecting piping sizes $2^{\prime \prime}$ and smaller in diameter. The Contractor is required to verify and measure in the field the routing and dimensions of 271 lines $2^{\prime \prime}$ and smaller in diameter so as to avoid interferences with structures, equipment and larger pipe and to accomplisin field fabrication of pipe sizes $2^{\prime \prime}$ and smaller in diameter in accordance with the Specifications. The term "Field Fabricate" as used in these specifications and on the drawings shall mean measuring, cutting and fitting in the field, and routing and installing in place by the Contractor, all of the pipe, fittings and valves shown on the drawings, and shall include any instrument connection that might not be indicated or the drawings.

AIl lines two (2) inches and smaller detailed and checked on the drawings are shown to designate the desired routing and general location and for estimating materials and quantities of such piping, but final dimensions and configurations to provide clearances for pipe, fittings, valves, insclation, equipment and strictures shall be the responsibjlity of the Contractor. Field routing of pipe shall be done in a neat and orderly manner consistent with good piping practice.

The Contractor shall generally follow the routing indicated on the drawings. If deviations from this routing are necessary or expedient, such deviations must be approvea by the City's construction superintendent before . 
deviation is made. The Contractor shall show the rerouting of all lines on sketches for the City"s use in preparing "As Built" drawings.

\section{PIPING SPOOLS}

Piping spool drawings are not furnished as part of these Specifications. Piping contractor shall make up his own spool drawings from the drawings listed herein. $\mathrm{He}$ is and shall be held responsible for any and all errors in shop or field fabrication due to inaccuracy in his spool drawings. The Contractor shall furnish the Engineer for his information three (3) copies of all drawings made for shop fabricated pipe, before fabrication.

\section{FITTING UP}

It shall be the responsibility of the Contractor to fit up all lines square and plumb. Under no conditions shall any pipe anchored to any piece of equipment be forced in place except where cold springing is required. To make certain that no piece of equipment is strained during pipe installation, all joints, connections or flanges between the equipment and pipe shall be left free until the pipe has been completely welded. The City's inspector shall then be called to make an examination of the line prior to making up the last connection to the equipment.

The orientation of hand wheels shall be as indicated on the drawings. Whenever orientation is not indicated, Contractor shall orient for best operation and passage clearance.

\section{STEAM BLOWOUT AND FLUSHING PIPING}

Steam Line Blowout

The blowout procedure is divided into three phases and is covered by Contract Drawings Nos. ES-1693 and ES-1694. Blowout procedure will be conducted by the City.

Phase I - Blow superheated and main steam line through turbine stop valve to atmosphere through stack line No. 2148-12"

Phase II - Blow cold reheat line from turbine to reverse current valve on boiler. After completion of main steam line blow-out as per Phase I, the Contractor shall remove stack line No. 2148-12", install line 2149-12" from main steam turbine valve to connect to line No. 2017SF-12" and proceed as indicated in Section X-X of drawing No. ES1694 adding flanged stack to RCV \#6 and using a portion of line No. 2148 to complete the installation.

Phase III - Blow hot reheat line through reheat stop valve to atmosphere. After completion of cold reheat blow Phase II. Contractor shall remove blowout stack from RCV \#6, and reassemble check valve. Contractor shall assemble stack from parts of ${ }^{\circ}$ Phase I and II as indicated on drawing ES-1694 for final blow from reheat stop valve. 

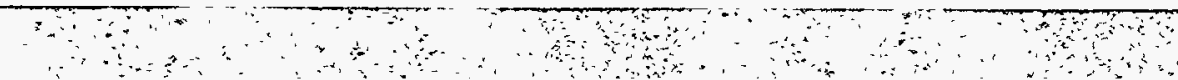


\section{Appendix D: Detailed Description of Selected Power Plants}

\section{D.1 Valley Steam Plant Units 1 and 2}

\section{D.1.0 Technical Description}

\section{D.1.1 Steam Generating Facilities}

\section{D.1.1.1 Boiler Structure - Structural}

The boiler structure is designed as two separate units under a common roof. Boilers Nos. 1 and 2 occupy the east half of the area and serve the unit No. 1 main and house turbines, while boilers Nos. 3 and 4 occupy the west half of the area and serve the unit No. 2 main and house turbines. Two reinforced concrete mats, each 3 $\mathrm{ft}-0$ in. thick, $66 \mathrm{ft}-6$ in. wide and $80 \mathrm{ft}-0$ in. long, serve as a foundation mat under each set of boilers.

Interconnected footing walls, built on these mats are 5 $\mathrm{ft}-4$ in. high to grade and vary in width from 42 in to 60 in. Sand backfill was provided between footing walls and a reinforced concrete floor slab 6 in. thick was poured flush to grade. A fuel oil piping trench makes a loop between the two boiler units, forming an island upon which the primary fuel oil pumps are located. Twenty-four main structural steel columns and eight canopy support columns rise $100 \mathrm{ft}$ to form the supporting steel for the boilers and the double hip roof structure. Beams and cross-bracing form five levels at grades $400,412,444,452$ and 470 . The firing aisle portion of grade 412 , between the two boiler units, has a reinforced concrete floor 6 in. thick. The remainder of 412 grade and all other levels have floors of galvanized steel grating. The double hip roof and sides down to grade $\mathbf{4 7 0}$ are covered with corrugated asbestos siding to protect the boiler steam drums from the weather. The remainder of the structure is open, except the central section down to grade 412 , which has corrugated asbestos siding on the north and south ends and $1 / 8$ in. steel plate flashing between boilers to effect a seal-off, thereby providing a sheltered firing aisle from grade 412 to the canopy at grade 470 .

\section{D.1.1.2 Boiler System}

Four Babcock \& Wilcox radiant type, single pass water tube boilers are installed in the boiler housing. Each boiler has a rated continuous capacity of $450,000 \mathrm{lb}$ of steam per hr at 1,380 psi, with a maximum $24 \mathrm{hr}$ capacity of $517,000 \mathrm{lb}$ per hr. Boilers are of the twodrum type, with a steam drum 72 in. inside diameter and $26 \mathrm{ft}-10 \mathrm{in}$. long of $515 / 16$ in. wall thickness and a lower mud drum 42 in. inside diam and $32 \mathrm{ft}$ long of 3 in. thickness. 165 generating tubes provide a total effective heating surface of $5,122 \mathrm{sq} \mathrm{ft}$. The bare tube water-cooled furnace is $21 \mathrm{ft}$ wide $\times 21 \mathrm{ft}$ deep $\times 56 \mathrm{ft}$ high, with a volume of $18,350 \mathrm{cu} \mathrm{ft}$ and an effective heating surface of $4,350 \mathrm{sq} \mathrm{ft}$. A pendant type, twosection superheater with bottom drum at temperature control is mounted above the fumace and has a total effective heating surface of $14,968 \mathrm{sq} \mathrm{ft}$. The economizer section situated where the flue gases pass from the superheater section into the air heaters is composed of 500,2 1/2 in. diam tubes each raising $522,675 \mathrm{lb}$ of feed water per hr from an inlet temperature of $375^{\circ} \mathrm{F}$ to a final temperature of $475^{\circ}$ with oil fuel and to $490^{\circ} \mathrm{F}$ with gas fuel. The flue gases then pass downward through the tubes of a vertical air heater. The air heater section contains $2,457,2$ 1/2 in. diam No. 14 gage tubes, each $42 \mathrm{ft}$ long mounted in a $21 \mathrm{ft} \mathrm{sq}$ bundle for a total effective heating surface of $67,600 \mathrm{sq} \mathrm{ft}$. When the boilers are being operated on oil fuel, the air heaters are designed to raise $493,000 \mathrm{lb}$ of air from an inlet temperature of $80^{\circ} \mathrm{F}$ to a final temperature of $562^{\circ} \mathrm{F}$. A return bend aerofin steam coil $14 \mathrm{ft}$ high by $20 \mathrm{ft}$ long covers the air inlet to the air heater to preheat the entering air during cold weather. This heater operates with 100 psi steam and has a capacity to raise $700,000 \mathrm{Ib}$ of air per hr from $30^{\circ} \mathrm{F}$ to $165^{\circ} \mathrm{F}$. Each boiler is equipped with 14,I.K. air driven soot blower units and six G9B calorized elements in the boiler and superheater sections. Three straight line soot blowers are located at the bottom of the air heater section. The soot blowers are powered by air motors and operate on 600 psi steam through sequential control from a master panel board.

The boiler draft system is composed of a single inlet forced draft fan mounted on a common shaft with a double inlet induced draft fan and powered by a 2,000 hp electric motor running at a speed of $715 \mathrm{rpm}$. The forced draft fan draws in $700,000 \mathrm{lb}$ of outside air per $\mathrm{hr}$ and forces it around the air heater tubes to the burner wind box at a pressure of 25 in. of water. The induced draft fan draws the flue gases from the boiler, through the air heater tubes and delivers the gases to the stack at the rate of $810,000 \mathrm{lb}$ per $\mathrm{hr}$ with a discharge pressure of 13.5 in. of water. Each boiler has one selfsupporting welded steel plate stack $11 \mathrm{ft}$ in diam and $140 \mathrm{ft}$ high. The stack interiors are lined the full length with a two in. thick coating of Haydite Lumnite gunite.

Each boiler is fired by six Peabody Engineering company constant differential pump type combination gas and oil burners mounted in two rows of three burners each across the furnace front wall, facing the 
grade 412 boiler firing aisle (each burner has a capacity of $36,200 \mathrm{lb}$ of oil per hr or $11,800 \mathrm{cfm}$ of gas). Fuel oil for these burners is stored in a tank farm composed of two 80,000 barrel and two 40,800 barrel welded steel tanks located approximately $500 \mathrm{ft}$ to the north of the boiler area. These tanks are all fitted with Horton floating roofs to eliminate evaporative losses and fire hazard and are surrounded and sectioned off by earth dikes in accordance with Section 53 of the National Fire Code. Fuel oil is drawn from these tanks through a horizontal straight tube primary suction heater with a $1,052 \mathrm{sq} \mathrm{ft}$ heating surface. Steam at $100 \mathrm{psi}$ is piped throughout the tank farm and is utilized as a heating medium. Fuel oil temperature is thermostatically controlled at $120 \mathrm{~F}$. Oil suction lines are spirally traced with steam coils and insulated with three-ply weatherproofed Asbestocel to retain this heat. Fuel oil is drawn through approximately $700 \mathrm{ft}$ of 12 in. dia. welded steel pipe to the primary fuel oil pumps, which are located directly beneath the boiler firing aisle at ground grade 385 in the boiler housing structure. Ten primary fuel oil suction pumps are mounted in a row with the 12 in. fuel oil suction piping looped around them in a trench covered with checkered plate. Five of these pumps serve boilers Nos. 1 and 2 of the primary fuel oil pumps are of the internal gear type, each having a capacity of approximately $28,000 \mathrm{lb}$ of oil per hr at a $400 \mathrm{psi}$ discharge pressure. Four of these pumps are powered by $60 \mathrm{hp}, 440 \mathrm{v}$ electric motors, connected to operate at two speeds by means of resistors and short circuiting air circuit breakers in the rotor circuit. The fifth pump is powered by a $60 \mathrm{hp}$, type DS-120 GE single stage steam turbine. An automatic sequence, activated by a 20-point drum controller, energizes these pumps as necessary to maintain constant primary discharge header pressure. The primary discharge fuel oil then passes through a series of three secondary fuel oil heaters located on the platform at grade 400 directly above the primary fuel oil pumps. These heaters are horizontal straight tube floating head closed heaters utilizing 100 psi steam for a heating medium. Each heater is $281 / 4$ in. in diam and $18 \mathrm{ft}-11 / 2 \mathrm{in}$. long with 338 tubes, having a total of $1,070 \mathrm{sq} f \mathrm{ft}$ of heating surface. Fuel oil is raised to a final temperature of 250 $F$ by the operation of thermostatically controlled heater by-pass valves and then enters the suction side of the secondary fuel oil pumps. There are eight secondary fuel oil pumps, each a four-stage centrifugal pump with a $75 \mathrm{gpm}$ capacity at $300 \mathrm{psi}$ differential, connected directly to a $40 \mathrm{hp}, 3,500 \mathrm{mpm}$ motor. Four secondary pumps are constantly in service delivering fuel oil at $250 \mathrm{~F}$ and 600 psi to the fuel oil manifold serving twelve Peabody burners, six for each boiler.

A 16 in. diam pipe line brings natural gas at 40 psi into the plant site from the Pacific Gas and Electric Company gas feeder to the Bakersfield area. The raw gas passes through a vertical involute separation tank, 42 in. in diam and $19 \mathrm{ft}-3$ in. high, where sand, dust and debris are removed by cyclonic action. The gas pressure is then reduced to $10 \mathrm{psi}$ at a dual reducing station and is fed through Bailey Gas-Air flow meters to the Peabody gas burner ring as a stand-by fuel.

\section{D.1.1.3 Power Plant Building - Structural}

The power plant building is a reinforced concrete structure. The building is $176 \mathrm{ft}$ wide by $198 \mathrm{ft}$ long and occupies approximately $31,400 \mathrm{sq} f \mathrm{ft}$ area. The structure is supported on spread footings, tied together with concrete struts.

The building is a three-level structure with a ground floor at grade 386, an intermediate piping and conduit level at grade 400 , and an operating level at grade 412 . The structure is divided into three bays, from south to north as follows: the turbine bay, the auxiliary bay and the control bay. The turbine bay is 159 long by $93 \mathrm{ft}$ wide and $80 \mathrm{ft}$ to the roof, and houses the two main turbine generator units. The auxiliary bay is $159 \mathrm{ft}$ long, $46 \mathrm{ft}$ wide and $58 \mathrm{ft}$ to the roof and houses air compressors and service pumps on the ground level; piping, heat exchangers and electrical conduit runs on the intermediate level; and the boiler feed pumps, evaporators and the two house unit turbine generators on the operating floor grade. The control bay is $159 \mathrm{ft}$ long, $40 \mathrm{ft}$ wide and $58 \mathrm{ft}$ to the roof and houses the station service switchgear on the ground level, electrical conduit and control piping on the intermediate level and the turbine generator and boiler control panels on the operating floor. A machine shop $40 \mathrm{ft}$ wide by $93 \mathrm{ft}$ long by $26 \mathrm{ft}$ high, with locker and wash facilities adjoins the turbine bay to the east. An entrance lobby, auditorium and first aid station occupy the northeast corner of the ground level. The northeast comer of the intermediate level is occupied by a battery charging room and the entire east end of the auxiliary and control bay operating level is devoted to six large office rooms, storage rooms and toilet facilities for the operating personnel.

A passenger elevator which is framed into the surge tank tower serves all floors, including the auxiliary bay roof and the upper levels of the adjacent boiler housing.

\section{D.1.2 Power Plant - Mechanical}

\section{D.1.2.1 Unit No. 1}


Steam at 1,350 psi and $925 \mathrm{~F}$ is carried from boilers Nos. 1 and 2 across the auxiliary bay roof in a schedule 160 carbon molybdenum steam header 14 in. in diam, and then drops into the power station building to the stop valves to the main unit and house unit No. 1 turbines.

The unit No. 1 main generating unit consists of a General Electric 20-stage, single casing, single flow turbine, extraction, condensing type, direct connected to a General Electric alternating current generator nunning at a speed of $1,800 \mathrm{rpm}$. Steam is extracted from the turbine at the fifth state (228.5 psi) for heater No. 1, at the ninth stage (46 psi) for the evaporator supply, at the sixteenth stage ( $9.6 \mathrm{psi}$ ) for heater No. 4 and the exhaust steam flows into the condenser at 3 in. $\mathrm{Hg}$ absolute pressure.

The alternating current generator has a rated capacity of $60,000 \mathrm{kw}$ and a maximum of $75,000 \mathrm{kva}$ at $0.8 \mathrm{pf}$, $1,800 \mathrm{rpm}$ for $13,800,3$ phase, 60 cycle service. The generator is air-cooled through a water-cooled heat exchanger in a closed duct work system and is protected from fire by 21 fifty-lb $\mathrm{CO}_{2}$ cylinders which are automatically released by thermostatic bulbs in the air duct.

The main unit condenser is a Foster Wheeler crossflow type consisting of 5,900 tubes, each 7/8 in. by 18 BWG by $26 \mathrm{ft}-21 / 8 \mathrm{in}$. long for a total of $35,000 \mathrm{sq} \mathrm{ft}$ of condensing surface. Two Foster Wheeler Corporation single stage horizontal water pumps, each with a capacity of $32,500 \mathrm{gpm}$ at $55 \mathrm{ft}$ th and $495 \mathrm{rpm}$ are driven by $600 \mathrm{hp}, 2,300$ volt squirrel cage motors to circulate cooling water through the condenser tubing. A Foster Wheeler Corporation twin element two-stage air ejector utilizes 200 psi steam to remove any air leakage into the condenser at a maximum rate of $202.5 \mathrm{lbs}$ of air vapor mixture per $\mathrm{hr}$ for each two-stage element.

The unit No. 1 house unit turbine generator consists of a General Electric Company six-stage automatic extraction-admission condensing turbine running at 3,600 rpm to drive a General Electric Company alternating current generator. Power generation is at 2,400 volt, 3 phase, 60 cycle with a rated capacity of $6,000 \mathrm{kw}$ and a maximum output of $7,500 \mathrm{kva}$ at $0.8 \mathrm{pf}$. Only one extraction stage is provided on the house unit turbine to supply 5 psi gage steam for the unit No. 1 deaerating heater. The generator is air-cooled by a closed duct work system with a water-cooled heat exchanger. The generator is protected from fire by five $50 \mathrm{lb} \mathrm{CO}$ cylinders which are automatically released into the air duct by thermostats set at $210 \mathrm{~F}$. The turbine exhaust steam flows into a Foster Wheeler
Corporation single pass reverse flow condenser consisting of 972 tubes, each $7 / 8$ in. by 18 BWG by 18 $\mathrm{ft}-2$ 1/8 in. long having a total condensing surface of $4,000 \mathrm{sq} \mathrm{ft}$. A Foster Wheeler Corporation single stage horizontal double suction pump powered by a $150 \mathrm{hp}$, 2,300 volt, $700 \mathrm{rpm}$ motor circulates $9,000 \mathrm{gpm}$ through the condenser tubing at $51.5 \mathrm{ft} \mathrm{th}$.

A Foster Wheeler twin element two-stage air ejector, utilizing 200 psi steam, removes air leakage to the condenser at a maximum rate of $202.5 \mathrm{lb}$ per lb per hr for each element.

Condensate from the hot well of the main condenser is drawn into either one of a dual condensate pump unit mounted directly beneath the condenser. The pumps are Foster Wheeler Corporation three-stage horizontal pumps powered by $100 \mathrm{hp}, 400 \mathrm{v}$ motors and each has a discharge capacity of $1,200 \mathrm{gpm}$ at $185 \mathrm{ft}$ th. The condensate is pumped first through the inner and aftercooling chests of the air ejector as a condensing medium for the 200 psi ejector steam. A regulating bypass valve then returns a portions of the condensate to the condenser hot well as required to maintain a constant hot well water level.

Condensate from the house unit condenser hot well is drawn into a similar dual condensate pump umit installed directly beneath the hot well. The two condensate pumps are Foster Wheeler Corporation two-stage horizontal pumps driven by $25 \mathrm{hp}, 400 \mathrm{v}$ motors. The condensate is first pumped through the inner and aftercoolers of the house unit air ejector as a condensing hot well as required to maintain the required hot well level. The remainder of the condensate is joined with the main unit condensate after the air ejector and is forced through feed water heater No. 4 .

Feed water heater No. 4 is a Foster Wheeler Corporation vertical type heater. The heater is $371 / 2$ in. inside diam by $22 \mathrm{ft}-3$ in. long with 545 tubes each 7/8 in. by $18 \mathrm{BWG}$ by $18 \mathrm{ft}-107 / 8$ in. long. Sixteenth stage extraction steam at $9.6 \mathrm{psi}$ is fed into the shell of this heater to raise the condensate being pumped through the tubes from $118 \mathrm{~F}$ entering temperature to $189 \mathrm{~F}$ discharge temperature.

The condensate is then pumped to deaerating feed water heater No. 3 located on the auxiliary bay roof.

The $825,000 \mathrm{lb}$ per hr Elliot deaerating heater and vent condenser consist of a horizontal tank $12 \mathrm{ft}-6$ in diam by $13 \mathrm{ft}-4$ in, upon which is mounted a vent condenser 22 in. diam by $7 \mathrm{ft} 111 / 4$ in. long. The feed water passes over a series of cast iron deaerating trays within 
the heater where its temperature is raised from $189 \mathrm{~F}$ to $228 \mathrm{~F}$ and the oxygen content is removed to a maximum of $0.005 \mathrm{cc}$ of oxygen per liter. A diaphragm valved by-pass assembly, operated by a deaerator normal level float, by-passes excess condensate to a 17,000 gallon surge tank, mounted on top of the elevator shaft, to provide a "floating" storage for maintaining the deaerator normal level under rapid load change demands.

The deaerated and heated condensate is drawn from heater No. 4 through an 18 in downcomer to a header 16 in in diam at grade 401.33, from which 12 in. suction headers take off to the primary suction of boiler feed pumps Nos. 1, 2 and 3 located on the auxiliary bay operating floor at grade 412 .

Each Ingersoll Rand Company boiler feed pump consists of a primary and secondary pump mounted on a single bedplate with a 2,000 hp, 2,300 volt General Electric Company 3,570 rpm constant speed motor as a common driver for both pumps. The primary pumps are fourstage centrifugal units with a capacity of $575,000 \mathrm{lb}$ per hour of boiler feed water at a discharge pressure of 500 psi and $228 \mathrm{~F}$. The secondary boiler feed pumps are seven-stage centrifugal pumps with a capacity of $575,000 \mathrm{lb}$ of feed water at $1,400 \mathrm{psi}$ discharge pressure and $400 \mathrm{~F}$.

The primary boiler feed water discharge is pumped through the Foster Wheeler Corporation evaporator condenser where its temperature is raised from $228 \mathrm{~F}$ to $240 \mathrm{~F}$. The feed water then passes through a Foster Wheeler Corporation heater drain cooler $271 / 2$ in. in diam by $15 \mathrm{ft}-0$ long and its temperature is raised from $240 \mathrm{~F}$ to $254 \mathrm{~F}$. The feed water then passes through heater No. 2, a Foster Wheeler Corporation vertical heater $411 / 2$ in. ID and $22 \mathrm{ft}-43 / 4$ in long, where its temperature is raised from $254 \mathrm{~F}$ to $330 \mathrm{~F}$. The feed water then passes to the final feed water heater No. 1, a Foster Wheeler Corporation vertical heater 41 1/2 in. ID by $22 \mathrm{ft}-51 / 2$ in. long, where its temperature is raised to a final $402 \mathrm{~F}$. The feed water is then drawn into the secondary boiler feed pumps and discharged into the boiler feed header at a pressure of 2,300 psi. A feed water control valve at each boiler regulates this pressure to approximately 1,400 psi and admits feed water to maintain a constant water level in the boiler drum. through the economizer.

The unit 1 Turbine requires a flow of $74,000 \mathrm{gpm}$ of cooling water through the main and house unit No. 1 condensers, to hold a condenser vacuum of 3 in. $\mathrm{Hg}$ absolute. This water load is circulated through the condenser water tubes by the Foster Wheeler
Corporation circulating pumps described previously and is discharged into a pipe 60 in. in diam running to two Foster Wheeler Corporation forced draft cooling towers. The heat is dissipated to the atmosphere by forced evaporative cooling and the water is again returned to the circulating water pumps through a suction header 66 in. in diam.

\section{D.1.2.2 Unit No. 2}

Steam from boilers Nos. 3 and 4 is carried across the auxiliary bay roof in two parallel carbon molybdenum schedule 160 headers 12 in. in diam which are joined into one 16 in. header that drops to the stop valve of the main unit No. 2 turbine. A six in header drops to the stop valve of the house unit No. 2 turbine from the high pressure side of the reducing station steam header.

The unit No. 2 main generating unit consists of a General Electric 17-stage, single casing, single flow turbine, extraction, condensing type, direct connected to a General Electric hydrogen cooled alternating current generator rumning at a speed of $1,800 \mathrm{rpm}$. Steam is extracted from the turbine at the fourth stage ( $363.0 \mathrm{psi})$ for heater No. 1, at the sixth stage (224.0 psi) for heater No. 2, at the ninth stage ( 84.0 psi) for heater No. 3 and evaporator steam supply, and at the fourteenth stage (7.5 psi) for heater No. 5. Exhaust steam flows into the condenser at 3 in. $\mathrm{Hg}$ absolute.

The hydrogen-cooled alternating current generator has a rated capacity of $80,000 \mathrm{kw}$ with a maximum of $100,000 \mathrm{kva}$ at $.8 \mathrm{pf}, 1,800 \mathrm{rpm}$ for 13,800 volt 3 phase, 60 cycle service at 0.5 psi hydrogen pressure. The generator is cooled by a water-cooled hydrogen atmosphere that may be raised to $15 \mathrm{psi}$. The rated capacity of the generator is raised to $100,000 \mathrm{kw}$ under a hydrogen pressure of $15 \mathrm{psi}$. A hydrogen seal oil unit separates the air and salvages the entrained hydrogen from the shaft sealing and bearing oil system. An eightbottle hydrogen rack with manifold provides for makeup of hydrogen losses and a six-bottle $\mathrm{CO}_{2}$ manifold provides purging gas to displace the hydrogen when generator repairs are necessary.

The main unit No. 2 condenser is an Ingersoll Rand Company crossflow type with 7,974, 7/8 in. by 18 BWG tubes, each $26 \mathrm{ft}-25 / 16 \mathrm{in}$. long for a total of $47,500 \mathrm{sq}$ $\mathrm{ft}$ of surface area. Two Ingersoll Rand Company No. 36 AFV single stage circulating pumps with 48 in. diam suction and 36 in diam discharge, each circulate 47,500 gpm of water at $65 \mathrm{ft}$ tdh through the condenser tubing. These pumps are driven by General Electric Company $1,000 \mathrm{hp}, 4,160$ volt squirrel cage motors. An Ingersoll Rand Company two-stage twin element steam jet pump 
air ejector, operating on $1,350 \mathrm{psi}, 935 \mathrm{~F}$ throttle steam orificed to 200 psi removes air leakage at a maximum rate of $202.5 \mathrm{lb}$ of air per $\mathrm{hr}$ for each element.

The unit No. 2 house turbine generator consists of a General Electric six-stage automatic extractionadmission, condensing unit running at a speed of 3,600 rpm to drive a General Electric Company alternating current generator. Power is generated by this unit at 4,160 volts, 3 phase, 60 cycle, with a rated output of $7,500 \mathrm{kw}$ and maximum of $9,375 \mathrm{kw}$, or $10,714 \mathrm{kva}$ at 0.7 pf. One extraction stage provides 22 psi steam for deaerating heater NO. 4 located on the auxiliary bay roof. The generator is air-cooled by a closed duct work system with a General Electric water-coled surface heat exchanger. The generator is protected from fire by five $50 \mathrm{Ib} \mathrm{CO}_{2}$ cylinders which are automatically released into the air duct by thermostats set at $220 \mathrm{~F}$. Manually operated fog nozzles located in the bell ends of the generator are also provided to extinguish a generator fire. One $50 \mathrm{lb} \mathrm{CO}$ cylinder is automatically released into the turbine lubricating oil tank by "rate of rise" thermostat in case of a fire in the lubricating oil storage and pumping unit. The $972,7 / 8$ in OD, 18 BWG tubes, each $18 \mathrm{ft}-2$ 1/8 in. long having a total of 4,000 sq $\mathrm{ft}$ of surface area. A Foster Wheeler Corporation single stage 18 in horizontal double suction circulating water pump forces $9,000 \mathrm{gpm}$ of cooling water through the house unit condenser at $51.5 \mathrm{ft}$ th. The pump is driven by a $150 \mathrm{hp}, 4,160$ volt Coninental motor at 705 rpm. A Foster Wheeler Corporation twin element twostage air ejector, utilizing 1,500 psi 935 F steam, orificed to $200 \mathrm{psi}$, removes air leakage to he condenser at a maximum rate of $150 \mathrm{lb}$ per hr per element.

Condensate from the hot well of the main unit condenser is drawn into either one of a dual condensate pump unit set directly beneath the condenser hot well. The two main unit condensate pumps are Ingersoll Rand Company, two-stage horizontal pumps with 14 in. suction and 12 in. discharge, having a capacity of 1,600 gpm at $185 \mathrm{ft} t \mathrm{th}$, and are driven by $125 \mathrm{hp}, 400$ volt squirrel cage splashproof General Electric Company motors. The condensate is pumped through the inner and aftercooling chests of the main unit air ejector as a cooling medium for the air ejector jet steam. A regulatory by-pass valve then returns a portion of the condensate hot well as required to maintain a constant hot well level.

The condensate from the house unit condenser hot well is drawn into a similar dual condensate pump unit beneath its condenser. Two Foster Wheeler Corporation, two-stage horizontal pumps, with five in. suction and three in discharge having a $170 \mathrm{gpm}$ capacity at $185 \mathrm{ft}$ dynamic head, are driven at 1,750 rpm by $10 \mathrm{hp}$, medium for the jet steam, and is then bypassed back to the condenser hot well as needed to maintain constant level. The remainder of the condensate is joined with the main unit condensate, and the combined flow passed through heater No. 5 where its temperature is raised from $117 \mathrm{~F}$ to $170^{\circ} \mathrm{F}$.

Heater No. 5 is a C. F. Bram Company vertical heater, 38 in ID by $19 \mathrm{ft}-3$ in. long, with $1,152,3 / 4$ in. by 16 gage tubes each $16 \mathrm{ft}-0$ in. long, and has a capacity of $710,000 \mathrm{lb}$ of water per $\mathrm{hr}$. Heat is supplied to the shell by the 14th stage extraction from the main turbine (180 $F$ at 7.5 psi gage).

The condensate leaves heater No. 5 and is forced by the condensate pump discharge head to deaerating feed water heater No. 4 located on the auxiliary bay roof at grade 444. A by-pass valve assembly, operated by a normal level Mercoid float switch on the deaerator, maintains constant working level in the deaerator tank and diverts excess condensate to storage in the 25,000 gallon surge tank mounted on top of the elevator shaft at grade 490 . The surge tank provides a "floating storage" on the deaerator to supply instant boiler feed make-up in case of rapid load changes.

Deaeratoring feed water heater No. 4 is a Worthington Pump and Machinery Corporation unit with a rated capacity of $1,093,000 \mathrm{lb}$ per hr. The unit consists of a horizontally mounted tank, $12 \mathrm{ft}-0$ in in diam by $22 \mathrm{ft}-0$ in. long, upon which are mounted two vent condensers 2 $\mathrm{ft}-2$ in. in diam by $6 \mathrm{ft}-6$ in. long. The condensate passes over a series of trays within the heater and its temperature is raised from $167 \mathrm{~F}$ to $228 \mathrm{~F}$. The five psi gage steam utilized for heating and venting is obtained from the single extraction stage on the house unit turbine. The equipment is designed to remove oxygen from the feed water so that the quantity remaining will not exceed $0.005 \mathrm{cc}$ of oxygen per liter. The heated and deaerated feed water is drawn through an 18 in. downcomer into a header 16 in. in diam at grade 401 , from which 12 in. diam headers take off to the suction inlets of primary boiler feed pumps Nos. 4 and 5. This 16 in. diam feed water header runs through to connect with a similar header from unit No. 1 deaerator. Block valves are installed on each side of the primary suction to boiler feed pump No. 3, thereby tying the feed water systems of the two units together and making it possible to utilize boiler feed pump No. 3 as a stand-by pump for either unit No. 1 or unit No. 2.

Boiler feed pumps Nos. 4 and 5 are identical Ingersoll Rand combination primary and secondary pumps and have a common $2,000 \mathrm{hp}$ driver as described for unit 
No. 1, but the motors for pumps Nos. 4 and 5 are powered from the 4,160 volt system supplied by the unit No. 2 house turbine. All five boiler feed pumps are equipped with baffled orifices and recirculation flow control valves on both primary and secondary discharge, so that the pumps on stand-by service are always kept heated and ready for instant service. The labyrinth seals of the secondary pumps are fed by injection from the primary pump discharge at 500 psi and $220 \mathrm{~F}$. This sealing water is bled from the pumps seals by labyrinth leak-off back pressure flow control valves into either of two closed drip tanks 36 in. diam by $8 \mathrm{ft}$ long which are suspended just below the 400 grade.

The boiler feed water is discharged from primary feed pumps Nos. 4 and 5 at 500 psi and $228 \mathrm{~F}$ and forced through the Griscom Russell evaporator condenser where its temperature is raised from $220 \mathrm{~F}$ to $247 \mathrm{~F}$.

The evaporator condenser is a horizontal two-pass, tube and shell heat exchanger 31 inc. OD by $19 \mathrm{ft}$ long with $2,205 \mathrm{sq} \mathrm{ft}$ effective surface.

The feed water leaves this unit and is then forced through No. 3 extraction heater, where its temperature is raised from $247 \mathrm{~F}$ to $303 \mathrm{~F}$.

No. 3 extraction heater is a vertical tube and shell type heat exchanger manufactured by the American Locomotive Company. The heater is $441 / 4$ in ID by $23 \mathrm{ft}-9$ in. long, contains $1,230,3 / 4$ in. No. 18 BWG tubes $18 \mathrm{ft}-9$ in. long, and has a capacity of $1,040,800$ lb per hr.

The feed water leaves No. 3 heater and is then forced through No. 2 heater, where its temperature is raised from $303 \mathrm{~F}$ to $382 \mathrm{~F}$.

No. 2 heater is a vertical shell and tube heat exchanger also manufactured by the American Locomotive Company. The shell is $441 / 4$ in. ID by $23 \mathrm{ft}-91 / 2$ in. long and contains $1,200,3 / 4$ in. No. 18 BWG tubes each $18 \mathrm{ft}-9$ in. long.

The feed water leaves No. 2 heater and is then forced through No. 1 heater where its temperature is raised from $382 \mathrm{~F}$ to $425 \mathrm{~F}$.

No. 1 heater is also a vertical shell and tube heat exchanger built by American Locomotive Company. It is $441 / 4$ in. inside diam by $19 \mathrm{ft}-3$ in. long and has $1,238,3 / 4$ in. No. 18 BWG tubes each $14 \mathrm{ft}-8$ in. long.

The feed water is drawn from No. 1 heater by the secondary boiler feed pump suction and is discharged into the boiler feed header at 2,300 psi. Feed water control valves regulate this pressure to $1,400 \mathrm{psi}$ at each boiler and admit make-up water through the economizer to maintain constant boiler drum level in boilers Nos. 3 and 4, thus completing the steam and condensate cycle for unit No. 2.

The Unit 2 turbine requires a flow of $104,000 \mathrm{gpm}$ of cooling water through main and house unit No. 2 condensers. This quantity is circulated through the condenser water tubes and out to three Foster Wheeler Corporation induced draft cooling towers through a pipe 72 in in diam. An 80 in diam pipe returns this water to the circulators after the heat has been released by evaporative cooling.

The evaporative effect required to release the heat at the cooling towers amounts to approximately $11 / 2 \%$ of the water circulated, or 1,110 gpm for unit No. 1 and 1,560 gpm for unit No. 2. The hardness residue left behind by evaporation causes a hardness concentration buildup in the circulating water and blowdown facilities eight in. in diam are provided to blow approximately $1,000 \mathrm{gpm}$ from each system to the sewer. This water loss is constantly being replenished to the individual systems from the 750,000 gallon raw water storage tank, the flow being regulated by Republic Flow Meter Company level controllers located at each of the cooling tower suction wells. These controllers operate one $12 \mathrm{in}$. diam butterfly make-up valve for each unit and inject metered make-up water into the respective systems at the point where the return water pipe enters the building.

\section{D.1.3 Emergency Power}

\section{D.13.1 125 Volt d-c System}

125 volt d-c power for controls, alarms, motor operated valves and emergency lighting is provided by the station storage battery located in a battery room in the northeast corner of the building on grade 400.0. This battery consists of 60 chloride cells, Exide type FM-17, rated $640 \mathrm{amp}$ hrs (8 hr rate).

Two Electric Products Company motor generator sets comprising $40 \mathrm{hp}$ induction motors for 440 volt, 1,750 rpm service, $25 \mathrm{kw}$ diverter pole generators for 140 volt d-c service are located adjacent to the battery room and are used for battery charging. 
D. 2 , HUMBOLDT BAY FOSSIL FUEL POWER PLANT UNITS 1 AND 2

1. PIAINI DESIGI

\section{SECTION INDEX}

A. Locetion

B. Design Summary

C. Steam Design Conditions.

D. Heat Balences and Performence Curves

\section{REFFEREITCE DRAKINGS}

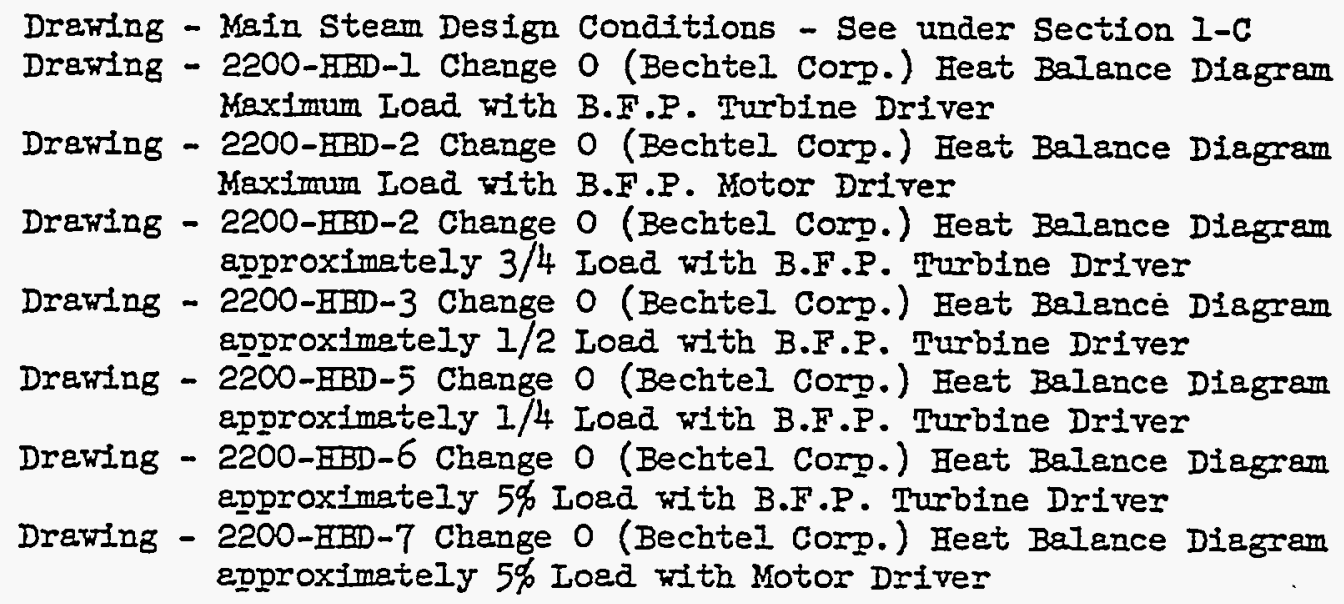

\section{A. Iocetion}

The site of the Eumbolat Bay Steam Power Plant consists of 137 acres of land located on Buhne Point epproximately three miles south of the City Iimits of Eureka, Fumboldt County, California.

The property lies northwesterly of the Northwestern Pacific Railroad and occupies aII of Buhne point except the King SaImon resort area. The northerly boundary is on the main ship channel of Humboldt Bay. An arm of the property extends southwesterly to the Field's Ianding navigation channel.

Terrain varies from submerged and low tidal land protected by dikes and tiaje gates to $a$ high precipitous bluef along the northwestern boundry. Elevations range from approximately $-30^{\prime}$ to $+75^{\prime}$ based upon a datum of. mean sea level.

The ground floor level of the Power bullding is at elevation +12 and the natural 12' contour passes through the plant location. The switchyard is located on filled ground. General characteristics of the site and its development are shown as a frontispiece to this volume.

\section{B. Design Sumery}

\section{Connection to system}

Power is generated at $13.8 \mathrm{kv}$ and carried thru insulated cabie generator 


\section{B. Design Sumary}

Connection to System (Con't)

leads to open bus work furnishing the main transformer low voltage connections. The transformer bank steps the voltage.up from $13.8 \mathrm{kv}$ to 60 (nominal) $\mathrm{kv}$.

Power is then supplied to the Pacific Gas \& Electric Company's $60 \mathrm{kv}$ power transmission system serving the Humboldt Bey area. Three transmission Iines leave the steam plant's $60 \mathrm{kv}$ bus switching station. One Iine terminates at the Humboldt substation southeast of Eureke. Another Iine terminates at the Bridgeville substation after serving several substation taps along the way. The third Iine terminates at Humboldt Junction where It may be connected to either of two IInes between the Humboldt substation and Station $\mathrm{E}$ at Eureka.

AII three Iines are protected by high speed Impedance relays and the station control system is arrenged to provide testing, reclosing and similar leatures as used in Pacific Ges \& klectric Company's standara autometic substations.

The circuft breakers are rated to interrupt 1,000,000 kve.

Auxiliery power is provided through elther of two house transformers, one belng connected to the $13.8 \mathrm{kv}$ bus and the other to the $60 \mathrm{kV}$ bus. AII plant auxiliaries operate at 2300 volts or 480 volts.

Rating and Capability of Principle Equipment

The present plant Unit No. I consists of a steam generator and its associated equipment serving a turbine generator and its associated equipment. The station unit has a nominal rated generating capacity of 50,000 kilowatts.

Principle equipment for the plant is rated at the following continuous operating conditions:

\begin{tabular}{|c|c|c|}
\hline Numioer Per Unit & Equipment & Rated Capacity \\
\hline 1 & Steam Generator & $\begin{array}{l}475,000 \mathrm{Ib} / \mathrm{hr} \text { steam at } \\
900 \mathrm{psig} \text { and } 900^{\circ} \mathrm{F} .\end{array}$ \\
\hline$I$ & Turbine Generator & 50,000 kilowatts \\
\hline 3 & Main Transformers & $\begin{array}{l}\text { Iow voltage }-13,800 \\
\text { delts } \\
\text { High voltage - } 36,400 / \\
63,000 \text { grounded- wye } \\
13,330 \text { kva self-cooled } \\
17,777 \text { kva forced air cooled } \\
22,220 \text { kva forced oll - } \\
\text { air cooled }\end{array}$ \\
\hline
\end{tabular}




\section{B. Design Summary}

Rating and Capability of Principle Equipment (Con'd)

At meximum plant load (corresponding to guaranteed maximum turbine throttle plow) the expected total plent generation is approximately 54,500 kw grose and 53,100 kr net. To allow for manufacturing tolerances the turbine is designed for a throttle flow 5\% greater than the guaranteed flow. With the plant operating at this design load, it is estimated that the total gross generation will be $56,000 \mathrm{~kW}$.

Design Conditions

Two transmission lines normally supply the power used in the Humboldt area and therefore, the power plant is designed as backup capacity for these Ines, which are subject to unavoidable outages as a result of the severe winter weather conditions to wish they are exposed. The basic design of the present single boiler-turbine installation provices for the plant to operate normelly at 5\% load and to Increase to maximum load in two minutes In case of the loss of etther one of the two transmission lines. In case of the loss of both transmission Iines the plant is designed to automatically increase to maximum load in three seconds.

In order to obtain the required fast load pickup of the plant, the boller arm accumlative capacity is utilized. Throttle pressure at the turbine varles Iinearly with steam flow from $1050 \mathrm{psig}$ at $5 \%$ loed to 850 psig at maximum guaranteed throttle flow. During fast load pickup conditions the required throttle pressure of the turbine drops causing the boiler arm water to flash into steem thus providing the necessary flow to the turbine until the combustion control can accuate the fuel valves and bring the heat releese in the furnace up to the necessary high load condition.

In order to maintain maxinim plant capability during upset electrical conditions $a 11$ essential electric motors in the plant as well as their oriven equipment are designed to carry full plant load with the system electrical frequency at $90 \%$ of normal and/or the voltage at $65 \%$ of norme?.

In order to provide meximum electrical porer output during peak station requirements one of the boiler feed pumps is driven by a steem turbine driver. This steam turbine driven pump is normaily the operating unit with the motor driven unit a spare.

For the purpose of economic evaluations in the design of the plant the following loed distribution was assumed.

Ioad

$50,000 \mathrm{kw}$

25,000 kw

$2500 \mathrm{~kW}$

Outage
Duration of time

$10 \%$

$25 \%$

$50 \%$

工5\% 


\section{B. Design Sumary}

Design Conditions (Con'a)

The following economic evaluation factors were used:

Bnergy Charge
Capitalization
Capacity cost

Main Turbine Generator

\author{
3.0 mils per kwhr \\ $13.5 \%$ \\ $\$ 75$ per $\mathrm{kw}$
}

The turbine generator manufactured by the Westinghouse Electric Corporation, is a 3600 rpm tandem compound, dovble llow, condensing, non re-heat, non-automatic extraction turbine directly connected to a 2 pole, 3 phase, 60 cycle, $3600 \mathrm{rpm}$, 13,800 volt hydrogen cooled generator. At rated throttle flow the turbine is designed to operate with $850 \mathrm{psig}, 9000 \mathrm{~F}$ steam and with 1-I/2 Inches of mercury absolute exhaust pressure. Field excitation for the generator is supplied by a shaft driven exciter and controlled by a static voltage regulator through a megnetic emplifier.

Steam for the turbine is condensed in a double path, cross flow surface condenser haping $27,500 \mathrm{sq}$. Pt. of eifective surface. Cooling water is supplied through an intake canal from Humboldt Bay and after passing through traveling screens is pumped by two circulating water pumps operating in parallel through inlet pipes to the main condenser. Cooling water leaving the condenser is returned to the Bay via discharge pipes and a canal.

\section{Auxiliery Power System}

Power for the plant axiliaries is suppliea by the main turbine generetor through 3 phase transformers and a 2400 volt bus system. Power is distributed from the bus system to the varlous auxiliaries at four voltage levels: 2400 volt, 480 volt, and $120 / 208$ volts. Power at 480 volts and $120 / 208$ volts is reduced from 2400 volts first by 3 phase transformers to 480 volts, and secondly, from 480 to $120 / 208$ volts by lighting transformers.

An alternate source of 2400 volt power for operation of plant auxiliaries is aveilable through house transformer number two supplied directIy from the $60 \mathrm{kv}$ liner. Automatic transfer to this system is provided in the event of an emergency.

\section{Condensate and Feedweter Flow}

Feedwater for each unit is heated in five major stages by four shell and tube feed heaters and one direct contact steam deaerator. At maximm Ioad, feedwater temperature at the boiler inlet is approximately $424 \mathrm{~F}$. 


\section{B. Design Summary}

\section{Steam Generators.}

The draft system for the steam generator includes one forced draft fan, one induced draft fan, and one steel stack approximately $120 \mathrm{ft}$. high by $10^{\prime}-0^{\prime \prime}$ inside diameter. Combustion air entering each Ijungstrom preheater is semi-automatically regulated by the steam air heater and controller for cold end. corrosion protection.

Combustion and feedwater controls are pneunetically operated and provide for automatic and remote manual operation of the steam generator.

At low loads steam temperature control is achieved by introducing cold air into the rear of the furnace has much the same effect with respect to superheat temperature as has the utilization of gas recircuIation (see Pittsburg and Morro Bay Data Books). The cold air, furnished. by the forced draft fan and controlles: by a Bailey operated damper, has a blanketing effect on the rear water wall tubes, increases the fuel flow. due both to the necessity of heating the incoming air as well to the increased generating duty of front and side walls, increased furnace exit temperature, and increases the mass flow in the superheater section of the boiler thus improving heat transfer by virtue of increased gas velocity. The introduction of an automaticeliy controlled amount of cold air into the botiom of the furnace is somewhat unique in steam generator design and actual setting of control of this air with respect to desired final S.H. temperature will be determined by operating experience.

\section{Fuel System}

Fuel oil is delivered to the plant from ocean-going tenkers through a I4" fill Iine. The I4" 1117 line is sized to deliver a 1500 SSF viscosity oll at approximately 2000 barrels per hour after it is up to the pumping temperature of $155^{\circ} \mathrm{F}$. During perlods when the line is inoperative and when it is being brought up to temperature it is necessary to keep the line filled with a relatire light oil (650 SSU at the pumping temperature of $155^{\circ} \mathrm{F}$ ).

A fuel oil transfer system for transferring the oil from the 65,000 barrel storage tank to the 3000 barrel fuel oll service tank is provided and consists of rotary gear type transfer pumps and shell and tube heat exchengers.

Fuel oil from the service tank is supplied to the boiler through positive displacement primary pumps and through a secondary heat exchange and pumping system. 


\section{B. Destgen Summery}

The heating system in the secondary fuel oil circuit consists of in tube type fuel oil heaters supplied with heaing steam from a closed circuit reboller system ihich in turn receives its heating steam from the 142 psig auxiliary steam system.

The quantity of oil admitied to the boiler is automatically regulated by recirculation control which, operating in response to the combustion control signal, sets the secondery system pressure.

A light oil tank and punp is providen for the start up of the boiler and for purging the heavy oil lines when they are not in use.

A Propane tant and reducing vaive provides the necessary gas for the ignitors at the burners.

\section{Miscelianeous Services}

Hater for the fire water system, the domestic water system, and for the bearing lubrication of the circulating weter pump is furnished from the fresh water tanks. These taniss in turn ere supplied from the shallow well pumps. A comestic water booster pump provides the necessary pumping power for the domestic water systex and a main and spare fire pump are provided for the fire trater system. Water for the bearings of the circulating water pums flows by gravity from the fresh water tanks.

Water for the gland sealing water system flows by gravity from a gland seal supply tank, filied by the rein comdensate pumps, to the turibine gland seal and the Dump shaft seals. Ireak off from the turbine shaft and from some of tine pumps is returzed to a gland seal return tank for discharge to heater Ho. 5 .

The plant cooling wate: system utilizes chemically treated distilled water which is pumped in a closed system frow two cooling water pumps, one of which is a spare, to the unt requiring cooling. The pump are mounted in a concrete pit and the water is returned to this pit after cooling the units. Circulating water srom the main circulating water pumps is discharged through either of two full capacity heat exchangers utilized for cooling tine closed distilled water system.

An interconnected serrise and instzment air system ts provided. Tho $230 \mathrm{scfm}$ air comaressori and gftercoolers serve this system. Instrument air is distributed from the instmment air secelver through an air aryer at several pressure levels. Air for the service air system is removed from the service air receiver and distributed at a pressure level of 100 psig.

A continuous by-pass lubrication cil filter system is provided for the main turbine. A clean and dirty lube o:l storage tank and a transfer oll pump are also profided. Provision is mane for the installation of a portable centrifuge at strategic locations. 
SECTION INDEX

A. Steam Generation - General

B. Steam Generator

Boiler and Furnace

Predicted Performence Deta

Performence Curves

Superheater

Ijungstrom Afr Preheater

Safety and Power Relief Valves

Burmers and Igniters

Soot Blowers

C, Fans - Forced and Induced Draft

D. Steam Air Heater

E. Pumps

Boiler Test Pump

- Distilled Hater Transfer Pump

Dist1lied Hater Transfer Punp Performance Curves

F. Tenks and Vessels

BIow-off Drum

Chemfcal Hixing Tank

Chemicel Injection Dmm

G. Burner Cleaning Station

E. Combustion \& Feedweter Controls

\section{REEERREMCE DRAFIINGS}

Drewing 54223-R, Chenge 2, P \& I Diegrem - Boller

Drawing 54221-R, Change 2, P \& I Diagram - Steam \& Condensate

Drawing 54225-R, Change 2, P \& I Diagrem - Fuel Oil

Drawing 54226-R, Change 2, P \& I Diagram - Compressed Air

Drawing 7O43F (B. \& W. Co.) Sectional Side View, Boiler Arrangement

Drawing 22898E (B. \& W. Co.) Arrangement of Primary Superheater

Drawing 32184E (B. \& W. Co.) Arrangement of Secondary Superheater

Drawing A-232141 (Air Preheater Corp.) General Arrg't. Ijungstrom Atr Preheater

Drawing A-24386-D (Feabody Fingr. Corp.) Type E-26 Burner Assembly

Drating Fig. AP-7, Seçt. 5 (Diamond Pwr. Specielty Corp.) Soot Blower

Air Control System

Drawing K-17921 (American Blower Corp.) \#675 American "H.S." Forced Dreft Fan

Drawing 60-A-6322 (Hestinghouse Elect. Corp.) \#2073 H.D. Fạ, 2/3 D.W.D.I. (I.D.)

Drawing 3779 (Walter R. Cole \& Co.) Boller Blow-Off Mank

Drawing E-5022419 (Bailey Meter Co.) Combustion \& Feedwater Control.Dia.

\section{A. Steam Generation - Generel}

\section{Steam Generator}

For steem generation there is installed one two-drum type Babcock \& H1lcox Company Unit, rated at $475,000 \mathrm{lb} / \mathrm{hr}$ and designed for a maximum continuous gene, at in 9 Ing capacity of 533,750 lb/hr for all purposes, including auxiliary steam requirements, with conditions at the superheater, outlet of 498,750 I0/hr steam 1 low, 900 


\section{A. Steam Generation - General}

psig and 900 FIT, with feedwater at $420 \mathrm{~F}$ and an entering air temperature of $80 \mathrm{~F}$, burning oil fuel. The unit is comprised to two-drum boiler section, water-cooled furnace, continuous tube two stage pendant convection superheater, a Ijungstrom regenerative type air preheater and Peabody mechanical atomizing oil burners. The unit is equipped with Diamond retractable soot blowers, airdriven, using steam as the blowing medium. For controling superheated steam temperature a B \& $F$ spray type attemperator and a cold alr connection at the rear of the furnace is provided.

The entire unit is top supported from a structural steel framework designed to carry all loading to which the unit may be subjected, including all Iive and dead loads, platform loads, earthquake and wind loads. The boiler section consists of a $72^{\prime \prime}$ I.D. Helded steam drum, $3 I^{\prime}-0^{\prime \prime} 10 n g$, of $6-7 / 16^{n}$ and $3-7 / 16^{n}$ shelI plate thickness and a lower drum 42" I.D., 24 '-0" Iong, of 3-9/16" plate thickness, the drums connected by 1,617 generating tubes $2-1 / 2^{\prime \prime} 0 . D$. swage to $2^{\prime \prime}$ O.D. and expanded into the drums. The pressure parts are designed for 1,125 psig, drum plates of 70,000 psi T.S. Heating surface of the boiler section is $19,481 \mathrm{sq}$. ft.

The steam drum is fitted internally with $36-14^{\prime \prime}$ dia. by $27^{\prime \prime}$ high cyclone type steam and water separators for the circulation system and a steam beffle, Type TB Scrubber, $28 \mathrm{ft}$. long, designed to pass high purity steam with less then $I$ ppm of solids cerryover. Boiler water is introduced directly Into the drum through an $8^{\prime \prime}$ internal perforated feed pipe. Chemical feed and continuous blowdown connections are also provided in addition to the usual drum mountings. The steam drum water level is indicated by Yarway illuminated water gages and may be observed at the firing floor through a combination of mirrors. The level is also indicated, recorded, controlled and high and low level annunciated on the instrument boord. At normal operating level the boiler holds approximetely 179,000 lb. of Hater.

The water holaing capecity and the operating pressure of the boiler is utilized in providing the quick pick up feature of the plant. At minimum plant loads the controlled throttle steam pressure of the turbine is 2050 psig. This controlled pressure drops linearly with load to 850 psig at maximum plant load. As plant load picks up rapialy (by reason of 2 power linebreals) from minimum to maximum, the required turbine throttle pressure drops to $850 \mathrm{psig}$. The stored water in the boiler (which before the Ioad increase was at a temperature level corresponding to $1050 \mathrm{psig}$ ), is therefore free to expand and to flash into steam at the lower pressure. The flashed steam provides the necessary capacity for the turbine to pick-up to maximum Ioad in 3 seconds (see Turbine-Generator Section of Data Book), and to maintain the load until the furnace fires are increased by combustion control to the necessery heat release.

The furnace is completely enclosed by water-cooled walls of the plain tangent-tube type. Water supply to the walls is taken from the lawer drum through downcomer tubes connected to the lower headers. Discharge tubes connect the upper sidekall headers to the steam drum. All wall tubes, supply and discharge tubes are field welded to stubs in the headers which were installed in the factory. Tube connections into the arums are expanded into grooved tube seats. Each wall is iftted at the lower header with a drain connection and a blenked connection for acid cleaning. The furance rear well

NUREG/CR-6239

D-14 


\section{A. Steam Generation - General}

design provides for a future television installation for burner observation.

The furnace volume is approximately 16,200 cu. ft. and has a heating surface of $4,138 \mathrm{sq}$. ft. Studs for attaching plastic and insulation are welded to the tubes. A system of buckstays, tie bars and guides provide support for the water walls with full allowance for expansion movements.

The superheater is of the continuous tube type designed for a pressure of 1,125 psig. With an operating pressure at the outlet of $900 \mathrm{psig}$ and a temperature of $900 \mathrm{FTT}$. The superheater is divided into two pendant non-drainable sections, a primary and a secondary section, with the tubes connected to headers located outside and above the furnace roof tubes. The primary section recelves saturated steam from the steam drum through connecting tubes. After passing through the primary section the steam enters Into a cross-over pipe, wherein is located the spray attemperator, and thence into the secondary section. On leeving the secondary section the . steam is conducted through the main steam line to the turbine.

Steam temperature at the superheater outlet is controlled by regulating the flow of attemperator spray water and by introducing cold air into the rear of the furnace. The cold air-by-pass damper will be open at low boller ratings and then close off as soon as the superheat set point has been reached. At higher boiler ratings the attemperator water valve opens to admit spray water to hold constant temperature. A single spray type desuperheater provides the attemperation necessary to meintain the steam temperature at $900 \mathrm{~F}$ at the superheater outlet. The spray nozzle discharges feedwater into the steam and is of the Venturi type equipped with a thermel sleeve to insure mixing and to prevent thermal shock in the pipe wall. The amount of spray water added to the steam attemperators is regulated by temperature controllers, actuating regulating valves through the combustion control system. For curves of superheater performence and desuperheater spray water requirements see Section 2.B.

Combustion and feedwater controis (described in Section 2.H) are pneumatically operated and provide for automatic, remote and menual operation of the steam generators. Control boards with their associated instruments are located adjacent to the boiler on the firing floor.

Safety valves required for the protection of the boiler and superheater are provided. The drum and superheater valves are of the Consolidated Maxiflow type; in addition there is installed an auxiliary electrically operated relief valve mounted on the secondary superheater outlet header. This valve is set to open automatically due to a preset pressure signal from either the superheater outlet or the steam drum and may also be manually opened by closing a switch at the control panel. The valve functions as a purging device and also acts to prevent the main safety valves from lifting except on major over-pressures. The power control valve, as it is 


\section{A. Steam Generation - General}

generally called, is a Consolidated Blectromatic Relief Valve, Type 1533D. An Edward Fig. 15II-Y-A shut-off valve with a by-pass is installed between the Blectromatic valve and the header to facilitate meintenance. Safety valve capecities and settings are included in the data under section 2.B.

\section{Soot Blowing System}

The soot blowing equipment consists of 7 Diamond Power Specialty Corporation Type IK retractable blowers, driven by air motors, of which 4 are located in the boiler section and 3 in the superheater section. Frovision is made for 2 additional future blowers in the superheater section should they be re.quired. Blowing steam is taken from the primary superheater outlet header and reduced to 600 psig through a pressure reducing valve. A safety valve is provided to protect the blowing line from over-pressure. The Ijungstrom alr preheater is equipped with a steam cleaning derice in the gas outlet duct and a combination steam-keter cleaning device in the gas inlet duct, both using steam from the soot blower header through a branch line.

A Diamond automatic sequential air control system is provided to perforim all functions of operation from a central control panel. A blowing program is set up on the panel for the blowers to be operated and after starting the blowing cycle each blower lance in sequence is automatically inserted and retracted from the furnace. During insertion and retraction steam is blown from nozzles located at the end of the rotating lance. An alarm is provided to annunciate upon failure of power air or blowing steam. (See Steam Section 5 for precautionery notes relative to use of soot blowing steam).

Fuel Burning Equipment

The boiler is fired by 6 Peabody Engineering Corporation oil burners mounted in air registers and arrenged in a double tier of 3 each across the front of the windbox. The oil burners are Type BL, wide range, mechanical atomizing, set in Type H-26 insulated swing front air registers. The burners are equipped with a retracting gear of the rack and pinion type, Ensco swivel joints and Peaiody Type SI-I automatic gas-electric ignitors. (See also Section 3, Fuel System).

Draft and Air Preheating Equipment

One forced draft fan and one induced draft fan, each fitted with suitable control dempers, are provided to supply the air required in burning the fuel and for removal of the gaseous products of combustion. The forced draft fan draws air from outdoors and discharges the air through a steam type air heater located in the fan discherge duct and a regenerative type air preheater installed at the boiler gas flue outlet. The heated air then passes through secondary ducts, located on each side of the furnace, entering the windbox at each end where it is distributed to the separate air registers and thence into the furnace. Flue gas leaving the boiler section is passed through the gas side of the regenerative air preheater to the induced draft fan which discharges directly into a $10^{\prime}-0^{\prime \prime}$ I.D. by $120 \mathrm{ft}$. high steel stack mounted on a steel structure above the fan. 


\section{B. Steam Generator}

Steam Generetor Unft

Furnished by

Specification No.

Purchase Order No.

Number of Units

Location.
Bebcock \& Wilcox Co.

4404

23-3

1

Area 4, Elevation $+12^{\prime}-0^{\prime \prime}$

Equipment furnished under above contract:

One Boller with Water-Cooled Furnace.

One Frimary Superheater

One Secondery Superheater

One Attemperator with Controls

One I-jungstrom Air Preheater and Accessories

Six Peabody 011 Burners with Retracting Mechenism and Automatic Ignitors

Two Constant Differential Fuel Oil Pums and Motors. (Secondary Fuel 01I Pumps, See Section 3)

Seven Diamond Sootblowers, With Steam Reducing Station and Automatic Controls

Flues

Ducts

Boiler to Air Preheater

Air Preheater Outlet to Burners

Refractories and Insulation

Structurel SteeI Semports

Appurtenences, Sefety Valves and Fittings, Power Control Valve

Notes:

(1) All pressure parts are designed and constructed in accordance with the ASME Boiler Code, the Califormia State Boiler Safety Orders, the A.S.A. Code for Pressure Plping, Reguletions of the National Boerd of Fire Underwriters and other applicable codes.

(2) For data on Secondery Fuel Oil Pumps, see Section 3B. 


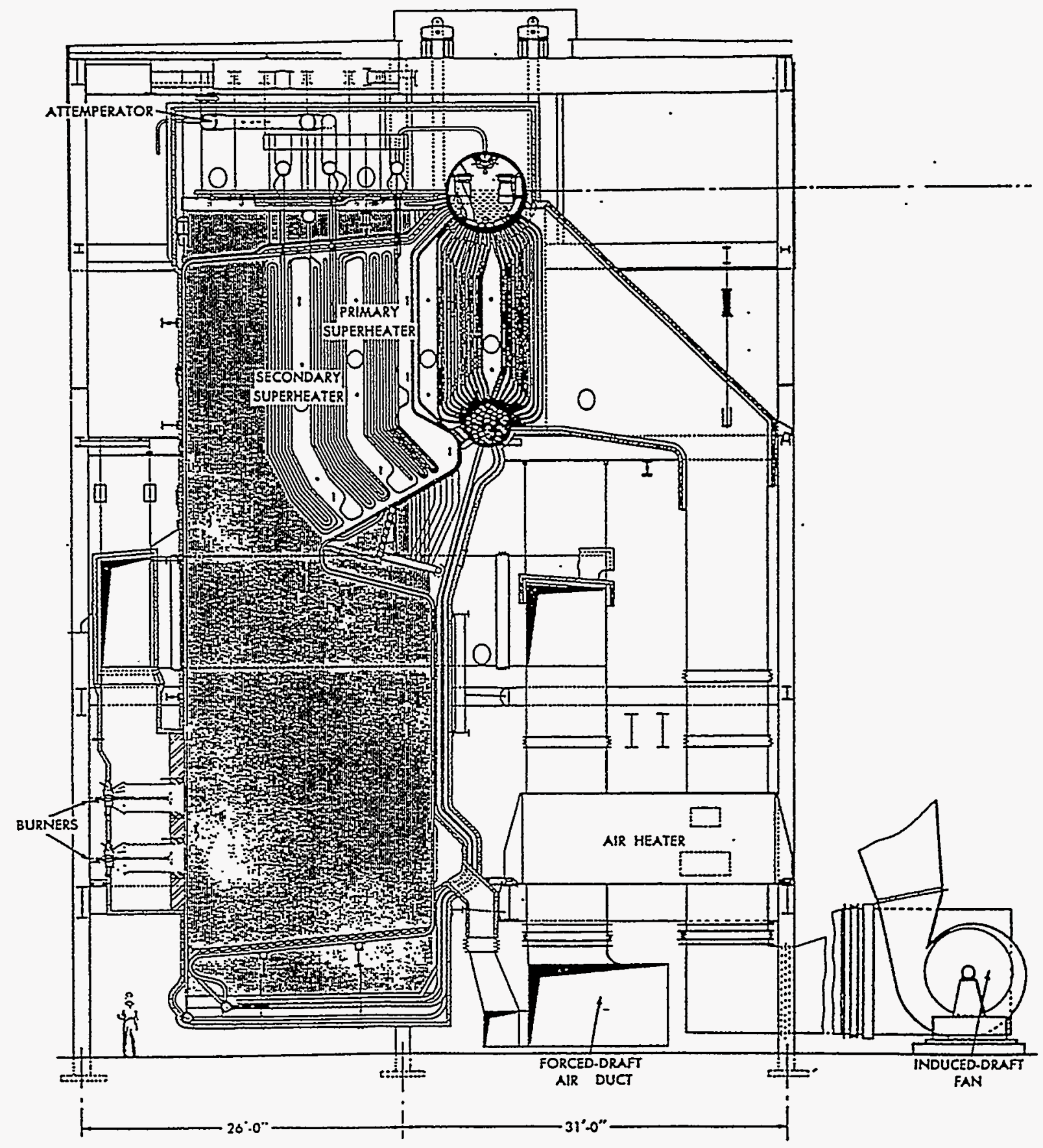

Figure D.1 PACIFIC GAS \& ELECTRIC COMPANY HUMBOLDT BAY STEAM PLANT BUHNE POINT, EUREKA, CALIFORNIA B \& W CONTRACT NO. S-989I 


\section{B. Steam Generator}

Boiler and Furnace

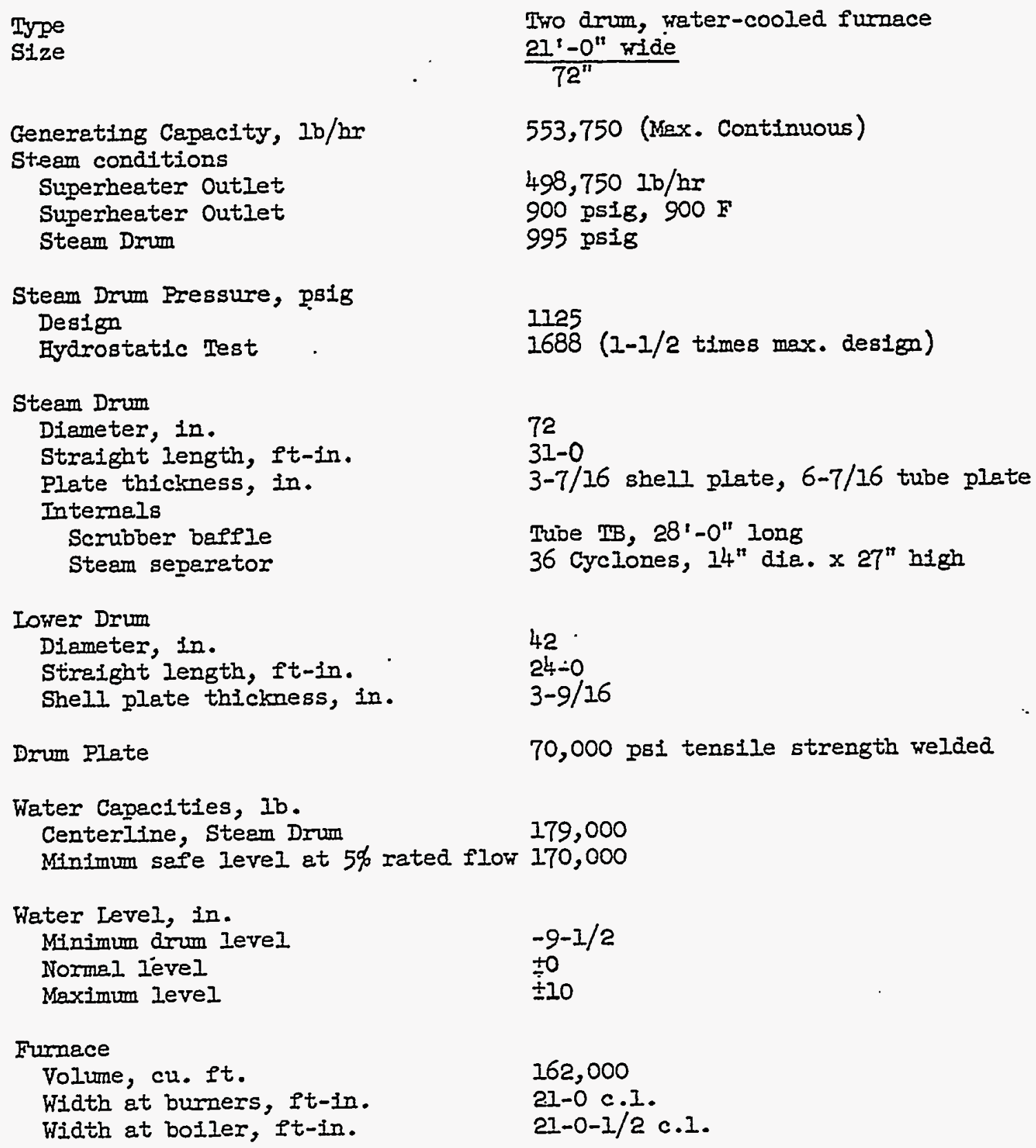




\section{B. Steam Generator}

Boiler and Furnace (Cont'd.)

Area

Sides

Front and furnace roof

Rear

Furnace floor

Total

'Heating Surface, sq. ft. Boiler

Water cooled walls

Total

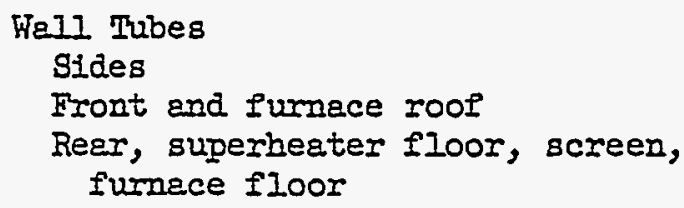

Water WaII Headers

Generating Tubes
Circulator Tubes
Supply
Discharge

Welghts, pounds

Boiler

Water cooled furnece falls

Casing (top vestibule only)

Structural steel

Baffle mix, Kaocast $K-20$

Refractory and insuretion see B\&W drawings 3I170E through 31119E

\section{Valves}

Safety

Continuous blowdown

Feedwater regulator

Power control

Steam sampling

Vent

Blowoff
Bare Tubes. Refractory Covered

1,580

1,328

815

4,138

415

19,481

4,138

23,619

158-3" dia. spaced $3^{\prime \prime}$ and $6^{\prime \prime}$

$83-3^{\prime \prime}$ dia. spaced $3^{\prime \prime}$ and $6^{\prime \prime}$

83-3" dia, spacea $3^{\prime \prime}$ and 6"

11-3/4" $x$ 1" thick for sides, front and rear walls

$1617-2-1 / 2^{\prime \prime}$ O.D.

$35-4-1 / 2^{\prime \prime}$ diem.. .220" thick

$50-3^{n}$ diem., . $150^{\prime \prime}$ thick

314,372

278,040

22,315

745,000

65,000
See Safety Valve section

$2-2^{11}$ Hancock 538EP

3 - I" Hancock 535EP

2 - I" Hencock 535EP

2 - I" Hencock 535파

3 - $1-1 / 2^{11}$ Hancock $537 \mathrm{EP}$

2 sets $1-I / 2^{\prime \prime}$ Yarway 398I-81 


\section{B. Steam Generator}

\section{PREDICTHED FERFORMANCE DATA}

Ioad Condition with Oil Fuel**

Steam at Drum Outlet

Steam at SH Outlet

FLOW

SH Desup. Spray

Feedwater

Air from FD Fan

Gas to ID Fan

Fuel

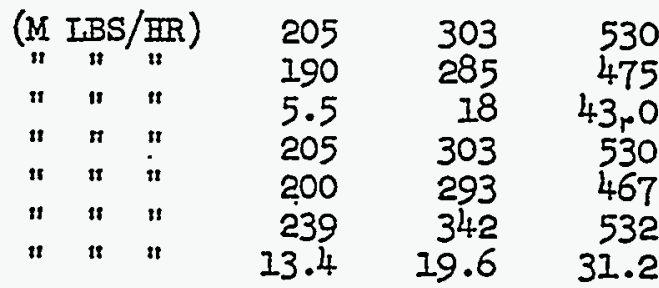

PRESS. Steam Drum

Superheater Outlet

$\begin{array}{llll}\text { (PSIG) } & 916 & 935 & 995 \\ & 900 & 900 & 900\end{array}$

Steam at SH Outlet

Feedwater

Flue Gas Entering AF

Temp. Flue Ges Ieaving AI (Uncorr.)

Flue Ges Leaving AH (Corr.)

Air Ieaving $\mathrm{AH}^{\circ}$.

Air Entering AB

$\begin{array}{crrr}\left({ }^{\circ} \mathrm{F}\right) & 900 & 900 & 900 \\ " & 340 & 370 & 420 \\ " & 595 & 630 & 710 \\ " & 282 & 304 & 350 \\ " & 262 & 285 & 330 \\ " & 489 & 496 & 528 \\ " & 80 & 80 & 80\end{array}$

Ducts, Dempers, Oxifice, SAH, Etc. :(INS. W.G.) $0.08 \cdot 0.13 \quad 2.83$

Air Heeter

AIR Burner

LOSSES (Iess) Furnace Stack Fffect

Steam Air Heater

Total

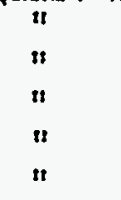

0.08
0.6
1.8
0.5
0.23
3.21

$1: 0$

2.2

3.5

7.9

0.6

0.6

Furnace

Boiler SH, RH, \& Econ.

DRAFT Air Heater

IOSSES Ducts, Dampers

Stack Effect (Boiler Back Pass)

Total

\begin{tabular}{|c|c|c|c|}
\hline $\begin{array}{c}\text { (IR. } \\
" \\
" \\
" \\
" \\
"\end{array}$ & $\begin{array}{c}\text { W.G. } \\
n \\
" \\
" \\
n\end{array}$ & $\begin{array}{l}0.1 \\
0.5 \\
0.5 \\
0.3 \\
0.2 \\
1.6\end{array}$ & $\begin{array}{l}0.1 \\
1.0 \\
0.9 \\
0.6 \\
0.3 \\
2.9\end{array}$ \\
\hline
\end{tabular}

Number of Burners in Use

Heat Release

Excess Air Ieaving Furnace*

(M BTU/FT $/ \mathrm{FR}^{3} / \mathrm{HR}^{2} \quad 15.3$

$6 \quad 6$

0.8

0.42

14.3

Efficiency Overall

(\%) 87.62

Total Allow. Aux. Steam: Drum Pri SH Outiet (M IBS/HR)

Max. Allowable Boiler Concentration

Solids in Steam

PFM 150

15

22.3

21

$87,4 ?$

18

35.6

36.72

55

* Based on 10\% excess air at burners.

** Type $\frac{11}{16} 6,18,500 \mathrm{BIU} / 1 \mathrm{~b}$. U.A. \% by wt. Ash 0.15, S 2.0, H2 10.0, C 86.2, $\mathrm{N}_{2}-\mathrm{O}_{2} \div .65$. 
Appendix E: Photographs Showing Typical Piping and Support Installations for the Power Plants Surveyed

\section{E.1 Piping Layouts}

In Figures E.1 through E.17 are shown typical small bore piping installations in the power plants surveyed which experienced strong motion earthquakes equal to or greater than $0.2 \mathrm{~g}$ ZPGA.

\section{E.2 Piping Support}

In Figures E.18 to E.68 are shown typical piping support installations in the same power plants. 


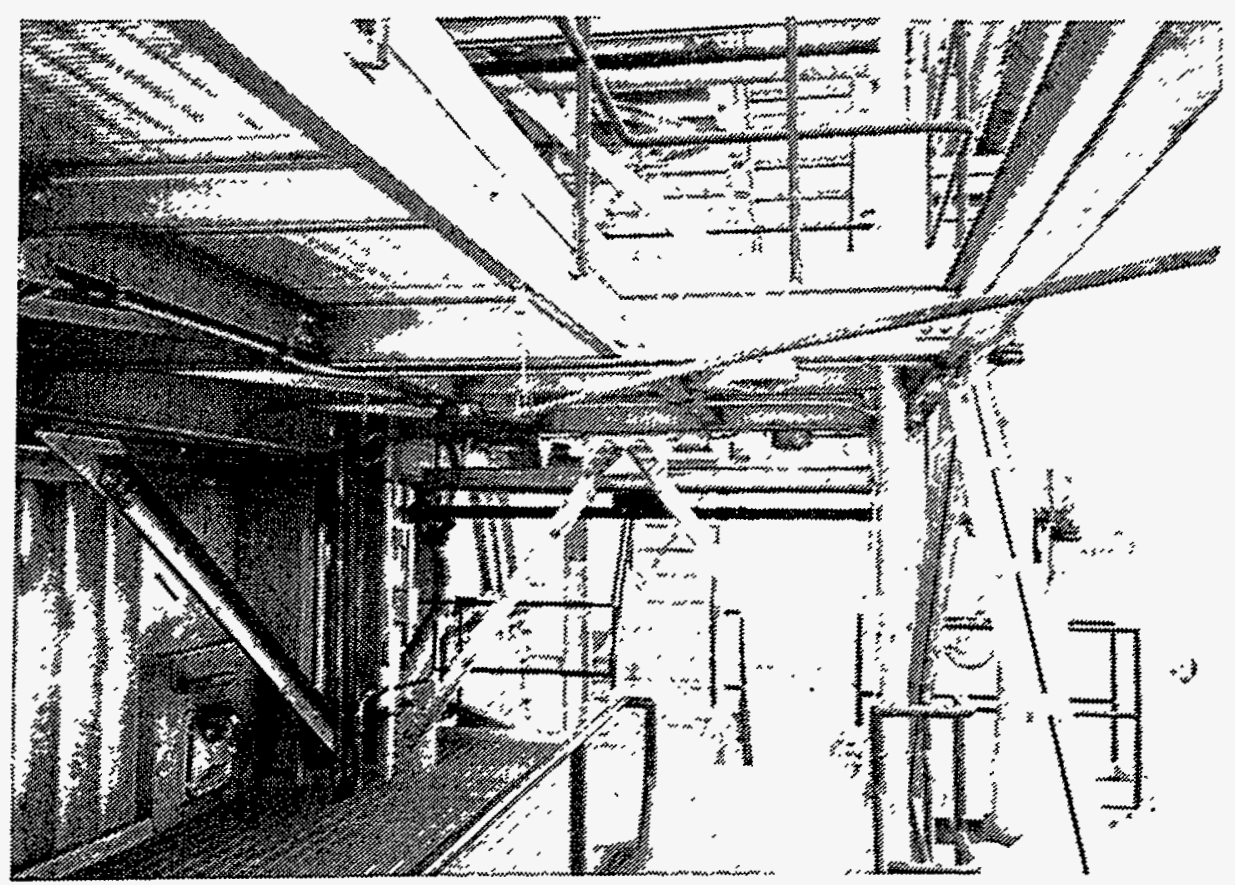

Figure E.5 Unsupported Small Bore Piping in El Centro Unit 1

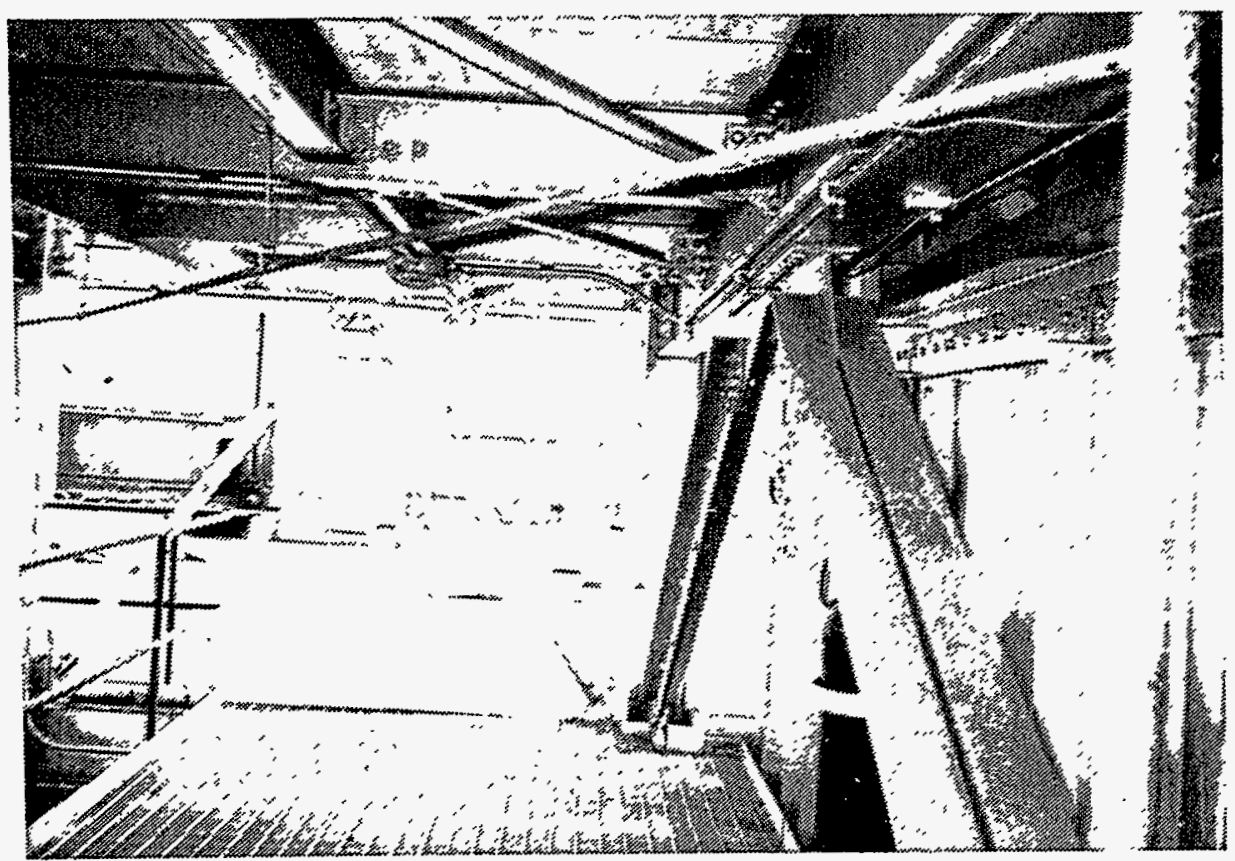

Figure E.6 Unsupported Small Bore Piping in El Centro Unit 3 


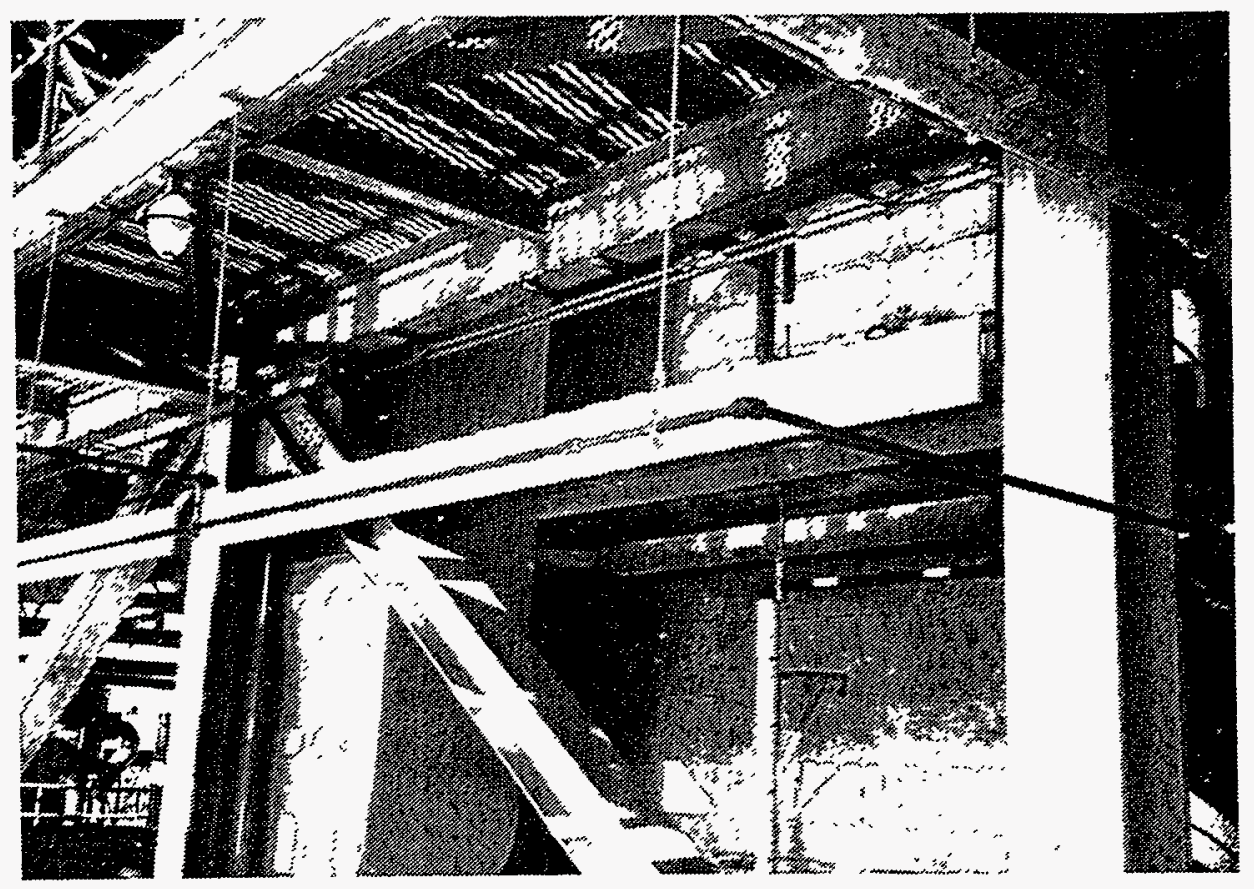

Figure E.7 Unsupported Long Span Small Bore Pipe in Valley Unit 3

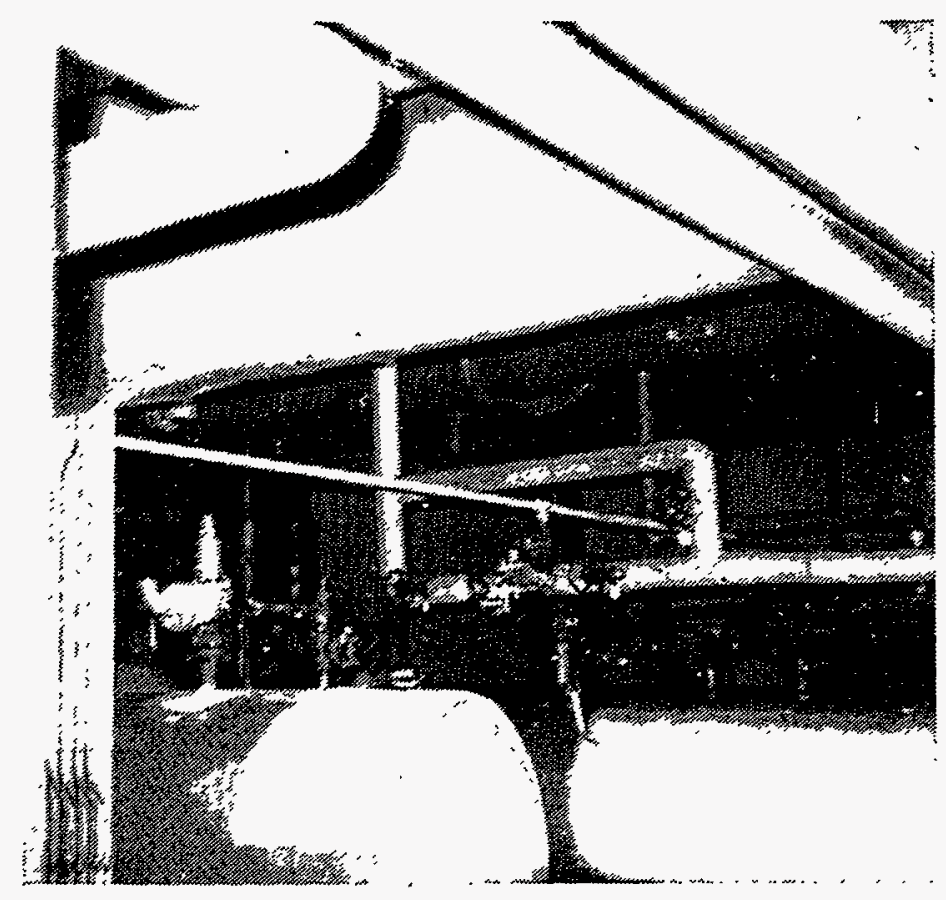

Figure E.8 Unsupported Small Bore Pipe in Olive Unit 2 


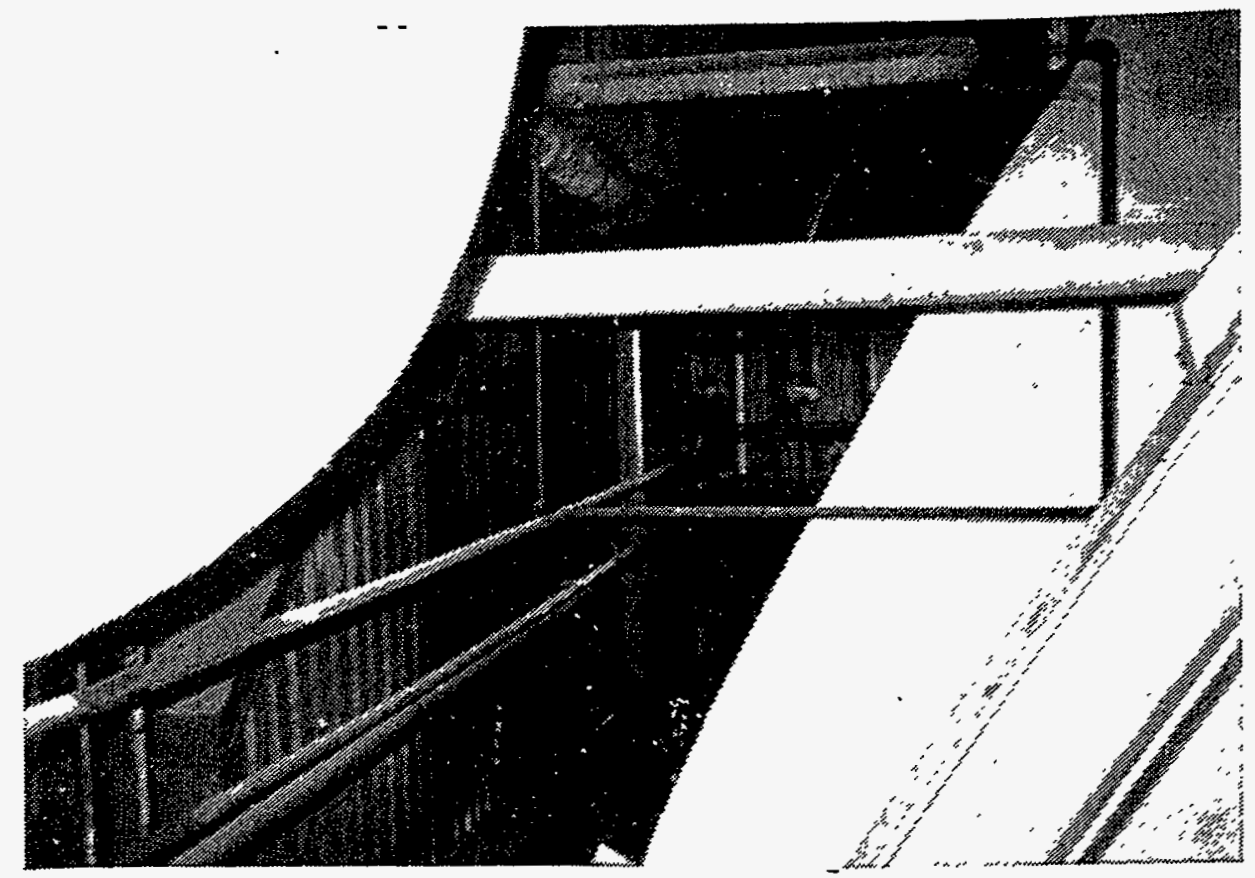

Figure E.9 Unsupported Small Bore Pipe in Magnolia Unit 3

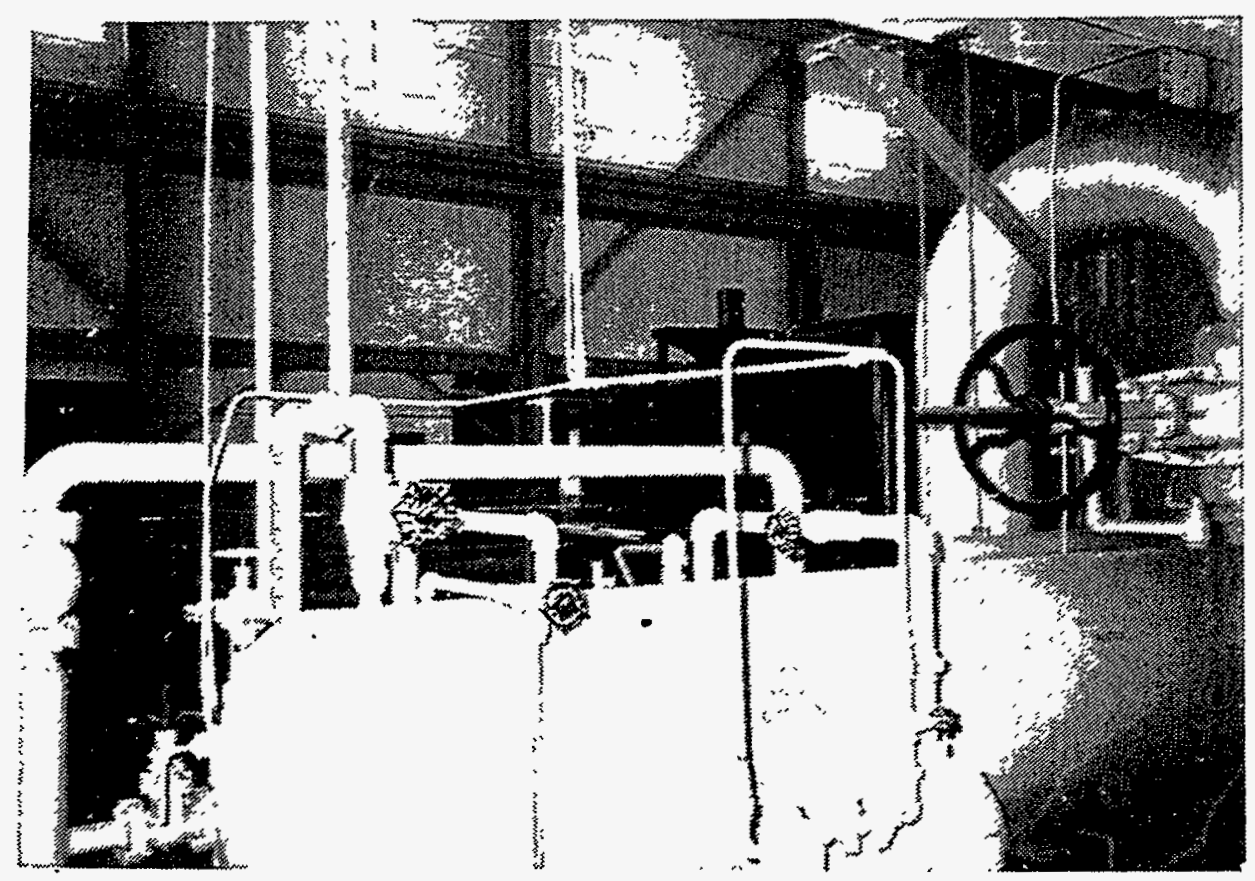

Figure E.10 Unsupported Small Bore Pipe in El Centro Unit 2 


\section{† 7!ष}

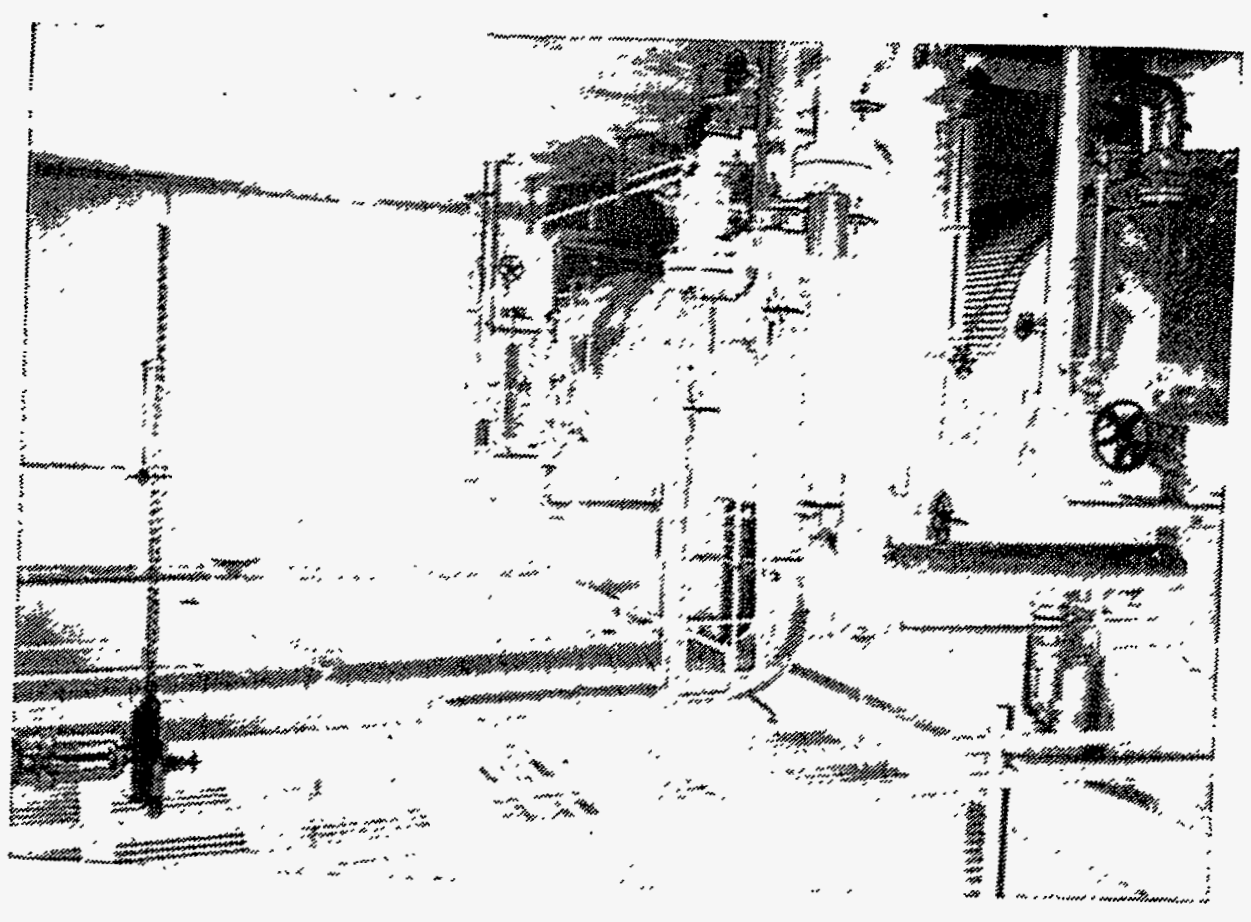


† भ!ณ

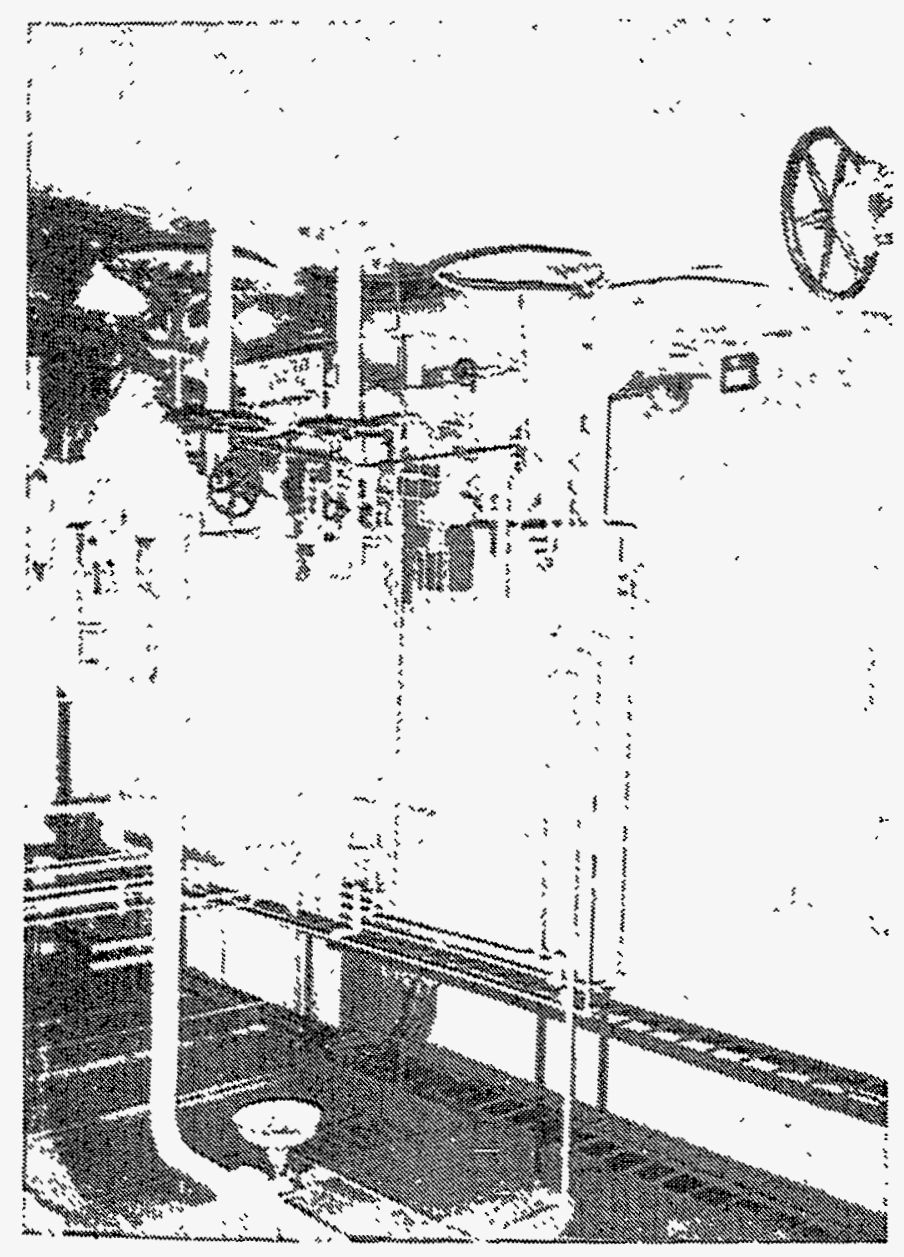




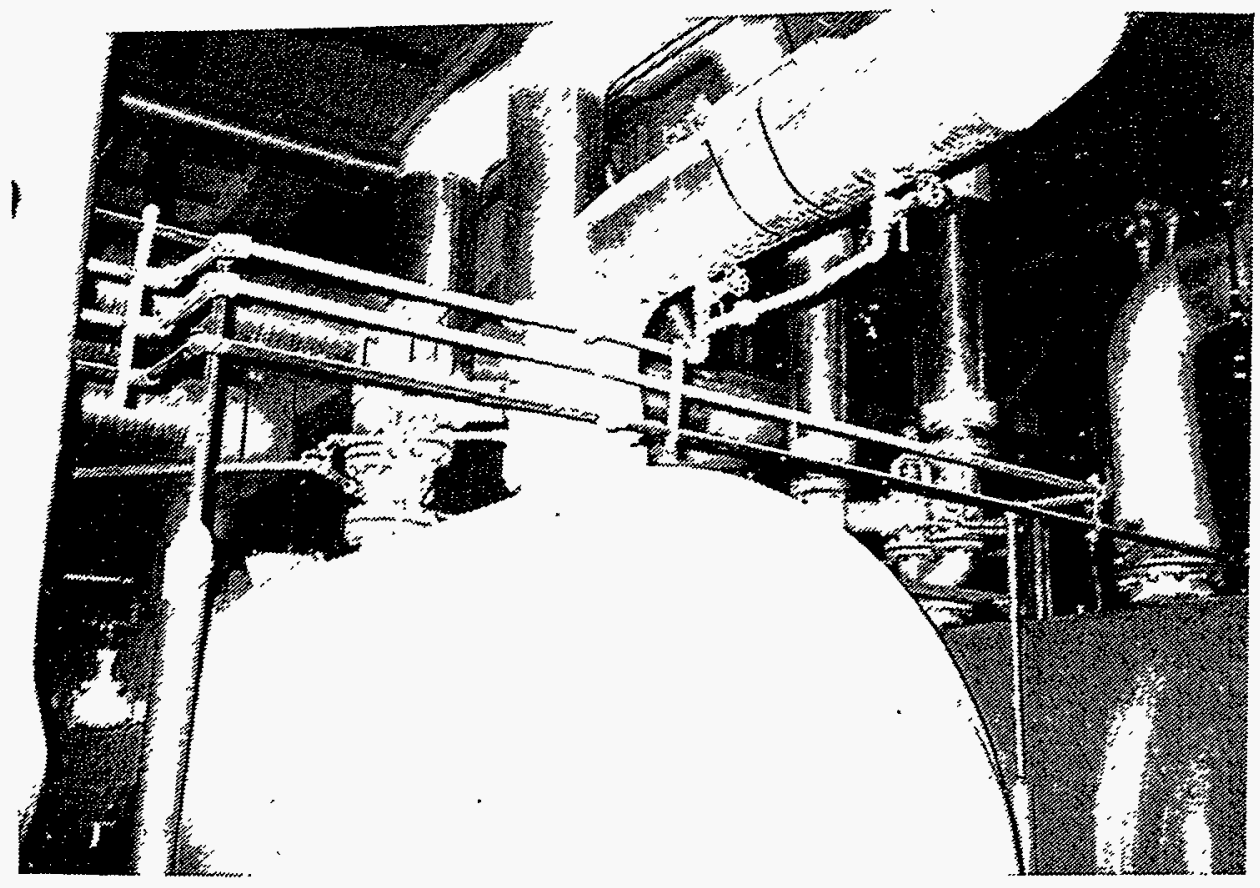

Figure E.13 Small Bore Piping Supporting Other Small Bore Pipe in Kern Unit 1

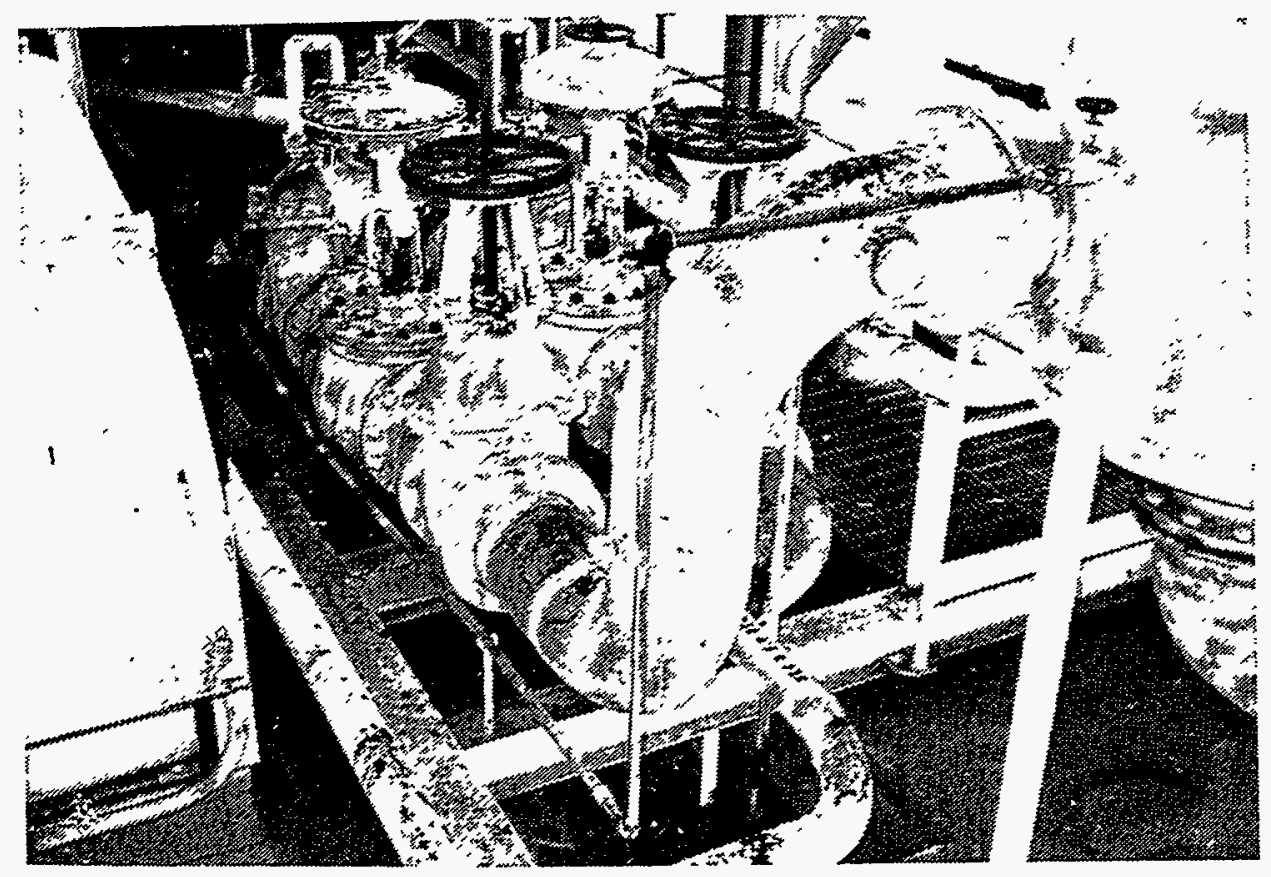

Figure E.14 Unsupported Small Bore Piping Kern Unit 1 


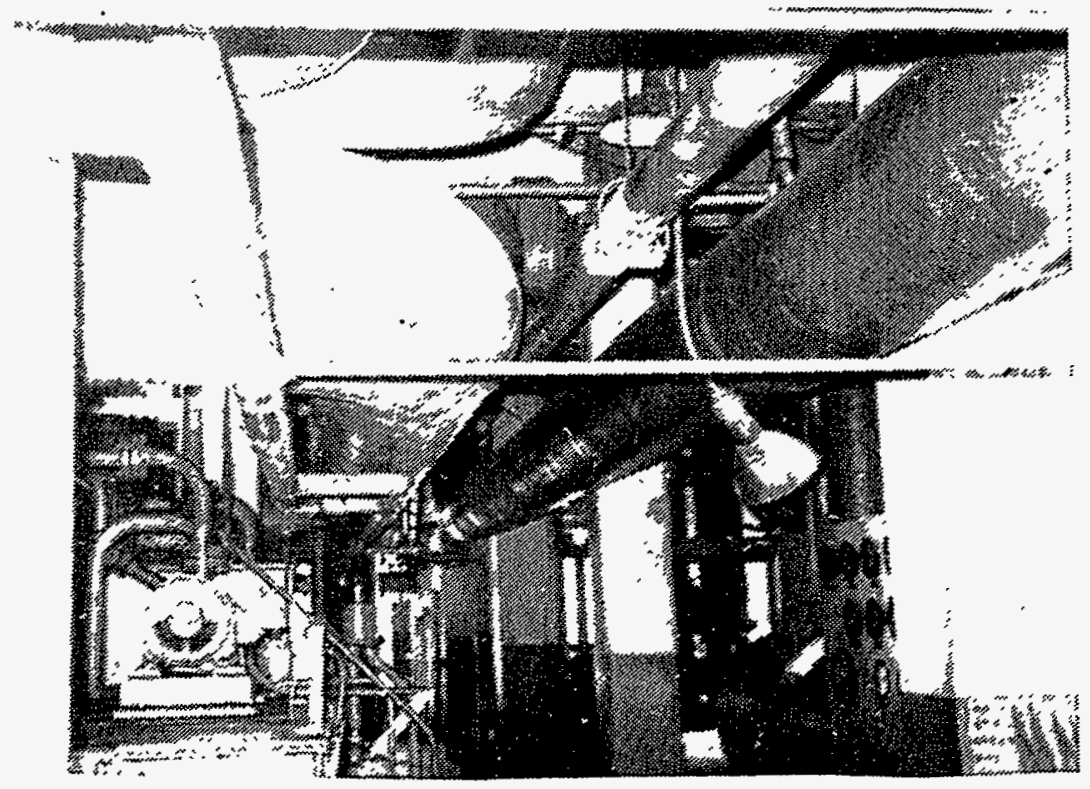

Figure E.15 Example of Non-Flexible Branch Line Connection in Olive Unit 2

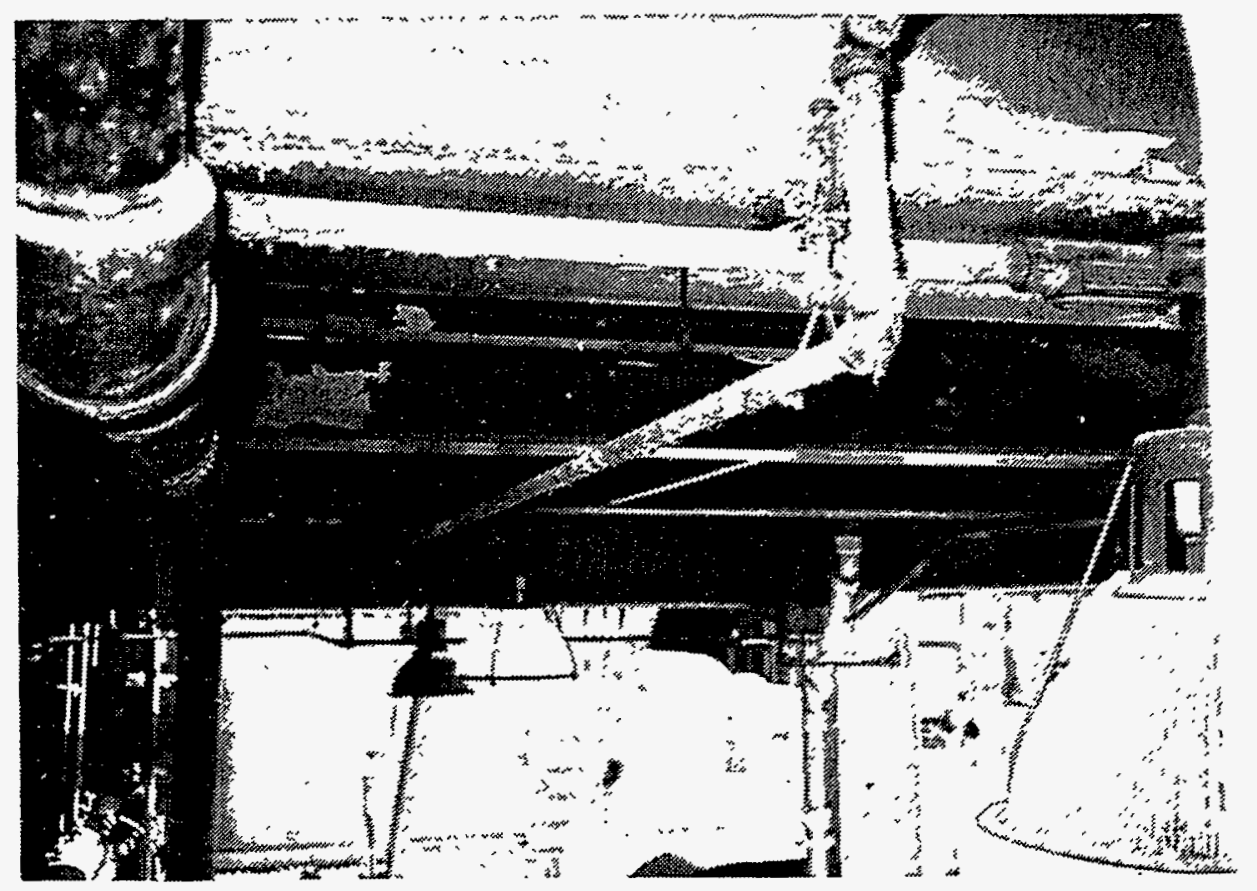

Figure E.16 Unsupported Corroded Bore Line in Valley Unit 3 

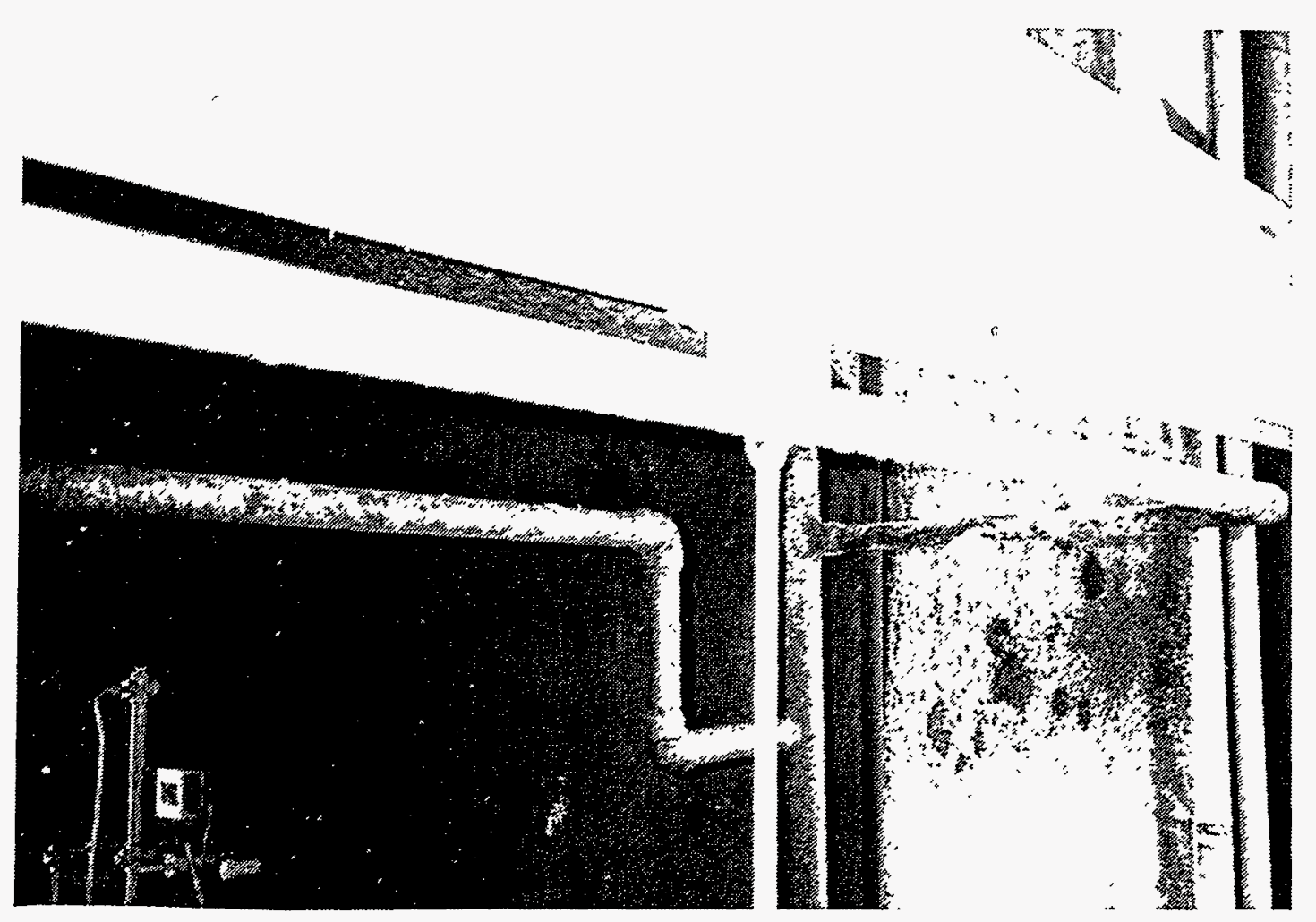

Figure E.17 Unsupported Corroded Small Bore Line in Humboldt Bay Unit 1

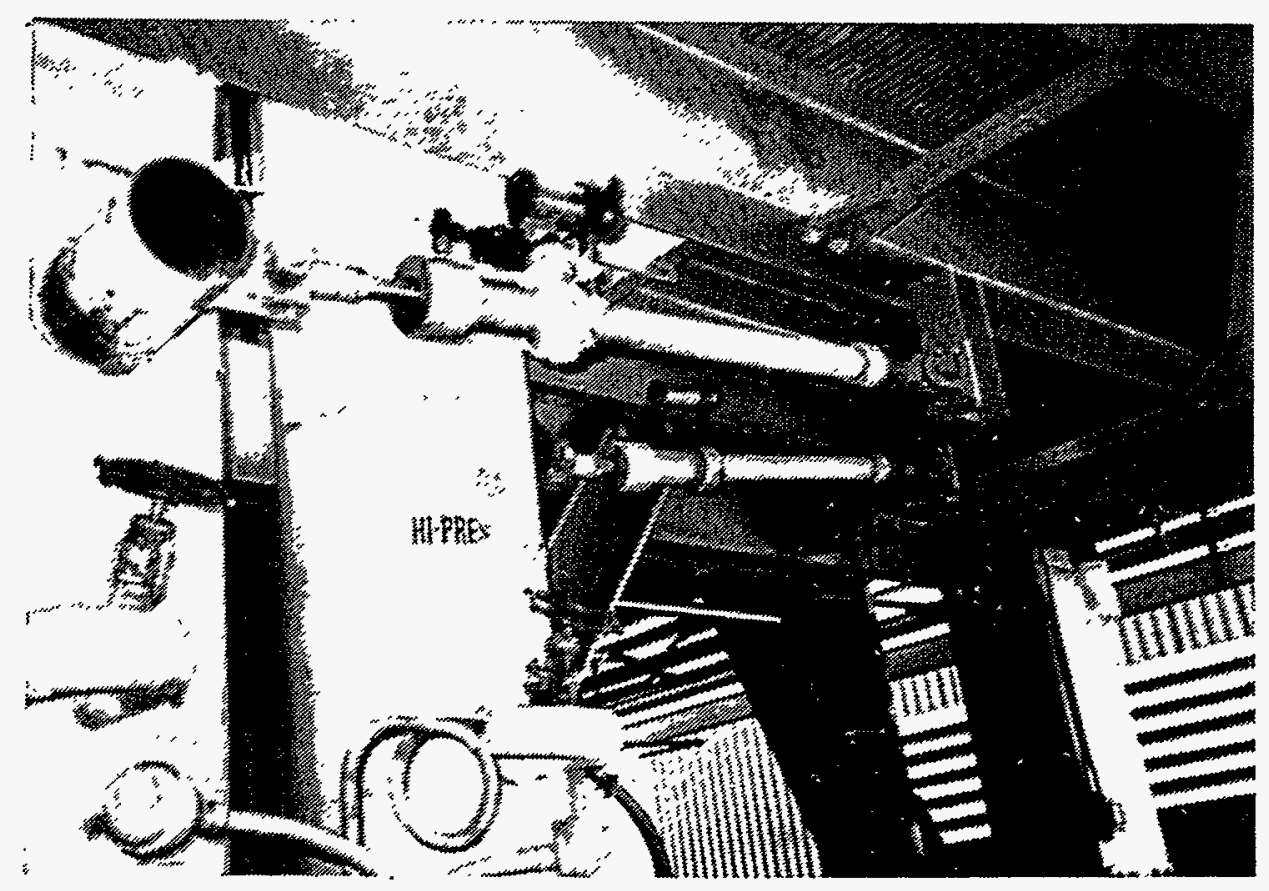

Figure E.18 Snubber Support of Main Steam Line on Magnolia Unit 3 


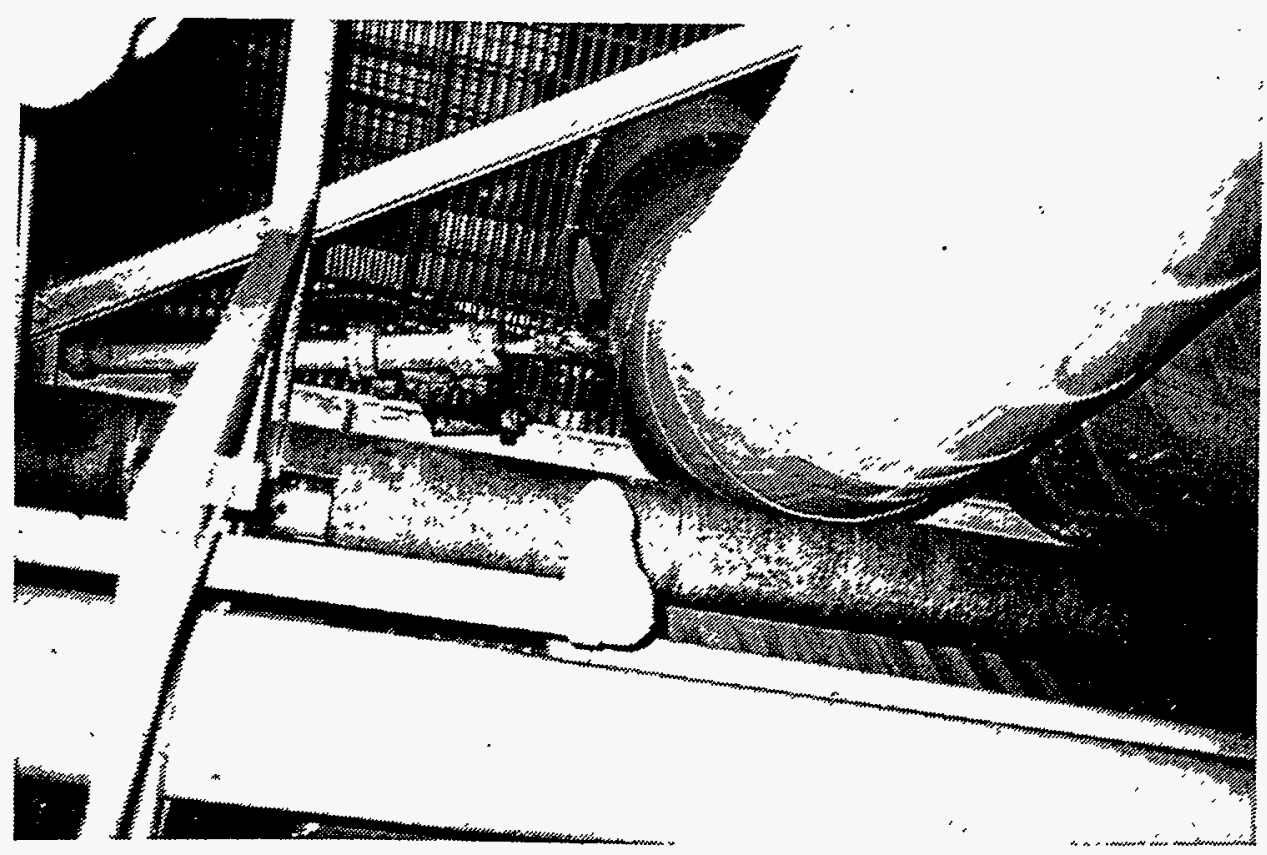

Figure E.19 Snubber Support of Main Steam Line on Pasedena Broadway Unit 3 


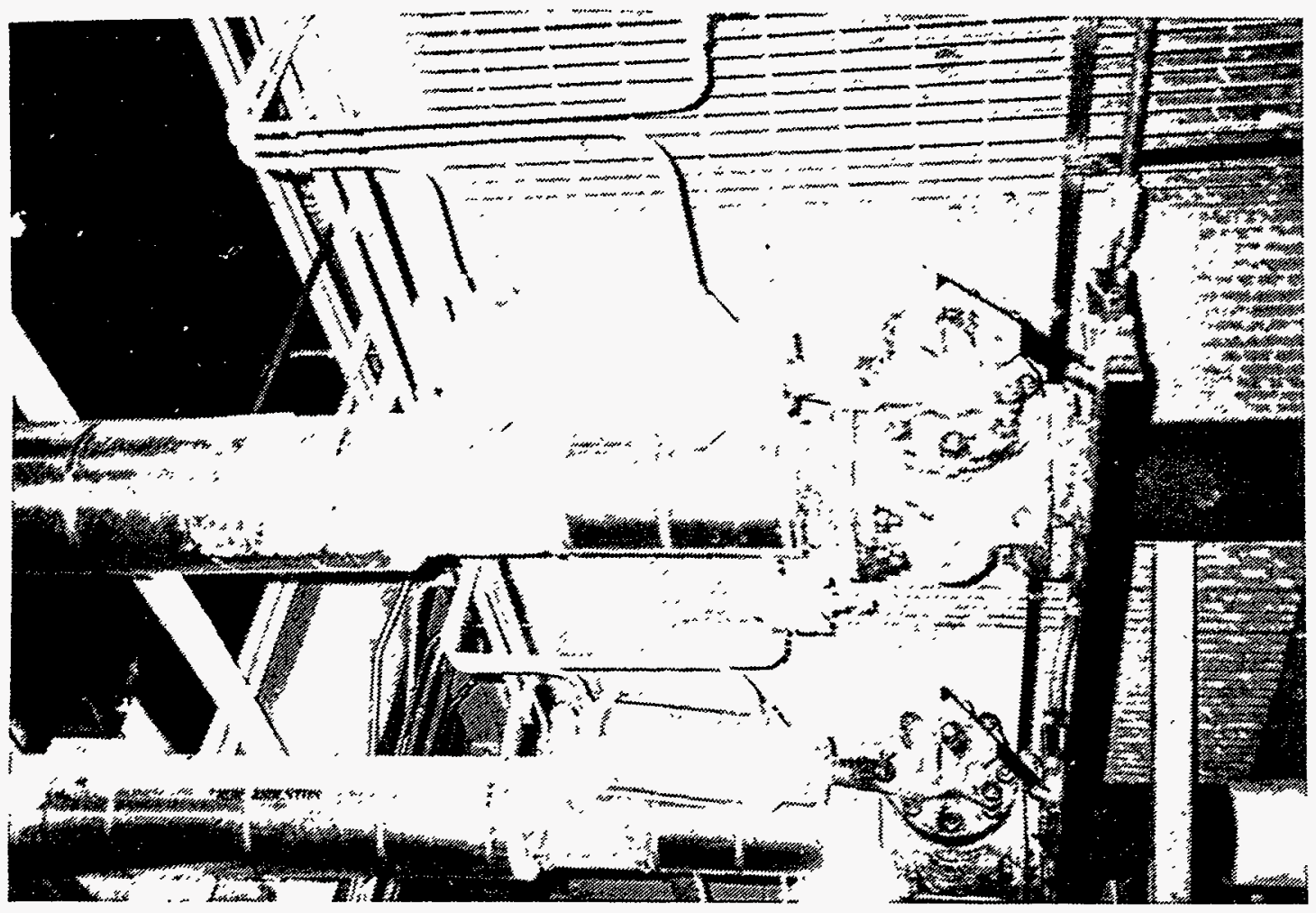

Figure E. 20 Snubber Support of Oil Feed Lines to Boiler on Humboldt Bay Unit 2 


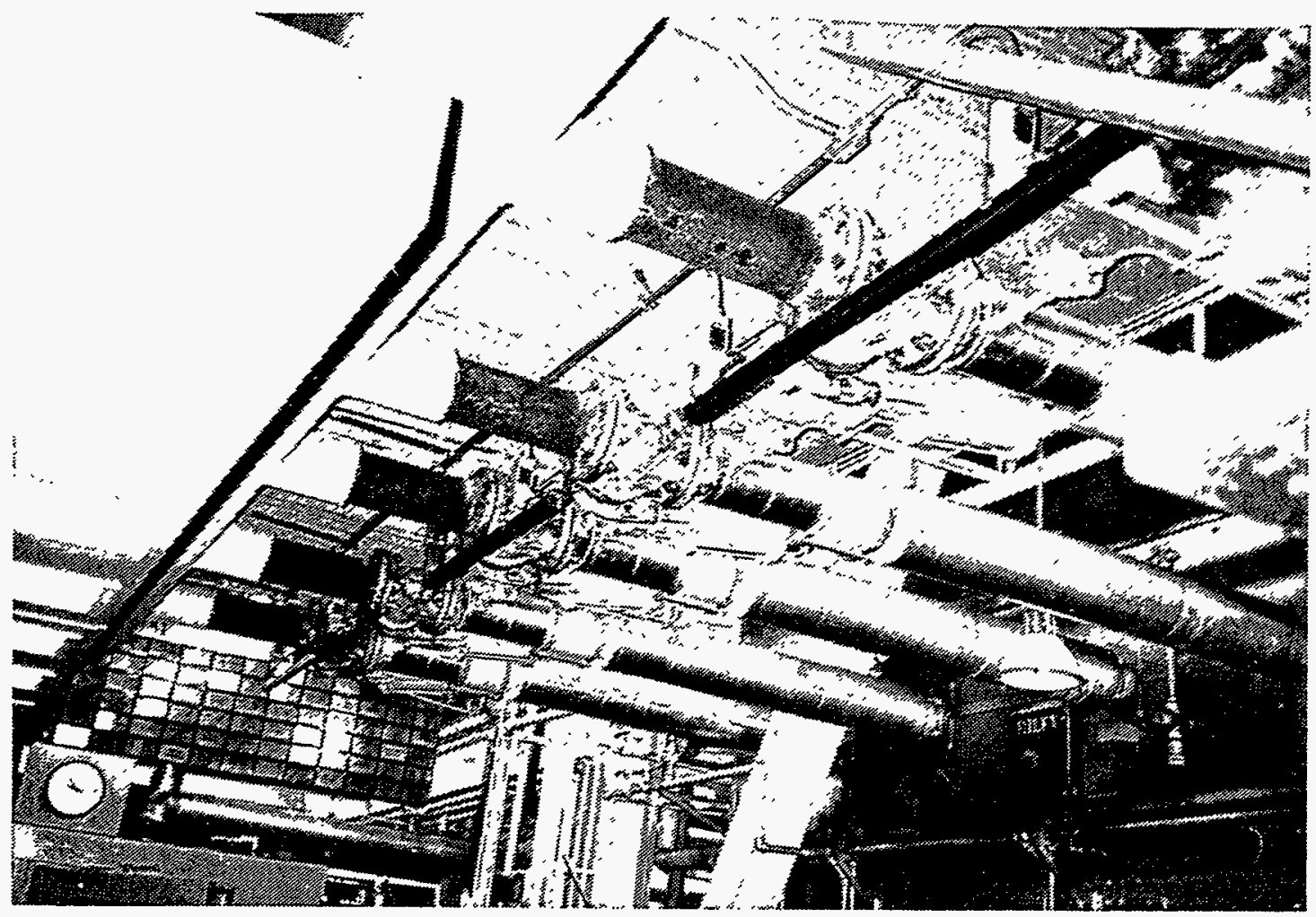

Figure E.21 Snubber Support of Oil Feed Lines to Boiler on Humboldt Bay Unit 2 


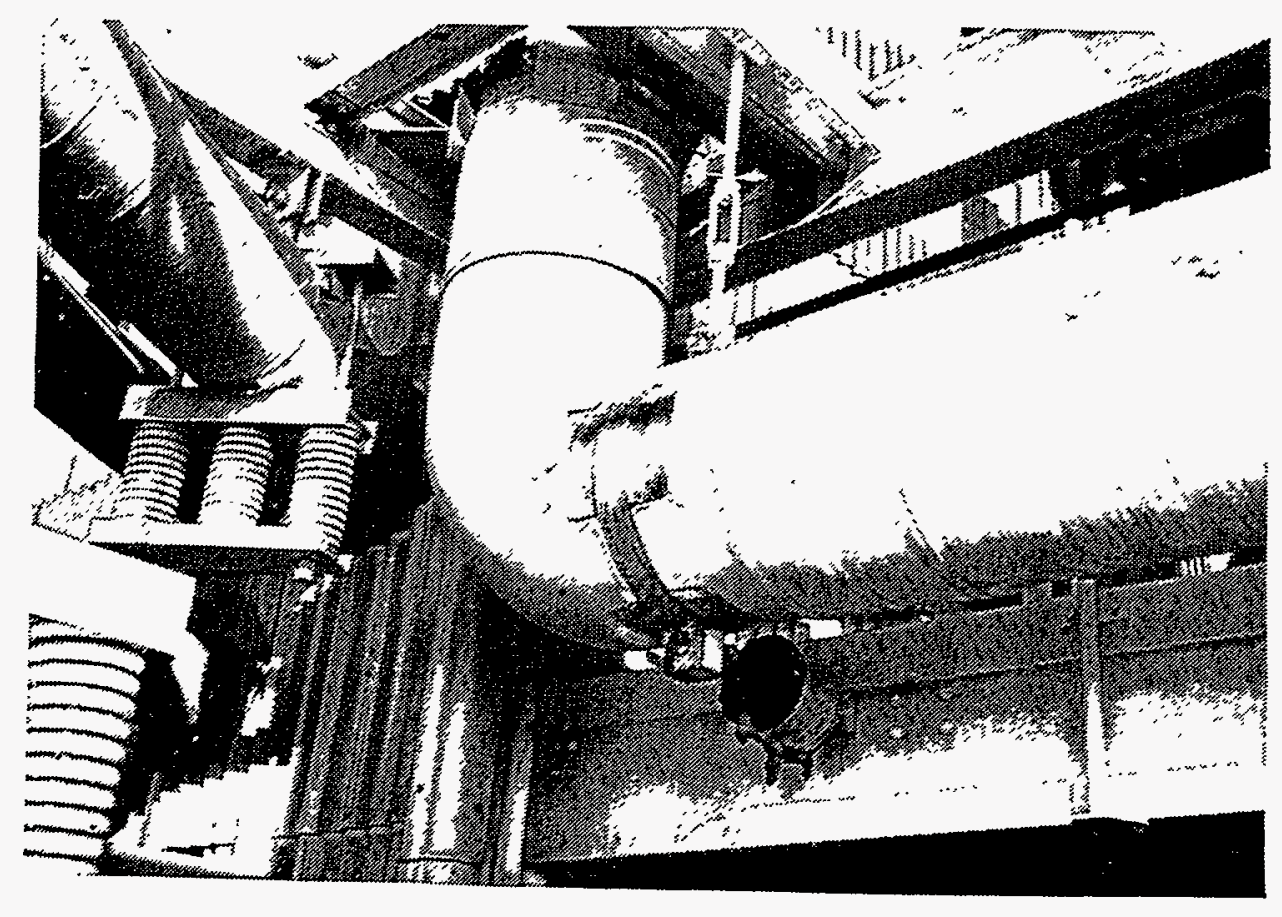

Figure E.22 Snubber Support of Feedwater Line on Kern Unit 1 


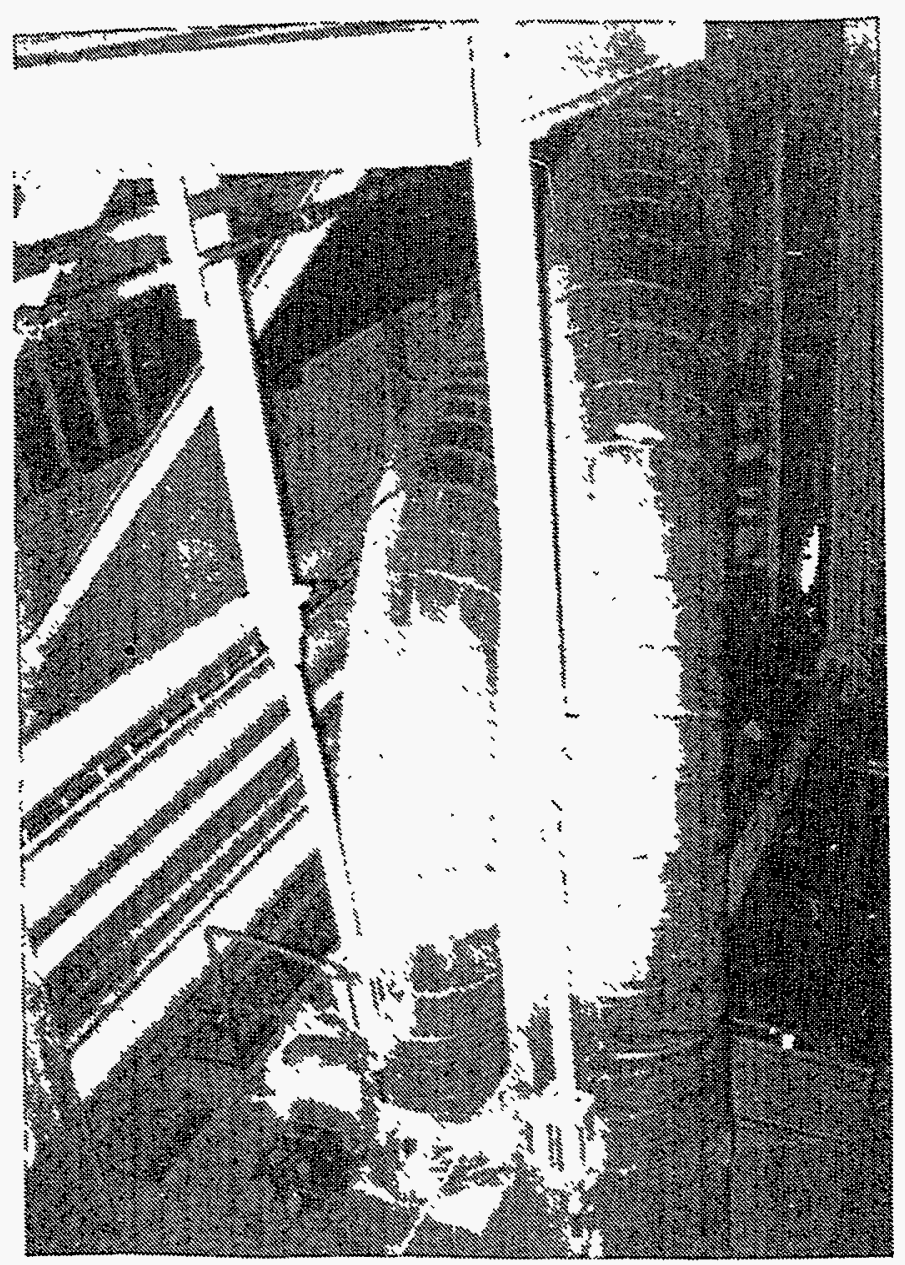

Figure E.23 Snubber Support of Main Steam Lines of EI Centro Unit 4 


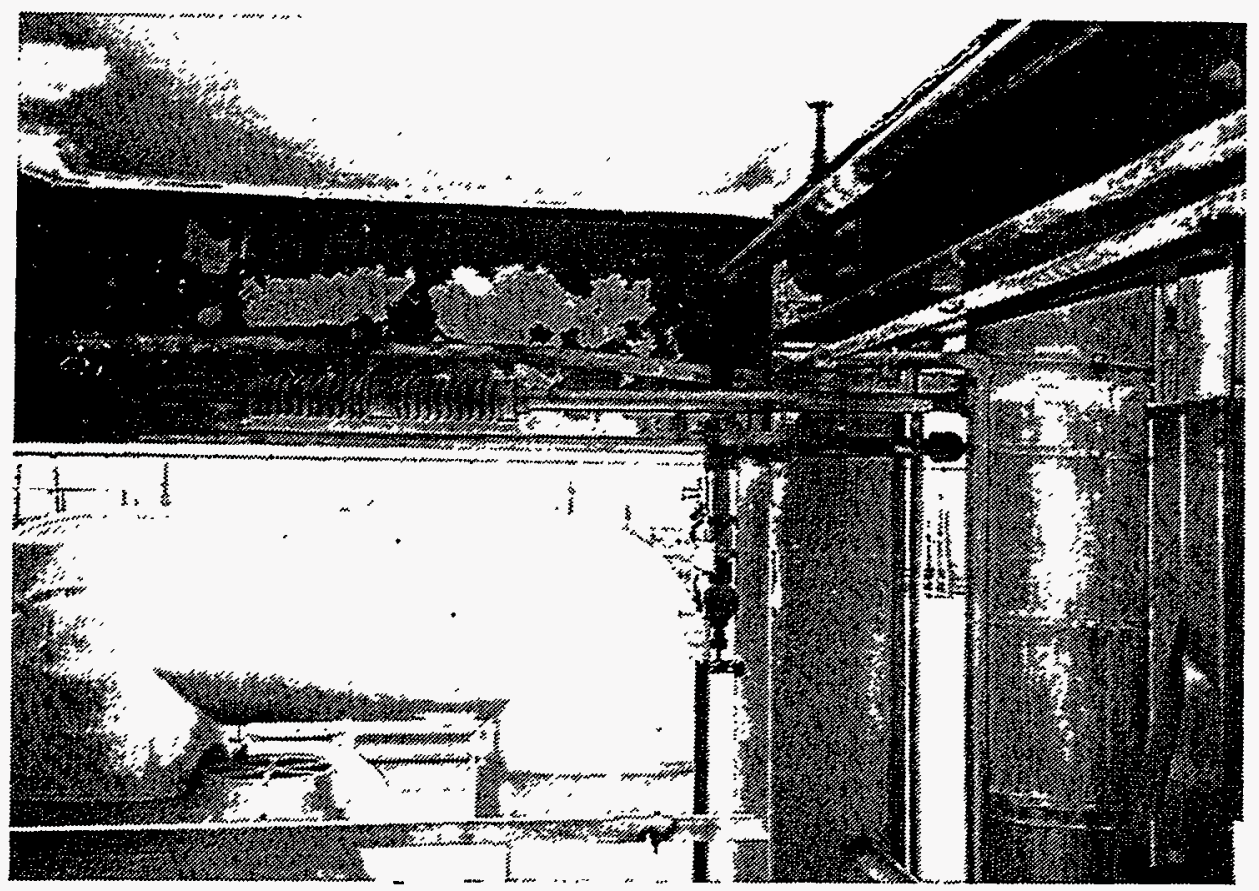

Figure E.24 Lateral Sway Brace Support of Large Bore Hot Line in Valley Unit 3 


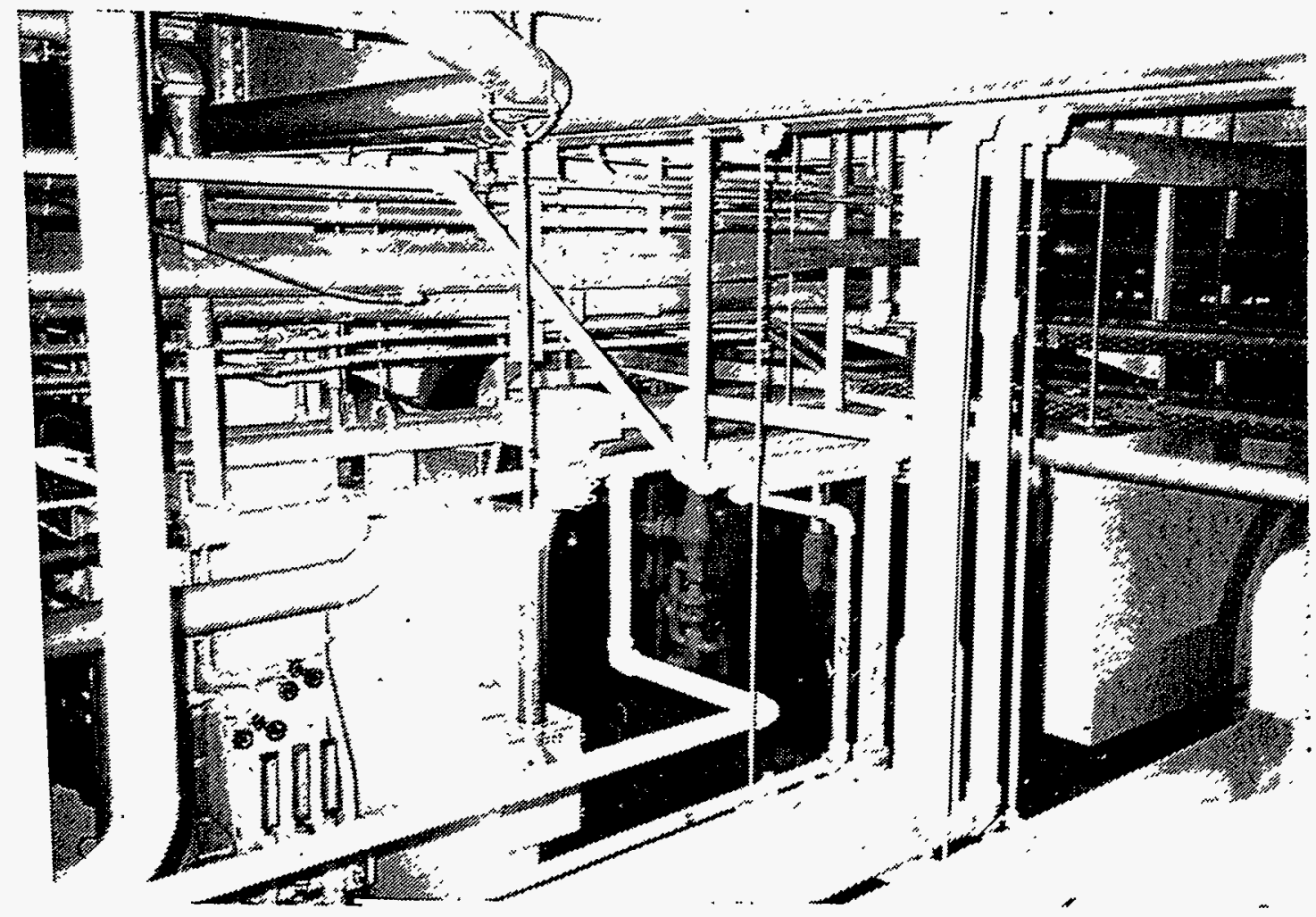

Figure E.25 Pipe Supporting Pipe in Humboldt Bay Unit 2 


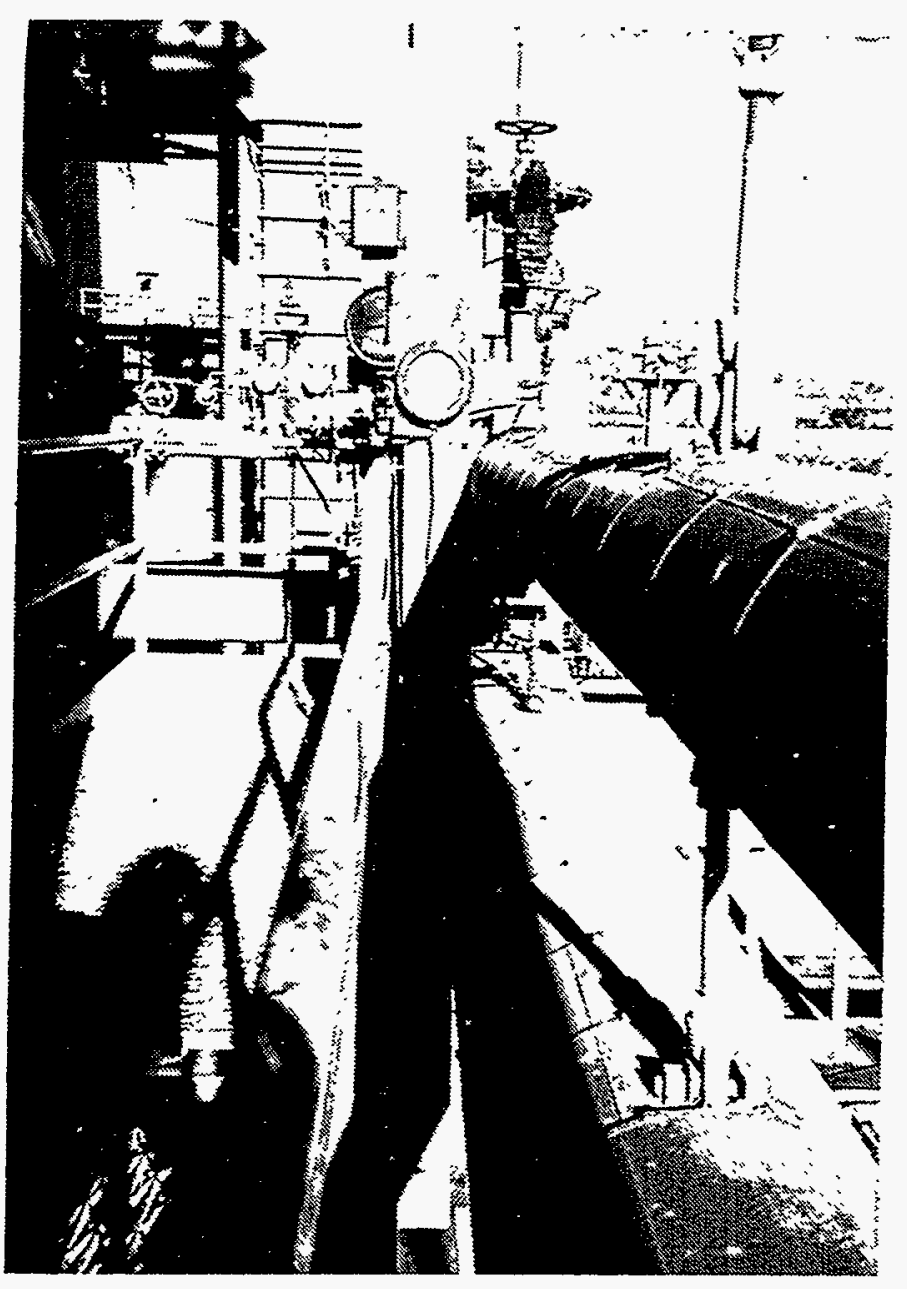

Figure E.26 Pipe Supporting Pipe in Valley Unit 3 


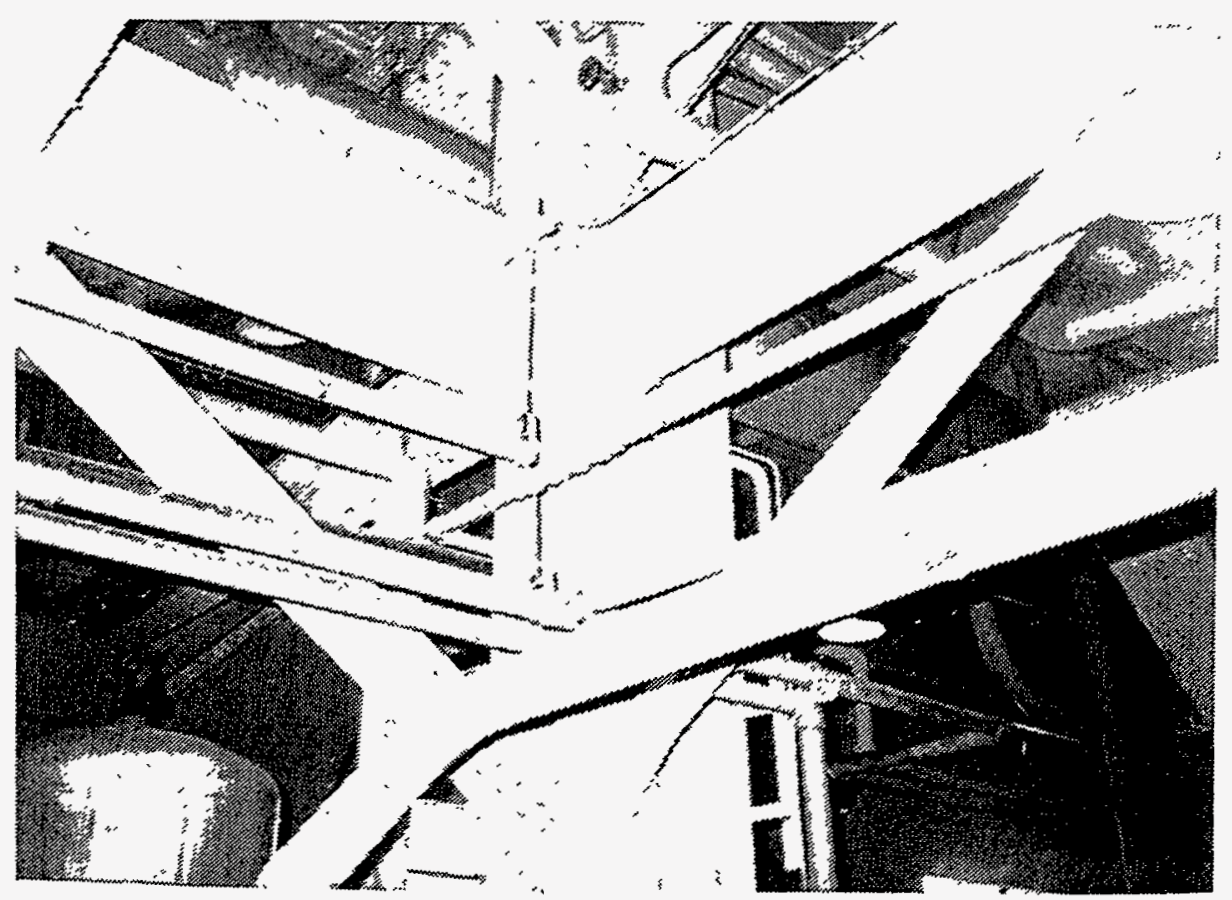

Figure E.27 Pipe Supporting Pipe in Centro Unit 1

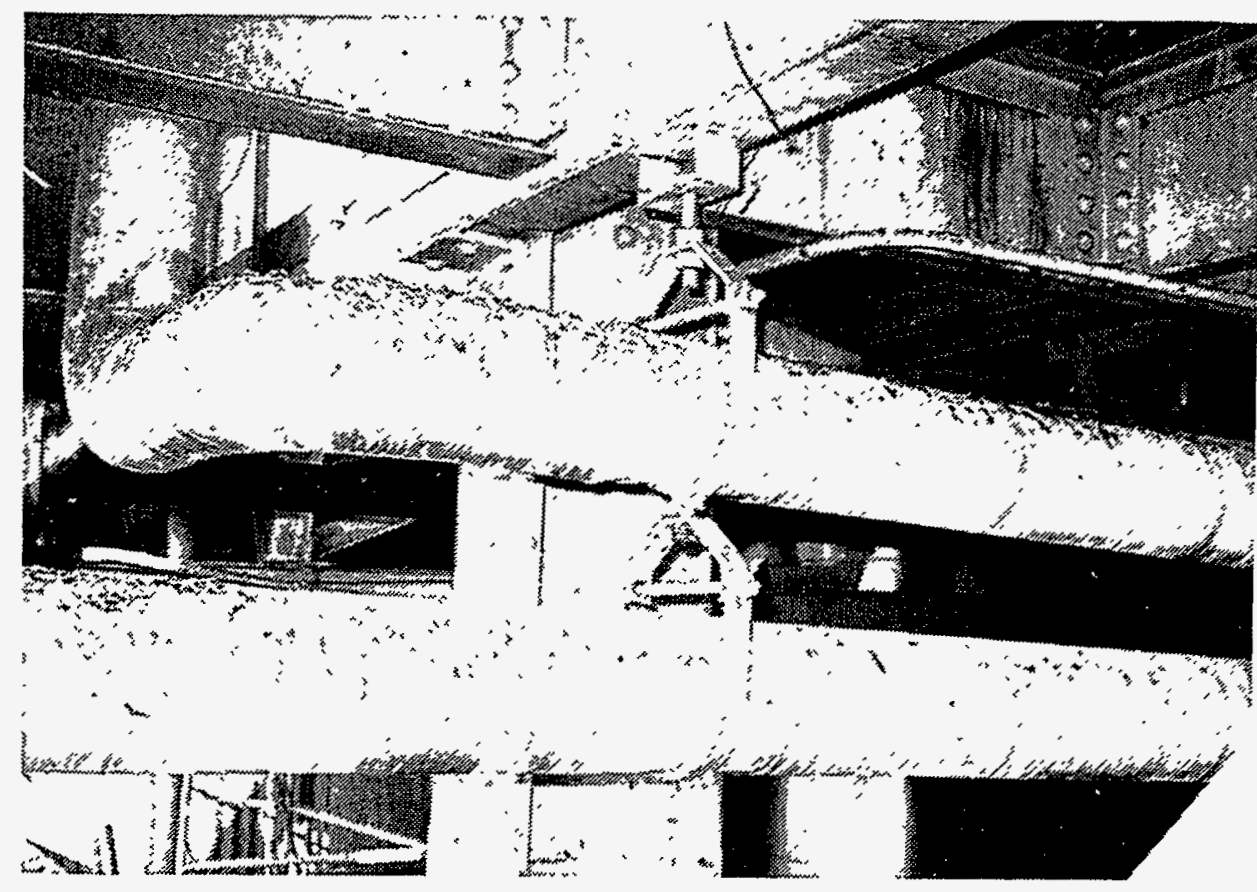

Figure E.28 Pipe Supporting Pipe in Kern Unit 1 


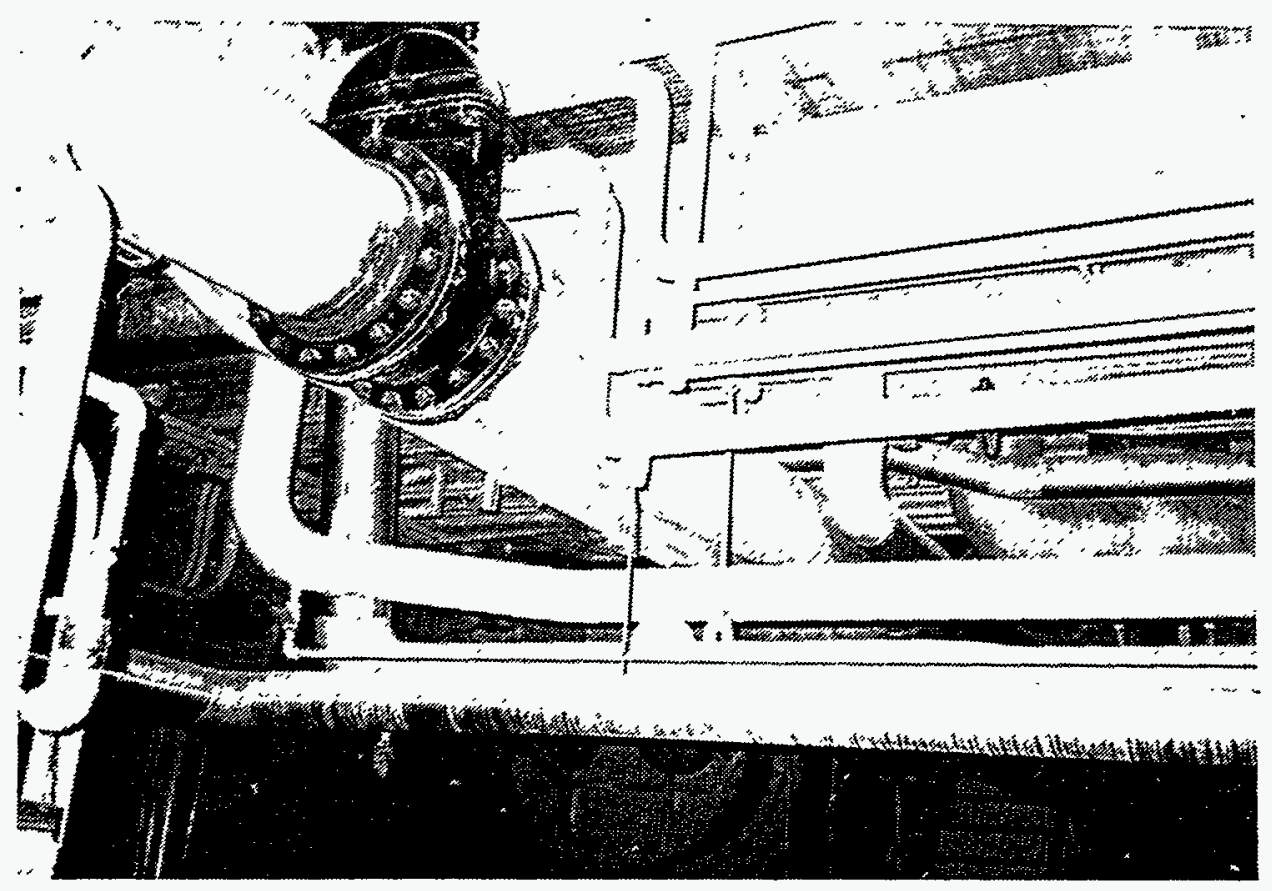

Figure E29 Pipe Supporting Pipe in Kern Unit 1

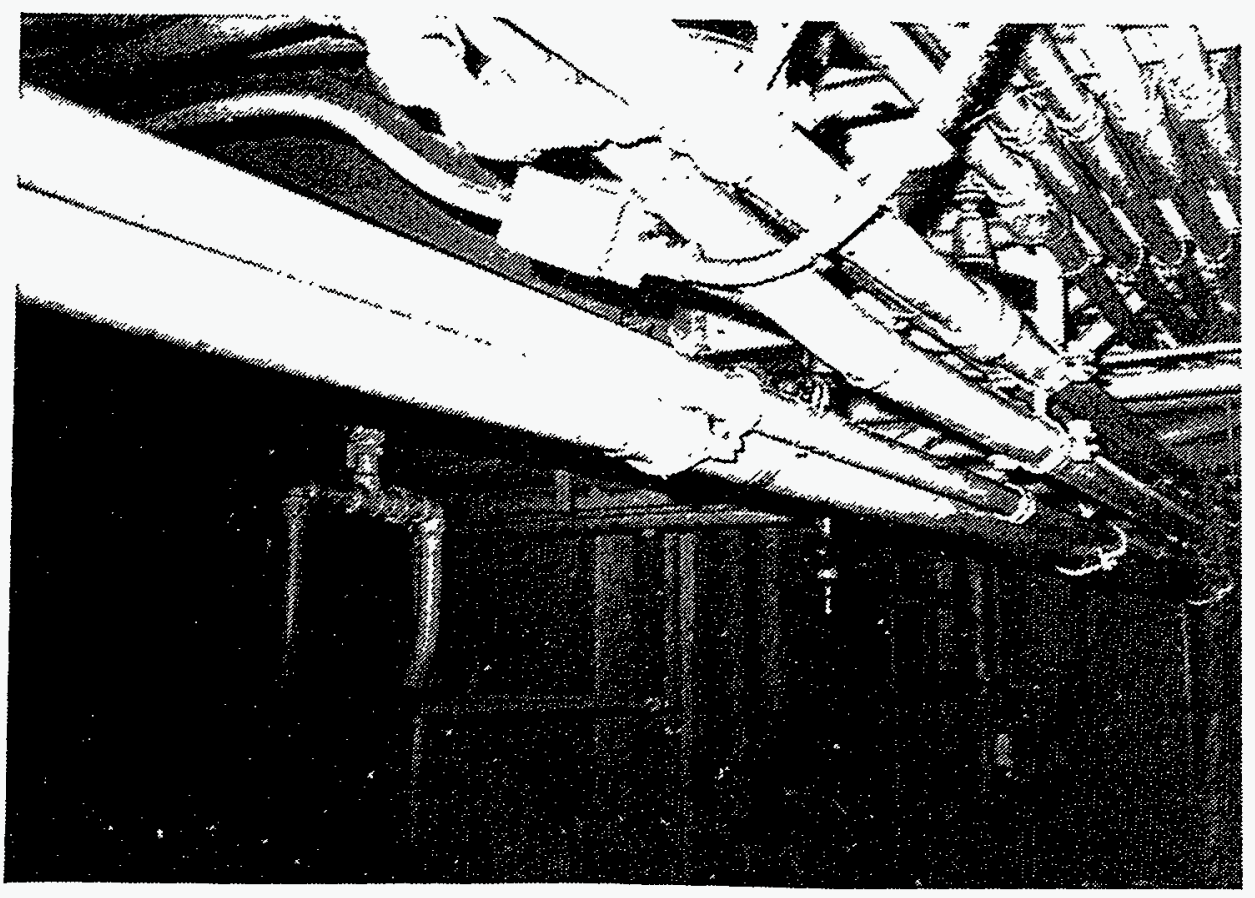

Figure E.30 Pipe Supporting Pipe in Kern Unit 1 


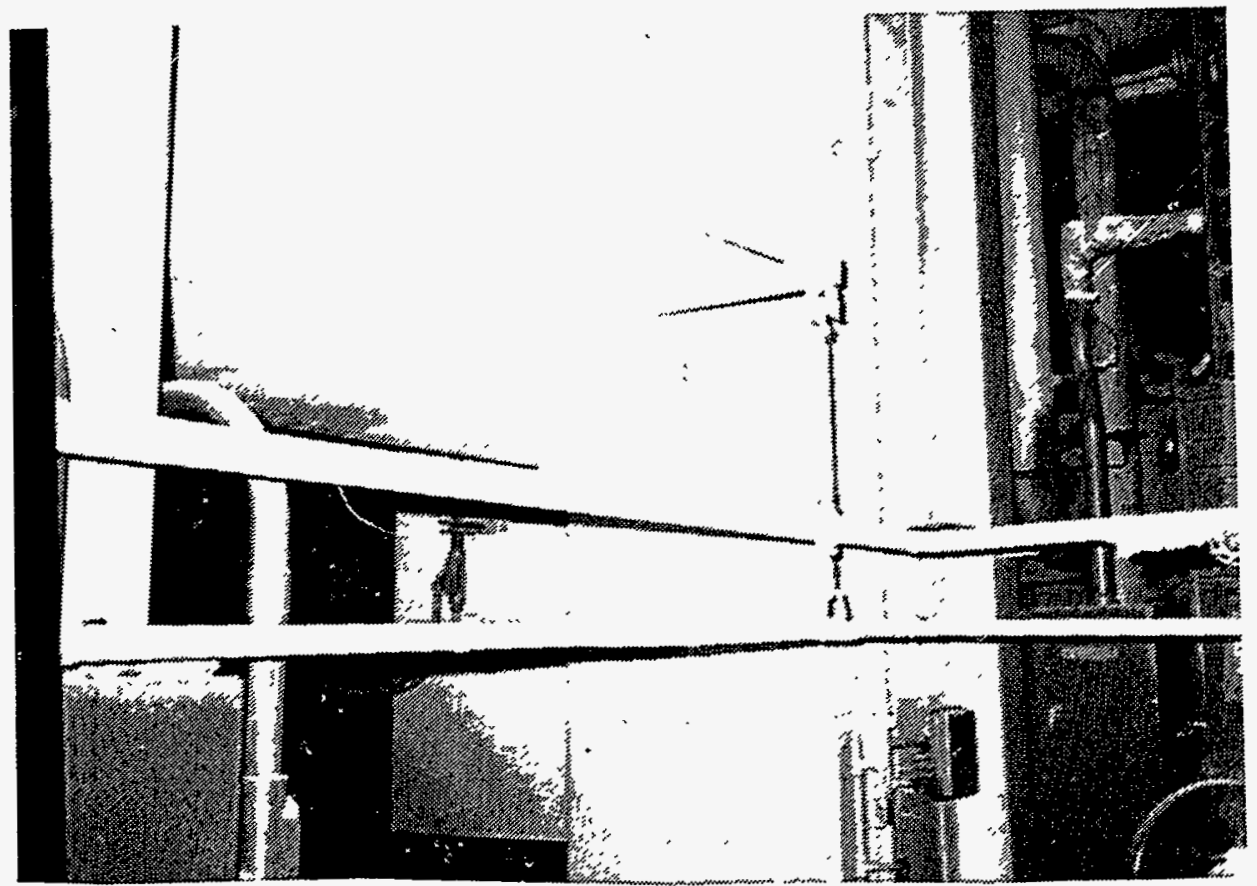

Figure E.31 Pipe Supporting Pipe in Centro Unit 4

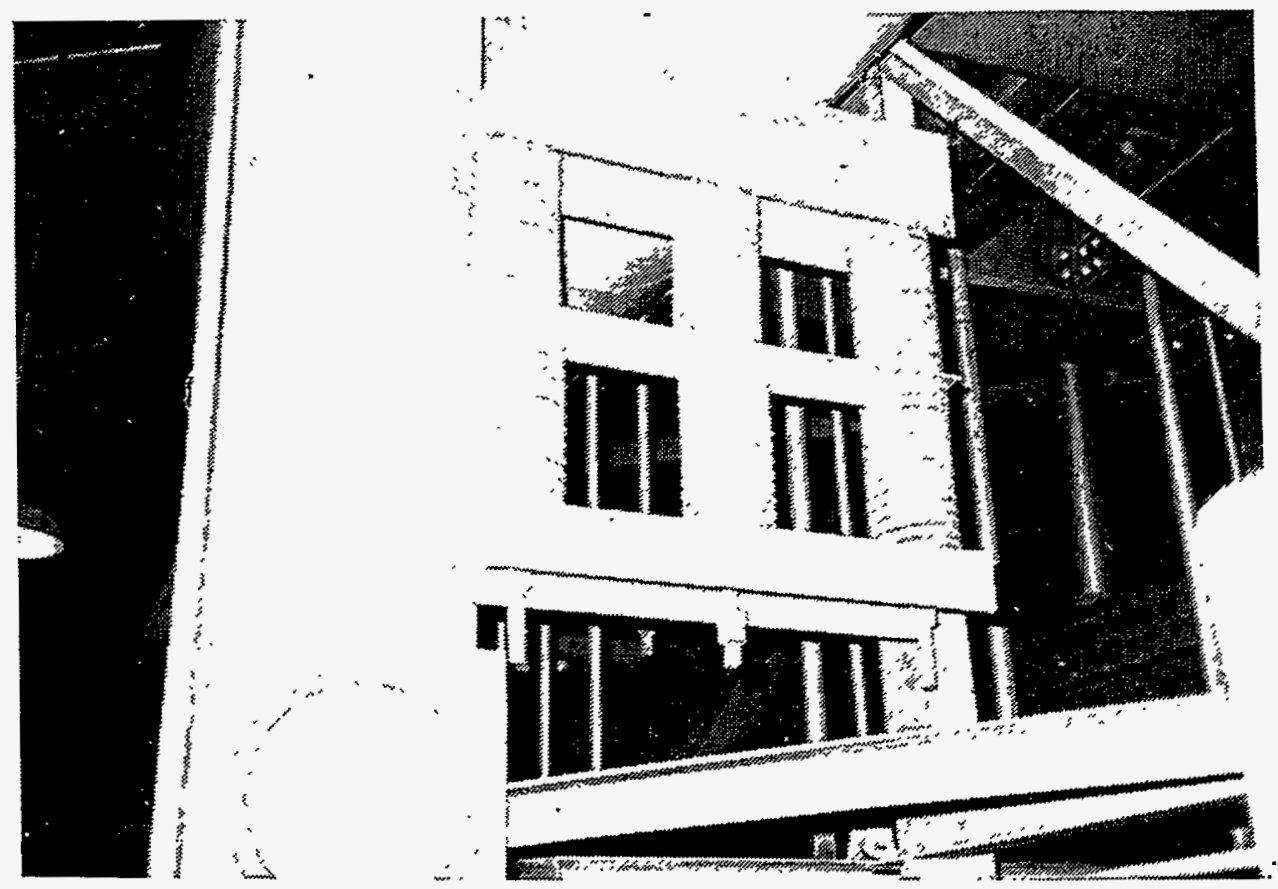

Figure E.32 Field Fabricated Spring Hanger in Kern Unit 1 


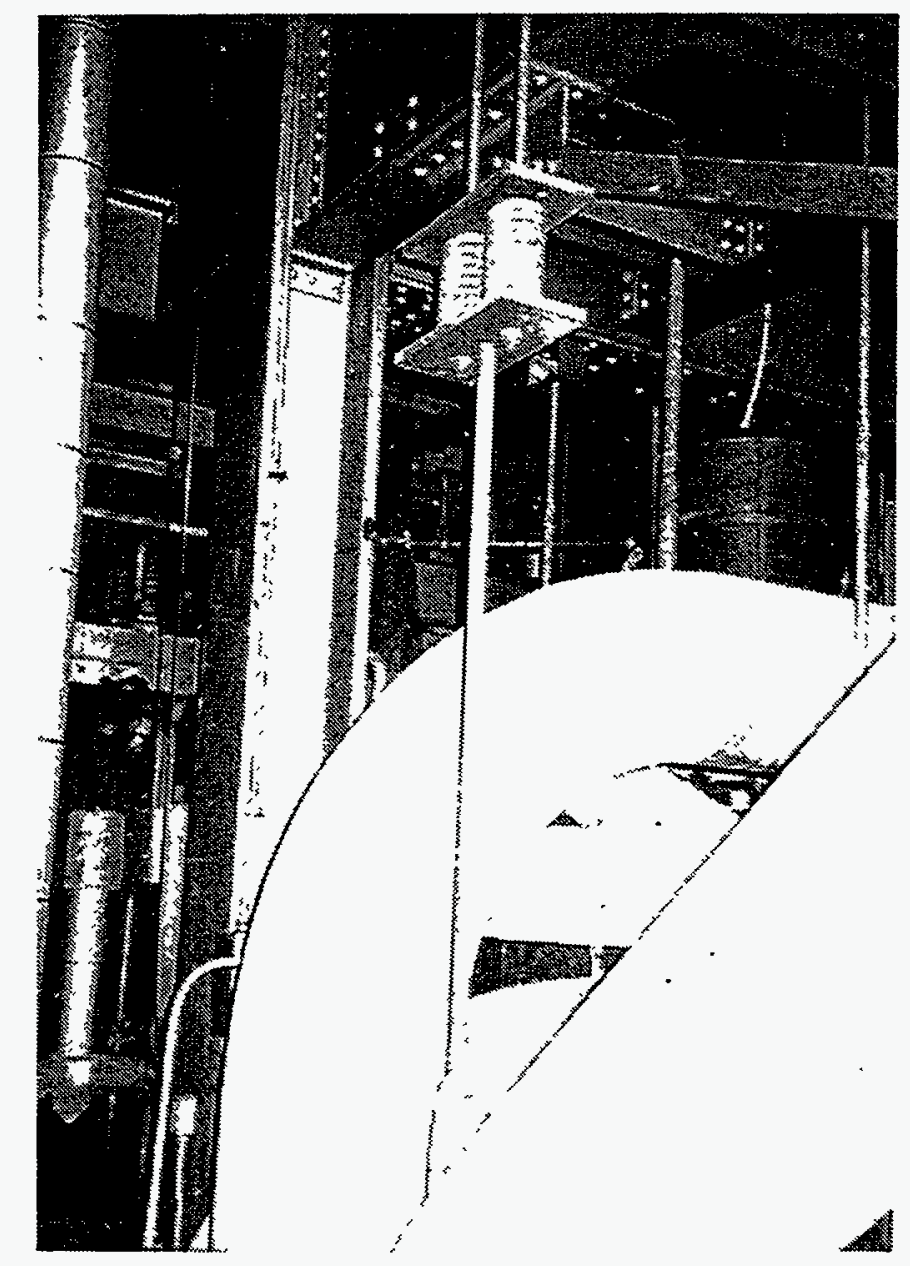

Figure E.33 Field Fabricated Spring Hanger in Kern Unit 1 


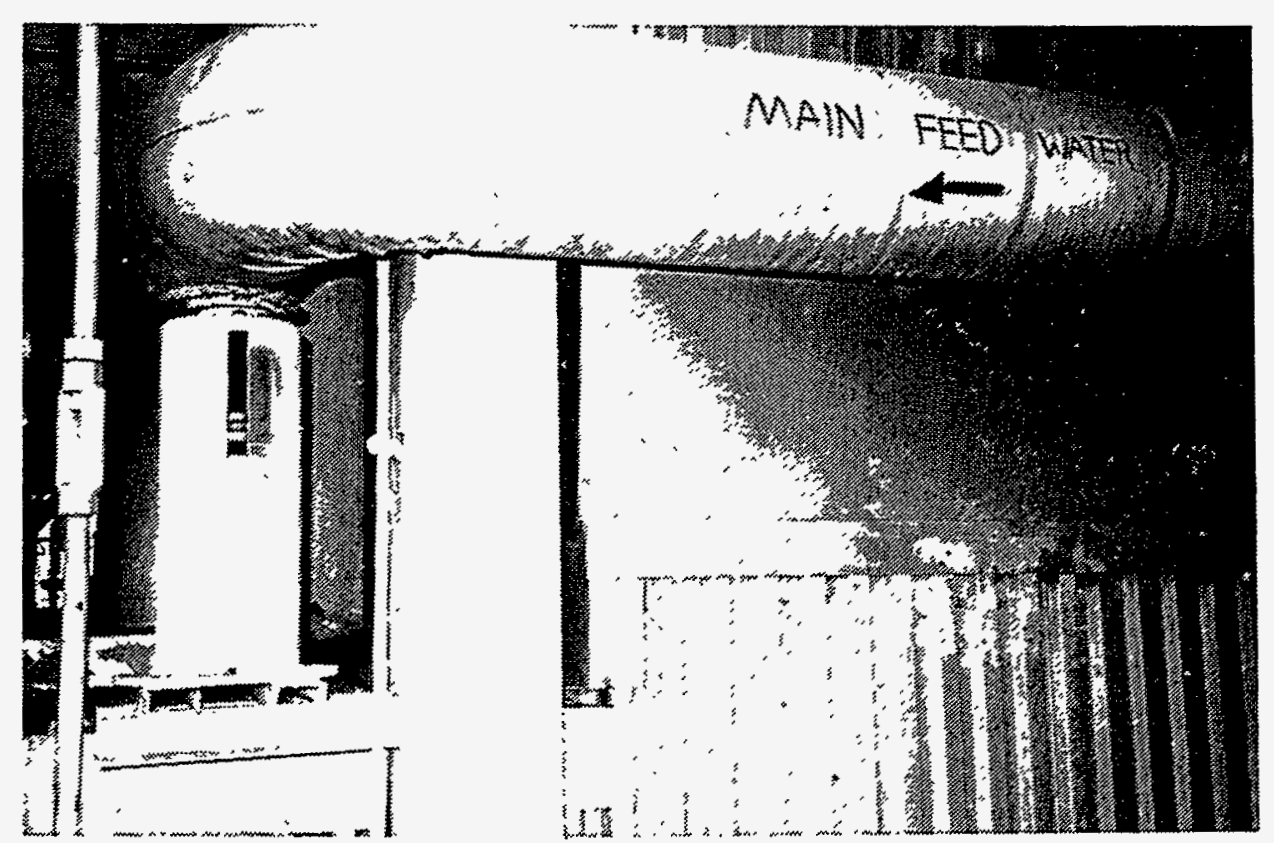

Figure E.34 Spring Support for Main Feedwater Line for Pasadena Broadway Unit 2 


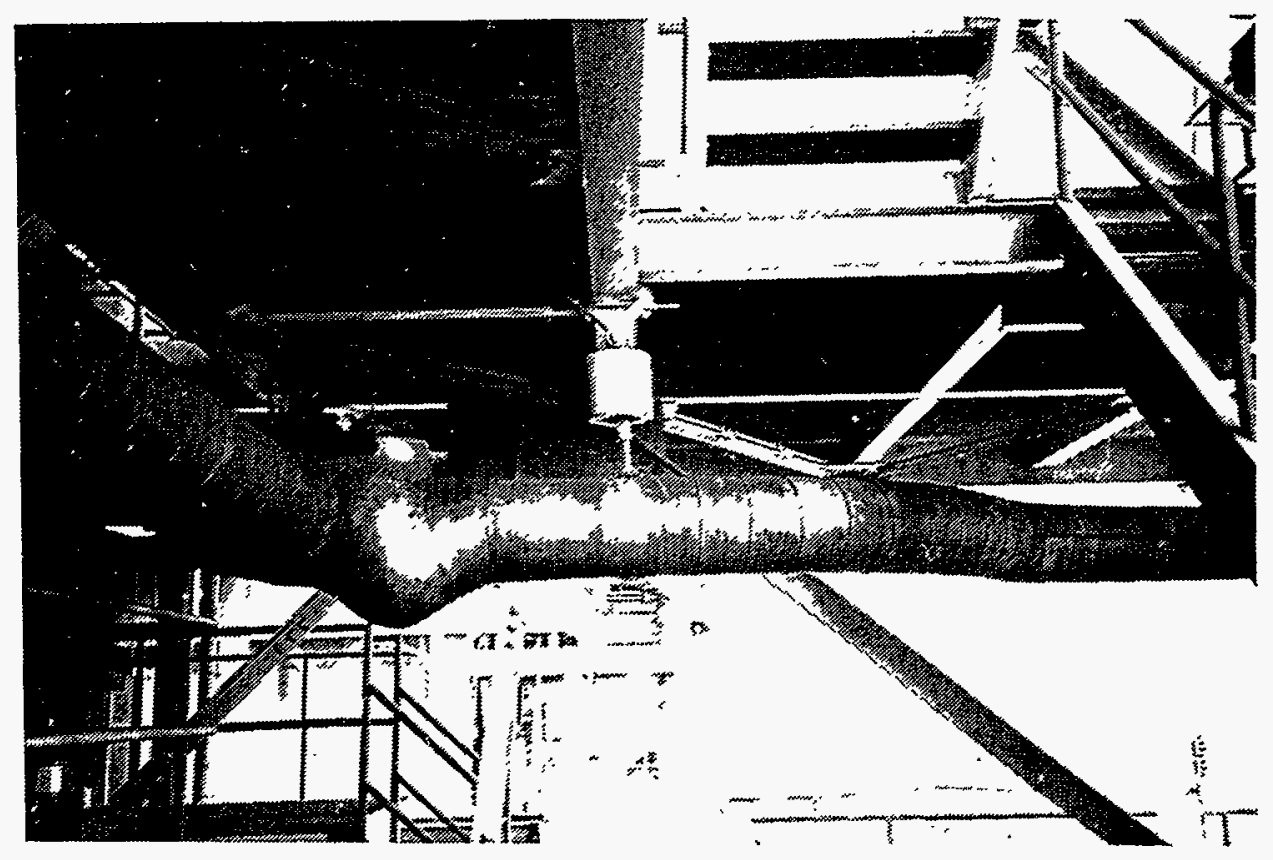

Figure E.35 Spring Hanger for Large Bore Hot Line for Pasadena Broadway Unit 1

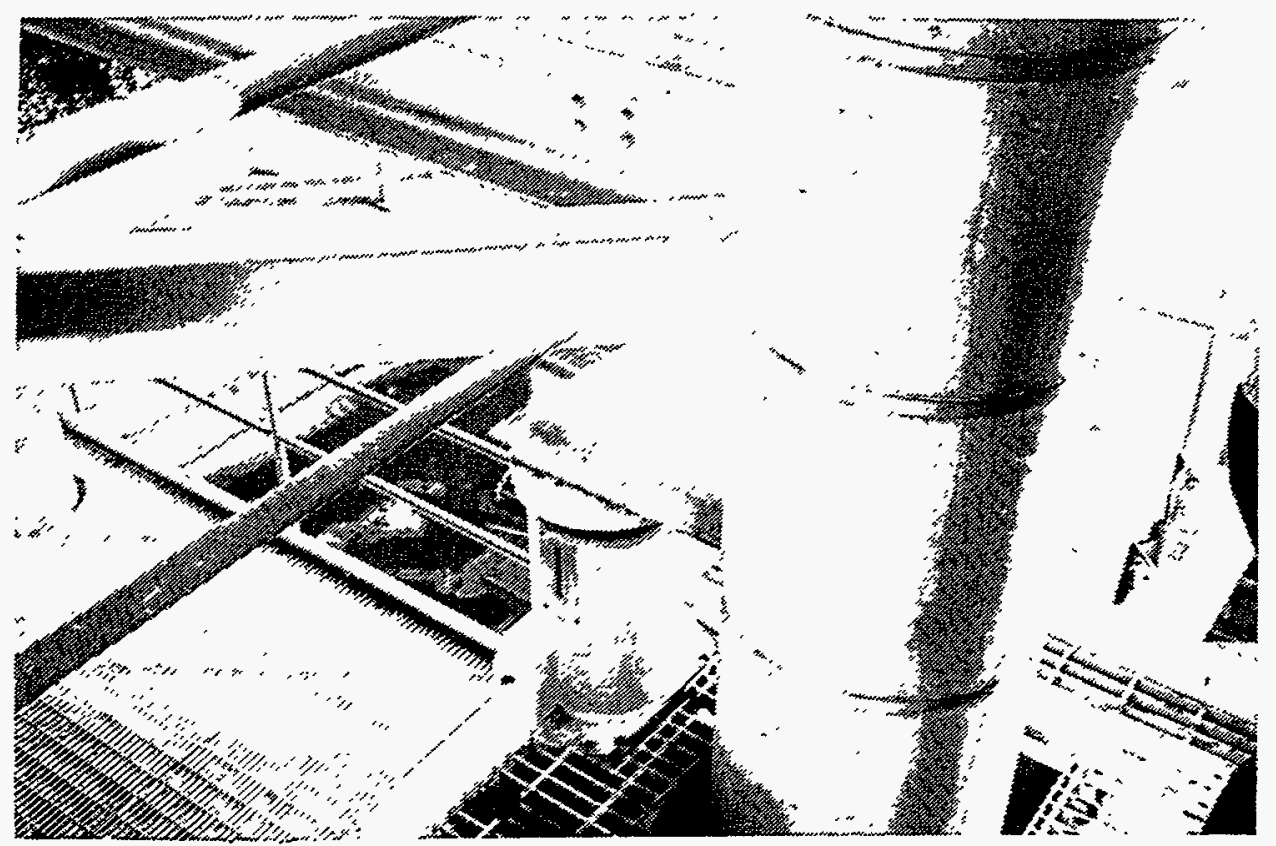

Figure E36 Spring Support for Main Steam Line for Pasadena Broadway Unit 2 


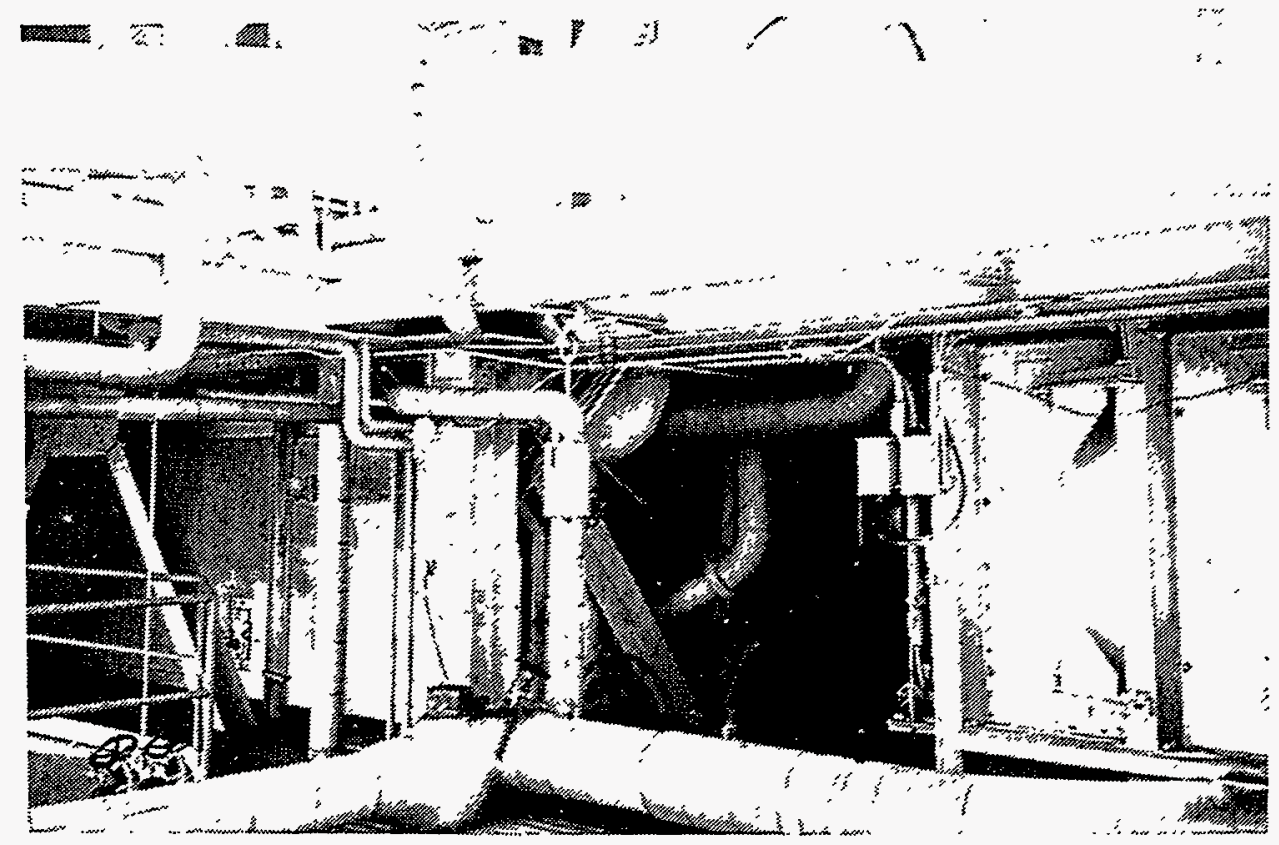

Figure E.37 Spring Hanger for Large Bore Hot Line in Pasadena Broadway Unit 1

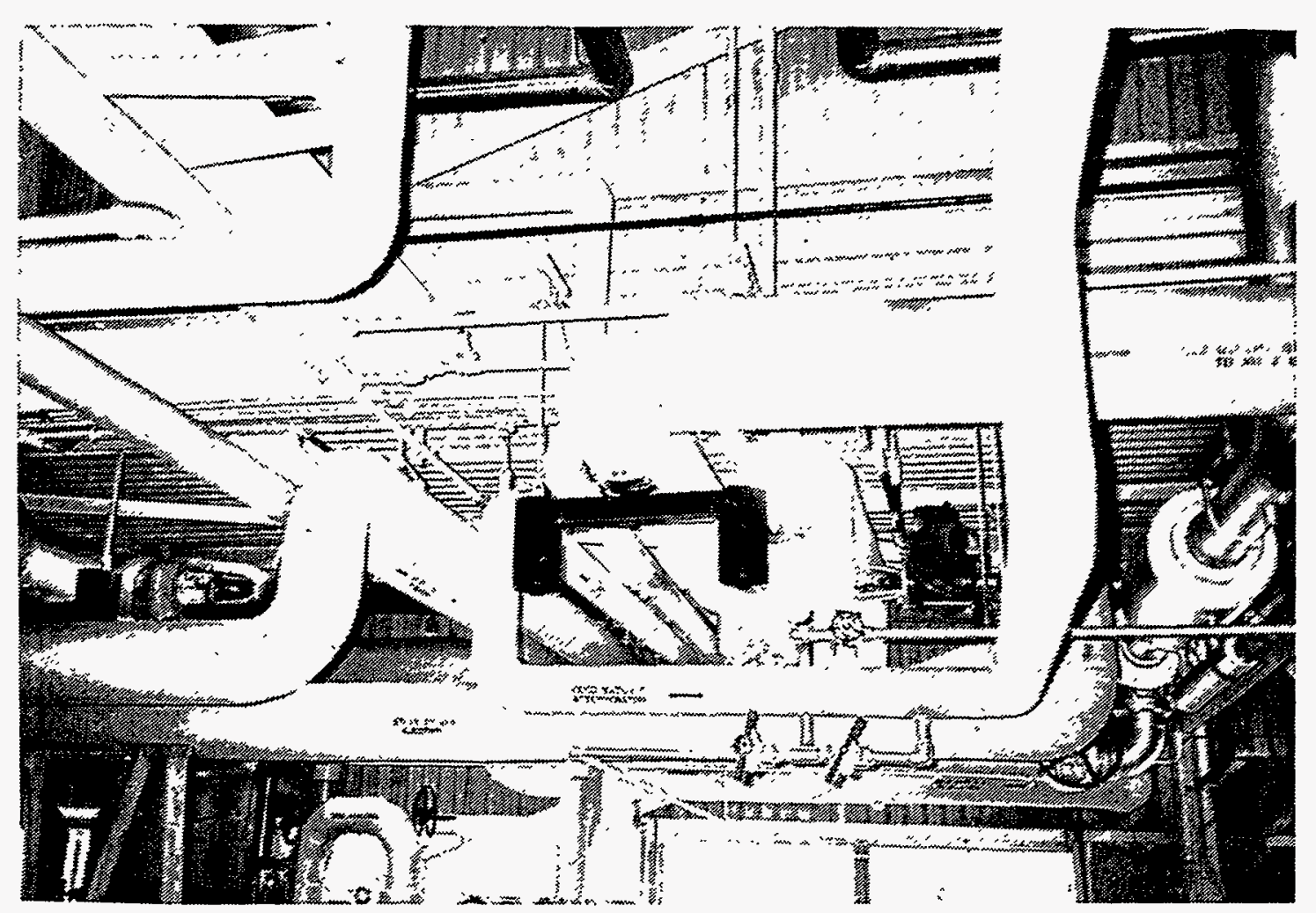

Figure E.38 Spring Trapeze Support Large Bore Hot Line in Humboldt Bay Unit 2 


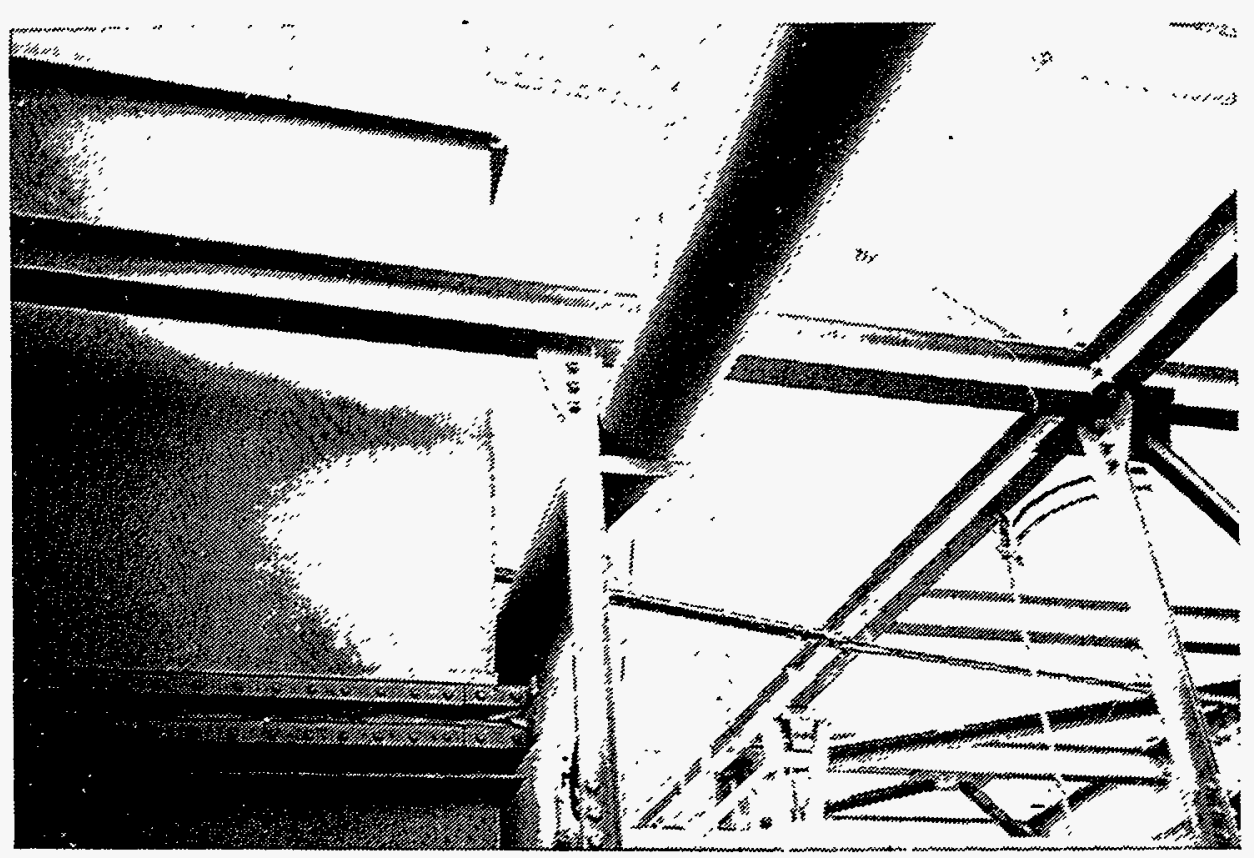

Figure E.39 Knee Brace Support for Large Bore Cold Line in Pasadena Broadway Unit 2

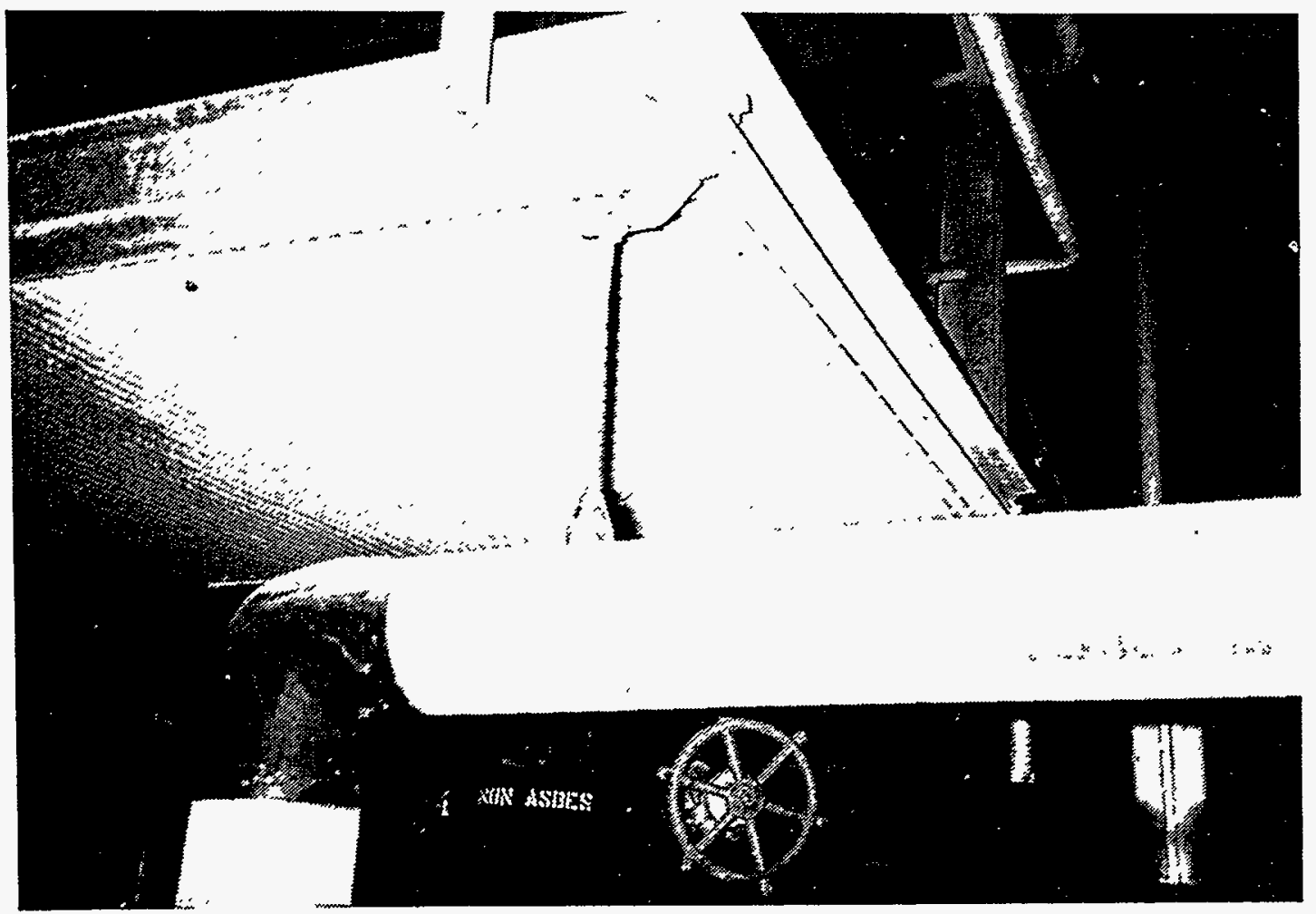

Figure E.40 Field Fabricated Support from Platform Steel in Humboldt Bay Unit 1 


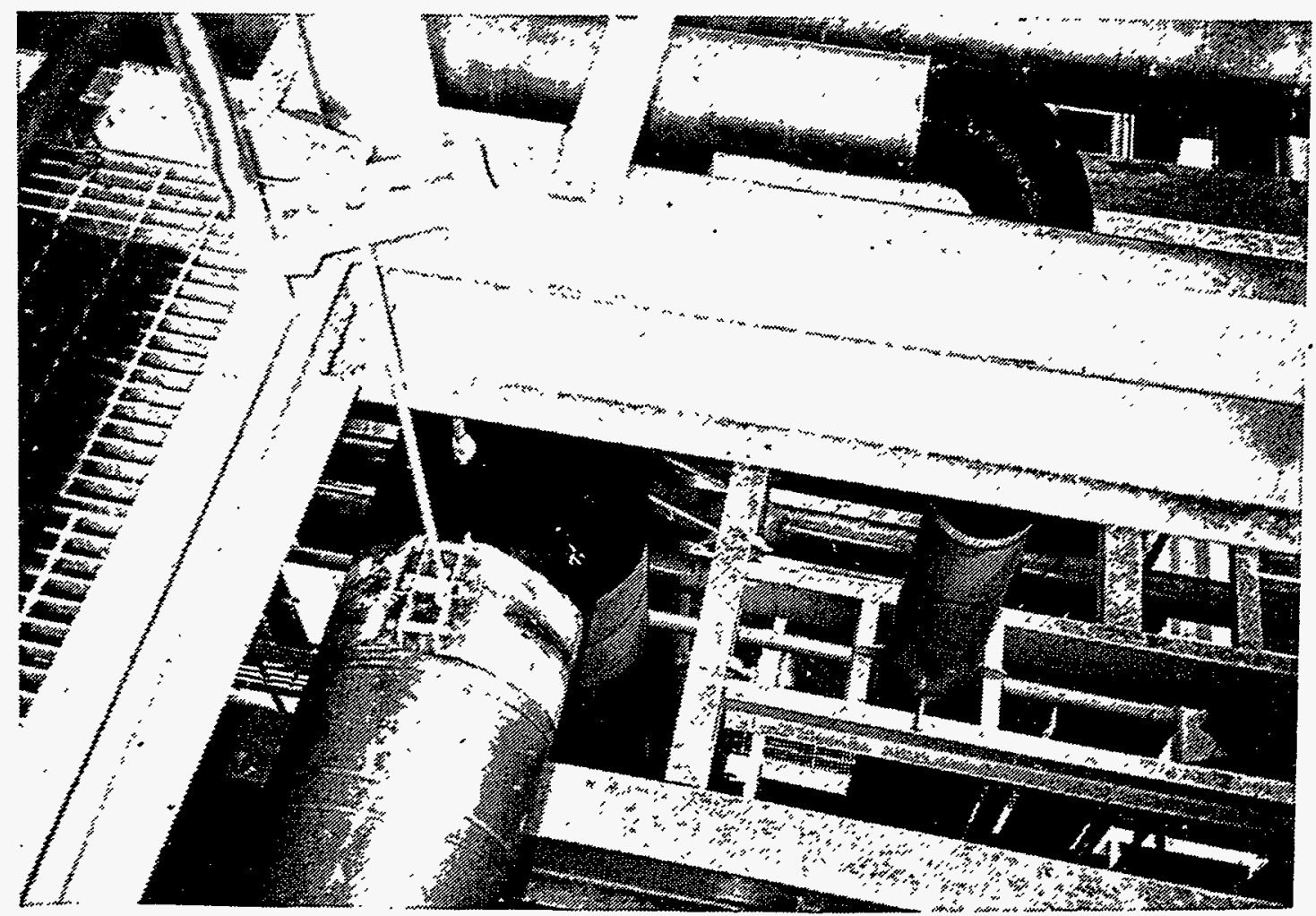

Figure E.41 Unseated Support of Large Bore Hot Line in Humboldt Bay Unit 1 


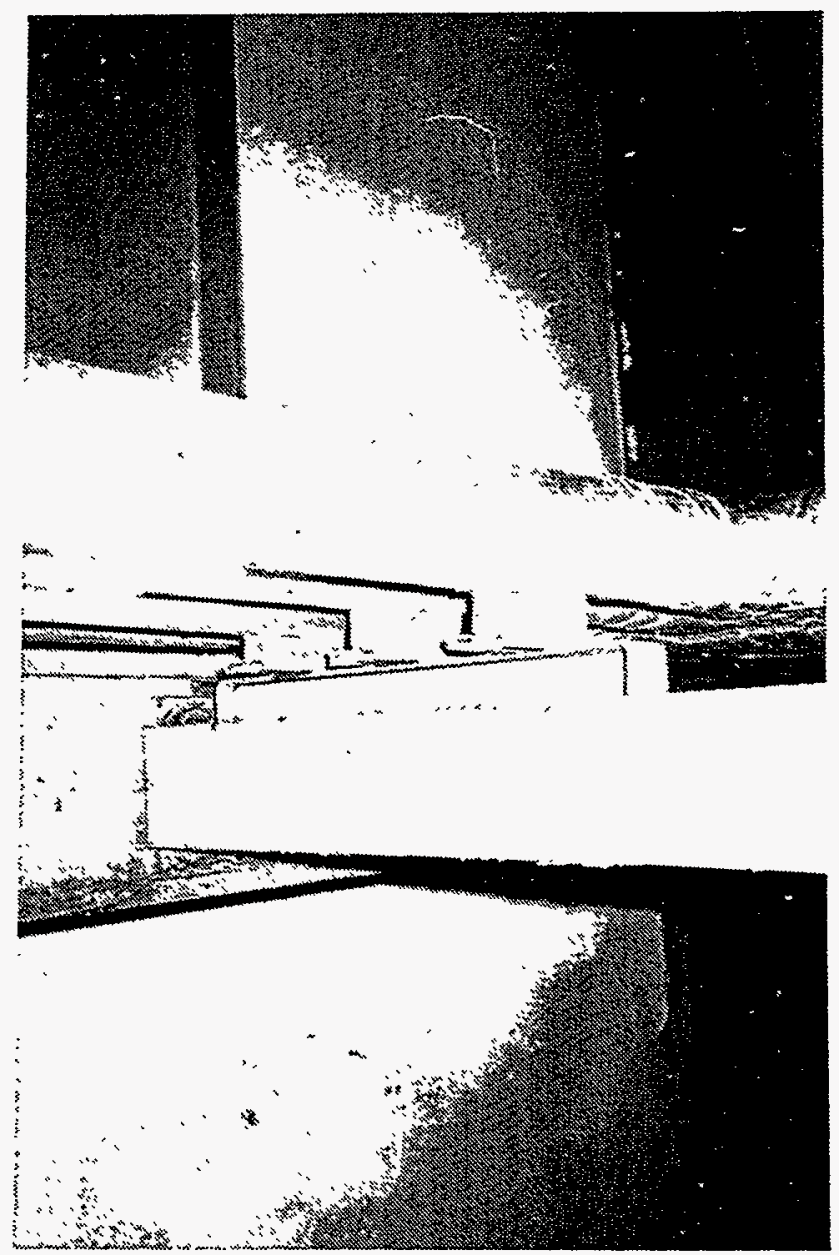

Figure E.42 Guide Supports for Large Bore Hot Line in Glendale Unit 4 


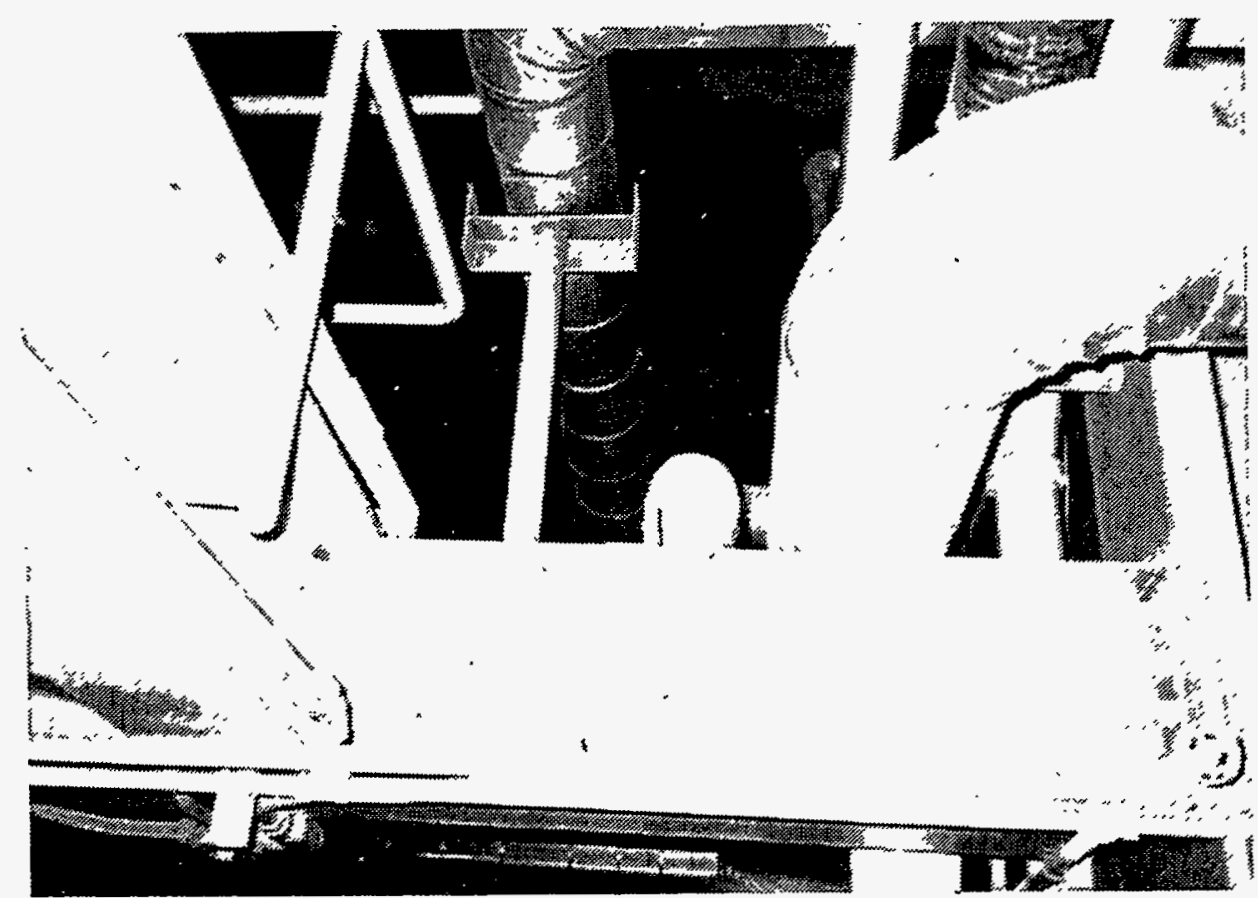

Figure E. 47 Guided Support for Large Bore Hot Lines in El Centro Unit 3
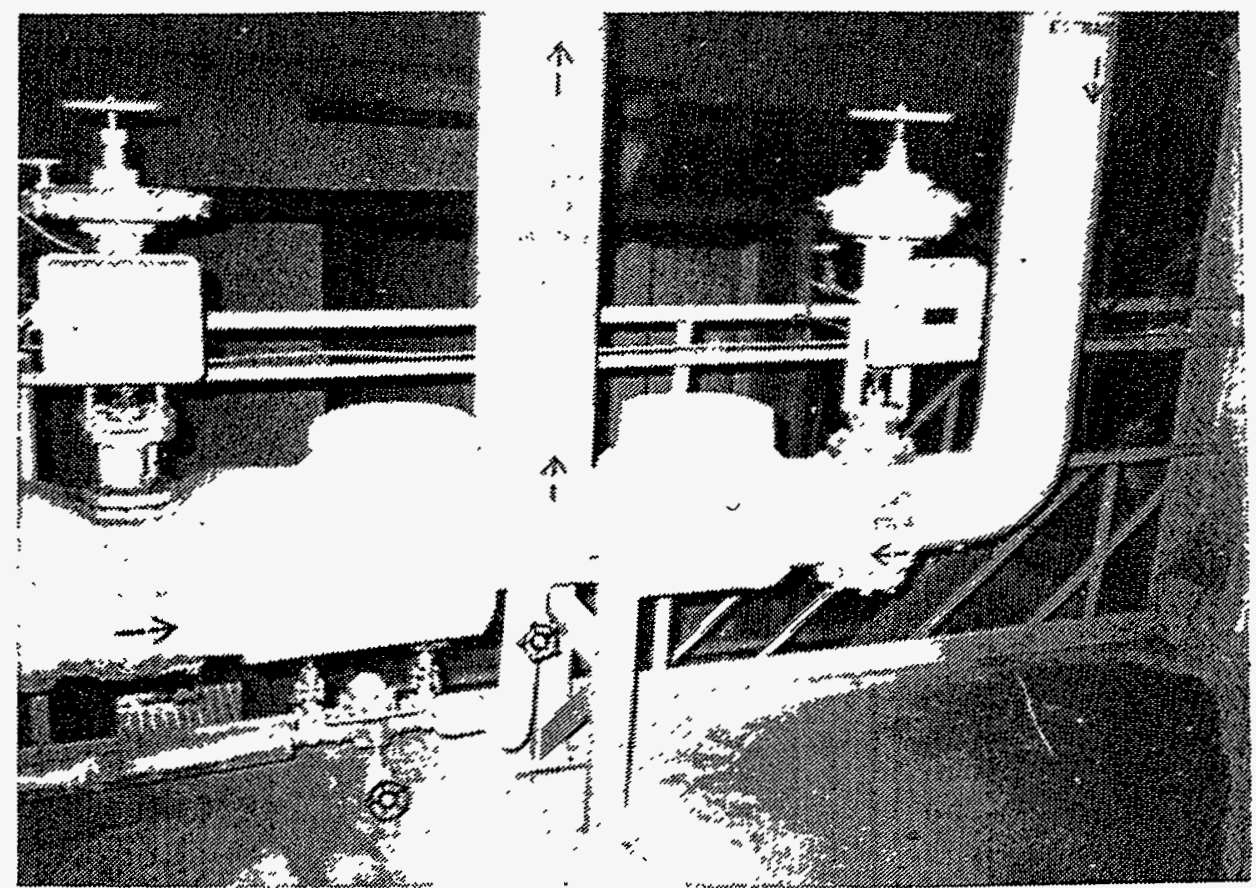

Figure E. 48 Guided Support for Large Bore Hot Line in El Centro Unit 4 


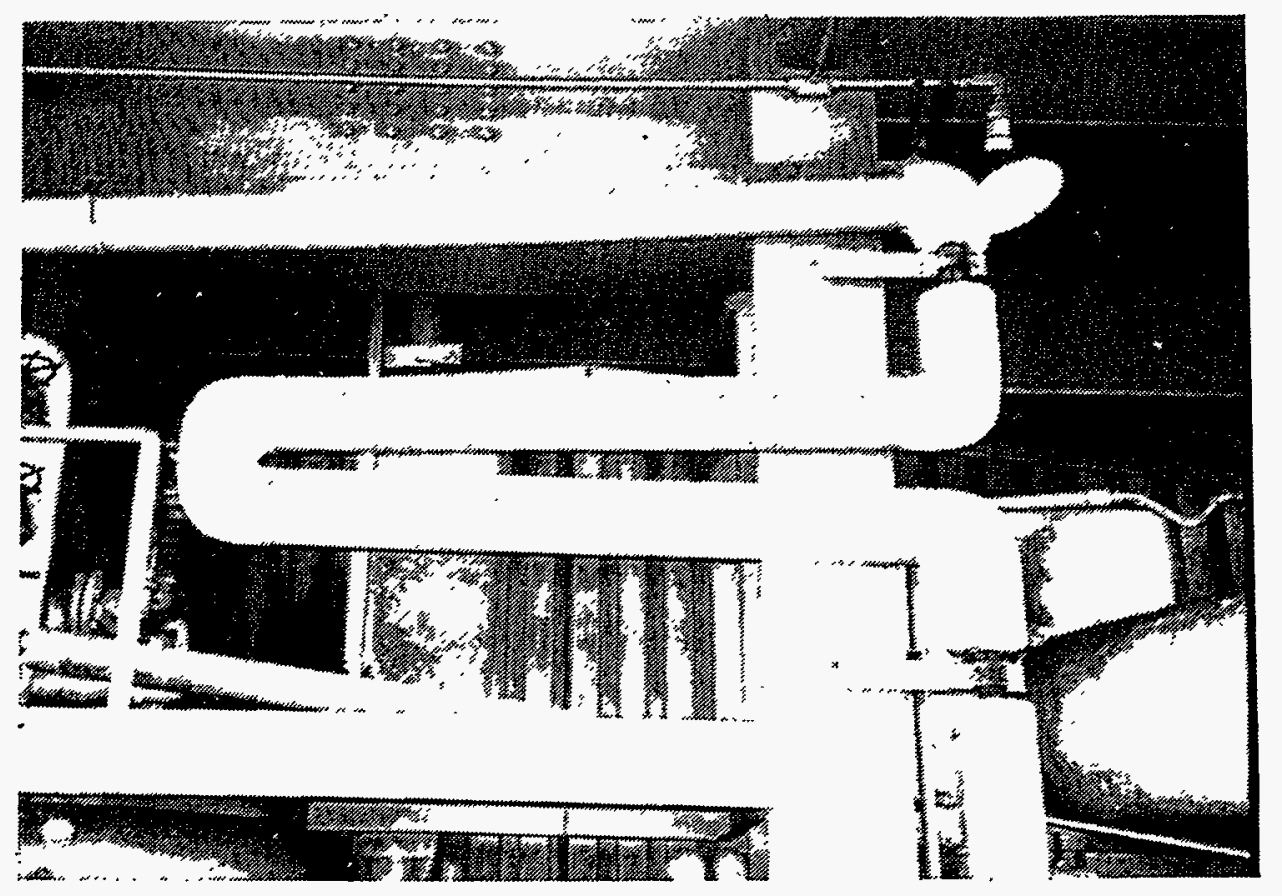

Figure E.49 Expansion Loop in Small Bore Hot Line in Olive Unit 1

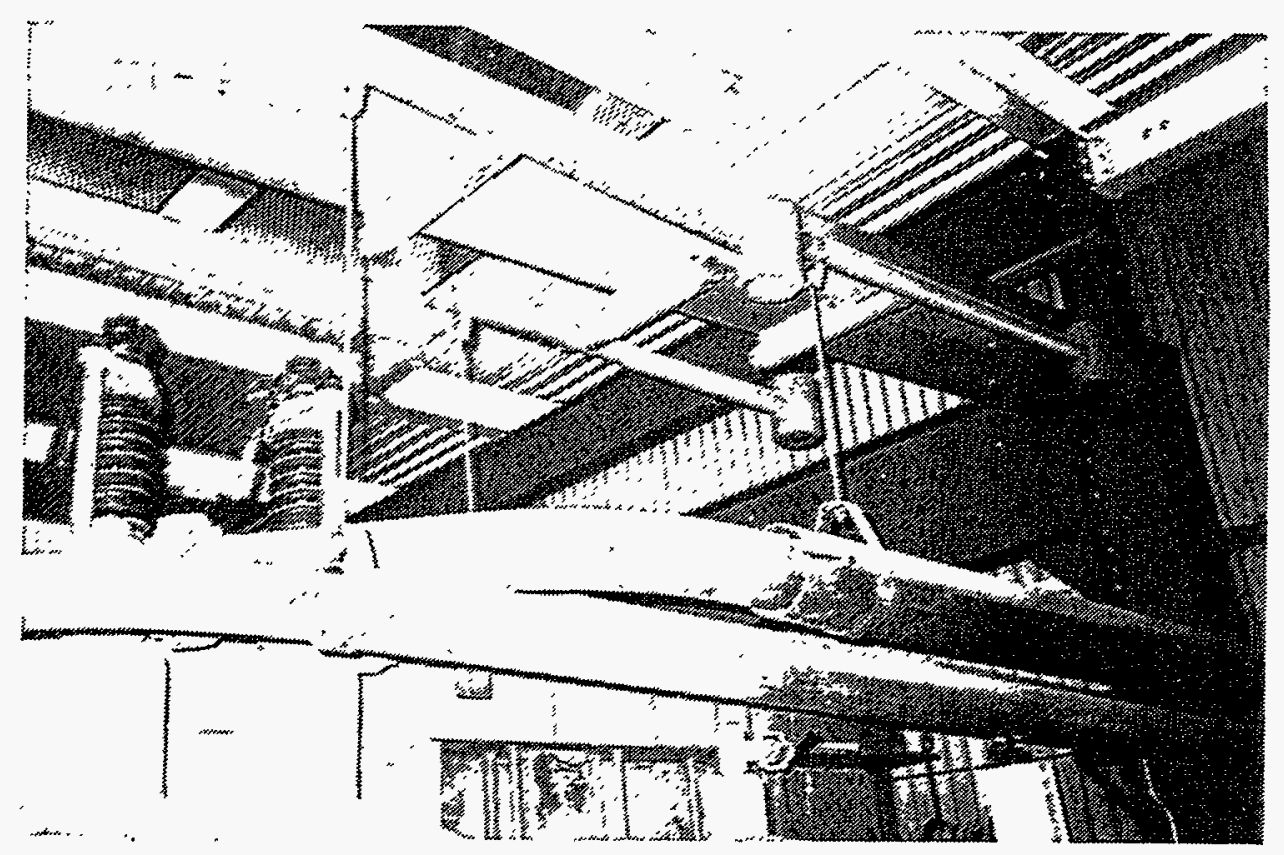

Figure E.50 Guide Pipe and Support for Large Bore Cold Lines in Glendale Unit 3 


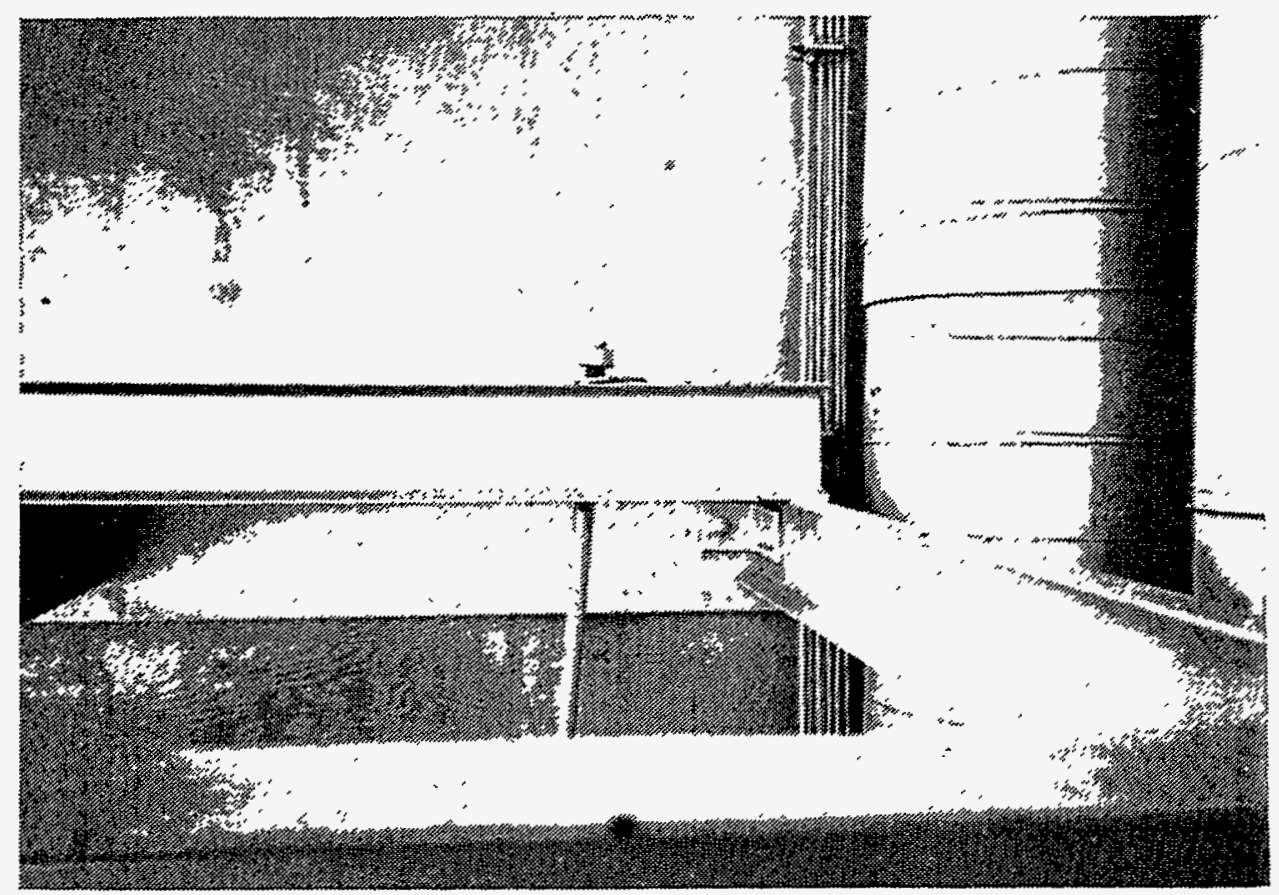

Figure E.51 Unseated Vertical Support in El Centro Unit 2

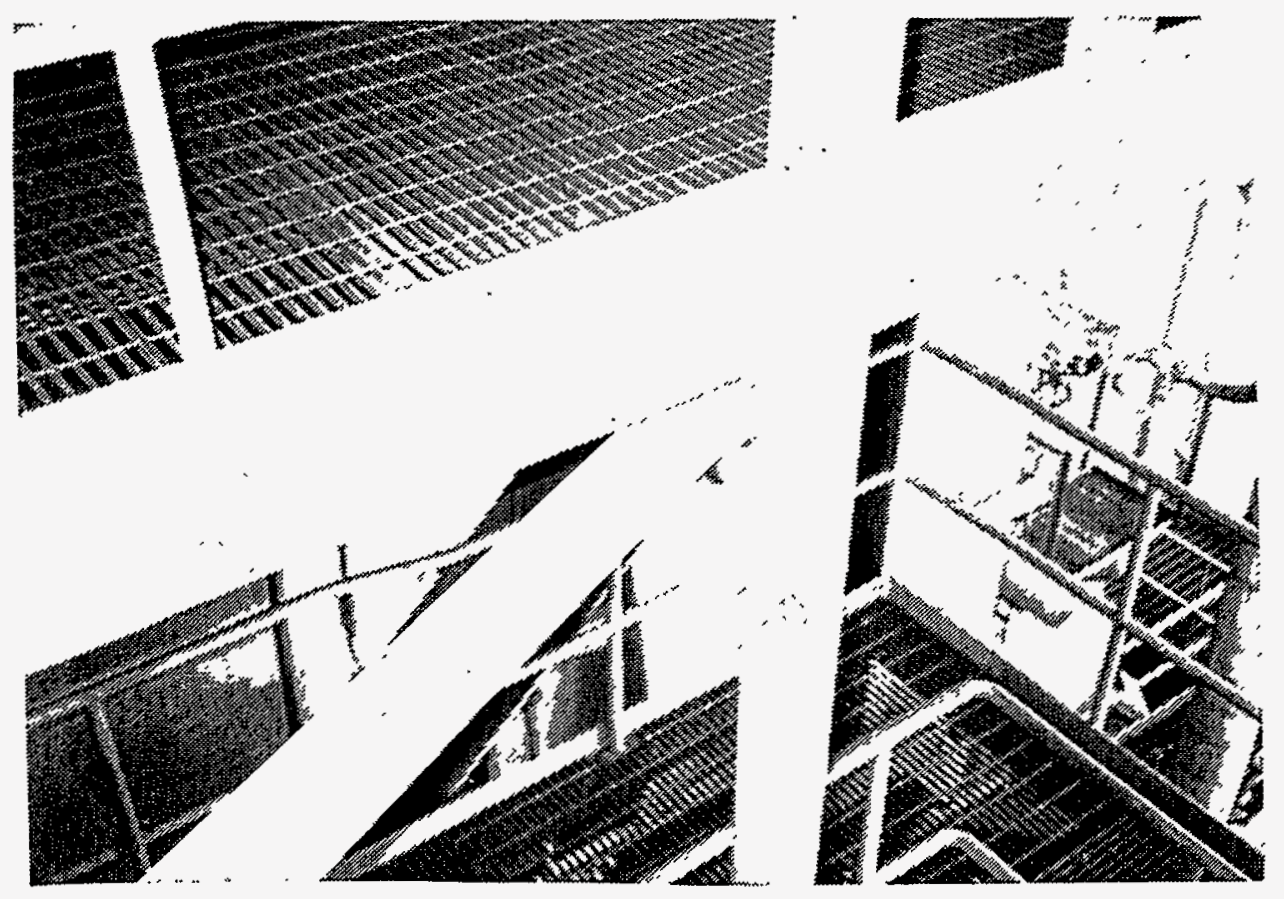

Figure E.52 U-Bolt Vertical Lateral Restraint in Small Bore Hot Pipe in Olive Unit 1 


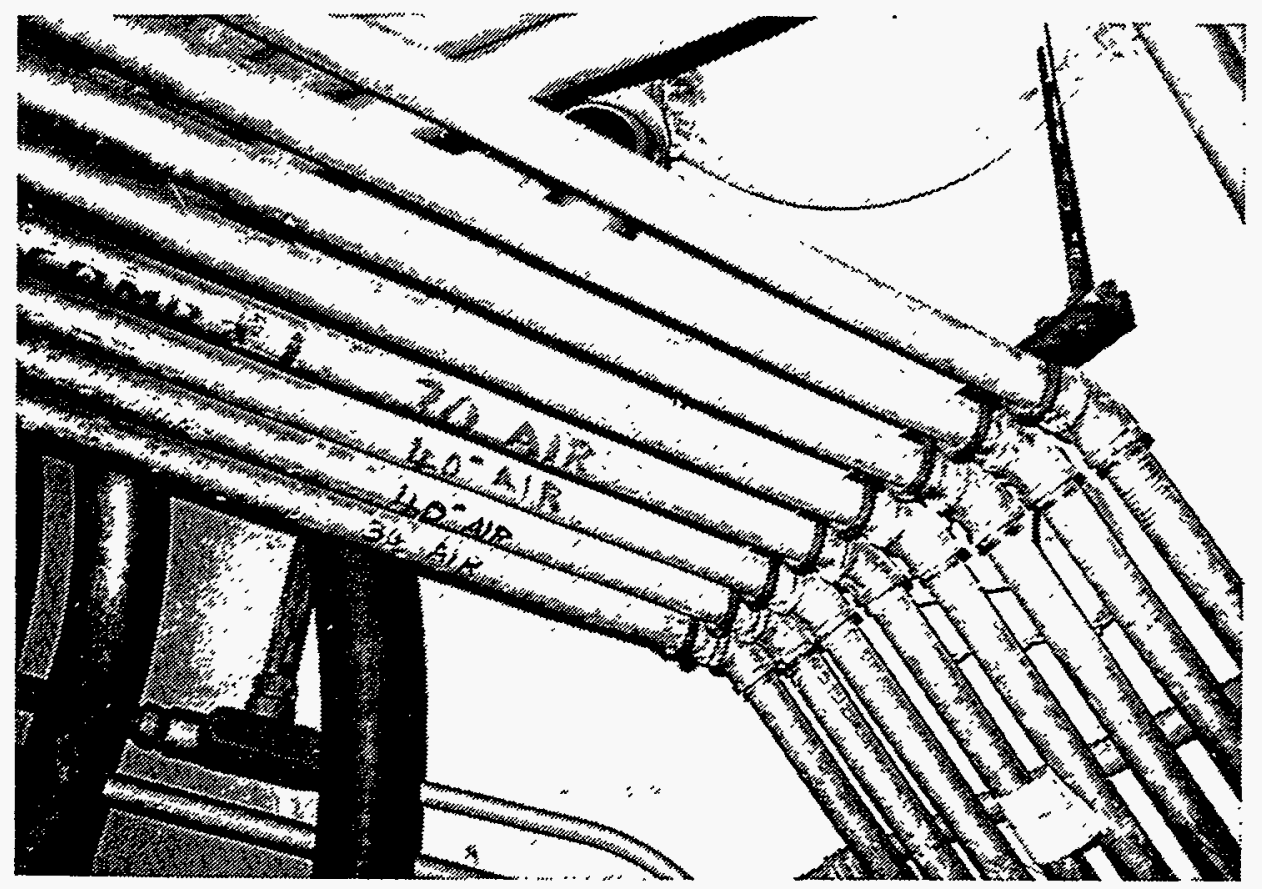

Figure E.53 Trapeze and U-Bolt Supported Small Bore Cold Piping in Kern Unit 1

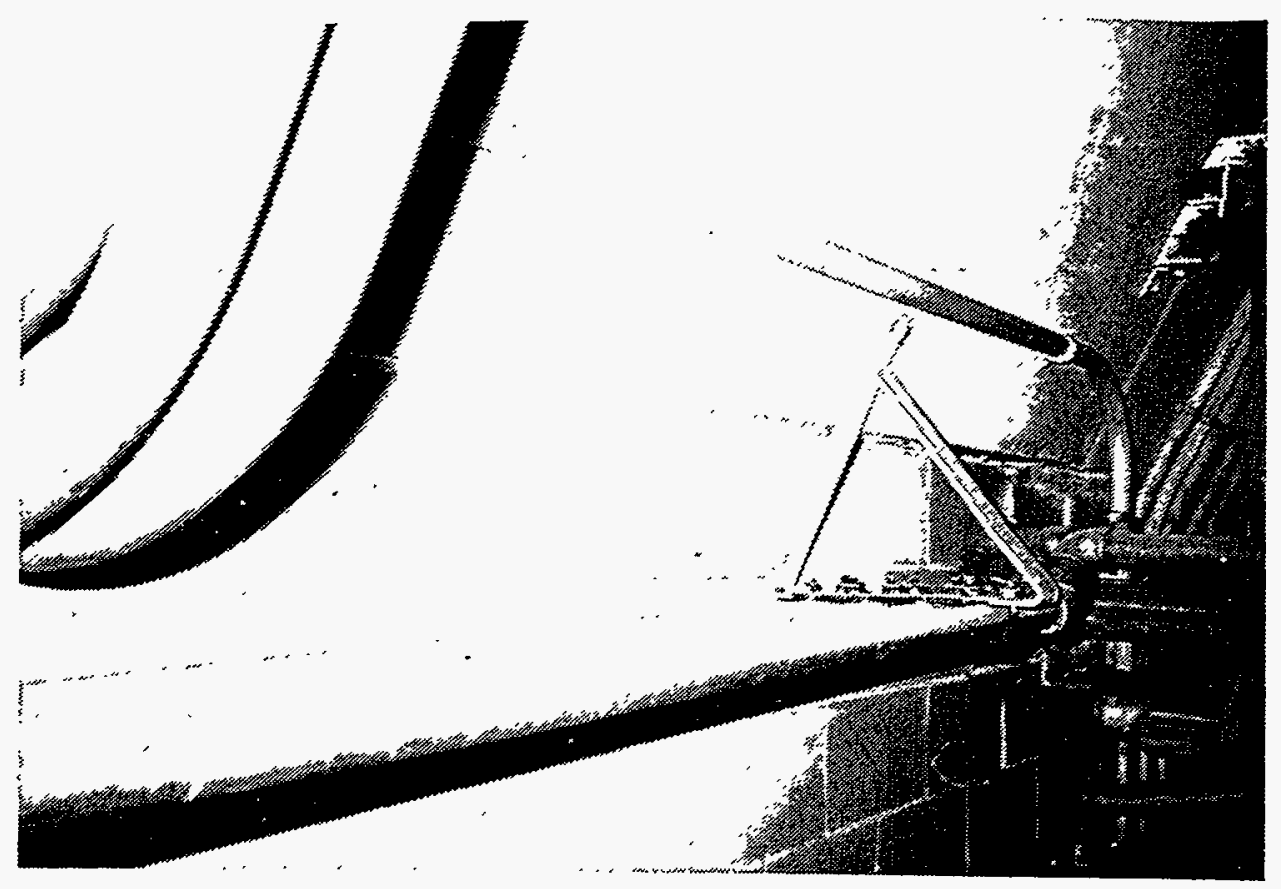

Figure E.54 Field Fabricated Support in Kern Unit 1 
E 7!ณ

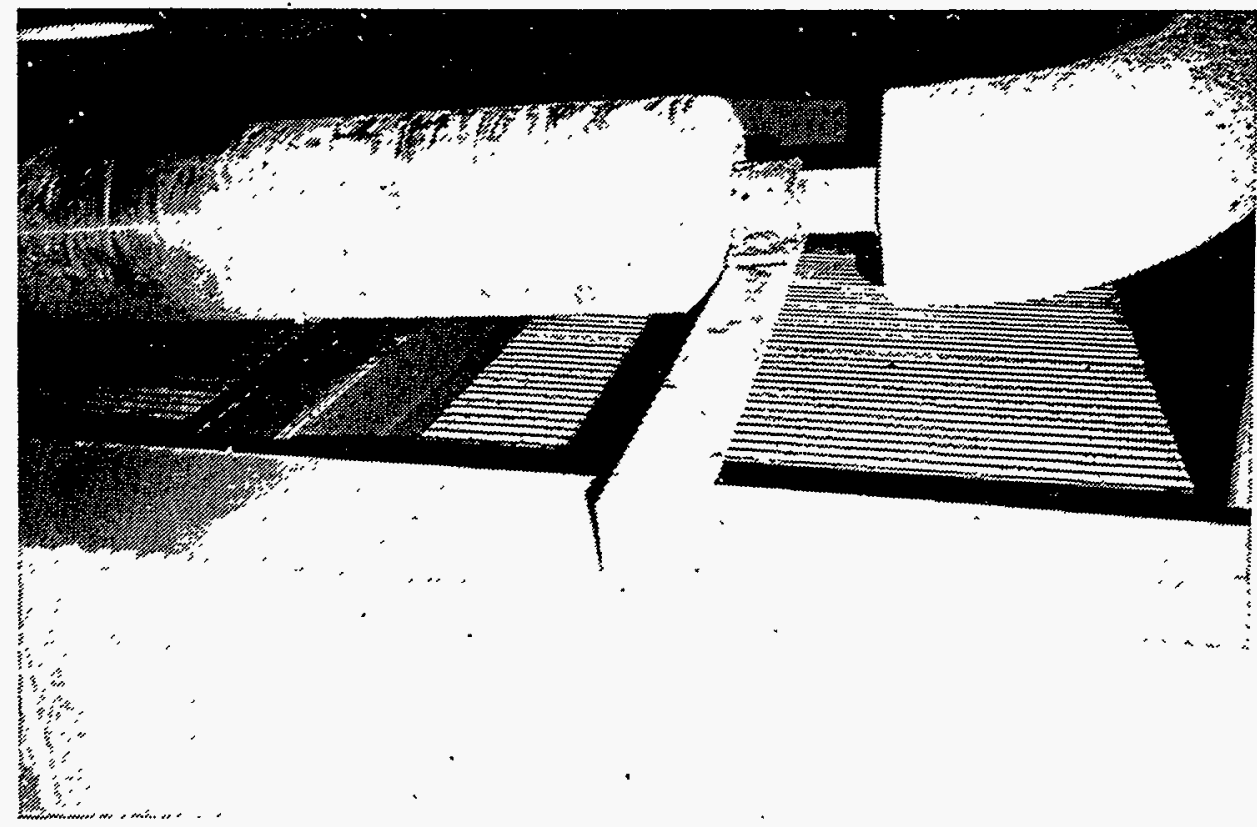

E ๆ!u

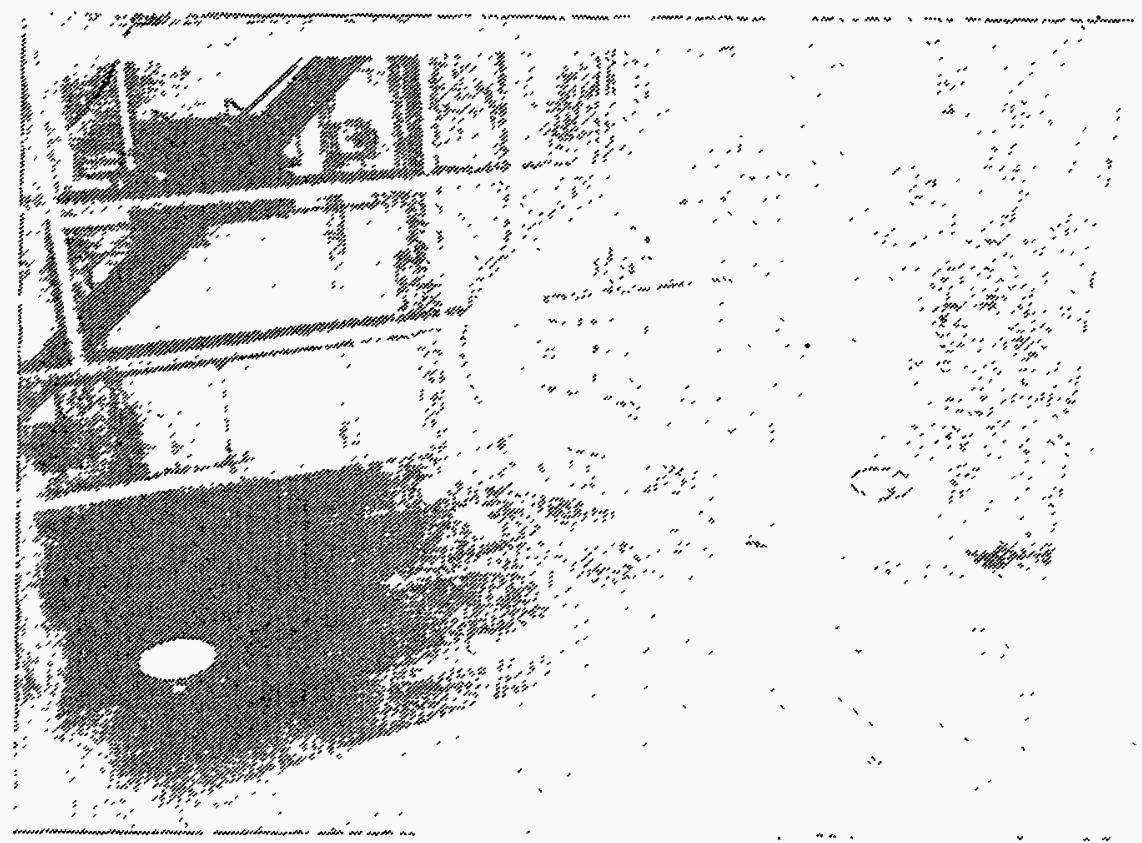




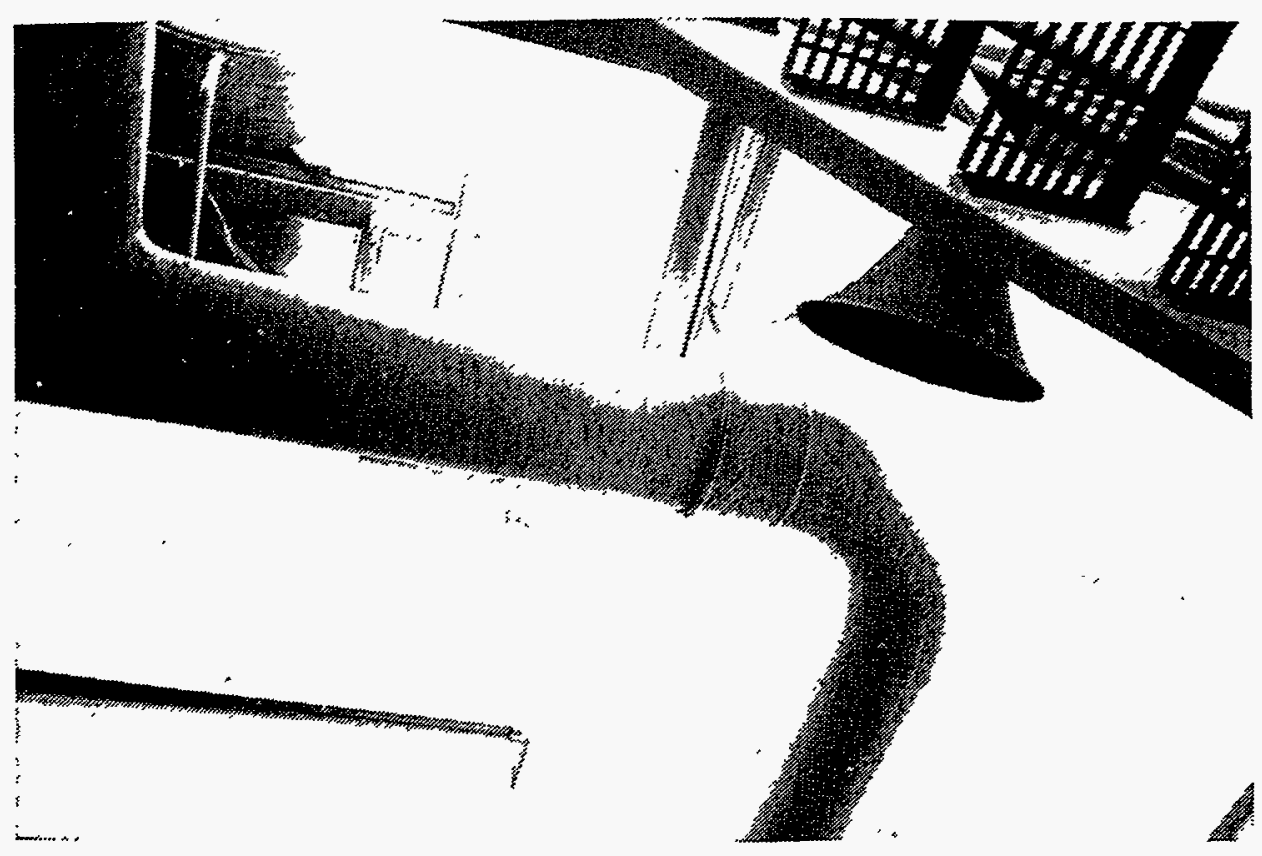

Figure E.57 U-Bolt Support of Large Bore Hot Line in Pasadena Broadway Unit 2

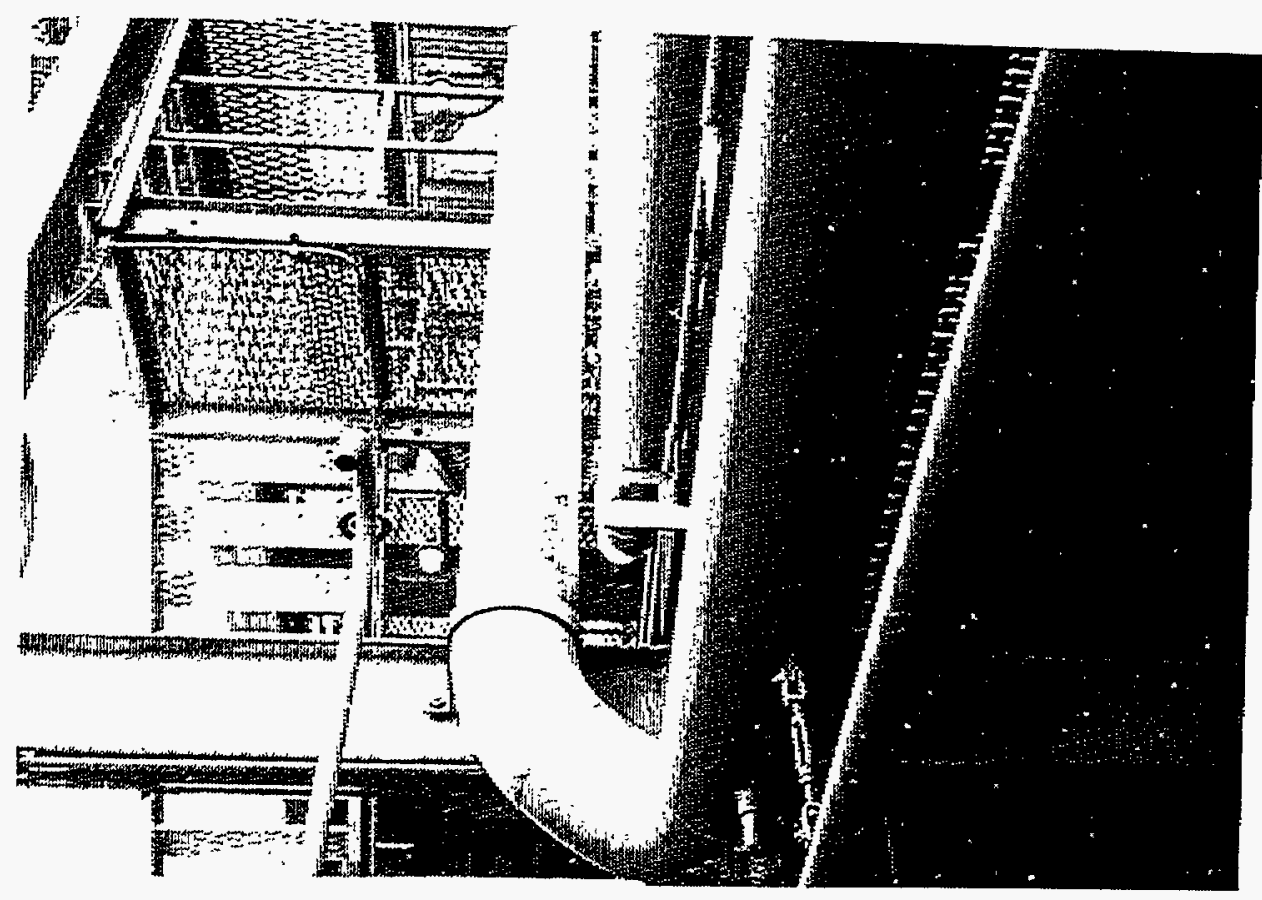

Figure E.58 U-Bolt Support of Large Bore Cold Line and Pipe Supporting Pipe in Valley Unit 1 


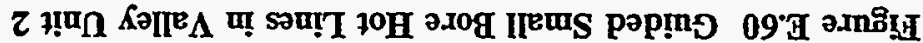

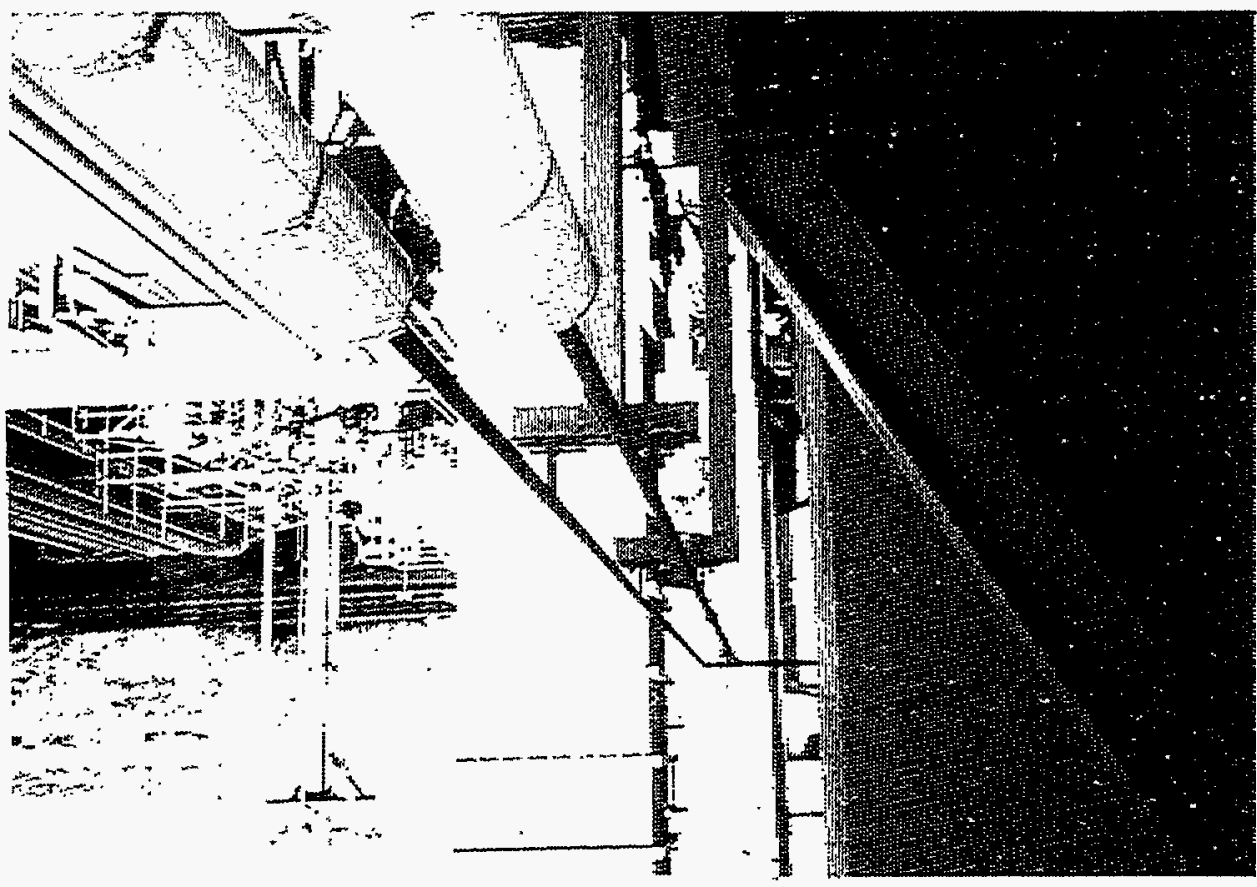

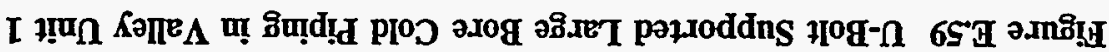

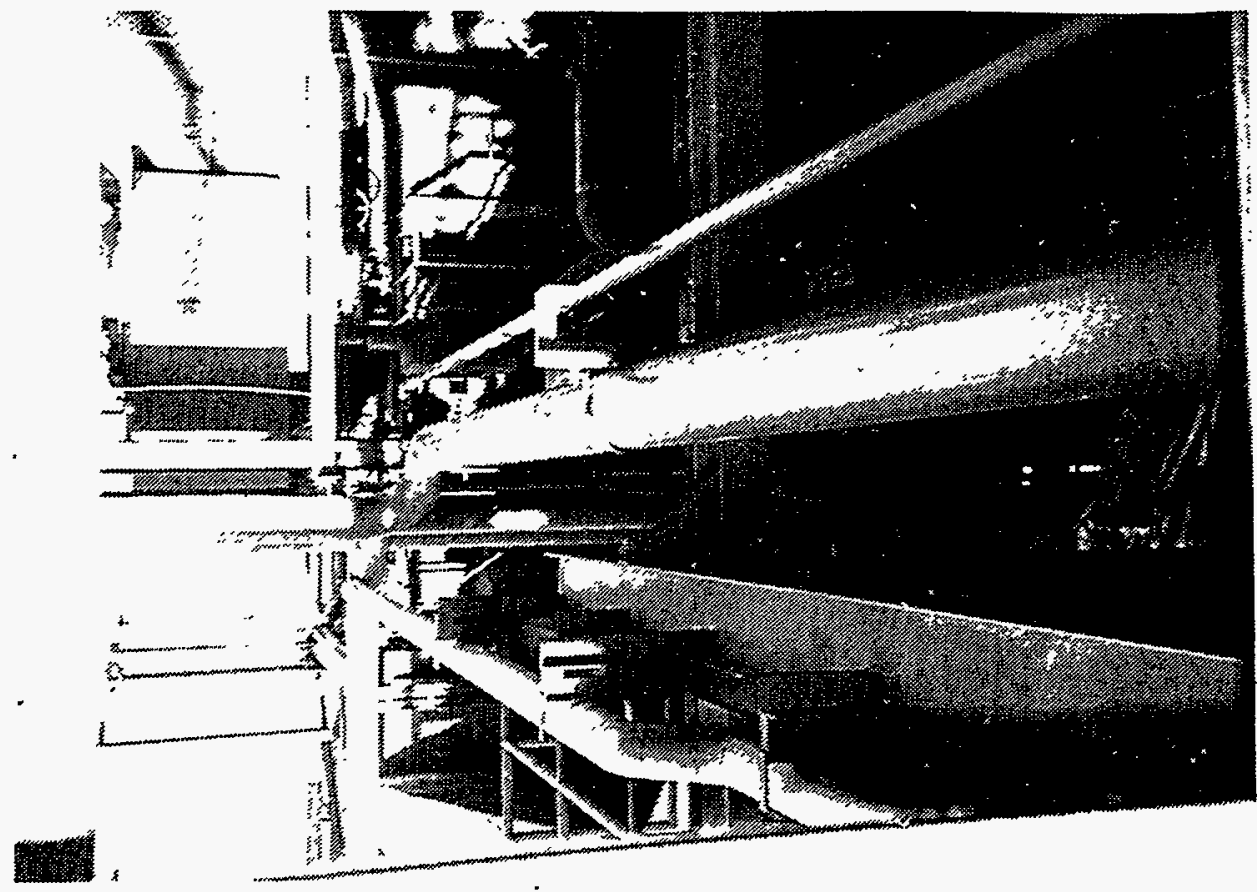




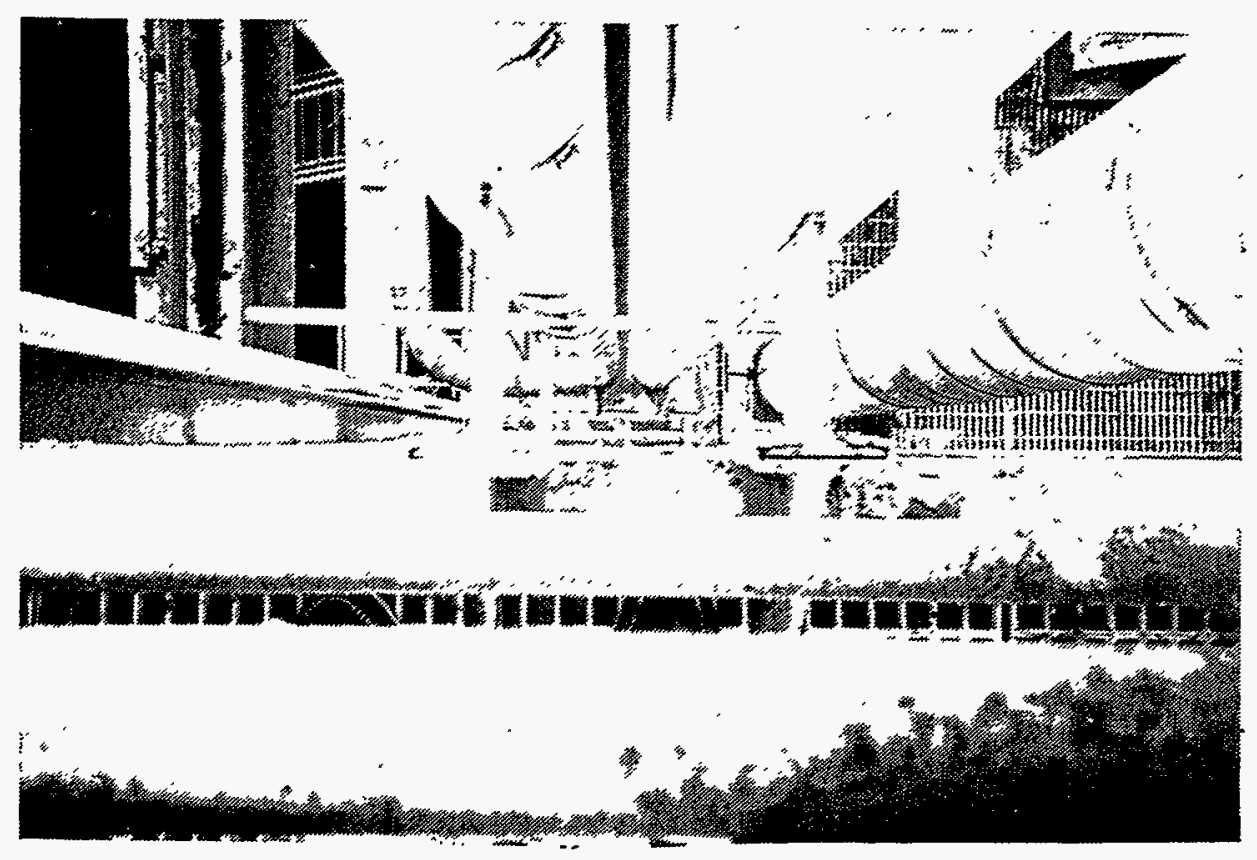

Figure E.61 Guided Large Bore Hot Lines in Pasadena Broadway Unit 3 


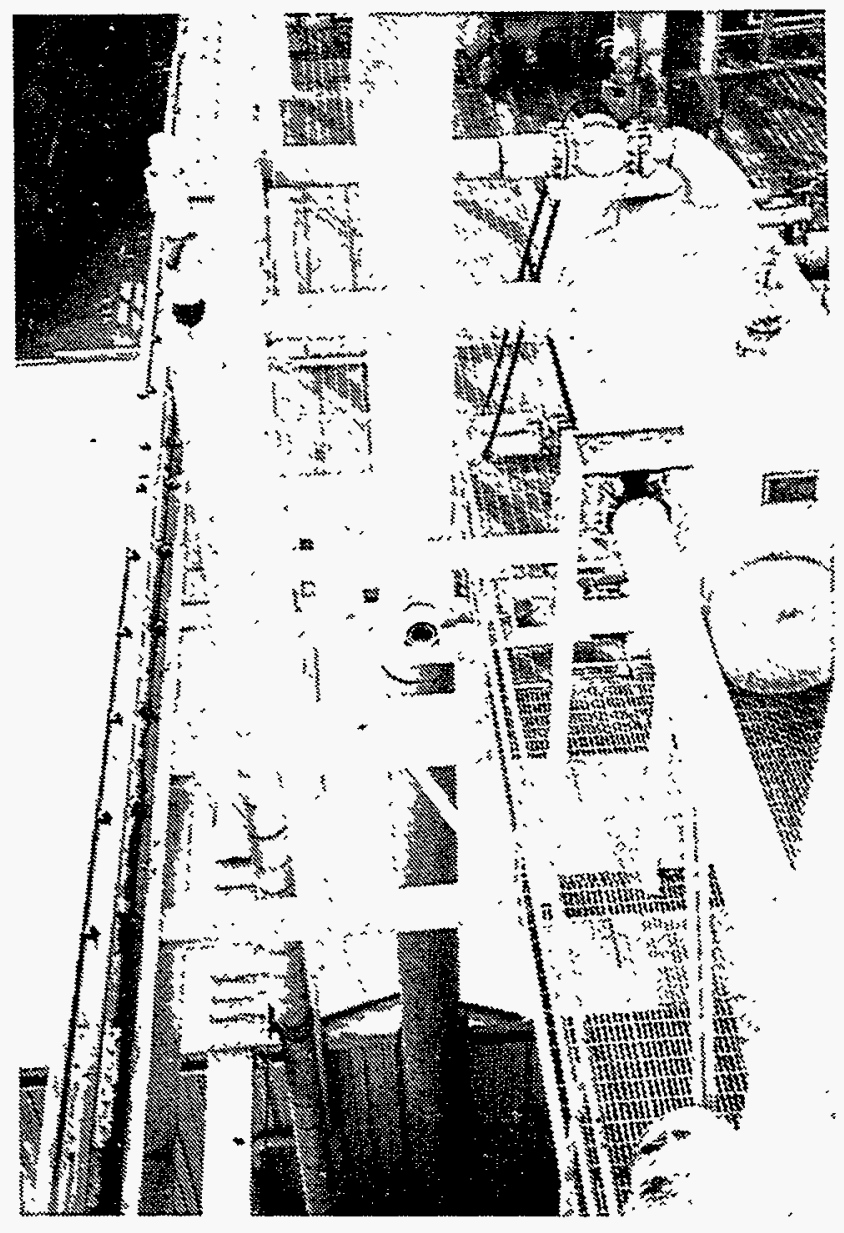

Figure E.62 Anchor or Large Bore Hot Line in Pasadena Broadway Unit 2 


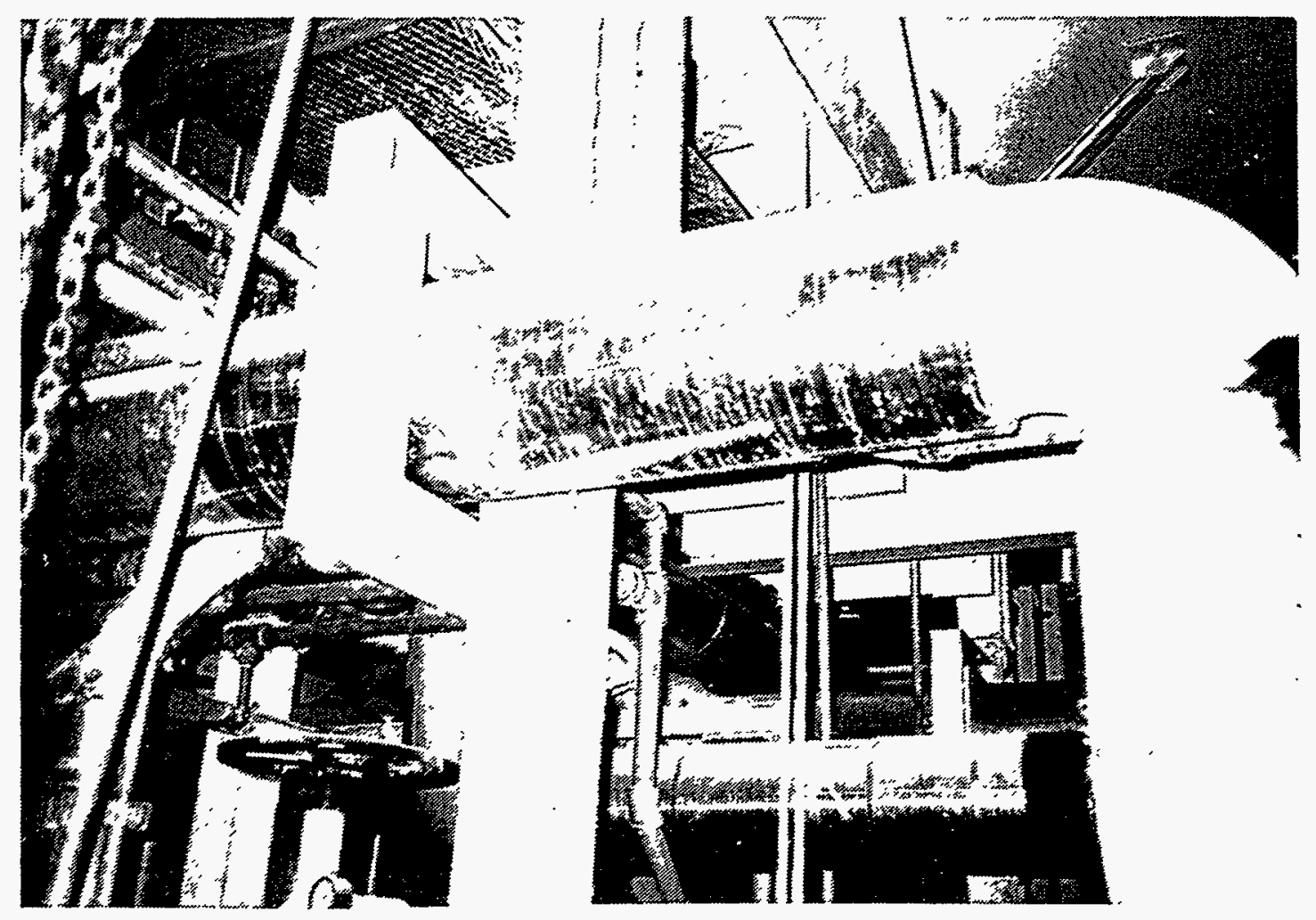

Figure E.63 Guided Restraint on Large Bore Hot Line in Humboldt Bay Unit 3 


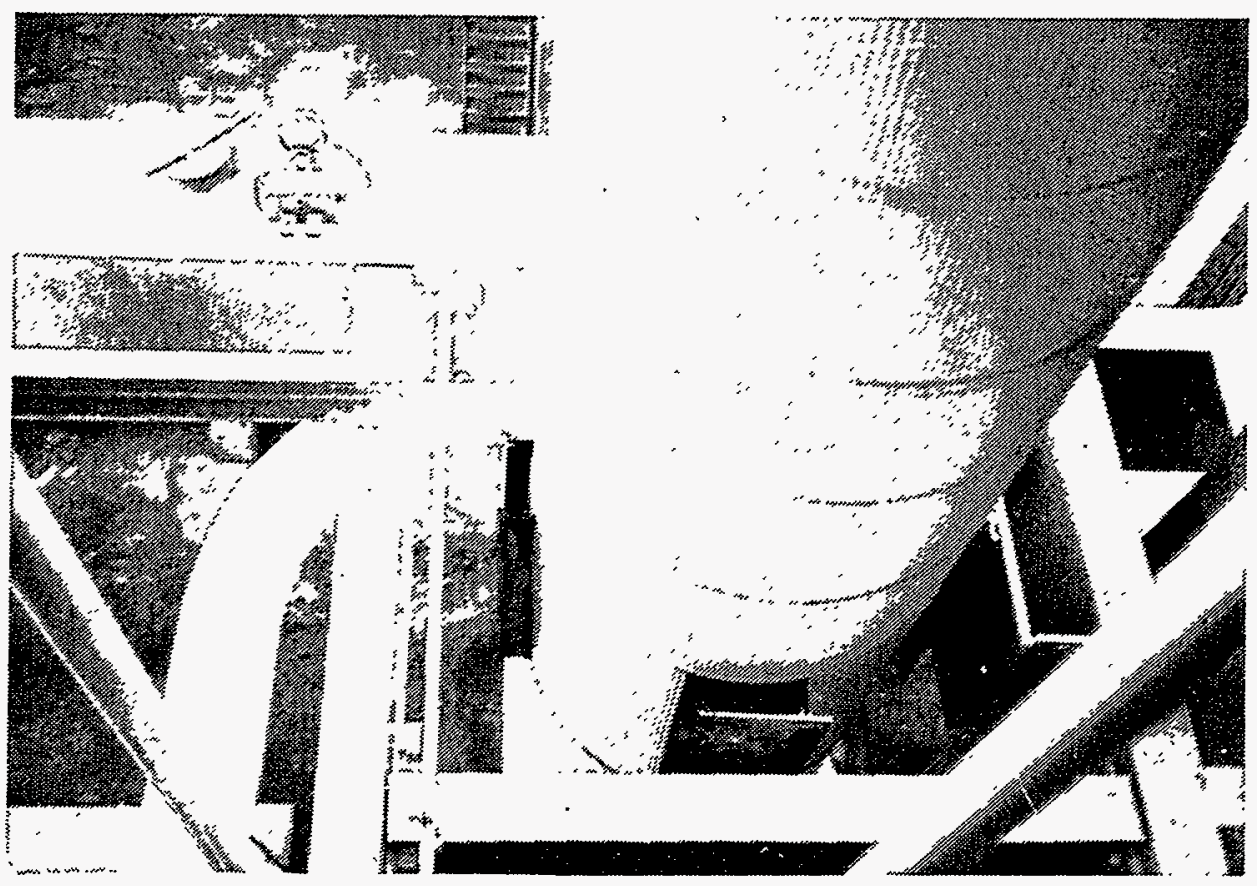

Figure E.64 Guided Restraint for Main Steam Line in El Centro Unit 3 


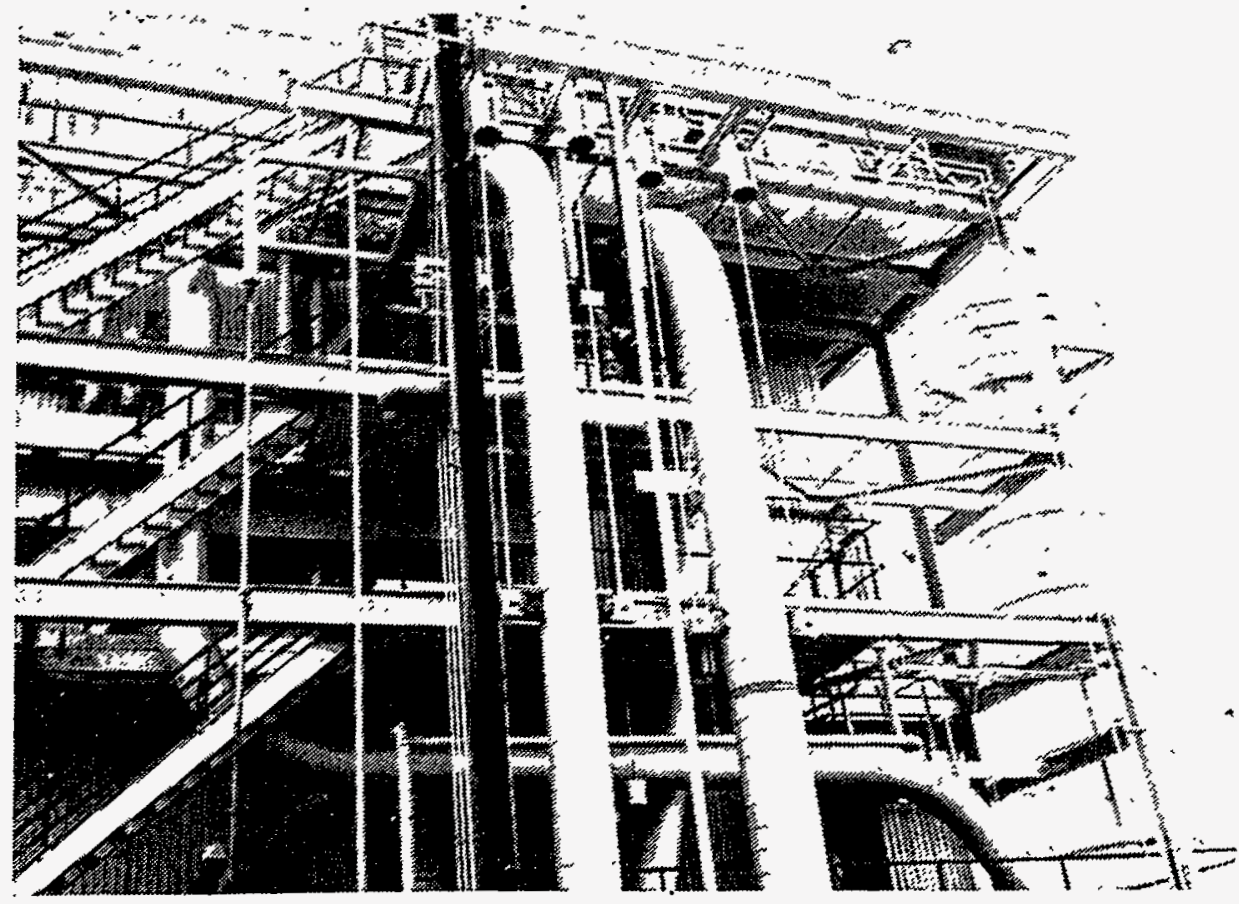

Figure E.65 Long Vertical Hangers and Springs for Main Steam Line on El Centro Unit 2 


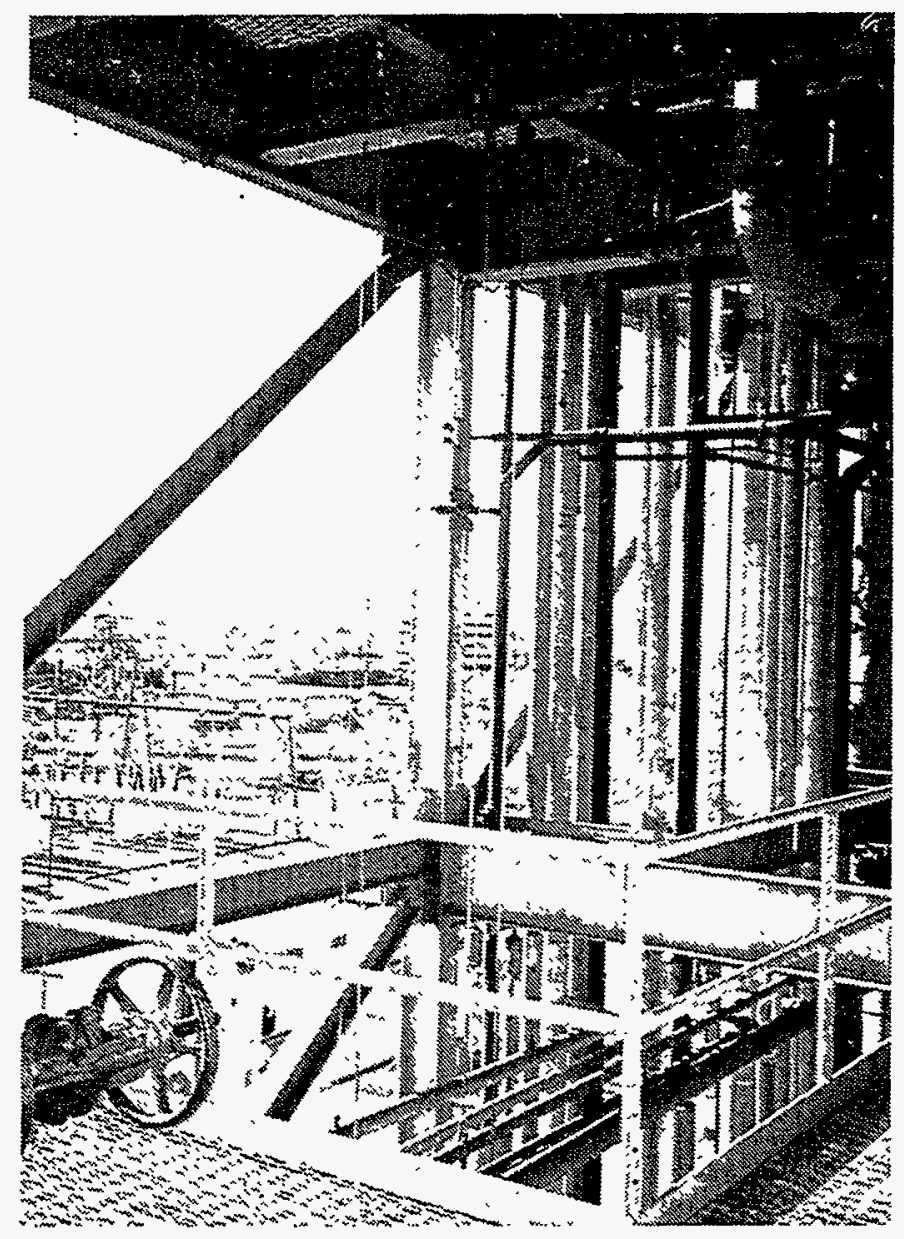

Figure E.66 Long Vertical Hangers for Large Bore Hot Lines in Valley Unit 3 


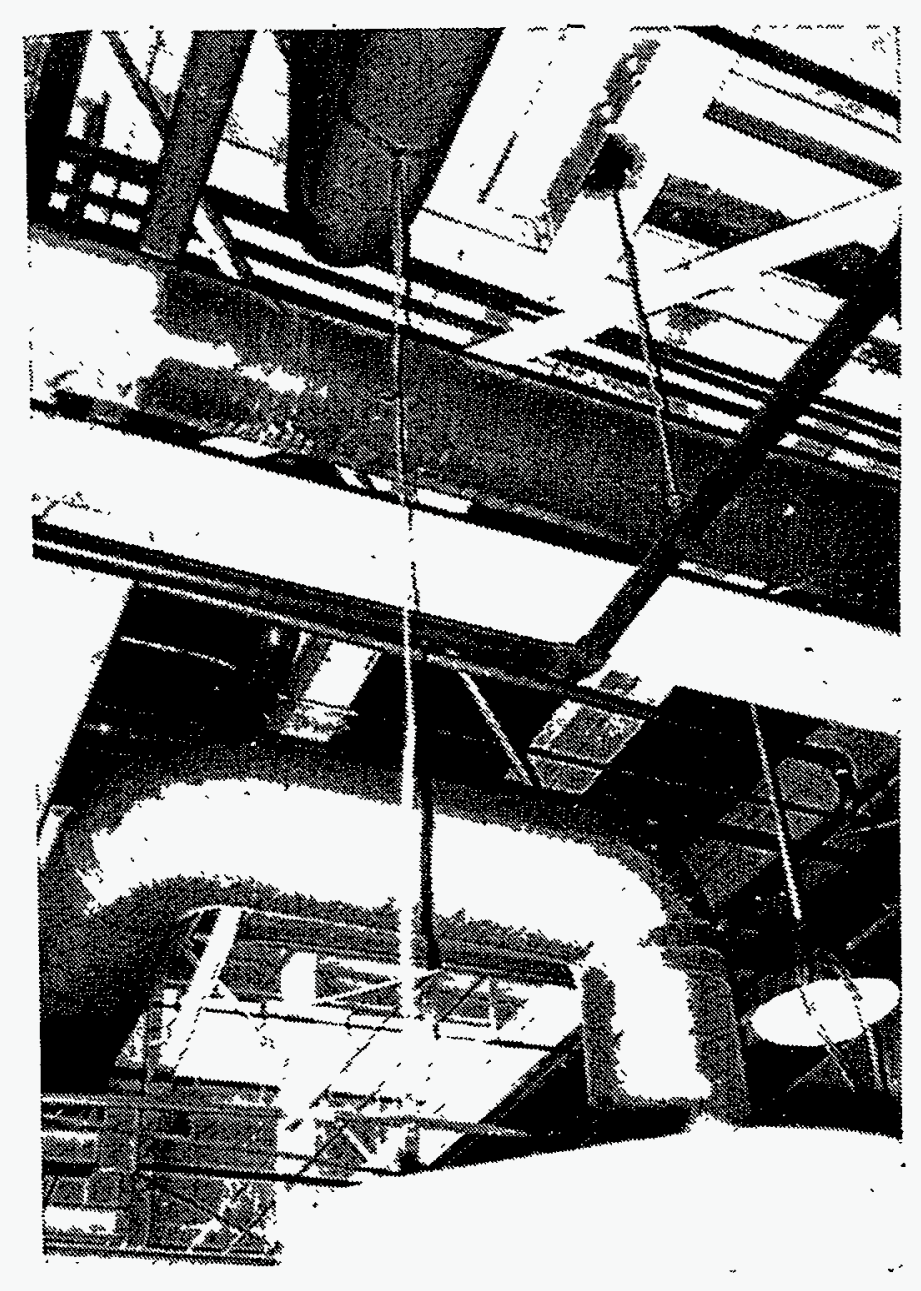

Figure E.67 Field Fabricated Hangers in Olive Unit 2 


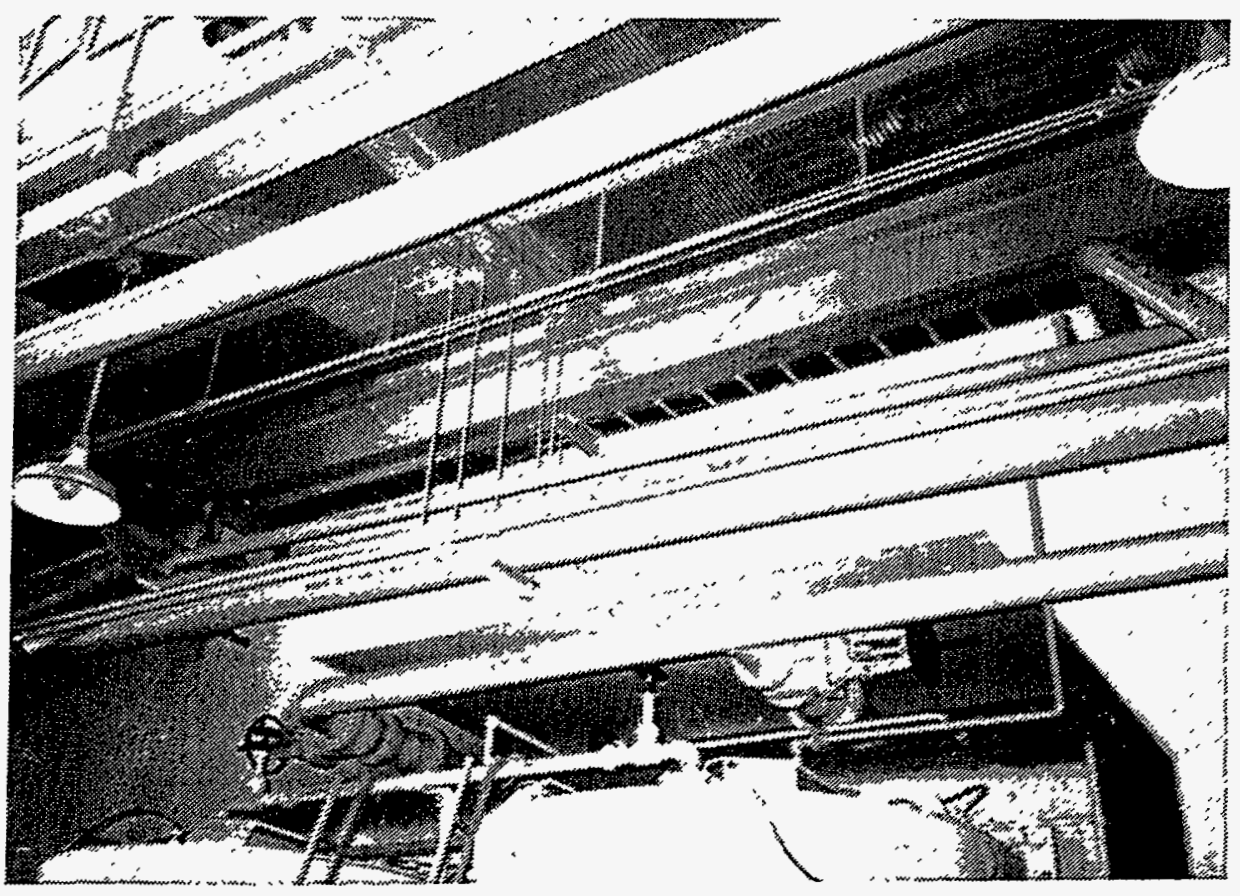

Figure E.68 Long Trapeze Supports for Large and Small Bore Cold Lines in El Centro Unit 4 
Appendix F: Piping Support Data Base Developed from Valley Steam Plants Units 1 to 4, El Centro Plants Units 1-4 and Moss Landing Units 1-5 


\begin{tabular}{|c|c|c|c|c|c|c|c|c|c|c|c|}
\hline $\begin{array}{l}\text { Line } \\
\text { No }\end{array}$ & Unit & $\begin{array}{l}\text { Pipe } \\
\text { Size } \\
\text { (in) }\end{array}$ & Temp & $\begin{array}{l}\text { Conn } \\
\text { Type }\end{array}$ & $\begin{array}{l}\text { Support } \\
\text { Type }\end{array}$ & $\begin{array}{l}\text { Vert } \\
\text { Span } \\
(\mathrm{ft})\end{array}$ & $\begin{array}{l}\text { Horia } \\
\text { Span } \\
\text { (ft) }\end{array}$ & $\begin{array}{l}\text { Norm } \\
\text { Vert } \\
\text { Span } \\
\text { (ft) }\end{array}$ & $\begin{array}{l}\text { Norm } \\
\text { Horz } \\
\text { Span } \\
\text { (ft) }\end{array}$ & $\begin{array}{l}\text { Plant } \\
\text { Elevation } \\
\text { Above } \\
\text { Grade }\end{array}$ & Remarks \\
\hline $1 \mathrm{a}$ & 1 & 12 & 1000 & $\mathrm{w}$ & steam drum & 0 & & 0 & & 100 & \\
\hline $1 \mathrm{a}$ & 1 & 12 & 1000 & w & $\operatorname{csh}$ & 20 & & 0.67 & & 100 & \\
\hline $1 \mathrm{a}$ & 1 & 12 & 1000 & $\mathbf{w}$ & $\operatorname{csh}$ & 6 & & 0.2 & & 100 & \\
\hline $1 a$ & 1 & 12 & 1000 & $\mathbf{w}$ & $\operatorname{csh}$ & 14 & 40.0 & 0.47 & 1.33 & 100 & \\
\hline $1 \mathrm{a}$ & 1 & 12 & 1000 & w & downcomer & 0 & & 0 & & 100 & \\
\hline $1 b$ & 2 & 12 & 1000 & $w$ & steam drum & 0 & & 0 & & 100 & \\
\hline $1 b$ & 2 & 12 & 1000 & $\mathbf{w}$ & $\operatorname{csh}$ & 20 & & 0.67 & & 100 & \\
\hline $1 b$ & 2 & 12 & 1000 & $\mathbf{w}$ & $\operatorname{csh}$ & 6 & & 0.2 & & 100 & \\
\hline $1 b$ & 2 & 12 & 1000 & $\mathbf{w}$ & $\operatorname{csh}$ & 14 & 40.0 & 0.47 & 1.33 & 100 & \\
\hline 16 & 2 & 12 & 1000 & $w$ & downcomer & 0 & & 0 & & 100 & \\
\hline $2 a$ & 1 & 3 & hot & $w$ & pump & 0 & & 0 & & 100 & \\
\hline $2 a$ & 1 & 3 & hot & $\mathrm{w}$ & sh & 2 & & 0.13 & & 100 & \\
\hline $2 a$ & 1 & 3 & hot & $w$ & sh & 10 & & 0.67 & & 100 & \\
\hline $2 a$ & 1 & 3 & hot & $\mathrm{w}$ & sh & 8 & & 0.53 & & 100 & \\
\hline $2 a$ & 1 & 3 & hot & $\mathrm{w}$ & sh & 12 & & 0.8 & & 100 & \\
\hline $2 \mathbf{a}$ & 1 & 3 & hot & $w$ & sh & 10 & & 0.67 & & 100 & \\
\hline $2 a$ & 1 & 3 & hot & $\mathbf{w}$ & downcomer & 12 & 54.0 & 0.8 & 3.60 & 100 & \\
\hline $2 b$ & 2 & 3 & hot & $\mathbf{w}$ & pump & 0 & & 0 & & 100 & \\
\hline $2 b$ & 2 & 3 & hot & $\mathbf{w}$ & $\operatorname{sh}$ & 2 & & 0.13 & & 100 & \\
\hline $2 b$ & 2 & 3 & hot & $\mathbf{w}$ & sh & 10 & & 0.67 & & 100 & \\
\hline $2 b$ & 2 & 3 & hot & w & sh & 8 & & 0.53 & & 100 & \\
\hline $2 b$ & 2 & 3 & hot & $w$ & $\operatorname{sh}$ & 12 & & 0.8 & & 100 & \\
\hline $2 b$ & 2 & 3 & hot & $w$ & $\operatorname{sh}$ & 10 & & 0.67 & & 100 & \\
\hline $2 b$ & 2 & 3 & hot & $w$ & downcomer & 12 & 54.0 & 0.8 & 3.60 & 100 & \\
\hline $3 a$ & 1 & 3 & hot & w & downcomer & 0 & & 0 & & 100 & \\
\hline $3 a$ & 1 & 3 & hot & $w$ & h & 1 & & 0.07 & & 100 & \\
\hline $3 \mathbf{a}$ & 1 & 3 & hot & $w$ & $\mathbf{h}$ & 15 & & 1 & & 100 & \\
\hline $3 \mathbf{a}$ & 1 & 3 & hot & $w$ & $\mathrm{~h}$ & 12 & & 0.8 & & 100 & \\
\hline $3 a$ & 1 & 3 & hot & $\mathbf{w}$ & $\mathbf{h}$ & 12 & & 0.8 & & 100 & \\
\hline $3 a$ & 1 & 3 & hot & $\mathrm{w}$ & h & 12 & & 0.8 & & 100 & \\
\hline $3 \mathbf{a}$ & 1 & 3 & hot & $w$ & hor el & 8 & & 0.53 & & 100 & \\
\hline $3 a$ & 1 & 3 & hot & $w$ & h & 3 & & 0.2 & & 100 & \\
\hline
\end{tabular}




\begin{tabular}{|c|c|c|c|c|c|c|c|c|c|c|c|}
\hline $\begin{array}{l}\text { Line } \\
\text { No }\end{array}$ & Unit & $\begin{array}{l}\text { Pipe } \\
\text { Size } \\
\text { (in) }\end{array}$ & Temp & $\begin{array}{l}\text { Conn } \\
\text { Type }\end{array}$ & $\begin{array}{l}\text { Support } \\
\text { Type }\end{array}$ & $\begin{array}{l}\text { Vert } \\
\text { Span } \\
\text { (ft) }\end{array}$ & $\begin{array}{l}\text { Horia } \\
\text { Span } \\
\text { (ft) }\end{array}$ & $\begin{array}{l}\text { Norm } \\
\text { Vert } \\
\text { Span } \\
\text { (ft) }\end{array}$ & $\begin{array}{l}\text { Norm } \\
\text { Horz } \\
\text { Span } \\
\text { (ft) }\end{array}$ & $\begin{array}{l}\text { Plant } \\
\text { Elevation } \\
\text { Above } \\
\text { Grade }\end{array}$ & Remarks \\
\hline $3 a$ & 1 & 3 & hot & $w$ & sway brace & 1 & 64.0 & 0.07 & 427 & 100 & \\
\hline $3 a$ & 1 & 3 & hot & $\mathrm{w}$ & $\mathrm{h}$ & 3 & & 0.2 & & 100 & \\
\hline $3 a$ & 1 & 3 & hot & $w$ & tank & 27 & 30.0 & 1.8 & 2.00 & 100 & \\
\hline $3 b$ & 2 & 3 & hot & $\mathrm{w}$ & down comme & 0 & & 0 & & 100 & \\
\hline $3 b$ & 2 & 3 & hot & w & $\mathrm{h}$ & 1 & & 0.07 & & 100 & \\
\hline $3 b$ & 2 & 3 & hot & $\mathrm{w}$ & $\mathrm{h}$ & 15 & & 1 & & 100 & \\
\hline $3 b$ & 2 & 3 & hot & w & $\mathrm{h}$ & 12 & & 0.8 & & 100 & \\
\hline $3 b$ & 2 & 3 & hot & w & $\mathrm{h}$ & 12 & & 0.8 & & 100 & \\
\hline $3 b$ & 2 & 3 & hot & w & $\mathrm{h}$ & 12 & & 0.8 & & 100 & \\
\hline $3 b$ & 2 & 3 & hot & $w$ & hor el & 8 & & 0.53 & & 100 & \\
\hline $3 b$ & 2 & 3 & hot & $w$ & $\mathrm{~h}$ & 3 & & 02 & & 100 & \\
\hline $3 b$ & 2 & 3 & hot & $w$ & sway brace & 1 & 64.0 & 0.07 & 4.27 & 100 & \\
\hline $3 b$ & 2 & 3 & hot & $w$ & $h$ & 3 & & 0.2 & & 100 & \\
\hline $3 b$ & 2 & 3 & hot & $\mathrm{w}$ & $\operatorname{tank}$ & 27 & 30.0 & 1.8 & 2.00 & 100 & \\
\hline $4 a$ & 1 & 4 & cold & $w$ & $\mathrm{U}$ bolt & 0 & & 0 & & 100 & \\
\hline $4 a$ & 1 & 4 & cold & $\mathrm{w}$ & $\mathrm{h}$ & 12 & & 0.85 & & 100 & \\
\hline $4 a$ & 1 & 4 & cold & $\mathrm{w}$ & $\mathrm{h}$ & 10 & & 0.71 & & 100 & \\
\hline $4 a$ & 1 & 4 & cold & w & $\mathrm{h}$ & 10 & & 0.71 & & 100 & \\
\hline $4 a$ & 1 & 4 & cold & $w$ & $\mathrm{U}$ bolt & 12 & 15.0 & 0.85 & 1.07 & 100 & \\
\hline $4 a$ & 1 & 4 & cold & $w$ & $U$ bolt & 14 & 14.0 & 1 & 1.00 & 100 & \\
\hline $4 a$ & 1 & 4 & cold & $w$ & $\mathrm{~h}$ & 9 & & 0.67 & & 100 & \\
\hline $4 a$ & 1 & 4 & cold & $w$ & $\mathrm{~h}$ & 12 & & 0.85 & & 100 & \\
\hline $4 a$ & 1 & 4 & cold & $\mathrm{w}$ & $\mathrm{U}$ bolt & 12 & 32.0 & 0.71 & 2.29 & 100 & \\
\hline $4 a$ & 1 & 4 & cold & $\mathrm{w}$ & $\mathrm{h}$ & 10 & 10.0 & 0.71 & 0.71 & 100 & \\
\hline $4 b$ & 2 & 4 & cold & w & $U$ bolt & 0 & & 0 & & 100 & \\
\hline $4 b$ & 2 & 4 & cold & w & $\mathbf{h}$ & 12 & & 0.85 & & 100 & \\
\hline $4 b$ & 2 & 4 & cold & $w$ & $\mathrm{~h}$ & 10 & & 0.71 & & 100 & \\
\hline $4 b$ & 2 & 4 & cold & $w$ & $\mathrm{~h}$ & 10 & & 0.71 & & 100 & \\
\hline $4 b$ & 2 & 4 & cold & $w$ & U bolt & 12 & 15.0 & 0.85 & 1.07 & 100 & \\
\hline $4 b$ & 2 & 4 & cold & $w$ & U bolt & 14 & 14.0 & 1 & 1.00 & 100 & \\
\hline $4 b$ & 2 & 4 & cold & $w$ & h & 9 & & 0.67 & & 100 & \\
\hline $4 b$ & 2 & 4 & cold & $\mathrm{w}$ & $h$ & 12 & & 0.85 & & 100 & \\
\hline
\end{tabular}




\begin{tabular}{|c|c|c|c|c|c|c|c|c|c|c|c|}
\hline $\begin{array}{l}\text { Line } \\
\text { No }\end{array}$ & Unit & $\begin{array}{l}\text { Pipe } \\
\text { Size } \\
\text { (in) }\end{array}$ & Temp & $\begin{array}{l}\text { Conn } \\
\text { Type }\end{array}$ & $\begin{array}{l}\text { Support } \\
\text { Type }\end{array}$ & $\begin{array}{l}\text { Vert } \\
\text { Span } \\
\text { (ft) }\end{array}$ & $\begin{array}{l}\text { Horia } \\
\text { Span } \\
\text { (ft) }\end{array}$ & $\begin{array}{l}\text { Norm } \\
\text { Vert } \\
\text { Span } \\
\text { (ft) }\end{array}$ & $\begin{array}{l}\text { Norm } \\
\text { Horz } \\
\text { Span } \\
\text { (ft) }\end{array}$ & $\begin{array}{l}\text { Plant } \\
\text { Elevation } \\
\text { Above } \\
\text { Grade }\end{array}$ & Remarks \\
\hline $4 b$ & 2 & 4 & cold & w & U bolt & 12 & 32.0 & 0.85 & 2.29 & 100 & \\
\hline $4 b$ & 2 & 4 & cold & w & h & 10 & 10.0 & 0.71 & 0.71 & 100 & \\
\hline $5 a$ & 1 & 8 & hot & w & tank & 0 & & 0 & & 100 & \\
\hline $5 a$ & 1 & 8 & hot & $\mathrm{w}$ & hor el & 2 & & 0.08 & & 100 & \\
\hline $5 a$ & 1 & 8 & hot & $\mathrm{w}$ & sh & 8 & & 0.33 & & 100 & \\
\hline $5 a$ & 1 & 8 & hot & $\mathrm{w}$ & sh & 18 & & 0.75 & & 100 & \\
\hline $5 a$ & 1 & 8 & hot & $\mathrm{w}$ & hor brace & 1 & 29.0 & 0.04 & 1.21 & 100 & \\
\hline $5 a$ & 1 & 8 & hot & $\mathrm{w}$ & $\mathrm{sh}$ & 1 & & 0.04 & & 100 & \\
\hline $5 a$ & 1 & 8 & hot & $\mathrm{w}$ & downcomer & 16 & 17.0 & 0.66 & 0.71 & 100 & \\
\hline $5 b$ & 1 & 8 & hot & $w$ & tank & 0 & & 0 & & 100 & \\
\hline $5 b$ & 1 & 8 & hot & w & hor el & 2 & & 0.08 & & 100 & \\
\hline $5 b$ & 1 & 8 & hot & $\mathrm{w}$ & sh & 8 & & 0.33 & & 100 & \\
\hline $5 b$ & 1 & 8 & hot & w & sh & 18 & & 0.75 & & 100 & \\
\hline $5 b$ & 1 & 8 & hot & w & hor brace & 1 & 29.0 & 0.04 & 1.21 & 100 & \\
\hline $5 b$ & 1 & 8 & hot & $\mathrm{w}$ & sh & 1 & & 0.04 & & 100 & \\
\hline $5 b$ & 1 & 8 & hot & $\mathrm{w}$ & downcomer & 16 & 17.0 & 0.66 & 0.71 & 100 & \\
\hline $6 a$ & 1 & 1 & cold & $\mathrm{t}$ & downcomer & 0 & & 0 & & 80 & \\
\hline $6 a$ & 1 & 1 & cold & $t$ & $\mathrm{~h}$ & 5 & & 0.71 & & 80 & \\
\hline $6 a$ & 1 & 1 & cold & $\mathbf{t}$ & h & 5 & & 0.71 & & 80 & \\
\hline $6 a$ & 1 & 1 & cold & $\mathrm{t}$ & hor el & 14 & & 2 & & 80 & \\
\hline $6 a$ & 1 & 1 & cold & $t$ & h & 1 & & 0.14 & & 80 & \\
\hline $6 a$ & 1 & 1 & cold & $t$ & hor el & 6 & & 0.86 & & 80 & \\
\hline $6 a$ & 1 & 1 & cold & $t$ & tank & 2 & 33.0 & 0.28 & 4.71 & 80 & \\
\hline $6 b$ & 1 & 1 & cold & $\mathbf{t}$ & downcomer & 0 & & 0 & & 80 & \\
\hline $6 \mathrm{~b}$ & 1 & 1 & cold & $t$ & $\mathrm{~h}$ & 5 & & 0.71 & & 80 & \\
\hline $6 b$ & 1 & 1 & cold & $\mathrm{t}$ & h & 5 & & 0.71 & & 80 & \\
\hline $6 \mathrm{~b}$ & 1 & 1 & cold & $t$ & hor el & 14 & & 2 & & 80 & \\
\hline $6 b$ & 1 & 1 & cold & $t$ & $\mathrm{~h}$ & 1 & & 0.14 & & 80 & \\
\hline $6 \mathrm{~b}$ & 1 & 1 & cold & $\mathrm{t}$ & hor el & 6 & & 0.86 & & 80 & \\
\hline $6 \mathrm{~b}$ & 1 & 1 & cold & $t$ & tank & 2 & 33.0 & 0.29 & 4.71 & 80 & \\
\hline $6 c$ & 1 & 1 & cold & $\mathrm{t}$ & downcomer & 0 & & 0 & & 80 & \\
\hline $6 c$ & 1 & 1 & cold & $t$ & $\mathrm{~h}$ & 10 & & 1.43 & & 80 & \\
\hline
\end{tabular}




\begin{tabular}{|c|c|c|c|c|c|c|c|c|c|c|c|}
\hline $\begin{array}{l}\text { Line } \\
\text { No }\end{array}$ & Unit & $\begin{array}{l}\text { Pipe } \\
\text { Size } \\
\text { (in) }\end{array}$ & Temp & $\begin{array}{l}\text { Conn } \\
\text { Type }\end{array}$ & $\begin{array}{l}\text { Support } \\
\text { Type }\end{array}$ & $\begin{array}{l}\text { Vert } \\
\text { Span } \\
\text { (ft) }\end{array}$ & $\begin{array}{l}\text { Horia } \\
\text { Span } \\
\text { (ft) }\end{array}$ & $\begin{array}{l}\text { Norm } \\
\text { Vert } \\
\text { Span } \\
\text { (ft) }\end{array}$ & $\begin{array}{l}\text { Norm } \\
\text { Horz } \\
\text { Span } \\
\text { (ft) }\end{array}$ & $\begin{array}{l}\text { Plant } \\
\text { Elevation } \\
\text { Above } \\
\text { Grade }\end{array}$ & Remarks \\
\hline $6 c$ & 1 & 1 & cold & $t$ & h & 12 & & 1.71 & & 80 & \\
\hline $6 c$ & 1 & 1 & cold & $t$ & h & 14 & & 2 & & 80 & \\
\hline $6 c$ & 1 & 1 & cold & $t$ & hor el & 10 & & 1.43 & & 80 & \\
\hline $6 c$ & 1 & 1 & cold & $t$ & h & 2 & & 0.29 & & 80 & \\
\hline $6 c$ & 1 & 1 & cold & $t$ & downcomer & 3 & 51.0 & 0.43 & 7.29 & 80 & \\
\hline $6 d$ & 1 & 1 & cold & $t$ & downcomer & 0 & & 0 & & 80 & \\
\hline $6 d$ & 1 & 1 & cold & $t$ & $\mathbf{h}$ & 10 & & 1.43 & & 80 & \\
\hline $6 d$ & 1 & 1 & cold & $t$ & $h$ & 12 & & 1.71 & & 80 & \\
\hline $6 d$ & 1 & 1 & cold & $t$ & h & 14 & & 2 & & 80 & \\
\hline $6 d$ & 1 & 1 & cold & $t$ & hor el & 10 & & 1.43 & & 80 & \\
\hline $6 d$ & 1 & 1 & cold & $t$ & h & 2 & & 0.29 & & 80 & \\
\hline $6 d$ & 1 & 1 & cold & $t$ & downcomer & 3 & 51.0 & 0.43 & 7.29 & 80 & \\
\hline $7 \mathrm{a}$ & 1 & 3 & hot & $w$ & downcomer & 0 & & 0 & & 80 & \\
\hline $7 a$ & 1 & 3 & hot & $w$ & sh & 6 & & 0.4 & & 80 & \\
\hline $7 a$ & 1 & 3 & hot & $w$ & sh & 18 & & 1.2 & & 80 & \\
\hline $7 a$ & 1 & 3 & hot & $w$ & sh & 15 & & 1 & & 80 & \\
\hline $7 a$ & 1 & 3 & hot & $\mathbf{w}$ & $s$ brace ho & 2 & 51.0 & 0.13 & 3.40 & 80 & \\
\hline $7 a$ & 1 & 3 & hot & $\mathbf{w}$ & sh & 9 & & 0.6 & & 80 & \\
\hline $7 a$ & 1 & 3 & hot & $w$ & hor el & 16 & & 1.07 & & 80 & \\
\hline $7 a$ & 1 & 3 & hot & $w$ & sh & 1 & & 0.07 & & 80 & \\
\hline $7 a$ & 1 & 3 & hot & w & vert riser & 4.5 & 30.5 & 0.3 & 2.03 & 80 & \\
\hline $7 a$ & 1 & 3 & hot & $\mathbf{w}$ & downcomer & 4.5 & & 0.3 & & 80 & \\
\hline $7 a$ & 1 & 3 & hot & $w$ & downcomer & 1 & & 0.07 & & 80 & \\
\hline $7 a$ & 1 & 3 & hot & $\mathbf{w}$ & sh & 2 & & 0.13 & & 80 & \\
\hline $7 a$ & 1 & 3 & hot & $w$ & sh & 10 & & 0.67 & & 80 & \\
\hline $7 a$ & 1 & 3 & hot & $\mathbf{w}$ & downcomer & 2 & 19.5 & 0.13 & 130 & 80 & \\
\hline $7 b$ & 2 & 3 & hot & $\mathbf{w}$ & downcomer & 0 & & 0 & & 80 & \\
\hline $7 b$ & 2 & 3 & hot & $\mathbf{w}$ & sh & 6 & & 0.4 & & 80 & \\
\hline $7 \mathrm{~b}$ & 2 & 3 & hot & $\mathrm{w}$ & sh & 18 & & 1.2 & & 80 & \\
\hline $7 \mathrm{~b}$ & 2 & 3 & hot & $w$ & sh & 15 & & 1 & & 80 & \\
\hline $7 b$ & 2 & 3 & hot & $\mathrm{w}$ & $s$ brace ho & 2 & 51.0 & 0.13 & 3.40 & 80 & \\
\hline $7 b$ & 2 & 3 & hot & $w$ & sh & 9 & & 0.6 & & 80 & \\
\hline
\end{tabular}




\begin{tabular}{|c|c|c|c|c|c|c|c|c|c|c|c|}
\hline $\begin{array}{l}\text { Line } \\
\text { No }\end{array}$ & Unit & $\begin{array}{l}\text { Pipe } \\
\text { Size } \\
\text { (in) }\end{array}$ & Temp & $\begin{array}{l}\text { Conn } \\
\text { Type }\end{array}$ & $\begin{array}{l}\text { Support } \\
\text { Type }\end{array}$ & $\begin{array}{l}\text { Vert } \\
\text { Span } \\
\text { (ft) }\end{array}$ & $\begin{array}{l}\text { Horia } \\
\text { Span } \\
\text { (ft) }\end{array}$ & $\begin{array}{l}\text { Norm } \\
\text { Vert } \\
\text { Span } \\
\text { (ft) }\end{array}$ & $\begin{array}{l}\text { Norm } \\
\text { Horz } \\
\text { Span } \\
\text { (ft) }\end{array}$ & $\begin{array}{l}\text { Plant } \\
\text { Elevation } \\
\text { Above } \\
\text { Grade }\end{array}$ & Remarks \\
\hline $7 \mathrm{~b}$ & 2 & 3 & hot & $w$ & hor el & 16 & & 1.07 & & 80 & \\
\hline $7 \mathrm{~b}$ & 2 & 3 & hot & $\mathrm{w}$ & sh & 1 & & 0.07 & & 80 & \\
\hline $7 b$ & 2 & 3 & hot & $\mathbf{w}$ & vert riser & 4.5 & 30.5 & 0.3 & 2.03 & 80 & \\
\hline$T b$ & 2 & 3 & hot & $\mathbf{w}$ & downcomer & 4.5 & & 0.3 & & 80 & - \\
\hline $7 b$ & 2 & 3 & hot & $\mathbf{w}$ & downcomer & 1 & & 0.07 & & 80 & \\
\hline $7 b$ & 2 & 3 & hot & $w$ & $\mathrm{sh}$ & 2 & & 0.13 & & 80 & \\
\hline $7 \mathrm{~b}$ & 2 & 3 & hot & $\mathrm{w}$ & sh & 10 & & 0.67 & & 80 & \\
\hline $7 \mathrm{~b}$ & 2 & 3 & hot & $\mathbf{w}$ & downcomer & 2 & 19.5 & 0.13 & 130 & 80 & \\
\hline $8 a$ & 1 & 3 & cold & $\mathbf{w}$ & downcomer & 0 & & 0 & & 80 & \\
\hline $8 a$ & 1 & 3 & cold & $w$ & hor el & 2 & & 0.17 & & 80 & \\
\hline $8 a$ & 1 & 3 & cold & w & h & 3 & & 0.25 & & 80 & \\
\hline $8 a$ & 1 & 3 & cold & $\mathrm{w}$ & $h$ & 10 & & 0.83 & & 80 & \\
\hline $8 a$ & 1 & 3 & cold & w & $h$ & 18 & & 1.5 & & 80 & \\
\hline $8 a$ & 1 & 3 & cold & w & downcomer & 2 & 8.0 & 0.17 & 0.67 & 80 & \\
\hline $8 a$ & 1 & 3 & cold & $\mathbf{w}$ & $h$ & 5 & & 0.42 & & 80 & \\
\hline $8 a$ & 1 & 3 & cold & $\mathbf{w}$ & h & 12 & & 1 & & 80 & \\
\hline $8 a$ & 1 & 3 & cold & $\mathbf{w}$ & $h$ & 13 & & 1.08 & & 80 & \\
\hline $8 a$ & 1 & 3 & cold & $\mathrm{w}$ & $\mathrm{h}$ & 15 & & 1.25 & & 80 & \\
\hline $8 a$ & 1 & 3 & cold & $\mathrm{w}$ & hor el & 3 & & 0.25 & & 80 & \\
\hline $8 a$ & 1 & 3 & cold & $\mathrm{w}$ & vert drum & 2 & 85.0 & 0.17 & 7.08 & 80 & \\
\hline $8 b$ & 2 & 3 & cold & $w$ & downcomer & 0 & & 0 & & 80 & \\
\hline $8 b$ & 2 & 3 & cold & $\mathbf{w}$ & hor el & 2 & & 0.17 & & 80 & \\
\hline $8 b$ & 2 & 3 & cold & $w$ & $\mathrm{~h}$ & 3 & & 0.25 & & 80 & \\
\hline $8 b$ & 2 & 3 & cold & $w$ & h & 10 & & 0.83 & & 80 & \\
\hline $8 b$ & 2 & 3 & cold & $w$ & h & 18 & & 1.5 & & 80 & \\
\hline $8 b$ & 2 & 3 & cold & $\mathbf{w}$ & downcomer & 2 & 8.0 & 0.17 & 0.67 & 80 & \\
\hline $8 b$ & 2 & 3 & cold & $\mathbf{w}$ & $\mathbf{h}$ & 5 & & 0.42 & & 80 & \\
\hline $8 \mathrm{~b}$ & 2 & 3 & cold & $\mathbf{w}$ & $\mathbf{h}$ & 12 & & 1 & & 80 & \\
\hline $8 b$ & 2 & 3 & cold & $\mathbf{w}$ & $\mathbf{h}$ & 13 & & 1.08 & & 80 & \\
\hline $8 \mathrm{~b}$ & 2 & 3 & cold & $\mathbf{w}$ & h & 15 & & 1.25 & & 80 & \\
\hline $8 b$ & 2 & 3 & cold & $w$ & hor el & 3 & & 0.25 & & 80 & \\
\hline $8 b$ & 2 & 3 & cold & w & vert drum & 2 & 85.0 & 0.17 & 7.08 & 80 & \\
\hline
\end{tabular}




\begin{tabular}{|c|c|c|c|c|c|c|c|c|c|c|c|}
\hline $\begin{array}{l}\text { Line } \\
\text { No }\end{array}$ & Unit & $\begin{array}{l}\text { Pipe } \\
\text { Size } \\
\text { (in) }\end{array}$ & Temp & $\begin{array}{l}\text { Conn } \\
\text { Type }\end{array}$ & $\begin{array}{l}\text { Support } \\
\text { Type }\end{array}$ & $\begin{array}{l}\text { Vert } \\
\text { Span } \\
\text { (ft) }\end{array}$ & $\begin{array}{l}\text { Horia } \\
\text { Span } \\
\text { (ft) }\end{array}$ & $\begin{array}{l}\text { Norm } \\
\text { Vert } \\
\text { Span } \\
\text { (ft) }\end{array}$ & $\begin{array}{l}\text { Norm } \\
\text { Horz } \\
\text { Span } \\
\text { (ft) }\end{array}$ & $\begin{array}{l}\text { Plant } \\
\text { Elevation } \\
\text { Above } \\
\text { Grade }\end{array}$ & Remarks \\
\hline $9 a$ & 1 & 1 & cold & sw & downcomer & 0 & & 0 & & 80 & \\
\hline $9 a$ & 1 & 1 & cold & sw & $\mathrm{h}$ & 1 & & 0.14 & & 80 & \\
\hline $9 a$ & 1 & 1 & cold & sw & hor el & 1 & & 0.14 & & 80 & \\
\hline $9 a$ & 1 & 1 & cold & sw & hor el & 1.5 & & 0.21 & & 80 & \\
\hline $9 a$ & 1 & 1 & cold & sw & h & 1 & & 0.14 & & 80 & \\
\hline $9 a$ & 1 & 1 & cold ${ }^{\circ}$ & sw & h & 10 & & 1.43 & & 80 & \\
\hline $9 a$ & 1 & 1 & cold & sw & h & 10 & & 1.43 & & 80 & \\
\hline $9 a$ & 1 & 1 & cold & sw & $\mathrm{h}$ & 13 & & 1.86 & & 80 & \\
\hline $9 a$ & 1 & 1 & cold & sw & hor el & 2 & & 0.29 & & 80 & \\
\hline $9 a$ & 1 & 1 & cold & sw & wall & 8 & 47.5 & 1.14 & 6.79 & 80 & \\
\hline $9 b$ & 1 & 1 & cold & sw & downcomer & 0 & & 0 & & 80 & \\
\hline $9 b$ & 1 & 1 & cold & sw & $\mathrm{h}$ & 1 & & 0.14 & & 80 & \\
\hline $9 b$ & 1 & 1 & cold & sw & hor el & 1 & & 0.14 & & 80 & \\
\hline $9 b$ & 1 & 1 & cold & SW & hor el & 1.5 & & 0.21 & & 80 & \\
\hline $9 b$ & 1 & 1 & cold & sw & h & 1 & & 0.14 & & 80 & \\
\hline $9 b$ & 1 & 1 & cold & sw & $\mathrm{h}$ & 10 & & 1.43 & & 80 & \\
\hline $9 b$ & 1 & 1 & cold & sw & h & 10 & & 1.43 & & 80 & \\
\hline $9 b$ & 1 & 1 & coid & sw & $\mathrm{h}$ & 13 & & 1.86 & & 80 & \\
\hline $9 b$ & 1 & 1 & cold & sw & hor el & 2 & & 0.29 & & 80 & \\
\hline $9 \mathrm{~b}$ & 1 & 1 & cold & sw & wall & 8 & 47.5 & 1.14 & 6.79 & 80 & \\
\hline $9 c$ & 2 & 1 & cold & sw & downcomer & 0 & & 0 & & 80 & \\
\hline $9 c$ & 2 & 1 & cold & sw & h & 1 & & 0.14 & & 80 & \\
\hline $9 c$ & 2 & 1 & cold & SW & hor el & 1 & & 0.14 & & 80 & \\
\hline $9 c$ & 2 & 1 & cold & sw & hor el & 1.5 & & 0.21 & & 80 & \\
\hline $9 c$ & 2 & 1 & cold & sw & h & 1 & & 0.14 & & 80 & \\
\hline $9 c$ & 2 & 1 & cold & sw & $\mathrm{h}$ & 10 & & 1.43 & & 80 & \\
\hline $9 c$ & 2 & 1 & cold & $s w$ & h & 10 & & 1.43 & & 80 & \\
\hline $9 c$ & 2 & 1 & cold & sw & h & 13 & & 1.86 & & 80 & \\
\hline $9 c$ & 2 & 1 & cold & sw & hor el & 2 & & 0.29 & & 80 & \\
\hline $9 c$ & 2 & 1 & cold & sw & wall & 8 & 47.5 & 1.14 & 6.79 & 80 & \\
\hline $9 d$ & 2 & 1 & cold & sw & downcomer & 0 & & 0 & & 80 & \\
\hline $9 \mathrm{~d}$ & 2 & 1 & cold & sw & $\mathrm{h}$ & 1 & & 0.14 & & 80 & \\
\hline
\end{tabular}




\begin{tabular}{|c|c|c|c|c|c|c|c|c|c|c|c|}
\hline $\begin{array}{l}\text { Line } \\
\text { No }\end{array}$ & Unit & $\begin{array}{l}\text { Pipe } \\
\text { Size } \\
\text { (in) }\end{array}$ & Temp & $\begin{array}{l}\text { Conn } \\
\text { Type }\end{array}$ & $\begin{array}{l}\text { Support } \\
\text { Type }\end{array}$ & $\begin{array}{l}\text { Vert } \\
\text { Span } \\
\text { (ft) }\end{array}$ & $\begin{array}{l}\text { Horia } \\
\text { Span } \\
\text { (ft) }\end{array}$ & $\begin{array}{l}\text { Norm } \\
\text { Vert } \\
\text { Span } \\
\text { (ft) }\end{array}$ & $\begin{array}{l}\text { Norm } \\
\text { Horz } \\
\text { Span } \\
\text { (ft) }\end{array}$ & $\begin{array}{l}\text { Plant } \\
\text { Elevation } \\
\text { Above } \\
\text { Grade }\end{array}$ & Remarks \\
\hline $9 d$ & 2 & 1 & cold & sw & hor el & 1 & & 0.14 & & 80 & \\
\hline $9 d$ & 2 & 1 & cold & sw & hor el & 1.5 & & 0.21 & & 80 & \\
\hline $9 d$ & 2 & 1 & cold & sw & $\mathbf{h}$ & 1 & & 0.14 & & 80 & \\
\hline $9 d$ & 2 & 1 & cold & sw & h & 10 & & 1.43 & & 80 & \\
\hline $9 d$ & 2 & 1 & cold & sw & h & 10 & & 1.43 & & 80 & \\
\hline $9 d$ & 2 & 1 & cold & sw & h & 13 & & 1.86 & & 80 & \\
\hline $9 d$ & 2 & 1 & cold & sw & hor el & 2 & & 0.29 & & 80 & \\
\hline $9 d$ & 2 & 1 & cold & sw & wall & 8 & 47.5 & 1.14 & 6.79 & 80 & \\
\hline $10 a$ & 1 & 1 & cold & $t$ & pipe main & 0 & & 0 & & 80 & \\
\hline $10 a$ & 1 & 1 & cold & $t$ & h & 5 & & 0.71 & & 80 & \\
\hline $10 a$ & 1 & 1 & cold & $\mathbf{t}$ & $U$ bolt & 5 & 10.0 & 0.71 & 1.43 & 80 & \\
\hline $10 a$ & 1 & 1 & cold & $\mathbf{t}$ & h & 8 & & 1.14 & & 80 & \\
\hline $10 a$ & 1 & 1 & cold & $t$ & reel & 5 & 13.0 & 0.71 & 1.86 & 80 & \\
\hline $10 b$ & 2 & 1 & cold & $\mathbf{t}$ & pipe main & 0 & & 0 & & 80 & \\
\hline $10 \mathrm{~b}$ & 2 & 1 & cold & $t$ & $\mathrm{~h}$ & 5 & & 0.71 & & 80 & \\
\hline $10 \mathrm{~b}$ & 2 & 1 & cold & $t$ & U bolt & 5 & 10.0 & 0.71 & 1.43 & 80 & \\
\hline $10 \mathrm{~b}$ & 2 & 1 & cold & $t$ & h & 8 & & 1.14 & & 80 & \\
\hline $10 \mathrm{~b}$ & 2 & 1 & cold & $t$ & hose reel & 5 & 13.0 & 0.71 & 1.86 & 80 & \\
\hline $10 c$ & 1 & 1 & cold & sw & riser & 0 & & 0 & & 80 & \\
\hline $10 c$ & 1 & 1 & cold & sw & h & 15 & & 2.14 & & 80 & \\
\hline edit & 1 & 1 & edit & sw & hor el & 2 & & 0.29 & & 80 & \\
\hline $10 c$ & 1 & 1 & cold & sw & $\mathrm{h}$ & 2 & & 0.29 & & 80 & \\
\hline $10 c$ & 1 & 1 & cold & SW & vert el & 0.5 & & 0.07 & & 80 & \\
\hline $10 c$ & 1 & 1 & cold & sw & vert & 15 & & 2.14 & & 80 & \\
\hline $10 c$ & 1 & 1 & cold & sw & vert el & 10 & & 1.43 & & 80 & \\
\hline $10 c$ & 1 & 1 & cold & sw & h & 10 & & 1.43 & & 80 & \\
\hline $10 c$ & 1 & 1 & cold & sw & hor el & 8 & & 1.14 & & 80 & \\
\hline $10 c$ & 1 & 1 & cold & Sw & equip nozz & 2 & 40.0 & 0.29 & 5.71 & 80 & \\
\hline $10 d$ & 2 & 1 & cold & sw & riser & 0 & & 0 & & 80 & \\
\hline $10 d$ & 2 & 1 & cold & sw & $\mathrm{h}$ & 15 & & 2.14 & & 80 & \\
\hline $10 \mathrm{~d}$ & 2 & 1 & cold & sw & hor el & 2 & & 0.29 & & 80 & \\
\hline $10 d$ & 2 & 1 & cold & sw & h & 2 & & 0.29 & & 80 & \\
\hline
\end{tabular}




\begin{tabular}{|c|c|c|c|c|c|c|c|c|c|c|c|}
\hline $\begin{array}{l}\text { Line } \\
\text { No }\end{array}$ & Unit & $\begin{array}{l}\text { Pipe } \\
\text { Size } \\
\text { (in) }\end{array}$ & Temp & $\begin{array}{l}\text { Conn } \\
\text { Type }\end{array}$ & $\begin{array}{l}\text { Support } \\
\text { Type }\end{array}$ & $\begin{array}{l}\text { Vert } \\
\text { Span } \\
\text { (ft) }\end{array}$ & $\begin{array}{l}\text { Horia } \\
\text { Span } \\
\text { (ft) }\end{array}$ & $\begin{array}{l}\text { Norm } \\
\text { Vert } \\
\text { Span } \\
\text { (ft) }\end{array}$ & $\begin{array}{l}\text { Norm } \\
\text { Horz } \\
\text { Span } \\
\text { (ft) }\end{array}$ & $\begin{array}{l}\text { Plant } \\
\text { Elevation } \\
\text { Above } \\
\text { Grade }\end{array}$ & Remarks \\
\hline $10 \mathrm{~d}$ & 2 & 1 & cold & sw & vert el & 0.5 & & 0.07 & & 80 & \\
\hline $10 d$ & 2 & 1 & cold & $\mathbf{s w}$ & vert & 15 & & 2.14 & & 80 & \\
\hline $10 d$ & 2 & 1 & cold & sw & vert el & 10 & & 1.43 & & 80 & \\
\hline $10 \mathrm{~d}$ & 2 & 1 & cold & sw & h & 10 & & 1.43 & & 80 & \\
\hline $10 d$ & 2 & 1 & cold & sw & hor el & 8 & & 1.14 & & 80 & \\
\hline $10 \mathrm{~d}$ & 2 & 1 & cold & sw & equip nozz & 2 & 40.0 & 0.29 & 5.71 & 80 & \\
\hline $11 \mathrm{a}$ & 1 & 8 & hot & $w$ & downcomer & 0 & & 0 & & 60 & \\
\hline $11 a$ & 1 & 8 & hot & $w$ & sh & 2 & & 0.08 & & 60 & \\
\hline $11 a$ & 1 & 8 & hot & $\mathbf{w}$ & hor el & 12 & & 0.5 & & 60 & \\
\hline $11 a$ & 1 & 8 & hot & $\mathbf{w}$ & sh & 1 & & 0.04 & & 60 & \\
\hline $11 \mathrm{a}$ & 1 & 8 & hot & $\mathbf{w}$ & sh & 12 & & 0.5 & & 60 & \\
\hline $11 a$ & 1 & 8 & hot & $\mathbf{w}$ & downcomer & 4 & 31.0 & 0.17 & 1.29 & 60 & \\
\hline $11 b$ & 2 & 8 & hot & $\mathbf{w}$ & downcomer & 0 & & 0 & & 60 & \\
\hline $11 b$ & 2 & 8 & hot & $\mathbf{w}$ & sh & 2 & & 0.08 & & 60 & \\
\hline $11 b$ & 2 & 8 & hot & w & hor el & 12 & & 0.5 & & 60 & \\
\hline $11 b$ & 2 & 8 & hot & $\mathbf{w}$ & sh & 1 & & 0.04 & & 60 & \\
\hline $11 \mathrm{~b}$ & 2 & 8 & hot & $\mathbf{w}$ & sh & 12 & & 0.5 & & 60 & \\
\hline $11 b$ & 2 & 8 & hot & w & downcomer & 4 & 31.0 & 0.17 & 1.29 & 60 & \\
\hline $12 a$ & 1 & 1.5 & cold & sw & wall & 0 & & 0 & & 60 & \\
\hline $12 \mathrm{a}$ & 1 & 1.5 & cold & sw & $\mathrm{h}$ & 6 & & 0.71 & & 60 & \\
\hline $12 a$ & 1 & 1.5 & cold & $s w$ & h & 9 & & 1.06 & & 60 & \\
\hline $12 a$ & 1 & 1.5 & cold & sw & hor el & 4 & & 0.47 & & 60 & \\
\hline $12 a$ & 1 & 1.5 & cold & sw & $\mathfrak{h}$ & 1 & & 0.12 & & 60 & \\
\hline $12 a$ & 1 & 1.5 & cold & sw & $\mathrm{h}$ & 4 & & 0.47 & & 60 & \\
\hline $12 a$ & 1 & 1.5 & cold & sw & h & 6 & & 0.71 & & 60 & \\
\hline $12 a$ & 1 & 1.5 & cold & sw & hor el & 3 & & 0.35 & & 60 & \\
\hline $12 a$ & 1 & 15 & cold & sw & $\mathbf{h}$ & 6 & & 0.71 & & 60 & \\
\hline $12 a$ & 1 & 1.5 & cold & sw & $\mathbf{h}$ & 12 & & 1.41 & & 60 & \\
\hline $12 a$ & 1 & 1.5 & cold & sw & hor el & 10 & & 1.18 & & 60 & \\
\hline $12 a$ & 1 & 1.5 & cold & sw & $\mathrm{h}$ & 3 & & 0.35 & & 60 & \\
\hline $12 a$ & 1 & 1.5 & cold & sw & riser & 1 & & 0.12 & & 60 & \\
\hline $12 a$ & 1 & 1.5 & cold & sw & h & 10 & & 1.18 & & 60 & \\
\hline
\end{tabular}




\begin{tabular}{|c|c|c|c|c|c|c|c|c|c|c|c|}
\hline $\begin{array}{l}\text { Line } \\
\text { No }\end{array}$ & Unit & $\begin{array}{l}\text { Pipe } \\
\text { Size } \\
\text { (in) }\end{array}$ & Temp & $\begin{array}{l}\text { Conn } \\
\text { Type }\end{array}$ & $\begin{array}{l}\text { Support } \\
\text { Type }\end{array}$ & $\begin{array}{l}\text { Vert } \\
\text { Span } \\
\text { (ft) }\end{array}$ & $\begin{array}{l}\text { Horia } \\
\text { Span } \\
\text { (ft) }\end{array}$ & $\begin{array}{l}\text { Norm } \\
\text { Vert } \\
\text { Span } \\
\text { (ft) }\end{array}$ & $\begin{array}{l}\text { Norm } \\
\text { Horz } \\
\text { Span } \\
\text { (ft) }\end{array}$ & $\begin{array}{l}\text { Plant } \\
\text { Elevation } \\
\text { Above } \\
\text { Grade }\end{array}$ & Remarks \\
\hline $12 a$ & 1 & 1.5 & cold & sw & downcomer & 1 & 76.0 & 0.12 & 8.94 & 60 & \\
\hline $12 b$ & 2 & 1.5 & cold & sw & wall & 0 & & 0 & & 60 & \\
\hline $12 b$ & 2 & 1.5 & cold & sw & $\mathbf{h}$ & 6 & & 0.71 & & 60 & \\
\hline $12 \mathrm{~b}$ & 2 & 1.5 & cold & sw & $\mathbf{h}$ & 9 & & 1.06 & & 60 & \\
\hline $12 b$ & 2 & 1.5 & cold & sw & hor el & 4 & & 0.47 & & 60 & \\
\hline $12 b$ & 2 & 1.5 & cold & sw & h & 1 & & 0.12 & & 60 & \\
\hline $12 b$ & 2 & 1.5 & cold & sw & $\mathbf{h}$ & 4 & & 0.47 & & 60 & \\
\hline $12 b$ & 2 & 1.5 & cold & sw & $\mathbf{h}$ & 6 & & 0.71 & & 60 & \\
\hline $12 b$ & 2 & 1.5 & cold & sw & hor el & 3 & & 0.35 & & 60 & \\
\hline $12 b$ & 2 & 1.5 & cold & sw & $\mathbf{h}$ & 6 & & 0.71 & & 60 & \\
\hline $12 b$ & 2 & 1.5 & cold & SW & $\mathbf{h}$ & 12 & & 1.41 & & 60 & \\
\hline $12 b$ & 2 & 15 & cold & sw & hor el & 10 & & 1.18 & & 60 & \\
\hline $12 b$ & 2 & 1.5 & cold & sw & $\mathbf{h}$ & 3 & & 0.35 & & 60 & \\
\hline $12 b$ & 2 & 15 & cold & sw & riser & 1 & & 0.12 & & 60 & \\
\hline $12 b$ & 2 & 15 & cold & sw & $\mathbf{h}$ & 10 & & 1.18 & & 60 & \\
\hline $12 \mathrm{~b}$ & 2 & 1.5 & cold & sw & downcomer & 1 & 76.0 & 0.12 & 8.94 & 60 & \\
\hline $13 a$ & 1 & 2 & cold & sw & $\operatorname{tank}$ & 0 & & 0 & & 35 & \\
\hline $13 a$ & 1 & 2 & cold & sw & downcomer & 2 & & 02 & & 35 & \\
\hline $13 a$ & 1 & 2 & cold & sw & vert el & 5 & & 0.5 & & 35 & \\
\hline $13 a$ & 1 & 2 & cold & sw & h & 1 & & 0.1 & & 35 & \\
\hline $13 a$ & 1 & 2 & cold & sw & h & 10 & & 1 & & 35 & \\
\hline $13 a$ & 1 & 2 & cold & sw & hor el & 1 & & 0.1 & & 35 & \\
\hline $13 a$ & 1 & 2 & cold & sw & hor el & 10 & & 1 & & 35 & \\
\hline $13 a$ & 1 & 2 & cold & sw & $\mathbf{h}$ & 4 & & 0.4 & & 35 & \\
\hline $13 a$ & 1 & 2 & cold & sw & $\mathbf{h}$ & 14 & & 1.4 & & 35 & \\
\hline $13 a$ & 1 & 2 & cold & sw & $\mathbf{h}$ & 9 & & 0.9 & & 35 & \\
\hline $13 a$ & 1 & 2 & cold & sw & hor el & 2 & & 0.2 & & 35 & \\
\hline $13 a$ & 1 & 2 & cold & sw & $\mathbf{h}$ & 4 & & 0.4 & & 35 & \\
\hline $13 a$ & 1 & 2 & cold & sw & downcomer & 1 & 63.0 & 0.1 & 6.30 & 35 & \\
\hline $13 b$ & 1 & 2 & cold & sw & tank & 0 & & 0 & & 35 & \\
\hline $13 b$ & 1 & 2 & cold & sw & downcomer & 2 & & 0.2 & & 35 & \\
\hline $13 b$ & 1 & 2 & cold & sw & vert el & 5 & & 0.5 & & 35 & \\
\hline
\end{tabular}




\begin{tabular}{|c|c|c|c|c|c|c|c|c|c|c|c|}
\hline $\begin{array}{l}\text { Line } \\
\text { No }\end{array}$ & Unit & $\begin{array}{l}\text { Pipe } \\
\text { Size } \\
\text { (in) }\end{array}$ & Temp & $\begin{array}{l}\text { Conn } \\
\text { Type }\end{array}$ & $\begin{array}{l}\text { Support } \\
\text { Type }\end{array}$ & $\begin{array}{l}\text { Vert } \\
\text { Span } \\
\text { (ft) }\end{array}$ & $\begin{array}{l}\text { Horia } \\
\text { Span } \\
\text { (ft) }\end{array}$ & $\begin{array}{l}\text { Norm } \\
\text { Vert } \\
\text { Span } \\
\text { (ft) }\end{array}$ & $\begin{array}{l}\text { Norm } \\
\text { Horz } \\
\text { Span } \\
\text { (ft) }\end{array}$ & $\begin{array}{l}\text { Plant } \\
\text { Elevation } \\
\text { Above } \\
\text { Grade }\end{array}$ & Remarks \\
\hline $13 b$ & 1 & 2 & cold & sw & $\mathrm{h}$ & 1 & & 0.1 & & 35 & \\
\hline $13 b$ & 1 & 2 & cold & $\mathbf{s w}$ & $h$ & 10 & & 1 & & 35 & \\
\hline $13 b$ & 1 & 2 & cold & sw & hor el & 1 & & 0.1 & & 35 & \\
\hline $13 b$ & 1 & 2 & cold & sw & hor el & 10 & & 1 & & 35 & \\
\hline $13 b$ & 1 & 2 & cold & sw & $h$ & 4 & & 0.4 & & 35 & \\
\hline $13 b$ & 1 & 2 & cold & sw & $\mathrm{h}$ & 14 & & 1.4 & & 35 & \\
\hline $13 \mathrm{~b}$ & 1 & 2 & cold & sw & h & 9 & & 0.9 & & 35 & \\
\hline $13 \mathrm{~b}$ & 1 & 2 & cold & sw & hor el & 2 & & 0.2 & & 35 & \\
\hline $13 b$ & 1 & 2 & cold & sw & $\mathrm{h}$ & 4 & & 0.4 & & 35 & \\
\hline $13 b$ & 1 & 2 & cold & sw & downcomer & 1 & 63.0 & 0.1 & 6.30 & 35 & \\
\hline $13 c$ & 1 & 2 & cold & sw & tank & 0 & & 0 & & 35 & \\
\hline $13 c$ & 1 & 2 & cold & sw & downcomer & 2 & & 0.2 & & 35 & \\
\hline $13 c$ & 1 & 2 & cold & sw & vert el & 5 & & 0.5 & & 35 & \\
\hline $13 c$ & 1 & 2 & cold & $\mathbf{s w}$ & $\mathrm{h}$ & 1 & & 0.1 & & 35 & \\
\hline $13 c$ & 1 & 2 & cold & sw & $\mathrm{h}$ & 10 & & 1 & & 35 & \\
\hline $13 \mathrm{c}$ & 1 & 2 & cold & sw & hor el & 1 & & 0.1 & & 35 & \\
\hline $13 c$ & 1 & 2 & cold & sw & hor el & 10 & & 1 & & 35 & \\
\hline $13 c$ & 1 & 2 & cold & sw & $h$ & 4 & & 0.4 & & 35 & \\
\hline $13 c$ & 1 & 2 & cold & $\mathrm{sw}$ & $\mathrm{h}$ & 14 & & 1.4 & & 35 & \\
\hline $13 c$ & 1 & 2 & cold & sw & h & 9 & & 0.9 & & 35 & \\
\hline $13 c$ & 1 & 2 & cold & sw & hor el & 2 & & 0.2 & & 35 & \\
\hline $13 c$ & 1 & 2 & cold & sw & h & 4 & & 0.4 & & 35 & \\
\hline $13 c$ & 1 & 2 & cold & sw & downcomer & 1 & 63.0 & 0.1 & 6.30 & 35 & \\
\hline $13 d$ & 2 & 2 & cold & sw & $\operatorname{tank}$ & 0 & & 0 & & 35 & \\
\hline $13 d$ & 2 & 2 & cold & sw & downcomer & 2 & & 0.2 & & 35 & \\
\hline $13 d$ & 2 & 2 & cold & sw & vert el & 5 & & 0.5 & & 35 & \\
\hline $13 d$ & 2 & 2 & cold & sw & $\mathrm{h}$ & 1 & & 0.1 & & 35 & \\
\hline $13 d$ & 2 & 2 & cold & sw & h & 10 & & 1 & & 35 & \\
\hline $13 d$ & 2 & 2 & cold & sw & hor el & 1 & & 0.1 & & 35 & \\
\hline $13 d$ & 2 & 2 & cold & sw & hor el & 10 & & 1 & & 35 & \\
\hline $13 d$ & 2 & 2 & cold & sw & $h$ & 4 & & 0.4 & & 35 & \\
\hline $13 d$ & 2 & 2 & cold & sw & $h$ & 14 & & 1.4 & & 35 & \\
\hline
\end{tabular}




\begin{tabular}{|c|c|c|c|c|c|c|c|c|c|c|c|}
\hline $\begin{array}{l}\text { Line } \\
\text { No }\end{array}$ & Unit & $\begin{array}{l}\text { Pipe } \\
\text { Size } \\
\text { (in) }\end{array}$ & Temp & $\begin{array}{l}\text { Conn } \\
\text { Type }\end{array}$ & $\begin{array}{l}\text { Support } \\
\text { Type }\end{array}$ & $\begin{array}{l}\text { Vert } \\
\text { Span } \\
\text { (ft) }\end{array}$ & $\begin{array}{l}\text { Horia } \\
\text { Span } \\
(\mathrm{ft})\end{array}$ & $\begin{array}{l}\text { Norm } \\
\text { Vert } \\
\text { Span } \\
\text { (ft) }\end{array}$ & $\begin{array}{l}\text { Norm } \\
\text { Horz } \\
\text { Span } \\
\text { (ft) }\end{array}$ & $\begin{array}{l}\text { Plant } \\
\text { Elevation } \\
\text { Above } \\
\text { Grade }\end{array}$ & Remarks \\
\hline $13 d$ & 2 & 2 & cold & sw & $\mathbf{h}$ & 9 & & 0.9 & & 35 & \\
\hline $13 d$ & 2 & 2 & cold & sw & hor el & 2 & & 02 & & 35 & \\
\hline $13 d$ & 2 & 2 & cold & sw & $\mathbf{h}$ & 4 & & 0.4 & & 35 & \\
\hline $13 d$ & 2 & 2 & cold & sw & downcomer & 1 & 63.0 & 0.1 & 6.30 & 35 & \\
\hline $13 e$ & 2 & 2 & cold & sw & $\operatorname{tank}$ & 4 & & 0.4 & & 35 & \\
\hline $13 e$ & 2 & 2 & cold & SW & downcomer & 2 & & 0.2 & & 35 & \\
\hline $13 \mathrm{e}$ & 2 & 2 & cold & sw & vert el & 5 & & 0.5 & & 35 & \\
\hline $13 \mathrm{e}$ & 2 & 2 & cold & Sw & h & 1 & & 0.1 & & 35 & \\
\hline $13 e$ & 2 & 2 & cold & sw & $\mathbf{b}$ & 10 & & 1 & & 35 & \\
\hline $13 \mathrm{e}$ & 2 & 2 & cold & $\mathrm{sw}$ & hor el & 1 & & 0.1 & & 35 & \\
\hline $13 e$ & 2 & 2 & cold & sw & hor el & 10 & & 1 & & 35 & \\
\hline $13 e$ & 2 & 2 & cold & sw & $\mathbf{h}$ & 4 & & 0.4 & & 35 & \\
\hline $13 \mathrm{e}$ & 2 & 2 & cold & sw & $\mathbf{h}$ & 14 & & 1.4 & & 35 & \\
\hline $13 e$ & 2 & 2 & cold & sw & h & 9 & & 0.9 & & 35 & \\
\hline $13 e$ & 2 & 2 & cold & $\mathrm{SW}$ & hor el & 2 & & 0.2 & & 35 & \\
\hline $13 \mathrm{e}$ & 2 & 2 & cold & sw & $\mathbf{h}$ & 4 & & 0.4 & & 35 & \\
\hline $13 e$ & 2 & 2 & cold & sw & downcomer & 1 & 63.0 & 0.1 & 6.30 & 35 & \\
\hline $13 f$ & 2 & 2 & cold & sw & $\operatorname{tank}$ & 0 & & 0 & & 35 & \\
\hline $13 \mathrm{f}$ & 2 & 2 & cold & $\mathrm{sw}$ & downcomer & 2 & & 0.2 & & 35 & \\
\hline $13 \mathrm{f}$ & 2 & 2 & cold & sw & vert el & 5 & & 0.5 & & 35 & \\
\hline $13 f$ & 2 & 2 & cold & sw & h & 1 & & 0.1 & & 35 & \\
\hline $13 f$ & 2 & 2 & cold & sw & h & 10 & & 1 & & 35 & \\
\hline $13 \mathrm{f}$ & 2 & 2 & cold & sw & hor el & 1 & & 0.1 & & 35 & \\
\hline $13 \mathrm{f}$ & 2 & 2 & cold & $\mathbf{S W}$ & hor el & 10 & & 1 & & 35 & \\
\hline $13 f$ & 2 & 2 & cold & sw & h & 4 & & 0.4 & & 35 & \\
\hline $13 f$ & 2 & 2 & cold & sw & h & 14 & & 1.4 & & 35 & \\
\hline $13 f$ & 2 & 2 & cold & sw & $\mathrm{h}$ & 9 & & 0.9 & & 35 & \\
\hline $13 f$ & 2 & 2 & cold & sw & hor el & 2 & & 0.2 & & 35 & \\
\hline $13 f$ & 2 & 2 & cold & sw & h & 4 & & 0.4 & & 35 & \\
\hline $13 \mathrm{f}$ & 2 & 2 & cold & sw & downcomer & 1 & 63.0 & 0.1 & 6.30 & 35 & \\
\hline $14 a$ & 1 & 0.75 & cold & $t$ & downcomer & 0 & & 0 & & 35 & \\
\hline $14 a$ & 1 & 0.75 & cold & $\mathbf{t}$ & valve & 6 & & 12 & & 35 & \\
\hline
\end{tabular}




\begin{tabular}{|c|c|c|c|c|c|c|c|c|c|c|c|}
\hline $\begin{array}{l}\text { Line } \\
\text { No }\end{array}$ & Unit & $\begin{array}{l}\text { Pipe } \\
\text { Size } \\
\text { (in) }\end{array}$ & Temp & $\begin{array}{l}\text { Conn } \\
\text { Type }\end{array}$ & $\begin{array}{l}\text { Support } \\
\text { Type }\end{array}$ & $\begin{array}{l}\text { Vert } \\
\text { Span } \\
\text { (ft) }\end{array}$ & $\begin{array}{l}\text { Horia } \\
\text { Span } \\
\text { (ft) }\end{array}$ & $\begin{array}{l}\text { Norm } \\
\text { Vert } \\
\text { Span } \\
\text { (ft) }\end{array}$ & $\begin{array}{l}\text { Norm } \\
\text { Horz } \\
\text { Span } \\
\text { (ft) }\end{array}$ & $\begin{array}{l}\text { Plant } \\
\text { Elevation } \\
\text { Above } \\
\text { Grade }\end{array}$ & Remarks \\
\hline $14 a$ & 1 & 0.75 & cold & $\mathbf{t}$ & hor el & 9 & & 1.8 & & 35 & \\
\hline $14 a$ & 1 & 0.75 & cold & $t$ & tee & 8 & 43.0 & 1.6 & 8.60 & 35 & \\
\hline $14 a$ & 1 & 0.75 & cold & $t$ & h & 12 & & 2.4 & & 35 & \\
\hline $14 a$ & 1 & 0.75 & cold & $\mathbf{t}$ & downcomer & 4 & 16.0 & 0.8 & 3.20 & 35 & \\
\hline $14 a$ & 1 & 0.75 & cold & $t$ & $\mathbf{h}$ & 0.5 & & 0.1 & & 35 & \\
\hline $14 a$ & 1 & 0.75 & cold & $t$ & $\mathbf{h}$ & 6 & & 12 & & 35 & \\
\hline $14 a$ & 1 & 0.75 & cold & $t$ & U bolt & 6 & 12.5 & 1.2 & 2.50 & 35 & \\
\hline $14 a$ & 1 & 0.75 & cold & $\mathrm{t}$ & $\mathbf{h}$ & 6 & & 1.2 & & 35 & \\
\hline $14 a$ & 1 & 0.75 & cold & $\mathbf{t}$ & $\mathbf{h}$ & 6 & & 1.2 & & 35 & \\
\hline $14 a$ & 1 & 0.75 & cold & $\mathrm{t}$ & U bolt & 6 & 18.0 & 1.2 & 3.60 & 35 & \\
\hline $14 a$ & 1 & 0.75 & cold & $\mathfrak{t}$ & $\mathrm{h}$ & 2 & & 0.4 & & 35 & \\
\hline $14 a$ & 1 & 0.75 & cold & $t$ & hor el & 1 & & 0.2 & & 35 & \\
\hline $14 a$ & 1 & 0.75 & cold & $t$ & $\mathrm{~h}$ & 5 & & 1 & & 35 & \\
\hline $14 a$ & 1 & 0.75 & cold & $\mathrm{t}$ & downcomer & 1 & 9.0 & 0.2 & 1.80 & 35 & \\
\hline $14 \mathrm{~b}$ & 2 & 0.75 & cold & $t$ & downcomer & 0 & & 0 & & 35 & \\
\hline $14 b$ & 2 & 0.75 & cold & $t$ & valve & 6 & & 1.2 & & 35 & \\
\hline $14 b$ & 2 & 0.75 & cold & $\mathbf{t}$ & hor el & 9 & & 1.8 & & 35 & \\
\hline $14 b$ & 2 & 0.75 & cold & $\mathbf{t}$ & tee & 8 & 43.0 & 1.6 & 8.60 & 35 & \\
\hline $14 b$ & 2 & 0.75 & cold & $t$ & $\mathbf{h}$ & 12 & & 2.4 & & 35 & \\
\hline $14 b$ & 2 & 0.75 & cold & $t$ & downcomer & 4 & 16.0 & 0.8 & 3.20 & 35 & \\
\hline $14 b$ & 2 & 0.75 & cold & $t$ & $\mathrm{~h}$ & 0.5 & & 0.1 & & 35 & \\
\hline $14 b$ & 2 & 0.75 & cold & $t$ & $\mathbf{h}$ & 6 & & 1.2 & & 35 & \\
\hline $14 b$ & 2 & 0.75 & cold & $\mathbf{t}$ & $U$ bolt & 6 & 12.5 & 1.2 & 2.50 & 35 & 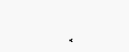 \\
\hline $14 b$ & 2 & 0.75 & cold & $\mathbf{t}$ & h & 6 & & 1.2 & & 35 & \\
\hline $14 b$ & 2 & 0.75 & cold & $\mathbf{t}$ & $\mathbf{h}$ & 6 & & 1.2 & & 35 & \\
\hline $14 b$ & 2 & 0.75 & cold & $\mathbf{t}$ & $\mathrm{U}$ bolt & 6 & 18.0 & 1.2 & 3.60 & 35 & \\
\hline $14 b$ & 2 & 0.75 & cold & $t$ & $\mathrm{~h}$ & 2 & & 0.4 & & 35 & \\
\hline $14 b$ & 2 & 0.75 & cold & $t$ & hor el & 1 & & 0.2 & & 35 & \\
\hline $14 b$ & 2 & 0.75 & cold & $t$ & $h$ & 5 & & 1 & & 35 & \\
\hline $14 b$ & 2 & 0.75 & cold & $\mathbf{t}$ & downcomer & 1 & 9.0 & 0.2 & 1.80 & 35 & \\
\hline $15 \mathrm{a}$ & 1 & 8 & hot & $w$ & vert el & 1 & & 0.04 & & 20 & \\
\hline $15 a$ & 1 & 8 & hot & $w$ & riser to $\mathrm{v}$ & 20 & & 0.83 & & 20 & \\
\hline
\end{tabular}




\begin{tabular}{|c|c|c|c|c|c|c|c|c|c|c|c|}
\hline $\begin{array}{l}\text { Line } \\
\text { No }\end{array}$ & Unit & $\begin{array}{l}\text { Pipe } \\
\text { Size } \\
\text { (in) }\end{array}$ & Temp & $\begin{array}{l}\text { Conn } \\
\text { Type }\end{array}$ & $\begin{array}{l}\text { Support } \\
\text { Type }\end{array}$ & $\begin{array}{l}\text { Vert } \\
\text { Span } \\
\text { (ft) }\end{array}$ & $\begin{array}{l}\text { Horia } \\
\text { Span } \\
\text { (ft) }\end{array}$ & $\begin{array}{l}\text { Norm } \\
\text { Vert } \\
\text { Span } \\
\text { (ft) }\end{array}$ & $\begin{array}{l}\text { Norm } \\
\text { Horz } \\
\text { Span } \\
\text { (ft) }\end{array}$ & $\begin{array}{l}\text { Plant } \\
\text { Elevation } \\
\text { Above } \\
\text { Grade }\end{array}$ & Remarks \\
\hline $15 a$ & 1 & 8 & hot & $w$ & sh & 1 & & 0.04 & & 20 & \\
\hline $15 a$ & 1 & 8 & hot & $w$ & hor el & 1 & & 0.04 & & 20 & \\
\hline $15 a$ & 1 & 8 & hot & $w$ & $\mathrm{sh}$ & 1 & & 0.04 & & 20 & \\
\hline $15 a$ & 1 & 8 & hot & $w$ & sh & 12 & & 0.5 & & 20 & \\
\hline $15 a$ & 1 & 8 & hot & $w$ & sh & 12 & & 0.5 & & 20 & \\
\hline $15 a$ & 1 & 8 & hot & $\mathrm{w}$ & sway brace & 1 & 28.0 & 0.04 & 1.17 & 20 & \\
\hline $15 a$ & 1 & 8 & hot & $w$ & hor el & 4 & & 0.17 & & 20 & \\
\hline $15 a$ & 1 & 8 & hot & $w$ & sh & 3 & & 0.13 & & 20 & \\
\hline $15 a$ & 1 & 8 & hot & $\mathrm{w}$ & tee & 18 & 25.0 & 0.75 & 1.04 & 20 & . \\
\hline $15 \mathrm{a}$ & 1 & 6 & hot & $w$ & $\mathbf{h}$ & 12 & 12.0 & 0.57 & 0.57 & 20 & \\
\hline $15 \mathrm{a}$ & 1 & 6 & hot & $w$ & $\operatorname{sh}$ & 6 & & 0.29 & & 20 & \\
\hline $15 \mathrm{a}$ & 1 & 6 & hot & $w$ & sh & 21 & & 1 & & 20 & \\
\hline $15 a$ & 1 & 6 & hot & w & 45 sway b & 1 & & 0.05 & & 20 & \\
\hline $15 a$ & 1 & 6 & hot & $w$ & tee & 1 & 29.0 & 0.05 & 1.38 & 20 & \\
\hline $15 a$ & 1 & 3 & hot & $w$ & h & 8 & 8.0 & 0.53 & 0.53 & 20 & \\
\hline $15 a$ & 1 & 3 & hot & $w$ & 45 sway b & 2 & 2.0 & 0.13 & 0.13 & 20 & \\
\hline $15 a$ & 1 & 3 & hot & $w$ & sh & 21 & & 1.4 & & 20 & \\
\hline $15 a$ & 1 & 3 & hot & $w$ & hor el & 3 & & 0.2 & & 20 & \\
\hline $15 a$ & 1 & 3 & hot & $w$ & sh & 10 & & 0.67 & & 20 & \\
\hline $15 a$ & 1 & 3 & hot & $\mathbf{w}$ & sway brace & 6 & 40.0 & 0.4 & 2.67 & 20 & \\
\hline $15 a$ & 1 & 3 & hot & $\mathbf{w}$ & sh & 8 & & 0.53 & & 20 & \\
\hline $15 a$ & 1 & 3 & hot & $\mathbf{w}$ & sh & 6 & & 0.4 & & 20 & \\
\hline $15 a$ & 1 & 3 & hot & $w$ & sh & 18 & & 12 & & 20 & \\
\hline $15 a$ & 1 & 3 & hot & $\mathbf{w}$ & sh & 18 & & 12 & & 20 & \\
\hline $15 a$ & 1 & 3 & hot & $w$ & sh & 18 & & 1.2 & & 20 & \\
\hline $15 \mathrm{a}$ & 1 & 3 & hot & $\mathbf{w}$ & sh & 18 & & 1.2 & & 20 & \\
\hline $15 a$ & 1 & 3 & hot & W & tank & 2 & 88.0 & 0.13 & 5.87 & 20 & \\
\hline $15 b$ & 2 & 8 & hot & $\mathbf{w}$ & vert el & 1 & & 0.04 & & 20 & \\
\hline $15 b$ & 2 & 8 & hot & $\mathbf{w}$ & riser to $\mathrm{v}$ & 20 & & 0.83 & & 20 & \\
\hline $15 b$ & 2 & 8 & hot & $\mathbf{w}$ & sh & 1 & & 0.04 & & 20 & \\
\hline $15 b$ & 2 & 8 & hot & $\mathbf{w}$ & hor el & 1 & & 0.04 & & 20 & \\
\hline $15 b$ & 2 & 8 & hot & $w$ & sh & 1 & & 0.04 & & 20 & \\
\hline
\end{tabular}




\begin{tabular}{|c|c|c|c|c|c|c|c|c|c|c|c|}
\hline $\begin{array}{l}\text { Line } \\
\text { No }\end{array}$ & Unit & $\begin{array}{l}\text { Pipe } \\
\text { Size } \\
\text { (in) }\end{array}$ & Temp & $\begin{array}{l}\text { Conn } \\
\text { Type }\end{array}$ & $\begin{array}{l}\text { Support } \\
\text { Type }\end{array}$ & $\begin{array}{l}\text { Vert } \\
\text { Span } \\
(\mathrm{ft})\end{array}$ & $\begin{array}{l}\text { Horia } \\
\text { Span } \\
\text { (ft) }\end{array}$ & $\begin{array}{l}\text { Norm } \\
\text { Vert } \\
\text { Span } \\
\text { (ft) }\end{array}$ & $\begin{array}{l}\text { Norm } \\
\text { Horz } \\
\text { Span } \\
\text { (ft) }\end{array}$ & $\begin{array}{l}\text { Plant } \\
\text { Elevation } \\
\text { Above } \\
\text { Grade }\end{array}$ & Remark \\
\hline $15 b$ & 2 & 8 & hot & $w$ & $\operatorname{sh}$ & 12 & & 0.5 & & 20 & \\
\hline $15 \mathrm{~b}$ & 2 & 8 & hot & $w$ & sh & 12 & & 0.5 & & 20 & \\
\hline $15 b$ & 2 & 8 & hot & $w$ & sway brace & 1 & 28.0 & 0.04 & 1.67 & 20 & \\
\hline $15 \mathrm{~b}$ & 2 & 8 & hot & $w$ & hor el & 4 & & 0.17 & & 20 & \\
\hline $15 \mathrm{~b}$ & 2 & 8 & hot & $w$ & sh & 3 & & 0.13 & & 20 & \\
\hline $15 \mathrm{~b}$ & 2 & 8 & hot & $w$ & tee & 18 & 25.0 & 0.75 & 1.04 & 20 & \\
\hline $15 b$ & 2 & 6 & hot & $w$ & $\mathrm{~h}$ & 12 & 12.0 & 0.57 & 0.57 & 20 & \\
\hline $15 b$ & 2 & 6 & hot & $w$ & sh & 6 & & 029 & & 20 & \\
\hline $15 b$ & 2 & 6 & hot & $\mathbf{w}$ & $\operatorname{sh}$ & 21 & & 1 & & 20 & \\
\hline $15 b$ & 2 & 6 & hot & $w$ & 45 sway b & 1 & & 0.05 & & 20 & \\
\hline $15 b$ & 2 & 6 & hot & $w$ & tee & 1 & 29.0 & 0.05 & 1.38 & 20 & \\
\hline $15 \mathrm{~b}$ & 2 & 3 & hot & $w$ & h & 8 & 8.0 & 0.53 & 0.53 & 20 & \\
\hline $15 b$ & 2 & 3 & hot & $w$ & 45 sway b & 2 & 2.0 & 0.13 & 0.13 & 20 & \\
\hline $15 b$ & 2 & 3 & hot & $w$ & sh & 21 & & 1.4 & & 20 & \\
\hline $15 \mathrm{~b}$ & 2 & 3 & hot & $w$ & hor el & 3 & & 0.2 & & $20=$ & \\
\hline $15 \mathrm{~b}$ & 2 & 3 & hot & w & $\operatorname{sh}$ & 10 & & 0.67 & & 20 & \\
\hline $15 \mathrm{~b}$ & 2 & 3 & hot & $\mathbf{w}$ & sway brace & 6 & 40.0 & 0.4 & 2.67 & 20 & \\
\hline $15 \mathrm{~b}$ & 2 & 3 & hot & $\mathbf{w}$ & sh & 8 & & 0.53 & & 20 & \\
\hline $15 b$ & 2 & 3 & hot & $w$ & $\operatorname{sh}$ & 6 & & 0.4 & & 20 & \\
\hline $15 b$ & 2 & 3 & hot & $\mathbf{w}$ & sh & 18 & & 12 & & 20 & \\
\hline $15 b$ & 2 & 3 & hot & $w$ & $\operatorname{sh}$ & 18 & & 1.2 & & 20 & \\
\hline $15 b$ & 2 & 3 & hot & $w$ & sh & 18 & & 1.2 & & 20 & \\
\hline $15 b$ & 2 & 3 & hot & $w$ & sh & 18 & & 1.2 & & 20 & \\
\hline $15 \mathrm{~b}$ & 2 & 3 & hot & $\mathbf{w}$ & $\operatorname{tank}$ & 2 & 88.0 & 0.13 & 5.87 & 20 & \\
\hline $16 \mathrm{a}$ & 1 & 2 & cold & $\mathrm{t}$ & equip nozz & 0 & & 0 & & 0 & \\
\hline $16 a$ & 1 & 2 & cold & $t$ & hor el & 3 & & 03 & & 0 & \\
\hline $16 a$ & 1 & 2 & cold & $\mathbf{t}$ & $\mathbf{h}$ & 2 & & 02 & & 0 & \\
\hline $16 a$ & 1 & 2 & cold & $\mathrm{t}$ & $\mathbf{h}$ & 9 & & 0.9 & & 0 & \\
\hline $16 a$ & 1 & 2 & cold & $t$ & h & 9 & 23.0 & 0.9 & 2.30 & 0 & \\
\hline $16 a$ & 1 & 2 & cold & $t$ & h & 6 & & 0.6 & & 0 & \\
\hline $16 a$ & 1 & 2 & cold & $\mathbf{t}$ & $\mathrm{h}$ & 6 & & 0.6 & & 0 & \\
\hline $16 a$ & 1 & 2 & cold & $\mathrm{t}$ & hor el & 5 & & 0.5 & & 0 & \\
\hline
\end{tabular}




\begin{tabular}{|c|c|c|c|c|c|c|c|c|c|c|c|}
\hline $\begin{array}{l}\text { Line } \\
\text { No }\end{array}$ & Unit & $\begin{array}{l}\text { Pipe } \\
\text { Size } \\
\text { (in) }\end{array}$ & Temp & $\begin{array}{l}\text { Conn } \\
\text { Type }\end{array}$ & $\begin{array}{l}\text { Support } \\
\text { Type }\end{array}$ & $\begin{array}{l}\text { Vert } \\
\text { Span } \\
(\mathrm{ft})\end{array}$ & $\begin{array}{l}\text { Horia } \\
\text { Span } \\
(\mathrm{ft})\end{array}$ & $\begin{array}{l}\text { Norm } \\
\text { Vert } \\
\text { Span } \\
\text { (ft) }\end{array}$ & $\begin{array}{l}\text { Norm } \\
\text { Horz } \\
\text { Span } \\
\text { (ft) }\end{array}$ & $\begin{array}{l}\text { Plant } \\
\text { Elevation } \\
\text { Above } \\
\text { Grade. }\end{array}$ & Remarks \\
\hline $16 a$ & 1 & 2 & cold & $t$ & h & 1 & & 0.1 & & 0 & \\
\hline $16 a$ & 1 & 2 & cold & $t$ & h & 6 & & 0.6 & & 0 & \\
\hline $16 a$ & 1 & 2 & cold & $t$ & hor el & 1 & & 0.1 & & 0 & \\
\hline $16 a$ & 1 & 2 & cold & $t$ & sway brace & 8 & 33.0 & 0.8 & 3.30 & 0 & \\
\hline $16 b$ & 2 & 2 & cold & $t$ & equip nozz & 0 & & 0 & & 0 & \\
\hline $16 b$ & 2 & 2 & cold & $t$ & hor el & 3 & & 0.3 & & 0 & \\
\hline $16 \mathrm{~b}$ & 2 & 2 & cold & $t$ & h & 2 & & 02 & & 0 & \\
\hline $16 \mathrm{~b}$ & 2 & 2 & cold & $t$ & h & 9 & & 0.9 & & 0 & \\
\hline $16 \mathrm{~b}$ & 2 & 2 & cold & $t$ & h & 9 & 23.0 & 0.9 & 2.30 & 0 & \\
\hline $16 b$ & 2 & 2 & cold & $t$ & h & 6 & & 0.6 & & 0 & \\
\hline $16 b$ & 2 & 2 & cold & $t$ & h & 6 & & 0.6 & & 0 & \\
\hline $16 b$ & 2 & 2 & cold & $t$ & hor el & 5 & & 0.5 & & 0 & \\
\hline $16 b$ & 2 & 2 & cold & $\mathbf{t}$ & $\mathbf{h}$ & 1 & & 0.1 & & 0 & \\
\hline $16 \mathrm{~b}$ & 2 & 2 & cold & $t$ & $\mathbf{h}$ & 6 & & 0.6 & & 0 & \\
\hline $16 \mathrm{~b}$ & 2 & 2 & cold & $t$ & hor el & 1 & & 0.1 & & 0 & \\
\hline $16 b$ & 2 & 2 & cold & $t$ & sway brace & 8 & 33.0 & 0.8 & 330 & 0 & \\
\hline $17 a$ & 1 & 1.5 & cold & $t$ & vert riser & 0 & & 0 & & 0 & \\
\hline $17 a$ & 1 & 1.5 & cold & $t$ & hor tee & 10 & & 1.18 & & 0 & \\
\hline $17 a$ & 1 & 15 & cold & $t$ & h & 2 & & 0.24 & & 0 & \\
\hline $17 a$ & 1 & 1.5 & cold & $t$ & $\mathrm{~h}$ & 10 & & 1.18 & & 0 & \\
\hline $17 a$ & 1 & 15 & cold & $t$ & h & 12 & & 1.41 & & 0 & \\
\hline $17 a$ & 1 & 1.5 & cold & $t$ & $\mathbf{h}$ & 10 & & 1.18 & & 0 & \\
\hline $17 \mathrm{a}$ & 1 & 15 & cold & $t$ & vert el & 0.5 & & 0.06 & & 0 & \\
\hline $17 a$ & 1 & 1.5 & cold & $\mathrm{t}$ & vert drop, & 3 & & 0.35 & & 0 & \\
\hline $17 a$ & 1 & 1.5 & cold & $\mathrm{t}$ & vert el & 0 & & 0 & & 0 & \\
\hline $17 \mathrm{a}$ & 1 & 1.5 & cold & $\mathrm{t}$ & $\mathbf{h}$ & 4 & & 0.47 & & 0 & \\
\hline $17 \mathrm{a}$ & 1 & 1.5 & cold & $\mathrm{t}$ & $\mathbf{h}$ & 8 & & 0.94 & & 0 & \\
\hline $17 \mathrm{a}$ & 1 & 15 & cold & $\mathrm{t}$ & $\mathbf{h}$ & 8 & & 0.94 & & 0 & \\
\hline $17 a$ & 1 & 15 & cold & $t$ & hor tie ro & 6 & 73.5 & 0.71 & 8.65 & 0 & \\
\hline $17 \mathrm{a}$ & 1 & 1.5 & cold & $\mathbf{t}$ & & 3 & & 0.35 & & 0 & \\
\hline $17 \mathrm{a}$ & 1 & 1.5 & cold & $t$ & $\mathrm{~h}$ & 6 & & 0.71 & & 0 & \\
\hline $17 a$ & 1 & 15 & cold & $t$ & $\mathrm{~h}$ & 12 & & 1.41 & & 0 & \\
\hline
\end{tabular}




\begin{tabular}{|c|c|c|c|c|c|c|c|c|c|c|c|}
\hline $\begin{array}{l}\text { Line } \\
\text { No }\end{array}$ & Unit & $\begin{array}{l}\text { Pipe } \\
\text { Size } \\
\text { (in) }\end{array}$ & Temp & $\begin{array}{l}\text { Conn } \\
\text { Type }\end{array}$ & $\begin{array}{l}\text { Support } \\
\text { Type }\end{array}$ & $\begin{array}{l}\text { Vert } \\
\text { Span } \\
(\mathrm{ft})\end{array}$ & $\begin{array}{l}\text { Horia } \\
\text { Span } \\
\text { (ft) }\end{array}$ & $\begin{array}{l}\text { Norm } \\
\text { Vert } \\
\text { Span } \\
\text { (ft) }\end{array}$ & $\begin{array}{l}\text { Norm } \\
\text { Horz } \\
\text { Span } \\
\text { (ft) }\end{array}$ & $\begin{array}{l}\text { Plant } \\
\text { Elevation } \\
\text { Above } \\
\text { Grade }\end{array}$ & Remarks \\
\hline $17 \mathrm{a}$ & 1 & 1.5 & cold & $\mathrm{t}$ & $h$ & 6 & & 0.71 & & 0 & \\
\hline $17 \mathrm{a}$ & 1 & 1.5 & cold & $t$ & vert riser & 3 & 30.0 & 0.35 & 3.53 & 0 & \\
\hline $17 \mathrm{~b}$ & 2 & 1.5 & cold & $t$ & vert riser & 0 & & 0 & & 0 & \\
\hline $17 \mathrm{~b}$ & 2 & 1.5 & cold & $t$ & tee & 10 & & 1.18 & & 0 & \\
\hline $17 \mathrm{~b}$ & 2 & 1.5 & cold & $\mathrm{t}$ & $\mathrm{h}$ & 2 & & 0.24 & & 0 & \\
\hline $17 \mathrm{~b}$ & 2 & 1.5 & cold & $\mathbf{t}$ & $h$ & 10 & & 1.18 & & 0 & \\
\hline $17 \mathrm{~b}$ & 2 & 1.5 & cold & $t$ & $h$ & 12 & & 1.41 & & 0 & \\
\hline $17 \mathrm{~b}$ & 2 & 1.5 & cold & $t$ & $\mathbf{h}$ & 10 & & 1.18 & & 0 & \\
\hline $17 \mathrm{~b}$ & 2 & 1.5 & cold & $\mathbf{t}$ & vert el & 0.5 & & 0.06 & & 0 & \\
\hline $17 \mathrm{~b}$ & 2 & 1.5 & cold & $t$ & vert drop, & 3 & . & 0.35 & & 0 & \\
\hline $17 \mathrm{~b}$ & 2 & 1.5 & cold & $\mathbf{t}$ & vert el & 0 & & 0 & & 0 & \\
\hline $17 \mathrm{~b}$ & 2 & 1.5 & cold & $\mathbf{t}$ & $\mathbf{h}$ & 4 & & 0.47 & & 0 & \\
\hline $17 \mathrm{~b}$ & 2 & 15 & cold & $\mathbf{t}$ & $\mathbf{h}$ & 8 & & 0.94 & & 0 & \\
\hline $17 b$ & 2 & 1.5 & cold & $\mathbf{t}$ & $\mathbf{h}$ & 8 & & 0.94 & & 0 & \\
\hline $17 \mathrm{~b}$ & 2 & 1.5 & cold & $t$ & hor tie ro & 6 & 73.5 & 0.71 & 8.65 & 0 & \\
\hline $17 \mathrm{~b}$ & 2 & 1.5 & cold & $t$ & & 3 & & 0.35 & & 0 & \\
\hline $17 \mathrm{~b}$ & 2 & 1.5 & cold & $t$ & h & 6 & & 0.71 & & 0 & \\
\hline $17 \mathrm{~b}$ & 2 & 1.5 & cold & $\mathbf{t}$ & $\mathbf{h}$ & 12 & & 1.41 & & 0 & \\
\hline $17 b$ & 2 & 1.5 & cold & $\mathbf{t}$ & $\mathbf{h}$ & 6 & & 0.71 & & 0 & \\
\hline $17 \mathrm{~b}$ & 2 & 1.5 & cold & $t$ & vert riser & 3 & 30.0 & 0.35 & 3.53 & 0 & \\
\hline $18 \mathrm{a}$ & 3 & 4 & hot & $\mathbf{w}$ & downcomer & 5 & & 0.29 & & 90 & Valley Steam Pl \\
\hline $18 \mathrm{a}$ & 3 & 4 & hot & $w$ & tee & 3 & 8.0 & 0.18 & 0.47 & 90 & \\
\hline $18 \mathrm{a}$ & 3 & 4 & hot & $w$ & branch & 0 & & 0 & & 90 & \\
\hline $18 \mathrm{a}$ & 3 & 4 & hot & $\mathbf{w}$ & h & 15 & & 0.88 & & 90 & \\
\hline $18 a$ & 3 & 4 & hot & w & tee & 15 & 33.0 & 0.88 & 1.94 & 90 & \\
\hline $18 \mathrm{a}$ & 3 & 4 & hot & $\mathbf{w}$ & h/brch w 1 & 8 & & 0.47 & & 90 & \\
\hline $18 \mathrm{a}$ & 3 & 4 & hot & $w$ & h & 3 & & 0.18 & & 90 & \\
\hline $18 a$ & 3 & 4 & hot & $w$ & h & 12 & & 0.71 & & 90 & \\
\hline $18 a$ & 3 & 4 & hot & $\mathbf{w}$ & h & 12 & & 0.71 & & 90 & \\
\hline $18 a$ & 3 & 4 & hot & $w$ & sh & 18 & & 1.06 & & 90 & \\
\hline $18 a$ & 3 & 4 & hot & $w$ & hor el & 6 & & 0.35 & & 90 & \\
\hline $18 a$ & 3 & 4 & hot & $w$ & hor el & 5 & & 0.29 & & 90 & \\
\hline
\end{tabular}




\begin{tabular}{|c|c|c|c|c|c|c|c|c|c|c|c|}
\hline $\begin{array}{l}\text { Line } \\
\text { No }\end{array}$ & Unit & $\begin{array}{l}\text { Pipe } \\
\text { Size } \\
\text { (in) }\end{array}$ & Temp & $\begin{array}{l}\text { Conn } \\
\text { Type }\end{array}$ & $\begin{array}{l}\text { Support } \\
\text { Type }\end{array}$ & $\begin{array}{l}\text { Vert } \\
\text { Span } \\
\text { (ft) }\end{array}$ & $\begin{array}{l}\text { Horia } \\
\text { Span } \\
\text { (ft) }\end{array}$ & $\begin{array}{l}\text { Norm } \\
\text { Vert } \\
\text { Span } \\
\text { (ft) }\end{array}$ & $\begin{array}{l}\text { Norm } \\
\text { Horz } \\
\text { Span } \\
\text { (ft) }\end{array}$ & $\begin{array}{l}\text { Plant } \\
\text { Elevation } \\
\text { Above } \\
\text { Grade }\end{array}$ & Remarks \\
\hline $18 \mathrm{a}$ & 3 & 4 & hot & $w$ & sh & 1 & & 0.06 & & 90 & \\
\hline $18 \mathrm{a}$ & 3 & 4 & hot & $w$ & hor el & 15 & & 0.88 & & 90 & \\
\hline $18 \mathrm{a}$ & 3 & 4 & hot & $w$ & sh & 1 & & 0.06 & & 90 & \\
\hline $18 \mathrm{a}$ & 3 & 4 & hot & w & downcomer & 1 & 82.0 & 0.06 & 4.82 & 90 & \\
\hline $18 b$ & 4 & 4 & hot & $w$ & downcomer & 5 & & 0.29 & & 90 & \\
\hline $18 \mathrm{~b}$ & 4 & 4 & hot & $w$ & tee & 3 & 8.0 & 0.18 & 0.47 & 90 & \\
\hline $18 b$ & 4 & 4 & hot & $w$ & branch & 0 & & 0 & & 90 & \\
\hline $18 b$ & 4 & 4 & hot & w & h & 15 & & 0.88 & & 90 & \\
\hline $18 b$ & 4 & 4 & hot & $w$ & tee & 15 & 33.0 & 0.88 & 1.94 & 90 & \\
\hline $18 \mathrm{~b}$ & 4 & 4 & hot & w & $\mathrm{h} / \mathrm{brch}$ w 1 & 8 & & 0.47 & & 90 & \\
\hline $18 b$ & 4 & 4 & hot & $w$ & h & 3 & & 0.18 & & 90 & \\
\hline $18 b$ & 4 & 4 & hot & $w$ & h & 12 & & 0.71 & & 90 & \\
\hline $18 \mathrm{~b}$ & 4 & 4 & hot & w & h & 12 & & 0.71 & & 90 & \\
\hline $18 \mathrm{~b}$ & 4 & 4 & hot & $w$ & sh & 18 & & 1.06 & & 90 & \\
\hline $18 \mathrm{~b}$ & 4 & 4 & hot & $w$ & hor el & 6 & & 0.35 & & 90 & \\
\hline $18 \mathrm{~b}$ & 4 & 4 & hot & $w$ & hor el & 5 & & 0.29 & & 90 & \\
\hline $18 \mathrm{~b}$ & 4 & 4 & hot & w & sh & 1 & & 0.06 & & 90 & \\
\hline $18 \mathrm{~b}$ & 4 & 4 & hot & $w$ & hor el & 15 & & 0.88 & & 90 & \\
\hline $18 \mathrm{~b}$ & 4 & 4 & hot & $w$ & sh & 1 & & 0.06 & & 90 & \\
\hline $18 \mathrm{~b}$ & 4 & 4 & hot & $w$ & downcomer & 1 & 82.0 & 0.06 & 4.82 & 90 & \\
\hline $19 a$ & 3 & 3 & cold & $w$ & h & 0 & & 0 & & 90 & \\
\hline $19 a$ & 3 & 3 & cold & $w$ & hor el & 12 & & 1 & & 90 & \\
\hline $19 a$ & 3 & 3 & cold & $w$ & h & 3 & & 0.25 & & 90 & \\
\hline $19 a$ & 3 & 3 & cold & $w$ & $h$ & 12 & & 1 & & 90 & \\
\hline $19 a$ & 3 & 3 & cold & $w$ & h & 12 & & 1 & & 90 & \\
\hline $19 a$ & 3 & 3 & cold & $w$ & vert rise & 12 & 51.0 & 1 & 4.25 & 90 & \\
\hline $19 a$ & 3 & 3 & cold & $\mathrm{w}$ & h & 1 & & 0.08 & & 90 & \\
\hline $19 a$ & 3 & 3 & cold & $w$ & h & 12 & & 1 & & 90 & \\
\hline $.19 a$ & 3 & 3 & cold & $w$ & $h$ & 12 & & 1 & & 90 & \\
\hline $19 \mathrm{a}$ & 3 & 3 & cold & $w$ & $h$ & 12 & & 1 & & 90 & \\
\hline $19 \mathrm{a}$ & 3 & 3 & cold & $w$ & $h$ & 12 & & 1 & & 90 & \\
\hline $19 \mathrm{a}$ & 3 & 3 & cold & $w$ & $\mathbf{h}$ & 12 & & 1 & & 90 & \\
\hline
\end{tabular}




\begin{tabular}{|c|c|c|c|c|c|c|c|c|c|c|c|}
\hline $\begin{array}{l}\text { Line } \\
\text { No }\end{array}$ & Unit & $\begin{array}{l}\text { Pipe } \\
\text { Size } \\
\text { (in) }\end{array}$ & Temp & $\begin{array}{l}\text { Conn } \\
\text { Type }\end{array}$ & $\begin{array}{l}\text { Support } \\
\text { Type }\end{array}$ & $\begin{array}{l}\text { Vert } \\
\text { Span } \\
(\mathrm{ft})\end{array}$ & $\begin{array}{l}\text { Horia } \\
\text { Span } \\
\text { (ft) }\end{array}$ & $\begin{array}{l}\text { Norm } \\
\text { Vert } \\
\text { Span } \\
\text { (ft) }\end{array}$ & $\begin{array}{l}\text { Norm } \\
\text { Horz } \\
\text { Span } \\
\text { (ft) }\end{array}$ & $\begin{array}{l}\text { Plant } \\
\text { Elevation } \\
\text { Above } \\
\text { Grade }\end{array}$ & Remarks \\
\hline $19 a$ & 3 & 3 & cold & $\mathbf{w}$ & $\mathbf{h}$ & 12 & & 1 & & 90 & \\
\hline $19 a$ & 3 & 3 & cold & $\mathbf{w}$ & h & 12 & & 1 & & 90 & \\
\hline $19 \mathrm{a}$ & 3 & 3 & cold & $\mathbf{w}$ & $\mathbf{h}$ & 15 & 100.0 & 1.25 & 8.33 & 90 & \\
\hline $19 b$ & 4 & 3 & cold & $\mathbf{w}$ & $\mathbf{h}$ & 0 & & 0 & & 90 & \\
\hline $19 \mathrm{~b}$ & 4 & 3 & cold & $\mathbf{w}$ & hor el & 12 & & 1 & & 90 & \\
\hline $19 b$ & 4 & 3 & cold & $\mathbf{w}$ & $\mathbf{h}$ & 3 & & 0.25 & & 90 & \\
\hline $19 \mathrm{~b}$ & 4 & 3 & cold & $\mathbf{w}$ & $\mathrm{h}$ & 12 & & 1 & & 90 & \\
\hline $19 \mathrm{~b}$ & 4 & 3 & cold & $w$ & $\mathbf{h}$ & 12 & & 1 & & 90 & \\
\hline $19 \mathrm{~b}$ & 4 & 3 & cold & $w$ & vert rise & 12 & 51.0 & 1 & 4.25 & 90 & \\
\hline $19 b$ & 4 & 3 & cold & $w$ & h & 1 & & 0.25 & & 90 & \\
\hline $19 b$ & 4 & 3 & cold & $w$ & $\mathbf{h}$ & 12 & & 1 & & 90 & \\
\hline $19 b$ & 4 & 3 & cold & $\mathbf{w}$ & b & 12 & & 1 & & 90 & \\
\hline $19 \mathrm{~b}$ & 4 & 3 & cold & $\mathbf{w}$ & $\mathbf{h}$ & 12 & & 1 & & 90 & \\
\hline $19 b$ & 4 & 3 & cold & $\mathbf{w}$ & h & 12 & & 1 & & 90 & \\
\hline $19 b$ & 4 & 3 & cold & $\mathbf{w}$ & h & 12 & & 1 & & 90 & \\
\hline $19 b$ & 4 & 3 & cold & $\mathbf{w}$ & h & 12 & & 1 & & 90 & \\
\hline $19 b$ & 4 & 3 & cold & $\mathbf{w}$ & h & 12 & & 1 & & 90 & \\
\hline $19 b$ & 4 & 3 & cold & $\mathbf{w}$ & h & 12 & 100.0 & 1 & 8.33 & 90 & \\
\hline $20 \mathrm{al}$ & 3 & 0.75 & cold & sw & wall & 0 & & 0 & & 90 & \\
\hline $20 \mathrm{a1}$ & 3 & 0.75 & cold & sw & U-bolt tra & 3 & 3.0 & 0.6 & 0.60 & 90 & \\
\hline $20 \mathrm{a} 1$ & 3 & 0.75 & cold & sw & vert el & 1 & & 0.2 & & 90 & \\
\hline $20 \mathrm{al}$ & 3 & 0.75 & cold & sw & vert drop & 3 & & 0.6 & & 90 & \\
\hline $20 \mathrm{a} 1$ & 3 & 0.75 & cold & sw & vert elbow & 3 & 10.0 & 0.6 & 2.00 & 90 & \\
\hline $20 \mathrm{a} 2$ & 3 & 0.75 & cold & sw & wall & 0 & & 0 & & 90 & \\
\hline $20 \mathrm{a} 2$ & 3 & 0.75 & cold & sw & U-bolt tra & 3 & 3.0 & 0.6 & 0.60 & 90 & \\
\hline $20 a 2$ & 3 & 0.75 & cold & sw & vert el & 1 & & 0.2 & & 90 & \\
\hline $20 \mathrm{a} 2$ & 3 & 0.75 & cold & sw & vert drop & 3 & & 0.6 & & 90 & \\
\hline $20 \mathrm{a} 2$ & 3 & 0.75 & cold & sw & vert elbow & 3 & 10.0 & 0.6 & 2.00 & 90 & \\
\hline $20 \mathrm{~b} 1$ & 4 & 0.75 & cold & sw & wall & 0 & & 0 & & 90 & \\
\hline $20 \mathrm{bl}$ & 4 & 0.75 & cold & $\mathbf{s w}$ & U-bolt tra & 3 & 3.0 & 0.6 & 0.60 & 90 & \\
\hline $20 \mathrm{~b} 1$ & 4 & 0.75 & cold & $\mathbf{s w}$ & vert el & 1 & & 0.2 & & 90 & \\
\hline $20 \mathrm{~b} 1$ & 4 & 0.75 & cold & sw & vert drop & 3 & & 0.6 & & 90 & \\
\hline
\end{tabular}




\begin{tabular}{|c|c|c|c|c|c|c|c|c|c|c|c|}
\hline $\begin{array}{l}\text { Line } \\
\text { No }\end{array}$ & Unit & $\begin{array}{l}\text { Pipe } \\
\text { Size } \\
\text { (in) }\end{array}$ & Temp & $\begin{array}{l}\text { Conn } \\
\text { Type }\end{array}$ & $\begin{array}{l}\text { Support } \\
\text { Type }\end{array}$ & $\begin{array}{l}\text { Vert } \\
\text { Span } \\
(\mathrm{ft})\end{array}$ & $\begin{array}{l}\text { Horia } \\
\text { Span } \\
\text { (ft) }\end{array}$ & $\begin{array}{l}\text { Norm } \\
\text { Vert } \\
\text { Span } \\
\text { (ft) }\end{array}$ & $\begin{array}{l}\text { Norm } \\
\text { Horz } \\
\text { Span } \\
\text { (ft) }\end{array}$ & $\begin{array}{l}\text { Plant } \\
\text { Elevation } \\
\text { Above } \\
\text { Grade }\end{array}$ & Remarks \\
\hline $20 \mathrm{~b} 1$ & 4 & 0.75 & cold & sw & vert elbow & 3 & 10.0 & 0.6 & 2.00 & 90 & \\
\hline $20 \mathrm{~b} 2$ & 4 & 0.75 & cold & Sw & wall & 0 & & 0 & & 90 & \\
\hline $20 \mathrm{~b} 2$ & 4 & 0.75 & cold & sw & U-bolt tra & 3 & 3.0 & 0.6 & 0.60 & 90 & \\
\hline $20 \mathrm{~b} 2$ & 4 & 0.75 & cold & sw & vert $\mathrm{el}$ & 1 & & 0.2 & & 90 & \\
\hline $20 \mathrm{~b} 2$ & 4 & 0.75 & cold & sw & vert drop & 3 & & 0.6 & & 90 & \\
\hline $20 \mathrm{~b} 2$ & 4 & 0.75 & cold & SW & vert elbow & 3 & 10.0 & 0.6 & 2.00 & 90 & \\
\hline $21 a$ & 3 & 1 & cold & $t$ & vert el & 1 & & 0.14 & & 90 & \\
\hline $21 a$ & 3 & 1 & cold & $t$ & vert elbow & 2 & & 0.29 & & 90 & \\
\hline $21 a$ & 3 & 1 & cold & $\mathfrak{t}$ & h & 2 & & 0.29 & & 90 & \\
\hline $21 a$ & 3 & 1 & cold & $t$ & $h$ & 6 & & 0.86 & & 90 & \\
\hline $21 a$ & 3 & 1 & cold & $t$ & h & 6 & & 0.86 & & 90 & \\
\hline $21 a$ & 3 & 1 & cold & $t$ & hor el & 9 & & 1.29 & & 90 & \\
\hline $21 a$ & 3 & 1 & cold & $t$ & lateral re & 6 & 32.0 & 0.86 & 4.57 & 90 & \\
\hline $21 a$ & 3 & 1 & cold & $t$ & $\mathbf{h}$ & 9 & & 1.29 & & 90 & \\
\hline $21 a$ & 3 & 1 & cold & $t$ & $\mathrm{~h}$ & 9 & & 1.29 & & 90 & \\
\hline $21 a$ & 3 & 1 & cold & $i$ & lateral re & 1 & 19.0 & 0.14 & 2.71 & 90 & \\
\hline $21 b$ & 4 & 1 & cold & $\mathrm{t}$ & vert el & 1 & & 0.14 & & 90 & \\
\hline $21 b$ & 4 & 1 & cold & $t$ & vert elbow & 2 & & 0.29 & & 90 & \\
\hline $21 b$ & 4 & 1 & cold & $t$ & h & 2 & & 0.29 & & 90 & \\
\hline $21 b$ & 4 & 1 & cold & $\mathbf{t}$ & $\mathrm{h}$ & 6 & & 0.86 & & 90 & \\
\hline $21 b$ & 4 & 1 & cold & $t$ & $h$ & 6 & & 0.86 & & 90 & \\
\hline $21 b$ & 4 & 1 & cold & $t$ & hor el & 9 & & 1.29 & & 90 & \\
\hline $21 b$ & 4 & 1 & cold & $t$ & lateral re & 6 & 32.0 & 0.86 & 4.57 & 90 & \\
\hline $21 b$ & 4 & 1 & cold & $t$ & $h$ & 9 & & 1.29 & & 90 & \\
\hline $21 b$ & 4 & 1 & cold & $t$ & $\mathbf{h}$ & 9 & & 1.29 & & 90 & \\
\hline $21 b$ & 4 & 1 & cold & $t$ & lateral re & 1 & 19.0 & 0.14 & 2.71 & 90 & \\
\hline $22 a$ & 3 & 0.75 & cold & sw & downcomer & 0 & & 0 & & 90 & \\
\hline $22 a$ & 3 & 0.75 & cold & sw & $\mathbf{h}$ & 2 & & 0.4 & & 90 & \\
\hline $22 a$ & 3 & 0.75 & cold & sw & hor el & 0.5 & & 0.1 & & 90 & \\
\hline $22 a$ & 3 & 0.75 & cold & SW & $\mathbf{h}$ & 4 & & 0.8 & & 90 & \\
\hline $22 a$ & 3 & 0.75 & cold & sw & hor el & 1 & & 0.2 & & 90 & \\
\hline $22 a$ & 3 & 0.75 & cold & sw & downcomer & 3 & 10.5 & 0.6 & 2.10 & 90 & \\
\hline
\end{tabular}




\begin{tabular}{|c|c|c|c|c|c|c|c|c|c|c|c|}
\hline $\begin{array}{l}\text { Line } \\
\text { No }\end{array}$ & Unit & $\begin{array}{l}\text { Pipe } \\
\text { Size } \\
\text { (in) }\end{array}$ & Temp & $\begin{array}{l}\text { Conn } \\
\text { Type }\end{array}$ & $\begin{array}{l}\text { Support } \\
\text { Type }\end{array}$ & $\begin{array}{l}\text { Vert } \\
\text { Span } \\
\text { (ft) }\end{array}$ & $\begin{array}{l}\text { Horia } \\
\text { Span } \\
\text { (ft) }\end{array}$ & $\begin{array}{l}\text { Norm } \\
\text { Vert } \\
\text { Span } \\
\text { (ft) }\end{array}$ & $\begin{array}{l}\text { Norm } \\
\text { Horz } \\
\text { Span } \\
\text { (ft) }\end{array}$ & $\begin{array}{l}\text { Plant } \\
\text { Elevation } \\
\text { Above } \\
\text { Grade }\end{array}$ & Remarks \\
\hline $22 b$ & 4 & 0.75 & cold & sw & downcomer & 0 & & 0 & & 90 & \\
\hline $22 b$ & 4 & 0.75 & cold & sw & h & 2 & & 0.4 & & 90 & \\
\hline $22 b$ & 4 & 0.75 & cold & sw & hor el & 0.5 & & 0.1 & & 90 & \\
\hline $22 b$ & 4 & 0.75 & cold & sw & $\mathrm{h}$ & 4 & & 0.8 & & 90 & \\
\hline $22 b$ & 4 & 0.75 & cold & sw & hor el & 1 & & 0.2 & & 90 & \\
\hline $22 b$ & 4 & 0.75 & cold & sw & downcomer & 3 & 10.5 & 0.6 & 2.1 & 90 & \\
\hline 23 & 4 & 0.75 & cold & sw & downcomer & 0 & & 0 & & 75 & Begin El Centro \\
\hline 23 & 4 & 0.75 & cold & sw & b & 2 & & 0.4 & & 75 & \\
\hline 23 & 4 & 0.75 & cold & sw & h & 1 & & 02 & & 75 & \\
\hline 23 & 4 & 0.75 & cold & sw & h & 4 & & 0.8 & & 75 & \\
\hline 23 & 4 & 0.75 & cold & sw & hor el & 1 & & 0.2 & & 75 & \\
\hline 23 & 4 & 0.75 & cold & sw & hor U-bolt & 8 & & 1.6 & & 75 & \\
\hline 23 & 4 & 0.75 & cold & sw & downcomer & 0.5 & 20.0 & 0.1 & 4.00 & 75 & \\
\hline $24 a$ & 4 & 0.75 & cold & sw & riser U-bo & 1 & & 0.2 & & 75 & \\
\hline $24 a$ & 4 & 0.75 & cold & sw & tee & 4 & & 0.8 & & 75 & \\
\hline $24 a$ & 4 & 0.75 & cold & sw & U-bolt tie & 6 & & 1.2 & & 75 & \\
\hline $24 a$ & 4 & 0.75 & cold & sw & riser & 2 & 13.0 & 0.4 & 2.60 & 75 & . \\
\hline $24 b$ & 4 & 0.75 & cold & sw & riser U-bo & 1 & & 0.2 & & 75 & \\
\hline $24 b$ & 4 & 0.75 & cold & sw & tee & 4 & & 0.8 & & 75 & \\
\hline $24 b$ & 4 & 0.75 & cold & sw & U-bolt tie & 6 & & 12 & & 75 & \\
\hline $24 b$ & 4 & 0.75 & cold & sw & riser & 2 & 13.0 & 0.4 & 2.60 & 75 & \\
\hline 25 & 4 & 3 & hot & $\mathbf{w}$ & downcomer & 0 & & 0 & & 70 & \\
\hline 25 & 4 & 3 & hot & w & h & 1 & & 0.07 & & 70 & \\
\hline 25 & 4 & 3 & hot & $w$ & h & 12 & & 0.8 & & 70 & \\
\hline 25 & 4 & 3 & hot & $w$ & $\mathbf{h}$ & 14 & & 0.93 & & 70 & \\
\hline 25 & 4 & 3 & hot & $w$ & h & 14 & & 0.93 & & 70 & \\
\hline 25 & 4 & 3 & hot & $w$ & hor el & 6 & & 0.4 & & 70 & \\
\hline 25 & 4 & 3 & hot & w & h & 2 & & 0.13 & & 70 & \\
\hline 25 & 4 & 3 & hot & w & $\mathbf{h}$ & 6 & & 0.4 & & 70 & \\
\hline 25 & 4 & 3 & hot & $w$ & hor el & 10 & & 0.67 & & 70 & \\
\hline 25 & 4 & 3 & hot & $w$ & & 3 & 68.0 & 0.2 & 4.53 & 70 & \\
\hline 26 & 4 & 0.75 & cold & $\mathrm{sw}$ & downcomer & 0 & & 0 & & 70 & \\
\hline
\end{tabular}




\begin{tabular}{|c|c|c|c|c|c|c|c|c|c|c|c|}
\hline $\begin{array}{l}\text { Line } \\
\text { No }\end{array}$ & Unit & $\begin{array}{l}\text { Pipe } \\
\text { Size } \\
\text { (in) }\end{array}$ & Temp & $\begin{array}{l}\text { Conn } \\
\text { Type }\end{array}$ & $\begin{array}{l}\text { Support } \\
\text { Type }\end{array}$ & $\begin{array}{l}\text { Vert } \\
\text { Span } \\
\text { (ft) }\end{array}$ & $\begin{array}{l}\text { Horia } \\
\text { Span } \\
(\mathrm{ft})\end{array}$ & $\begin{array}{l}\text { Norm } \\
\text { Vert } \\
\text { Span } \\
\text { (ft) }\end{array}$ & $\begin{array}{l}\text { Norm } \\
\text { Horz } \\
\text { Span } \\
\text { (ft) }\end{array}$ & $\begin{array}{l}\text { Plant } \\
\text { Elevation } \\
\text { Above } \\
\text { Grade }\end{array}$ & Remarks \\
\hline 26 & 4 & 0.75 & cold & sw & $\mathbf{h}$ & 2 & & 0.4 & & 70 & \\
\hline 26 & 4 & 0.75 & cold & sw & $\mathbf{h}$ & 12 & & 2.4 & & 70 & \\
\hline 26 & 4 & 0.75 & cold & sw & $\mathbf{h}$ & 14 & & 2.8 & & 70 & \\
\hline 26 & 4 & 0.75 & cold & sw & $\mathbf{h}$ & 12 & & 2.4 & & 70 & \\
\hline 26 & 4 & 0.75 & cold & sw & hor el & 1 & & 0.2 & & 70 & \\
\hline 26 & 4 & 0.75 & cold & sw & hor el & 10 & & 2 & & 70 & $\cdots$ \\
\hline 26 & 4 & 0.75 & cold & sw & hor el & 2 & 53.0 & 0.4 & 10.60 & 70 & \\
\hline 27 & 4 & 1 & hot & Sw & downcomer & 0 & & 0 & & 70 & \\
\hline 27 & 4 & 1 & hot & sw & U-bolt & 2 & & 0.22 & & 70 & \\
\hline 27 & 4 & 1 & hot & $\mathbf{s w}$ & downcomer & 8 & 10.0 & 0.89 & 1.11 & 70 & \\
\hline 27 & 4 & 1 & hot & $\mathbf{S w}$ & U-bolt & 4 & & 0.44 & & 70 & \\
\hline 27 & 4 & 1 & hot & SW & downcomer & 4 & & 0.44 & & 70 & \\
\hline 27 & 4 & 1 & hot & sw & wall & 2 & 10.0 & 0.22 & 1.11 & 70 & \\
\hline 28 & 3 & 3 & hot & $\mathbf{w}$ & downcomer & 0 & & 0 & & 60 & \\
\hline 28 & 3 & 3 & hot & w & downcomer & 6 & & 0.4 & & 60 & \\
\hline 28 & 3 & 3 & hot & $\mathbf{w}$ & U-bolt & 3 & & 0.2 & & 60 & \\
\hline 28 & 3 & 3 & hot & $\mathbf{w}$ & $10 \mathrm{ft} \mathrm{rise}$ & 20 & & 1.33 & & 60 & \\
\hline 28 & 3 & 3 & hot & $\mathbf{w}$ & riser lat & 10 & & 0.67 & & 60 & \\
\hline 28 & 3 & $3^{\circ}$ & hot & $\mathbf{w}$ & $\mathbf{h}$ & 1 & & 0.07 & & 60 & \\
\hline 28 & 3 & 2 & hot & $\mathbf{w}$ & riser & 1 & 41.0 & 0.08 & 3.15 & 60 & \\
\hline $28 a$ & 3 & 2 & hot & $\mathbf{w}$ & h & 12 & & 0.92 & & 60 & \\
\hline $28 \mathrm{a}$ & 3 & 2 & hot & w & wall & 10 & 22.0 & 0.77 & 1.69 & 60 & \\
\hline $28 \mathrm{~b}$ & 3 & 3 & hot & $w$ & h & 1 & & 0.07 & & 60 & \\
\hline $28 b$ & 3 & 3 & hot & $\mathrm{w}$ & hor el & 10 & & 0.67 & & 60 & \\
\hline $28 b$ & 3 & 3 & hot & $\mathbf{w}$ & sh & 20 & & 1.33 & & 60 & \\
\hline $28 b$ & 3 & 3 & hot & w & sh & 10 & & 0.67 & & 60 & \\
\hline $28 b$ & 3 & 3 & hot & $w$ & riser & 10 & 51.0 & 0.67 & 3.40 & 60 & \\
\hline 29 & 3 & 4 & hot & $\mathbf{w}$ & downcomer & 6 & & 0.35 & & 30 & \\
\hline 29 & 3 & 4 & hot & $w$ & h & 7 & & 0.41 & & 30 & \\
\hline 29 & 3 & 4 & hot & $\mathbf{w}$ & $\mathrm{h}$ & 10 & & 0.59 & & 30 & \\
\hline 29 & 3 & 4 & hot & $w$ & h & 12 & & 0.71 & & 30 & \\
\hline 29 & 3 & 4 & hot & $w$ & hor el & 3 & & 0.18 & & 30 & \\
\hline
\end{tabular}




\begin{tabular}{|c|c|c|c|c|c|c|c|c|c|c|c|}
\hline $\begin{array}{l}\text { Line } \\
\text { No }\end{array}$ & Unit & $\begin{array}{l}\text { Pipe } \\
\text { Size } \\
\text { (in) }\end{array}$ & Temp & $\begin{array}{l}\text { Conn } \\
\text { Type }\end{array}$ & $\begin{array}{l}\text { Support } \\
\text { Type }\end{array}$ & $\begin{array}{l}\text { Vert } \\
\text { Span } \\
(\mathrm{ft})\end{array}$ & $\begin{array}{l}\text { Horia } \\
\text { Span } \\
\text { (ft) }\end{array}$ & $\begin{array}{l}\text { Norm } \\
\text { Vert } \\
\text { Span } \\
\text { (ft) }\end{array}$ & $\begin{array}{l}\text { Norm } \\
\text { Horz } \\
\text { Span } \\
\text { (ft) }\end{array}$ & $\begin{array}{l}\text { Plant } \\
\text { Elevation } \\
\text { Above } \\
\text { Grade }\end{array}$ & Remarks \\
\hline 29 & 3 & 4 & hot & $w$ & h & 10 & & 0.59 & & 30 & \\
\hline 29 & 3 & 4 & hot & $\mathbf{w}$ & downcomer & 4 & 52.0 & 0.24 & 3.06 & 30 & \\
\hline 30 & 3 & 1 & hot & $t$ & downcomer & 0 & & 0 & & 30 & \\
\hline 30 & 3 & 1 & hot & $t$ & h & 3 & & 0.33 & & 30 & \\
\hline 30 & 3 & 1 & hot & $\mathbf{t}$ & h & 10 & & 1.11 & & 30 & \\
\hline 30 & 3 & 1 & cold & $\mathbf{t}$ & h & 10 & & 1.43 & & 30 & \\
\hline 30 & 3 & 1 & cold & $\mathbf{t}$ & hor el & 10 & & 1.43 & & 30 & \\
\hline 30 & 3 & 1 & cold & $t$ & h & 3 & & 0.43 & & 30 & \\
\hline 30 & 3 & 1 & cold & $t$ & h & 15 & . & 2.14 & & 30 & \\
\hline 30 & 3 & 0.75 & cold & $t$ & hor el & 6 & & 1.2 & & 30 & \\
\hline 30 & 3 & 0.75 & cold & $t$ & U-bolt & 16 & 73.0 & 3.2 & 14.60 & 30 & \\
\hline $30 a$ & 3 & 0.75 & cold & $t$ & hor el & 12 . & & 2.4 & & 30 & \\
\hline $30 a$ & 3 & 0.75 & cold & $\mathrm{t}$ & U-bolt to & 5 & & 1 & & 30 & \\
\hline $30 a$ & 3 & 0.75 & cold & $t$ & vert el to & 10 & 27.0 & 2 & 5.40 & 30 & \\
\hline $30 \mathrm{~b}$ & 3 & 0.75 & cold & $t$ & vert el & 12 & & 2.4 & & 30 & \\
\hline $30 \mathrm{~b}$ & 3 & 0.75 & cold & $t$ & U-bolt to & 5 & & 1 & & 30 & \\
\hline $30 \mathrm{~b}$ & 3 & 0.75 & cold & $\mathrm{t}$ & vert elbow & 10 & 27.0 & 2 & 5.40 & 30 & \\
\hline 31 & 4 & 6 & cold & $w$ & downcomer & 0 & & 0 & & 0 & \\
\hline 31 & 4 & 6 & cold & $w$ & $\mathrm{~h}$ & 2 & & 0.12 & & 0 & \\
\hline 31 & 4 & 6 & cold & $w$ & $\mathrm{~h}$ & 14 & & 0.82 & & 0 & \\
\hline 31 & 4 & 6 & cold & $\mathbf{w}$ & hor el & 3. & & 0.18 & & 0 & \\
\hline 31 & 4 & 6 & cold & $\mathbf{w}$ & $\mathbf{h}$ & 6 & & 0.35 & & 0 & \\
\hline 31 & 4 & 6 & cold & $w$ & hor el & 30 & & 1.76 & & 0 & \\
\hline 31 & 4 & 6 & cold & $\mathrm{w}$ & riser & 2 & 57.0 & 0.12 & 3.35 & 0 & \\
\hline 32 & 4 & 8 & cold & $\mathbf{w}$ & downcomer & 0 & & 0 & & 0 & \\
\hline 32 & 4 & 8 & cold & $\mathrm{w}$ & hor el & 6 & & 0.32 & & 0 & \\
\hline 32 & 4 & 8 & cold & $\mathrm{w}$ & U-bolt tra & 15 & & 0.79 & & 0 & \\
\hline 32 & 4 & 8 & cold & $w$ & U-bolt tra & 15 & & 0.79 & & 0 & \\
\hline 32 & 4 & 8 & cold & $\begin{array}{l}\text { flang } \\
\mathrm{e}\end{array}$ & & 12 & 48.0 & 0.63 & 2.53 & 0 & \\
\hline 32 & 4 & 6 & cold & $\mathbf{w}$ & riser & 3 & & 0.18 & & 0 & \\
\hline 32 & 4 & 6 & cold & $w$ & tank & 6 & 9.0 & 0.35 & 0.53 & 0 & \\
\hline
\end{tabular}




\begin{tabular}{|c|c|c|c|c|c|c|c|c|c|c|c|}
\hline $\begin{array}{l}\text { Line } \\
\text { No }\end{array}$ & Unit & $\begin{array}{l}\text { Pipe } \\
\text { Size } \\
\text { (in) }\end{array}$ & Temp & $\begin{array}{l}\text { Conn } \\
\text { Type }\end{array}$ & $\begin{array}{l}\text { Support } \\
\text { Type }\end{array}$ & $\begin{array}{l}\text { Vert } \\
\text { Span } \\
(\mathrm{ft})\end{array}$ & $\begin{array}{l}\text { Horia } \\
\text { Span } \\
(\mathrm{ft})\end{array}$ & $\begin{array}{l}\text { Norm } \\
\text { Vert } \\
\text { Span } \\
\text { (ft) }\end{array}$ & $\begin{array}{l}\text { Norm } \\
\text { Horz } \\
\text { Span } \\
\text { (ft) }\end{array}$ & $\begin{array}{l}\text { Plant } \\
\text { Elevation } \\
\text { Above } \\
\text { Grade }\end{array}$ & Remarks \\
\hline 32 & 4 & 2 & cold & sw & vert el & 16 & & 1.6 & & 0 & \\
\hline 32 & 4 & 2 & cold & SW & riser & 3 & 19.0 & 0.3 & 1.90 & 0 & \\
\hline 33 & 3 & 8 & cold & $\mathbf{w}$ & downcomer & 0 & & 0 & & 0 & \\
\hline 33 & 3 & 8 & cold & $\mathbf{w}$ & sh & 15 & & 0.79 & & 0 & \\
\hline 33 & 3 & 8 & cold & $\mathbf{w}$ & guide & 22 & 37.0 & 1.16 & 1.95 & 0 & \\
\hline 33 & 3 & 8 & cold & $\mathbf{w}$ & sh & 21 & & 1.11 & & 0 & \\
\hline 33 & 3 & 8 & cold & $\mathbf{w}$ & sh & 12 & & 0.63 & & 0 & \\
\hline 33 & 3 & 8 & cold & $\mathbf{w}$ & guide & 24 & 57.0 & 1.26 & 3.00 & 0 & \\
\hline 34 & 3 & 3 & cold & $\mathbf{w}$ & downcomer & 0 & & 0 & & 0 & \\
\hline 34 & 3 & 3 & cold & $\mathbf{w}$ & wall & 15 & & 1.25 & & 0 & \\
\hline 34 & 3 & 3 & cold & $\mathbf{w}$ & U-bolt tra & 22 & & 1.83 & & 0 & \\
\hline 34 & 3 & 3 & cold & $\mathrm{w}$ & downcomer & 8 & & 0.67 & & 0 & \\
\hline 34 & 3 & 3 & cold & $w$ & & 15 & 60.0 & 125 & 5.00 & 0 & \\
\hline$\cdot 35$ & 3 & 6 & hot & $\mathbf{w}$ & downcomer & 0 & & 0 & & 0 & \\
\hline 35 & 3 & 6 & hot & $\mathbf{w}$ & vert el & 3 & & 0.14 & & 0 & \\
\hline 35 & 3 & 6 & hol & $\mathbf{w}$ & riser & 3 & & 0.14 & & 0 & \\
\hline 35 & 3 & 6 & hot & $\mathbf{w}$ & sh & 15 & & 0.71 & & 0 & \\
\hline 35 & 3 & 6 & hot & $w$ & $\operatorname{sh}$ & 20 & & 0.95 & & 0 & \\
\hline 35 & 3 & 6 & hot & w & lateral re & 6 & 47.0 & 0.29 & 2.24 & 0 & \\
\hline 35 & 3 & 6 & hot & $\mathrm{w}$ & $\mathbf{h}$ & 15 & & 0.71 & & 0 & \\
\hline 35 & 3 & 6 & hot & $w$ & hor el & 6 & & 0.29 & & 0 & \\
\hline 35 & 3 & 6 & hot & $w$ & $\mathbf{h}$ & 12 & 33.0 & 0.57 & 1.57 & 0 & \\
\hline 36 & 1 & 1.5 & hot & sw & wall & 0 & & 0 & & 0 & \\
\hline 36 & 1 & 1.5 & hot & $\mathbf{s w}$ & $\mathbf{h}$ & 1 & & 0.09 & & 0 & \\
\hline 36 & 1 & 1.5 & hot & sw & hor el & 18 & & 1.64 & & 0 & \\
\hline 36 & 1 & 1.5 & hot & sw & $\mathbf{h}$ & 2 & & 0.18 & & 0 & \\
\hline 36 & 1 & 15 & hot & $\mathrm{sw}$ & $\mathrm{h}$ & 13 & & 1.18 & & 0 & \\
\hline 36 & 1 & 15 & hot & sw & $\mathbf{h}$ & 12 & & 1.09 & & 0 & \\
\hline 36 & 1 & 1.5 & hot & sw & hor el & 2 & 48.0 & 0.18 & 4.36 & 0 & \\
\hline 36 & 1 & 1.5 & hot & sw & riser & 0 & & 0 & & 0 & \\
\hline 37 & & 1 & hot & $\mathbf{w}$ & downcomer & 0 & & 0 & & 0 & \\
\hline 37 & & 1 & hot & $\mathbf{w}$ & hor el & 10 & & 1.11 & & 0 & \\
\hline
\end{tabular}




\begin{tabular}{|c|c|c|c|c|c|c|c|c|c|c|c|}
\hline $\begin{array}{l}\text { Line } \\
\text { No }\end{array}$ & Unit & $\begin{array}{l}\text { Pipe } \\
\text { Size } \\
\text { (in) }\end{array}$ & Temp & $\begin{array}{l}\text { Conn } \\
\text { Type }\end{array}$ & $\begin{array}{l}\text { Support } \\
\text { Type }\end{array}$ & $\begin{array}{l}\text { Vert } \\
\text { Span } \\
\text { (ft) }\end{array}$ & $\begin{array}{l}\text { Horia } \\
\text { Span } \\
\text { (ft) }\end{array}$ & $\begin{array}{l}\text { Norm } \\
\text { Vert } \\
\text { Span } \\
\text { (ft) }\end{array}$ & $\begin{array}{l}\text { Norm } \\
\text { Horz } \\
\text { Span } \\
\text { (fi) }\end{array}$ & $\begin{array}{l}\text { Plant } \\
\text { Elevation } \\
\text { Above } \\
\text { Grade }\end{array}$ & Remarks \\
\hline 37 & & 1 & hot & $\mathbf{w}$ & U-bolt & 0.3 & 10.0 & 0.03 & 1.11 & 0 & \\
\hline 37 & & 1 & bot & $\mathrm{w}$ & hor el & 3 & & 0.33 & & 0 & \\
\hline 37 & & 1 & hot & $w$ & guide & 8 & 11.0 & 0.89 & 1.22 & 0 & \\
\hline 37 & & 1 & hot & $\mathbf{w}$ & guide & 8 & 8.0 & 0.89 & 0.89 & 0 & \\
\hline 37 & & 1 & hot & $\mathbf{w}$ & guide & 8 & 8.0 & 0.89 & 0.89 & 0 & \\
\hline $38 \mathrm{a}$ & 1 & 1.25 & cold & $t$ & hor el & 20 & & 2.5 & & 0 & \\
\hline $38 a$ & 1 & 1.25 & cold & $t$ & h & 2 & & 0.25 & & 0 & \\
\hline $38 a$ & 1 & 1.25 & cold & $t$ & $\mathbf{h}$ & 15 & & 1.88 & & 0 & \\
\hline $38 a$ & 1 & 1.25 & cold & $t$ & h & 12 & & 1.5 & & 0 & \\
\hline $38 a$ & 1 & 1.25 & cold & $t$ & $\mathbf{h}$ & 15 & & 1.88 & & 0 & \\
\hline $38 a$ & 1 & 1.25 & cold & $\mathbf{t}$ & hor el & 1 & & 0.13 & & 0 & \\
\hline $38 a$ & 1 & 1.25 & cold & $t$ & h & 1 & & 0.13 & & 0 & \\
\hline $38 a$ & 1 & 1.25 & cold & $t$ & $\mathrm{~h}$ & 14 & & 1.75 & & 0 & \\
\hline $38 \mathrm{a}$ & 1 & 1.25 & cold & $t$ & $\mathrm{~h}$ & 14 & & 1.75 & & 0 & \\
\hline $38 a$ & 1 & 1.25 & cold & $t$ & h & 18 & & 2.25 & & 0 & \\
\hline $38 a$ & 1 & 1.25 & cold & $t$ & b & 15 & & 1.88 & & 0 & \\
\hline $38 a$ & 1 & 1.25 & cold & $\mathfrak{t}$ & b & 12 & & 15 & & 0 & \\
\hline $38 a$ & 1 & 1.25 & cold & $t$ & hor el & 3 & $\cdot$ & 0.38 & & 0 & \\
\hline $38 a$ & 1 & 1.25 & cold & $\mathrm{t}$ & downcomer & 4 & 146.0 & 0.5 & 18.25 & 0 & \\
\hline $38 \mathrm{~b}$ & 1 & 1.25 & cold & $\mathrm{t}$ & hor el & 20 & & 2.5 & & 0 & \\
\hline $38 \mathrm{~b}$ & 1 & 1.25 & cold & $t$ & $\mathrm{~h}$ & 2 & & 0.25 & & 0 & \\
\hline $38 \mathrm{~b}$ & 1 & 1.25 & cold & $t$ & $\mathrm{~h}$ & 15 & & 1.88 & & 0 & \\
\hline $38 b$ & 1 & 1.25 & cold & $\mathrm{t}$ & $h$ & 12 & & 15 & & 0 & \\
\hline $38 \mathrm{~b}$ & 1 & 1.25 & cold & $\mathrm{t}$ & $\mathrm{h}$ & 15 & & 1.88 & & 0 & \\
\hline $38 b$ & 1 & 1.25 & cold & $t$ & hor el & 1 & & 0.13 & & 0 & \\
\hline $38 \mathrm{~b}$ & 1 & 1.25 & cold & 2 & h & 1 & & 0.13 & & 0 & \\
\hline $38 b$ & 1 & 1.25 & cold & $t$ & h & 14 & & 1.75 & & 0 & \\
\hline $38 \mathrm{~b}$ & 1 & 1.25 & cold & $t$ & $\mathrm{~h}$ & 14 & & 1.75 & & 0 & \\
\hline $38 \mathrm{~b}$ & 1 & 1.25 & cold & $t$ & h & 18 & & 225 & & 0 & \\
\hline $38 \mathrm{~b}$ & 1 & 1.25 & cold & $t$ & $\mathrm{~h}$ & 15 & & 1.88 & & 0 & \\
\hline $38 \mathrm{~b}$ & 1 & 1.25 & cold & $t$ & $h$ & 12 & & 1.5 & & 0 & \\
\hline $38 \mathrm{~b}$ & 1 & 1.25 & cold & $t$ & hor el & 3 & & 0.38 & & 0 & \\
\hline
\end{tabular}




\begin{tabular}{|c|c|c|c|c|c|c|c|c|c|c|c|}
\hline $\begin{array}{l}\text { Line } \\
\text { No }\end{array}$ & Unit & $\begin{array}{l}\text { Pipe } \\
\text { Size } \\
\text { (in) }\end{array}$ & Temp & $\begin{array}{l}\text { Conn } \\
\text { Type }\end{array}$ & $\begin{array}{l}\text { Support } \\
\text { Type }\end{array}$ & $\begin{array}{l}\text { Vert } \\
\text { Span } \\
\text { (ft) }\end{array}$ & $\begin{array}{l}\text { Horia } \\
\text { Span } \\
(\mathrm{ft})\end{array}$ & $\begin{array}{l}\text { Norm } \\
\text { Vert } \\
\text { Span } \\
\text { (ft) }\end{array}$ & $\begin{array}{l}\text { Norm } \\
\text { Horz } \\
\text { Span } \\
\text { (ft) }\end{array}$ & $\begin{array}{l}\text { Plant } \\
\text { Elevation } \\
\text { Above } \\
\text { Grade }\end{array}$ & Remarks \\
\hline $38 b$ & 1 & 1.25 & cold & $t$ & downcomer & 4 & 146.0 & 0.5 & 18.25 & 0 & \\
\hline $39 a$ & 1 & 4 & cold & $w$ & downcomer & 0 & & 0 & & 0 & \\
\hline $39 a$ & 1 & 4 & cold & $\mathrm{w}$ & $\mathrm{h}$ & 12 & & 0.86 & & 0 & \\
\hline $39 a$ & 1 & 4 & cold & $w$ & $\mathrm{~h}$ & 12 & & 0.86 & & 0 & \\
\hline $39 a$ & 1 & 4 & cold & $\mathbf{w}$ & $h$ & 12 & & 0.86 & & 0 & \\
\hline $39 a$ & 1 & 4 & cold & $w$ & $\mathrm{~h}$ & 12 & & 0.86 & & 0 & \\
\hline $39 a$ & 1 & 4 & cold & $w$ & $\mathrm{~h}$ & 15 & & 1.07 & & 0 & \\
\hline $39 a$ & 1 & 4 & cold & $w$ & $\mathrm{~h}$ & 15 & & 1.07 & & 0 & \\
\hline $39 a$ & 1 & 4 & cold & $\mathbf{w}$ & $\mathbf{h}$ & 10 & & 0.71 & & 0 & \\
\hline $39 a$ & 1 & 4 & cold & w & $\mathbf{h}$ & 12 & & 0.86 & & 0 & \\
\hline $39 a$ & 1 & 4 & cold & $\mathbf{w}$ & h & 12 & & 0.86 & & 0 & \\
\hline $39 a$ & 1 & 4 & cold & $\mathbf{w}$ & $\mathrm{h}$ & 12 & & 0.86 & & 0 & \\
\hline $39 a$ & 1 & 4 & cold & $\mathbf{w}$ & h & 12 & & 0.86 & & 0 & \\
\hline $39 a$ & 1 & 4 & cold & $w$ & h & 12 & & 0.86 & & 0 & \\
\hline $39 a$ & 1 & 4 & cold & $w$ & $\mathrm{~h}$ & 24 & & 1.71 & & 0 & \\
\hline $39 a$ & 1 & 4 & cold & $\mathrm{w}$ & pump & 4 & 176.0 & 0.29 & 1257 & 0 & \\
\hline $39 \mathrm{~b}$ & 2 & 4 & cold & $\mathbf{w}$ & downcomer & 0 & & 0 & & 0 & \\
\hline $39 b$ & 2 & 4 & cold & $w$ & $\mathbf{h}$ & 12 & & 0.86 & & 0 & \\
\hline $39 \mathrm{~b}$ & 2 & 4 & cold & $w$ & $h$ & 12 & & 0.86 & & 0 & \\
\hline $39 b$ & 2 & 4 & cold & $\mathbf{w}$ & $\mathrm{h}$ & 12 & & 0.86 & & 0 & \\
\hline $39 b$ & 2 & 4 & cold & $\mathbf{w}$ & $\mathbf{h}$ & 12 & & 0.86 & & 0 & \\
\hline $39 b$ & 2 & 4 & cold & $w$ & $h$ & 15 & & 1.07 & & 0 & \\
\hline $39 \mathrm{~b}$ & 2 & 4 & cold & $\mathrm{w}$ & $\mathrm{h}$ & 15 & & 1.07 & & 0 & \\
\hline $39 b$ & 2 & 4 & cold & $w$ & $\mathrm{~h}$ & 10 & & 0.71 & & 0 & \\
\hline $39 b$ & 2 & 4 & cold & $w$ & $\mathrm{~h}$ & 12 & & 0.86 & & 0 & \\
\hline $39 b$ & 2 & 4 & cold & $w$ & h & 12 & & 0.86 & & 0 & \\
\hline $39 b$ & 2 & 4 & cold & $w$ & h & 12 & & 0.86 & & 0 & \\
\hline $39 b$ & 2 & 4 & cold & $w$ & $\mathbf{b}$ & 12 & & 0.86 & & 0 & \\
\hline $39 \mathrm{~b}$ & 2 & 4 & cold & $\mathbf{w}$ & h & 12 & & 0.86 & & 0 & \\
\hline $39 b$ & 2 & 4 & cold & $\mathbf{w}$ & h & 24 & & 1.71 & & 0 & \\
\hline $39 b$ & 2 & 4 & cold & $\mathbf{w}$ & pump & 4 & 176.0 & 0.29 & 12.57 & 0 & \\
\hline 40 & 2 & 15 & hot & sw & downcomer & 0 & & 0 & & 0 & \\
\hline
\end{tabular}




\begin{tabular}{|c|c|c|c|c|c|c|c|c|c|c|c|}
\hline $\begin{array}{l}\text { 1Line } \\
\text { No }\end{array}$ & Unit & $\begin{array}{l}\text { Pipe } \\
\text { Size } \\
\text { (in) }\end{array}$ & Temp & $\begin{array}{l}\text { Conn } \\
\text { Type }\end{array}$ & $\begin{array}{l}\text { Support } \\
\text { Type }\end{array}$ & $\begin{array}{l}\text { Vert } \\
\text { Span } \\
\text { (ft) }\end{array}$ & $\begin{array}{l}\text { Horia } \\
\text { Span } \\
\text { (ft) }\end{array}$ & $\begin{array}{l}\text { Norm } \\
\text { Vert } \\
\text { Span } \\
\text { (ft) }\end{array}$ & $\begin{array}{l}\text { Norm } \\
\text { Horz } \\
\text { Span } \\
\text { (ft) }\end{array}$ & $\begin{array}{l}\text { Plant } \\
\text { Elevation } \\
\text { Above } \\
\text { Grade }\end{array}$ & Remarks \\
\hline 40 & 2 & 1.5 & hot & sw & h & 6 & & 0.55 & & 0 & \\
\hline 40 & 2 & 1.5 & hot & Sw & h & 24 & & 2.18 & & 0 & \\
\hline 40 & 2 & 1.5 & hot & sw & tank & 18 & 48.0 & 1.64 & 4.36 & 0 & \\
\hline $41 a$ & 5 & 12.00 & hot & & dearator & 0.0 & & 0.00 & & 85 & $\begin{array}{l}\text { Begin Moss Landing } \\
\text { Units } 4 \text { \& } 5\end{array}$ \\
\hline $41 a$ & 5 & 12.00 & hot & & hor el & 4.0 & & 0.13 & & 85 & \\
\hline $41 \mathrm{a}$ & 5 & 12.00 & hot & & sh & 4.0 & & 0.13 & & 85 & \\
\hline $41 a$ & 5 & 12.00 & hot & & sh & 10.0 & & 0.33 & & 85 & \\
\hline $41 a$ & 5 & 12.00 & hot & & $\mathrm{dc}$ & 8.0 & 26.0 & 0.24 & 0.86 & 85 & \\
\hline $41 b$ & 4 & 12.00 & hot & & dearator & 0.0 & & 0.00 & & 85 & \\
\hline $41 b$ & 4 & 12.00 & hot & & hor el & 4.0 & & 0.13 & & 85 & \\
\hline $41 b$ & 4 & 12.00 & hot & & sh & 4.0 & & 0.13 & & 85 & \\
\hline $41 b$ & 4 & 12.00 & hot & & sh & 10.0 & & 0.33 & & 85 & \\
\hline $41 b$ & 4 & 12.00 & hot & & $\mathrm{dc}$ & 8.0 & 26.0 & 024 & 0.86 & 85 & \\
\hline $42 a$ & 5 & 2.00 & hot & & $\mathrm{dc}$ & 0.0 & & 0.00 & & 85 & \\
\hline $42 a$ & 5 & 2.00 & hot & & $u b$ & 6.0 & 6.0 & 0.46 & 0.46 & 85 & \\
\hline $42 a$ & 5 & 2.00 & hot & & $\mathrm{ub}$ & 12.0 & 12.0 & 0.92 & 0.92 & 85 & \\
\hline $42 a$ & 5 & 2.00 & hot & & $\mathrm{ab}$ & 12.0 & 12.0 & 0.92 & 0.92 & 85 & \\
\hline $42 a$ & 5 & 2.00 & hot & & u b & 12.0 & 12.0 & 0.92 & 0.92 & 85 & \\
\hline $42 a$ & 5 & 2.00 & hot & & $\mathrm{dc}$ & 6.0 & 6.0 & 0.46 & 0.46 & 85 & \\
\hline $42 \mathrm{~b}$ & 4 & 2.00 & hot & sw & dc & 0.0 & & 0.00 & & 85 & \\
\hline $42 b$ & 4 & 2.00 & hot & SW & $\mathbf{u} \mathbf{b}$ & 6.0 & 6.0 & 0.46 & 0.46 & 85 & \\
\hline $42 b$ & 4 & 2.00 & hot & sw & $\mathrm{ub}$ & 12.0 & 12.0 & 0.92 & 0.92 & 85 & \\
\hline $42 a$ & 4 & 2.00 & hot & sw & $u b$ & 12.0 & 12.0 & 0.92 & 0.92 & 85 & \\
\hline $42 b$ & 4 & 2.00 & hot & sw & $\mathrm{dc}$ & 6.0 & 6.0 & 0.46 & 0.46 & 85 & \\
\hline $43 a$ & 5 & 3.00 & cold & $\mathbf{w}$ & $\mathrm{dc}$ & 0.0 & & 0.00 & & 70 & \\
\hline $43 a$ & 4 & 3.00 & cold & $w$ & h & 4.0 & & 0.33 & & 70 & \\
\hline $43 a$ & 5 & 3.00 & cold & $\mathbf{w}$ & h & 15.0 & & 1.25 & & 70 & \\
\hline $43 a$ & 5 & 3.00 & cold & $\mathbf{w}$ & hor el & 15.0 & & 125 & & 70 & \\
\hline $43 a$ & 5 & 3.00 & cold & $\mathbf{w}$ & $\mathrm{h}$ & 1.0 & & 0.08 & & 70 & \\
\hline $43 a$ & 5 & 3.00 & cold & $\mathbf{w}$ & $\mathrm{h}$ & 18.0 & & 1.50 & & 70 & \\
\hline $43 a$ & 5 & 3.00 & cold & $\mathbf{w}$ & Lat restraint & 15.0 & 68.00 & 1.25 & 5.67 & 70 & \\
\hline
\end{tabular}




\begin{tabular}{|c|c|c|c|c|c|c|c|c|c|c|c|}
\hline $\begin{array}{l}\text { 1Line } \\
\text { No }\end{array}$ & Unit & $\begin{array}{l}\text { Pipe } \\
\text { Size } \\
\text { (in) }\end{array}$ & Temp & $\begin{array}{l}\text { Conn } \\
\text { Type }\end{array}$ & $\begin{array}{l}\text { Support } \\
\text { Type }\end{array}$ & $\begin{array}{l}\text { Vert } \\
\text { Span } \\
\text { (ft) }\end{array}$ & $\begin{array}{l}\text { Horia } \\
\text { Span } \\
(\mathrm{ft})\end{array}$ & $\begin{array}{l}\text { Norm } \\
\text { Vert } \\
\text { Span } \\
\text { (ft) }\end{array}$ & $\begin{array}{l}\text { Norm } \\
\text { Horz } \\
\text { Span } \\
\text { (ft) }\end{array}$ & $\begin{array}{l}\text { Plant } \\
\text { Elevation } \\
\text { Above } \\
\text { Grade }\end{array}$ & Remarks \\
\hline $43 b$ & 4 & 3.00 & cold & $\mathrm{w}$ & dc & 0.0 & & 0.00 & & 70 & \\
\hline $43 \mathrm{~b}$ & 4 & 3.00 & cold & $w$ & $\mathbf{h}$ & 4.0 & & 0.33 & & 70 & \\
\hline $43 b$ & 4 & 3.00 & cold & $\mathbf{w}$ & $\mathbf{h}$ & 15.0 & & 1.25 & & 70 & \\
\hline $43 b$ & 4 & 3.00 & cold & $w$ & hor el & 15.0 & & 1.25 & & 70 & \\
\hline $43 b$ & 4 & 3.00 & cold & $\mathbf{w}$ & h & 1.0 & & 0.08 & & 70 & \\
\hline $43 \hat{b}$ & 4 & 3.00 & cold & $\mathrm{w}$ & h & 18.0 & & 1.50 & & 70 & \\
\hline $43 b$ & 4 & 3.00 & cold & $w$ & Lat restraint & 15.0 & 68.00 & 1.25 & 5.67 & 70 & \\
\hline $44 a$ & 5 & 1.00 & cold & SW & dc & 0.0 & & 0.00 & & $30 \times 2$ & \\
\hline $44 a$ & 5 & 1.00 & cold & SW & $\mathbf{u} \mathbf{b}$ & 4.0 & 4.0 & 0.57 & 0.57 & 30 & \\
\hline $44 a$ & 5 & 1.00 & cold & Sw & $\mathbf{u} \mathbf{b}$ & 9.0 & 9.0 & 1.29 & 1.29 & 30 & \\
\hline $44 a$ & 5 & 1.00 & cold & SW & $\mathbf{u} \mathbf{b}$ & 6.0 & 6.0 & 0.86 & 0.86 & 30 & \\
\hline $44 b$ & 4 & 1.00 & cold & SW & $\mathrm{dc}$ & 0.0 & & 0.00 & & 30 & \\
\hline $44 b$ & 4 & 1.00 & cold & SW & de & 4.0 & 4.0 & 0.57 & 0.57 & 30 & \\
\hline $44 b$ & 4 & 1.00 & cold & SW & dc & 9.0 & 9.0 & 1.29 & 1.29 & 30 & \\
\hline $44 b$ & 4 & 1.00 & cold & SW & dc & 6.0 & 6.0 & 0.86 & 0.86 & 30 & \\
\hline $44 c$ & 5 & 1.50 & cold & Sw & dc & 0.0 & & 0.00 & & $30 \times 3$ & \\
\hline $44 c$ & 5 & 1.50 & cold & SW & $u b$ & 4.0 & 4.0 & 0.47 & 0.47 & 30 & \\
\hline $44 c$ & 5 & 1.50 & cold & SW & $u b$ & 9.0 & 9.0 & 1.06 & 1.06 & 30 & \\
\hline $44 c$ & 5 & 1.50 & cold & SW & ub & 6.0 & 6.0 & 0.71 & 0.71 & 30 & \\
\hline $44 d$ & 4 & 1.50 & cold & sw & $\mathrm{dc}$ & 0.0 & & 0.00 & & $30 \times 3$ & \\
\hline $44 d$ & 4 & 1.50 & cold & sw & $u b$ & 4.0 & 4.0 & 0.47 & 0.47 & 30 & \\
\hline $44 d$ & 4 & 1.50 & cold & sw & $\mathbf{u} b$ & 9.0 & 9.0 & 1.06 & 1.06 & 30 & \\
\hline $44 d$ & 4 & 1.50 & cold & SW & $\mathbf{u} b$ & 6.0 & 6.0 & 0.71 & 0.71 & 30 & \\
\hline $45 a$ & 5 & 4.00 & hot & $w$ & $\mathrm{dc}$ & 0.0 & & 0.00 & & 30 & \\
\hline $45 a$ & 5 & 4.00 & hot & $\mathbf{w}$ & $\operatorname{sh}$ & 2.0 & & 0.12 & & 30 & \\
\hline $45 a$ & 5 & 4.00 & hot & $\mathbf{w}$ & hor el & 18.0 & & 1.06 & & 30 & \\
\hline $45 a$ & 5 & 4.00 & hot & $w$ & sh & 1.0 & & 0.06 & & 30 & \\
\hline $45 a$ & 5 & 4.00 & hot & w & sh & 14.0 & & 0.82 & & 30 & \\
\hline $45 a$ & 5 & 4.00 & hot & $\mathbf{w}$ & de & 15.0 & 50.00 & 0.88 & 2.94 & 30 & \\
\hline $45 b$ & 4 & 4.00 & hot & $w$ & dc & 0.0 & & 0.00 & & 30 & \\
\hline $45 b$ & 4 & 4.00 & hot & $\mathbf{w}$ & sh & 2.0 & & 0.12 & & 30 & \\
\hline $45 b$ & 4 & 4.00 & hot & $\mathbf{w}$ & hor el & 18.0 & & 1.06 & & 30 & \\
\hline
\end{tabular}




\begin{tabular}{|c|c|c|c|c|c|c|c|c|c|c|c|}
\hline $\begin{array}{l}\text { 1Line } \\
\text { No }\end{array}$ & Unit & $\begin{array}{l}\text { Pipe } \\
\text { Size } \\
\text { (in) }\end{array}$ & Temp & $\begin{array}{l}\text { Conn } \\
\text { Type }\end{array}$ & $\begin{array}{l}\text { Support } \\
\text { Type }\end{array}$ & $\begin{array}{l}\text { Vert } \\
\text { Span } \\
\text { (ft) }\end{array}$ & \begin{tabular}{|l} 
Horia \\
Span \\
(ft)
\end{tabular} & $\begin{array}{l}\text { Norm } \\
\text { Vert } \\
\text { Span } \\
\text { (ft) }\end{array}$ & $\begin{array}{l}\text { Norm } \\
\text { Horz } \\
\text { Span } \\
\text { (ft) }\end{array}$ & $\begin{array}{l}\text { Plant } \\
\text { Elevation } \\
\text { Above } \\
\text { Grade }\end{array}$ & Remarks \\
\hline $45 b$ & 4 & 4.00 & hot & $w$ & sh & 1.0 & & 0.06 & & 30 & \\
\hline $45 b$ & 4 & 4.00 & hot & w & sh & 14.0 & & 0.82 & & 30 & \\
\hline $45 b$ & 4 & 4.00 & hot & $\mathrm{w}$ & $\mathrm{dc}$ & 15.0 & & 0.88 & 2.94 & 30 & \\
\hline $46 a$ & 5 & 2.00 & hot & sw & PUMP & 0.0 & & 0.00 & & 30 & \\
\hline $46 a$ & 5 & 2.00 & hot & sw & vert el & 10.0 & & 0.77 & & 30 & \\
\hline $46 a$ & 5 & 2.00 & hot & sw & hor el & 2.0 & & 0.15 & & 30 & \\
\hline $46 a$ & 5 & 2.00 & hot & sw & hor el & 8.0 & & 0.62 & & 30 & \\
\hline $46 a$ & 5 & 2.00 & hot & SW & sh & 4.0 & & 0.31 & & 30 & \\
\hline $46 a$ & 5 & 2.00 & hot & sw & hor el & 6.0 & & 0.46 & & 30 & \\
\hline $46 a$ & 5 & 2.00 & hot & sw & h & 11.0 & & 0.85 & & 30 & \\
\hline $46 a$ & 5 & 2.00 & hot & SW & b & 12.0 & & 0.92 & & 30 & \\
\hline $46 a$ & 5 & 2.00 & hot & SW & $\mathrm{h}$ & 12.0 & & 0.92 & & 30 & \\
\hline $46 a$ & 5 & 2.00 & hot & sw & wall & 10.0 & 75.0 & 0.77 & 5.77 & 30 & \\
\hline $46 a$ & 5 & 2.00 & hot & sw & h & 3.0 & & 0.23 & & 30 & \\
\hline $46 a$ & 5 & 2.00 & hot & sw & h & 12.0 & & 0.92 & & 30 & \\
\hline $46 a$ & 5 & 2.00 & hot & sw & riser & 6.0 & 21.0 & 0.46 & 1.62 & 30 & \\
\hline $46 \mathrm{~b}$ & 5 & 2.00 & hot & SW & pump & 0.0 & & 0.00 & & 30 & \\
\hline $46 \mathrm{~b}$ & 5 & 2.00 & hot & SW & vert el & 10.0 & & 0.77 & & 30 & \\
\hline $46 \mathrm{~b}$ & 5 & 2.00 & hot & sw & hor el & 2.0 & & 0.15 & & 30 & \\
\hline $46 \mathrm{~b}$ & 5 & 2.00 & hot & SW & u b & 8.0 & & 0.62 & & 30 & \\
\hline 46b & 5 & 1.00 & hot & sw & sh & 4.0 & & 0.31 & & 30 & \\
\hline 46b & 5 & 2.00 & hot & SW & hor el & 6.0 & & 0.46 & & 30 & \\
\hline $46 \mathrm{~b}$ & 5 & 2.00 & hot & sw & $\mathrm{h}$ & 11.0 & & 0.85 & & 30 & \\
\hline $46 \mathrm{~b}$ & 5 & 2.00 & hot & sw & $\mathrm{h}$ & 11.0 & & 0.85 & & 30 & \\
\hline $46 \mathrm{~b}$ & 5 & 2.00 & hot & sw & $\mathrm{h}$ & 12.0 & & 0.92 & & 30 & \\
\hline $46 \mathrm{~b}$ & 5 & 2.00 & hot & sw & $\mathrm{h}$ & 12.0 & & 0.92 & & 30 & \\
\hline $46 \mathrm{~b}$ & 5 & 2.00 & hot & SW & wall & 10.0 & 75.0 & 0.77 & 5.77 & 30 & \\
\hline 46b & 5 & 2.00 & hot & sw & $\mathrm{h}$ & 3.0 & & 0.23 & & 30 & \\
\hline $46 \mathrm{~b}$ & 5 & 2.00 & hot & SW & h & 12.0 & & 0.92 & & 30 & \\
\hline $46 b$ & 5 & 2.00 & hot & SW & riser & 6.0 & 21.0 & 0.46 & 1.62 & 30 & \\
\hline $47 a$ & 5 & 1.00 & cold & $t$ & $d c$ & 0.0 & & 0.00 & & 30 & \\
\hline $47 a$ & 5 & 1.00 & cold & $t$ & u b & 6.0 & 6.0 & 0.86 & 0.86 & 30 & \\
\hline
\end{tabular}




\begin{tabular}{|c|c|c|c|c|c|c|c|c|c|c|c|}
\hline $\begin{array}{l}\text { 1Line } \\
\text { No }\end{array}$ & Unit & $\begin{array}{l}\text { Pipe } \\
\text { Size } \\
\text { (in) }\end{array}$ & Temp & $\begin{array}{l}\text { Conn } \\
\text { Type }\end{array}$ & $\begin{array}{l}\text { Support } \\
\text { Type }\end{array}$ & $\begin{array}{l}\text { Vert } \\
\text { Span } \\
\text { (ft) }\end{array}$ & $\begin{array}{l}\text { Horia } \\
\text { Span } \\
\text { (ft) }\end{array}$ & $\begin{array}{l}\text { Norm } \\
\text { Vert } \\
\text { Span } \\
\text { (ft) }\end{array}$ & $\begin{array}{l}\text { Norm } \\
\text { Horz } \\
\text { Span } \\
\text { (ft) }\end{array}$ & $\begin{array}{l}\text { Plant } \\
\text { Elevation } \\
\text { Above } \\
\text { Grade }\end{array}$ & Remarks \\
\hline $47 a$ & 5 & 1.00 & cold & $t$ & hor el & 12.0 & & 1.71 & & 30 & \\
\hline $47 a$ & 5 & 1.00 & cold & $t$ & $u b$ & 1.0 & 13.0 & 0.14 & 1.86 & 30 & \\
\hline $47 a$ & 5 & 1.00 & cold & $t$ & $\mathbf{u b}$ & 6.0 & & 0.86 & & 30 & \\
\hline $47 a$ & 5 & 1.00 & cold & $t$ & hor el & 1.0 & & 0.14 & & 30 & \\
\hline $47 a$ & 5 & 1.00 & cold & $t$ & $\mathbf{u} \mathbf{b}$ & 6.0 & 7.0 & 0.86 & 1.0 & 30 & \\
\hline $47 a$ & 5 & 1.00 & cold & $t$ & hor el & 2.0 & & 0.28 & & 30 & \\
\hline $47 a$ & 5 & 1.00 & cold & $t$ & $\mathbf{u} \mathbf{b}$ & 6.0 & 8.0 & 0.86 & 1.14 & 30 & \\
\hline $47 a$ & 5 & 1.00 & cold & $\mathrm{t}$ & riser & 2.0 & 2.0 & 0.28 & 0.28 & 30 & \\
\hline $47 \mathrm{~b}$ & 4 & 1.00 & cold & $t$ & $\mathrm{dc}$ & 0.0 & & 0.00 & & 30 & \\
\hline $47 \mathrm{~b}$ & 4 & 1.00 & cold & $\mathrm{t}$ & u b & 6.0 & 6.0 & 0.86 & 0.86 & 30 & \\
\hline $47 b$ & 4 & 1.00 & cold & $t$ & hor el & 12.0 & & 1.71 & & 30 & \\
\hline $47 b$ & 4 & 1.00 & cold & $\mathrm{t}$ & u b & 1.0 & 13.0 & 0.14 & 1.86 & 30 & \\
\hline $47 \mathrm{~b}$ & 4 & 1.00 & cold & $t$ & ub & 6.0 & & 0.86 & & 30 & \\
\hline $47 b$ & 4 & 1.00 & cold & $t$ & hor el & 1.0 & & 0.14 & & 30 & \\
\hline $47 \mathrm{~b}$ & 4 & 1.00 & cold & $t$ & u b & 6.0 & 7.0 & 0.86 & 1.0 & 30 & \\
\hline $47 b$ & 4 & 1.00 & cold & $t$ & hor el & 2.0 & & 0.28 & & 30 & \\
\hline $47 \mathrm{~b}$ & 4 & 1.00 & cold & $t$ & u b & 6.0 & 8.0 & 0.86 & 1.14 & 30 & \\
\hline $48 a$ & 5 & 2.00 & hot & SW & preheater & 0.0 & & 0.00 & & 30 & \\
\hline $48 a$ & 5 & 2.00 & hot & SW & hor el & 12.0 & & 0.92 & & 30 & \\
\hline $48 a$ & 5 & 2.00 & hot & SW & $\mathrm{ub}$ & 8.0 & 20.00 & 0.62 & 1.54 & 30 & \\
\hline $48 a$ & 5 & 2.00 & hot & SW & $\mathrm{u} b$ & 14.0 & 14.00 & 1.08 & 1.08 & 30 & \\
\hline $48 a$ & 5 & 2.00 & hot & SW & tat restraint & 5.0 & 5.00 & 0.38 & 0.38 & 30 & \\
\hline $48 \mathrm{a}$ & 5 & 2.00 & hot & SW & u b & 6.0 & 6.00 & 0.42 & 0.42 & 30 & \\
\hline $48 a$ & 5 & 2.00 & hot & SW & dc & 8.0 & 8.00 & 0.62 & 0.62 & 30 & \\
\hline $48 \mathrm{~b}$ & 4 & 2.00 & hot & SW & preheater & 0.0 & & 0.00 & & 30 & \\
\hline $48 \mathrm{~b}$ & 4 & 2.00 & hot & SW & hor et & 12.0 & & 0.92 & & 30 & \\
\hline $48 \mathrm{~b}$ & 4 & 2.00 & hot & SW & $u b$ & 8.0 & 20.00 & 0.62 & 1.54 & 30 & \\
\hline $48 \mathrm{~b}$ & 4 & 2.00 & hot & SW & u b & 14.0 & 14.00 & 1.08 & 1.08 & 30 & \\
\hline $48 \mathrm{~b}$ & 4 & 2.00 & hot & sw & tat restraint & 5.0 & 5.00 & 0.42 & 0.42 & 30 & \\
\hline $48 \mathrm{~b}$ & 4 & 2.00 & hot & SW & $u b$ & 6.0 & 6.00 & 0.42 & 0.42 & 30 & \\
\hline $48 \mathrm{~b}$ & 4 & 2.00 & hot & SW & dc & 8.0 & 8.00 & 0.62 & 0.62 & 30 & \\
\hline $49 a$ & 5 & 0.75 & cold & SW & vert et & 0.0 & & 0.00 & & 15 & \\
\hline
\end{tabular}




\begin{tabular}{|c|c|c|c|c|c|c|c|c|c|c|c|}
\hline $\begin{array}{l}1 \text { Line } \\
\text { No }\end{array}$ & Unit & $\begin{array}{l}\text { Pipe } \\
\text { Size } \\
\text { (in) }\end{array}$ & Temp & $\begin{array}{l}\text { Conn } \\
\text { Type }\end{array}$ & $\begin{array}{l}\text { Support } \\
\text { Type }\end{array}$ & $\begin{array}{l}\text { Vert } \\
\text { Span } \\
\text { (ft) }\end{array}$ & $\begin{array}{l}\text { Horia } \\
\text { Span } \\
\text { (ft) }\end{array}$ & $\begin{array}{l}\text { Norm } \\
\text { Vert } \\
\text { Span } \\
\text { (ft) }\end{array}$ & $\begin{array}{l}\text { Norm } \\
\text { Horz } \\
\text { Span } \\
\text { (ft) }\end{array}$ & $\begin{array}{l}\text { Plant } \\
\text { Elevation } \\
\text { Above } \\
\text { Grade }\end{array}$ & Remarks \\
\hline $49 a$ & 5 & 0.75 & cold & sw & vert et & 25.0 & & 5.00 & & 15 & \\
\hline $49 a$ & 5 & 0.75 & cold & sw & vert el & 21.0 & & 420 & & 15 & \\
\hline $49 a$ & 5 & 0.75 & cold & SW & h & 21.0 & & 4.20 & & 15 & \\
\hline $49 a$ & 5 & 0.75 & cold & sw & cantilever & 4.0 & 71.00 & 0.80 & 14.2 & 15 & \\
\hline $49 b$ & 4 & 0.75 & cold & Sw & vert et & 0.0 & & 0.00 & & 15 & \\
\hline$-49 b$ & 4 & 0.75 & cold & sw & vert et & 25.0 & & 5.00 & & 15 & \\
\hline $49 b$ & 4 & 0.75 & cold & sw & h & 21.0 & & 4.20 & & 15 & \\
\hline $49 \mathrm{~b}$ & 4 & 0.75 & cold & SW & h & 21.0 & & 4.20 & & 15 & \\
\hline $49 a$ & 4 & 0.75 & cold & SW & cantilever & 4.0 & 71.00 & 0.80 & 142 & 15 & \\
\hline $50 a$ & 5 & 1.00 & hot & sw & vert et & 0.0 & & 0.00 & & 15 & \\
\hline $50 a$ & 5 & 1.00 & hot & sw & vert et & 3.0 & & 0.33 & & 15 & \\
\hline $50 a$ & 5 & 1.00 & hot & sw & $\mathrm{ub}$ & 10.0 & 13.00 & 1.11 & 1.44 & 15 & \\
\hline $50 a$ & 5 & 1.00 & hot & SW & $\mathbf{h}$ & 6.0 & & 0.67 & & 15 & \\
\hline $50 \mathrm{a}$ & 5 & 1.00 & hot & SW & hor et & 4.0 & & 0.44 & & 15 & \\
\hline $50 a$ & 5 & 1.00 & hot & SW & h & 9.0 & & 1.00 & & 15 & \\
\hline $50 \mathrm{a}$ & 5 & 1.00 & hot & SW & h & 10.0 & & 1.11 & & 15 & \\
\hline $50 a$ & 5 & 1.00 & hot & SW & h & 10.0 & & 1.11 & & 15 & \\
\hline $50 a$ & 5 & 1.00 & hot & SW & hor tee & 1.0 & 40.00 & 0.11 & 4.44 & 15 & \\
\hline $50 \mathrm{a}$ & 5 & 1.00 & hot & sw & $\mathrm{h}$ & 9.0 & & 1.00 & & 15 & \\
\hline $50 \mathrm{a}$ & 5 & 1.00 & hot & sw & hor tee & 10.0 & 19.00 & 1.11 & 2.11 & 15 & \\
\hline $50 \mathrm{a}$ & 5 & 1.00 & hot & sw & $\mathrm{h}$ & 1.0 & & 0.11 & & 15 & \\
\hline $50 \mathrm{a}$ & 5 & 1.00 & hot & SW & $h$ & 12.0 & & 1.33 & & 15 & \\
\hline $50 \mathrm{a}$ & 5 & 1.00 & hot & SW & hor et & 1.0 & & 0.11 & & 15 & \\
\hline $50 \mathrm{a}$ & 5 & 1.00 & hot & sw & wall & 8.0 & 22.00 & 0.89 & 2.44 & 15 & \\
\hline $50 \mathrm{~b}$ & 4 & 1.00 & hot & SW & vert et & 0.0 & & 0.00 & & 15 & \\
\hline $50 \mathrm{~b}$ & 4 & 1.00 & hot & sw & vert et & 3.0 & & 0.33 & & 15 & \\
\hline $50 \mathrm{~b}$ & 4 & 1.00 & hot & sw & $\mathbf{u ~ b}$ & 10.0 & 13.00 & 1.11 & 1.44 & 15 & \\
\hline $50 \mathrm{~b}$ & 4 & 1.00 & hot & sw & h & 6.0 & & 0.67 & & 15 & \\
\hline $50 \mathrm{~b}$ & 4 & 1.00 & hot & sw & hor et & 4.0 & & 0.44 & & 15 & \\
\hline $50 \mathrm{~b}$ & 4 & 1.00 & hot & sw & $\mathrm{h}$ & 9.0 & & 1.00 & & 15 & \\
\hline $50 \mathrm{~b}$ & 4 & 1.00 & hot & & $\mathrm{h}$ & 10.0 & & 1.11 & & 15 & \\
\hline $50 \mathrm{~b}$ & 4 & 1.00 & hot & & $\mathrm{h}$ & 10.0 & & 1.11 & & 15 & \\
\hline
\end{tabular}

\begin{tabular}{|l|l|l|l|l|l|l|l|l|l|l|l|l|}
\hline $52 \mathrm{a}$ & 5 & 6.00 & hot & & $\mathrm{h}$ & 8.0 & & 0.38 & & 15 & \\
\hline
\end{tabular}




\begin{tabular}{|c|c|c|c|c|c|c|c|c|c|c|c|}
\hline $\begin{array}{l}\text { 1Line } \\
\text { No }\end{array}$ & Unit & $\begin{array}{l}\text { Pipe } \\
\text { Size } \\
\text { (in) }\end{array}$ & Temp & $\begin{array}{l}\text { Conn } \\
\text { Type }\end{array}$ & $\begin{array}{l}\text { Support } \\
\text { Type }\end{array}$ & $\begin{array}{l}\text { Vert } \\
\text { Span } \\
\text { (ft) }\end{array}$ & $\begin{array}{l}\text { Horia } \\
\text { Span } \\
\text { (ft) }\end{array}$ & $\begin{array}{l}\text { Norm } \\
\text { Vert } \\
\text { Span } \\
\text { (ft) }\end{array}$ & $\begin{array}{l}\text { Norm } \\
\text { Horz } \\
\text { Span } \\
\text { (ft) }\end{array}$ & $\begin{array}{l}\text { Plant } \\
\text { Elevation } \\
\text { Above } \\
\text { Grade }\end{array}$ & Remarks \\
\hline $50 \mathrm{~b}$ & 4 & 1.00 & hot & & hor tee & 1.0 & 40.00 & 0.11 & 4.44 & 15 & \\
\hline $50 \mathrm{~b}$ & 4 & 1.00 & hot & & $\mathbf{h}$ & 9.0 & & 1.00 & & 15 & \\
\hline $50 \mathrm{~b}$ & 4 & 1.00 & hot & & hor tee & 10.0 & 19.00 & 1.11 & 2.11 & 15 & \\
\hline $50 \mathrm{~b}$ & 4 & 1.00 & hot & & $\mathbf{h}$ & 1.0 & & 0.11 & & 15 & \\
\hline $50 \mathrm{~b}$ & 4 & 1.00 & hot & & h & 12.0 & & 1.33 & & 15 & \\
\hline $50 \mathrm{~b}$ & 4 & 1.00 & hot & & hor el & 1.0 & & 0.11 & & 15 & \\
\hline $50 \mathrm{~b}$ & 5 & 1.00 & hot & & waIL & 8.0 & 22.00 & 0.89 & 2.55 & 15 & \\
\hline $51 a$ & 5 & 2.50 & cold & & h & 0.0 & & 0.00 & & 15 & \\
\hline $51 a$ & 5 & 250 & cold & & h & 20.0 & & 1.82 & & 15 & \\
\hline $51 a$ & 5 & 250 & cold & & h & 20.0 & & 1.82 & & 15 & \\
\hline $51 \mathrm{a}$ & 5 & 2.50 & cold & & h & 20.0 & & 1.82 & & 15 & \\
\hline $51 a$ & 5 & 2.50 & cold & & hor el & 10.0 & & 0.91 & & 15 & \\
\hline $51 \mathrm{a}$ & 5 & 2.50 & cold & & h & 3.0 & & 0.27 & & 15 & \\
\hline $51 a$ & 5 & 2.50 & cold & & h & 18.0 & & 1.64 & & 15 & \\
\hline $51 a$ & 5 & 2.50 & cold & & $\mathbf{h}$ & 15.0 & & 1.36 & & 15 & \\
\hline $51 a$ & 5 & 2.50 & cold & & h & 10.0 & & 0.91 & & 15 & \\
\hline 512 & 5 & 2.50 & cold & & $\mathbf{h}$ & 10.0 & & 0.91 & & 15 & \\
\hline $51 a$ & 5 & 2.50 & cold & & h & 12.0 & & 1.09 & & 15 & \\
\hline $51 a$ & 5 & 250 & cold & & hor tee & 3.0 & 131.0 & 0.27 & 11.9 & 15 & \\
\hline $51 a^{\prime}$ & 5 & 4.00 & cold & & h & 3.0 & & 0.21 & & 15 & \\
\hline
\end{tabular}

\begin{tabular}{|c|c|c|c|c|c|c|c|c|c|c|c|}
\hline $\begin{array}{l}\text { 1Line } \\
\text { No }\end{array}$ & Unit & $\begin{array}{l}\text { Pipe } \\
\text { Size } \\
\text { (in) }\end{array}$ & Temp & $\begin{array}{l}\text { Conn } \\
\text { Type }\end{array}$ & $\begin{array}{l}\text { Support } \\
\text { Type }\end{array}$ & $\begin{array}{l}\text { Vert } \\
\text { Span } \\
\text { (ft) }\end{array}$ & $\begin{array}{l}\text { Horia } \\
\text { Span } \\
\text { (ft) }\end{array}$ & $\begin{array}{l}\text { Norm } \\
\text { Vert } \\
\text { Span } \\
\text { (ft) }\end{array}$ & $\begin{array}{l}\text { Norm } \\
\text { Horz } \\
\text { Span } \\
\text { (ft) }\end{array}$ & $\begin{array}{l}\text { Plant } \\
\text { Elevation } \\
\text { Above } \\
\text { Grade }\end{array}$ & Remarks \\
\hline $53 a$ & 5 & 1.00 & hot & sw & hor el & 6.0 & & 0.67 & & 15 & \\
\hline $53 a$ & 5 & 1.00 & hot & SW & $\mathbf{h}$ & 1.0 & & 0.11 & & 15 & \\
\hline $53 a$ & 5 & 1.00 & hot & SW & dc & 8.0 & 50.00 & 8.90 & 5.56 & 15 & \\
\hline $53 \mathrm{~b}$ & 4 & 1.00 & hot & SW & riser & 0.0 & & 0.00 & . & 15 & \\
\hline $53 \mathrm{~b}$ & 4 & 1.00 & hot & sw & h & 1.0 & & 0.11 & & 15 & \\
\hline $53 b$ & 4 & 1.00 & hot & SW & hor el & 18.0 & & 2.00 & & 15 & \\
\hline $53 b$ & 4 & 1.00 & hot & sw & $\mathbf{h}$ & 4.0 & & 0.44 & & 15 & \\
\hline $53 \mathrm{~b}$ & 4 & 1.00 & hot & SW & h & 12.0 & & 1.33 & & 15 & \\
\hline $53 b$ & 4 & 1.00 & hot & sw & hor $\mathrm{el}$ & 6.0 & & 0.67 & & 15 & \\
\hline $53 b$ & 4 & 1.00 & hot & SW & h & 1.0 & & 0.11 & & 15 & \\
\hline $53 b$ & 4 & 1.00 & hot & sW & $\mathrm{dc}$ & 8.0 & 50.00 & 0.89 & 5.56 & 15 & \\
\hline $54 a$ & 5 & 6.00 & cold & $w$ & $\mathrm{dc}$ & 0.0 & & 0.00 & & 15 & \\
\hline
\end{tabular}




\begin{tabular}{|c|c|c|c|c|c|c|c|c|c|c|c|}
\hline $\begin{array}{l}\text { 1Line } \\
\text { No }\end{array}$ & Unit & $\begin{array}{l}\text { Pipe } \\
\text { Size } \\
\text { (in) }\end{array}$ & Temp & $\begin{array}{l}\text { Conn } \\
\text { Type }\end{array}$ & $\begin{array}{l}\text { Support } \\
\text { Type }\end{array}$ & $\begin{array}{l}\text { Vert } \\
\text { Span } \\
\text { (ft) }\end{array}$ & $\begin{array}{l}\text { Horia } \\
\text { Span } \\
\text { (ft) }\end{array}$ & $\begin{array}{l}\text { Norm } \\
\text { Vert } \\
\text { Span } \\
\text { (ft) }\end{array}$ & $\begin{array}{l}\text { Norm } \\
\text { Horz } \\
\text { Span } \\
\text { (ft) }\end{array}$ & $\begin{array}{l}\text { Plant } \\
\text { Elevation } \\
\text { Above } \\
\text { Grade }\end{array}$ & Remarks \\
\hline $55 \mathrm{~b}$ & 5 & 1.00 & cold & $t$ & ub & 3.0 & 9.00 & 0.43 & 1.29 & 15 & \\
\hline $55 \mathrm{~b}$ & 4 & 1.00 & cold & $t$ & hor et & 6.0 & & 0.86 & & 15 & \\
\hline $55 \mathrm{~b}$ & 4 & 1.00 & cold & $t$ & $\mathrm{ub}$ & 2.0 & 8.00 & 0.29 & & 15 & \\
\hline $55 \mathrm{~b}$ & 4 & 1.00 & cold & $t$ & ub & 8.0 & 8.00 & 1.14 & 1.14 & 15 & \\
\hline $55 \mathrm{~b}$ & 4 & 1.00 & cold & $t$ & hor et & 2.0 & & 0.29 & & 15 & \\
\hline $55 \mathrm{~b}$ & 4 & 1.00 & cold & $t$ & ub & 8.0 & 10.00 & 1.14 & 1.43 & 15 & \\
\hline $55 \mathrm{~b}$ & 4 & 1.00 & cold & $t$ & ub & 6.0 & 6.00 & 0.86 & & 15 & \\
\hline $56 a$ & 5 & 1.00 & cold & Sw & F.W. Line & 0.0 & & 0.00 & & 15 & \\
\hline $56 a$ & 5 & 1.00 & cold & sw & hor et & 3.0 & & 0.43 & & 15 & \\
\hline $56 a$ & 5 & 1.00 & cold & sw & vert et & 6.0 & & 0.86 & & 15 & \\
\hline $56 a$ & 5 & 1.00 & cold & sw & $u b$ & 2.0 & 11.00 & 0.29 & 1.57 & 15 & \\
\hline $56 a$ & 5 & 1.00 & cold & sw & vert et & 2.0 & & 029 & & 15 & \\
\hline $56 a$ & 5 & 1.00 & cold & sw & h & 6.0 & & 0.86 & & 15 & \\
\hline $56 a$ & 5 & 1.00 & cold & sw & vert et & 1.0 & & 0.15 & & 15 & \\
\hline $56 a$ & 5 & 1.00 & cold & sw & vert et & 4.0 & & 0.88 & & 15 & \\
\hline $56 a$ & 5 & 1.00 & cold & sw & hor et & 4.0 & & 0.58 & & 15 & \\
\hline $56 a$ & 5 & 1.00 & cold & sw & $\mathrm{ub}$ & 3.0 & 20.0 & 0.43 & 2.86 & 15 & \\
\hline $56 a$ & 5 & 1.00 & cold & sw & $u b$ & 15.0 & 15.00 & 2.14 & 2.14 & 15 & \\
\hline $56 a$ & 5 & 1.00 & cold & sw & ub & 12.0 & 12.00 & 1.71 & 1.71 & 15 & \\
\hline $56 a$ & 5 & 1.00 & cold & sw & h & 12.0 & & 1.71 & & 15 & \\
\hline $56 a$ & 5 & 1.00 & cold & sw & hor et & 1.0 & & 0.14 & & 15 & \\
\hline $56 a$ & 5 & 1.00 & cold & sw & hor et & 10.0 & & 1.42 & & 15 & \\
\hline $56 a$ & 5 & 1.00 & cold & sw & vert et & 4.0 & & 0.57 & & 15 & \\
\hline $56 a$ & 5 & 1.00 & cold & sw & ub & 2.0 & 29.00 & 0.29 & 4.14 & 15 & \\
\hline $56 \mathrm{~b}$ & 4 & 1.00 & cold & sw & F.W. Line & 0.0 & & 0.00 & & 15 & \\
\hline $56 \mathrm{~b}$ & 4 & 1.00 & cold & sw & hor et & 3.0 & & 0.43 & & 15 & \\
\hline $56 \mathrm{~b}$ & 4 & 1.00 & cold & sw & vert et & 6.0 & & 0.86 & & 15 & \\
\hline $56 \mathrm{~b}$ & 4 & 1.00 & cold & sw & $\mathrm{ub}$ & 2.0 & 11.00 & 0.29 & 1.57 & 15 & \\
\hline $56 \mathrm{~b}$ & 4 & 1.00 & cold & sw & vert et & 2.0 & & 029 & & 15 & \\
\hline $56 \mathrm{~b}$ & 4 & 1.00 & cold & sw & $\mathrm{h}$ & 6.0 & & 0.86 & & 15 & \\
\hline $56 \mathrm{~b}$ & 4 & 1.00 & cold & sw & vert et & 1.0 & & 0.14 & & 15 & \\
\hline $56 b$ & 4 & 1.00 & cold & sw & vert et & 4.0 & & 0.58 & & 15 & \\
\hline
\end{tabular}




\begin{tabular}{|c|c|c|c|c|c|c|c|c|c|c|c|}
\hline $\begin{array}{l}\text { 1Line } \\
\text { No }\end{array}$ & Unit & $\begin{array}{l}\text { Pipe } \\
\text { Size } \\
\text { (in) }\end{array}$ & Temp & $\begin{array}{l}\text { Conn } \\
\text { Type }\end{array}$ & $\begin{array}{l}\text { Support } \\
\text { Type }\end{array}$ & $\begin{array}{l}\text { Vert } \\
\text { Span } \\
\text { (ft) }\end{array}$ & $\begin{array}{l}\text { Horia } \\
\text { Span } \\
\text { (ft) }\end{array}$ & $\begin{array}{l}\text { Norm } \\
\text { Vert } \\
\text { Span } \\
\text { (ft) }\end{array}$ & $\begin{array}{l}\text { Norm } \\
\text { Horz } \\
\text { Span } \\
\text { (ft) }\end{array}$ & $\begin{array}{l}\text { Plant } \\
\text { Elevation } \\
\text { Above } \\
\text { Grade }\end{array}$ & Remarks \\
\hline $56 \mathrm{~b}$ & 4 & 1.00 & cold & SW & hor et & 4.0 & & 0.58 & & 15 & \\
\hline $56 \mathrm{~b}$ & 4 & 1.00 & cold & SW & ub & 3.0 & 20.00 & 4.30 & 2.86 & 15 & \\
\hline $56 a$ & 5 & 1.00 & cold & SW & $\mathbf{u b}$ & 15.0 & 15.00 & 2.14 & 2.14 & 15 & \\
\hline $56 \mathrm{~b}$ & 4 & 1.00 & cold & SW & $u b$ & 12.0 & 12.00 & 1.71 & 1.71 & 15 & \\
\hline $56 \mathrm{~b}$ & 4 & 1.00 & cold & SW & $\mathbf{h}$ & 12.0 & & 1.71 & & 15 & \\
\hline $56 b$ & 4 & 1.00 & cold & Sw & hor et & 1.0 & & 0.14 & & 15 & \\
\hline $56 \mathrm{~b}$ & 4 & 1.00 & cold & SW & hor et & 10.0 & & 1.42 & & 15 & \\
\hline $56 \mathrm{~b}$ & 4 & 1.00 & cold & SW & vert et & 4.0 & & 0.57 & & 15 & \\
\hline $56 \mathrm{~b}$ & 4 & 1.00 & cold & & $\mathrm{ub}$ & 2.0 & 29.00 & 0.29 & 4.14 & 15 & \\
\hline $57 a$ & 5 & 6.00 & cold & & $\mathrm{dc}$ & 0.0 & & 0.00 & & 0 & \\
\hline $57 a$ & 5 & 6.00 & cold & & hor el & 3.0 & & 0.18 & & 0 & \\
\hline $57 a$ & 5 & 6.00 & cold & & h & 2.0 & & 0.12 & & 0 & \\
\hline $57 a$ & 5 & 6.00 & cold & & $\mathbf{h}$ & 25.0 & & 1.47 & & 0 & \\
\hline $57 a$ & 5 & 6.00 & cold & & h & 25.0 & & 1.47 & & 0 & \\
\hline $57 a$ & 5 & 6.00 & cold & & hor el & 3.0 & & 0.18 & & 0 & \\
\hline $57 a$ & 5 & 6.00 & cold & & h & 3.0 & & 0.18 & & 0 & \\
\hline $57 a$ & 5 & 6.00 & cold & & $\mathbf{h}$ & 21.0 & & 1.24 & & 0 & \\
\hline $57 a$ & 5 & 6.00 & cold & & $\mathbf{h}$ & 18.0 & & 1.06 & & 0 & \\
\hline $57 a$ & 6 & 6.00 & cold & & h & 18.0 & & 1.06 & & 0 & \\
\hline $57 a$ & 5 & 6.00 & cold & & h & 18.0 & 136.0 & 1.06 & 8.00 & 0 & \\
\hline $57 \mathrm{~b}$ & 4 & 6.00 & cold & & $\mathrm{dc}$ & 0.0 & & 0.00 & & 0 & \\
\hline $57 \mathrm{~b}$ & 4 & 6.00 & cold & & hor el & 3.0 & & 0.18 & & 0 & \\
\hline $57 \mathrm{~b}$ & 4 & 6.00 & cold & & $\mathbf{h}$ & 2.0 & & 0.12 & & 0 & \\
\hline $57 \mathrm{~b}$ & 4 & 6.00 & cold & & h & 25.0 & & 1.47 & & 0 & \\
\hline $57 \mathrm{~b}$ & 4 & 6.00 & cold & & $\mathbf{h}$ & 25.0 & & 1.47 & & 0 & \\
\hline $57 \mathrm{~b}$ & 4 & 6.00 & cold & & hor el & 3.0 & & 0.18 & & 0 & \\
\hline $57 \mathrm{~b}$ & 4 & 6.00 & cold & & h & 3.0 & & 0.18 & & 0 & \\
\hline $57 \mathrm{~b}$ & 4 & 6.00 & cold & & h & 21.0 & & 1.24 & & 0 & \\
\hline $57 \mathrm{~b}$ & 4 & 6.00 & cold & & $\mathbf{h}$ & 18.0 & & 1.06 & & 0 & \\
\hline $57 \mathrm{~b}$ & 4 & 6.00 & cold & & h & 18.0 & & 1.06 & & 0 & \\
\hline $57 b$ & 4 & 6.00 & cold & & $\mathbf{h}$ & 18.0 & 136.00 & 1.06 & 8.00 & 0 & \\
\hline $58 a$ & 5 & 4.00 & cold & & h & 0.0 & & 0.00 & & 0 & \\
\hline
\end{tabular}




\begin{tabular}{|c|c|c|c|c|c|c|c|c|c|c|c|}
\hline $\begin{array}{l}\text { 1Line } \\
\text { No }\end{array}$ & Unit & $\begin{array}{l}\text { Pipe } \\
\text { Size } \\
\text { (in) }\end{array}$ & Temp & $\begin{array}{l}\text { Conn } \\
\text { Type }\end{array}$ & $\begin{array}{l}\text { Support } \\
\text { Type }\end{array}$ & $\begin{array}{l}\text { Vert } \\
\text { Span } \\
\text { (ft) }\end{array}$ & $\begin{array}{l}\text { Horia } \\
\text { Span } \\
\text { (ft) }\end{array}$ & $\begin{array}{l}\text { Norm } \\
\text { Vert } \\
\text { Span } \\
(\mathrm{ft})\end{array}$ & $\begin{array}{l}\text { Norm } \\
\text { Horz } \\
\text { Span } \\
(\mathrm{ft})\end{array}$ & $\begin{array}{l}\text { Plant } \\
\text { Elevation } \\
\text { Above } \\
\text { Grade }\end{array}$ & Remarks \\
\hline $58 a$ & 5 & 4.00 & cold & & h & 10.0 & & 0.71 & & 0 & \\
\hline $58 a$ & 5 & 4.00 & cold & & hor el & 12.0 & & 0.86 & & 0 & \\
\hline $58 \mathrm{a}$ & 5 & 4.00 & cold & & $h$ & 3.0 & & 0.21 & & 0 & \\
\hline $58 a$ & 5 & 4.00 & cold & & tat rest & 12.0 & 37.00 & 0.86 & 2.64 & 0 & \\
\hline $58 a$ & 5 & 4.00 & cold & & tat rest & 18.0 & 18.00 & 1.29 & 1.29 & 0 & \\
\hline $58 \mathrm{a}$ & 5 & 4.00 & cold & & tat rest & 24.0 & 24.00 & 1.71 & 1.71 & 0 & \\
\hline $58 a$ & 5 & 4.00 & cold & & hor el & 3.0 & & 0.21 & & 0 & \\
\hline $58 a$ & 5 & 4.00 & cold & & stantion & 18.0 & 21.00 & 1.29 & 1.50 & 0 & \\
\hline $58 b$ & 4 & 4.00 & cold & & hor el & 10.0 & & 0.71 & & 0 & \\
\hline $58 \mathrm{~b}$ & 4 & 4.00 & cold & & hor el & 12.0 & & 0.85 & & 0 & \\
\hline $58 a$ & 4 & 4.00 & cold & & h & 3.0 & & 0.21 & & 0 & \\
\hline $58 b$ & 4 & 4.00 & cold & & tat rest & 12.0 & 37.00 & 0.86 & 2.64 & 0 & \\
\hline $58 b$ & 4 & 4.00 & cold & & tat rest & 18.0 & 18.00 & 1.29 & 1.29 & 0 & \\
\hline $58 a$ & 4 & 4.00 & cold & & tat rest & 24.0 & 24.00 & 1.71 & 1.71 & 0 & \\
\hline $58 \mathrm{~b}$ & 4 & 4.00 & cold & & hor el & 3.0 & & 0.00 & & 0 & \\
\hline $58 a$ & 4 & 4.00 & cold & & stantion & 18.0 & 21.00 & 1.29 & 1.50 & 0 & \\
\hline $59 a$ & 5 & 8.00 & cold & & ub & 0.0 & 0.00 & 0.00 & 0.00 & 0 & \\
\hline $59 a$ & 5 & 8.00 & cold & & b & 21.0 & 1.11 & 0.00 & 0.00 & 0 & \\
\hline $59 \mathrm{~b}$ & 4 & 8.00 & cold & & $\mathrm{dc}$ & 2.0 & 23.00 & 0.11 & 1.21 & 0 & \\
\hline $59 \mathrm{~b}$ & 4 & 8.00 & cold & & ub & 0.0 & & 0.00 & & 0 & \\
\hline $59 a$ & 4 & 8.00 & cold & & $h$ & 21.0 & 1.11 & 0.00 & 0.00 & 0 & \\
\hline $59 \mathrm{~b}$ & 4 & 8.00 & cold & & $\mathrm{dc}$ & 2.0 & 23.00 & 0.11 & 1.21 & 0 & \\
\hline $60 a$ & 5 & 2.00 & cold & sw & dc & 0.0 & & 0.00 & & 0 & \\
\hline $60 a$ & 5 & 2.00 & cold & sw & ub & 2.0 & 2.00 & 0.20 & 0.02 & 0 & \\
\hline $60 a$ & 5 & 2.00 & cold & SW & ub & 15.0 & 15.00 & 1.50 & 1.5 & 0 & \\
\hline $60 a$ & 5 & 2.00 & cold & SW & hor et & 15.0 & & 1.50 & & 0 & \\
\hline $60 a$ & 5 & 2.00 & cold & SW & ub & 6.0 & 21.00 & 0.60 & 2.1 & 0 & \\
\hline $60 \mathrm{a}$ & 5 & 2.00 & cold & SW & ub & 12.0 & 12.00 & 1.20 & 1.2 & 0 & \\
\hline $60 a$ & 5 & 2.00 & cold & sw & ub & 12.0 & 12.00 & 1.20 & 1.2 & 0 & \\
\hline $60 \mathrm{a}$ & 5 & 2.00 & cold & sw & $\mathrm{h}$ & 15.0 & & 1.50 & & 0 & \\
\hline $60 a$ & 5 & 2.00 & cold & sw & bracket & 12.0 & & 1.20 & & 0 & \\
\hline $60 a$ & 5 & 2.00 & cold & SW & hor et & 1.0 & & 0.10 & & 0 & \\
\hline
\end{tabular}




\begin{tabular}{|c|c|c|c|c|c|c|c|c|c|c|c|}
\hline $\begin{array}{l}1 \text { Line } \\
\text { No }\end{array}$ & Unit & $\begin{array}{l}\text { Pipe } \\
\text { Size } \\
\text { (in) }\end{array}$ & Temp & $\begin{array}{l}\text { Conn } \\
\text { Type }\end{array}$ & $\begin{array}{l}\text { Support } \\
\text { Type }\end{array}$ & $\begin{array}{l}\text { Vert } \\
\text { Span } \\
(\mathrm{ft})\end{array}$ & $\begin{array}{l}\text { Horia } \\
\text { Span } \\
\text { (ft) }\end{array}$ & $\begin{array}{l}\text { Norm } \\
\text { Vert } \\
\text { Span } \\
\text { (ft) }\end{array}$ & $\begin{array}{l}\text { Norm } \\
\text { Horz } \\
\text { Span } \\
(\mathrm{ft})\end{array}$ & \begin{tabular}{|l} 
Plant \\
Elevation \\
- Above \\
Grade
\end{tabular} & Remarks \\
\hline $60 a$ & 5 & 2.00 & cold & SW & bracket & 5.0 & & 0.50 & & 0 & \\
\hline $60 \mathrm{a}$ & 5 & 2.00 & cold & SW & h & 10.0 & & 1.00 & & 0 & \\
\hline $60 a$ & 5 & 2.00 & cold & SW & $\mathrm{ub}$ & 10.0 & 53.00 & 1.00 & 5.33 & 0 & \\
\hline $60 a$ & 5 & 2.00 & cold & SW & hor et & 1.0 & & 0.00 & 0.00 & 0 & \\
\hline $60 a$ & 5 & 2.00 & cold & SW & ub & 18.0 & 19.00 & 1.80 & 1.9 & 0 & \\
\hline $60 a$ & 5 & 2.00 & cold & SW & ub & 12.0 & 12.00 & 1.20 & 1.20 & 0 & \\
\hline $60 \mathrm{~b}$ & 5 & 2.00 & cold & SW & hor et & 15.0 & 0.00 & 1.50 & 0.00 & 0 & \\
\hline $60 a$ & 5 & 2.00 & cold & SW & ub & 1.0 & 16.00 & 0.10 & 1.6 & 0 & \\
\hline $60 \mathrm{a}$ & 5 & 2.00 & cold & SW & $u b$ & 12.0 & 12.00 & 120 & 1.0 & 0 & \\
\hline $60 \mathrm{a}$ & 5 & 1.00 & cold & SW & $\mathrm{ub}$ & 15.0 & 15.00 & 2.14 & 2.140 & 0 & \\
\hline $60 \mathrm{a}$ & 5 & 1.00 & cold & SW & $\mathrm{ub}$ & 15.0 & 15.00 & 0.00 & 0.00 & 0 & \\
\hline $60 a$ & 5 & 1.00 & cold & SW & $u b$ & 10.0 & 10.00 & 1.43 & 1.43 & 0 & \\
\hline $60 a$ & 5 & 1.00 & cold & SW & $h$ & 10.0 & 0.00 & 1.43 & 0 & 0 & \\
\hline $60 a$ & 5 & 1.00 & cold & SW & vert et & 10.0 & 0.00 & 1.43 & 0.00 & 0 & \\
\hline $60 a$ & 5 & 1.00 & cold & sw & ub & 12.0 & 32.00 & 1.71 & 4.75 & 0 & \\
\hline $60 a$ & 5 & 1.00 & cold & SW & $u b$ & 12.0 & 12.00 & 1.71 & 1.71 & 0 & \\
\hline $60 \mathrm{~b}$ & 4 & 2.00 & cold & SW & $\mathrm{dc}$ & 0.0 & 0.00 & 0.00 & 0.00 & 0 & \\
\hline $60 b$ & 4 & 2.00 & cold & SW & $u b$ & 2.0 & 2.0 & 0.20 & 0.20 & 0 & \\
\hline $60 \mathrm{~b}$ & 4 & 2.00 & cold & sw & $\mathbf{u b}$ & 15.0 & 15.00 & 1.50 & 1.50 & 0 & \\
\hline $60 \mathrm{~b}$ & 4 & 2.00 & cold & SW & hor et & 15.0 & & 1.50 & & 0 & \\
\hline $60 \mathrm{~b}$ & 4 & 2.00 & cold & SW & $u b$ & 6.0 & 21.00 & 0.60 & 2.10 & 0 & \\
\hline $60 \mathrm{~b}$ & 4 & 2.000 & cold & SW & ub & 12.0 & 12.00 & 1.20 & & 0 & \\
\hline $60 \mathrm{~b}$ & 4 & 2.000 & cold & SW & $\mathrm{h}$ & 15.0 & & 1.50 & & 0 & \\
\hline $60 \mathrm{~b}$ & 4 & 2.000 & cold & SW & bracket & 12.0 & & 1.20 & & 0 & \\
\hline $60 \mathrm{~b}$ & 4 & 2.000 & cold & sw & hor et & 1.0 & & 0.10 & & 0 & \\
\hline $60 \mathrm{~b}$ & 4 & 2.000 & cold & SW & bracket & 5.0 & & 0.50 & & 0 & \\
\hline $60 \mathrm{~b}$ & 4 & 2.000 & cold & SW & $\mathrm{h}$ & 10.0 & & 1.00 & & 0 & \\
\hline $60 \mathrm{~b}$ & 4 & 2.000 & cold & SW & $u b$ & 10.0 & 53.00 & 1.00 & 5.30 & 0 & \\
\hline $60 \mathrm{~b}$ & 4 & 2.000 & cold & SW & hor et & 1.0 & & 0.10 & & 0 & \\
\hline $60 a$ & 4 & 2.000 & cold & SW & ub & 18.0 & 19.00 & 1.80 & 1.9 & 0 & \\
\hline $60 \mathrm{~b}$ & 4 & 2.000 & cold & SW & $\mathrm{ub}$ & 12.0 & 12.00 & 1.20 & 1.20 & 0 & \\
\hline $60 \mathrm{~b}$ & 4 & 2.000 & cold & sW & hor et & 15.0 & & 1.50 & & 0 & \\
\hline
\end{tabular}




\begin{tabular}{|c|c|c|c|c|c|c|c|c|c|c|c|}
\hline $\begin{array}{l}1 \text { Line } \\
\text { No }\end{array}$ & Unit & $\begin{array}{l}\text { Pipe } \\
\text { Size } \\
\text { (in) }\end{array}$ & Temp & $\begin{array}{l}\text { Conn } \\
\text { Type }\end{array}$ & $\begin{array}{l}\text { Support } \\
\text { Type }\end{array}$ & $\begin{array}{l}\text { Vert } \\
\text { Span } \\
\text { (ft) }\end{array}$ & $\begin{array}{l}\text { Horia } \\
\text { Span } \\
\text { (ft) }\end{array}$ & $\begin{array}{l}\text { Norm } \\
\text { Vert } \\
\text { Span } \\
\text { (ft) }\end{array}$ & $\begin{array}{l}\text { Norm } \\
\text { Horz } \\
\text { Span } \\
\text { (ft) }\end{array}$ & $\begin{array}{l}\text { Plant } \\
\text { Elevation } \\
\text { Above } \\
\text { Grade }\end{array}$ & Remarks \\
\hline $60 b$ & 4 & 2.000 & cold & sw & ub & 1.0 & 16.00 & 0.10 & 1.60 & 0 & \\
\hline $60 b$ & 4 & 2.000 & cold & SW & $\mathrm{ub}$ & 12.0 & 12.00 & 120 & 1.20 & 0 & \\
\hline $60 \mathrm{~b}$ & 4 & 2.000 & cold & sw & $\mathrm{ub}$ & 15.0 & 15.00 & 1.50 & 1.50 & 0 & \\
\hline $60 \mathrm{~b}$ & 4 & 2.000 & cold & SW & $\mathrm{ub}$ & 15.0 & 15.00 & 1.50 & 1.50 & 0 & \\
\hline $60 \mathrm{~b}$ & 4 & 2.000 & cold & sw & $\mathrm{ub}$ & 10.0 & 10.00 & 1.00 & 1.00 & 0 & \\
\hline $60 \mathrm{~b}$ & 4 & 2.000 & cold & sw & $h$ & 10.0 & & 1.00 & & 0 & \\
\hline $60 \mathrm{~b}$ & 4 & 2.000 & cold & SW & vert et & 10.0 & & 1.00 & & 0 & \\
\hline $60 \mathrm{~b}$ & 4 & 2.000 & cold & SW & $u b$ & 12.0 & 32.00 & 1.20 & 3.20 & 0 & \\
\hline $60 \mathrm{~b}$ & 4 & 2.000 & cold & SW & $\mathrm{ub}$ & 12.0 & 12.00 & 1.20 & 1.20 & 0 & \\
\hline $61 a$ & 5 & 1.000 & hot & SW & hor el & 15.0 & & 1.70 & & 0 & \\
\hline $61 a$ & 5 & 1.000 & hot & SW & h & 1.0 & & 0.10 & & 0 & \\
\hline $61 a$ & 5 & 1.000 & hot & SW & h & 24.0 & & 2.70 & & 0 & \\
\hline $61 a$ & 5 & 1.000 & hot & SW & hor et & 2.0 & & 0.20 & & 0 & \\
\hline $61 \mathrm{a}$ & 5 & 1.000 & hot & sw & Lat rest & 1.0 & 43.00 & 0.10 & 4.80 & 0 & \\
\hline $61 a$ & 5 & 1.000 & hot & SW & h & 4.0 & & 0.40 & & 0 & \\
\hline $61 a$ & 5 & 1.000 & hot & SW & $h$ & 10.0 & & 1.10 & & 0 & \\
\hline $61 a$ & 5 & 1.000 & hot & SW & h & 6.0 & & 0.70 & & 0 & \\
\hline $61 a$ & 5 & 1.000 & hot & SW & h & 8.0 & & 0.80 & & 0 & \\
\hline $61 a$ & 5 & 1.000 & hot & SW & $h$ & 8.0 & & 0.80 & & 0 & \\
\hline $61 a$ & 5 & 1.000 & hot & SW & hor et & 2.0 & & 0.20 & & 0 & \\
\hline $61 a$ & 5 & 1.000 & hot & SW & h & 10.0 & & 1.10 & & 0 & \\
\hline $61 a$ & 5 & 1.000 & hot & SW & $h$ & 8.0 & & 0.80 & & 0 & \\
\hline $61 a$ & 5 & 1.000 & hot & SW & hor et & 2.0 & & 0.20 & & 0 & \\
\hline $61 a$ & 5 & 1.000 & hot & SW & $\mathrm{dc}$ & 2.0 & 60.00 & 0.20 & 6.70 & 0 & \\
\hline $61 b$ & 5 & 1.000 & hot & SW & Large pipe & 0.0 & & 0.00 & & 0 & \\
\hline $61 \mathrm{~b}$ & 5 & 1.000 & hot & SW & hor et & 15.0 & & 1.60 & & 0 & \\
\hline $61 \mathrm{~b}$ & 5 & 1.000 & hot & sw & $h$ & 1.0 & & 0.10 & & 0 & \\
\hline $61 \mathrm{~b}$ & 5 & 1.000 & hot & SW & h & 24.0 & & 2.70 & & 0 & \\
\hline $61 b$ & 5 & 1.000 & hot & SW & hor et & 2.0 & & 0.20 & & 0 & \\
\hline $61 b$ & 5 & 1.000 & hot & SW & $\begin{array}{l}\text { Lateral } \\
\text { restraint }\end{array}$ & 1.0 & 43.00 & 0.10 & 0.00 & 0 & \\
\hline $61 \mathrm{~b}$ & 5 & 1.000 & hot & SW & h & 4.0 & & 0.40 & & 0 & \\
\hline
\end{tabular}




\begin{tabular}{|c|c|c|c|c|c|c|c|c|c|c|c|}
\hline $\begin{array}{l}\text { 1Line } \\
\text { No }\end{array}$ & Unit & $\begin{array}{l}\text { Pipe } \\
\text { Size } \\
\text { (in) }\end{array}$ & Temp & $\begin{array}{l}\text { Conn } \\
\text { Type }\end{array}$ & $\begin{array}{l}\text { Support } \\
\text { Type }\end{array}$ & $\begin{array}{l}\text { Vert } \\
\text { Span } \\
\text { (ft) }\end{array}$ & $\begin{array}{l}\text { Horia } \\
\text { Span } \\
\text { (ft) }\end{array}$ & $\begin{array}{l}\text { Norm } \\
\text { Vert } \\
\text { Span } \\
\text { (ft) }\end{array}$ & $\begin{array}{l}\text { Norm } \\
\text { Horz } \\
\text { Span } \\
\text { (ft) }\end{array}$ & $\begin{array}{l}\text { Plant } \\
\text { Elevation } \\
\text { Above } \\
\text { Grade }\end{array}$ & Remarks \\
\hline $61 b$ & 5 & 1.000 & hot & SW & h & 10.0 & & 1.10 & & 0 & \\
\hline $61 b$ & 5 & 1.000 & hot & SW & h & 6.0 & & 0.70 & & 0 & \\
\hline $61 b$ & 5 & 1.000 & hot & SW & h & 8.0 & & 0.90 & & 0 & \\
\hline $61 b$ & 5 & 1.000 & hot & sw & $h$ & 8.0 & & 0.90 & & 0 & \\
\hline $61 b$ & 5 & 1.000 & hot & SW & hor et & 2.0 & & 0.20 & & 0 & \\
\hline $61 b$ & 5 & 1.000 & hot & SW & h & 10.0 & & 1.10 & & 0 & \\
\hline $61 b$ & 5 & 1.000 & hot & SW & h & 8.0 & & 0.90 & & 0 & \\
\hline $61 b$ & 5 & 1.000 & hot & SW & $\mathrm{dc}$ & 2.0 & 60.00 & 0.20 & 6.70 & 0 & \\
\hline $62 a$ & 5 & 1.500 & cold & $t$ & $\begin{array}{l}\text { Lateral } \\
\text { restraint }\end{array}$ & 0.0 & & 0.00 & & 0 & \\
\hline $62 a$ & 5 & 1.500 & cold & $\mathrm{t}$ & h & 6.0 & & 0.70 & & 0 & \\
\hline $62 a$ & 5 & 1500 & cold & $\mathbf{t}$ & h & 6.0 & & 0.70 & & 0 & \\
\hline $62 a$ & 5 & 1.500 & cold & $t$ & h & 8.0 & & 0.90 & & 0 & \\
\hline $62 a$ & 5 & 1.500 & hor et & $t$ & hor et & 8.0 & & 0.90 & & 0 & \\
\hline $62 a$ & 5 & 1.500 & cold & $\mathbf{t}$ & $\begin{array}{l}\text { Lateral } \\
\text { restraint }\end{array}$ & 3.0 & 31.00 & 0.30 & 3.60 & 0 & \\
\hline $62 a$ & 5 & 1500 & cold & $\mathbf{t}$ & hor tee & 10.0 & 10.00 & 1.20 & 1.20 & 0 & \\
\hline $62 a$ & 5 & 1.500 & cold & $t$ & $\mathbf{h}$ & 2.0 & & 0.30 & & 0 & \\
\hline $62 a$ & 5 & 1.500 & cold & $t$ & h & 12.0 & & 1.30 & & 0 & \\
\hline $62 a$ & 5 & 1.500 & cold & $\mathbf{t}$ & hor et & 4.0 & & 0.50 & & 0 & \\
\hline $62 a$ & 5 & 1.500 & cold & $\mathbf{t}$ & Large pipe & 4.0 & 22.00 & 0.50 & 2.70 & 0 & \\
\hline $62 b$ & 4 & 1.500 & cold & & $\begin{array}{l}\text { lateral } \\
\text { restraint }\end{array}$ & 0.0 & & 0.00 & & 0 & \\
\hline $62 b$ & 4 & 1.500 & cold & & h & 6.0 & & 0.70 & & 0 & \\
\hline $62 b$ & 4 & 1.500 & cold & & h & 6.0 & & 0.70 & & 0 & \\
\hline $62 b$ & 4 & 1.500 & cold & & h & 8.0 & 0.00 & 0.90 & & 0 & \\
\hline $62 b$ & 4 & 1.500 & cold & & hor et & 8.0 & & 0.90 & & 0 & \\
\hline $62 b$ & 4 & 1.500 & cold & & $\begin{array}{l}\text { lateral } \\
\text { restraint }\end{array}$ & 3.0 & 31.00 & 0.30 & 3.60 & 0 & \\
\hline $62 b$ & 4 & 1.500 & cold & & hor tee & 10.0 & 10.00 & 1.20 & 1.20 & 0 & \\
\hline $62 b$ & 4 & 1.500 & cold & & $\mathbf{h}$ & 2.0 & & 0.30 & & 0 & \\
\hline $62 b$ & 4 & 1.500 & cold & & hor eL & 4.0 & & 0.50 & & 0 & \\
\hline $63 a$ & 5 & 2.000 & cold & & riser & 0.0 & & 0.00 & & 0 & \\
\hline $63 a$ & 5 & 2.000 & cold & & $\mathrm{h}$ & 8.0 & & 0.80 & & 0 & \\
\hline
\end{tabular}




\begin{tabular}{|c|c|c|c|c|c|c|c|c|c|c|c|}
\hline $\begin{array}{l}1 \text { Line } \\
\text { No }\end{array}$ & Unit & $\begin{array}{l}\text { Pipe } \\
\text { Size } \\
\text { (in) }\end{array}$ & Temp & $\begin{array}{l}\text { Conn } \\
\text { Type }\end{array}$ & $\begin{array}{l}\text { Support } \\
\text { Type }\end{array}$ & $\begin{array}{l}\text { Vert } \\
\text { Span } \\
\text { (ft) }\end{array}$ & $\begin{array}{l}\text { Horia } \\
\text { Span } \\
\text { (ft) }\end{array}$ & $\begin{array}{l}\text { Norm } \\
\text { Vert } \\
\text { Span } \\
\text { (fi) }\end{array}$ & $\begin{array}{l}\text { Norm } \\
\text { Horz } \\
\text { Span } \\
\text { (ft) }\end{array}$ & $\begin{array}{l}\text { Plant } \\
\text { Elevation } \\
\text { Above } \\
\text { Grade }\end{array}$ & Remarks \\
\hline $63 a$ & 5 & 2.000 & cold & & $h$ & 6.0 & & 0.60 & & 0 & \\
\hline $63 a$ & 5 & 2.000 & cold & & $\mathbf{h}$ & 6.0 & & 0.60 & & 0 & \\
\hline $63 a$ & 5 & 2.000 & cold & & h & 8.0 & & 0.80 & & 0 & \\
\hline $63 a$ & 5 & 2.000 & cold & & $\mathrm{h}$ & 6.0 & & 0.60 & & 0 & \\
\hline $63 a$ & 5 & 2.000 & cold & & $h$ & 10.0 & & 1.00 & & 0 & \\
\hline $63 a$ & 5 & 2.000 & cold & & $\mathbf{h}$ & 10.0 & & 1.00 & & 0 & \\
\hline $63 a$ & 5 & 2.000 & cold & & hor et & 2.0 & & 0.20 & & 0 & \\
\hline $63 a$ & 5 & 2.000 & cold & & $\mathrm{h}$ & 4.0 & & 0.40 & & 0 & \\
\hline $63 a$ & 5 & 2.000 & cold & & h & 15.0 & & 150 & & 0 & \\
\hline $63 a$ & 5 & 2.000 & cold & & h & 12.0 & & 1.20 & & 0 & \\
\hline $63 a$ & 5 & 2.000 & cold & & hor et & 2.0 & & 0.20 & & 0 & \\
\hline $63 a$ & 5 & 2.000 & cold & & ub stantion & 1.0 & 90.00 & 0.10 & 9.00 & 0 & \\
\hline $63 b$ & 4 & 2.000 & cold & & riser & 0.0 & & 0.00 & & 0 & \\
\hline $63 b$ & 4 & 2.000 & cold & & h & 8.0 & & 0.80 & & 0 & \\
\hline $63 b$ & 4 & 2.000 & cold & & h & 6.0 & & 0.60 & & 0 & \\
\hline $63 \mathrm{~b}$ & 5 & 2.000 & cold & & $\mathbf{h}$ & 6.0 & & 0.60 & & 0 & \\
\hline $63 b$ & 5 & 2.000 & cold & & h & 8.0 & & 0.80 & & 0 & \\
\hline $63 b$ & 4 & 2.000 & cold & & $\mathbf{h}$ & 6.0 & & 0.60 & & 0 & \\
\hline $63 b$ & 4 & 2.000 & cold & & h & 10.0 & & 1.00 & & 0 & \\
\hline $63 \mathrm{~b}$ & 4 & 2.000 & cold & & $\mathrm{h}$ & 10.0 & & 1.00 & & 0 & \\
\hline $63 b$ & 4 & 2.000 & cold & & hor et & 2.0 & & 0.20 & & 0 & \\
\hline $63 \mathrm{~b}$ & 4 & 2.000 & cold & & h & 4.0 & & 0.40 & & 0 & \\
\hline $63 b$ & 4 & 2.000 & cold & & h & 15.0 & & 1.50 & & 0 & \\
\hline $63 \mathrm{~b}$ & 4 & 2.000 & cold & & h & 12.0 & & 1.20 & & 0 & \\
\hline $63 b$ & 4 & 2.000 & cold & & hor et & 2.0 & & 0.20 & & 0 & \\
\hline $63 \mathrm{~b}$ & 4 & 2.000 & cold & & ub stantion & 1.0 & 90.0 & 0.10 & 9.00 & 0 & \\
\hline $64 a$ & 5 & 1.000 & cold & & dc & 0.0 & & 0.00 & & 0 & \\
\hline $64 a$ & 5 & 1.000 & cold & & $u b$ & 2.0 & 2.00 & 0.30 & 0.30 & 0 & \\
\hline $64 a$ & 5 & 1.000 & cold & & $\mathrm{ub}$ & 4.0 & 4.00 & 0.60 & 0.60 & 0 & \\
\hline $64 a$ & 5 & 1.000 & cold & & ub & 24.0 & 24.00 & 3.40 & 3.40 & 0 & \\
\hline $64 a$ & 5 & 1.000 & cold & & $u b$ & 12.0 & 12.00 & 1.70 & 1.70 & 0 & \\
\hline $64 a$ & 5 & 1.000 & cold & & hor et & 12.0 & & 1.70 & & 0 & \\
\hline
\end{tabular}




\begin{tabular}{|c|c|c|c|c|c|c|c|c|c|c|c|}
\hline $\begin{array}{l}\text { 1Line } \\
\text { No }\end{array}$ & Unit & $\begin{array}{l}\text { Pipe } \\
\text { Size } \\
\text { (in) }\end{array}$ & Temp & $\begin{array}{l}\text { Conn } \\
\text { Type }\end{array}$ & $\begin{array}{l}\text { Support } \\
\text { Type }\end{array}$ & $\begin{array}{l}\text { Vert } \\
\text { Span } \\
\text { (ft) }\end{array}$ & $\begin{array}{l}\text { Horia } \\
\text { Span } \\
\text { (ft) }\end{array}$ & $\begin{array}{l}\text { Norm } \\
\text { Vert } \\
\text { Span } \\
\text { (ft) }\end{array}$ & $\begin{array}{l}\text { Norm } \\
\text { Horz } \\
\text { Span } \\
(\mathrm{ft})\end{array}$ & $\begin{array}{l}\text { Plant } \\
\text { Elevation } \\
\text { Above } \\
\text { Grade }\end{array}$ & Remarks \\
\hline $64 a$ & 5 & 1.000 & cold & & $u b$ & 1.0 & 13.00 & 0.10 & 1.90 & 0 & \\
\hline $64 a$ & 5 & 1.000 & cold & & ub & 15.0 & 15.00 & 2.10 & 2.10 & 0 & \\
\hline $64 a$ & 5 & 1.000 & cold & & ub & 15.0 & 15.00 & 2.10 & 2.10 & 0 & \\
\hline $64 a$ & 5 & 1.000 & cold & & ub & 2.0 & 2.00 & 0.30 & 0.30 & 0 & \\
\hline $64 b$ & 4 & 1.000 & cold & & dc & 0.0 & & 0.00 & & 0 & \\
\hline $64 b$ & 4 & 1.000 & cold & & ub & 2.0 & 2.0 & 0.30 & 0.30 & 0 & \\
\hline $64 \mathrm{~b}$ & 4 & 1.000 & cold & & ub & 4.0 & 4.00 & 0.60 & 0.60 & 0 & \\
\hline $64 b$ & 4 & 1.000 & cold & & ub & 24.0 & 24.00 & 3.40 & 3.40 & 0 & \\
\hline $64 b$ & 4 & 1.000 & cold & & $\mathrm{ub}$ & 12.0 & 12.00 & 1.70 & 1.70 & 0 & \\
\hline $64 b$ & 4 & 1.000 & cold & & hor el & 12.0 & & 1.70 & & 0 & \\
\hline $64 b$ & 4 & 1.000 & cold & & ub & 15.0 & 15.00 & 2.10 & 2.10 & 0 & \\
\hline $64 \mathrm{~b}$ & 4 & 1.000 & cold & & $u b$ & 15.0 & 15.00 & 2.10 & 2.10 & 0 & \\
\hline $64 b$ & 4 & 1.000 & cold & & ub & 2.0 & 2.00 & 0.30 & 0.30 & 0 & \\
\hline $65 a$ & 5 & 4.000 & cold & & riser & 0.0 & & 0.00 & & 0 & \\
\hline $65 a$ & 5 & 4.000 & cold & & h & 12.0 & & 0.90 & & 0 & \\
\hline $65 a$ & 5 & 4.000 & cold & & h & 15.0 & & 1.10 & & 0 & \\
\hline $65 a$ & 5 & 4.000 & cold & & h & 12.0 & & 0.90 & & 0 & \\
\hline $65 a$ & 5 & 4.000 & cold & & h & 18.0 & & 1.30 & & 0 & \\
\hline $65 a$ & 5 & 4.000 & cold & & $h$ & 24.0 & & 1.80 & & 0 & \\
\hline $65 a$ & 5 & 4.000 & cold & & h & 18.0 & & 1.30 & & 0 & \\
\hline $65 a$ & 5 & 4.000 & cold & & h & 16.0 & & 1.10 & & 0 & \\
\hline $65 a$ & 5 & 4.000 & cold & & vert el & 3.0 & & 0.20 & & 0 & \\
\hline $65 a$ & 5 & 4.000 & cold & & vert el & 8.0 & & 0.60 & & 0 & \\
\hline $65 a$ & 5 & 4.000 & cold & & bracket & 10.0 & & 0.70 & & 0 & \\
\hline $65 a$ & 5 & 4.000 & cold & & bracket & 10.0 & & 0.70 & & 0 & \\
\hline $65 a$ & 5 & 4.000 & cold & & bracket & 10.0 & & 0.70 & & 0 & \\
\hline 652 & 5 & 4.000 & cold & & bracket & 10.0 & & 0.70 & & 0 & \\
\hline $65 a$ & 5 & 4.000 & cold & & vert tee & 6.0 & 156.00 & 0.40 & 11.1 & 0 & \\
\hline $65 a$ & 5 & 4.000 & cold & & $h$ & 4.0 & & 0.30 & & 0 & \\
\hline $65 a$ & 5 & 4.000 & cold & & h & 15.0 & & 1.10 & & 0 & \\
\hline $65 a$ & 5 & 4.000 & cold & & $h$ & 15.0 & & 1.10 & & 0 & \\
\hline $65 a$ & 5 & 4.000 & cold & & h & 12.0 & & 0.90 & & 0 & \\
\hline
\end{tabular}




\begin{tabular}{|c|c|c|c|c|c|c|c|c|c|c|c|}
\hline $\begin{array}{l}\text { 1Line } \\
\text { No }\end{array}$ & Unit & $\begin{array}{l}\text { Pipe } \\
\text { Size } \\
\text { (in) }\end{array}$ & Temp & $\begin{array}{l}\text { Conn } \\
\text { Type }\end{array}$ & $\begin{array}{l}\text { Support } \\
\text { Type }\end{array}$ & $\begin{array}{l}\text { Vert } \\
\text { Span } \\
\text { (ft) }\end{array}$ & $\begin{array}{l}\text { Horia } \\
\text { Span } \\
\text { (ft) }\end{array}$ & $\begin{array}{l}\text { Norm } \\
\text { Vert } \\
\text { Span } \\
\text { (ft) }\end{array}$ & $\begin{array}{l}\text { Norm } \\
\text { Horz } \\
\text { Span } \\
\text { (ft) }\end{array}$ & $\begin{array}{l}\text { Plant } \\
\text { Elevation } \\
\text { Above } \\
\text { Grade }\end{array}$ & Remarks \\
\hline $65 \mathrm{a}$ & 5 & 4.000 & cold & & ub & 8.0 & 54.00 & 0.60 & 3.90 & 0 & \\
\hline $65 \mathrm{~b}$ & 4 & 4.000 & cold & & riser & 0.0 & & 0.00 & & 0 & \\
\hline $65 b$ & 4 & 4.000 & cold & & $\mathrm{h}$ & 12.0 & & 0.90 & & 0 & \\
\hline $65 \mathrm{~b}$ & 4 & 4.000 & cold & & h & 15.0 & & 1.10 & & 0 & \\
\hline $65 \mathrm{~b}$ & 4 & 4.000 & cold & & h & 12.0 & & 0.90 & & 0 & \\
\hline $65 \mathrm{~b}$ & 4 & 4.000 & cold & & h & 18.0 & & 130 & & 0 & \\
\hline $65 \mathrm{~b}$ & 4 & 4.000 & cold & & h & 24.0 & & 1.80 & & 0 & \\
\hline $65 \mathrm{~b}$ & 4 & 4.000 & cold & & h & 18.0 & & 1.00 & & 0 & \\
\hline $65 \mathrm{~b}$ & 4 & 4.000 & cold & & h & 16.0 & & 1.10 & & 0 & \\
\hline $65 b$ & 4 & 4.000 & cold & & vert el & 3.0 & & 0.20 & & 0 & \\
\hline $65 \mathrm{~b}$ & 4 & 4.000 & cold & & vert el & 8.0 & & 0.60 & & 0 & \\
\hline $65 \mathrm{~b}$ & 4 & 4.000 & cold & & bracket & 10.0 & & 0.70 & & 0 & \\
\hline $65 b$ & 4 & 4.000 & cold & & bracket & 10.0 & & 0.70 & & 0 & \\
\hline $65 \mathrm{~b}$ & 4 & 4.000 & cold & & bracket & 10.0 & & 0.70 & & 0 & \\
\hline $65 \mathrm{~b}$ & $4^{\circ}$ & 4.000 & cold & & bracket & 10.0 & & 0.70 & & 0 & \\
\hline $65 \mathrm{~b}$ & 4 & 4.000 & cold & & vert tee & 6.0 & 156.00 & 0.40 & 11.00 & 0 & \\
\hline \multirow[t]{16}{*}{$65 b$} & 4 & 4.000 & cold & & h & 4.0 & & 0.30 & & 0 & \\
\hline & 4 & 4.000 & cold & & h & 15.0 & & 1.10 & & 0 & \\
\hline & 4 & 4.000 & cold & & h & 15.0 & & 1.10 & 0.00 & 0 & \\
\hline & 4 & 4.000 & cold & & h & 12.0 & & 0.90 & & 0 & \\
\hline & 4 & 4.000 & cold & & $\mathrm{ub}$ & 8.0 & 54.00 & 0.60 & 3.90 & 0 & \\
\hline & 5 & 2.000 & cold & & pipe & 0.0 & & 0.00 & & 0 & \\
\hline & 5 & 2.000 & cold & & $\mathrm{h}$ & 6.0 & & 0.60 & & 0 & \\
\hline & 5 & 2.000 & cold & & $\mathrm{h}$ & 12.0 & & 1.20 & & 0 & \\
\hline & 5 & 2.000 & cold & & $\mathrm{h}$ & 12.0 & & 120 & & 0 & \\
\hline & 5 & 2.000 & cold & & $\mathrm{h}$ & 15.0 & & 1.50 & & 0 & \\
\hline & 5 & 2.000 & cold & & pipe & 8.0 & 53.00 & 0.80 & 5.30 & 0 & \\
\hline & 4 & 2.000 & cold & & pipe & 0.0 & & 0.00 & & 0 & \\
\hline & 4 & 2.000 & cold & & $\mathrm{h}$ & 6.0 & & 0.60 & & 0 & \\
\hline & 4 & 2.000 & cold & & $\mathbf{h}$ & 12.0 & & 1.20 & & 0 & \\
\hline & 4 & 2.000 & cold & & $\mathrm{h}$ & 12.0 & & 1.20 & & 0 & \\
\hline & 4 & 2.000 & cold & & $\mathbf{h}$ & 15.0 & & 150 & & 0 & \\
\hline
\end{tabular}




\begin{tabular}{|c|c|c|c|c|c|c|c|c|c|c|c|}
\hline $\begin{array}{l}\text { 1Line } \\
\text { No }\end{array}$ & Unit & $\begin{array}{l}\text { Pipe } \\
\text { Size } \\
\text { (in) }\end{array}$ & Temp & $\begin{array}{l}\text { Conn } \\
\text { Type }\end{array}$ & $\begin{array}{l}\text { Support } \\
\text { Type }\end{array}$ & $\begin{array}{l}\text { Vert } \\
\text { Span } \\
(\mathrm{ft})\end{array}$ & $\begin{array}{l}\text { Horia } \\
\text { Span } \\
\text { (ft) }\end{array}$ & $\begin{array}{l}\text { Norm } \\
\text { Vert } \\
\text { Span } \\
\text { (ft) }\end{array}$ & $\begin{array}{l}\text { Norm } \\
\text { Horz } \\
\text { Span } \\
\text { (ft) }\end{array}$ & $\begin{array}{l}\text { Plant } \\
\text { Elevation } \\
\text { Above } \\
\text { Grade }\end{array}$ & Remarks \\
\hline & 4 & 2.000 & cold & & pipe & 8.0 & 53.00 & 0.80 & 5.30 & 0 & \\
\hline & 5 & 0.750 & cold & & pump & 0.0 & & 0.00 & & 0 & \\
\hline & 5 & 0.750 & cold & & $\begin{array}{l}\text { vert } \\
\text { et }\end{array}$ & 8.0 & & 1.60 & & 0 & \\
\hline & 5 & 0.750 & cold & & ub & 1.0 & 9.00 & 0.20 & 0.20 & 0 & \\
\hline & 5 & 0.750 & cold & & $\begin{array}{l}\text { vert } \\
\text { hor et }\end{array}$ & 3.0 & 3.00 & 0.60 & 0.60 & 0 & \\
\hline & 5 & 0.750 & cold & & $\mathrm{ub}$ & 8.0 & 8.00 & 1.60 & 1.60 & 0 & \\
\hline & 5 & 0.750 & cold & & hor et & 1.0 & 1.00 & 0.20 & 0.20 & 0 & \\
\hline & 5 & 0.750 & cold & & $u b$ & 3.0 & 3.00 & 0.00 & 0.00 & 0 & \\
\hline & 5 & 0.750 & cold & & $\begin{array}{l}\text { vert } \\
\text { et }\end{array}$ & 1.0 & & 0.20 & & 0 & \\
\hline & 5 & 0.750 & cold & & pump & 8.0 & 9.00 & 1.60 & 1.80 & 0 & \\
\hline & 4 & 0.750 & cold & & pump & 0.0 & & 0.00 & & 0 & \\
\hline & 4 & 0.750 & cold & & $\begin{array}{l}\text { vert } \\
\text { et }\end{array}$ & 8.0 & & 1.60 & & 0 & \\
\hline & 4 & 0.750 & cold & & $u b$ & 1.0 & 9.0 & 0.20 & 1.80 & 0 & \\
\hline & 4 & 0.750 & cold & & $\begin{array}{l}\text { vert } \\
\text { hor et }\end{array}$ & 3.0 & 3.00 & 0.60 & 0.60 & 0 & \\
\hline & 4 & 0.750 & cold & & $\mathrm{ub}$ & 8.0 & 8.00 & 1.60 & 1.60 & 0 & \\
\hline & 4 & 0.750 & cold & & hor et & 1.0 & 1.00 & 0.20 & 0.20 & 0 & \\
\hline & 4 & 0.750 & cold & & $\mathrm{ub}$ & 3.0 & 3.00 & 0.60 & 0.60 & 0 & \\
\hline & 4 & 0.750 & cold & & $\begin{array}{l}\text { vert } \\
\text { et }\end{array}$ & 1.0 & & 2.00 & & 0 & \\
\hline & $1-3$ & 3.000 & hot & & waLL & 0.0 & & 0.00 & & 25 & \\
\hline 68 & $1-3$ & 3.000 & hot & $w$ & hor et & 3.0 & & 0.20 & & 25 & \\
\hline 68 & $1-3$ & 3.000 & hot & $\mathbf{w}$ & h & 2.0 & & 0.10 & & 25 & \\
\hline 68 & $1-3$ & 3.000 & hot & $\mathbf{w}$ & $\mathbf{h}$ & 15.0 & & 1.00 & & 25 & \\
\hline 68 & $1-3$ & 3.000 & hot & $w$ & h & 12.0 & & 8.00 & & 25 & \\
\hline 68 & $1-3$ & 3.000 & hot & $w$ & hor et & 1.0 & & 0.10 & & 25 & \\
\hline 68 & $1-3$ & 3.000 & hot & $w$ & $\mathbf{h}$ & 12.0 & & 0.80 & & 25 & \\
\hline 68 & $1-3$ & 3.000 & hot & $w$ & $\mathbf{h}$ & 12.0 & & 0.80 & & 0 & \\
\hline 68 & $1-3$ & 3.000 & hot & $w$ & $\mathbf{h}$ & 12.0 & & 0.80 & & 25 & \\
\hline 68 & $1-3$ & 3.000 & hot & w & $h$ & 12.0 & & 0.80 & & 25 & \\
\hline 68 & $1-3$ & 3.000 & hot & w & h & 12.0 & & 0.80 & & 25 & \\
\hline
\end{tabular}




\begin{tabular}{|c|c|c|c|c|c|c|c|c|c|c|c|}
\hline $\begin{array}{l}\text { 1Line } \\
\text { No }\end{array}$ & Unit & $\begin{array}{l}\text { Pipe } \\
\text { Size } \\
\text { (in) }\end{array}$ & Temp & $\begin{array}{l}\text { Conn } \\
\text { Type }\end{array}$ & $\begin{array}{l}\text { Support } \\
\text { Type }\end{array}$ & $\begin{array}{l}\text { Vert } \\
\text { Span } \\
\text { (ft) }\end{array}$ & $\begin{array}{l}\text { Horia } \\
\text { Span } \\
\text { (ft) }\end{array}$ & $\begin{array}{l}\text { Norm } \\
\text { Vert } \\
\text { Span } \\
\text { (ft) }\end{array}$ & $\begin{array}{l}\text { Norm } \\
\text { Horz } \\
\text { Span } \\
\text { (ft) }\end{array}$ & $\begin{array}{l}\text { Plant } \\
\text { Elevation } \\
\text { Above } \\
\text { Grade }\end{array}$ & Remarks \\
\hline 68 & $1-3$ & 3.000 & hot & $w$ & & 12.0 & & 0.80 & & 25 & \\
\hline 68 & $1-3$ & 3.000 & hot & $\mathbf{w}$ & stantion & 6.0 & 115.00 & 0.40 & 7.70 & 25 & \\
\hline 68 & $1-3$ & 3.000 & hot & $w$ & $\mathbf{h}$ & 6.0 & & 0.40 & & 25 & \\
\hline 68 & $1-3$ & 3.000 & hot & $w$ & $\mathbf{h}$ & 20.0 & & 1.30 & & 25 & \\
\hline 68 & $1-3$ & 3.000 & hot & $\mathbf{w}$ & $\mathbf{h}$ & 20.0 & 46.00 & 1.30 & 1.70 & 0 & \\
\hline 68 & $1-3$ & 12.00 & hot & $\mathbf{w}$ & wall & 0.0 & & 0.00 & & 0 & \\
\hline 69 & $1-3$ & 12.00 & hot & $\mathbf{w}$ & hor et & 10.0 & & 0.30 & & 0 & \\
\hline 69 & $1-3$ & 12.00 & hot & $\mathbf{w}$ & anchor & 10.0 & 20.00 & 0.30 & 0.60 & 0 & \\
\hline 69 & $1-3$ & 12.00 & hot & $\mathbf{w}$ & hor et & 10.0 & & 3.00 & & 0 & \\
\hline 69 & $1-3$ & 12,00 & hot & $\mathrm{w}$ & h & 6.0 & & 0.20 & & 0 & \\
\hline 69 & $1-3$ & 12.00 & hot & $w$ & h & 12.0 & & 0.40 & & 0 & \\
\hline 69 & $1-3$ & 12.00 & hot & $\mathbf{w}$ & hor et & 4.0 & & 0.10 & & 0 & \\
\hline 69 & $1-3$ & 12.00 & hot & $w$ & hor et & 10.0 & & 0.30 & & 0 & \\
\hline 69 & $1-3$ & 12.00 & hot & $\mathbf{w}$ & $\mathbf{h}$ & 4.0 & & 0.10 & & 0 & \\
\hline 69 & $1-3$ & 12.00 & hot & $\mathbf{w}$ & hor et & 4.0 & & 0.10 & & 0 & \\
\hline 69 & $1-3$ & 12.00 & hot & $\mathbf{w}$ & $\mathbf{h}$ & 8.0 & & 0.30 & & 0 & \\
\hline 69 & $1-3$ & 12.00 & hot & $\mathbf{w}$ & $\mathbf{h}$ & 24.0 & & 0.80 & & 0 & \\
\hline 69 & $1-3$ & 12.00 & hot & $\mathbf{w}$ & hor et & 21.0 & & 0.70 & & 0 & \\
\hline 69 & $1-3$ & 12.00 & bot & $\mathbf{w}$ & $\mathrm{h}$ & 1.0 & & 0.00 & & 0 & \\
\hline 69 & $1-3$ & 12.00 & hot & $w$ & hor et & 12.0 & & 0.30 & & 0 & \\
\hline 69 & $1-3$ & 12.00 & hot & $w$ & $\mathbf{h}$ & 4.0 & & 0.10 & & 0 & \\
\hline 69 & $1-3$ & 12.00 & hot & $\mathbf{w}$ & $\mathbf{h}$ & 15.0 & & 0.50 & & 0 & \\
\hline 69 & $1-3$ & 12.00 & hot & $\mathbf{w}$ & $\mathbf{h}$ & 15.0 & & 0.50 & & 0 & \\
\hline 69 & $1-3$ & 12.00 & hot & $\mathbf{w}$ & $\mathbf{h}$ & 15.0 & & 0.50 & & 0 & \\
\hline 69 & $1-3$ & 12.00 & hot & $\mathbf{w}$ & h & 15.0 & & 0.50 & & 0 & \\
\hline 69 & $1-3$ & 12.00 & hot & $\mathbf{w}$ & $\mathbf{h}$ & 18.0 & & 0.60 & & 0 & \\
\hline 69 & $1-3$ & 12.00 & hot & $\mathbf{w}$ & h & 18.0 & & 0.60 & & 0 & \\
\hline 69 & $1-3$ & 12.00 & hot & $\mathbf{w}$ & h & 18.0 & & 0.60 & & 0 & \\
\hline 69 & $1-3$ & 12.00 & hot & $\mathbf{w}$ & h & 16.0 & & 0.50 & & 0 & \\
\hline 69 & $1-3$ & 12.00 & hot & $\mathbf{w}$ & hor et & 10.0 & & 0.30 & & 0 & \\
\hline 69 & $1-3$ & 12.00 & hot & $\mathbf{w}$ & wall & 12.0 & 261.00 & 0.30 & 8.70 & 0 & \\
\hline 70 & $1-3$ & 3.000 & cold & $\mathbf{w}$ & $u b$ & 0.0 & & 0.00 & & 0 & \\
\hline
\end{tabular}




\begin{tabular}{|c|c|c|c|c|c|c|c|c|c|c|c|}
\hline $\begin{array}{l}\text { 1Line } \\
\text { No }\end{array}$ & Unit & $\begin{array}{l}\text { Pipe } \\
\text { Size } \\
\text { (in) }\end{array}$ & Temp & $\begin{array}{l}\text { Conn } \\
\text { Type }\end{array}$ & $\begin{array}{l}\text { Support } \\
\text { Type }\end{array}$ & $\begin{array}{l}\text { Vert } \\
\text { Span } \\
(\mathrm{ft})\end{array}$ & $\begin{array}{l}\text { Horia } \\
\text { Span } \\
(f t)\end{array}$ & $\begin{array}{l}\text { Norm } \\
\text { Vert } \\
\text { Span } \\
\text { (ft) }\end{array}$ & $\begin{array}{l}\text { Norm } \\
\text { Horz } \\
\text { Span } \\
\text { (ft) }\end{array}$ & $\begin{array}{l}\text { Plant } \\
\text { Elevation } \\
\text { Above } \\
\text { Grade }\end{array}$ & Remarks \\
\hline 70 & $1-3$ & 3.000 & cold & $w$ & hor et & 6.0 & & 0.50 & & 0 & \\
\hline 70 & $1-3$ & 3.000 & cold & w & h & 10.0 & & 0.80 & & 0 & \\
\hline 70 & $1-3$ & 3.000 & cold & $\mathbf{w}$ & $\mathrm{h}$ & 6.0 & & 0.50 & & 0 & \\
\hline 70 & $1-3$ & 3.000 & cold & $\mathbf{w}$ & $h$ & 18.0 & & 1.50 & & 0 & \\
\hline 70 & $1-3$ & 3.000 & cold & $\mathbf{w}$ & $h$ & 12.0 & & 1.00 & & 0 & \\
\hline 70 & $1-3$ & 3.000 & cold & $\mathbf{w}$ & h & 10.0 & & 0.80 & & 0 & \\
\hline 70 & $1-3$ & 3.000 & cold & $\mathbf{w}$ & $\mathbf{h}$ & 15.0 & & 1.30 & & 0 & \\
\hline 70 & $1-3$ & 3.000 & cold & $\mathbf{w}$ & $\mathbf{h}$ & 10.0 & & 0.80 & & 0 & \\
\hline 70 & $1-3$ & 3.000 & cold & $\mathbf{w}$ & h & 12.0 & & 1.00 & & 0 & \\
\hline 70 & $1-3$ & 3.000 & cold & $\mathrm{w}$ & $\mathbf{h}$ & $15.0^{\circ}$ & & 1.30 & & 0 & \\
\hline 70 & $1-3$ & 3.000 & cold & $\mathbf{w}$ & $\mathbf{h}$ & 15.0 & & 1.30 & & 0 & \\
\hline 70 & $1-3$ & 3.000 & cold & $\mathbf{w}$ & $\mathbf{h}$ & 15.0 & & 1.30 & & 0 & \\
\hline 70 & $1-3$ & 3.000 & cold & $\mathbf{w}$ & h & 12.0 & & 1.00 & & 0 & \\
\hline 70 & $1-3$ & 3.000 & cold & $\mathbf{w}$ & h & 12.0 & & 1.00 & & 0 & \\
\hline 70 & $1-3$ & 3.000 & cold & $\mathbf{w}$ & h & 12.0 & & 1.00 & & 0 & \\
\hline 70 & $1-3$ & 3.000 & cold & $w$ & $\mathrm{dc}$ & 2.0 & 182.00 & 0.20 & 15.20 & 0 & \\
\hline 71 & $1-3$ & 6.000 & cold & $w$ & $\mathrm{dc}$ & 0.0 & & 0.00 & & 0 & \\
\hline 71 & $1-3$ & 6.000 & cold & $\mathbf{w}$ & h & 3.0 & & 0.20 & & 0 & \\
\hline 71 & $1-3$ & 6.000 & cold & $\mathbf{w}$ & h & 24.0 & & 1.40 & & 0 & \\
\hline 71 & $1-3$ & 6.000 & cold & $\mathbf{w}$ & $\mathbf{h}$ & 32.0 & & 1.90 & & 0 & \\
\hline 71 & $1-3$ & 6.000 & cold & $w$ & hor el & 18.0 & & 1.10 & & 0 & \\
\hline 71 & $1-3$ & 6.000 & cold & $\mathbf{w}$ & h & 3.0 & & 0.20 & & 0 & \\
\hline 71 & $1-3$ & 6.000 & cold & $\mathrm{w}$ & h & 12.0 & & 0.70 & & 0 & \\
\hline 71 & $1-3$ & 6.000 & cold & $\mathbf{w}$ & h & 15.0 & 107.00 & 0.90 & 6.30 & 0 & \\
\hline 72 & 13 & 12.00 & hot & $\mathbf{w}$ & $d c$ & 0.0 & & 0.00 & & 60 & \\
\hline 72 & $1-3$ & 12.00 & hot & $\mathbf{w}$ & $\operatorname{sh}$ & 20.0 & & 0.60 & & 60 & \\
\hline 72 & $1-3$ & 12.00 & hot & $w$ & sh & 15.0 & & 0.50 & & 0 & \\
\hline 72 & $1-3$ & 12.00 & hot & $w$ & sh & 36.0 & & 1.20 & & 60 & \\
\hline 72 & $1-3$ & 12.00 & hot & $w$ & snubber & 30.0 & 91.00 & 1.00 & 3.00 & 0 & \\
\hline 72 & $1-3$ & 12.00 & hot & $w$ & sh & 36.0 & & 1.20 & & 0 & \\
\hline 72 & $1-3$ & 12.00 & hot & $\mathbf{w}$ & $\mathrm{dc}$ & 4.0 & 40.00 & 0.10 & 1.30 & 0 & \\
\hline 73 & $1-3$ & 4.000 & hot & $w$ & $d c$ & 0.0 & & 0.00 & & 60 & \\
\hline
\end{tabular}




\begin{tabular}{|c|c|c|c|c|c|c|c|c|c|c|c|}
\hline $\begin{array}{l}\text { 1Line } \\
\text { No }\end{array}$ & Unit & $\begin{array}{l}\text { Pipe } \\
\text { Size } \\
\text { (in) }\end{array}$ & Temp & $\begin{array}{l}\text { Conn } \\
\text { Type }\end{array}$ & $\begin{array}{l}\text { Support } \\
\text { Type }\end{array}$ & $\begin{array}{l}\text { Vert } \\
\text { Span } \\
\text { (ft) }\end{array}$ & $\begin{array}{l}\text { Horia } \\
\text { Span } \\
\text { (ft) }\end{array}$ & $\begin{array}{l}\text { Norm } \\
\text { Vert } \\
\text { Span } \\
\text { (ft) }\end{array}$ & $\begin{array}{l}\text { Norm } \\
\text { Horz } \\
\text { Span } \\
\text { (ft) }\end{array}$ & $\begin{array}{l}\text { Plant } \\
\text { Elevation } \\
\text { Above } \\
\text { Grade }\end{array}$ & Remarks \\
\hline 73 & $1-3$ & 4.000 & hot & w & h & 4.0 & & 0.20 & & 60 & \\
\hline 73 & $1-3$ & 4.000 & hot & $\mathbf{w}$ & anchor & 12.0 & 16.00 & 0.70 & 0.90 & 60 & \\
\hline 73 & $1-3$ & 4.000 & hot & $\mathbf{w}$ & hor el & 12.0 & & 0.70 & & 60 & \\
\hline 73 & $1-3$ & 4.000 & hot & $\mathbf{w} \cdot$ & $\mathrm{h}$ & 6.0 & & 0.30 & & 60 & \\
\hline 73 & $1-3$ & 4.000 & hot & $\mathbf{w}$ & $\mathrm{h}$ & 12.0 & & 0.70 & & 60 & \\
\hline 73 & $1-3$ & 4.000 & hot & $\mathbf{w}$ & h & 8.0 & & 0.50 & & 0 & \\
\hline 73 & $1-3$ & 4.000 & hot & $\mathbf{w}$ & hor el & 6.0 & & 0.30 & & 60 & \\
\hline 73 & $1-3$ & 4.000 & hot & w & hor el & 6.0 & & 0.30 & & 60 & \\
\hline 73 & $1-3$ & 4.000 & hot & $w$ & anchor & 8.0 & 58.00 & 0.50 & 3.40 & 60 & \\
\hline 73 & $1-3$ & 4.000 & hot & $\mathbf{w}$ & sh & 8.0 & 8.00 & 0.50 & 0.50 & 60 & \\
\hline 73 & $1-3$ & 4.000 & hot & $\mathbf{w}$ & riser & 2.0 & 10.0 & 0.10 & 0.60 & 60 & \\
\hline 74 & $1-3$ & 1.000 & cold & SW & dc & 0.0 & & 0.00 & & 0 & \\
\hline 74 & $1-3$ & 1.000 & cold & SW & ub & 2.0 & 2.00 & 0.30 & 0.30 & 0 & \\
\hline 74 & $1-3$ & 1.000 & cold & sw & hor el & 2.0 & & 0.30 & & 0 & \\
\hline 74 & $1-3$ & 1.000 & cold & sw & h & 10.0 & & 1.40 & & 0 & \\
\hline 74 & $1-3$ & 1.000 & cold & SW & hor el & 1.0 & & 0.10 & & 0 & \\
\hline 74 & $1-3$ & 1.000 & cold & SW & bracket & 12.0 & & 1.70 & & 0 & \\
\hline 74 & $1-3$ & 1.000 & cold & sw & bracket & 10.0 & & 1.40 & & 0 & \\
\hline 74 & $1-3$ & 1.000 & cold & SW & h & 30.0 & & 4.30 & & 0 & \\
\hline 74 & $1-3$ & 1.000 & cold & SW & $\mathrm{h}$ & 18.0 & & 2.60 & & 0 & \\
\hline 74 & $1-3$ & 1.000 & cold & SW & h & 15.0 & & 2.10 & & 0 & \\
\hline 74 & $1-3$ & 1.000 & cold & SW & hor el & 6.0 & & 0.90 & & 0 & \\
\hline 74 & $1-3$ & 1.000 & cold & SW & ub & 12.0 & 116.0 & 1.70 & 16.60 & 0 & \\
\hline 74 & $1-3$ & 1.000 & cold & SW & ub & 18.0 & 18.00 & 2.60 & 2.60 & 0 & \\
\hline 74 & $1-3$ & 1.000 & cold & sw & pipe & 8.0 & 8.00 & 1.10 & 1.10 & 0 & \\
\hline 75 & $1-3$ & 3.000 & hot & $\mathbf{w}$ & riser & 0.0 & & 0.00 & & 20 & \\
\hline 75 & $1-3$ & 3.000 & hot & $\mathbf{w}$ & hor el & 4.0 & & 3.00 & & 20 & \\
\hline 75 & $1-3$ & 3.000 & hot & $\mathbf{w}$ & hor el & 3.0 & & 0.20 & & 20 & \\
\hline
\end{tabular}


Notations:

$\begin{array}{ll}\mathrm{csh}= & \begin{array}{l}\text { constant spring hanger } \\ \text { design temperature equal to or less than } 150^{\circ} \mathrm{F}\end{array} \\ \mathrm{dc}= & \begin{array}{l}\text { discontinue mapping run } \\ \mathrm{h}=\end{array} \\ \text { hanger support } \\ \mathrm{hor} \text { el }= & \text { horizontal elbow } \\ \mathrm{hot}= & \text { design temperature greater than } 150^{\circ} \mathrm{F} \\ \mathrm{sh}= & \text { spring hanger support } \\ \mathrm{sw}= & \text { socket welded connection } \\ \mathrm{t}= & \text { threaded connection } \\ \mathrm{ub}= & \mathrm{u} \text { bolt support } \\ \mathrm{w}= & \text { welded connection }\end{array}$

Norm Vert Span = the horizontal span between vertical supports divided by the suggested horizontal deadweight span given in Table NF 3611.1 of ASME BPVC Code Section III

Norm Hor. Span = the horizontal span between lateral supports divided by the suggested horizontal deadweight span given in Table NF 3611.1 of ASME BPVC Code Section III 


\section{Appendix G: Burbank Power Plant}

\section{G.0 Burbank Power Plant}

\section{G.1 Plant Description}

The Burbank Public Service Department presently operates two steam power plants designated the Magnolia and Olive plants with four operating units each. The plants are located on the eastern edge of the central San Fernando Valley on a flat alluvial site as shown in Figure G.1.

The total continuous net capability for both plants is currently $226 \mathrm{Mwe}$ on oil and $233 \mathrm{Mwe}$ on gas. Operable generating units on the Magnolia-Olive site are:

\section{Magnolia Plant}

$\begin{array}{llccc}\text { Unit } & \text { Type } & \text { Oil } & \text { Gas } & \text { Installed } \\ \text { M-2 } & \begin{array}{l}\text { Steam Turbine } \\ \text { (Combined Cycle) }\end{array} & - & - & 1943 \\ & \text { Steam Turbine } & 20 \mathrm{MW} & 20 \mathrm{MW} & 1949 \\ \mathrm{M}-3 & \text { Steam Turbine } & 28 \mathrm{MW} & 30 \mathrm{MW} & 1953 \\ \mathrm{M}-5 & \text { Combustion Turbine } & 17 \mathrm{MW} & 17 \mathrm{MW} & 1969 \\ & & 76 \overline{\mathrm{MW}} & 78 \overline{\mathrm{MW}}^{*} & \end{array}$

*Includes 11 MW output from Magnolia 2 when operated in combined cycle with Olive 4.

Olive Plant

Net Continuous

Capability

\begin{tabular}{|c|c|c|c|c|}
\hline Unit & Type & $\underline{\text { Oil }}$ & $\underline{\text { Gas }}$ & Installed \\
\hline $0-1$ & Steam Turbine & $42 \mathrm{MW}$ & $42 \mathrm{MW}$ & 1959 \\
\hline $0-2$ & Steam Turbine & $60 \mathrm{MW}^{* *}$ & 1964 & \\
\hline a & Combustion Turbine & $19 \mathrm{MW}$ & $22 \mathrm{MW}$ & 1972 \\
\hline $0-6$ & Combustion Turbine & $31 \mathrm{MW}$ & $31 \mathrm{MW}$ & 1975 \\
\hline
\end{tabular}

$$
15 \overline{\mathrm{MW}} \quad 15 \overline{\mathrm{MW}}
$$

**Includes $5 \mathrm{MW}$ available from the Olive 3 heat recovery steam generator. The $M-3, M-4$ and $0-1$ and $0-2$ units are of particular interest because they are steam turbine units having piping which is more characteristic of nuclear power plants and 0-3 and 0-4 were not in existence at the time of the San Fernando earthquake. The 0-2 unit includes a $55 \mathrm{KW}$ turbine generator with reheat. The initial steam design pressure and temperature is 1450 psig and $1000^{\circ} \mathrm{F}$. The boiler has a maximum steam capacity of $440,000 \mathrm{Lbs} / \mathrm{hr}$. 
The Magnolia and Olive Units consist of steel-framed boiler structures, concrete turbine-steam generator pedestals, and a two-story concrete masonry control building that houses the switchgear and control rooms.

\section{G.2 Summary Description of Effects From The San Fernando Earthquake}

\section{G.2.1 Olive Plant}

The Olive units were tripped off the line by the earthquake on February 9th at 0600:42. Olive No. 1 was off the line 2 hours 9 minutes. Olive No. 2 was off the line 2 hours 24 minutes.

Both Olive Plant units 01 and 02 were tripped off the line by "Differential Relay" action resulting from shaking the relay contacts together during the earthquake. Relay action automatically transferred station power to the "Start-up Transformer."

The Watch Engineer made an attempt to reset the Olive No. 1 turbine stop valve but upon returning to the control room he determined that all station power was lost. Without auxiliary power turbines slowed down. Vacuum was not broken in an attempt to prolong the roll.

\section{G.2.2 Magnolia Plant}

Both Magnolia Units No. 2 and No. 3 which were in operation at the time of the earthquake were knocked off the line as a result of the earthquake. Magnolia No. 2 was off the line 2 hours 43 minutes. Magnolia No. 3 was off the line 3 hours 28 minutes.

During the earthquake a fuel oil gage line on the boiler front at Magnolia No. 3 was broken spraying fuel oil over the boiler front and floor and through the grating down to the first floor. The resulting reduced fuel oil pressure and poor boiler ignition convinced the Watch Engineer he had to kill M-3 boiler fires and trip the turbine.

On Magnolia No. 1 and 2 the Auxiliary Generator started. However, the draft fans and feed pumps could not be started so the boiler fires had to be killed and the turbine tripped.

The Auxiliary Generator continued to run and draw steam from the now unfired boiler so the Assistant Engineer closed the steam to the Auxiliary Turbine.
Both Magnolia No. 2 and 3 turbines were kept rolling with steam since both are equipped with steam driven oil pumps so bearing lubrication and hydraulic control of No. 3 stop valve is possible even without station power. 


\section{G.3 Time Sequence of Events Following The Earthquake}

The earthquake event sequence at the Burbank Power Plants due to the San Fernando earthquake as described in Power Plant log was as follows:

DATE

2/9/71

TIME

0600

\section{SYSTEMS}

System Load - $79.0 \mathrm{mw}$.

Generation - 34.0 MW.

Intertie - 46.0 MW.

0600:42

Strong earthquake.

0602

Lost all generation, several $4 \mathrm{Kv}$. feeders and $34.5 \mathrm{Kv}$. Transmission Lines OCB's relayed open, at 0610 Burbank-Toluca Valley $69 \mathrm{Kv}$. Lines were opened or relayed open at $R>S>$ "E" only, system black.

Set-up 34.5 Kv. busses at Burbank Sub. to get auxiliary power to Olive and Magnolia plants with Magnolia Generator No. 5 on Black-out condition, but was unable to due to earthquake closing contacts on critical relays, including main transformer.

Magnolia Terry Auxiliary Generator came on automatically, but dropped off.

0605 to $0635 \quad$ No communication with Los Angeles Dispatcher.

0625 Manually put Magnolia Terry Auxiliary Generator on $2500 \mathrm{~V}$. Bus No. 2 and $2500 \mathrm{~V}$. Bus No. 3 through 2500 V. Bus No. 4, unable to carry auxiliary equipment due to low steam pressure.

0630 Several attempts made to get Magnolia Generator No. 5 on, without success.

0635 Made contact with Los Angeles dispatcher on Bell System phone, they will get a hot line to them.

0637 Burbank-Toluca-Valley $69 \mathrm{Kv}$. Line closed at R.S. " $\mathrm{E}$ ", auxiliary equipment at Olive and Magnolia plants energized. Started picking up $4 \mathrm{Kv}$. Feeders at Alameda, Burbank and McCambridge Subx. BurbankToluca-Valley No. $169 \mathrm{Kv}$. Line loaded up to $40.0 \mathrm{MW}$.

0713 Cleared all $4 \mathrm{Kv}$. ACB's at Pacific Sub., bad regulators threw oil over entire rack.

$0720 \quad$ Energized NBC Sub.

0727 Los Angeles Dispatcher says to reduce draw at R.S. "E" to 5.0 MW Hoover, started opening 4 Kv. Feeders. Draw at R.S. "E" $33 \mathrm{MW}$.

0731 Made attempt to start Magnolia Generator No. 5, aborted.

0745 Closed Burbank-Toluca-Valley No. 269 Kv. Line at R.S. "E".

0749 Los Angeles Dispatcher says we are still overdrawing, we told Los Angeles Dispatcher wè were getting our 
generators on line and would reduce draw to $5.0 \mathrm{MW}$ Hoover.

0752

Draw at R.S. "E" reduced to 5.0 MW.

0757

Olive Generator No. 1 on line.

0800 Started picking up load as generation would permit.

0836 Olive Generator No. 2 on line.

0845 Magnolia Generator No. 2 on line.

$0930 \quad$ Magnolia Generator No. 3 on line.

\section{G.4 Earthquake Damage Summary}

\section{G.4.1 Olive Plant, Units 1 and 2}

Several relays tripped during the earthquake, taking both of the Olive units off line. According to the plant's trouble report, the two units were tripped by the action of one or more differential relays located on the main control panel on the second floor of the control building. Station power was still available at this time. Relay actuation caused the main steam stop valve to close in Unit 1. The watch engineer left the control room and reset the valve, returning the flow of steam to the turbine. At about this time, however, the two units lost their normal supply of station power front the outside grid. An attempt was made to supply station power to the Olive units by starting the Magnolia gas peaking unit however, tripped relays on the control panel prevented immediate start-up. Station power was lost for about half an hour until substation relays were reset in the Los Angeles power grid and station power returned from the outside. The furnaces of the two Olive units were purged, and the boilers were relit about an hour after the earthquake.

\section{G.4.1.1 Damage to Piping}

The following piping and related damage was noted at the Olive Plant:

1. A broken valve and pipe at the demineralizer tank

2. A broken front center-line guide on the Unit 2 boiler casing located at the top of the boiler structure.

The demineralized tank and attached piping that sustained damage in the earthquake are shown in Figure
2-4 of Appendix B of Reference G.1 and Figure 22 of Reference G.2.

\section{G.4.2 Magnolia Plant, Units 1 through 5}

Magnolia Units 2 and 3 were on line at the time of the earthquake and remained on line throughout the earthquake. A $11 / 2$ inch fuel-oil gage line as shown in Figure 4.22 of Volume 1 ruptured in Unit 3, spraying oil on the front face of the furnace and on the surrounding floor. This caused a drop in the fuel-oil pressure to the burners.

After the earthquake, the system load from the outside grid began to increase. the demand on the power generating stations remaining on line. This increased load on the small Magnolia units began to exceed their generating capacity. The increasing demand, combined with the reduced fuel-oil pressure and difficulty in maintaining proper builder combustion and steam pressure convinced the watch engineer that he had to manually trip both units of the Magnolia plant off line. All power to the station was lost. An attempt was then made to start the Magnolia Unit 5 gas peaking plant to supply the plant with power, but tripped relays prevented start-up. The main turbines on Magnolia Units 2 and 3 were kept rolling since they were equipped with steam-driven lubrication oil pumps supplied front eh residual steam in the boilers. About half an hour after the earthquake, station power was restored front eh outside grid. A few minutes later, plant engineers discovered the tripped relays on the Magnolia Unit 5 controls, reset them, and started a gas turbine fired peaking plant. Magnolia Units 2 and 3 were brought back on line about three hours after the earthquake.

\section{G.4.2.1 Damage to Piping}


The following piping and related damage was noted at the Maguolia Plant.

1. The demineralized-water tank in the plant yard was not anchored and shifted, breaking attached piping connections at near the base of the tank (see Figure 2-5 of Appendix B of Reference G.1 and Figure 23 of Reference G.2.

2. A fuel-oil gage line in Unit 3 broke (see Figure G.2).

3. A 2-inch-diameter pipe connecting to the Unit 3 main cooling-water line cracked. The plant operators thought this crack resulted in a minor leak since it did not impair restarting the plant.

4. The plant's demineralized cation tank shifted on its supports.

\section{G.5 Seismic Design Basis of Piping}

The Olive and Magnolia Units plant structures were designed for an equivalent static horizontal force of $0.20 \mathrm{~g}$. The design of equipment in the plant included no particular seismic design considerations other than normal floor anchorage based on operating requirements.' Piping is primarily rod-hung for deadweight support only. Generally, no provision for lateral restraint of piping was found.

The technical specification used for procurement of piping for the most recent steam turbine plant (Olive 2, 1964) is shown in Appendix C. It should be noted that the piping contractor was to supply all hangers, supports etc. to ASME B31.1, MSS SP-58 and AISC requirements. No mention was made of seismic requirements. The line list for the Olive 2 Unit is shown in Table 4.3 of Volume 1 of this report.

\section{G.6 Seismic Demand From The San Fernando Earthquake}

${ }^{1}$ Normally any rotating or reciprocal operating equipment would be bolted down in order to resist starting torques or reactions during normal operation. Such positive anchorage would normally be sufficient to resist earthquake effects up to a level to cause significant structural damage and failure of the building structure supporting and housing the equipment.
The Burbank Power plant is located about 14 miles from the epicenter of the San Fernando earthquake and about 4 miles from the causative fault. The estimated peak horizontal ground acceleration at the plant site was $0.35 \mathrm{~g}$ in the east-west direction and $0.29 \mathrm{~g}$ in the two horizontal directions and $0.14 \mathrm{~g}$ in the vertical direction. The plant is also supported by Alluvium. The $0.28 \mathrm{~g}$ PGA was scaled in the same ratio. The closest recorded time history motion and resultant ground response spectra demand for various values of damping in a nominal N-S, E-W and Vertical direction applicable to the Burbank Power Plant Site was recorded at 633 E. Broadway, Glendale is shown in Appendix C.4 of Reference G.3.

\section{G.7 References}

NRC Seismic Design Task Group and Stevenson and Associates, Report of the U.S. Regulatory Commission Piping Review Committee, "Summary and Evaluation of Historical Strong Motion Earthquake Seismic Response and Damage to Above Ground Industrial Piping," NUREG 1061 Vol. 2 Addendum, April 1985.

(G.2) Yanev, P.I. and Swan, S.W., "Pilot Program Report, Program for the Development of an Alternate Approach to Seismic Equipment Qualification," Vol. I Prepared for Seismic Qualification Utilities Group, by EQE Inc.

(G.3) Yanev, P.I. and Swan, S.W., "Pilot Program Report Appendices, Program for the Development of an Alternate Approach to Seismic Equipment Qualification," Vol. II Prepared for Seismic Qualification Utilities Group, by EQE Inc. 


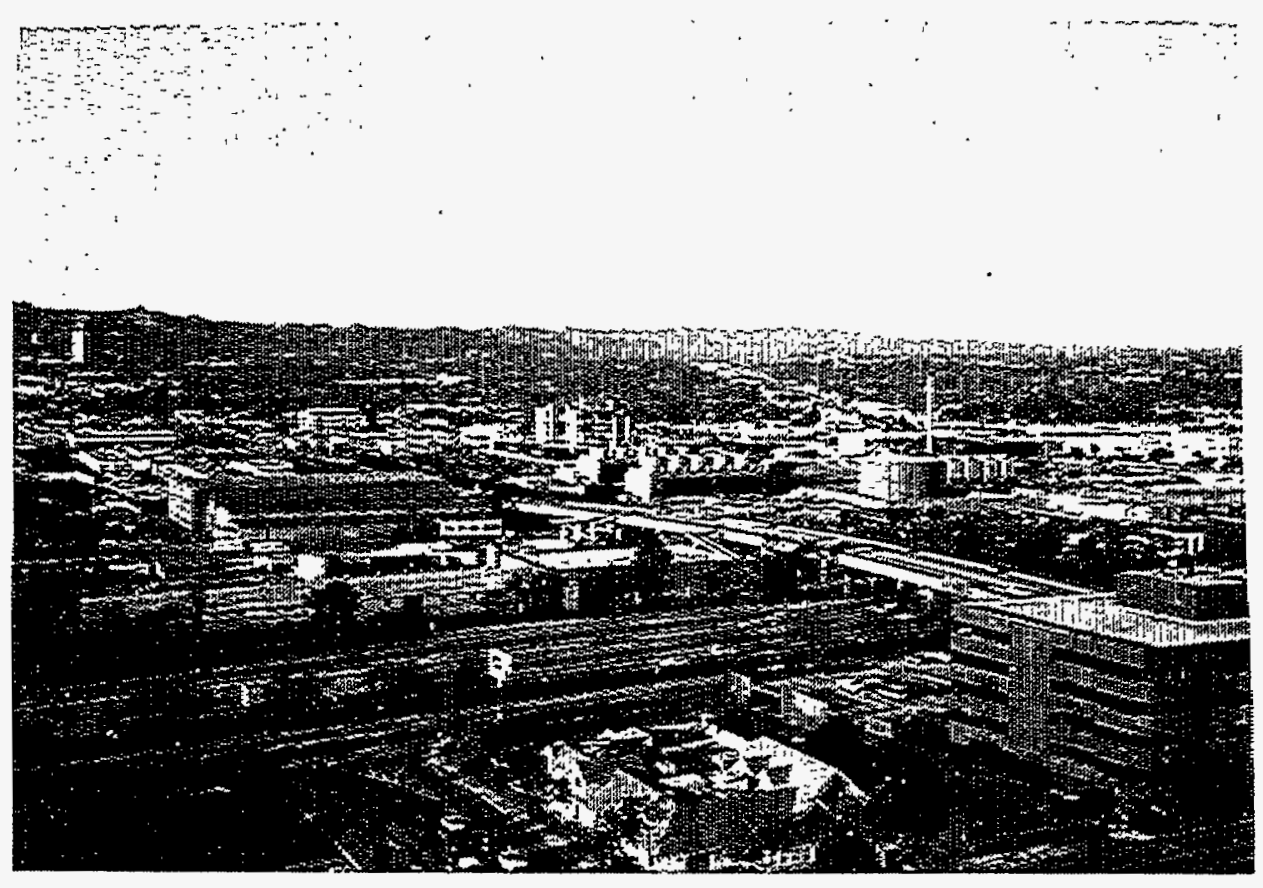

Figure G.1 Burbank Power Plant - Olive and Magnolia Units 


\section{Appendix H: El Centro Power Plant}

\section{H.0 El Centro Power Plant \\ H.1 Plant Description}

\section{H.1.1 Introduction}

The El Centro Power Plant is the principal electric power generating facility of the Imperial Irrigation District. The facility consists of four units that burn oil or natural gas. Units 1,2, and 3 were designed by Gibbs and Hill, and were built in 1949, 1952, and 1957, respectively. Unit 4 an $80-\mathrm{MW}$ facility designed by The Fluor Corporation, Ltd. was built in 1968. Figure H.I is a plot plan of the four units and associated fuel storage tank, cooling towers and transformer yard. In this evaluation most of the available information relates to Unit 4.

When Unit 4 was added, the existing station building was extended southward by adding three $31-\mathrm{ft}$ bays. There are no E-W walls between the units. A $2.75 \mathrm{ft}$ space between the last column line of Unit 3 and the first column line of Unit 4 was provided to allow for possible differential settlement. Thus, total southward extension was $95.75 \mathrm{ft}$. Figure H.2 is an elevation view that shows the three added bays of Unit 4 .

In the E-W direction, the width of each bay as well as the overall width of Unit 4 were made the same as those for the existing building. From east to west these widths are $30 \mathrm{ft}$ (service bay), $55 \mathrm{ft}$ (central or turbine bay), $25 \mathrm{ft}$ (heater bay), and $18 \mathrm{ft}$ (auxiliary bay), for a total of $128 \mathrm{ft}$. The boiler structure, from which the boilers are suspended, extends an additional $76.5 \mathrm{ft}$ westward from the building proper, for an overall E-W width of $204.5 \mathrm{ft}$ as shown in an elevation view in Figure H.3.

The heights of the service and turbine bays for unit 4 were the same as for the existing units. The operating floor remained at $20 \mathrm{ft}$ above grade. The height of the heater and auxiliary bays were increased to suit the requirements of the new equipment. The existing control room for Unit 3 was extended $34 \mathrm{ft}$ southward to serve Unit 4. A new air conditioning system was installed to serve the requirements of the larger control room and to provide make-up cooled air. The existing passenger elevator located at the southwest corner of Unit 3 provides access to the roof and the upper platforms of Boiler No. 4. This plant description was extracted from References $H .1$ and $H .2$ which contain additional description information.

\section{H.1.2 Foundation Media}

The soil at the El Centro Power Plant site consists of very deep alluvial deposits composed primarily of stiff to hard clay underlain with lamination of silty clay loam and sandy loam. Several sources of data were used to estimate the shear wave velocity to be used in calculating the soil stiffness:

- Dames \& Mcore report (H.3) indicates a shear strength of around 1500 psf.

- USGS report on the differential array gives average shear wave velocities as a function of depth (H.1, H.4).

- NUREG-0029, Vol. 1 (H.5) which indicates a shear wave velocity of about $650 \mathrm{ft} / \mathrm{s}$ at $10^{-2}$ percent shear strain These tests were for the soil at the Imperial Irrigation District Terminal Station located at the comer of Commercial Avenue and Third Street in El Centro, approximately $1 \mathrm{~km}$ from the plant.

In Ref. H.1 it was concluded that a shear wave velocity of $650 \mathrm{ft} / \mathrm{s}$ is representative of the site foundation media. This value is based primatily on the in-situ impulse test on soil conditions deemed representative of the plant. It represents an average value to a depth equal to the width of the foundation.

\section{H.1.3 Foundation}

The three main structures of Unit 4 the turbine building, the boiler support tower, and the turbinegenerator pedestal are founded on a single 12.2-ft-thick hollow honeycomb-like reinforced concrete foundations can be seen in Figures H.2 and H.3. The foundation of Unit 4 is structurally independent from the foundations for the other three units. The plan dimensions of the foundation are approximately $96 \mathrm{ft}$ by $207 \mathrm{ft}$. The bottom slab is 18-in. thick and rests atop unexcavated ground at El. $936.8 \mathrm{ft}$ The top of the foundation is at El. $949 \mathrm{ft}$ which corresponds to the existing site grade level. The top slab consists of 7-in.-thick pre-cast concrete panels supported on a girder system and 
"The area is also subject to seismic disturbances, and all equipment supplied shall be designed to resist seismic forces of $0.2 \mathrm{~g}$ magnitude."

\section{H.5. Seismic Demand from the Imperial 1979 Earthquake}

The dynamic characteristics and seismic demand requirements for the El Centro Steam Plant Unit 4 are perhaps the most thoroughly studied for a fossil power station to as yet appear in the literature.(H.1, H.2)

A significant set of time history accelerometer records was obtained for the Imperial 1979 earthquake from a 13-recording station local array that was located transverse to the Imperial fault through the town of El Centro. The time history motion (base line corrected) closest to the El Centro Steam Plant recorded by USGS station No. 5165 which was located at ground level in an instrument shelter at coordinates $32.796 \mathrm{~N}$ and $115.535 \mathrm{~W}$ is less than one half kilometer from the $\mathrm{El}$ Centro Power Plant as shown in Figure H.4.. It should be noted that the recording instrument was located on a relatively small concrete pad which is atypical of the location of most seismic strong motion recording instruments. Such instruments historically have been located on much larger building foundations. The larger mats are thought to have a smoothing effect on earthquake motions in much the same way large ships have less response to sea waves than do smaller ships. In order to compensate for this mat size effect it is suggested that the acceleration values shown in Figure H. 5 should be multiplied by a 0.6 factor.

In Ref. H.1 7 percent damped ground spectra based on the VSGS station No. 5165 recorded time history motions for the nominal N-S, E-W and vertical directions were developed as shown in Figures H.5a, b and $\mathrm{c}$ respectively. In addition the El Centro Unit \#4 building structures were dynamically modeled as shown in Figure 21 of Ref. H-1. Floor response spectra shown in Figures 3, 4 and 5 of Ref. H.1 were also developed for selected building locations as shown in Ref. H.1.

\section{H.6 Seismic Demand from the Superstition Hills Earthquake of November 24, 1987}

In Figure H.4 is also shown the location of the strong- motion recording accelerometers station in close proximity to the El Centro Steam Plant which recorded the Superstition Hills earthquake. This recording station is CSMIP Station 01335 and is located at the Imperial County Center in the free field at 9 th and Main St. El Centro within 0.75 miles of the El Centro steam plant. In Figures H.6 is shown the time history motion recorded (base line uncorrected) in El Centro from the November 24 Magnitude 6.0 event at CSMIP Station 01335.

Response spectra from the Superstition Hills earthquake time history acceleration recordings have not been generated. Peak ground acceleration at the plant is estimated to be the same as at the CSMIP Station, namely $0.36 \mathrm{~g}$ maximum horizontal component and $0.13 g$ vertical.

\section{H.7 References}

(H.1) Murray, R.C. et.al., "Equipment Response at the El Centro Steam Plant During the October 15, 1979 Imperial Valley Earthquake," NUREG/CR-1665 Prepared for the U.S. Nuclear Regulatory Commission, October 1980.

(H.2) Yanev, P.I. and Swan, S.W., "Pilot Program Report, Program for the Development of an Alternate Approach to Seismic Equipment Qualification," Vol. I Prepared for Seismic Qualification Utilities Group, by EQE Inc.

(H.3) Dames \& Moore, "Report of Soil and Foundation Investigation, El Centro Steam Station and Switching Station, El Centro, California," (1940).

(H.4) Bycroft, G. Noel, "El Centro California Differential Ground Motion Array," USGS Open-File Report No. $80-919$ (1980).

(H.5) Shannon \& Wilson, Inc., and Agbabian Associates, "Geotechnical and Strong Motion Earthquake Data from U.S. Accelerograph Stations, Ferndale, Cholame, and El Centro, California," NUREG-0029 (1976) Vol. 1.

The Fluor Corporation, Limited, "Ėngineering - Design and Construction Completion Report for the Imperial Irrigation District El Centro Steam Plant 80 MW Unit No. 4," Los Angeles, California (1968). 


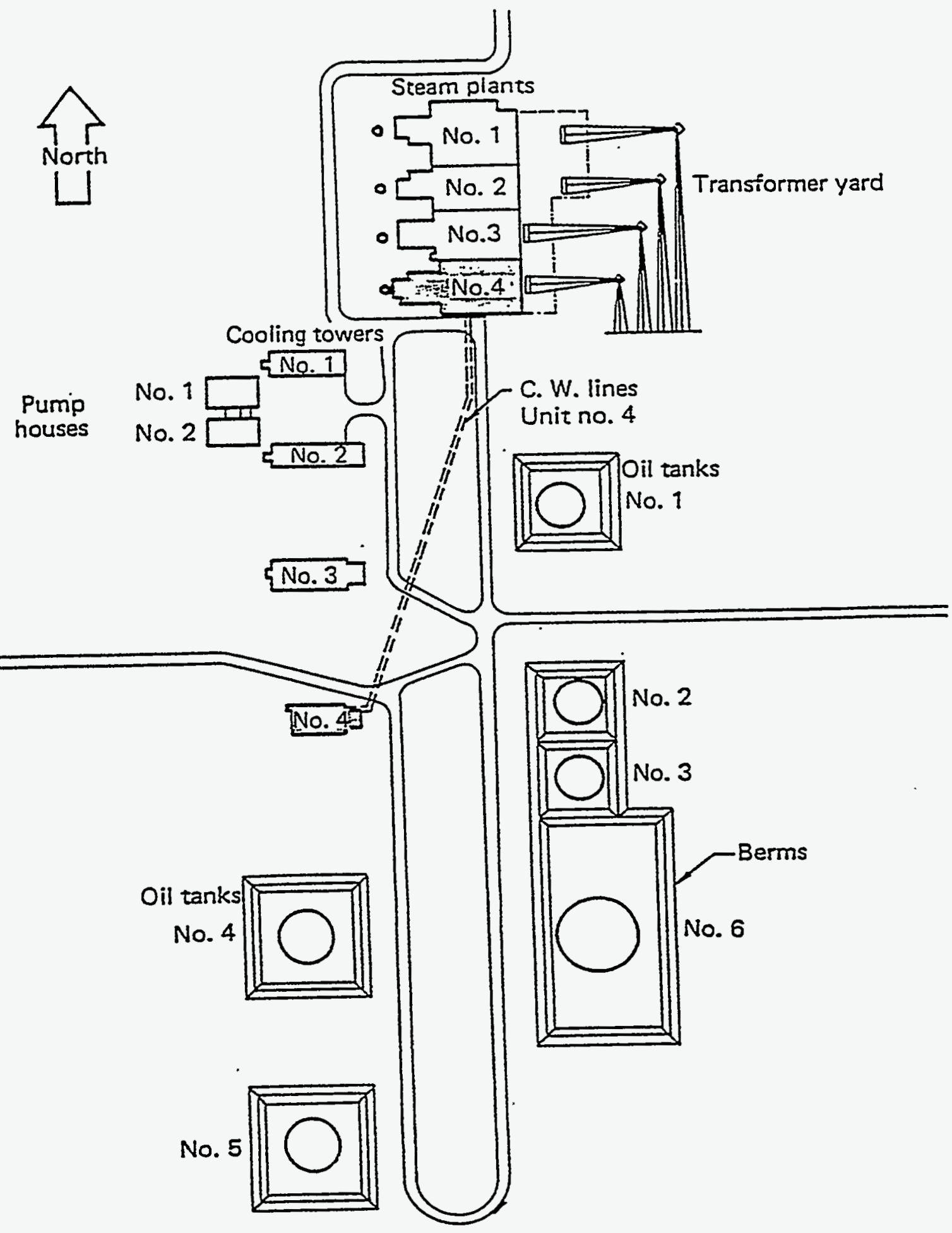

Figure H.1 Plot plan El Centro Steam Plant 


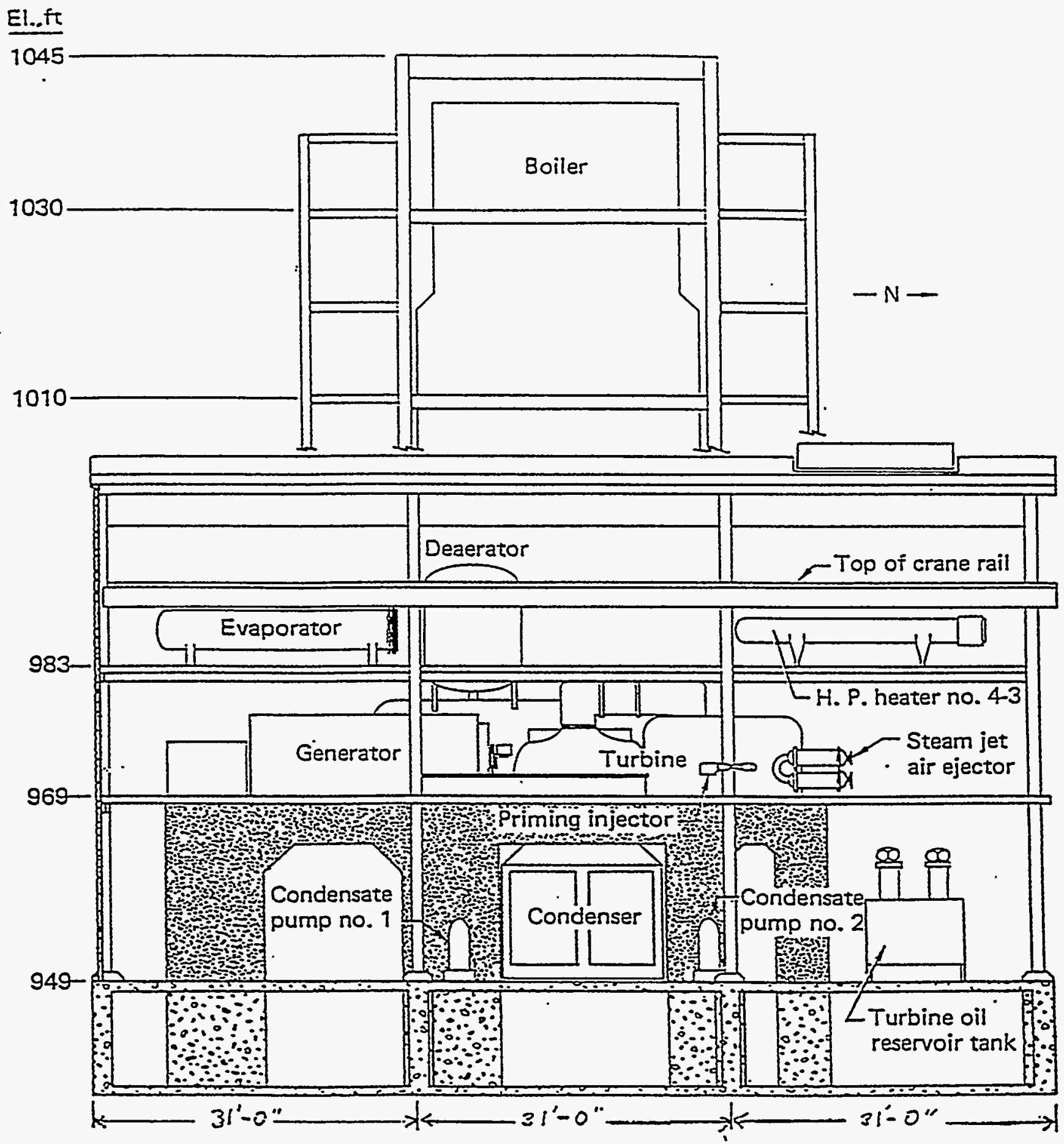

Figure H.2 N-S Elevation View of El Centro Unit 4 


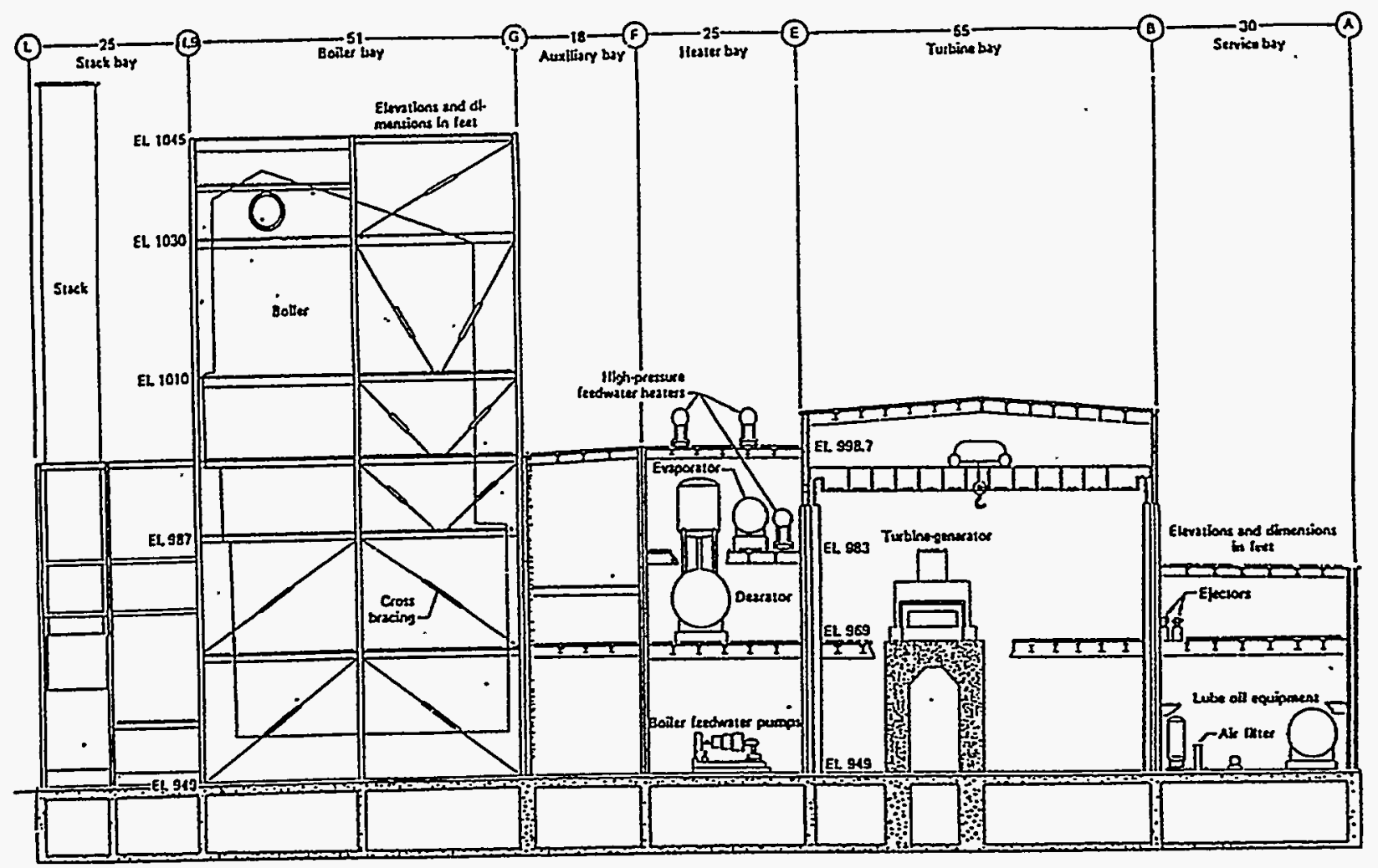

Figure H.3 E-W Elevation View of El Centro Unit 4 


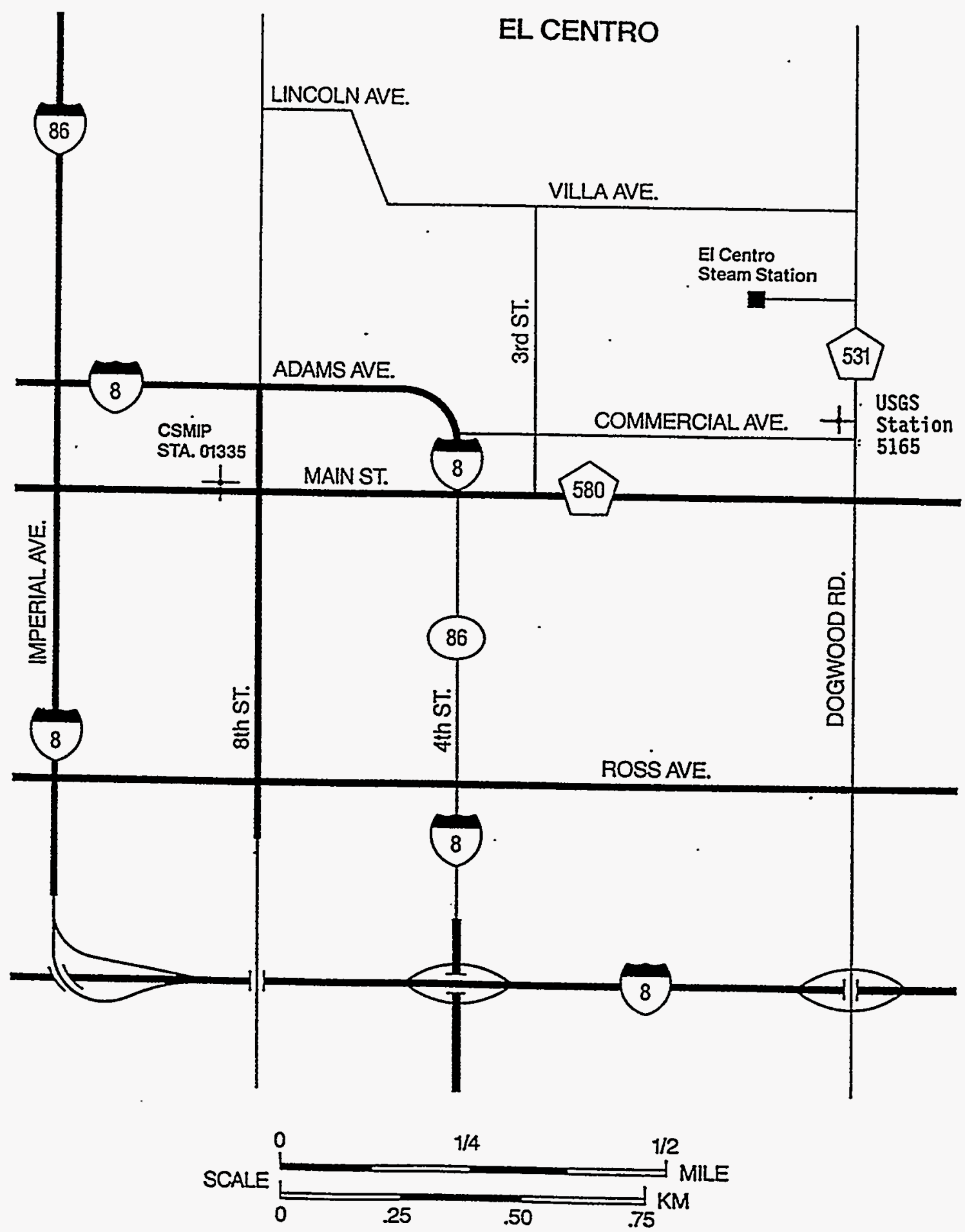

Figure H.4 Map of El Centro Showing Location of Recording Station CSMIP Station 01335 and USGS Station 5165 Relative to the El Centro Steam Station 

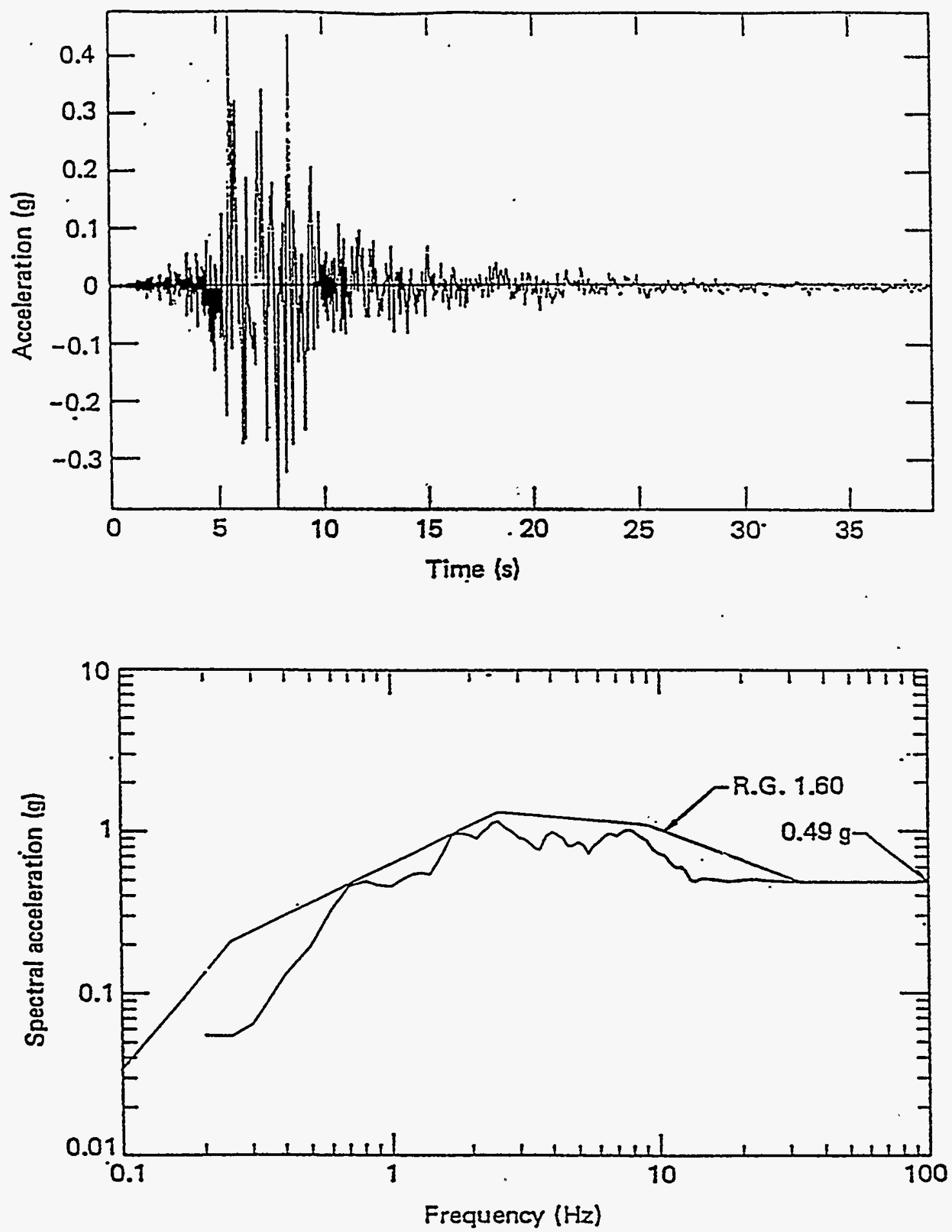

Figure H.5 (a) Recorded Time-History and Resultant Response Spectra at the VSGS Station No. 5165 Due to 1979 Earthquake in N-S Direction 


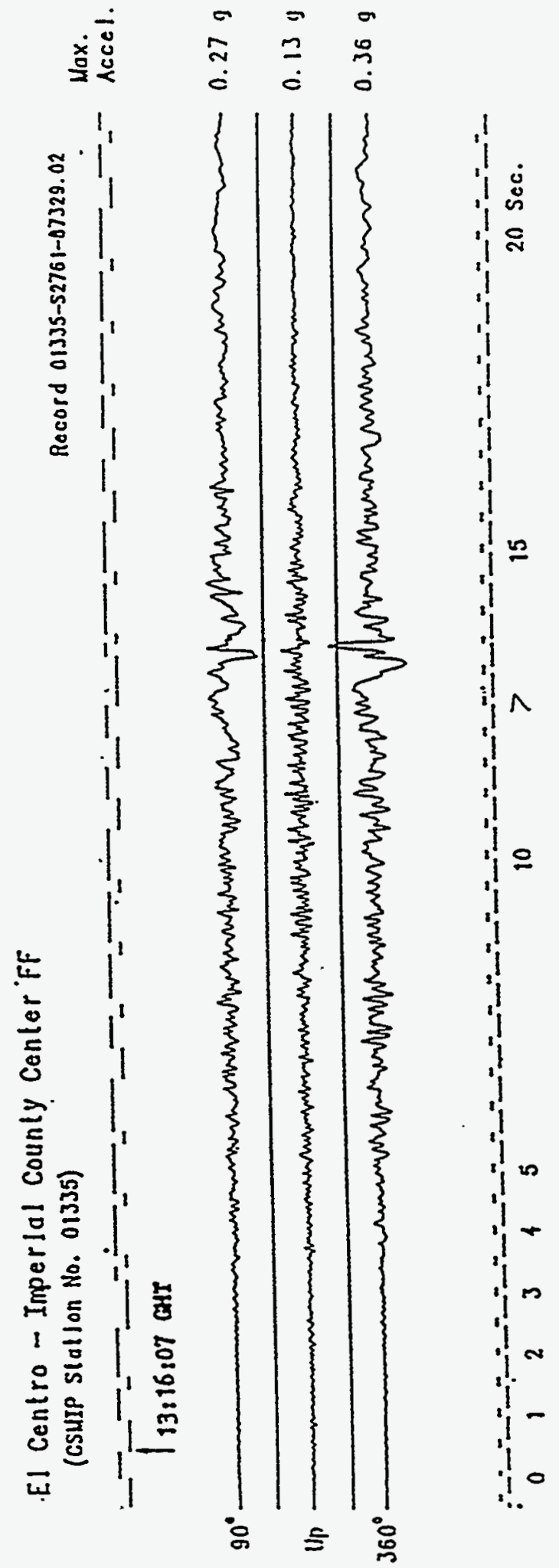

Figure H.6 Recorded Time-History at CSMIP Station No. 01335 Due to 1979 Earthquake 


\section{Appendix I: Glendale Power Plant}

\section{I.0 Glendale Power Plant}

\section{I.1 General Description}

The Glendale Power Station is owned and operated by the City of Glendale. It is located on the southern edge of the San Fernando valley on the west side of Interstate Highway 5 in a flat area of recent alluvia on the notth bank of the Los Angeles River. The plant currently consists of 8 units, 5 of which were installed at the time of the San Fernando earthquake in 1971. The basic data for these 5 stations is summarized as follows:

Duel Fired Gas and Oil Steam Turbine Generators

\begin{tabular}{|l|l|l|l|l|l|}
\hline & $\begin{array}{l}\text { No. 1 } \\
\text { Unit }\end{array}$ & $\begin{array}{l}\text { No. 2 } \\
\text { Unit }\end{array}$ & No. 3 Unit & No. 4 Unit & No. 5 Unit \\
\hline Date Installed & 1941 & 1947 & 1953 & 1959 & 1964 \\
\hline Name Plate KW & 20,000 & 20,000 & 20,000 & 44,000 & 44,000 \\
\hline Steam Pressure & $600 \mathrm{lb}$. & $600 \mathrm{lb}$. & $850 \mathrm{lb}$. & $1250 \mathrm{Ib}$. & $1250 \mathrm{lb}$. \\
\hline Turbine Manuf. & G.E. & G.E. & G.E. & G.E. & G.E. \\
\hline Steam Boiler Manuf. & $\begin{array}{l}\text { Combustion } \\
\text { Engineering }\end{array}$ & $\begin{array}{l}\text { Combustion } \\
\text { Engineering }\end{array}$ & $\begin{array}{l}\text { Babcock } \\
\text { \& Wilcox }\end{array}$ & $\begin{array}{l}\text { Riley } \\
\text { Stoker }\end{array}$ & $\begin{array}{l}\text { Riley } \\
\text { Stoker }\end{array}$ \\
\hline
\end{tabular}

All five units of the plant are housed in a continuous building, which consists of a large concrete basement and operating floor that supports steel-framed boiler structures similar in layout and appearance as shown in Figure 1.1. None of the units employ reheat. The turbine operating floor is located about 6 feet above grade which is closer to grade than any of the other power stations surveyed.

\section{I.2 Summary of Recorded Effects from the San Fernando Earthquake}

Units 3,4, and 5 were in operation at the time of the earthquake and they.continued to operate and to generate power during and after the earthquake. One and one-half hours after the earthquake, all three units were tripped because of system disturbances in the Los Angeles area grid. Units 3 and 4 were brought back on line 2 minutes later, Unit 5, nine minutes later.

\section{I.3 Time Sequence of Events Following the Earthquake}

The earthquake event sequence at the Glendale Plant due to the San Fernando earthquake as described in the Power Plant log was as follows: 
A. Steam generation 27 NMW.

B. Hydro generation 31 NMW.

0600 - Turbo-alternators in service.

A. No. 3 Unit @ $4 \mathrm{MW}$-on load block control.

B. No. 4 Unit (9) $13 \mathrm{MW}$-on load block control.

C. - No. 5 Unit @ $12.5 \mathrm{MW}$-on load block control.

1.Load Limit settings.
a. No. 3 Unit (9) 12.
b. $\quad$ No. 4 Unit (9) 29.
c. No. 5 Unit @ 33.

2. Boilers in service.
a. \#1-A \& 2 Boilers-pilot fire-gas fuel.
b. \#3 Boiler-gas fuel.
c. \#4 Boiler-oil fuel.
d. \#5 Boiler-gas fuel

(1) Gas fuel schedule-A-3.

0601 - Earthquake.

A. Received load block trip alarm on:

1. \#4 Unit and \#5 Unit.

a. \#3 Unit on load block control.

B. Received primary alarm:

1. \#1 Bank differential (\#1 Unit off the line).

2. Glendale-Rossmoyne \& Glendale-Grandview No. $34.5 \mathrm{KV}$ lines relayed.

3. Glendale-Howard North \& South, Glendale-Western $34.5 \mathrm{KV}$ lines remained in service.

4. Glendale-Grandview South, Glendale-Acacia East \& West, GlendaleFremont North \& South $34.5 \mathrm{KV}$ lines relayed at their respective stations.

5. Potential relay targets: \#2 Unit left (off the line), \#3 Unit both, \#4 Unit left, \#5 Unit left.

6. Nos. $3,4, \& 5$ Units stayed on the line, including auxiliary power.

C. High frequency.

1. Push back to receiving Station " $\mathrm{E}$ " approximately $14 \mathrm{MW}$.

a. Readjustment of units' output. 
(1) \#3 Unit-5Mw.

(2) \#4 Unit-5 MW.

(3) \#5 Unit- $5 \mathrm{MW}$.

Total 15 gross MW.

$0610 \quad-\quad$ Systems separation.

A. Reverse power to Receiving Station "E" 23 NMW.

1. Reverse power relay at Western (3) 58.5 Hertz $(-6 \mathrm{MW}$ to $-23 \mathrm{MW})$.

0611 - Messrs. Miller and Taylor arrived at steam plant.

A. Mr. Miller contacted Mr. Lou Barrell, Glendale Chief Substation Operator, asking him to pick up $34.5 \mathrm{KV}$ transmission lines to other sub-stations.

$0630 \quad-\quad$ No. 4 Unit on frequency control.

A. Glendale-Rossmoyne and Glendale-Grandview North $34.5 \mathrm{KV}$ line O.C.B.'s closed at steam plant.

0715-0729 - An attempt to automatic synchronize by Howard Sub-station (system $65 \mathrm{MW}$ ).

A. Howard Sub-station operator contacted Station " $\mathrm{E}$ " requesting that they synchronize to Glendale.

$0730 \quad-\quad$ Overcurrent relay trips.

A. \#3 Unit-2 phases B \& C.

\#4 Unit-3 phases.

\#5 Unit-3 phases.

B. \#4 Unit amplidyne tripped off; restarted same.

C. Glendale system on Station " $\mathrm{E}$ " at Western Sub-station with $56 \mathrm{MW}$.

D. Sub-station operator shedding stations to reduce load (Westem Sub on "E" @ 5 MW).

0732 - Nos. $3 \& 4$ Units on the line.

$0739 \quad-\quad$ No. 5 Unit on the line.

0735-0745 Picking up Glendale system.

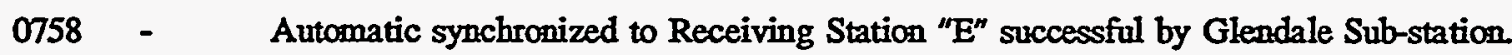

\section{I.4 Earthquake Damage Summary, Piping}

The originally reported damage in the San Fernando Earthquake consisted of two broken water lines, one in the cooling-water line to the induced-draft fan and air

preheated of the Unit 3 boiler, and the other on the Unit No. 2 influent water line to the demineralize tank The areas of these breaks is shown in Figure 2-7 of 
Appendix B of Reference I.1. During this survey, it was indicated by plant personnel that there also had been a small branch line break to the main coolant pipe of Unit G-3 as shown in Figure 4.19 of Vol. 1 of this report. San Fernando Earthquake at the Power Plant Site

For Glendale plant as for the Burbank plant, the closest strong motion recording for the San Fernando earthquake was at 633 E. Broadway Ave. Glendale. This recording station was 19 miles SSE of the epicenter. The Glendale plant is located 2.5 miles NW from the recording station and 17 miles SSE of the epicenter. The ground response spectra developed in Ref. I2 Appendix E Figure Spectra SF-G are considered applicable to the plant site. The site Glendale plant intensity was a Modified Mercalli VII.

\section{I.6 Reference}

I.1 NRC Seismic Design Task Group and Stevenson and Associates, Report of the U.S. Regulatory Commission Piping Review Committee, "Summary and Evahuation of Historical Strong Motion Earthquake Seismic Response and Damage to Above Ground Industrial Piping", NUREG 1061 Vol 2 Addendum, April 1985.

I.2 Yanev, P.I. and Swan, S.W., "Pilot Program Report Appendices, Program for Development of an Alternate Approach to Seismic Equipment Qualification", Vol. II Prepared for Seismic Qualification Utilities Group, by EQE Inc. 


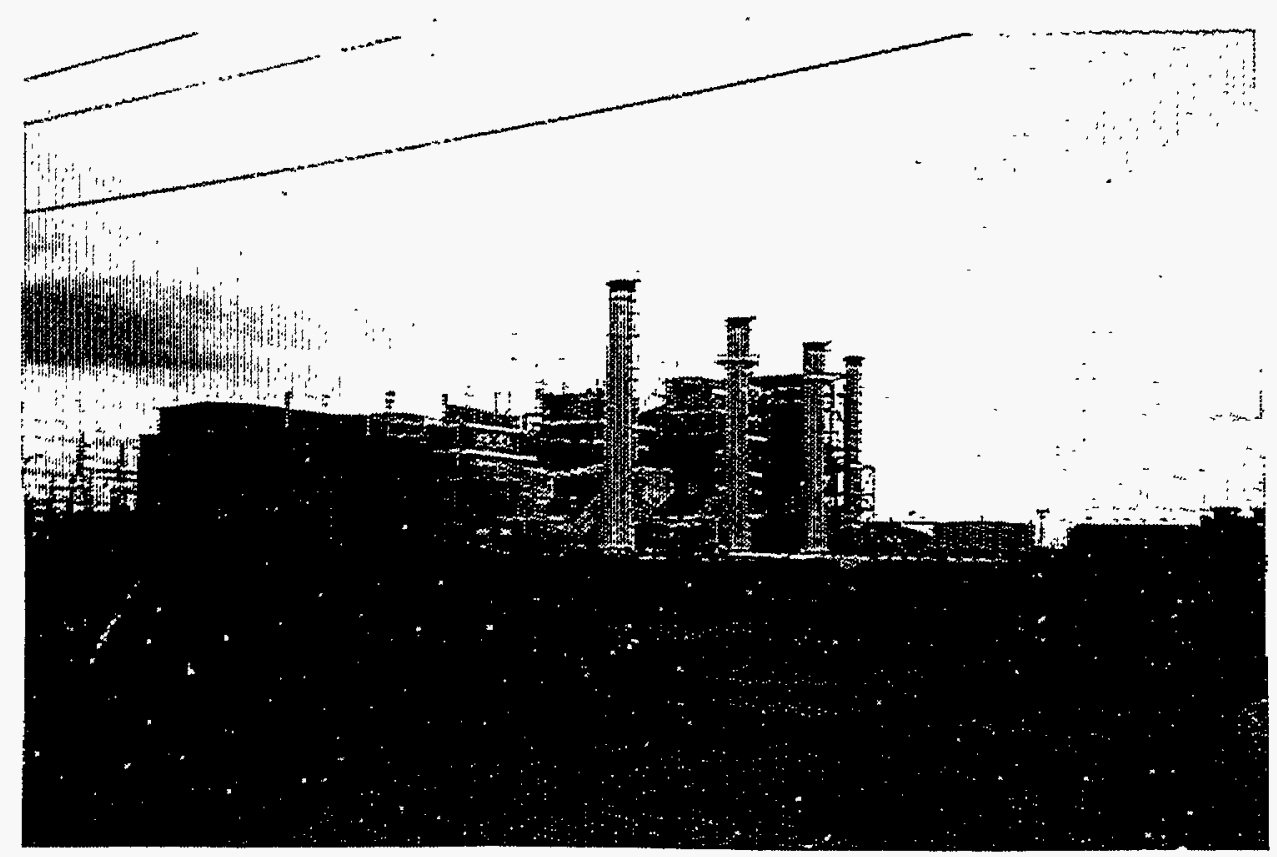

Figure I.1 Glendale Power Station I-5 
$\mid$ 


\section{Appendix J: Humboldt Bay Power Plant}

\section{J.0 Humboldt Bay Power Plant}

\section{J.1 Humboldt Bay Power Plant}

The Humboldt Bay power plant is located on Humboldt Bay, California, just northeast of the town of King Salmon and about 5 miles southwest of Eureka, California. The facility, owned and operated by Pacific Gas and Electric Company (PG\&E), consists of three umits. The nuclear plant (unit 3) is a $63 \mathrm{MW}$ plant. The other two units (unit 1 and 2) are older, $52 \mathrm{MWe}$ duel oil and gas fired boilers which drive steam turbine generators. Unit 1 began operation in 1956 . Units 2 and 3 began operation in 1958 and 1962 respectively. In Appendix D.2 is a more detailed description of Unit 1 which also applies to Unit 2.

A plan of the Humboldt Bay plant is shown in Figure J.1. Unit 3 is at the eastern end of the facility. The soil in the vicinity of the plant at grade consists of about 40 feet of clay overlain by several feet of fill. The Unit 3 reactor is housed in a steel dry well vessel surrounded by a reinforced concrete caisson beneath the structural steel refueling building as shown in elevation view in Figure J.2. About 300 feet south of the refueling building is the light, shallowly embedded storage building.

Units 1 and 2 are conventionally steam boilers supported by a structural steel frame metal sided structure as shown in Figure 1 of Ref. J.1.

\section{J.2 Summary of Recorded Earthquake Effects}

\section{J.2.1 Ferndale Earthquake - 1975}

Units 1 and 2 automatically tripped during the earthquake due to spurious action of some electrical relays. After Inspection, Units 1 \& 2 were both returned to the grid in less than one-half hour with no reported difficulties. The turbine vibration pick-ups on the outside of the bearing caps for Unit 1 and 2 reportedly did not alarm nor did their recorders indicate any above background vibration during the earthquake.

Humboldt Bay Unit-3 was in process of a refueling operation at the time of the earthquake. The earthquake was reported by plant personnel on duty in the refueling building as perceptible upward motion followed by smaller movements of brief duration. Choppy waves about 9" to 12 " high were observed in the spent fuel pool.

The reactor nuclear instrumentation and safety systems were checked for functional operation after the earthquake by plant personnel in accordance with Operating Instructions and all such instruments and controls were found operational. Tank volumes were also checked and no loss of contents was found.

The only Unit 3 device to inadvertently trip during the earthquake was the General Electric relay, 63ZZ, mounted in the Valve Control Center. This is not unexpected as this relay was previously identified by Bechtel as requiring seismic qualification. This $63 \mathrm{ZZ}$ is a redundant relay to $63 \mathrm{Z}$ which did not trip and $63 \mathrm{ZZ}$ was operational after the earthquake.

\section{J.2.2 Eureka Earthquake - 1980}

The effects of the earthquake on plant structures, piping, equipment, and components appeared to be minimal.

Both Units 1 and 2 were operating at the time of the earthquake and were shut down because of it. According to reports, they were shut down because:

(1) A protective relay for the Unit 1 generator phase differential voltage vibrated open and tripped the generator (the relay was GE type 2CFD 12B2A).

(2) Gas flow to both Units 1 and 2 was lost when vibration caused closure of mercoid switches on the low-to-high pressure gas piping isolation lines. The switch closure caused the valves to close.

(3) Air-flow indication was lost for Unit 2 because a float, riding on mercury came loose from the yoke for the indicator. Loss of indication necessitates unit shutdown.

\section{J.3 Time Sequence of Events Following the Earthquake}

\section{J.3.1 Ferndale Earthquake - 1975}

At 0146 on Jume 7, 1975 the status of the Humboldt Bay Plant was as follows: 
a. The oil and gas fired $52 \mathrm{MWe}$ fossil fuel Unit Nos. 1 and 2 were operating using gas fuel at 6 and $11 \mathrm{MWe}$, respectively.

b. Nuclear Unit No. 3 was out of service for a scheduled five-week refueling, maintenance and modification outage that had commenced on May 30, 1975.

At the time of the earthquake, a total of 13 plant personnel were in the plant. This augmented crew included an extra Shift Foreman, a Nuclear Engineer, and extra operating persomnel who were involved n reactor refueling work A Shift Foreman and two operators were on the reactor refueling platform at the time of the earthquake. These individuals left the refueling building shortly after the earthquake occurred. The Plant Superintendent and Supervisor of Operations, upon feeling the earthquake at home, came to the plant to provide assistance. They arrived at 0211 .

The effect of the earthquake on the operating Unit Nos. 1 and 2 was to trip both units' generator oil circuit breakers (OCB's) and auxiliary transformer OCB's. Auxiliary electrical equipment associated with these units transferred to the Plant start up bank which remained energized from the Plant's $60 \mathrm{KV}$ bus. The two fossil units continued to roll under control of a governor at approximate synchronous speed. This situation apparently resulted from spurious auxiliary relay action which caused a loss of generator field on both units. No primary relay "targets" were observed to have dropped. In addition, spurious relay action caused the closure of a motor-operated gas supply valve to Unit 1 which resulted in the tripping of the forced draft fan on Unit 1 boiler.

Unit Nos. 1 and 2 operators investigated these occurrences, "walked the units down," verified that no significant damage had occurred, purges and "lit off" No. 1 boiler, and restoted the fields to the generators on the two umits. At 0205 (19 minutes after the earthquake), Unit 2 was reparalleled to the system.

On nuclear Unit No. 3, the only abnormal condition caused by the earthquake involved spurious action of one of a pair of redundant relays in the refueling building high differential pressure protection system. These relays had been identified in the seismic review work then in progress as requiring qualification testing or replacement. This relay, designated 63ZZ, is a General Electric (GE) type HEA relay, as is its redundant counterpart, 63Z. The effect of this spurious relay action was to close the primary system isolation valves associated with the emergency condenser and reactor cleanup systems and to trip the reactor cleanup pump. These actions had no safety significance relative to the refueling mode of operation of Unit 3.

\section{J.3.2 Eureka Earthquake - 1980}

At this time there is not available a time sequence of events for this earthquake.

\section{J.4 Earthquake Damage Summary}

\section{J.4.1 Ferndale Earthquake - 1975}

No comprehensive description of the behavior of Humboldt Bay Station in the Ferndale earthquake has appeared in the published literature, hence it is included herein for completeness.

\section{J.4.1.1 Outdoor and Common Plant Facilities}

\section{A. Raw Water Storage Tank}

Very minor tank motions on their foundation but no permanent physical displacement. This was evidenced on the east side by small clumps of asphalt paving having broken loose from under the tank steel skirt in contact with the foumdation and above adjoining asphalt paving. Tank was reportedly filled to normal full capacity at the time of the earthquake. The tank sides, roof, and outside piping showed no visible sign of recent paint cracking and chipping or buckling. An apparent flat area in the tank southwest side near grade at the inlet pipe is due to an old field modification.

B. Fire Pump House

Hollow concrete block wall-concrete slab floor construction showed no indication of recent cracking, chipping, or displacement. Auto diesel fire pump, electric driven fire pumps and associated piping and control panels showed no visible signs of recent paint cracking and chipping or displacement. Loosely attached auxiliary equipment and piping showed no signs of any effects.

C. Diesel Supply Tank

Tank, concrete saddles and associated piping 
showed no visible signs of recent paint cracking and chipping or displacement. Earth dike adjacent to tank showed no visible signs of surface cracks or displacement.

D. Propane Tank

Tank, concrete saddles and associated piping showed no visible signs of recent paint cracking and chipping or displacement. Tank was filled to slightly more than one-half full capacity at time of earthquake.

\section{E. Unit 2 Condensate Storage Tanks}

Very minor evidence of small tank motion on foundation but no paint cracking and chipping or displacement. Recent very narrow disturbed soil line around periphery south portion of tank foundation.

F. Unit 1 Condensate Storage Tanks

No visible evidence of tank motion on foundations, paint cracking and chipping or displacement.

\section{G. Intake Structure Units 1,2 \& 3}

No discernible effects to structures or Unit 3 pumps, valves and control panels.

\section{H. 60KV Switchyard}

No discernible visible effects except for Oil Circuit Breaker No. 82 which weighs about 8 tons mounted about $4^{\prime}$ above ground on a slender metal frame support. The four support legs are bolted to a combination oil sump and concrete formdation. There appears to be a less than $1 / 4^{\prime \prime}$ displacement of one support relative to the concrete and some signs of paint cracking and chipping on the several bolts on one side. It is difficult to assess this local paint cracking phenomenon as the supports are of galvanized steel which is a poor undersurface for paint.

I. Unit 1, 2 \& 3 Main Transformers: 70KVA, Single Phase, Oil Filled

Main transformers are bolted to concrete pad foundations. No visible effects except on single phase transformer serving Unit No. 1. this transformer is phase $C$ and one of the anchor bolt attachments show some chipping of paint at the bolt nut. There was no indication of any horizontal displacement of this transformer.

\section{J. Unit 1, 2 \& 3 Bus Bar Towers Behind Transformers}

No discernible effects except for minor paint and concrete cracking and chipping at base of east and west towers of Unit 3. There towers are slender and constructed of galvanized steel members.

K. Storage Building

High hollow concrete block walls - concrete floor slab and timer roof construction which houses one accelerograph pick-up bolted to floor slab near east wall No discernible effects on storage building structure or its contents.

\section{J.4.1.2 Units $1 \& 2$}

The only minor discemible structural effects observed were as follows:

A. There were indications of some paint cracking and chipping on several bolts for secondary bracing on the south face of Unit 2. There was no evidence of plastic deformation. There was no visible sign of paint cracking and chipping or displacement on major columns or beams including concrete footings for Units 1 and 2.

B. A recent rotation of two secondary 1 inch square steel bar guides located inside of the Unit 2 air preheaters west support was observed. There was no visible displacement of the support or the larger outside restraints.

C. There is some evidence of upper portion Unit 2 boiler wall movement horizontally (less than $\pm 1 / 2^{\prime \prime}$ ) against its guides which could be partially attributed to thermal expansion movement. There was no visible permanent displacement.

D. The Unit $1 \& 2$ deaerators located on their respective boiler house roofs both indicated small movement by some minor signs of paint cracking and chipping on several support legs at their bolted anchorages to the structural steel.

E. The Unit 1 condenser and its spring supports were examined and there was no visible signs of paint 
cracking and chipping or displacement. Fragile dried paint drips and films between the coil springs were undisturbed.

F. No discernible visible effects on Units 1 \& 2 electrical panels were observed.

\section{J.4.1.3 Unit 3}

\section{A. Control Room}

There were no signs of any movement or stresses on the floor attachments or structural members of the panels. Board is approximately 7 feet wide, 15 feet long and 8 feet high with a considerable amount of electrical components mounted on the face panels. On one section of the board are 85 $\mathrm{lb}$ recorders mounts in rows from 2 feet to 7 feet above the floor. On the North-east comer of the board are radiation detector and magnetic tape recording equipment weighing approximately 200 $\mathrm{lb}$ and mounted directly to the Reactor Board without additional floor supports.

The Reactor Board shows no visible movements of equipment or any discernible effects of the seismic event. The control room structural steel and reinforced concrete, concrete block and transit siding showed no discernible effects. Recent signs of cracking were not observed in several expansion joints in the concrete walls and floor.

\section{B. Reactor Feed Pump Room}

This room encloses most of the Plant's cable trays. Inspection of tray supports as well as supports for raceways, junction boxes and wall mounted control cabinets indicated no visible effects due to the seismic event.

\section{Emergency Transformer at Grade}

Emergency Transformer $3 \mathrm{~L} 4$ is a $45 \mathrm{KVA}, 3-$ phase dry type transformer bolted directly to a 6 inch high concrete pad. No visible signs of transformer movement.

\section{Turbine Enclosure Concrete Panels}

The turbine of Unit 3 is enclosed by heavy concrete panels which are primarily held in position by gravity with a limited number of weak bolted connections between panels. There was no discemible movement of the vertical concrete panels or their bolted connections.

E. Roof Area and Parapets

There were no discernible signs of cracks or movement of the roofs or parapets of the auxiliaryturbine building or refueling building.

F. Chimney

The concrete chimney was observed from the refueling building roof and inside and outside of the base. Older cracks along cold construction joints and random cracking are visible, but it was difficult to ascertain the possible extent of recent crack development, if any.

G. Outside Condensate Storage Tank

The aluminum condensate tank and associated piping on the north side of the refueling building shows no discernible effects. Two tank anchorage bolts were bent due to earlier construction fit-up. Two small concrete piping supports at grade need replacement.

H. Outside Low-Level Liquid Radwaste Storage Tanks

No discemible effects around tank concrete foundation pads.

I. Pipe Gallery

There were no discernible structural effects in the main steam and feedwater pipe galleries.

J. Main Steam \& Feedwater Pipe Hangers and Supports

Other than apparent routine maintenance adjustments to certain piping hangers and supports, there were no discernible effects attributable to the earthquake.

K. Main Condenser

The Unit 3 Main Condenser room shows some signs of older concrete cracking but no discemible signs directly attributable to the earthquake.

L. Drywell Outer Concrete Surface 
The concrete surface on the outside of the drywell on the south side at elevation -14 in the reactor caisson shows signs of older cracking which could be attributable to a 1) dry shrinkage, or 2) reactive concrete, other than the possible effects of the earthquake. This statement also generally applies to other discussed massive concrete that exhibits older cracking.

\section{Reactor Caisson Access Shaft}

There is evidence of older concrete cracking along the vertical joints of the reactor caisson with the radial walls, some cold construction joints and some random wall cracks. It was difficult to ascertain if there was any possible development of these cracks as a result of the earthquake. An old concrete sealed construction opening for the drywell concrete at elevation -14 shows signs of cracking around the joint which is not directly attributable to the earthquake. There were no discernible signs of paint cracking or chipping on structural steel in the shaft. Certain critical equipment in the shaft was observed as follows:

1. Scram Dump Tank at elevation -66 had no visible signs of paint cracking and chipping or displacement on steel supports. Tank support bolts need routine maintenance tightening.

2. Suppression Tank Cooler at elevation -2 had no visible signs of paint cracking and chipping or displacement on steel supports.

3. The complex maze of accumulators and associated piping and valves at elevation 54 showed no discernible effects. Valve actuator hanger supports need routine maintenance.

N. Refueling Building Concrete Walls and Floor

There is evidence of older concrete cracking. It was difficult to ascertain if there was any possible recent development of these cracks.

There is evidence of a significant size concrete crack in the reinforced concrete column outside the upper air lock at elevation +27 . Subsequent review of detailed drawings indicates that this crack might possibly be attributed to a combination of loadings including the bridge crane. It is difficult to ascertain at this time if there was any recent development of this crack. It did appear that there was any damage to the strength of the column.

O. Poison Tank

The front steel support leg of the poison tank at elevation +12 inside the refueling building along the north wall shows minor signs of paint cracking at the contact with the concrete slab.

P. Emergency Condenser

There were no discernible signs of paint cracking and chipping or displacement of the lower supports.

Q. Spent Fuel Pool

There are older concrete cracks in the spent fuel pool curb on the refueling building floor which are apparently due to heavy loads being placed on it during fuel movement operations (casks).

\section{J.4.2 Eureka Earthquake - 1980}

\section{J.4.2.1 The Effects on Plant Structures, Tanks and Mechanical Equipment}

The effects of the Eureka Earthquake-1980 on the Humboldt Bay power station are summarized in Ref. J.2.

\section{J.4.2.2 Effects on Piping}

Effects on piping were minimal. Only two piping faihures and one support failure were noted for the fossil plant piping. None of these types of failures would be expected to occur in safety-related nuclear plant piping (and none did). One failure in the fossil piping was the result of a poor choice of a brittle material for a buried pipe. The other two failures appeared to be the result of severe deterioration caused by lack of inspection and maintenance.

The failure in the buried pipe was a leak in a 6-in. transite pipe for the fire loop around the plant. The pipe was buried about $6 \mathrm{ft}$. Reportedly, previous leaks in this piping were caused by water hammer and by heavy equipment passing over it. 
The second failure was a pinhole leak in a weld joint for a 2-inch boiler feedwater line for Unit 1 .

Reportedly, examination during repair revealed substantial wall erosion, necessitating the replacement of a complete spool piece. Figure 14 of Ref. J.1 shows the piping and configuration after the repair. The chipped grout at the bottom of the support base plate in Figure 14 should be noted. This figure does not show that only a vertical deadweight support was provided at the top of this piping configuration. Given the chipped grout and the piping configuration, it is obvious that the area where the leak occurred was highly stressed. The coupling of this stress with the pipe wall erosion apparently led to the development of the leak.

The third failure was a sheared bolt on a Grinnel vertical spring hanger for the Unit 1 main steam line (see Figure 15 of Ref. J.1).

The support was exposed to the weather and badly corroded. Examination of the sheared bolt indicated that the corrosion had frozen the bolt to the slot in which it was intended to slide. Only about two-thirds of the failure plane appeared to be attributable to the earthquake; about one-third of the surface appeared to have been cracked before the event. An identical hanger on the opposite side of the line (which appeared to have moved properly) appears to be undamaged. Failure appeared to be the result of the locking of a partially failed boit, which caused its overload.

The only effect noted in the Unit 3 safety-related piping was a deformed expansion bellows on the shutdown system discharge line in the shutdown room near the line's containment penetration into the valve gallery.

Figure 16 of Ref. J.1 shows spans of fossil plant piping about $60 \mathrm{ft}$. long, supported by deadweight hangers only, which were apparently undamaged. The hangers are about 2 to $3 \mathrm{ft}$. long. The direction of strongest motion was perpendicular to the spans. Interestingly, no denting of the insulation was obvious from vantage points approximately 15 to $20 \mathrm{ft}$ away. Figure 17 of Ref. J.1 shows typical weathered Unit 1 and 2 piping which was undamaged.

\section{J.5 Seismic Design Basis}

\section{J.5.1 Seismic Design Basis for Units 1 and 2 Building Structures and Piping}

It was PG\&E policy at the time of construction of the
Humboldt Bay Units to design all major structures for an $0.2 \mathrm{~g}$ static lateral load factor applied to dead and 50 percent of live load. Their is no evidence that this criteria resulted in any requirement to laterally restrain any piping or use snubbers.

After the 1975 earthquake the building structure of Unit 2 adjacent to Unit 3 was modified and strengthened as part of the seismic upgrade of Unit 3 performed in the 1975 - 1976 time frame.

\section{J.5.2 Seismic Design Basis for Unit 3 Building Structure and Piping}

This unit was originally (1962) designed for a $0.25 \mathrm{~g}$ horizontal static seismic load. In 1975 - 1976 the nuclear safety related building structures and piping were upgraded to meet a modern seismic Operational Basis Earthquake, OBE, load of $0.25 \mathrm{~g}$ horizontal and $0.17 \mathrm{~g}$ vertical zero period ground acceleration, defined dynamically by Regulatory Guide 1.60 ground response spectra and compatible floor spectra. A Safe Shutdown Earthquake, SSE, load of $0.5 \mathrm{~g}$ horizontal and 0.33 vertical zero period ground acceleration defined by the R.G. 1.60 ground response spectrum were also established in 1975 - 1976. This seismic design change from the original static $0.25 \mathrm{~g}$ load leads to significant modifications of Unit 3 structural steel and the addition of lateral restrains to piping systems.

\section{J.6 Earthquake Seismic Demand}

\section{J.6.1 Ferndale Earthquake - 1975}

\section{J.6.1.1 Strong-Motion Instrumentation and Calibration}

Seismic instrumentation at the Humboldt Bay Power Plant consists of an early Teledyne type MTS-100 seismic recording system. This system had been in operation since September 1971. Strong motion instruments are located at elevation +12 (plant grade level) and elevation -66 in the refueling building. A strong motion instrument is also situated in a storage building (elevation +12 ) a distance of about 300 feet south of the reactor caisson.

All three components of each strong-motion instruments are multiplexed onto on channel of a four channel FM recorder. Thus, 3 three-component accelerograms and a timing channel are present on one magnetic tape. 
The strong-motion instruments located at the Humboldt Bay Power Plant were calibrated on May 28, 1975, 10 days before the Ferndale earthquake. Since these devices have a dc frequency response, "till" calibrations procedures were used to properly calibrate the instruments. After the Ferndale earthquake the equipment calibration was again checked. The calibration factors computed at this time were found to be identical to those obtained prior to the earthquake. This would indicate that the strong-motion records obtained during the June 7, 1975 Ferndale earthquake are accurate.

Digitization of the magnetic tape was accomplished by using an analog to digital converter and sampling the analog FM signal at a rate of 0.005 seconds or 200 samples per second.

\section{J.6.1.2 Analyses of Digitized Data}

Maximum values of acceleration scaled from strip chart accelerograms of the original Humboldt Bay magnetic tape record are shown in parentheses on Table J.1. These were obtained by taking one-half of the maximum peak-to-peak value. Also shown on Table J.1 are maximum values of acceleration obtained after baseline correcting the digitized data. These values are the absolute maximum values and are not one-half of the maximum peak-to-peak value.

It can be seen from Table J.1 that at all three instrumented locations the maximum accelerations. occurred in the transverse direction.

Baseline corrected acceleration time histories for all three components at each of the three instrumented locations are shown in Figures J.3 to J.5. A total duration of 20 seconds was used for purposes of presentation and response spectra computation although the actual duration of strong shaking was only about three to five seconds. Response spectra were also computed using only 12 seconds of the digitized data and the results agreed reasonably well with those obtained using the entire 20 second duration.

Time histories of velocity and displacement were computed for all nine components of acceleration. These were obtained by integrating the baseline corrected acceleration time histories. The maximum values of velocity and displacement for all three components at each instrumented location are given in Table J.2.
Response spectra have been computed for all nine components of acceleration for structural damping values of 2,5 and 7 percent. These are shown in loglog tripartite form in Figures J.6 to J.8. Transverse response spectra are presented in Figure J.9 for the same components as compared to the R.G.1.60 spectrum for a 2 percent damping value. For both horizontal components the peak response occurs at a frequency of about 2 to $3 \mathrm{~Hz}$. For the longitudinal component at the fundamental response occurs at a frequency of about 3 $\mathrm{Hz}$ with a second peak at around 4 to $5 \mathrm{~Hz}$. At elevation -66 in the refueling building there is no welldefined peak present in the transverse component, however in the longitudinal direction the peak response occurs at about $5 \mathrm{~Hz}$. The vertical component in the storage building (elevation +12 ) contains no welldefined peak In the refueling building the peak vertical response occurs at a frequency of about $5 \mathrm{~Hz}$ at elevation +12 and about $3 \mathrm{~Hz}$ at elevation -66 . It appears that for all nine strong-motion records obtained at the Unit 3 Humboldt Bay Power Plant the peak response occurs in the frequency range of 2 to $5 \mathrm{~Hz}$ ( 0.20 to 0.50 seconds).

\section{J.6.1.3 Conclusions}

The strong-motion records measured at the Humboldt Bay Power Plant during the Ferndale earthquake of June 7, 1975 have been digitized and baseline corrected. Time histories of acceleration, velocity and displacement together with the maximum values of these response have been computed for all three components at each of the three instrumented locations. Response spectra have also been evaluated for all nine components for various structural damping values.

The results of this evaluation indicated that the duration of strong shaking for the seismic event was only about three to five seconds. Because of this short duration liquefaction of the sandy soils at the site would not have been expected. There was in fact no evidence of liquefaction in the immediate vicinity of the plant site.

The high level of acceleration $(0.35 \mathrm{~g})$ recorded in the storage building in the transverse direction is of interest since it exceeds the value assigned to the OBE $(0.25 \mathrm{~g})$ for use in seismic evaluation of the plant. Although information on the subsurface soil conditions at the storage building is not available at this time, borings previously drilled in the vicinity of the storage building can be used to approximate the soil profile. The upper soils consists of about 40 feet of clay overlain by several feet of fill. The large peak acceleration recorded in the storage building is thought to be the result of 
local site amplification effects produced by the relatively soft soil profile particularly in the upper clay layers. Alternatively if the free field ground (acceleration at grade is used as the reference acceleration design value there is an obvious reduction with embeddment. Results of one dimensional wave propagation analyses previously performed indicate that the peak acceleration at the ground surface is a function of the properties of the upper clayey soils. As the clay was made stiffer the peak acceleration at the ground level decreased and vice versa.

\section{J.6.2 Eureka Earthquake - 1980}

\section{J.6.2.1 Instrumentation Records}

The Humboldt Bay Power Plant at the time of the Eureka earthquake was equipped with a TERA Technology seismographic system to sense triaxial acceleration at three locations and record digital time histories on magnetic tape. Because of an apparently degraded low-voltage power supply in the recording system at the time of the quake, analysis of these accelerograph produced no useful record. The instrumentation was on a one-year service interval and was scheduled to be serviced one week after the Eureka earthquake.

As back-up for these accelerographs, the plant was equipped with three TERA Technology film recorders which sense and record the triaxial peak accelerations which occur at their locations. Thus, nine different readings were possible: Based on the staffs visual inspection of one of the instruments, it appears that these instruments were not maintained in such a way to prevent a build-up of dirt and grit on the internal mechanisms. As a result, they did not function properly. The only peak acceleration readings obtained from the potential total of nine were the preliminarily reported peak accelerations of $0.4 \mathrm{~g}$ (E-W), $0.2 \mathrm{~g}(\mathrm{~N}-\mathrm{S})$, and $0.16 \mathrm{~g}(\mathrm{v})$; moreover, because of the condition of the instruments, these readings are considered to be highly unreliable.

The only instrument which is believed to have functional properly was the Engdahl spectra recorder located at the operating floor (+12 ft elevation) in refueling building of Unit 3. This recorder provided triaxial peak spectral accelerations at selected frequencies; these data are presented in Tables J.3 to J.5. The Engdahl data show that the predominant direction of motion was in the plant-designated E-W direction (defined as being rotated counterclockwise 35 degrees from true E-W), with $N-S$ and vertical measured motions significantly less.

The 1975 spectrum should be viewed and compared to the 1980 event spectrum with care. The 1980 event spectrum was obtained directly from a $2 \%$ damped recorder; the spectrum for the 1975 event was available only at 5\% damping. Therefore, it was necessary to approximately adjust the $5 \%$ spectrum to a level consistent with $2 \%$ damping. This was accomplished in a simple manner by ratioing 84th percentile spectral amplification factors from NUREG/CR-0098 ${ }^{2}$ for two different damping and applying them to the 5\% damped spectrum. However, because the amplification factors in NUREG/CR-0098 are applicable to smoothed, broadband design ground spectra and correspond to a meanplus-one standard deviation of amplification factors considering a suite of earthquake time histories, this spectrum can be considered only approximate. It is useful for only a qualitative comparison; its quantitative value is questionable.

From a comparison of the two spectra, it appears that the 1980 earthquake had more energy associated with lower frequencies than did the 1975 event, although the 1975 earthquake had more energy associated with the higher frequencies than did the 1980 event. This observation is consistent with: (1) the near-field, shortduration nature of the 1975 event versus the far-field, longer-duration nature of the 1980 event; and (3) the types of damage (or lack therefore) observed.

Based on consideration of the above and of the results of previous seismic analyses of Humboldt Bay Power Plant Unit 3, it appears that the peak ground acceleration in the free-field at the plant from the Eureka earthquake was in the range of about $0.2 \mathrm{~g}$ to $0.25 \mathrm{~g}$. It should also be noted that the Intensity (MMVI) vicinity of the power plant was the same as the Ferndale 1975 relatively near field (15 miles) epicentral distance Magnitude 5.5 as compared to the Eureka 1980 ( 75 miles) epicentral distance Magnitude 7.1 earthquake.

\section{J.7 \\ Reference}

$$
\text { Herring, K.S., Rooney, V., and Chokshi, }
$$

\footnotetext{
2"Development of Criteria for Seismic Review of Selected Nuclear Power Plants," USNRC Report NUREG/CR-0098, Nathan M. Newmark, Consulting Engineering Services, June 1978.
} 
N.C., "Reconnaissance Report: Effects of

November 8, 1980 Earthquake on

Humboldt Bay Power Plant and Eureka,

California Area", NUREG 0766, U.S.

Nuclear Regulatory Commission, June,

1981.

Table J.1 - Maximum Values of Acceleration (G's) Measured During the Ferndale 1975 Earthquake

\begin{tabular}{||l|l|l|l|l|}
\hline Location & Transverse & Longitudinal & Vertical \\
\hline $\begin{array}{l}\text { Storage Bldg. } \\
\text { (Elev. +12) }\end{array}$ & $.35 \quad(.30)^{\star}$ & $.26 \quad(.19)$ & $.07 \quad(.03)$ \\
\hline $\begin{array}{l}\text { Refueling Bldg. } \\
\text { (Elev. +12) }\end{array}$ & $.25 \quad(.19)$ & $.20 \quad(.14)$ & $.13 \quad(.10)$ \\
\hline Refueling Bldg. & $.16 \quad(.12)$ & $.12 \quad(.09)$ & $.10 \quad(.08)$ \\
\hline
\end{tabular}

* Values in parentheses are the original base line uncorrected values obtained from strip chart records.

Table J.2 - *Maximum Values of Velocity and Displacement Computed from Measured Ferndale 1975 Accelerations

\begin{tabular}{||l|c|c|c|c|c|c|}
\hline \multirow{2}{*}{ Location } & \multicolumn{2}{|l|}{ Transverse } & \multicolumn{2}{l|}{ Longitudinal } & \multicolumn{2}{l|}{ Vertical } \\
\cline { 2 - 7 } & $\mathrm{V}$ & $\mathrm{D}$ & $\mathrm{V}$ & $\mathrm{D}$ & $\mathrm{V}$ & $\mathrm{D}$ \\
\hline $\begin{array}{l}\text { Storage Bldg. } \\
\text { (Elev. +12) }\end{array}$ & 1.08 & .23 & .41 & .40 & .11 & .13 \\
\hline $\begin{array}{l}\text { Refueling Bldg. } \\
\text { (Elev. +12) }\end{array}$ & .63 & .49 & .36 & .18 & .19 & .12 \\
\hline $\begin{array}{l}\text { Refueling Bldg. } \\
\text { (Elev. -66) }\end{array}$ & .32 & .10 & .22 & .14 & .16 & .09 \\
\hline \hline
\end{tabular}

$\begin{array}{ll}\text { *Velocity } & - \text { feet/second } \\ \text { Displacement } & - \text { feet }\end{array}$ 
Table J.3 - Peak Spectral Shock Recorder Humboldt Bay Power Station

$$
\text { PSR1200 - H (North/South) }
$$

$\begin{array}{lll}\text { Recorder S/N } & 898 \quad \text { Calibration Date } & 1-2-80\end{array}$

$\begin{array}{llllll}\text { Record Plates SN } & 14 \mathrm{H6} & \text { Surface } & \text { A } & \text { Date } & 11-12-80\end{array}$

\begin{tabular}{|c|c|c|c|c|c|c|}
\hline \multirow[t]{2}{*}{$\begin{array}{l}\text { Reed } \\
\text { Number }\end{array}$} & \multirow[t]{2}{*}{ Frequency } & \multicolumn{2}{|c|}{$\begin{array}{l}\text { Acceleration } \\
\text { Sensitivity }\end{array}$} & \multicolumn{2}{|c|}{ Displacement } & \multirow{2}{*}{$\begin{array}{l}\text { Equivalent Static } \\
\text { Acceleration } \\
\text { (g) }\end{array}$} \\
\hline & & g/inch & $\mathrm{g} / \mathrm{mm}$ & inches & $\mathrm{mm}$ & \\
\hline 1 & 1.96 & .336 & .0132 & 0.0531 & - & 0.18 \\
\hline 2 & 2.56 & .545 & .0215 & 0.367 & - & 0.20 \\
\hline 3 & 3.12 & .793 & .0312 & 0.287 & - & 0.23 \\
\hline 4 & 3.95 & 1.19 & .0468 & 0.124 & - & 0.15 \\
\hline 5 & 5.00 & 1.95 & .0767 & 0.130 & - & 0.25 \\
\hline 6 & 6.28 & 2.99 & .118 & 0.037 & - & 0.11 \\
\hline 7 & 7.92 & 4.61 & .181 & 0.016 & - & 0.07 \\
\hline 8 & 10.1 & 7.58 & .298 & 0.006 & - & 0.05 \\
\hline 9 & 12.7 & 5.85 & .230 & 0 & - & 0.00 \\
\hline 10 & 16.0 & 8.77 & .345 & $0.007 *$ & - & $0.06^{*}$ \\
\hline 11 & 20.2 & 16.0 & .630 & 0 & - & 0.00 \\
\hline 12 & 25.5 & 23.5 & .926 & 0 & - & 0.00 \\
\hline
\end{tabular}

* Doubtful record since .007 vs. .002

Damping: 2 percent viscous damping (Q of 25) displacement seems physically impossible. 
Table J.4 - Peak Spectral Shock Recorder Humboldt Bay Power Station

$$
\text { PSR1200 - H (East/West) }
$$

Recorder S/N $887 \quad$ Calibration Date $\quad 1-2-80$

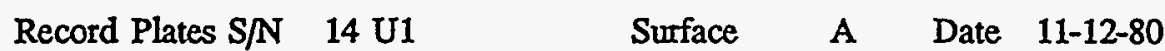

\begin{tabular}{|c|c|c|c|c|c|c|}
\hline \multirow[t]{2}{*}{$\begin{array}{l}\text { Reed } \\
\text { Number }\end{array}$} & \multirow[t]{2}{*}{ Frequency } & \multicolumn{2}{|c|}{$\begin{array}{l}\text { Acceleration } \\
\text { Sensitivity }\end{array}$} & \multicolumn{2}{|c|}{ Displacement* } & \multirow{2}{*}{$\begin{array}{l}\text { Equivalent Static } \\
\text { Acceleration }\end{array}$} \\
\hline & & g/inch & $\mathrm{g} / \mathrm{mm}$ & inches & $\mathrm{mm}$ & \\
\hline 1 & 1.98 & .353 & .0139 & 1.04 & - & 0.39 \\
\hline 2 & 2.49 & .509 & .0200 & 1.743 & - & 0.89 \\
\hline 3 & 3.14 & .791 & .0311 & 1.773 & - & 0.40 \\
\hline 4 & 3.99 & 1.24 & .0467 & 0.528 & - & 0.65 \\
\hline 5 & 4.98 & 1.91 & .0753 & 0.325 & - & 0.62 \\
\hline 6 & 6.40 & 2.91 & .114 & 0.104 & - & 0.30 \\
\hline 7 & 7.95 & 4.63 & .182 & 0.055 & - & 0.25 \\
\hline 8 & 10.1 & 7.35 & .289 & 0.024 & - & 0.21 \\
\hline 9 & 12.8 & 6.33 & .249 & 0.043 & - & 0.27 \\
\hline 10 & 16.0 & 8.70 & .342 & 0.025 & - & 0.22 \\
\hline 11 & 20.3 & 16.1 & .635 & 0.017 & - & 0.27 \\
\hline 12 & 25.4 & 24.1 & .949 & 0.015 & - & 0.36 \\
\hline
\end{tabular}

* Multiple zero lines, strongest zero used to measure dee peaks.

Damping: 2 percent viscous damping ( $Q$ of 25 ) 
Table J.5 - Peak Spectral Shock Recorder Humboldt Bay Power Station

$$
\text { PSR1200 - V (Vertical) }
$$

Recorder S/N $897 \quad$ Calibration Date 1-2-80

$\begin{array}{llllll}\text { Record Plates S/N } & 14 \mathrm{MO} & \text { Surface } & \text { A } & \text { Date } & 11-12-80\end{array}$

\begin{tabular}{|c|c|c|c|c|c|c|}
\hline \multirow[t]{2}{*}{$\begin{array}{l}\text { Reed } \\
\text { Number }\end{array}$} & \multirow[t]{2}{*}{ Frequency } & \multicolumn{2}{|c|}{$\begin{array}{l}\text { Acceleration } \\
\text { Sensitivity }\end{array}$} & \multicolumn{2}{|c|}{ Displacement* } & \multirow{2}{*}{$\begin{array}{l}\text { Equivalent Static } \\
\text { Acceleration } \\
\text { (g) }\end{array}$} \\
\hline & & g/inch & $\mathrm{g} / \mathrm{mm}$ & inches & $\mathbf{m m}$ & \\
\hline 1 & 1.98 & .318 & .0125 & 0.043 & - & 0.45 \\
\hline 2 & 2.55 & .506 & .0199 & 0.181 & - & 0.09 \\
\hline 3 & 3.17 & .794 & .0313 & NoRec. & - & 0 \\
\hline 4 & 4.07 & 1.12 & .0440 & $0.014^{\star}$ & - & 0.02 \\
\hline 5 & 4.97 & 1.90 & .0747 & 0.048 & - & 0.09 \\
\hline 6 & 6.35 & 3.07 & .121 & 0.010 & - & 0.031 \\
\hline 7 & 7.97 & 4.71 & .185 & 0 & - & 0 \\
\hline 8 & 9.98 & 7.46 & .294 & 0.008 & - & 0.06 \\
\hline 9 & 12.7 & 6.23 & .245 & 0 & - & 0 \\
\hline 10 & 16.0 & 9.17 & .361 & 0 & - & 0 \\
\hline 11 & 20.1 & 16.3 & .640 & 0 & - & 0 \\
\hline 12 & 25.4 & 25.6 & 1.01 & 0 & - & 0 \\
\hline
\end{tabular}

* Poor Record-Poor Contact

Damping: 2 percent viscous damping ( $Q$ of 25 ) 


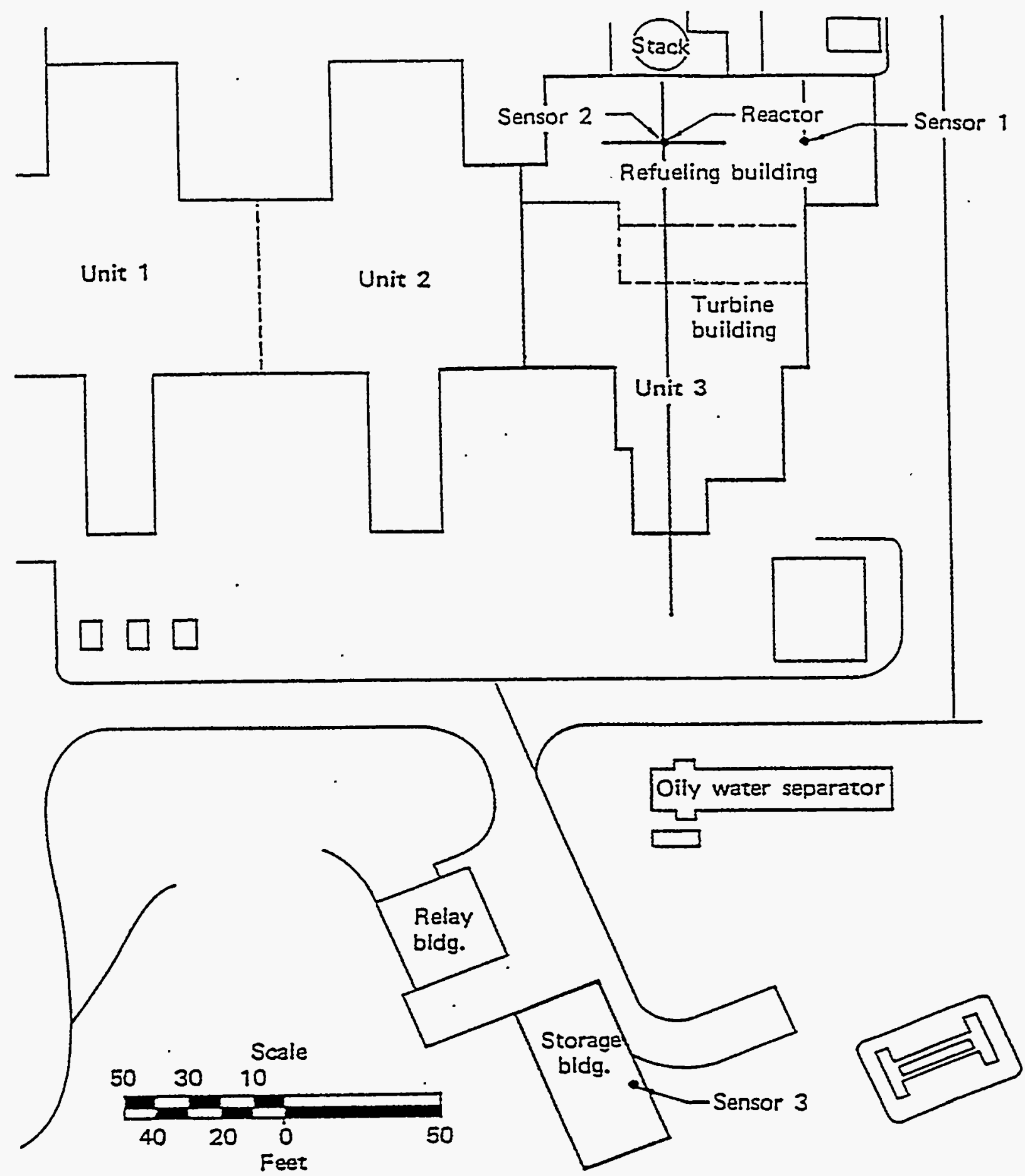

Figure J-1 - Plan of Humboldt Bay Power Plant Showing Location of Strong Motion Accelerations 


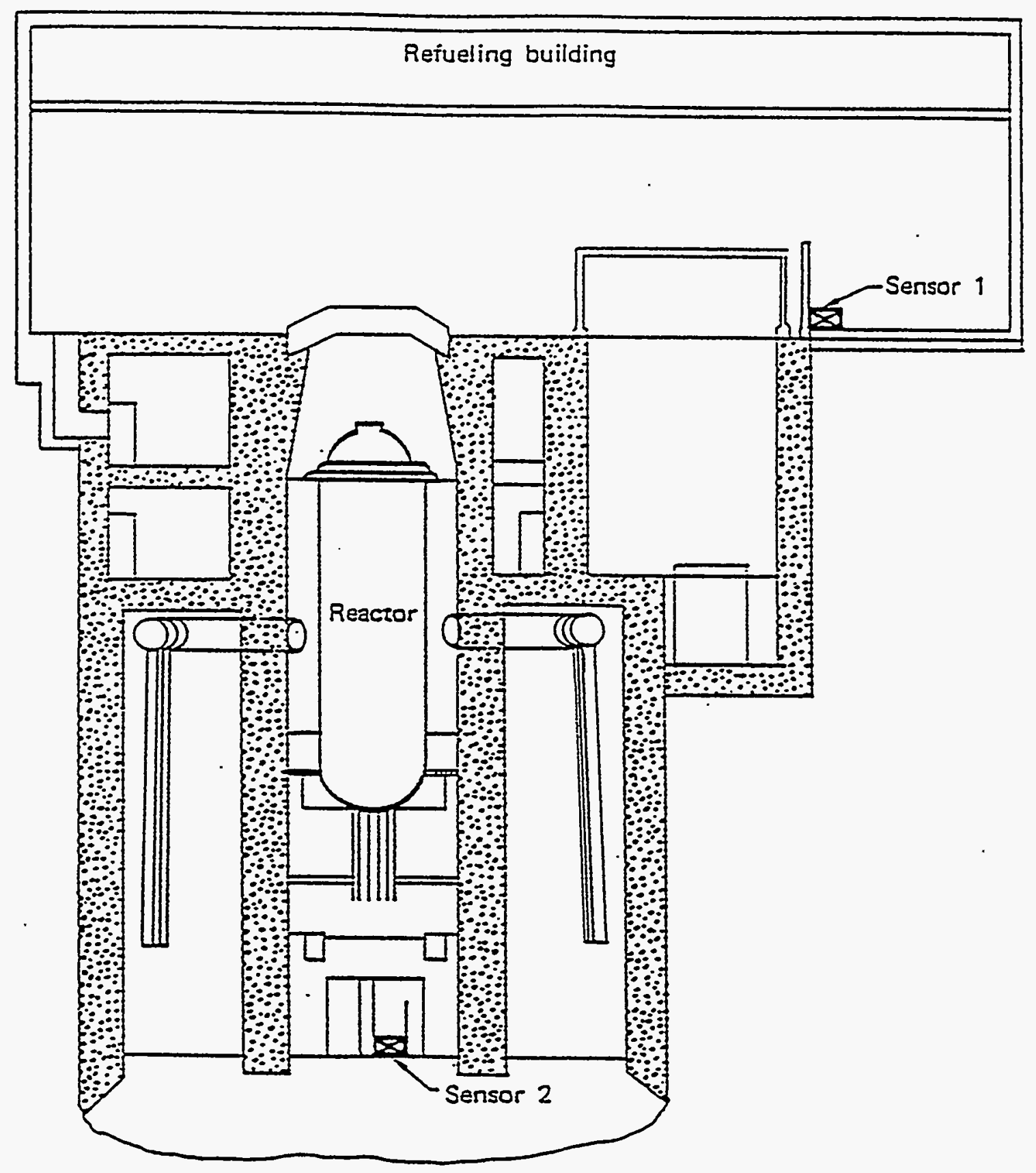

Figure J-2 - Elevation View of Refueling Building, Facing North, Showing Location of Strong Motion Accelerographs 

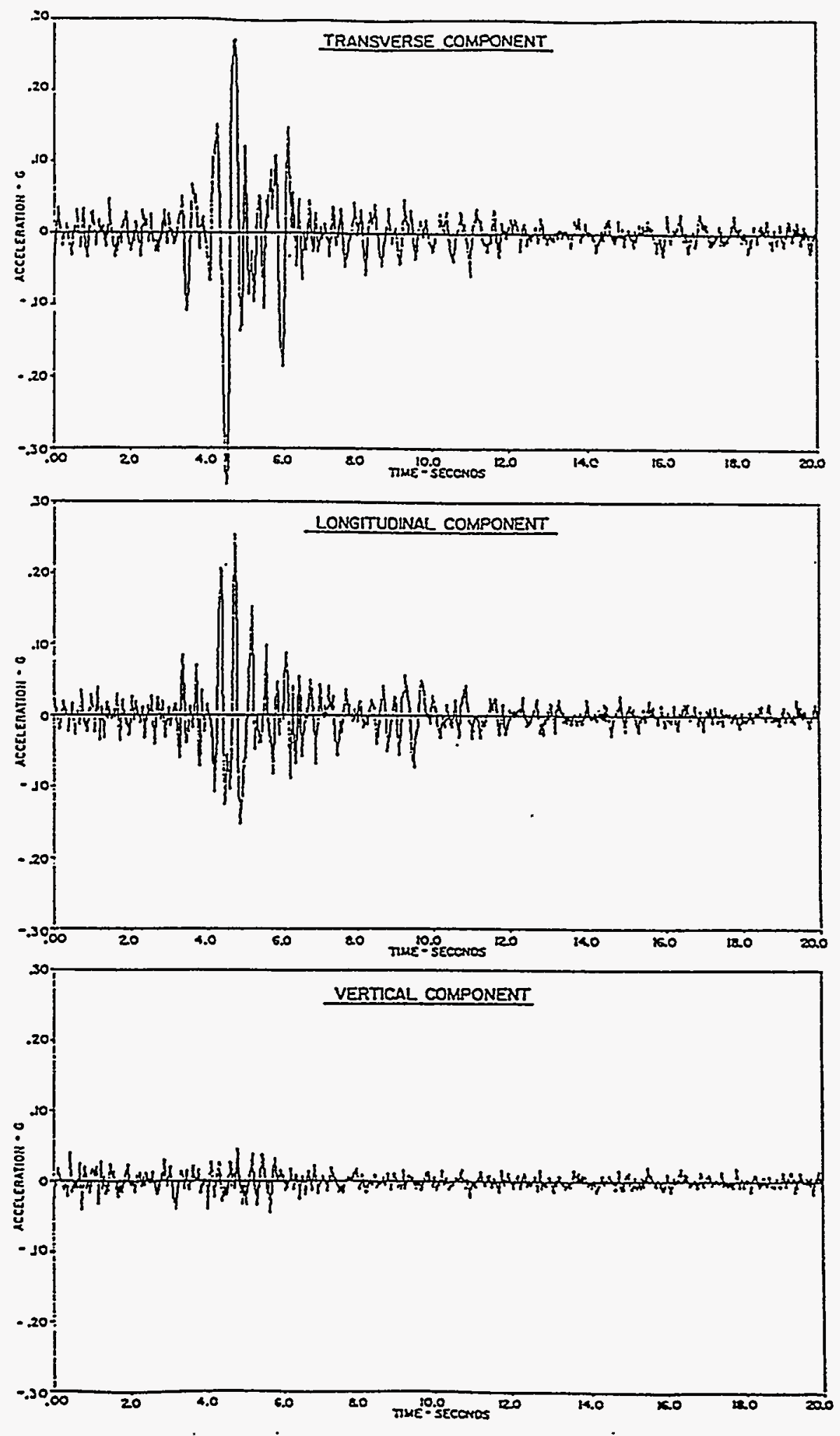

Figure J-3 - Acceleration Time-Histories in the Storage Building (Elevation +12) Due to 1975 Earthquake 

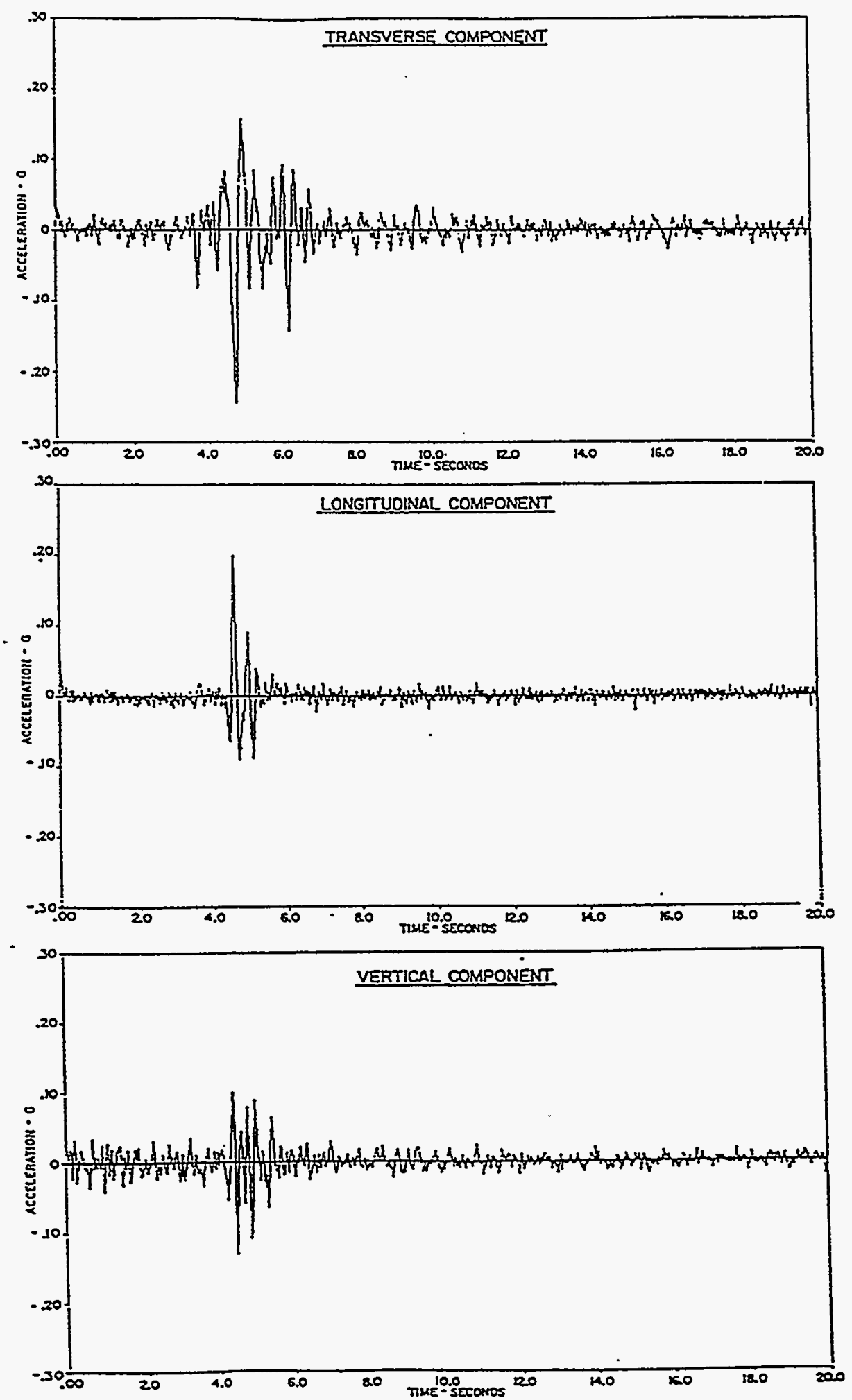

Figure J-4 - Acceleration Time-Histories in the Refueling Building (Elevation +12) Due to 1975 Earthquake 

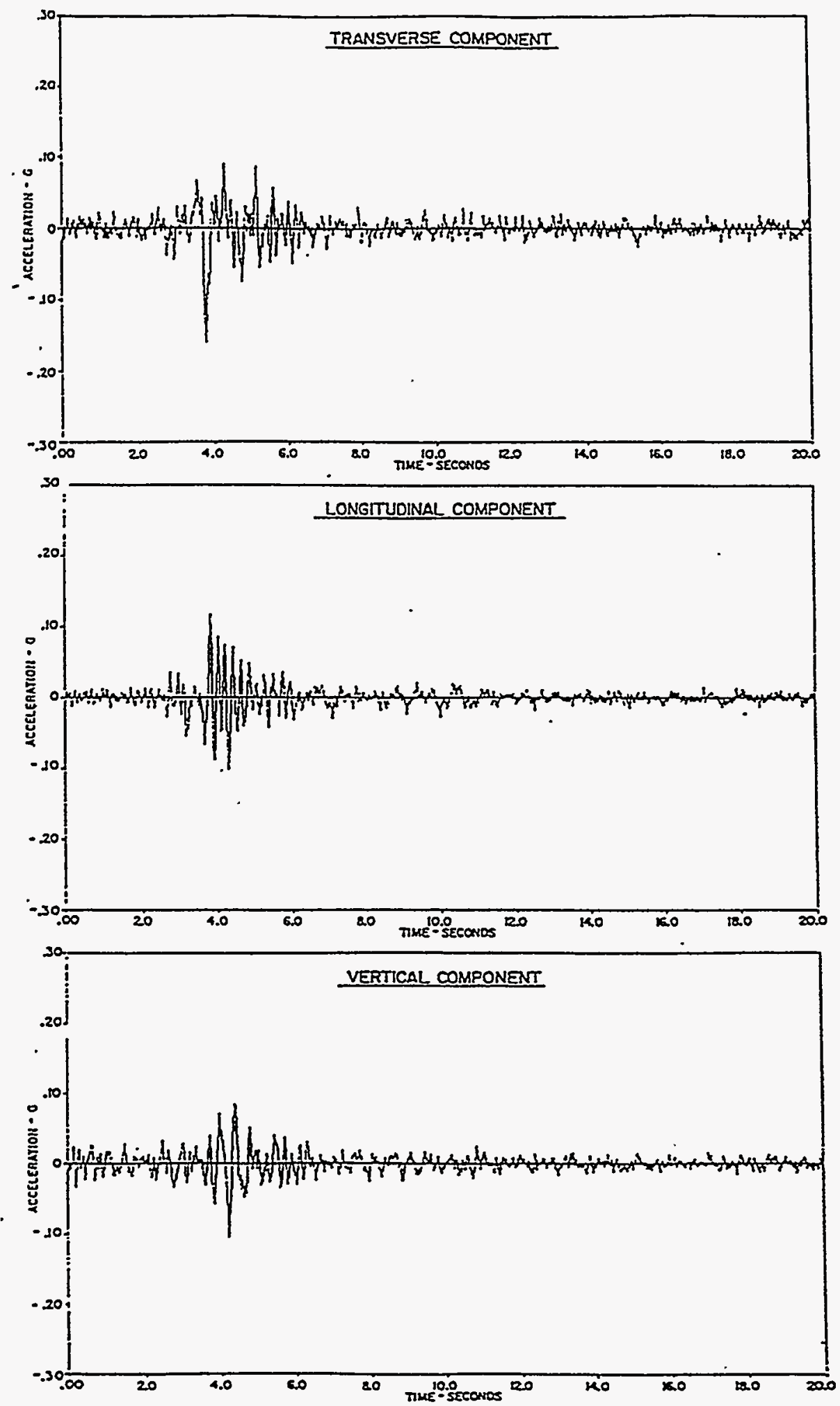

Figure J-5 - Acceleration Time-Histories in the Refueling Building (Elevation -66) Due to 1975 Earthquake 

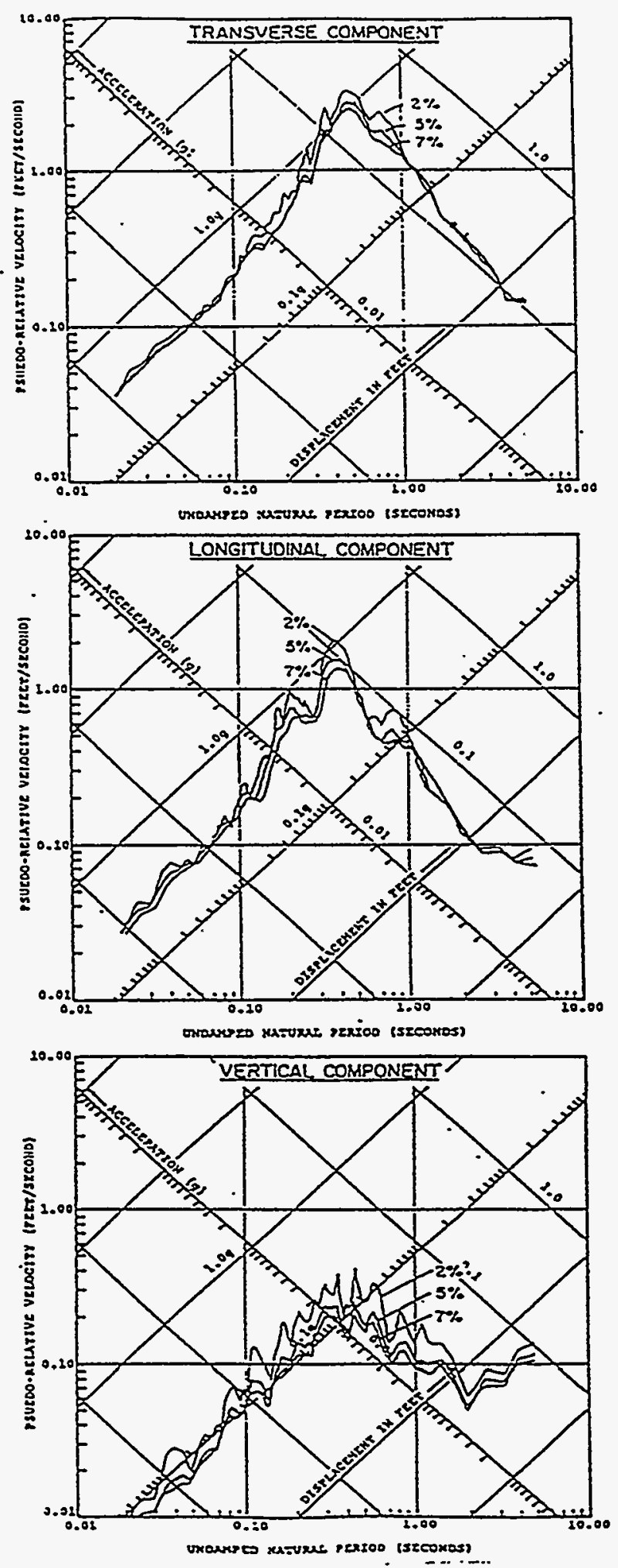

Figure J-6 - Response Spectra for Storage Building (Elevation +12) Due to 1975 Earthquake 

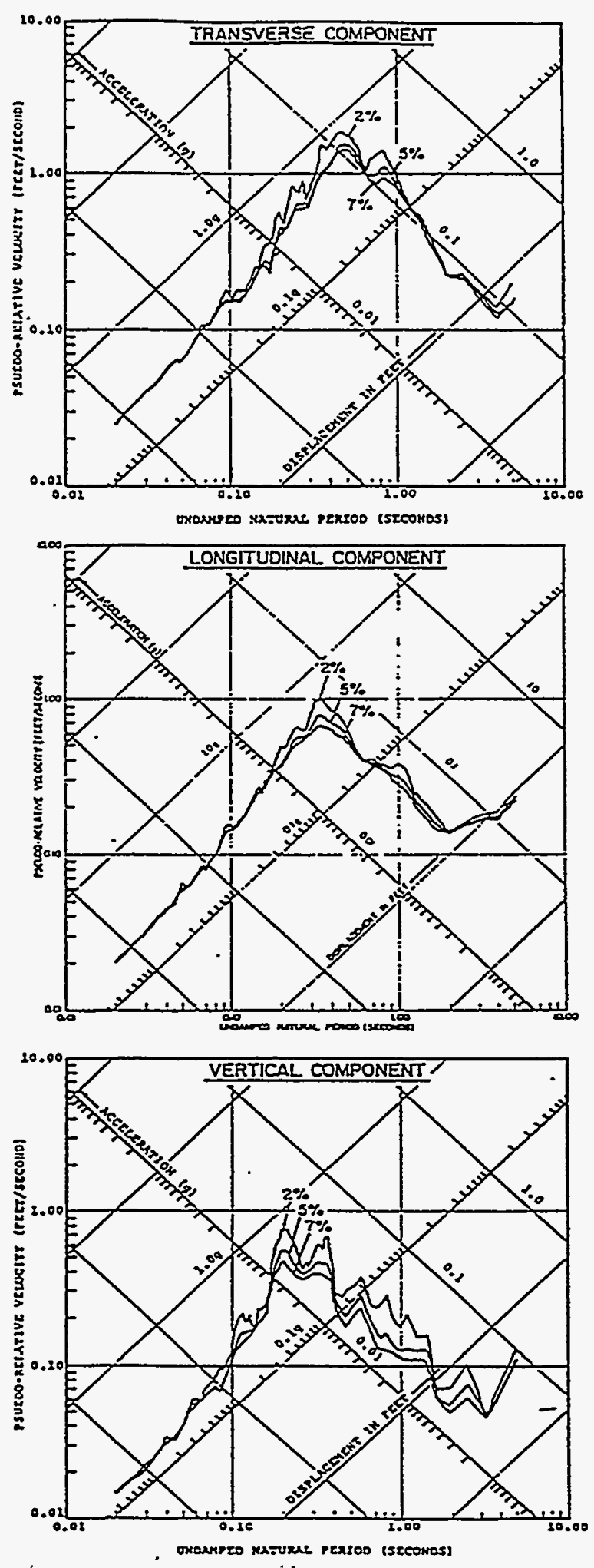

Figure J-7 - Response Spectra for Refueling Building (Elevation +12) Due to 1975 Earthquake 

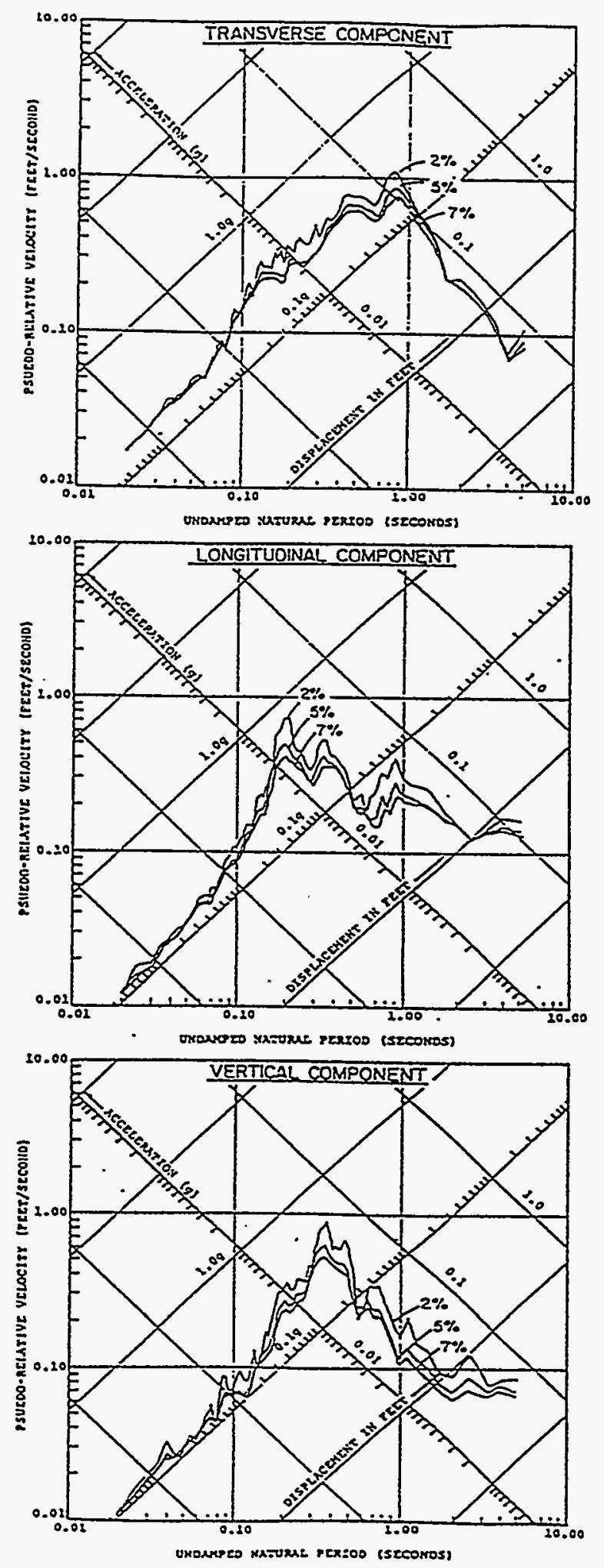

Figure J-8 - Response Spectra for Refueling Building (Elevation -66) Due to 1975 Earthquake 


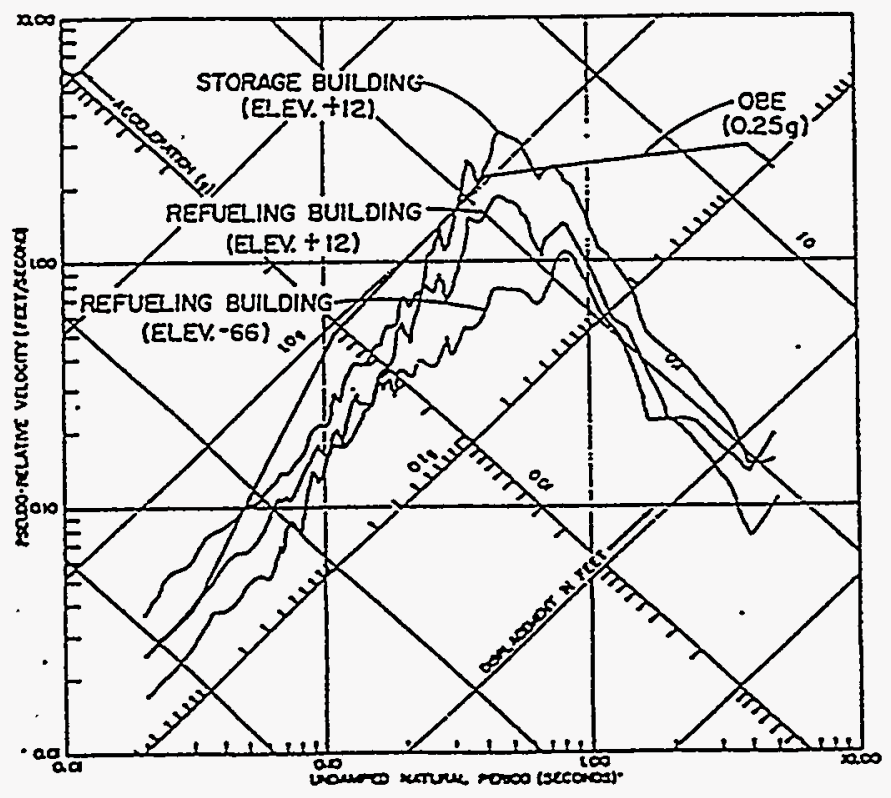

Figure J-9 - Response Spectra Comparison for 2 Percent Damped Transverse Spectra at Various Locations Due to 1975 Earthquake to a 0.25G NRC R.G. 1.60 Spectra 



\section{Appendix K: Kern Valley Power Plant}

\section{K.0 Kern Valley Power Plant}

\section{K.1 General Description}

The Kern Steam Power Plant is owned by the Pacific Gas and Electric Company and is located in the southern end of the San Joaquin Valley, approximately four miles west of the City of Bakersfield, Kern County, California. Construction work started on Units 1 and 2 in September 1946 and was completed in March 1950. The plant site consists of a 77.5 acre plot of level sandy soil, bordered on the north by Rosedale Highway, on the east by Coffee Road, and on the south by the A.T. \& S.F. Railroad. The power plant was designed to have a rated output of 173,500 kilowatts. Currently the plant is in a cold standby condition and has been since 1985 . Current plant arrangements are shown in Figures K.1 and K.2.

Four Babcock \& Wilcox radiant type boilers, each with a rated capacity of $450,000 \mathrm{lbs}$. and a maximum capacity of $517,000 \mathrm{lbs}$. of steam per hour at $1,380 \mathrm{psi}$ gage and $935^{\circ} \mathrm{F}$ total temperature are semi-enclosed in a structure 114 feet high. The boiler house structure is of structural steel, immediately adjacent to the power plant or turbine hall building. The boilers are equipped to burn either gas or fuel oil. A tank farm north of the boiler area provides storage for 241,600 barrels of fuel oil in two 80,000 barrel and two 40,800 barrel welded steel plate tanks with Horton floating roofs. Gas at 40 psi is supplied through a 16 inch underground pipe line connected to the Kettleman Hill feeder in Bakersfield.

The power plant building consists of structural steel framing and reinforced concrete walls, floors and roofs. The turbine bay houses the two main turbine generators, unit No. 1 rated at $60,000 \mathrm{kw}$ is air-cooled and unit No. 2 is rated at $100,000 \mathrm{kw}$ with hydrogen cooling gas at $15 \mathrm{psi}$. Both units operate at $1,800 \mathrm{mpm}$ with $1,350 \mathrm{psi}$ throttle steam at $925^{\circ} \mathrm{F}$ total temperature. Two house unit turbine generators, one rated at $6,000 \mathrm{kw}$ and the other at 7,500 kw, each air-cooled, supply all power required to run the auxiliary equipment in the plant. The remainder of the three-story structure is occupied by the auxiliary equipment, piping, conduit and electrical controls and switchgear necessary for modern fossil fuel steam power plant.

All water to meet the consumption of this plant is obtained from six wells located on the site in pairs, comprising one shallow well (120 feet deep) and one deep well (500 feet deep). Cooling water for the turbine condensers is circulated by low head pumps through the condensers require 74,000 gallons of water per minute from two Foster Wheeler Corporation forced draft cooling towers, to maintain a minimum condenser vacuum of 27 inch of mercury. The two unit No. 1 cooling towers are each 225 feet long, 39 feet wide and 24 feet high, of select redwood construction, built upon concrete basins. Fourteen four-bladed fans of 12 feet diam force air up through the drip trays for forced draft cooling. Unit No. 2 main and house turbine condensers require 104,000 gallons per min to 225 feet long and 29 feet high serve to cool the water for unit No. 2. These towers are also of select redwood construction mounted upon basins. Seven, four-bladed fans of 18 feet- 6 inch diameter are mounted horizontally on the top of each of these towers to promote air circulation through the drip baffles by drawing up air through the louvers along the tower base.

Other yard structures and equipment include a permanent stores and warehouse building of reinforced concrete construction, a transformer oil pump house, two 10,000 gallon oil storage tanks with a piping system to the $70 \mathrm{kv}$ and $110 \mathrm{kv}$ switchyards, and the main and station service transformers. A foam preparation building houses equipment which provides foam for oil fires. A precast concrete incinerator provides facilities for waste disposal.

\section{K.2 Summary of Recorded Earthquake Effects From the Kern County Earthquake of 7/21/52}

The plant operated through the earthquake with no significant damage. The plant was shutdown after the earthquake due to loss of load but was returned to service in a few hours. There was no recorded damage to power plant piping. Damage from the earthquake was limited to the Fuel Oil Storage Tanks, Boiler Controls and a small house turbine thrust bearings.

\section{K.2.1 Description of Repairs of Earthquake Induced Damage to Oil Storage Tanks}

K.2.1.1 No. 1 Fuel Oil Tank: Oil slopped through 
seal on to roof. Roof remained in guide bar. Several angle truss supports badly bent. Several rod supports for roof supports bent and twisted.

Estimated Cost for Repairs. $\$ 500.00$

(This cost excludes tank drainage and purging for internal inspection.)

K.2.1.2 No. 2 Fuel Oil Tank: Oil slopped through seal on to roof. Roof came out of guide bar and turned clockwise about 24 inches. Seal irregular at tank shell.

Estimated Cost for repairs. $\$ 800.00$

(This cost excludes tank drainage and purging for internal inspection.)

K.2.1.3 Fuel Oil Tank No. 3: Oil slopped over tank on the southeast side and on the northwest side. The seal ripped out between 2 1/2 trusses on the southeast side and between 3 trusses on the northwest side. Approximately 10 feet of roof came out of the guide bar and turned clockwise about 12 inches. The ladder broke away from supports and lay on the roof. A number of roof hanger assemblies were damaged. Five were thrown completely out of the seal space.

Estimated Cost for repairs........\$10,000.00

K.2.1.4 No. 4 Fuel Oil Tank: Oil slopped through seal on to the tank roof. The roof came out of guide bar and turned clockwise about 36 inches. Ladder wheels bounced off of their tracks. Several angle truss supports were badly bent.

Estimated Cost for repairs............ \$800.00

(This cost excludes tank drainage and purging for internal inspection.)

\section{K.2.2 Description of Earthquake Damage to Bailey Boiler Controls}

A quantity of mercury was spilled from the air flow meters on all boilers, these instruments required recalibration. for labor and repairs

\section{K.3 Earthquake Design Basis}

\section{K.3.1 Structures}

The structures of the Kern Valley Power Plant were designed for 0.2 lateral load on a static basis with stress limits increased by 0.33 for combined dead, live, and earthquake loadings. Foundations are soil bearing footings at shallow depth.

\section{K.3.2 Piping}

The spacing of hangers and supports for piping of other materials were in accordance with the current practice to carry dead and thermal loads with vertical support spacing as failures.
Pipe Size

$1 "$ and smaller

$11 / 4^{\prime \prime}$ to $21 / 2^{\prime \prime}$, inclusive

$3^{\prime \prime}$ and $4^{\prime \prime}$

$6^{\prime \prime}$ and $8^{\prime \prime}$

$10^{\prime \prime}$ and larger
Maximum Spacing of Hangers \& Supports

6 feet

10 feet

14 feet

18 feet

22 feet
All pipe hangers, supports, guides and anchors were attached to the steel and concrete building structures furnished by the Purchaser wherever practicable, otherwise auxiliary steel was used. The Contractor was responsible for the safety and appearance of this work and of these attachments to existing new or old structures, including their effect on these structures. As discussed in Section 5.5.2 only the main heat transport ruptures were seismically designed. In general no other lateral support was provided for piping.

\section{K.4 Seismic Demand from the Kern County Earthquake at the Kern Valley Power Station}

The Magnitude 7.7 Kern County Earthquake occurred at 0452 local time on July 21,1952 . Its epicenter was located at $35^{\circ} .00 \mathrm{~N}$ and $119^{\circ} .02 \mathrm{~W}$ at Wheeler Ridge on 
US Route 99 and Interstate 5 which is approximately 26.4 miles SSW of the Kern Valley power plant. The Earthquake Intensity at the Kern Valley Power Plant site was VIII. The earthquake ground motion was measured at the Lincoln School at $810 \mathrm{~N}$ Sixth St. in Taft, California which is approximately 30.3 miles NNW of the epicenter. The Intensity in Taft was VII with a recorded peak ground acceleration of $.17 \mathrm{~g}$. This suggests a zero period ground acceleration at the power plant site of between 0.25 and $0.3 \mathrm{~g}$. 


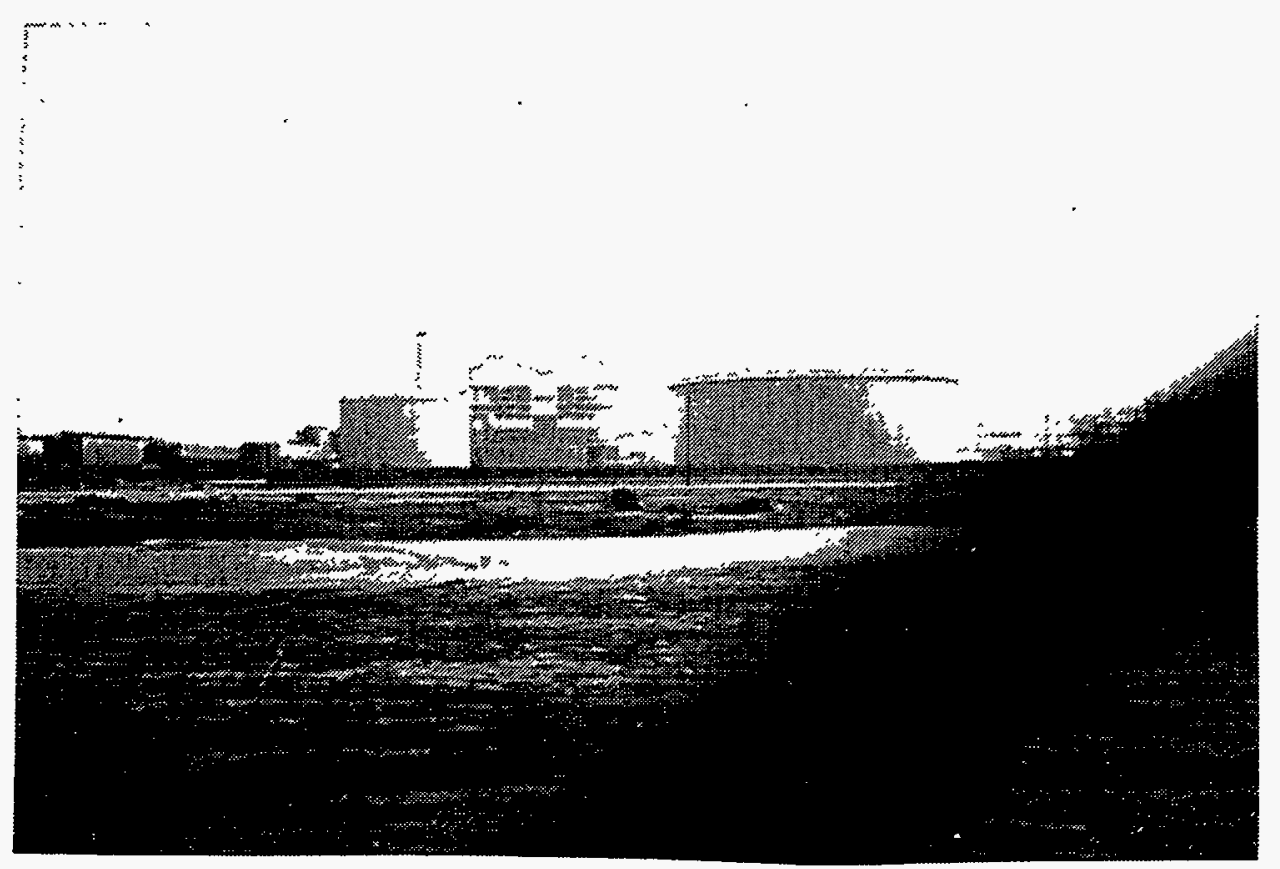

Figure K.1 - End View of Kern Valley Units 1 \& 2 Power Station 


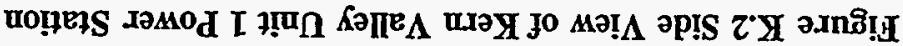

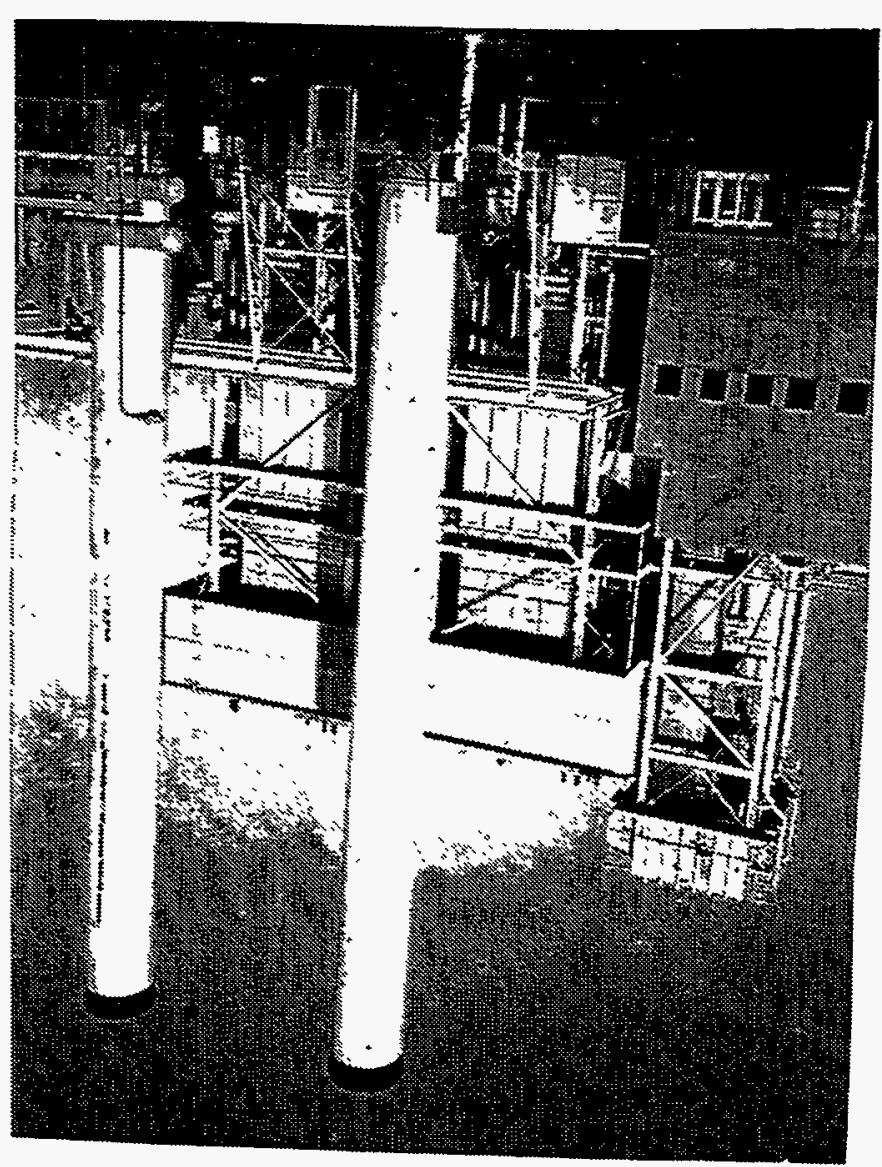




\section{Appendix L: Pasadena Power Plant}

\section{L.0 Pasadena Power Plant}

\section{L.1 Plant Description}

\section{L.1.1 General}

The Pasadena power plant is owned and operated by the city of Pasadena. It is located on the southern edge of the city of Pasadena, in the Los Angeles Basin adjacent to the San Fernando Valley. The plant at the time of the San Fernando earthquake had four generating units with a total capacity of 206 MWe. Broadway Units B1 and B2, each having a capacity of $45 \mathrm{MWe}$, were built in 1955 and 1957, respectively. The total height of the B1 Unit above grade is 62.0'. Broadway Unit B3 is a $71 \mathrm{MWe}$ unit and was built in 1965 and extends approximately 80 feet above grade. Unit 4 , the Glenarm Plant, was built in 1933 and has a capacity of $45 \mathrm{MWe}$ and has a total height of approximately 6 feet above grade.

All four units are in separate structures, and all the Broadway Units 1 to 3 except for the reinforced concrete turbine-generator pedestals are braced steelframed buildings as shown in Figure 2-8 of Appendix B of Ref. L.1. The Glenarm unit is enclosed primarily by a masonry structure with the boiler supported by overhead structural steel.

\section{L.1.2 Civil-Structural}

The Steam Generator (Boiler) and Precipitate support structures for all the B-1 to B-3 Broadway Units are conventional shear connected structural steel framing systems as shown in Figure L.1. Horizontal trusses are integrated with the boiler walk ways and platforms to provide lateral support to the steam generator support columns. Vertical diagonal bracing is provided in selected bays to transfer wind and seismic loads to the foundations.

The older Glenarm structure is masonry block and . reinforced concrete shear wall construction for the most part with a steel truss supported roof in the turbine hall and structural steel supports the boiler. Of all the units surveyed the Glenarm structure is the only one which contained significant quantities of masonry block. While the block showed significant cracking at openings as shown in Figure L.2 and some spalling of attached tile ash shown in Figure L.3 there was no collapse or loss of support of the masonry walls.

The steam drum and boiler support level for Units B1B3 have enclosed penthouses with corrugated asbestos cement siding and roof deck. The remainder of the structures are open.

Steel framing on B-1 is typically riveted. Steel framing on B-2 is typical shop riveted and field bolted. On unit B-3 the frame is typically shop welded and field bolted.

Foundations for boiler area structures and equipment are generally conventional reinforced concrete spread footings and equipment bases supported on compacted fill.

The turbine - generator foundation mat and pedestal is a $4.0 \mathrm{ft}$ thick reinforced concrete slab which supports the urbine-generated pedestal and the condenser. The pedestal is a massive reinforced concrete rigid frame structure which supports the turbine and generator equipment. A one-inch thick topping slab is placed over the top slab of the pedestal to form a part of the operating floor. A one-inch gap provides physical separation of the pedestal where it is adjacent to other structures. An independent reinforced concrete Exciter Room building is located at grade at the north end of the Turbine-Generator pedestal.

The control and service buildings are conventional steel framed structures with 6 inch thick reinforced concrete floor slabs at elevation 16 feet 6 inches. Roofs are of built-up construction over steel decking. The wall covering is steel siding.

\section{L.1.3 Systems}

\section{L.1.3.1 Turbine-Generator}

The turbine-generator units for B-1 and B-2 consist of 3600 rpm tandem compound, non-reheat, condensing, multi-valve steam turbine directly connected to a hydrogen cooled, 2-pole, 60-Hz, 3-phase generator and a direct driven exciter. The basic system parameters for the units are as follows:

- Throttle steam pressure

1250 psig

- Throttle steam temperature $950 \mathrm{~F}$

- Exhaust pressure $1.5 \mathrm{Hg}$

- Generator rated gross output 40,000 KW 
- Generator maximum gross output

$$
44,000 \mathrm{KW}
$$

- Hydrogen pressure at maximum output

$$
15 \text { psig }
$$

The turbine supplies extraction steam to five feedwater heaters, including a dearator. The condenser is fixed to the turbine exhaust flange and is spring-supported at its base.

Turbine supervisory instruments are as originally supplied, with the exception that Bentley-Nevada vibration and expansion monitoring systems and digital tachometers have been retro-fitted.

Plant design includes special design features to allow the plant to accept $20-\mathrm{MWe}$ load swings over a 20 minute period and to minimize maintenance Iequirements. These include: 1) automatic controls for the boiler combustion, feedwater and steam systems, 2) boiler design to permit full steam temperature to be maintained down to about 20 percent load, 3) an effort to eliminate gasketed piping joints, 4) use of comrosionresistant materials in valves and piping, and 5) welded feedwater heaters.

\section{L.1.3.2 Condensate and Feedwater}

The condensate and feedwater systems for units B-1 and B-2 provide the primary water supply to the boiler for steam generation. The condensate and feedwater systems consist of the following major equipment components:

- Main Condenser
- $\quad$ Condensate Pumps
- $\quad$ Deedwater Heaters
- $\quad$ Boiler Feed Booster Pump/High Pressure
Feed Pump

\section{L.1.3.3 Fuel Oil Supply}

The fuel oil supply system consists of fuel oil storage tanks $(56,000 \mathrm{bbls})$, and fuel oil burning tanks $(40,000$ bbls). The burning tank supplies the $63 \mathrm{gpm}$ primary fuel oil pumps. From here the oil is passed through heaters and then to the burners.

\section{L.1.4 Piping}

\section{L.1.4.1 Main Steam Piping}

Broadway Unit 1 and 2 main steam piping consists of a conventional single lead system routed from the boiler superheater outlet nozzle through the stop valve and to the turbine inlet nozzle. The main steam piping design temperature and pressure are $950^{\circ} \mathrm{F}$ and 1500 psig, respectively. there are six pipe support assemblies which consist of two variable springs, three rigid supports and one sway brace. The system is also equipped with a Bailey Meter flow nozzle located in the riser.

The piping material specified is CR-MO A158 Gr., P12 seamless pipe welding classification as shown on drawing 8-2-1250. The pipe is 10-inch diameter, schedule 160 .

\section{L.1.4.2 Top Heater Extraction Piping}

The extraction piping for Units B-1 and B-2 consists of a single lead system from the turbine Number 5 extraction to the heater Number 1 inlet nozzle. The extraction piping design temperature and pressure are $660^{\circ} \mathrm{F}$ and 330 psig, respectively. The piping system contains two manually operated gate valves and a check valve and is supported with rod type hanger supports.

The extraction steam piping specified material is A53 or A106 Gr. B seamless. The pipe is 6-inch diameter, schedule 40.

\section{L.1.4.3 Boiler Feedwater Piping}

The boiler feed piping for Units B-1 and B-2 consists of 4-inch diameter, schedule 120 discharge lines from the three main feedwater pump outlet nozzles into a single 6-inch diameter, schedule 120 line to the economizer inlet header. The boiler feedwater piping approximate design temperature and pressure are $420^{\circ} \mathrm{F}$ and 1400 psig, respectively. The boiler feedwater piping system contains six manually operated gate valves, four check valves and one Bailey regulator valve.

The boiler feedwater piping system for Units B-1 and B-2 has three supports which consist of one variable spring, one lateral rigid restraint and one two-direction rigid restrains. The piping material specified is A-A158 
P11 seamless.

\section{L.2 \\ Summary of Recorded}

Events

\section{L.2.1 San Fernando Earthquake - 1971}

At the time of the San Fernando earthquake, Units B1 and B3 were in operation, and Units B2 and Glenarm were on hot standby. According to the power Production Superintendent, the two operating units did not trip but continued to operate throughout the earthquake.

\section{L.2.2 Whittier Narrows Earthquake - 1987}

Two of four units in the Pasadena Power Plant were on line and operated through the earthquake. One unit was manually tripped by the operators immediately afterward, due to a false reading of air flow to the boilers.

\section{L.3 Time Sequence of Events} Following the Earthquake

\section{L.3.1 San Fernando Earthquake - 1971}

The following is the outage report prepared by the power dispatching supervisor.

0601 February 9, 1971 Earthquake

0601 Dispatch Center

Load Frequency Control tripped. B-1 and B-3 picked up $22 \mathrm{MW}$. System frequency to 59.4 (per Southern California Edison). Was taking $10 \mathrm{MW}$ from SCE. Picked up to balance. 3408 O.C.B. relayed B o target.

0601 Glenarm Substation

G-2 Circuit relayed. Ground target. Wires down at Church Street and Romney Avenue.

0601 Santa Anita Substation

34-8 O.C.b. relayed. A o overcurrent relay.

34-10 O.C.B. relayed B o overcurrent relay.

3405 O.C.B. relayed. P.J.V. sudden pressure at E.O.S. 
Bans 1-A and 2-A A.C.B.'s relayed on undervoltage.

Bus ties closed.

$0601 \quad$ E.O.S. Substation

Sudden pressure relay operated. Station picked up on E-3.

0601 Chester Substation

Banks 1-A, 2-A and 3-A A.C.B.'s relayed on undervoltage.

Bus ties closed.

C-11 Circuit relayed and re-closed. One operation, no targets.

$0618 \quad$ Dispatch Center

Closed 34-8 O.C.B.

0618 Santa Anita Substation

Closed 34-8 O.C.B.

0620 Closed 34-10 O.C.B.

0700 Hastings Substation

Opened 34-5 in South G \& W.

Closed 34-K.V. tie position in south $G$ \& W.

0715 E.O.S. Substation

Opened 34-5 position in West $\mathrm{G} \& \mathrm{~W}$.

0752 Closed $34-5$ position in west $G$ \& W.

0754 Santa Anita Substation

Closed 34-5 O.C.B.

0755 E.O.S. Substation

Closed Bank main A.C.B.

Opened Bus tie A.C.B.

Opened E-3 emergency feed.

0759 Hastings Substation

Closed 34-5 in South G \& W.

Opened 34-K.V. tie position.

$0837 \quad$ Glenarm Substation 
All Load picked up on G-2 Circuit. Back to normal.

\section{L.3.2 Whittier Narrows Earthquake - 1987}

A time sequence of events for this earthquake relative to the Pasadena Power Plant is not currently available.

\section{L.4 Earthquake Damage Summary}

\section{L.4.1 San Fernando Earthquake - 1971}

The only reported malfumction during the earthquake was in an air-flow monitor that records the intake of air into the Unit B-3 furnace. The monitor is mounted several floors above grade, in the boiler structure. A linkage in the monitor became disconnected during the earthquake so that erroneous air-flow readings were monitored in the control room. No other damage or malfunction was reported in the plant's trouble report or by the operators who were on duty at the time.

\section{L.4.2 Whittier's Narrows Earthquake - 1987}

A false air-flow reading was caused by the disconnection of a mechanical linkage in the flowmeter. It should be noted that this was the same air flowmeter that had malfumctioned during the San Fernando Earthquake as discussed in Section L.4.1.

\section{L.5 Seismic Design Basis for Building Structures and Piping}

Units B1 and B2 structures were probably designed to Los Angeles City Building Code which is equivalent to the then current (1955 - 1957) Uniform Building Code. Main heat transport piping for Units B1 and B2 were probably designed to a $0.2 \mathrm{~g}$ static load. However, there is no evidence during a walkdown that Units B1 and B2 piping support was affected by seismic considerations.

Unit B3 structure also appears to have been designed for the then current Los Angeles or Uniform Building Code (1965). There was however explicit seismic design of main heat transport piping to resist seismic effects. Piping Isometrics are as shown in Figures 5.1 to 5.5 of
Volume 1 of this report. The seismic analysis on the lines shown was performed by Basic Engineers, Pittsburgh, Pa. during August - December 1963. The seismic analysis was performed by applying a static $0.2 \mathrm{~g}$ acceleration times mass in two orthogonal horizontal directions simultaneously and computing resultant stresses. Resultant stresses were required to meet the provisions of the ASA B.31.1.0-1955 Code. One result of this analysis was to require a main steam line snubber as shown in Figure L.3.

There is no indication that the Glenarm Unit structure or piping were seismically designed.

\section{L.6 Seismic Demand}

In Figure 3.6 of Volume 1 of this report is shown the location of a) the Pasadena power plant, b) the closest strong motion record locations for the San Fernando and Whittier Narrows earthquakes and c) the epicenter locations for the two earthquakes.

\section{L.6.1 San Fernando Earthquake}

The Pasadena plant is located about 21 miles from the epicenter of the San Fernando earthquake. There was no ground breakage at the plant. The Intensity at the plant site was VII. PGA was estimated to be $0.20 \mathrm{~g}$ and $0.16 \mathrm{~g}$ in the two horizontal directions. The ground motion recorded at Millikan Library of the California Institute of Technology, Pasadena, was considered representative of the motion at the power plant site because the geologic and soil conditions at that location are similar to those of the plant site and because of its proximity to the plant ( 1.5 miles). Both sites are on intermediate alluvium and are approximately the same distance from the epicenter of the San Fernando earthquake. The Millikan Library records had PGA's of $0.22 \mathrm{~g}$ (north-south), $0.18 \mathrm{~g}$ (east-west) and $0.12 \mathrm{~g}$ (vertical).

\section{L.6.2 Whittier Narrows Earthquake - 1987}

The October 1, 1987 Whittier Narrows Earthquake $\left(\mathrm{M}_{\mathrm{L}}\right.$ = 5.9) occurred at 7:42 a.m., Pacific Daylight Time (PDT) at an epicentral location of $34^{\circ} 3.0 \mathrm{~N}, 118^{\circ} 4.8 \mathrm{~W}$, about $15 \mathrm{~km}$ northeast of downtown Los Angeles, at a focal depth of about $14 \mathrm{~km}$ approximately 12 miles SSE 
of the Pasadena power plant site. The maximum Modified Mercalli Intensity (MMI) assigned to the epicentral area was VII with a value of VII also being assigned to the Pasadena power plant site.

The closest strong motion acceleration recording instrument (approximately 1.25 miles) to the Pasadena power station (Southwestern Academy 2800 Monterey, Road, San Marino) for the Whitier Narrows earthquake recorded a peak acceleration of $0.2 \mathrm{~g} \mathrm{~N}-\mathrm{S}, 0.15 \mathrm{~g} \mathrm{E}-\mathrm{W}$ and $0.14 \mathrm{~g}$ vertical.

\section{L.7 References}

(L.1) Seismic Design Task Group, "Report of the U.S. Nuclear Regulatory Commission Piping Review Committee: Summary and Evaluation of Historical Strong-Motion Earthquake Seismic Response and Damage to Above Ground Identical Piping", NUREG 1061, Volume 2 Addendum, U.S. Nuclear Regulatory Commission, April 1985. 


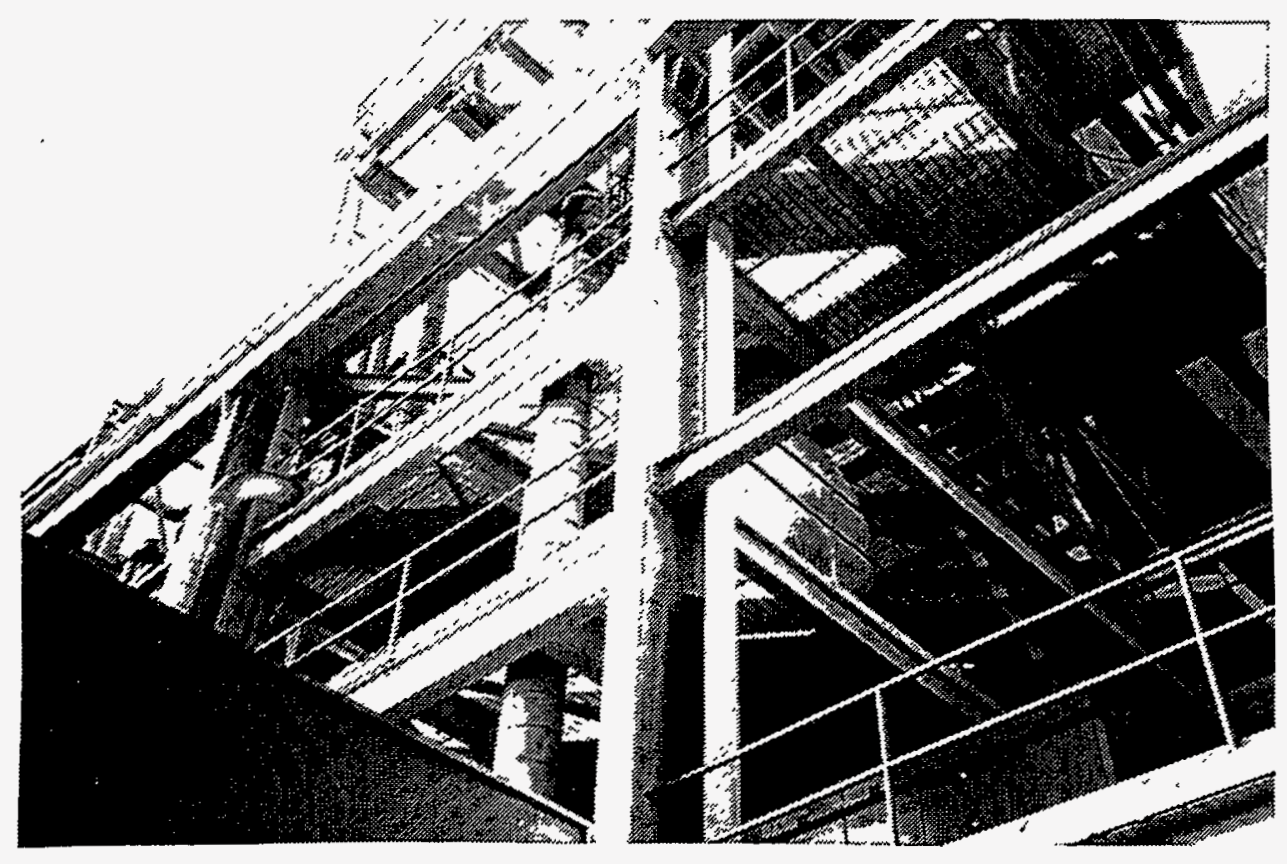

Figure L.1 - Structure Steel Framing for Broadway Unit 1 to 3 


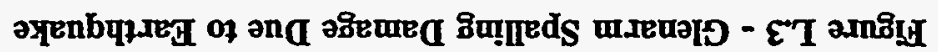
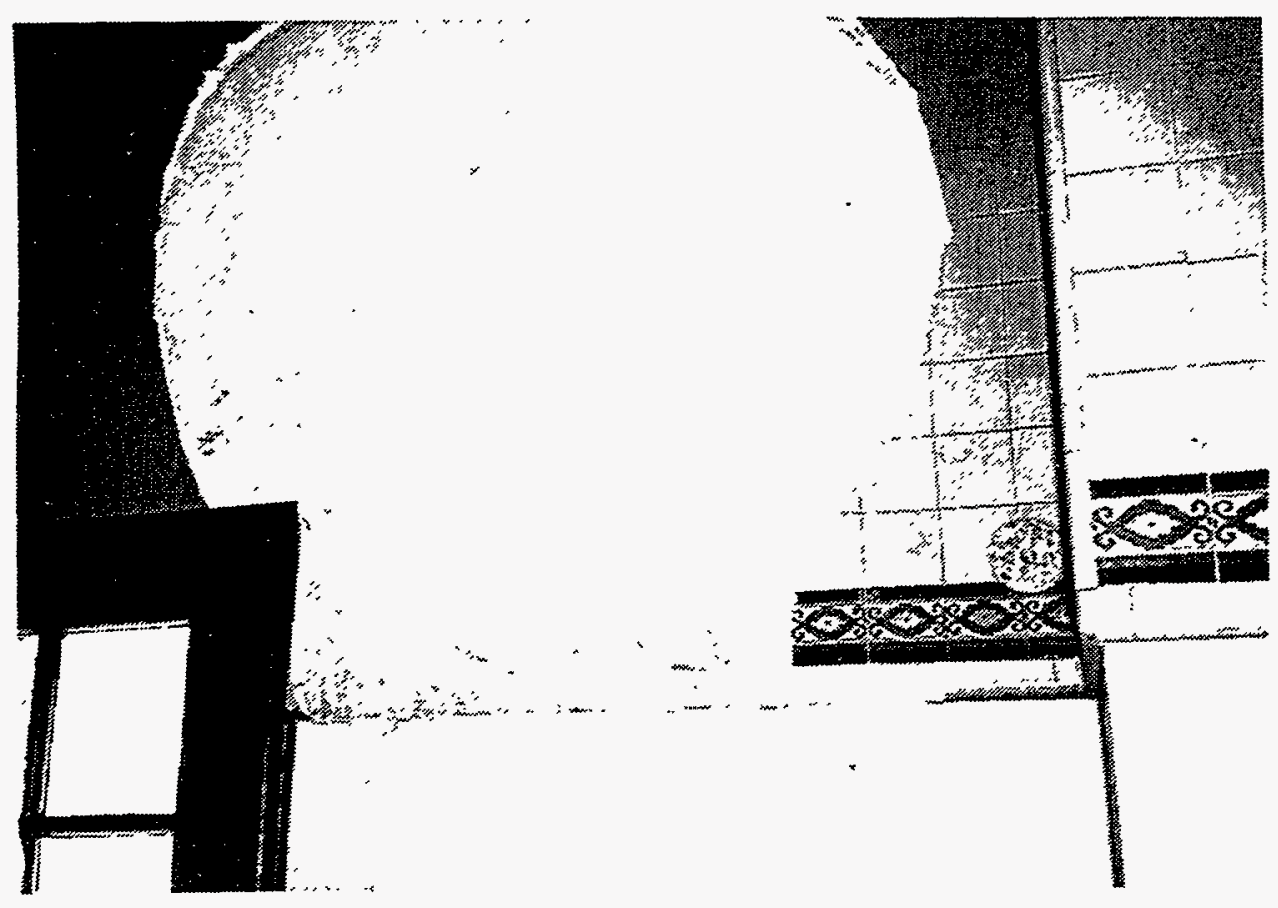

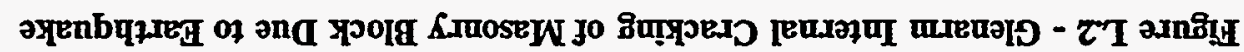

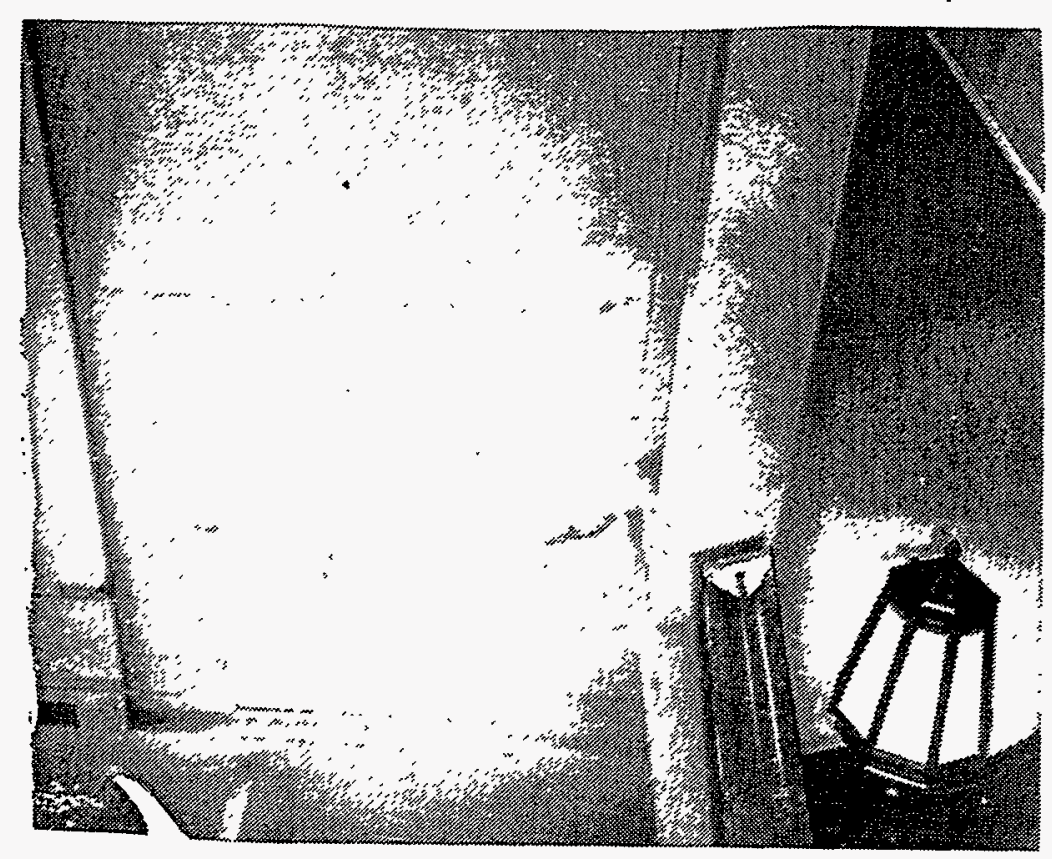




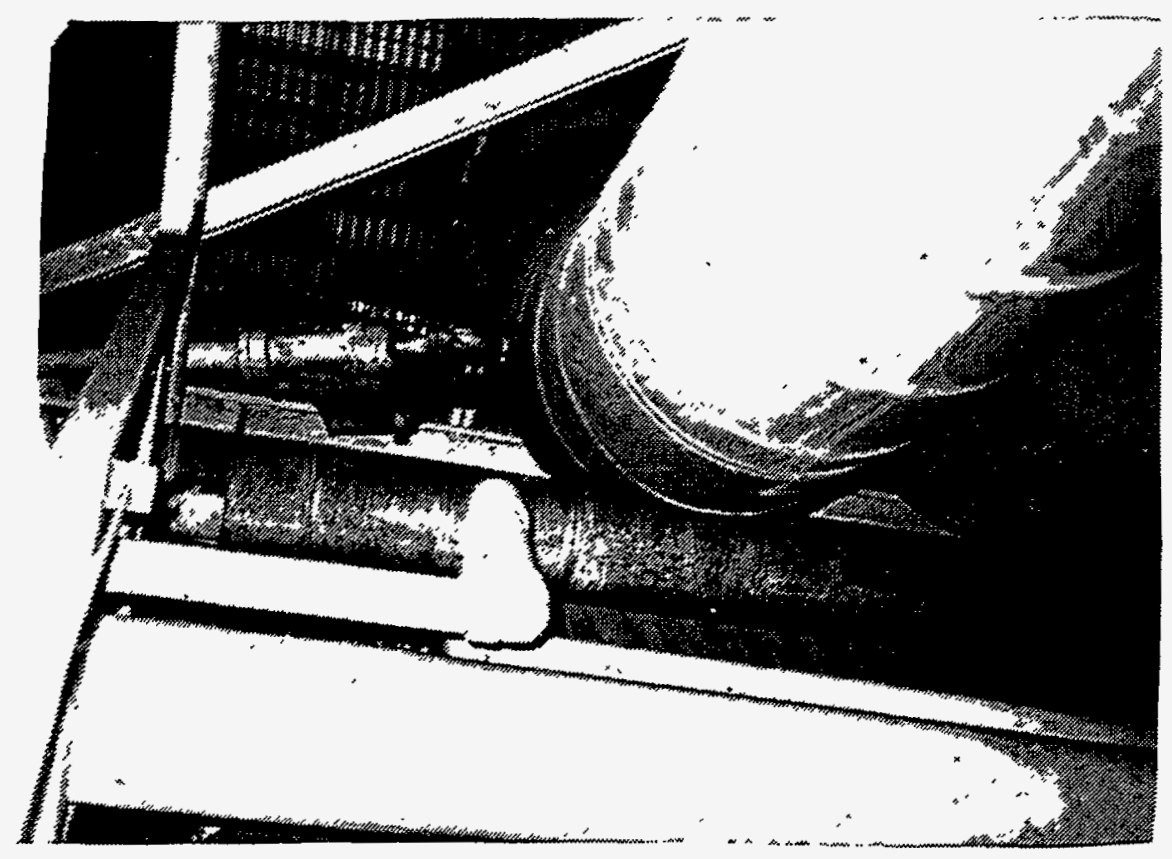

L4 - Snubber Support on Main Steam Line for Broadway Unit 3 


\section{Appendix M: Valley Power Plant}

\section{M.0 Valley Power Plant}

\section{M.1 Plant Description}

\section{M.1.1 General}

The Valley Steam Plant is located on a 150-acre site in the central San Fernando Valley and is owned and operated by the Los Angeles Department of Water and Power (see Figures 15 of Reference M.1). The plant has four generating units with a total capacity of 513 MWe. Units 1 through 4 were constructed in 1954, 1954,1955 , and 1956, respectively; and their individual capacities are 100,100,157, and $157 \mathrm{MWe}$, respectively. Because of the area's mild climate, much of the plant piping and equipment is located outdoors.

The main structures consist of braced steel frames supporting the boilers, concrete foundations for the turbine-generator units, and concrete-surfaced decks in the steel-framed turbine building. The plant is located in a flat, alluvial area, on sand, gravel, and boulders that extend to a depth of more than 500 feet. The permanent water table is about 200 feet below the surface.

The Valley Steam Plant, typical of other California power plants, is essentially an outdoor plant. Complete housing is provided only for operating personnel and for equipment that, for practical or economic reasons, cannot be located outdoors. All major equipment, including the boilers, turbines, generators, and unit auxiliary power centers are weatherproofed and located outdoors.

The main plant structure consists of steel framework supporting the boilers, concrete foundations for the turbine generator units, and concrete surfaced decks to provide accessibility to plant equipment for operation and maintenance. To handle heavy equipment a traveling gantry crane capable of lifting 225 tons is installed on the turbine generator deck

Each of the four generating units is designed to operate as an independent power plant with individual boiler, transformer, switchgear, and auxiliary equipment.

The boilers that supply steam to the turbine generator units either burn fuel oil, or natural gas, and can be converted to the use of coal as a fuel if required in the future. The boilers for the 100,000 kilowatt Units 1 and 2 are 115 feet high and the boilers for the 156,250 kilowatt Units 3 and 4 are 150 feet high. Each boiler for Units 1 and 2 is capable of producing 850,000 pounds of steam per hour at a pressure of 1500 pounds per square inch and a temperature of $1000^{\circ} \mathrm{F}$. Each boiler for Units 3 and 4 is capable of producing $1,200,000$ pounds of steam per hour at 1850 pounds per square inch with an initial temperature of $1000^{\circ} \mathrm{F}$ and reheat temperature of $1000^{\circ} \mathrm{F}$. Operating at full load, the four units consume about 630,000 barrels of fuel oil per month. Six fuel oil storage tanks are installed to insure a dependable fuel supply, and space has been reserved for the storage of coal, in case of future conversion to coal.

The steam generated provides the power for driving the generators at 3600 revolutions per minute. Each generator delivers power directly to a three-phase transformer which steps up the voltage from 13,800 volts for Units 1 and 2 and from 18,000 volts for Units 3 and 4, to 138,000 volts for transmission through the switchyard to the transmission lines and on to power receiving stations. The exhaust steam is discharged from the turbines into the condensers where the steam is condensed into feed water and returned to the boilers. With the four generating units in operation, the Valley Steam Plant requires about 284,000 gallons of condenser circulating water per minute for condensing the exhaust steam from the turbines. After passing through the condensers, the water is cooled by evaporation in eight cooling towers. Water required for plant use is supplied by means of a 48 inch pipeline connected with the Los Angeles Owens River Aqueduct and supplemented with wells on or near the plant site.

\section{M.1.2 Structural Aspects of the Plant}

\section{M.1.2.1 Site Preparation and Excavation}

A total of 600,000 cubic yards of earth work was required for the project. The amount of cut and full was balanced to provide backfill wherever necessary and to provide material to construct the earth dikes surrounding the fuel oil storage tanks. Earth material at the site is a well graded sand and gravel capable of being compacted to high densities.

M.1.2.2 Column and Equipment Foundations 
The soil is known to be sand, gravel and boulders to depths of over 500 feet, with the permanent water table fluctuating around 200 feet below the surface in the recent past.

Most of the plant footings are isolated square or rectangular footings. Due to the magnitude of the boiler column loads, which are as high as 800 tons per column, it was necessary to use a number of combined footings in these areas.

Construction of the smaller footings presented no unusual problems. In order to prevent cold joints, the large combined boiler footings, which were up to 7-1/2 feet thick, were poured by beginning at one end and placing inclined rather than horizontal layers. Approximately 2400 cubic yards of concrete and 120 tons of reinforcing steel were used in the building and boiler feed pump foundations for the four units.

\section{M.1.2.3 Turbine Generator Foundations}

In designing the turbine generator foundations, consideration was given to the vibration of the turbine and generator. In order to dampen the effects of the vibration of these units, massive foundations were provided having a weight ratio of foundation to the machine of approximately 5 to 1 .

In constructing the foundations, the largest monolithic pours in the entire project were made. The matt foundation for each of these structures contained 1100 cubic yards of concrete. A total of 9400 cubic yards of concrete and 470 tons of reinforcing steel were used for the foundations of the four units.

\section{M.1.2.4 Structural Steel Frame}

The structural steel frame in the boiler bay for Units 3 and 4 attains the height of a 13 story building. At the top of this bay are welded plate girders that support the boilers and carry over 1000 tons each. These girders are approximately 10 feet deep and 55 feet long with 3 inch by 28 inch flanges. A planned sequence of welding and preheating to $200^{\circ} \mathrm{F}$. was used to avoid distortion and residual weld stresses. Cover plated columns weighing up to 730 pounds per foot are required to support these girders.

In addition to equipment loads, the steel frame supports floor live loads ranging from 100 to 250 pounds per square foot, the latter loading being used for the turbine bay floor.
In Units 1 and 2 rivets were used for all connections; however, in keeping with the latest construction developments, high tensile bolts were used for all field connections and a majority of the shop connections in Units 3 and 4.

In Figures M.1 and M.2 are shown typical structural steel framing used in construction of the Valley Power Plant.

A total of 4200 tons of structural steel was required for the four units.

\section{M.1.2.5 Superstructure}

The superstructure includes the concrete floor slabs, stairways, concrete and plaster filler walls, equipment supports, and miscellaneous platforms that are required to complete the Main Building. Concrete floors are used wherever heavy usage, vibration or protection from the weather is required. Steel grating floors are used to provide access to the many operating platforms around the boiler.

\section{M.1.3 Steam Boilers}

\section{M.1.3.1 Boiler Units 1 and 2}

The steam capacity of each of the boiler units is $850,000 \mathrm{lbs} / \mathrm{hr}$ at a temperature of $1000^{\circ} \mathrm{F}$ and 1500 psi-g at the superheater outlet. The steam drum is 66 inches ID with a 5 inch wall thickness and is 47 feet 4 inches in length. The boiler contains approximately 33,000 gallons (275,000 pounds) of water when filled to the normal water level in the drum. The total weight of the boiler in operation, including the air heater, is $2,675,000$ poumds which is entirely supported by hanger rods from overhead steel.

As the boiler is hung from the top and is tied at the front and one side by seismic ties, the boiler expands downward, toward the rear, and toward one side due to thermal expansion when placed in operation. The approximate linear expansions are 43/4 inches downward, $1-3 / 4$ inches to the rear, and 1-1/2 inches to the side.

The top part of the boiler above the water wall tubes and furnace roof tubes is enclosed in a metal casing with an inner layer of insulation. The refractory and insulation enclosing the tangent tube furnace water walls and the tubes forming the convection area enclosure are attached to and supported by the tubes. With the 
exception of the top portion of the boiler, a relatively expensive outer steel casing has been eliminated and a canvas and adhesive weatherproof coating used in its place to protect the insulation and provide an airtight enclosure.

The steam turbines for Valley Steam Plant, Units 1 and 2 are each rated at 100,000 kwe maximum capability. the turbines are of the tandem compound double flow type and consist of on Curtis stage and 36 reaction stages. Steam from the boiler is supplied at $1450 \mathrm{psi}$ gauge and $1000^{\circ} \mathrm{F}$. to turbine. The steam passes through the high pressure turbine through the cross-over, and then is divided in half as it goes through the low pressure urbine, each half flowing in opposite directions and then exhausting to the condenser.

About 800,000 pounds per hour of steam is admitted to the inlet valves under full load. Each pound of steam increases in volume about 550 times from the time it enters the machine to the time it leaves the machine. The temperature changes from $1000^{\circ} \mathrm{F}$. to $100^{\circ} \mathrm{F}$. and the pressure changes from 1450 psi gauge to about one psi absolute. In the low pressure turbine, the last stage blades are 23 inches in length and the velocity at the tips of the blades is about 1000 miles an hour. Due to centrifugal force, there is a pull at the base of each of these 23 inch blades (there are 250 of them) of about 30 tons when rotating at the operating speed of $3600 \mathrm{rpm}$.

Steam is extracted from the turbine at the 16th, 22nd, 28th, 33rd, and 35th stages for feedwater heating in a regenerative cycle. However, unlike Units 3 and 4 there is no reheat cycle on these turbines. The regenerative cycle increases the turbine cycle efficiency by about 13 percent and also reduces the amount of steam going to the condenser requiring smaller condensing equipment.

\section{M.1.3.2 Units 3 and 4}

The design for Units 3 and 4 is essentially identical with respect to plant arrangement. Units 3 and 4 differ from Units 1 and 2 in that they are each rated $156,250 \mathrm{kw}$ and the turbines employ reheat.

The boiler for each of Units 3 and 4 is rated 1,200,000 pounds of steam per hour at a pressure of 1850 psi and a temperature of $1000^{\circ} \mathrm{F}$ and unlike Units 1 and 2 employs a reheat cycle. Each turbine is of the tandem compound triple flow reheat type. After the steam has passed through the high pressure stage of the turbine, the steam is returned to the boiler at a lower pressure and temperature and is reheated to $1000^{\circ} \mathrm{F}$. After reheat, the steam is passed through the intermediate and low pressure stages of the turbine and then exhausted to the condenser.

\section{M.2 Summary of Recorded Effects from the San Fernando Earthquake}

At the time of the San Fernando earthquake, Units 1, 3, and 4 were on line. Unit 2 was down for scheduled maintenance. The earthquake tripped Units 1 and 4 off line. The trip is attributed to the sudden-pressure relays, located on the floor below the control room, that are associated with the high-voltage switchyard equipment tying the plant into the Los Angeles power grid. Both Unit 1 and Unit 4 lost station power, and all equipment came to a stop. Unit 3 stayed on line throughout the earthquake; however, the flow of gas fuel was interrupted by the closing of a control valve that was activated by the vibration of a Mercoil switch. Because Unit 3 was still on line, the operators energized the tie buses between the three units so that Unit 3 funnace were relit at 6:20 a.m., 19 minutes after the earthquake. With the plant's lighting system functioning, the operators were able to make a cursory inspection of Units 1 and 4 to determine whether any obvious damage had occurred. Nothing was seen that.would prevent the units from restarting. The plant's log shows Unit 4 coming back on line at 6:50 a.m, 49 minutes after the earthquake, and Unit 1 at 7:12 a.m.

The local gas utility requested the plant to switch from gas to oil fuel after the earthquake. Ruptrires of underground gas lines in the San Fernando Valley had created problems in the normal supply of gas fuel. Subsequently, the plant's log notes that Unit 2 switched to oil fuel at 7:25 a.m., Unit 3 at 7:45 a.m., and Unit 4 at 8:20 a.m. Oil fuel is supplied from large tanks located on the plant site northeast of the four units. Switching from gas to oil (fuel required activation of a completely different system of pumps, piping, valves, and controls that feed the furnace burners. No malfunction of any component in the fuel oil system was reported for any of the three operating units. At 10:55 a.m., the log notes that load was reduced in Unit 4 for inspection of the condenser, which was later found to contain some ruptured tubes.

\section{M.3 Time Sequence of Events Following the Earthquake}




\section{M.3.1}

\section{Description of Incident}

On Tuesday, February 9, 1971 at 0601 hours, Units 1 and 4 were tripped off the line by an earthquake. Unit 1 was resynchronized at 0704 and Unit 4 at 0650.

\section{M.3.2 Plant Conditions Prior to Trouble}

Unit $1-32 \mathrm{MW}$

Unit 2 - S.I.R.

Station Services energized from No. $2138 / 230 \mathrm{KV}$ line.

\section{M.3.3 Excerpts from Plant Logs}

Control Room "A" Log:

0601 - Unit 1 off line - Earthquake. Lost both buses 138/230 KV and everything else.

0704

- Unit 1 on line.

Control Room "B" Log:

0602 - Lose of all units due to earthquake.

0620 - Unit 3 on line.

0650 - Unit 4 on line.

0712 - Unit 1 on line.

0725 - Unit 1 fuel change to all fuel oil.

0740 - Closed Valley - Hollywood OCB to No. 2 Bus. Would not close.

0741 - Closed Transformer Bank C OCB to No. 2 Bus. Would not close.

0745 - Unit 3 fuel change - all oil.

0749 - Closed Valley - Hollywood Line 1 OCB to No. 2 after resetting MG-6 relay to No.l 2 Bus.

0750 - Closed OCB's from 3 and 4 Units and Transformer Banks B and C to No. 2 Bus. No. $2138 \mathrm{KV}$ Bus normal.
0752 Closed OCB's on Valley - Rinaldi Lines 1 and 2 to Bus No.2.

0754 - Transferred Outside Service to normal.

0820 - Fuel change on Unit No. 4 to all fuel oil.

1055 - Load Limit on No. 4 Unit of $100 \mathrm{MW}$ to take condenser out one side at a time to check for leaks.

\section{M.3.4 Analysis of Incident}

Units 1 and 4 were tripped by their CFD relays which were actuated by severe jolts from the earthquake.

Unit 3 remained on the line, however, during the confusion it was assumed that all units including the Station Service had been lost. No. 3 boiler fires were tripped by the earthquake actuating the low pressure fuel gas mercoid switch. When it was discovered that Unit 3 was still on the line, the tie buses were energized to supply Units 1 and 4 and Station Service with power. The boiler was purged and burners lighted.

No. 2 138/230 KV Bus was tripped by the Sudden Pressure Relay on $230 \mathrm{KV}$ Tank F. When an attempt was made to energize the bus, the breakers failed to reclose and it was assumed that the bus was damaged. Later it was discovered that the MG-6 relay had not been reset which is a requirement before the bus can be energized after a trip. No. 1 138/230 KV Bus did not trip as reported in the " $\mathrm{B}$ " Control Room Log.

In addition to the above information, some of the problems and damage caused by the earthquake were as follows:

(1) No. 4 Unit main bank " $A$ " phase lightning arrestor was broken.

No. 4 boiler water was highly contaminated by some ruptured tubes in the condenser.

On all units, loads were increased and fuel changes made with controls on hand due to automatic components being jolted severely enough to throw them out of calibration or in some instances linkage on metering devices had become disconnected.
Lack of normal lighting during the period the 
Station Service was de-energized added to the confusion.

(5) Due to high turbidity of the city water supply, the Raw Water Storage Tank was isolated to use for makeup to the deminerialzer and fire lines were used to maintain cooling tower basin levels.

\section{M.4 Earthquake Damage Summary}

The plant's trouble report notes the following damage to equipment.

- A lightning arrestor in the switchyard was broken.

- At Unit 4, a few circulating water tubes in the condenser were ruptured. The damage was noticed when contamination began to appear in the boiler feedwater. This was the only reported failure of piping and tubing of any kind at the plant as a result of the earthquake.

- The plant was operated manually following the earthquake because the operators were not confident of the automatic control systems and in particular the condition of relays which initiate or impede operation of the automatic control.

\section{M.5 Seismic Design Basis}

\section{M.5.1 Building Structure and Foundations}

The building structure was designed for a $0.2 \mathrm{~g}$ static acceleration.

The soil is sand, gravel and boulders to depths of over 500 feet, with the permanent water table fluctuating around 200 feet below the surface.

Most of the plant footings are isolated square or rectangular footings. Due to the magnitude of the boiler column loads, which are as high as $\mathbf{8 0 0}$ tons per column for Units 3 and 4, it was necessary to use a number of combined footings in these areas. Seismic shear reactions up to 250 tons from bracing frames were transmitted to the soil by friction and passive resistance using ties between footings where necessary. Seismic uplift reactions were resisted by the dead loads plus the weight of footings and soil and the standards for spread footings. Seismic shear loads were transmitted from the bracing to the concrete by means of horizontal dowels welded to the edge of the column plates. These plates were recessed into the tops of the footings.

The structural steel framing in the boiler bay for Units 1 and 2 attain the height of a 9 story building. Units 3 and 4 attain the height of a 13 story building. In Units 3 and 4 at the top of the boiler bay are welded plate girders that support the boilers and carry over 1000 tons each. These girders are approximately 10 feet deep and 55 feet long with 3 inch by 28 inch flanges.

In an outdoor plant, the elimination of concrete shear walls necessitates the use of cantilever shear frames to resist seismic forces. These frames transmit the seismic forces to the footings and shear loads of up to 250 tons are induced in individual members. The seismic coefficient used to calculated the shear loads of the boiler and other equipment was 20 of gravity; and for the structure, a modified coefficient higher than required by the then current Los Angeles City Building Code was used, starting at 20 gravity instead of .13 .

In addition to equipment loads, the steel frame supports floor live loads ranging from 100 to 250 pounds per square foot, the latter loading being used for the turbine bay floor.

The major pipe system in the plant also appears to have been designed for a $0.2 \mathrm{~g}$ static load. However, after the San Fernando earthquake there was a seismic upgrade program instituted for all LADWAP facilities. This program resulted in the addition of $\mathbf{4 5}$ degree sway braces on a few piping systems as typically shown in Figure M.3. In total approximately 50 such sway braces were observed on Units 1-4 piping. However, there appears to be no uniform sway brace policy having been followed. Several small bore pipe were braced while adjacent large bore pipe were not.

\section{M.6 Seismic Demand from the San Fernando Earthquake}

The closest strong motion record of the San Fernando earthquake to the Valley Power Plant was in the Hollywood Inn located at 8244 Orion Avenue, Sepulveda, thirteen miles SSW of the epicenter and five miles west of the power station. The power plant was located approximately 11 miles SSE of the epicenter. The Magnitude at or near the epicenter was estimated at Magnitude XI. The Magnitude at the 
strong motion recording station closest to the power plant site and at the Valley Power Plant Site is estimated as VIII.

Strong motion time histories were recorded on the ground floor at the Holiday Inn at 8244 Orion Avenue location is shown in Section C3 of Reference M.2. The resultant response spectra for various values of damping are also shown in Section C3 of Reference M.2. It should be noted the peak acceleration (base line corrected) was $0.27 \mathrm{~g}$ in the N-S direction. This suggests that the peak zero period ground acceleration at the power plant site since it is somewhat closer to the epicenter was approximately $0.3 \mathrm{~g}$. It should be noted that in Reference M.2 a ground response spectrum was scaled up from the 8244 Orion Avenue record from 0.27 $\mathrm{g}$ to $0.4 \mathrm{~g}$ peak zero period acceleration $(\mathrm{N}-\mathrm{S})$ at the Valley Power Plant site. Both SSRAP ${ }^{(\mathrm{NM} 3)}$ and the NRC Staff have noted the Valley Power Plant zero period ground acceleration as reported in Reference M.2 may have been over estimated. ${ }^{\text {asd) }}$ SSRAP has suggested a 0.6 multiplication factor on the Reference Bounding Spectra ( $0.6 \times 5 \mathrm{ZPGA}=.3 \mathrm{ZPGA})$ and the NRC Staff a 0.5 factor. It is not clear on what basis SSRAP and the NRC Staff have developed their multiplies but a simple look at the recorded peak of $0.27 \mathrm{~g}$ at 8244 Orion Avenue and relative epicentral distances of 13 miles versus 11 miles suggest a maximum ZPGA of about $0.3 \mathrm{~g}$ at the Valley Power Plant site. An estimated ground spectra for the Valley Power Plant site based on the spectra given in Reference M.2 normalized to a $0.3 \mathrm{~g}$ zero period ground acceleration is given in Figure M.4.

\section{M.7 References}

(M.1) Yanev, P.I. and Swan, S.W., "Program for the Development of an Alternate Approach to Seismic Equipment Qualification-Pilot Program Report", Volume I, EQE, Incorporated, Prepared for Seismic Qualification Utilities Group.

(M.2) Yanev, P.I. and Swan, S.W., "Program for the Development of an Altermate Approach to Seismic Equipment Qualification-Pilot Program Report", Volume II Appendices, EQE, Incorporated, Prepared for Seismic Qualification Utilities Group.

Kennedy, R.P. et.al., "Use of Seismic Experience and Test Data to Show Ruggedness of Equipment in Nuclear Power Plants", Prepared for the Seismic
Qualification Utility Group and in Cooperation with the U.S. NRC, Rev. 4 February 1991.

(M.4) Internal NRC Letter Communication to G. Bajchi Concerning the Acceleration Levels Associated with the San Fernando Earthquake at the Valley Power Station Site. 


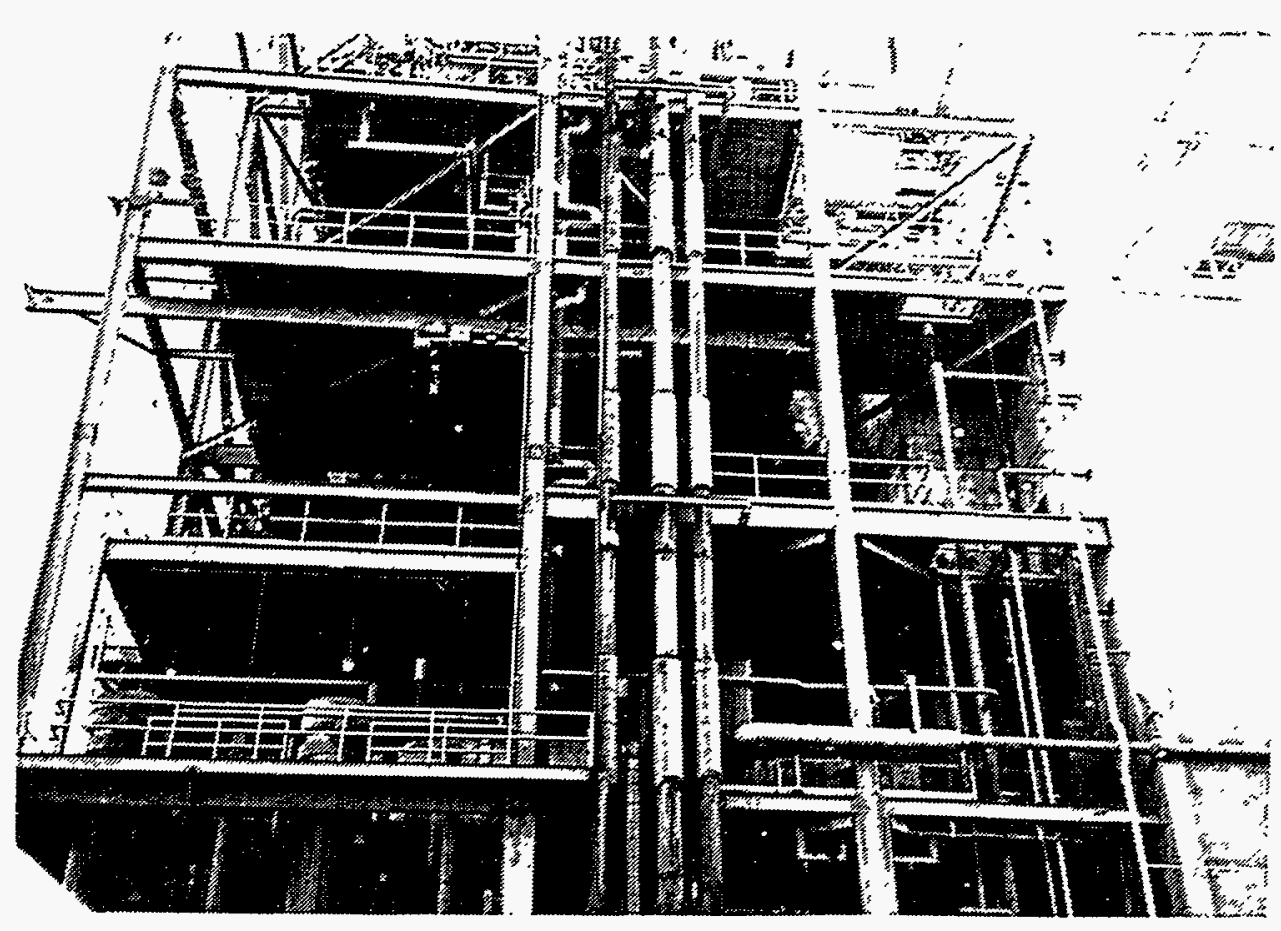

Figure M.1 - Structural Steel Framing for Valley Unit 3 


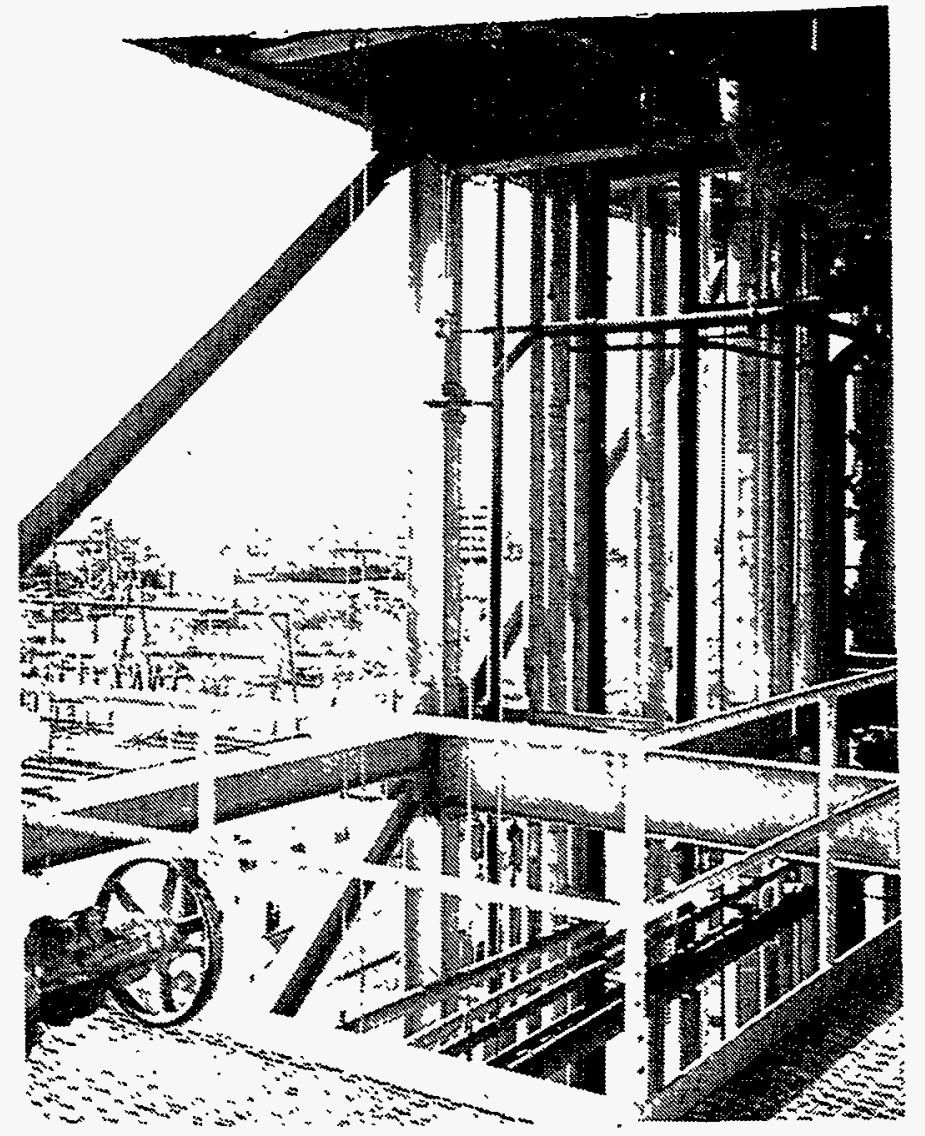

Figure M.2 - Structural Steel Framing for Valley Unit 3 Showing Diagonal Vertical Bracing 


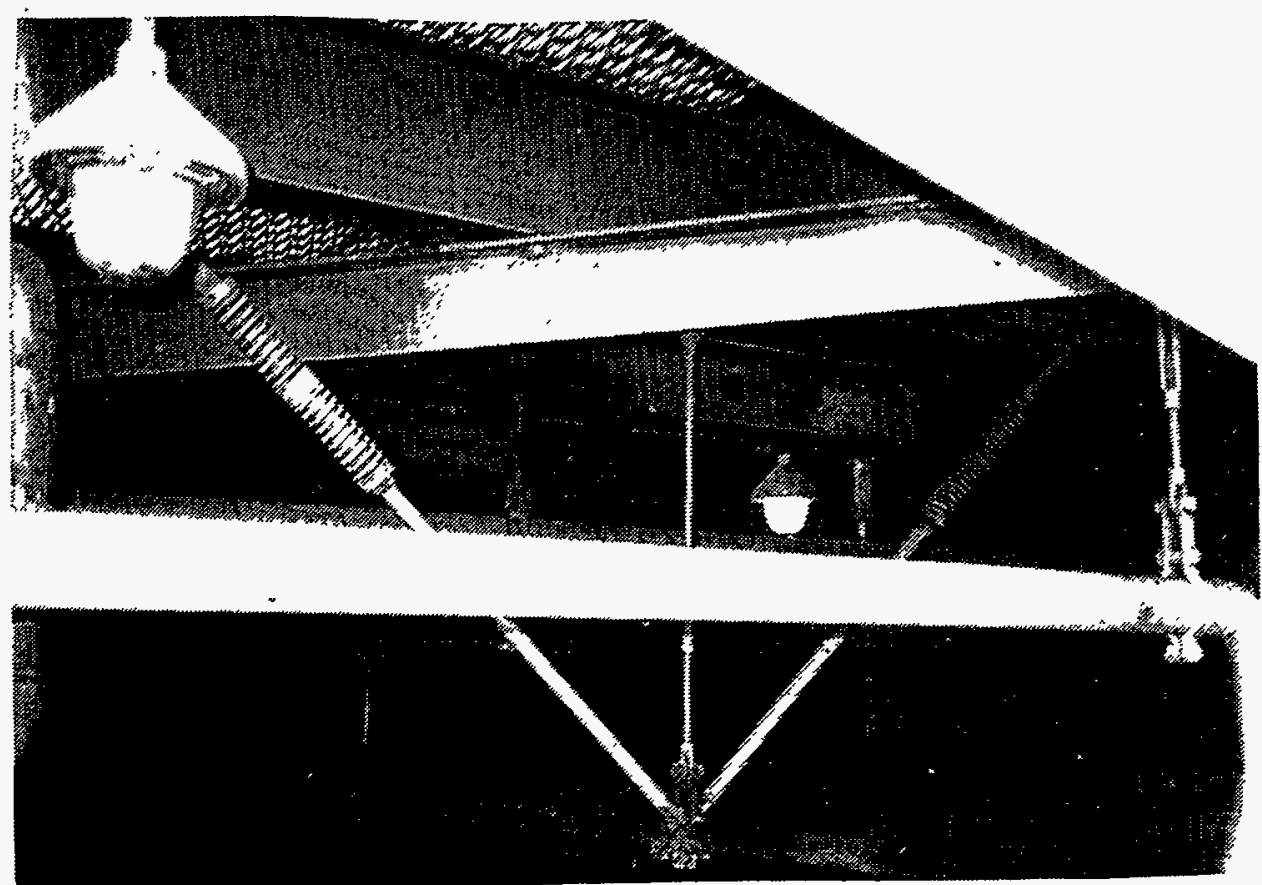

Figure M.3 - Typical Sway Brace Used in Support of Pipe Valley Unit 1 


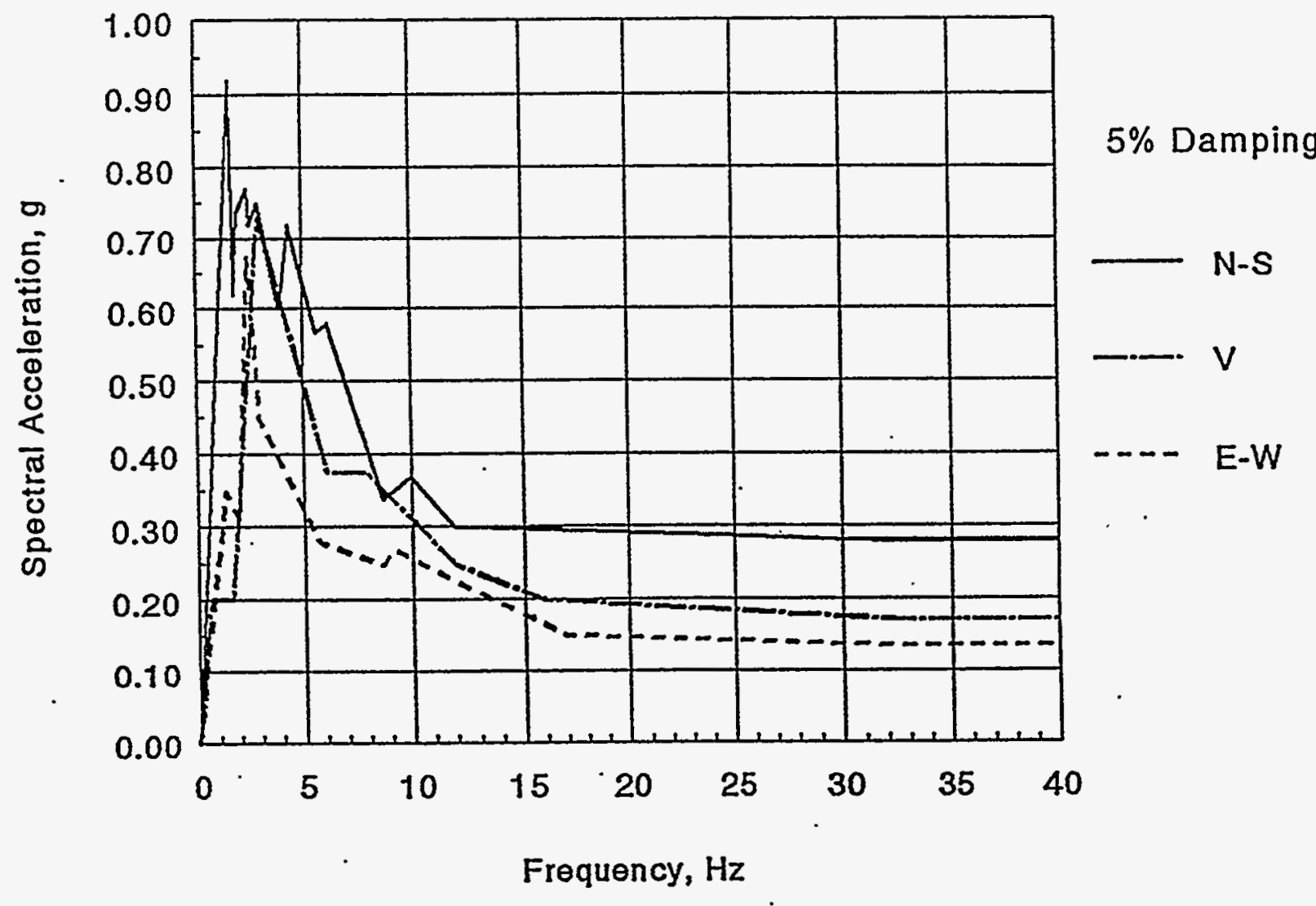

Figure M.4 - Estimated San Fernando Earthquake, Valley Steam Plant Site Ground R.S. 
(See instructions on the reverse)

2. TITLE AND SUBTITLE

Survey of Strong Motion Earthquake Effects on Thermal Power

Plants in California with Emphasis on Piping Systems

Appendices

5. AUTHOR(S)

J.D. Stevenson

3. DATE REPORT PUBLISHED November 1995

4. FIN OR GRANT NUMBER B0850

6. TYPE OF REPORT

7. PERIOD COVERED (Inclusive Dates)

8. PERFORMING ORGANIZATION - NAME AND ADDRESS IIf NAC, provide Division, Office or Region, U.S. Nuclear Regulatory Commission, and mailing address, if contractor, provide Stevenson and Associates

9217 Midwest Avenue

Cleveland, $\mathrm{OH} 44125$

Under contract to:

Oak Ridge National Laboratory

Oak Ridge, TN 37831-6285

9. SPONSORING ORGANIZATION - NAME AND ADDRESS IIf NRC, type "Same as above"; if contractor, provide NRC Division, Office or Region, U.S. Nuclear Regulatory Commission, and mailing address.)

Division of Engineering Technology

Office of Nuclear Regulatory Research

U.S. Nuclear Regulatory Commission

Washington, DC 20555-0001

10. SUPPLEMENTARY NOTES

N. Chokshi, NRC Project Manager

11. ABSTRACT (200 words or less)

Volume 2 of the "Survey of Strong Motion Earthquake Effects on Thermal Power Plants in California with Emphasis on Piping Systems" contains Appendices which detail the detail design and seistric response of several power plants subjected to strong motion earthquakes. The particular plants considered include the Ormond Beach, Long Beach and Seal Beach, Burbank, El Centro, Glendale, Humboldt Bay, Kern Valley, Pasadena and Valley power plants. Included is a typical power plant piping specification and photographs of typical power plant piping specification and photographs of typical piping and support installations for the plants surveyed. Detailed piping support spacing data are also included. 